ES/WM-30

\title{
OAK RIDGE RESERVATION WASTE MANAGEMENT PLAN
}

\author{
Project director \\ C. E. Frye
}

Project coordinator

F. J. Sweeney

$\begin{array}{ccr}\text { W. R. McCauley } & \text { Technical coordinators } & \\ \text { Oak Ridge Y-12 Plant } & \text { S. H. Reece } & \text { W. S. Christenberry } \\ & \text { Oak Ridge National Laboratory } & \text { Oak Ridge K-25 Site } \\ & \begin{array}{c}\text { Coordinating editor } \\ \text { J. W. Turner }\end{array}\end{array}$

Date Published: February 1995
Prepared by the
Energy Systems Waste Management Organization
Oak Ridge, TN 37831-7357
Prepared for the
U.S. DEPARTMENT OF ENERGY
Office of Environmental Management
under budget and reporting code EW 20
Environmental Restoration and Waste Management Programs
Oak Ridge Y-12 Plant
Oak Ridge National Laboratory
Oak Ridge K-25 Site
managed by
MARTIN MARIETTA ENERGY SYSTEMS, INC.
for the
U.S. DEPARTMENT OF ENERGY
under contract DE-AC05-OR21400


This report has been reproduced directiy from the best available copy.

Available to DOE and DOE contractors from the Office of Scientific and Technical Information, P.O. Box 62, Oak Ridge, TN 37831; prices available from (615) 576-8401.

Available to the public from the National Technical Information Service, U.S. Department of Commerce, 5285 Port Royal Rd., Springfield, VA 22161.

This report was prepared as an account of work sponsored by an agency of the United States Government. Neither the United States Govemment nor any agency thereof, nor any of their employees, makes any warranty, express or implied, or assumes any legal liability or responsibility for the accuracy, completeness, or usefulness of p:.y information, apparatus, product, or process disclosed, or represents that its use would not infringe privately owned rights. Reterence herein to any specific commercial product, process, or service by trade name, trademark, manufacturer, or otherwise, does not necessarily constitute or imply its endorsement, recommendation, or favoring by the United States Government or any agency thereof. The riews and opinions of euthors expressed herein do not necessarily state or reflect those of the United States Government or any agency thereot. 


\section{DISCLAIMER}

Portions of this document may be illegible in electronic image products. Images are produced from the best available original document. 


\section{Contents}

List of Figures $\ldots \ldots \ldots \ldots \ldots \ldots \ldots \ldots \ldots \ldots \ldots \ldots \ldots \ldots \ldots \ldots$

List of Tables $\ldots \ldots \ldots \ldots \ldots \ldots \ldots \ldots \ldots \ldots \ldots \ldots \ldots \ldots \ldots \ldots$

Acronyms and Initialisms $\ldots \ldots \ldots \ldots \ldots \ldots \ldots \ldots \ldots \ldots \ldots \ldots \ldots \ldots \ldots$

Executive Summary $\ldots \ldots \ldots \ldots \ldots \ldots \ldots \ldots \ldots \ldots \ldots \ldots \ldots \ldots \ldots$ xvii

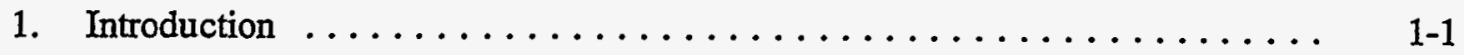

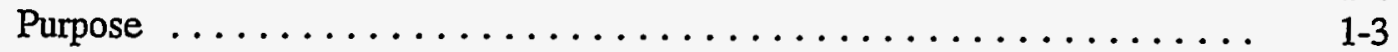

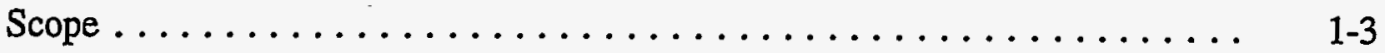

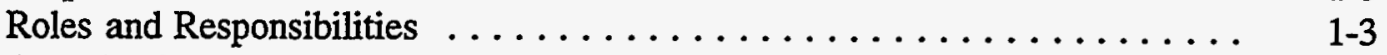

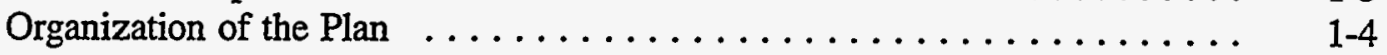

Related Documents .......................... $1-4$

Regulatory Requirements ....................... 1-5

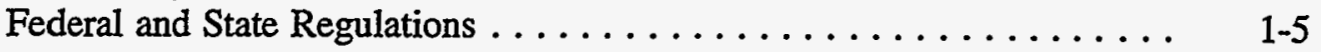

DOE Orders . . . . . . . . . . . . . . . . . . . . . .

Overview of Waste Management on the ORR .............. 1-10

ORR-Wide Waste Management Activities $\ldots \ldots \ldots \ldots \ldots \ldots \ldots \ldots . \ldots \ldots \ldots$

References ............................. 1-16

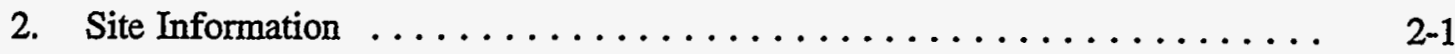

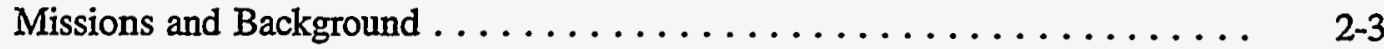

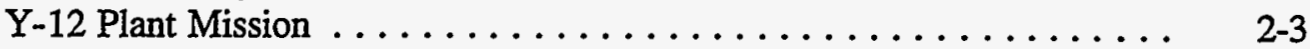

ORNL Mission ......................... 2-3

K-25 Site Mission . . . . . . . . . . . . . . . . . .

Background of Waste Management Practices on the ORR ....... 2-4

Site Descriptions ......................... 2-5

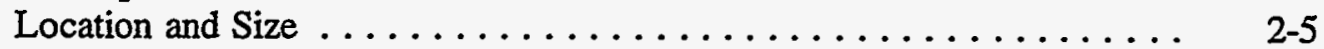

Demography . . . . . . . . . . . .

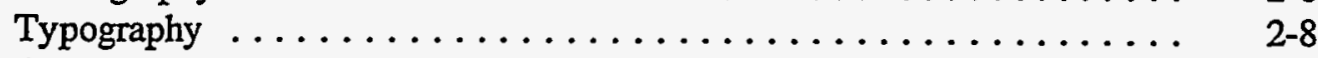

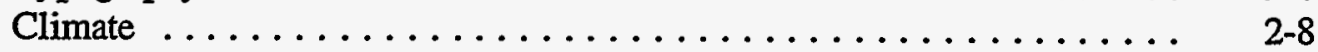

Geologic and Hydrogeologic Conditions ............. 2-8

Waste Management Organizational Structures .............. 2-11

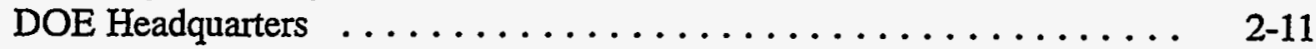

DOE-ORO .......................... 2-12

Martin Marietta Energy Systems, Inc. . . . . . . . . . . . . 2-12

Documentation Management . . . . . . . . . . . . . . . . . 2-22

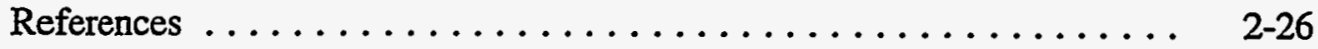

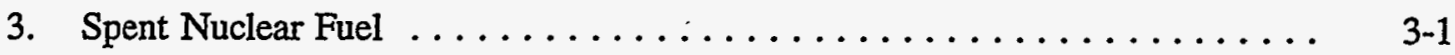

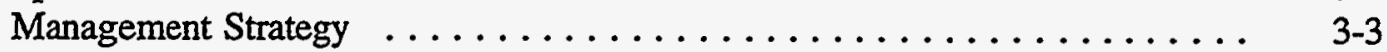

Current Generation and Projections . . . . . . . . . . . . . .

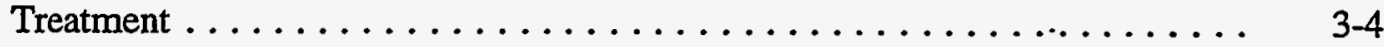

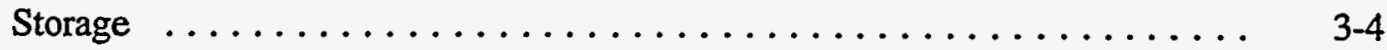

Disposal . . . . . . . . . . . . . . . . . . . . . . . .

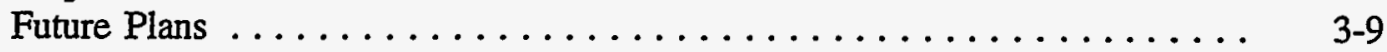




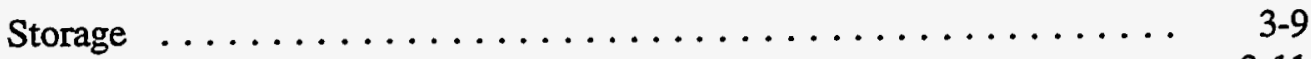

Alternatives Under the PDEIS $\ldots \ldots \ldots \ldots \ldots \ldots \ldots \ldots \ldots \ldots$ 3-11

Schedules and Milestones . . . . . . . . . . . . . . . . . 3-15

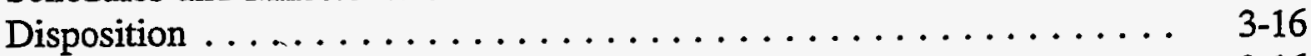

References ........................... 3-16

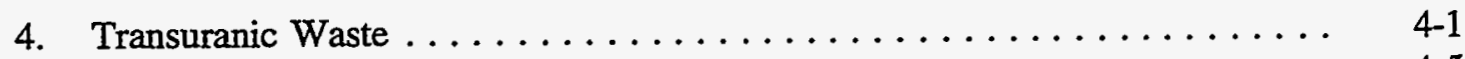

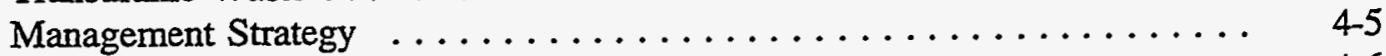

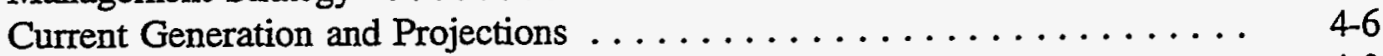

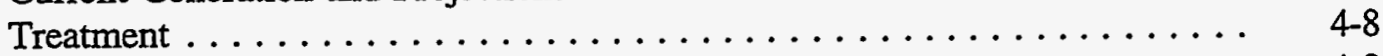

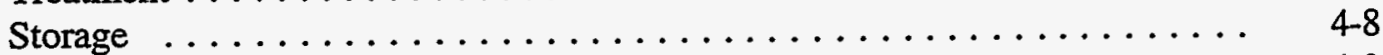

Disposal ..................................... 4-9

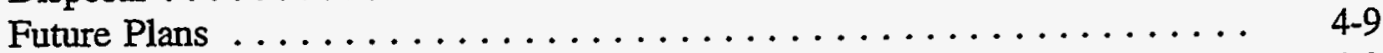

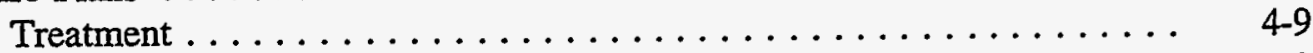

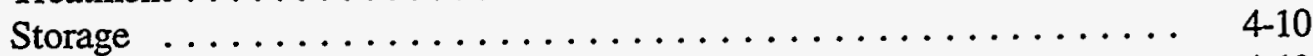

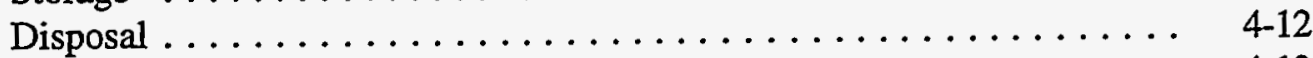

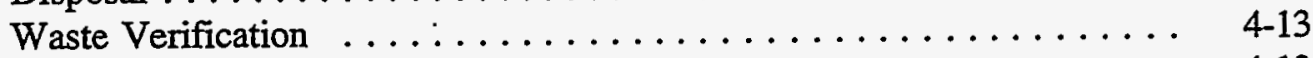

Waste Minimization/Pollution Prevention .............. 4-13

Reference ........................... 4-13

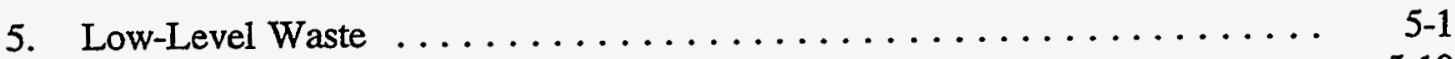

Management Strategy ........................ 5-10

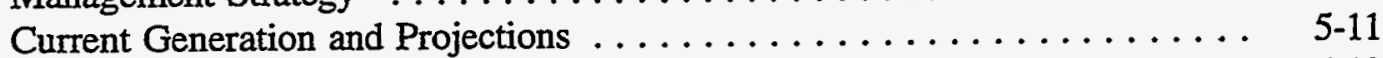

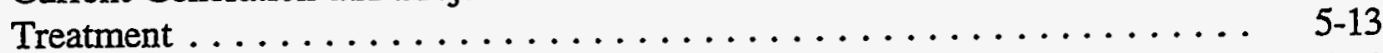

Solid Low-Level Waste . . . . . . . . . . . . . . . . . . . . . . 5-13

Liquid Low-Level Waste $\ldots \ldots \ldots \ldots \ldots \ldots \ldots \ldots \ldots \ldots$ 5-18

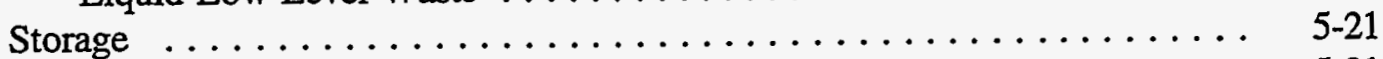

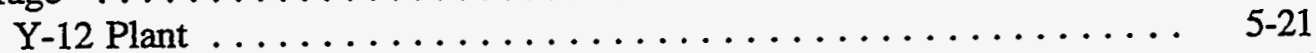

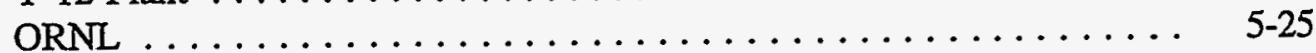

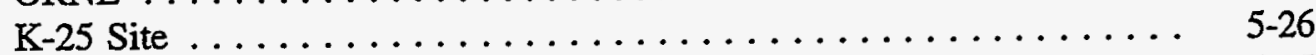

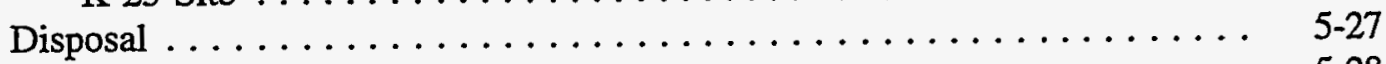

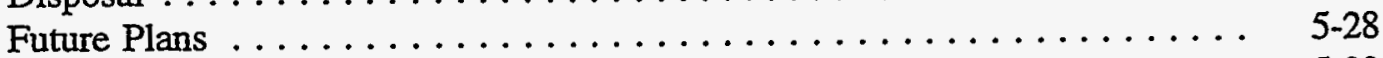

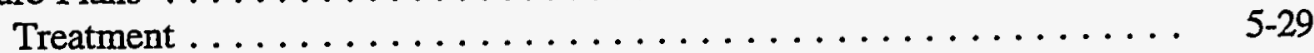

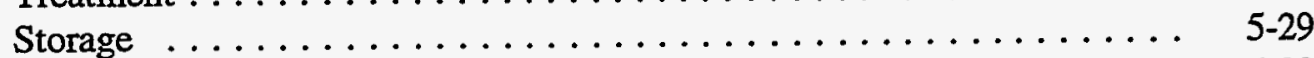

Disposal . . . . . . . . . . . . . . . . . . . . . $5-32$

Waste Certification ......................... $5-32$

Waste Minimization/Pollution Prevention .............. $5-32$

Performance Assessments . . . . . . . . . . . . . . . . . . . . 5 5-33

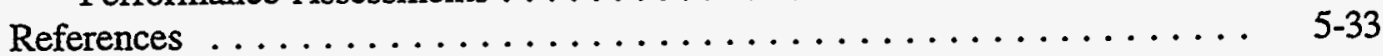

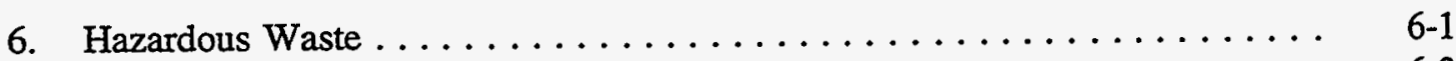

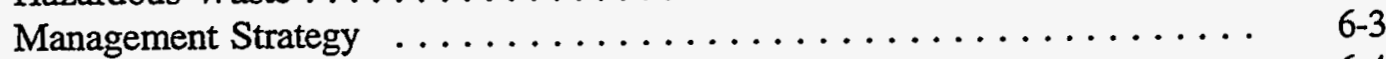

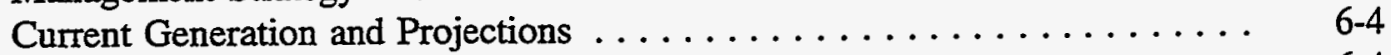

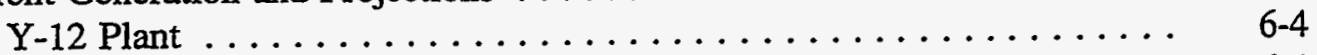

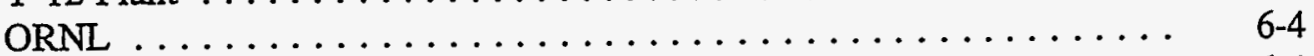

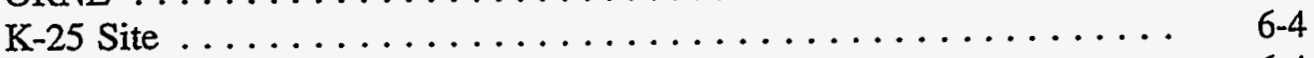

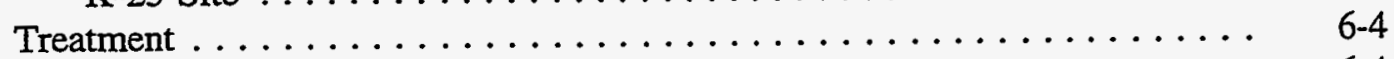

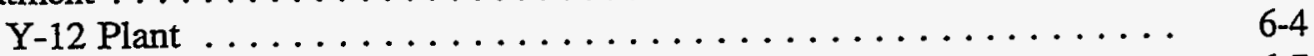

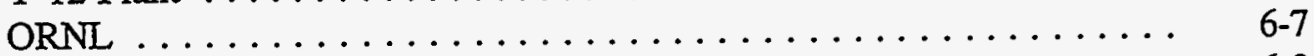

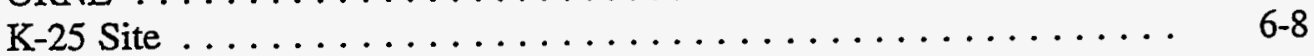

iv Oak Ridge Reservation Waste Management Plan 


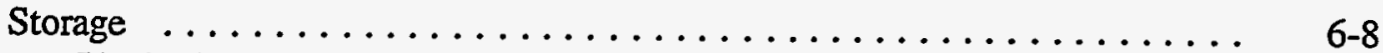

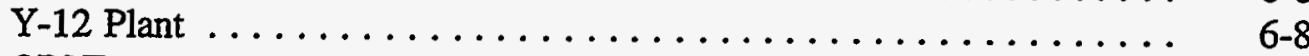

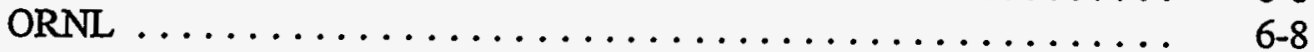

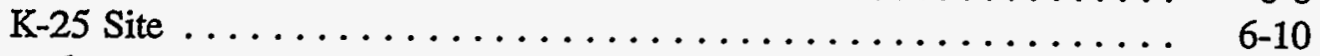

Disposal .............................. 6-10

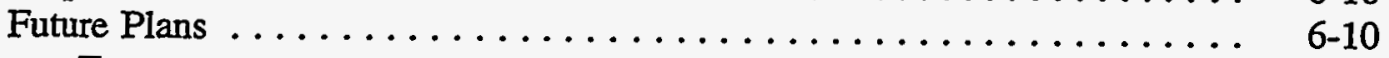

Treatment .............................. 6-10

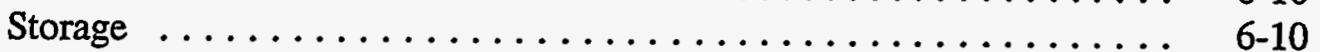

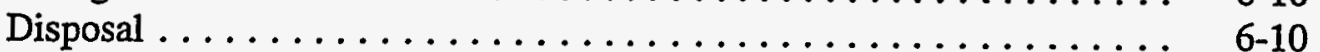

Waste Certification ........................ 6-10

Waste Minimization/Pollution Prevention . . . . . . . . . . . . . 6-10

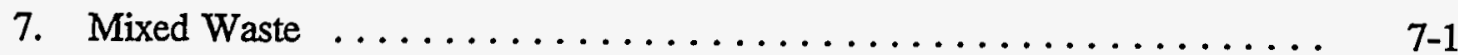

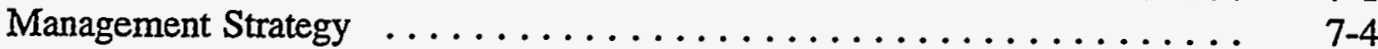

Current Generation and Projections $\ldots \ldots \ldots \ldots \ldots \ldots \ldots \ldots \ldots$ 7-6

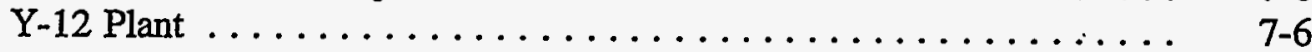

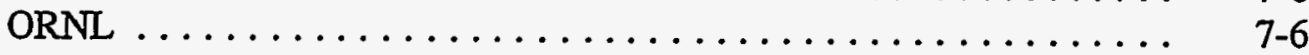

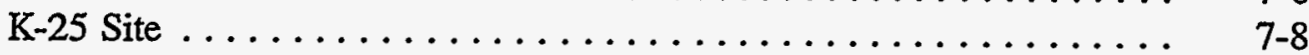

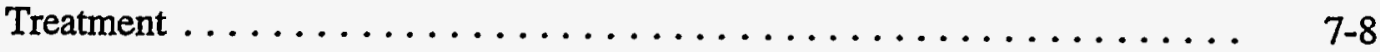

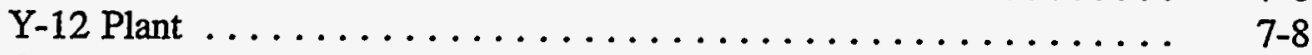

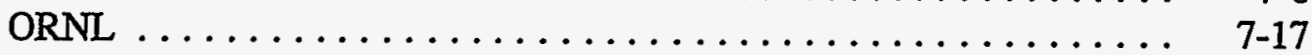

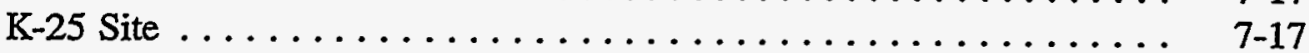

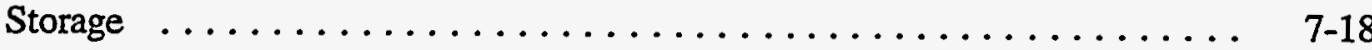

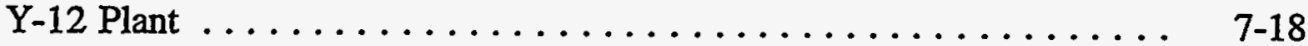

ORNL ........................... 7-26

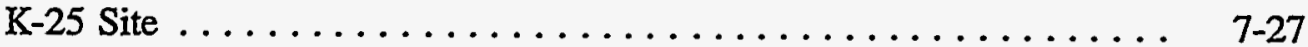

Disposal ............................. 7-30

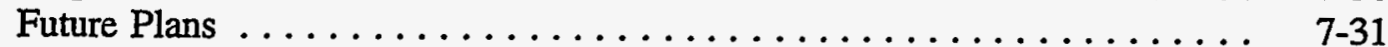

Treatment ....................... 7-31

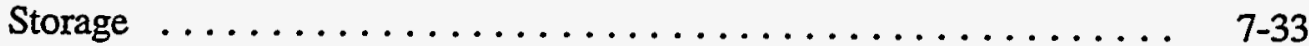

Disposal ........................... 7-36

Waste Characterization $\ldots \ldots \ldots \ldots \ldots \ldots \ldots \ldots \ldots \ldots \ldots$ 7-36

Waste Tracking ....................... 7-37

Waste Minimization/Pollution Prevention .............. 7-37

References ........................... 7-39

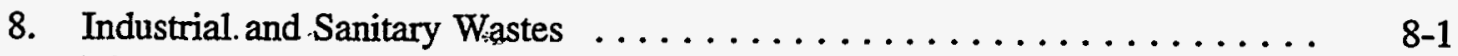

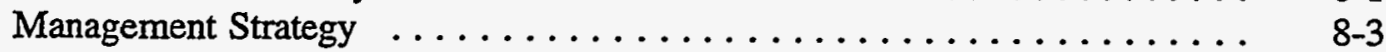

Current Generation and Projections $\ldots \ldots \ldots \ldots \ldots \ldots \ldots \ldots . \ldots \ldots$ 8. $8 \ldots \ldots$

Treatment $\ldots \ldots \ldots \ldots \ldots \ldots \ldots \ldots \ldots \ldots \ldots \ldots \ldots \ldots . \ldots \ldots \ldots$

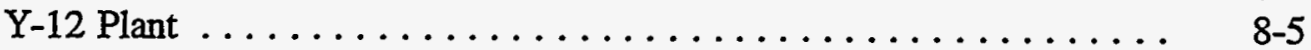

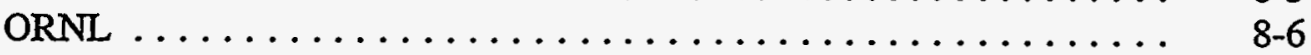

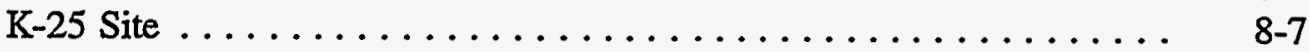

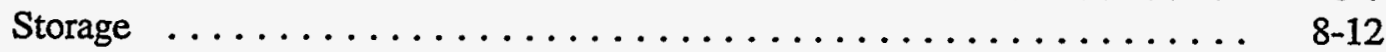

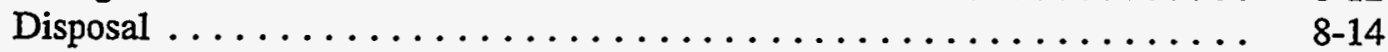

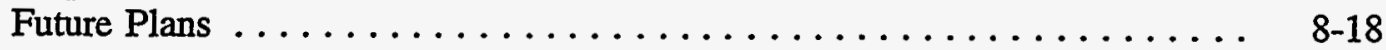

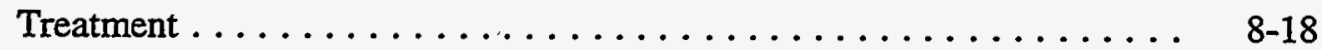

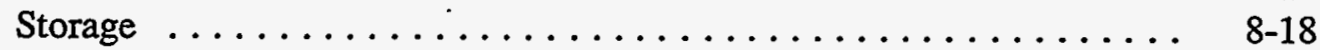

Disposal . . . . . . . . . . . . . . . . . . . . . . .

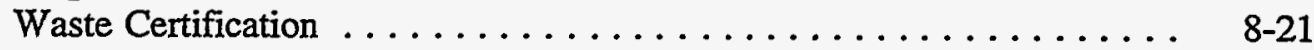


Waste Minimization/Pollution Prevention . . . . . . . . . . 8-22

References .......................... 8-23

Appendix A. Waste Management Documentation Requirements .......... A A

Appendix B. ORR Waste Treatment, Storage, and Disposal Facilities . . . . . . . . B-1

Appendix C. Planned ORR Waste Treatment, Storage, and Disposal Facilities . ... . C-1

Appendix D. DOE Order 5820.2A Implementation Summary . . . . . . . . . D D-1

vi Oak Ridge Reservation Waste Management Plan 


\section{List of Figures}

Figure

Page

1.1 FY 1995 distribution of expense and capital funding for waste management and corrective actions $\ldots \ldots \ldots \ldots \ldots \ldots \ldots \ldots \ldots \ldots \ldots \ldots$

1.2 FY 1995 distribution of funding for waste management and

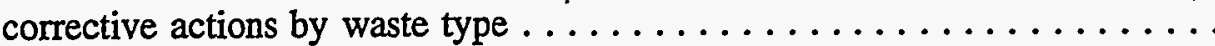

1.3 Solid waste generation on the Oak Ridge Reservation for CY 1993

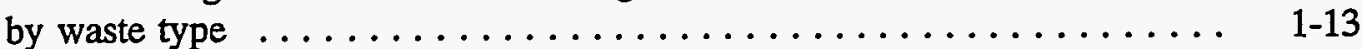

1.4 Waste stored on the Oak Ridge Reservation as of June 30, $1994 \ldots \ldots \ldots$. . 1-13

2.1 Location of the city of Oak Ridge .................. $2-6$

2.2 The Oak Ridge Reservation ....................... 2-6

2.3 Locations and populations of towns nearest to the Oak Ridge Reservation .......................... 2- 2

2.4 Geologic formations within the Oak Ridge Reservation . . . . . . . . . . . 2-9

$2.5 \quad$ U.S. Department of Energy Headquarters . . . . . . . . . . . . . . . . 2-13

2.6 AMERWM Organization for the U.S. Department of Energy's Oak Ridge Operations Office ......................

2.7 Energy Systems Environmental Restoration and Waste Management Programs . . . . . . . . . . . . . . . . . . .

2.8 Energy Systems Waste Management Organization . . . . . . . . . . . 2-16

2.9 Energy Systems Waste Management Organization at the Oak Ridge Y-12 Plant . . . . . . . . . . . . . . . . . . . . . .

2.10 Energy Systems Waste Management Organization at Oak Ridge National Laboratory . . . . . . . . . . . . . . . . . . .

2.11 Energy Systems Waste Management Organization at the

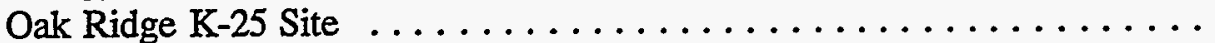

2.12 Organizational chart for the Toxic Substances Control Act

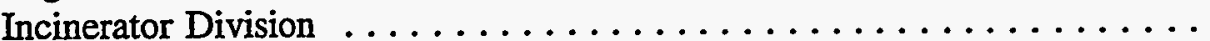

3.1 Schedule and milestones for spent nuclear fuel $\ldots \ldots \ldots \ldots \ldots \ldots \ldots \ldots$

4.1 Flow sheet for handling newly generated contact-handled transuranic waste ............................ 4-4

4.2 Projected solid transuranic waste generation under the Environmental Restoration and Decontamination and

Decommissioning Programs on the Oak Ridge Reservation

4.3 Concrete casks in storage bunker at Oak Ridge National Laboratory . . . . . .

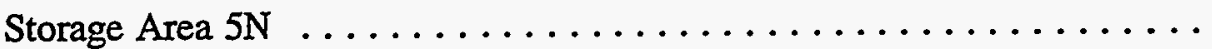

4.4 Locations of transuranic waste storage facilities in Solid Waste

4.5 Concrete casks for storing remote-handled transuranic waste in a trench in Solid Waste Storage Area $5 \mathrm{~N}$ at Oak Ridge

National Laboratory . . . . . . . . . . . . . . . . . . . .

4.6 Conceptual Waste Handling and Packaging Plant cutaway $\ldots \ldots \ldots \ldots$. . 4-11

4.7 Projected contact-handled transuranic waste for storage . . . . . . . . . 4-11

4.8 Projected remote-handled transuranic waste for storage . . . . . . . . . . 4-12

5.1 Volumes of solid low-level waste generated on the Oak Ridge Reservation during CY $1993 \ldots . . \ldots \ldots \ldots \ldots \ldots \ldots$. . . . . . . . . . . . . . . 5-4

5.2 Volumes of solid low-level waste stored on the Oak Ridge Reservation as of June 30, 1994 
5.3 Projected solid low-level waste generation under the Environmental

Restoration and Decontamination and Decommissioning Programs . . . . . . .

$5.4 \quad$ Uranium Chip Oxidizer Facility at the Oak Ridge Y-12 Plant . . . . . . . .

5.5 Trash-Monitoring Station at the Oak Ridge $Y-12$ Plant . . . . . . . . . . 5-17

5.6 The Waste Feed Preparation Facility at the Oak Ridge Y-12 Plant . . . . . 5-17

5.7 Process flow of solid low-level waste at the Oak Ridge Y-12 Plant . . . . . 5-18

5.8 Schematic of the Liquid Low-Level Waste System at Oak Ridge National

Laboratory . . . . . . . . . . . . . . . . . . . . . . . 5-19

5.9 Central Treatment/Storage System . . . . . . . . . . . . . . 5-20

5.10 Flow diagram of the Nonradiological Wastewater Treatment Plant at

Oak Ridge National Laboratory . . . . . . . . . . . . . . . . . 5-22

5.11 Depleted uranium oxide storage vaults $I$ and $I I$ at the

Oak Ridge $\mathrm{Y}-12$ Plant $\ldots \ldots \ldots \ldots \ldots \ldots \ldots \ldots \ldots \ldots \ldots \ldots$ 5-23

5.12 The Containerized Waste Storage Area at the Oak Ridge Y-12 Plant . . . . 5-24

5.13 The Above-Grade Storage Facility at the Oak Ridge Y-12 Plant . . . . . . 5 5-25

5.14 Schematic of the Interim Waste Management Facility at Oak Ridge

National Laboratory showing vaults, pad, drain lines, and

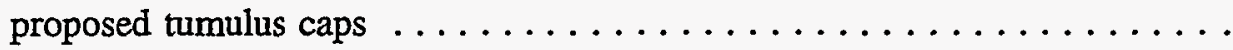

5.15 Projected storage required for solid low-level waste. . . . . . . . . 5-30

6.1 Solid hazardous waste generation projections under the

Environmental Restoration Program .................. 6-5

6.2 Process flow for hazardous wastes at Oak Ridge National Laboratory . . . . 6 6-6

6.3 The Resource Conservation and Recovery Act Storage and Staging

Facility at the Oak Ridge $\mathrm{Y}-12$ Plant $\ldots \ldots \ldots \ldots \ldots \ldots \ldots \ldots \ldots \ldots \ldots$

7.1 Solid mixed waste generation projections under the Environmental

Restoration and Decontamination and Decommissioning Programs on the

Oak Ridge Reservation .......................

7.2 The Central Pollution Control Facility at the Oak Ridge Y-12 Plant . . . . . 7-10

7.3 Plating Rinsewater Treatment Facility process flow at the

Oak Ridge $Y-12$ Plant $\ldots \ldots \ldots \ldots \ldots \ldots \ldots \ldots \ldots \ldots \ldots \ldots$ 7-11

7.4 The Groundwater Treatment Facility at the Oak Ridge Y-12 Plant . . . . . 7-13

7.5 The Waste Coolant Processing Facility at the Oak Ridge Y-12 Plant .... . 7-14

7.6 West End Treatment Facility at the Oak Ridge Y-12 Plant ......... 7-16

7.7 Schematic showing mixed waste process flow at the

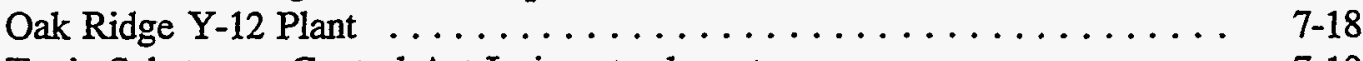

7.8 Toxic Substances Control Act Incinerator layout . . . . . . . . . . . . 7-19

7.9 Process flow at the Toxic Substances Control Act Incinerator . . . . . . . . 7-19

7.10 The Flammable Mixed Waste Storage Facility, Oil Dike 10, at the
Oak Ridge Y-12 Plant $\ldots \ldots \ldots \ldots \ldots \ldots \ldots \ldots \ldots \ldots \ldots \ldots \ldots \ldots \ldots$

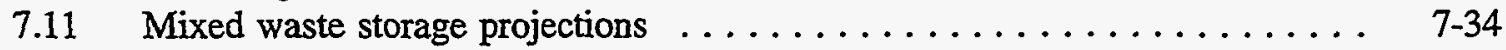

Projected Environmental Restoration Program industrial and
sanitary solid waste generation on the Oak Ridge Reservation . . . . . . . . 8-6

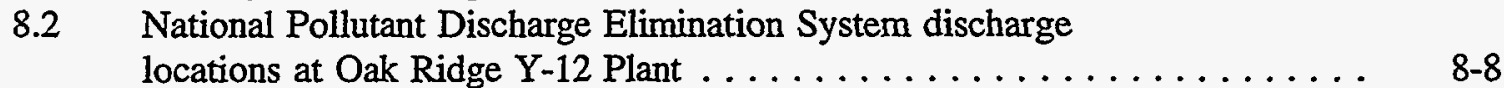

8.3 ORNL surface water, NPDES, and reference sampling locations . . . . . . 8-9

8.4 National Pollutant Discharge Elimination System discharge

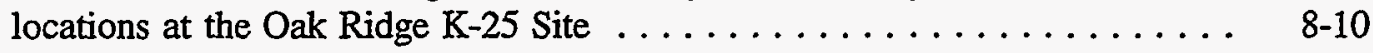

8.5 Steam Plant Wastewater Treatment Facility process flow at the

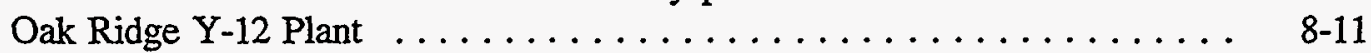


8.6 Flow diagram of the Coal Yard Runoff Treatment Facility at Oak Ridge National Laboratory . . . . . . . . . . . . . . . 8-12

8.7 Flow diagram for the Sewage Treatment Facility at Oak Ridge National Laboratory . . . . . . . . . . . . . . . . . . . . . 8-13

8.8 Flow diagram for the Oak Ridge K-25 Site Sewage Treatment System (Building K-1203) . . . . . . . . . . . . . . . . .

8.9 Flow diagram for the Oak Ridge K-25 Site Central Neutralization Facility . . . . . . . . . . . . . . . . . . . . 8-15

8.10 The New Salvage Yard at the Oak Ridge $Y-12$ Plant . . . . . . . . . 8-16

8.11 East End Waste Facility at the Oak Ridge $Y-12$ Plant $\ldots \ldots \ldots \ldots \ldots \ldots$ 8-16

8.12 Industrial Landfill $V$ at the Oak Ridge $Y-12$ Plant $\ldots \ldots \ldots \ldots \ldots \ldots \ldots$. 8 .17

8.13 Industrial Landfills $I I$ and $V$ and Construction/Demolition Landfill VI locations near the Oak Ridge Y-12 Plant . . . . . . . . . . . 8-17 


\section{List of Tables}

2.1 Waste management Activity Data Sheets for FY 1995 and related regulatory drivers . . . . . . . . . . . . . . . . . .

3.1 Spent nuclear fuel data on the Oak Ridge Reservation:

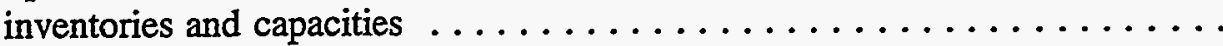

3.2 Short-term storage plan for spent nuclear fuel on the Oak Ridge Reservation . . . . . . . . . . . . . . . . . . .

3.3 Long-term interim storage options for spent nuclear fuel on the Oak Ridge Reservation . . . . . . . . . . . . . . . . . .

4.1 Summary of solid transuranic waste generation at Oak Ridge National Laboratory . . . . . . . . . . . . . . . . . . .

4.2 Volumes of stored remote- and contact-handled solid transuranic wastes at Oak Ridge National Laboratory . . . . . . . . . . . . .

5.1 Current solid low-level waste (SLLW) segregation categories on the Oak Ridge Reservation . . . . . . . . . . . . . . . . . . . Previously proposed classification system for low-level waste $\ldots \ldots \ldots \ldots$ Proposed revised classification system for low-level waste $\ldots \ldots \ldots \ldots \ldots$

5.4 Summary of solid low-level waste generation on the Oak Ridge Reservation . . . . . . . . . . . . . . . . . .

Summary of liquid low-level waste generation on the

Oak Ridge Reservation . . . . . . . . . . . . . . . . . .

5.6 Summary of contaminated scrap metal generation on the

Oak Ridge Reservation . . . . . . . . . . . . . . . . . . .

5.7 Summary of low-level waste treatment on the Oak Ridge Reservation ..... Off-site treatment of solid low-level waste $\ldots \ldots \ldots \ldots \ldots \ldots \ldots$

5.10 Storage of solid low-level waste at Oak Ridge National Laboratory . . . . . . .

5.11 Storage of solid low-level waste at the Oak Ridge K-25 Site . . . . . . . . . .

5.13 Possible candidates for disposal off-site at the Nevada Test

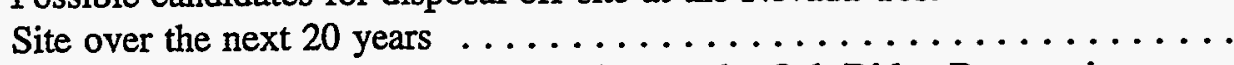

Summary of hazardous waste generation on the Oak Ridge Reservation . . . . Summary of hazardous waste treatment on the Oak Ridge Reservation ..... Off-site treatment of hazardous waste $\ldots \ldots \ldots \ldots \ldots \ldots \ldots \ldots \ldots$ Storage of hazardous waste at Oak Ridge National Laboratory . . . . . . . . Toxic Substances Control Act Incinerator Operations Division

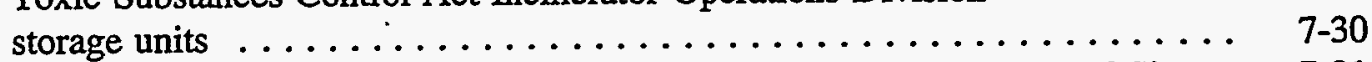

7.4 Pond Waste Management Project storage units at the Oak Ridge K-25 Site . 7-31

7.5 Summary of mixed waste inventory and storage on the Oak Ridge Reservation . . . . . . . . . . $\ldots \ldots \ldots \ldots \ldots \ldots$ 7-32

7.6 Summary of mixed waste disposed of off-site $\ldots \ldots \ldots \ldots \ldots \ldots \ldots \ldots$ 
8.1 State of Tennessee industrial and sanitary solid waste disposal facility classifications . . . . . . . . . . . . . . . .

8.2 Summary of industrial and sanitary solid and liquid waste generation on the Oak Ridge Reservation

8.3 Industrial and sanitary liquid wastes treated on the Oak

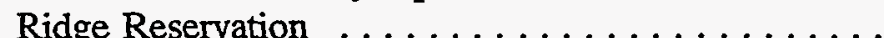

8.4 Summary of industrial and sanitary waste disposal capacity on the Oak Ridge Reservation . . . . . . . . . . . . . . . . . . . 8-18

8.5 Waste types for disposal at the Y-12 Industrial Landfill V

8.6 Waste types for disposal at the Y-12 Plant Construction/Demolition Landfill VI (CDI VI) . . . . . . . . . . . . . . .

8.7 Discharges on the Oak Ridge Reservation not considered industrial or sanitary waste 


\section{Acronyms and Initialisms}

\begin{tabular}{|c|c|}
\hline AcDM & Activities Description Memorandum \\
\hline ADM & Action Description Memorändum \\
\hline $\mathrm{ADS}$ & Activity Data Sheet \\
\hline AEA & Atomic Energy Act \\
\hline ALARA & as low as reasonably achievable \\
\hline AMERD & Assistant Manager for Energy Research and Development \\
\hline AMERWM & Assistant Manager for Environmental Restoration and Waste Management \\
\hline ANS & Advanced Neutron Source \\
\hline ANSI & American National Standards Institute \\
\hline ARAR & Applicable or Relevant and Appropriate Requirement \\
\hline ASME & American Society of Mechanical Engineers \\
\hline BAT & Best Available Technology \\
\hline BMP & Best Management Practices \\
\hline BSR & Bulk Shielding Reactor \\
\hline CAA & Clean Air Act \\
\hline CAT & collection and transfer \\
\hline CDL VI & Construction/Demolition Landfill VI \\
\hline CDR & Conceptual Design Report \\
\hline CEQ & Council on Environmental Quality \\
\hline CERCLA & Comprehensive Environmental Response, Compensation, and Liability Act \\
\hline CFR & Code of Federal Regulations \\
\hline $\mathrm{CH}$ & contact-handled \\
\hline CNF & Central Neutralization Facility \\
\hline COM & commercially held, DOE-owned radioactive material \\
\hline COR & contractor officer's representative \\
\hline CPCF & Central Pollution Control Facility \\
\hline $\mathrm{CV}$ & cell ventilation \\
\hline CWA & Clean Water Act \\
\hline $\mathrm{CWCH}$ & central waste collection header \\
\hline CWMD & Central Waste Management Division \\
\hline CWSA & Containerized Waste Storage Area \\
\hline CWSF & Classified Waste Storage Facility \\
\hline CWTS & Central Waste Tracking System \\
\hline CY & current year \\
\hline CYRTF & Coal Yard Runoff Treatment Facility \\
\hline CYRTS & Coal Yard Runoff Treatment System \\
\hline CYWP & Current Year Work Plan \\
\hline $\mathrm{D} \& \mathrm{D}$ & decontamination and decommissioning \\
\hline DDDP & Defense Decontamination and Decommissioning Program \\
\hline DMC & Documentation Management Center \\
\hline DMS & Documentation Management System \\
\hline DOE & U.S. Department of Energy \\
\hline DOE-HQ & U.S. Department of Energy, Headquarters \\
\hline DOE-ORO & U.S. Department of Energy, Oak Ridge Operations Office \\
\hline DOT & U.S. Department of Transportation \\
\hline $\mathrm{DP}$ & Defense Programs \\
\hline
\end{tabular}




\begin{tabular}{|c|c|}
\hline DSTP & Draft Site Treatment Plan \\
\hline EA & Environmental Assessment \\
\hline EASC & Emergency Avoidance Solidification Campaign \\
\hline EIS & Environmental Impact Statement \\
\hline EM & DOE's Environmental Restoration and Waste Management Program \\
\hline EPA & U.S. Environmental Protection Agency \\
\hline ER & environmental restoration \\
\hline ERP & Environmental Restoration Program \\
\hline ERW & environmental remediation waste \\
\hline ES\&H & Environmental, Safety, and Health (Protection Division) \\
\hline ESWMO & Energy Systems Waste Management Organization \\
\hline FFA & Federal Facility Agreement \\
\hline FFCA & Federal Facility Compliance Agreement \\
\hline FFCAct & Federal Facility Compliance Act \\
\hline FSTP & Final Site Treatment Plan \\
\hline FY & fiscal year \\
\hline GCD & greater confinement disposal \\
\hline GPP & general plant project \\
\hline GTCC & greater than Class $\mathrm{C}$ \\
\hline G-M & Geiger-Mueller \\
\hline GWTF & Groundwater Treatment Facility \\
\hline HAZWDDD & Hazardous Waste Development, Demonstration, and Disposal (Program) \\
\hline HDTF & Hillcut Disposal Test Facility \\
\hline HEPA & high-efficiency particulate air (filter) \\
\hline HFIR & High Flux Isotope Reactor \\
\hline HII & high-level incidental waste \\
\hline HLW & high-level waste \\
\hline HPRR & Health Physics Research Reactor \\
\hline HRLAL & High-Radiation-Level Analytical Laboratory \\
\hline HRLEL & High-Radiation-Level Examination Laboratory \\
\hline HSWA & Hazardous and Solid Waste Amendments \\
\hline HWMA & Hazardous Waste Management Area \\
\hline HWOG & Hazardous Waste Operations Group \\
\hline HWTS & Hazardous Waste Tracking System \\
\hline ILF V & Industrial Landfill V \\
\hline INEL & Idaho National Engineering Laboratory \\
\hline ITE & in-tank evaporation $\quad-$ \\
\hline IWMF & Interim Waste Management Facility \\
\hline LDR & Land Disposal Restrictions \\
\hline LGWOD & Liquid and Gaseous Waste Operations Department \\
\hline LI & line item \\
\hline LLLW & liquid low-level waste \\
\hline LLW & low-level waste \\
\hline LLWDDD & Low-Level Waste Disposal Development and Demonstration (Program) \\
\hline LRP & ORNL Waste Management Long-Range Plan \\
\hline LWSP & Liquid Waste Solidification Project \\
\hline MLLW & mixed low-level waste \\
\hline MPC & Mixed Parameter Category \\
\hline MSRE & Molten Salt Reactor Experiment \\
\hline MTRU & mixed transuranic \\
\hline
\end{tabular}




\begin{tabular}{|c|c|}
\hline MVST & Melton Valley storage tank \\
\hline MWIR & Mixed Waste Inventory Report \\
\hline MWTF & Mixed Waste Treatment Facility \\
\hline NARM & naturally occurring and accelerator-produced radioactive material \\
\hline NCP & National Contingency Plan \\
\hline NDA & nondestructive assay \\
\hline NDE & nondestructive examination \\
\hline NEPA & National Environmental Policy Act \\
\hline NESHAP & National Emission Standards for Hazardous Air Pollutants \\
\hline NFS & Nuclear Fuel Services \\
\hline NG & newly generated \\
\hline NHF & New Hydrofracture Facility \\
\hline NPDES & National Pollutant Discharge Elimination System \\
\hline NPL & National Priorities List \\
\hline NRC & Nuclear Regulatory Commission \\
\hline NRWTP & Nonradiological Wastewater Treatment Plant \\
\hline NSY & New Salvage Yard \\
\hline OHF & Old Hydrofracture Facility \\
\hline ORNL & Oak Ridge National Laboratory \\
\hline ORO-WMTDD & Waste Management and Technology Development Division, ORO \\
\hline ORR & Oak Ridge Reservation \\
\hline OSHA & Occupational Safety and Health Administration \\
\hline OSY & Old Salvage Yard \\
\hline P\&E & Plant and Equipment (Division) \\
\hline PA & Performance Assessment \\
\hline PAL & Performance Assessment limiting \\
\hline PCB & polychlorinated biphenyl \\
\hline PCBTS & PCB Tracking System \\
\hline PDEIS & Preliminary Draft Environmental Impact Statement \\
\hline PIDAS & Perimeter Intrusion Detection and Assessment System \\
\hline PMRO & Precious Metals Recovery Operations \\
\hline PPOA & Pollution Prevention Opportunity Assessment \\
\hline PRTF & Plating Rinsewater Treatment Facility \\
\hline PVC & polyvinylchloride \\
\hline PWA & Process Waste Assessment \\
\hline PWMP & Pond Waste Management Project \\
\hline PWS & Process Waste System \\
\hline PWTP & Process Waste Treatment Plant \\
\hline QA & quality assurance \\
\hline $\mathrm{R} \& \mathrm{D}$ & research and development \\
\hline RCRA & Resource Conservation and Recovery Act \\
\hline REDC & Radiochemical Engineering Development Center \\
\hline REOI & requests for expressions of interest \\
\hline RH & remote-handled \\
\hline RTR & real-time radiography \\
\hline RMMA & Radioactive Materials Management Area \\
\hline RWMD & Reservation Waste Management Division \\
\hline S\&M & surveillance and maintenance \\
\hline SARA & Superfund Amendments and Reauthorization Act \\
\hline SARUP & Safety Analysis Report Update Program \\
\hline
\end{tabular}




$\begin{array}{ll}\text { SC } & \text { special case } \\ \text { SCFP } & \text { Surplus Contaminated Facilities Program } \\ \text { SDWA } & \text { Safe Drinking Water Act } \\ \text { SFMP } & \text { Surplus Facilities Management Program } \\ \text { SLF II } & \text { Y-12 Sanitary Landfill II } \\ \text { SLLW } & \text { solid low-level waste } \\ \text { SNF } & \text { spent nuclear fuel } \\ \text { SPWTF } & \text { Steam Plant Wastewater Treatment Facility } \\ \text { SRD } & \text { Systems Requirements Document } \\ \text { SRS } & \text { Savannah River Site } \\ \text { SSP } & \text { Site Specific Plan } \\ \text { STP } & \text { Site Treatment Plan } \\ \text { SWIMS } & \text { Solid Waste Information Management System } \\ \text { SWSA } & \text { Solid Waste Storage Area } \\ \text { SWOD } & \text { Solid Waste Operations Department } \\ \text { TDDP } & \text { Tumulus Disposal Demonstration Project } \\ \text { TDEC } & \text { Tennessee Department of Environment and Conservation } \\ \text { TEC } & \text { total estimated cost } \\ \text { TOA } & \text { Tennessee/U.S. DOE Oversight Agreement } \\ \text { TRU } & \text { transuranic } \\ \text { TSCA } & \text { Toxic Substances Control Act } \\ \text { TSD } & \text { treatment, storage, and disposal } \\ \text { TSR } & \text { Tower Shielding Reactor } \\ \text { TVA } & \text { Tennessee Valley Authority } \\ \text { UC } & \text { uncertified or uncharacterized } \\ \text { UCOF } & \text { Uranium Chip Oxidizer Facility } \\ \text { VLA } & \text { very low activity } \\ \text { WAC } & \text { Waste Acceptance Criteria } \\ \text { WAG } & \text { Waste Area Group } \\ \text { WACCC } & \text { Waste Acceptance Criteria Certification Committee } \\ \text { WCCF } & \text { Waste Certification and Characterization Facility } \\ \text { WCPF } & \text { Waste Coolant Processing Facility } \\ \text { WEAF } & \text { Waste Examination and Assay Facility } \\ \text { WFPF } & \text { Waste Feed Preparation Facility } \\ \text { WETF } & \text { West End Treatment Facility } \\ \text { WHPP } & \text { Waste Handling and Packaging Plant } \\ \text { WIPP } & \text { Waste Isolation Pilot Plant } \\ \text { WMRAD } & \text { Waste Management and Remedial Action Division } \\ \text { WOC } & \text { White Oak Creek } \\ \text { WOCC } & \text { Waste Operations Control Center } \\ \text { WPU } & \text { Waste Pile Unit } \\ \text { WTF } & \text { West Tank Farm } \\ \text { WQS } & \text { Water Quality Standards } \\ \text { WTTF } & \text { Wastewater Treatment Test Facility } \\ & \end{array}$

xvi Oak Ridge Reservation Waste Management Plan 


\section{Executive Summary}

U.S. Department of Energy (DOE) Order 5820.2A, Radioactive Waste Management, requires that each DOE site prepare a waste management plan for radioactive waste generation, treatment, storage, and disposal (TSD) operations. In previous years each site on the Oak Ridge Reservation (ORR) - Oak Ridge National Laboratory (ORNL), the Oak Ridge Y-12 Plant, and the Oak Ridge K-25 Site prepared its own waste management plan. At the direction of the DOE Oak Ridge Operations Office (DOE-ORO), these plans were consolidated into the present document. The consolidation reflects the organizational and operational changes within Martin Marietta Energy Systems, Inc. (Energy Systems), the managing and operating contractor of the three sites for DOE, and within the Energy Systems Waste Management Organization (ESWMO), the organization responsible for waste management activities on the ORR.

The primary purpose of this plan is compilation and consolidation of an annual report on how waste management operations are conducted, what facilities are being used to manage wastes, what forces are acting to change current waste management systems, and what plans are in store for the coming fiscal year.

This plan covers all wastes generated, treated, stored and disposed of on the ORR. While DOE Order 5820.2A specifically excludes Environmental Restoration Program (ERP) activities, at the direction of DOE-ORO, waste generation estimates by ERP are included in this plan. In addition, Defense Program and Energy Research waste management activities are discussed. Also described are industrial and sanitary wastes, special case waste, and spent nuclear fuel (SNF) management practices that are not governed by DOE Order 5820.2A.

ESWMO employs approximately 1100 people to manage waste operations on the $\mathrm{ORR}$, including approximately 450 people matrixed from other Energy Systems support organizations. The total fiscal year 1995 budget for ESWMO is $\$ 260 \mathrm{M}$.

During calendar year (CY) 1993 approximately $64,000 \mathrm{~m}^{3}$ (2.3 million $\left.\mathrm{ft}^{3}\right)$ of solid waste was generated (see table), and approximately $54,000 \mathrm{~m}^{3}$ (1.9 million $\mathrm{ft}^{3}$ ) of waste was disposed of on the ORR. In the Interim Waste Management Facility (IWMF), currently the only operating lowlevel waste (LLW) disposal facility on the ORR, $606 \mathrm{~m}^{3}\left(21,398 \mathrm{ft}^{3}\right)$ of solid LLW was disposed of. No hazardous, mixed, or transuranic (TRU) wastes were disposed of on the ORR during CY 1993. Over $111,800 \mathrm{~m}^{3}\left(3,951,000 \mathrm{ft}^{3}\right)$ of waste was stored on the ORR as of June 30, 1994 (see table).

\section{Significant Events}

Significant events affecting waste management activities on the ORR include:

- $\quad$ State of Tennessee audits. ESWMO conducted the operation of more than 90 facilities for TSD of hazardous, mixed, low-level, and industrial and sanitary wastes without significant incident. The state of Tennessee conducted Resource Conservation and Recovery Act audits and inspections of the K-25 Site, the Y-12 Plant, and $O R N L$, and no negative findings were indicated.

- Landfill permits. The permit to construct and to operate Industrial 
Summary of solid waste generation on the Oak Ridge Reservation

\begin{tabular}{|c|c|c|}
\hline \multirow{2}{*}{ Solid waste type } & \multicolumn{2}{|c|}{ CY 1993 generation } \\
\hline & $\mathrm{m}^{3}$ & $\left(\mathrm{ft}^{3}\right)$ \\
\hline Hazardous & 1,163 & $(41,070)$ \\
\hline Low-level & 5,658 & $(199,807)$ \\
\hline Transuranic (remote- and contact-handled) & 118 & $(4,167)$ \\
\hline Industrial and sanitary & 52,766 & $(1,863,208)$ \\
\hline Scrap metal & 2,377 & $(83,941)$ \\
\hline Mixed waste (including mixed transuranic) & 1,684 & $(59,469)$ \\
\hline Total & 63,766 & $(2,251,662)$ \\
\hline
\end{tabular}

Summary of waste storage on the Oak Ridge Reservation

\begin{tabular}{lrr}
\hline \multicolumn{1}{c}{ Waste type } & \multicolumn{2}{c}{$\begin{array}{c}\text { Inventory as of } \\
\text { June } 30,1994\end{array}$} \\
\cline { 2 - 3 } & \multicolumn{1}{c}{$\mathrm{m}^{\mathbf{3}}$} & \multicolumn{1}{c}{$\left(\mathrm{ft}^{3}\right)$} \\
\hline Low-level & 19,137 & $(675,800)$ \\
Transuranic (remote- and contact-handled) & 263 & $(9,300)$ \\
$\begin{array}{l}\text { Industrial and sanitary } \\
\text { Scrap metal }\end{array}$ & 37,387 & $(1,320,300)$ \\
$\begin{array}{l}\text { Mixed waste (including hazardous and mixed } \\
\text { transuranic) }\end{array}$ & 55,096 & $(1,945,700)$ \\
$\quad$ Total & 111,883 & \\
\hline
\end{tabular}

Landfill $\mathrm{V}$ was issued by the Tennessee Department of Environment and Conservation (TDEC) in April 1993. Construction was completed on the new Construction/Demolition Landfill VI, and TDEC operational approval was granted.

- Liquid low-level waste (LLW) solidification. The second Liquid Waste Solidification Project campaign was completed. Fifty-eight solidified waste forms were produced, and approximately $182,000 \mathrm{~L}$ (48,000 gal) of LLLW supernatant concentrate was solidified. The campaign produced additional storage space for LLLW concentrate in the Melton Valley storage tanks to facilitate remediation of underground LLLW storage tanks.

- The Central Waste Tracking System. The Central Waste Tracking System document was delivered to the TDEC as required by the Tennessee Oversight Agreement. The system was delivered ahead of schedule, and a viewing session was provided for TDEC and DOE-ORO representatives.

- The Private Sector Treatment Program. Three subcontracts were issued as part of the Private Sector Treatment Program for mixed waste. The contracts include Phase I activities (i.e., 
proof of technology) for mixed waste sludges and Phase II activities (i.e., full-scale) for scintillation fluids and fluorescent light bulbs.

- ORR Waste Acceptance and Waste Certification Program Plans. ORR Waste Acceptance Criteria and Waste Certification Program Plans were completed. Implementation of these documents will facilitate the transfer of wastes among the three Oak Ridge sites and will result in improved efficiency and cost savings.

- The SNF Program. The SNF Program for the ORR was organized, and management activities were initiated. Significant support was provided to the national SNF Program in the areas of the Programmatic Environmental Impact Statements (EISs) for SNF, the EIS for foreign research reactor fuel, and the Environmental Assessment for fuel located at General Atomics, Inc.

- Receipt of off-site TRU waste. The receipt of contact-handled (CH) TRU waste from Nuclear Fuel Services, Inc., of Irwin, Tennessee, was completed. A total of 822 drums were received, including one drum of mixed waste and 20 drums that were originally packaged as mixed-oxide waste. This project involved receipt, inspection, and storage in CH TRU waste storage facilities at ORNL.

- The Waste Examination and Assay Facility (WEAF). The upgrade to WEAF was completed. A patent application covering nondestructive assay techniques was approved, and a second application has been submitted. The PING System has been installed at the Y-12 Plant to verify the absence of high explosives in nuclear weapon trainers before dismantlement. A nonintrusive inspection system was developed to verify the presence of cadmium and to measure its thickness in High Flux Isotope Reactor spent-fuel shroud assemblies.
- Off-site disposal at the Nevada Test Site. The application and supporting documentation for shipment of solidified LLLW to the Nevada Test Site was submitted to DOE-ORO and DOE-NVO. DOE-NVO conducted an audit and approved a partial shipment to their facilities.

- The "No-Rad Added" Policy. ESWMO-Y-12 received approval from DOE Headquarters (DOE-HQ) for four procedures certifying No Rad Added to allow off-site shipment of hazardous wastes. The K-25 Site received approval for procedures certifying No Rad Added for sealed unopened containers of waste using surface contamination surveys. These procedures allow both surface- and volume-contaminated materials to be shipped by certifying that no radioactive contamination has been added.

- Off-site hazardous waste shipments. The first two shipments of polychlorinated biphenyl (PCB) capacitors released from a radiologically controlled area occurred with 7700 PCB capacitors shipped off-site to a commercial incinerator. These waste shipments are the first from a radiologically controlled area that have met the formal DOE and Energy Systems Readiness Review criteria for No Rad Added.

- Off-site mixed waste disposal at Envirocare. The first shipment of mixed waste for commercial disposal from the ORR was completed. The commercial disposal facility approved the waste profile record submitted and issued the notice to transport on August 10, 1994. Through September, 11 boxcars containing 858 drums of concrete monolith from the Pond Waste Management Project have been shipped to Envirocare of Utah.

- Drum crushing. Through September 20,573 empty drums have been staged, crushed at the K-1417 drum crusher, 
and containerized for treatment in support of the Pond Waste Management Project. In the K-1423 drum-crusher facility, which is supporting the removal of empty drums from the K-770 Scrap Metal Yard, 1681 drums have been crushed. The crushed drums from both facilities are packaged for shipment to a commercial smelter.

- On-site $L L W$ disposal facility Performance Assessment (PA). The Solid Waste Storage Area 6 PA was issued to DOE-ORO for approval in December 1993. It was determined that above-grade tumulus disposal at the IWMF can meet the performance objectives by restricting disposal of specific radionuclides and by removing two vaults before facility closure.

- The Toxic Substances Control Act (TSCA) Incinerator. Shipments of hazardous liquid waste sent to the TSCA Incinerator for treatment have exceeded initial goals. Portsmouth exceeded initial estimates by shipping $286,360 \mathrm{~kg}(631,320 \mathrm{lb})$ of the 272,154 $\mathrm{kg}(600,000 \mathrm{lb})$ projected to be sent to the K-15 Site in FY 1994. ESWMO shipped a total of $1,759,119 \mathrm{~kg}$ $(3,878,213 \mathrm{lb})$ of waste, or approximately $180 \%$ of planned amounts during FY 1994.

- Conceptual and Draft Site Treatment Plans for mixed waste. The Mixed Waste Program's Conceptual and Draft Site Treatment Plans were completed on schedule and delivered to DOEORO and the state of Tennessee. The plans provide information on the DOEORO treatment needs, capabilities, and options. Information was provided to DOE-HQ to facilitate the national rollup effort to support mixed waste planning. A Final Site Treatment Plan is currently being prepared.

- Mixed Waste Inventory Report (MWIR). The Waste Stream and Treatment Systems data forms, developed to support the MWIR update required under the Federal Facility Compliance Agreement (FFCA), were completed and satisfy regulatory requirements. Data for over 400 waste stream groups on the ORR were included. New appendixes for Table A and Table B wastes were completed in accordance with the FFCA. The plan to implement these appendixes in each of the sitespecific waste tracking systems is in progress.

- Land Disposal Restriction (LDR) treatment implementation. The LDR waste treatment implementation for Table $\mathrm{A}$ waste by stabilization and incineration continues. A total of $189,000 \mathrm{~kg}(416,674 \mathrm{lb})$ of supernatant was stabilized, and $777,750 \mathrm{~kg}$ $(1,714,645 \mathrm{lb})$ of Table A waste was treated by incineration.

- The Mixed Waste Treatment Facility (MWTF). Conceptual design and development tasks were initiated under the MWTF Program. A Waste Stream Identification and Characterization Program was begun to substantially improve the information base for wastes to be treated at the MWTF. Onand off-site disposal options were evaluated with respect to cost, risk, and liability; regualatory compliance; and public acceptance. Off-site disposal was recommended by the study.

- The Defense Nuclear Facilities Safety Board (DNFSB). ESWMO has continued to address DNFSB recommendations of concern by development of Standards/ Requirements Identification Documents, completion of the TSCA. Incinerator Order Compliance Assessment, and completion of Nuclear Safety Compliance Inspections for the $\mathrm{K}-25$ Site process buildings categorized as nuclear facilities.

- Off-site scrap metal smelting. During FY $1994,909,000 \mathrm{~kg}(2,005,000 \mathrm{lb})$ of radioactively contaminated scrap metal was shipped from the ORR to 
Scientific Ecology Group (SEG), a private subcontractor. The existing contract with SEG for volume reduction and smelting of LLW and scrap metal was extended through March 31, 1994. 


\section{Introduction}

U.S. Department of Energy (DOE) Order 5820.2A, Radioactive Waste Management, requires that each DOE site prepare a waste management plan for radioactive waste generation, treatment, storage, and disposal (TSD) operations. In previous years each site on the Oak Ridge Reservation (ORR)-Oak Ridge National Laboratory (ORNL), the Oak Ridge Y-12 Plant, and the Oak Ridge K-25 Site-prepared its own waste management plan. At the direction of the DOE Oak Ridge Operations Office (DOE-ORO), these plans were consolidated into this one document. The consolidation reflects the organizational and operational changes within Martin Marietta Energy Systems, Inc. (Energy Systems), the managing and operating contractor of the three sites for DOE, and within the Energy Systems Waste Management Organization (ESWMO), the organization responsible for waste management activities on the ORR.

\section{Purpose}

The primary purpose of this plan is compilation and consolidation of an annual report on how waste management operations are conducted, what facilities are being used to manage wastes, what forces are acting to change current waste management systems, and what plans are in store for the coming fiscal year.

\section{Scope}

This plan covers all wastes generated, treated, stored, and disposed of on the ORR. While DOE Order 5820.2A specifically excludes Environmental Restoration Program (ERP) activities, at the direction of DOE-ORO, waste generation estimates by ERP are included in this plan. In addition, Defense Programs (DP) and Energy Research waste management activities are discussed. Also described are industrial and sanitary wastes, special case waste, and spent nuclear fuel management practices that are not governed by DOE Order 5820.2A.

\section{Roles and Responsibilities}

The ORR is a government-owned, contractor-operated facility of DOE. DOEORO is the government agency responsible for operation of the ORR and, in this capacity, is both an owner and co-operator of TSD facilities managing wastes. As the prime management and operating contractor for DOE-ORO on the ORR, Energy Systems is also a co-operator of TSD facilities managing Resource Conservation and Recovery Act (RCRA) Land Disposal Restriction (LDR) waste. As a result of these relationships, the management plan for waste treatment and disposal involves the interaction of DOE-ORO and Energy Systems. 
DOE-ORO has overall responsibility for implementation of this management strategy plan and has line responsibility for the organizations generating the waste [i.e., Energy Research, DP, and Environmental Restoration and Waste Management (EM)] and the organizations treating, storing, and disposing of the waste. This role is consistent with the current policy of establishing direct-line responsibility within DOE such that each program office is responsible for the planning, budgeting, and execution of all operations at facilities under its management. The DOE Headquarters (DOE-HQ) Office of Environmental Restoration and Waste Management (EM-1) and, within it, the Office of Waste Operations (EM-30) have responsibility for the facilities and operations throughout the nationwide DOE Complex that involve the management of waste once it is received from generators. Within DOE-ORO, under the assistant manager for Environmental Restoration and Waste Management, waste management operations are the responsibility of the director of the Waste Management and Technology Development Division (OROWMTDD). ORO-WMTDD is responsible for the technical leadership and implementation of this waste management plan.

Energy Systems has developed an organizational structure to implement waste management needs through a waste management organization. ESWMO integrates the overall program through its waste management divisions at each site.

\section{Organization of the Plan}

Section 1 provides the introduction, purpose, scope, regulatory requirements, and a general overview of waste management activities on the ORR. Section 2 presents site information including missions, geology and hydrology, and descriptions and structure of organizations with waste management responsibility. The remainder of the plan is organized by waste type managed on the ORR: Sect. 3, "Spent Nuclear Fuel"; Sect. 4, "Transuranic (TRU) Waste"; Sect. 5, "Low-Level Waste (LLW)"; Sect. 6, "Hazardous Waste"; Sect. 7, "Mixed Waste"; and Sect. 8, "Industrial and Sanitary Wastes." These sections are organized as follows: management strategy, waste generation and projections, TSD, and future plans.

Appendix A describes waste management documentation required under DOE Order 5820.2A. Appendix B presents summary information describing TSD facilities on the ORR, organized by waste type. Appendix $C$ presents planned line items and general plant projects for waste management facilities on the ORR. Appendix $\mathrm{D}$ provides a summary compliance assessment with DOE Order 5820.2A for each site.

\section{Related Documents}

Draft Site Treatment Plan for Mixed Waste on the U.S. Department of Energy Oak Ridge Reservation (DSTP). The DSTP is the intermediate product of the process by which DOE-ORO will produce the site treatment plan (STP) required by the Federal Facility Compliance Act (FFCAct). The DSTP will be developed into the final proposed site treatment plan (FSTP) based on the results of continuing technology development and waste characterization efforts and extensive interactions with federal, State, and local regulatory agencies, other DOE sites, and the public.

Mixed Waste Inventory Report for 1993 (MWIR). Required by the FFCAct, the MWIR provides an inventory of mixed waste currently stored or generated, or expected to be generated, over the next 5 years at each DOE site and an inventory of treatment capacities and technologies.

Oak Ridge Reservation Waste Storage Report for Period Ending June 30, 1994. Issued semiannually, the storage report 
updates the status of waste storage

activities at the three DOE ORR

installations managed by Energy Systems.

It provides information for a 6-month

period and addresses changes in storage

requirements and capacities as well as issues affecting waste storage on the ORR.

Oak Ridge Reservation Environmental

Report for 1992. Issued annually, this

report details radiation dose received by the

public from ORR operations, airborne

discharges, ambient air, and meteorological

measurements, waterborne discharges and

surface monitoring, radionuclide discharges

to surface streams, groundwater

monitoring, and biological monitoring

results.

Waste Generation Forecast for DOE-

ORO's Environmental Restoration OR-1

Project: FY 1994-FY 2001, September

1993 Revision. This document reports

current estimates of the waste volumes

expected to be generated as a result of

Environmental Restoration activities at

DOE-ORO sites. Considered in the scope

of this document are volumes of waste expected to be generated as a result of remedial action and decontamination and decommissioning (D\&D) activities taking place at these sites. Sites contributing to the total estimates include the Y-12 Plant, ORNL, the K-25 Site, the Paducah Gaseous Diffusion Plant, the Portsmouth Gaseous Diffusion Plant, and off-site contaminated areas adjacent to the Oak Ridge facilities. Estimates are available for the entire life of all waste-generating activities.

\section{Regulatory Requirements}

\section{- Federal and State Regulations}

Waste management requirements on the ORR are imposed by federal and State regulations as well as Executive and DOE orders. The Atomic Energy Act of 1954 as amended (AEA) and RCRA of 1976 as amended are the primary driving forces behind their implementation. The AEA regulates research and development activities related to atomic energy and provides for the safe processing and management of source, special nuclear, and by-product materials. Through RCRA the U.S. Environmental Protection Agency (EPA) is given the responsibility for a nationwide program that regulates most aspects of hazardous waste management. The state of Tennessee has been authorized to administer the hazardous waste management program. The EPA also regulates the handling of polychlorinated biphenyls (PCBs) and asbestos under the Toxic Substances Control Act (TSCA).

Operations programs must comply with the federal, State, and local statutes and regulations, the $\mathrm{AEA}$, and DOE orders. The major federal and State statutes applicable to waste management operations are summarized in the following paragraphs.

RCRA, as amended by the Hazardous and Solid Waste Amendments of 1984 (HSWA), regulates the activities associated with hazardous waste management. Its primary objective is to protect human health and the environment; its secondary objective, to conserve valuable material and energy resources. RCRA requires cradle-to-grave tracking of hazardous waste. Those hazardous waste disposal sites that were closed or abandoned before November 19, 1980 (effective date of RCRA regulations), are regulated under the Comprehensive Environmental Response, Compensation, and Liability Act of 1980 (CERCLA).

Persons (including a federal facility) who generate, transport, treat, store, or dispose of RCRA hazardous waste, as well as persons who produce, burn, distribute, or market any hazardous waste-derived fuels or store regulated substances in underground tanks, must comply with RCRA by notifying the EPA or authorized States of their activities. As amended by HSWA, RCRA Sect. 3004(u) requires corrective actions for releases of hazardous 
constituents. RCRA Sect. 3004(v) mandates off-site corrective actions. The RCRA provisions for corrective actions overlap to some degree with CERCLA

provisions-creating the need for coordination of RCRA and CERCLA activities.

The state of Tennessee is authorized (1) to administer its own RCRA program in lieu of the federal program (in most cases new RCRA regulations that become effective after the authorization date must be adhered to pending issuance of corresponding State regulations) and (2) to regulate mixtures of hazardous and radioactive wastes. The Tennessee Hazardous Waste Management Act and its implementing regulations are administered by the Tennessee Department of Environment and Conservation (TDEC), Division of Solid Waste Management. EPA Region IV administers the federal RCRA program including certain HWSA provisions that have been enacted by the TDEC.

TSCA regulates, among other things, the use and disposal of materials containing greater than or equal to $50 \mathrm{ppm}$ of PCBs. These regulations apply to Waste Management Operations projects involving PCBs and asbestos. Energy Systems policy is to regulate the storage and disposal of materials containing greater than $2 \mathrm{ppm}$ of PCBs. Disposal of wastewaters is regulated to $3 \mathrm{ppb}$ PCBs. Disposal of wastes containing greater than $10 \mathrm{ppm}$ and less than $50 \mathrm{ppm}$ of PCBs are regulated for land disposal under solid waste regulations.

CERCLA, as amended by the

Superfund Amendments and

Reauthorization Act of 1986 (SARA), provides a federal mechanism to respond to the hazards posed by abandoned disposal sites and federal authority to respond to current uncontrolled releases of hazardous and radioactive (since May 1989) substances from a vessel (including transportation vehicles) or from any onshore or offshore facilities. The act imposes strict liability on a broad class of potentially responsible parties and establishes the funding (i.e., the "Superfund") that enables the government either to order the responsible parties to clean up the spill or to seek reimbursement from the responsible parties after the government has completed cleanup.

CERCLA also imposes reporting requirements on owners and operators of currently operating vessels and facilities. In general, any releases of a reportable quantity of "hazardous substances" must be reported, and the responsible party must clean it up. A "hazardous substance" is anything included on a "list of lists" compiled by referring to the four major environmental statutes including the Clean Air Act (CAA), the Clean Water Act (CWA), RCRA, and TSCA. As a result of the incorporation of the CAA into CERCLA, CERCLA regulates releases of radioactive source, special nuclear, or byproduct material. The EPA is authorized to expand the CERCLA list by adding compounds or mixtures that, when released into the environment, may present substantial danger to public health or welfare or the environment.

Section 105 of CERCLA states that the government's cleanup activity must be conducted in accordance with the National Contingency Plan (NCP). The NCP establishes a blueprint for cleaning up releases to the water, land, or air and assigns response authority to federal and State governments and private parties. The NCP details response procedures including both immediate removal and long-term remedial actions. Section 105 also authorizes the EPA to designate sites for inclusion of sites requiring remedial action on the National Priorities List (NPL).

SARA amended CERCLA by inter alia (i.e., adding provisions specifically aimed at federal facilities) and by increasing EPA enforcement authority. As amended by SARA, CERCLA provides the framework for determining cleanup standards, schedules, and evaluation of remedies. 
The ORR was placed on the NPL December 21, 1989. The Federal Facility Agreement (FFA) between EPA Region IV, the TDEC, and DOE requires ORR cleanups to be conducted in compliance with both RCRA and CERCLA/SARA. The FFA, which became effective on January 1, 1992, is intended to satisfy the requirements for an interagency agreement under Sect. 120 of CERCLA. The agreement establishes a procedural framework and schedule for developing, implementing, and monitoring appropriate response actions at the site in accordance with CERCLA, the NCP, the National Environmental Policy Act of 1970 (NEPA), and Tennessee law. The agreement contains provisions for coordinating response actions under CERCLA, RCRA, and applicable state laws. Specifically, the agreement establishes requirements for performing Remedial

Investigation/Feasibility Studies and identifies the nature, objective, and schedule of response actions to be taken at the site. The agreement provides the basis for the creation of operable units and the implementation of final remediation actions. The agreement also establishes requirements for underground liquid lowlevel waste (LLLW) tank systems to ensure structural integrity, containment and detection of releases, and source control for LLLW tank systems pending final remedial action at the site.

Effective May 13, 1991, DOE entered into an agreement with the state of Tennessee regarding DOE's provision of financial and technical support for State oversight activities. The Tennessee/U.S. DOE Oversight Agreement (TOA) applies to TDEC participation in the FFA for environmental restoration of the ORR, oversight, monitoring, access, and emergency response initiatives to ensure compliance with applicable environmental laws and regulations. The three sites are obligated to a number of action items including a source reduction/zero discharge study, an air emissions inventory, waste and residue characterization, and others. Through this agreement the state of Tennessee has become a major stakeholder. in future operations at all sites on the ORR. Strategic planning, waste operations, and environmental, safety, and health activities will all receive significant input from the State as they assume their role under the TOA.

Effective June 12, 1992, DOE entered into a Federal Facility Compliance Agreement (FFCA) with the EPA to ensure compliance by DOE with LDRs under RCRA. The FFCA became necessary because many of the radioactive mixed wastes (mixed wastes) generated by DOE sites had no available treatment capacity, which resulted in a noncompliance situation. The FFCA dictates the steps required to bring ORR facilities into compliance with respect to the management of mixed wastes.

NEPA requires every federal agency to address publicly (prior to initiation) the environmental impact of major federal actions that may significantly affect the environment. These concerns are addressed in documents such as Environmental Assessments or Environmental Impact Statements, which are made available to the public and are circulated to other interested agencies. Secretary of Energy Notice 15-90 provides guidance for developing NEPA documentation. DOE Notice 5400.4 establishes DOE policy on integrating NEPA and CERCLA processes for ERP projects. NEPA implementation procedures to be used by DOE were promulgated in the Federal Register on April 24, 1992.

The CAA is a comprehensive and complex federal statute designed to prevent and to control air pollution from stationary and mobile sources. The CAA authorizes the EPA to establish national standards for air quality that must be met by the States through compliance with EPA-approved state implementation plans. These plans are also required to contain standards for preventing significant deterioration of air 
quality in areas where the ambient standards are already being met. Permits are required for specific air emissions. $\mathrm{CAA}$ requirements may also become Applicable or Relevant and Appropriate Requirements (ARARs) for CERCLA cleanups. Radionuclides are also regulated under the CAA and 40 CFR Pt. 61, Subpart $\mathrm{H}$.

Air emissions from ORR facilities are managed in accordance with DOE Orders 5400.1, 5400.5, 5480.1A, 5480.1B, 5480.4, and 5820.2A and guidelines of the CAA as regulated by the TDEC Division of Air Pollution Control. The TDEC has the primary responsibility for ensuring compliance with the CAA within the state of Tennessee and for protecting and maintaining Tennessee ambient air quality standards pursuant to the Tennessee Air Quality Control Act. The TDEC's Division of Air Quality administers the air permits program.

In May 1992 DOE and the EPA entered into an FFCA to achieve compliance in all CAA issues at the ORR. This agreement committed the three sites to a number of actions including monthly reporting, air emission inventories, quality assurance plans, and system upgrades.

The CWA sets standards for, and regulates discharges into, surface waters and sets pretreatment standards for discharges into publicly owned treatment works. Facilities that directly discharge wastewaters must obtain a National Pollutant Discharge Elimination System (NPDES) permit. CWA regulations address technology-based effluent limitations, water quality-based effluent limitations, new source performance standards, control strategies for toxic pollutants, and thermal discharges. Water quality criteria established under the CWA may become ARARs for CERCLA cleanups. At the State level, water pollution is controlled through the Tennessee Water Quality Control Act and implementing regulations. The NPDES permit program is administered by the Division of Water Pollution Control within the TDEC.

On October 6, 1992, the FFCAct became law. This statute amended RCRA such that the federal government would be liable to all solid and hazardous waste regulations in the same manner as private persons and companies. This constitutes the waiver of sovereign immunity by the U.S. government allowing civil suits to be filed against it by the states and private parties. Some of the provisions of this act include a 3-year moratorium on the enforcement of mixed waste and radioactive regulations, an inventory of mixed wastes at all federal facilities, and a listing of available treatment technologies for those inventories. It is possible that this act will replace the FFCA as the mechanism for establishing compliance in mixed waste on the ORR. However, at this time both the FFCAct and the FFCA are being adhered to separately.

The Safe Drinking Water Act (SDWA) sets regulatory standards for organic chemicals and other pollutants in drinking water through two regulatory programs: National Drinking Water Standards for Public Water Systems and Underground Well Injection. SDWA Primary Drinking Water Standards are frequently used to establish groundwater protection standards pursuant to RCRA and CERCLA.

Numerous other State regulations are applicable to ORR waste management activities, for which compliance must be ensured. The bulk of these fall under a series of rules identified as Tenn. 1200 rules.

\section{DOE Orders}

DOE and DOE contractors are subject to the requirements of DOE orders in addition to the requirements of federal and State regulatory agencies. Therefore DOE orders impact waste management processes as well. DOE orders of most significance 
to waste management are summarized in the following paragraphs.

DOE Order 5820.2A, the principal regulation that governs management of radioactive waste on the ORR, establishes requirements to ensure that all $\mathrm{DOE}$ operations involving management of radioactive waste, waste by-products, and surplus facilities are conducted in a manner that will ensure protection of public health and safety in accordance with DOE Orders 5480.1B and 5400.5. DOE Order 5820.2A has four major subsections that address specific procedures and requirements related to $D \& D$ of surplus facilities. Several other DOE orders referred to in DOE Order 5820.2A have supplemental and related requirements. This plan complies with DOE Order 5820.2A, Chap. VI, and provides a comprehensive description of current ORR waste management activities and strategies.

DOE Order 5820.2A establishes policies, guidelines, and minimum requirements for managing radioactive and mixed wastes. This order requires that DOE LLW be managed to protect public health and safety and to preserve the environment. The order also requires that a Performance Assessment of all aspects of waste management be conducted.

Chapter V of DOE Order 5820.2A sets forth requirements for decommissioning radioactively contaminated facilities. Planning for facility decommissioning must be initiated during the Design Phase for new facilities and before termination of operations for existing operational facilities, and must consider the 2-year budget cycle to ensure adequate funding availability. Decommissioning project activities include facility characterization, the environmental review process (i.e., NEPA, RCRA, CERCLA, and SARA), and technical engineering planning, which includes a Decommissioning Project Plan. Status reports on project activities must be prepared in accordance with DOE Order 1332.1A or 4700.1 .
In December 1991 several rules appeared in the Code of Federal Regulations codifying existing DOE orders. Following is a summary of those rules:

- "Procedural Rules for DOE Nuclear Activities" (10 CFR Pt. 820) sets forth the procedures to govern the conduct of persons involved in DOE nuclear activities and, in particular, to achieve compliance with the DOE Nuclear Safety Requirements by all persons subject to those requirements. The subparts of 10 CFR Pt. 820 are "Enforcement Process," "Compliance Orders," "Interpretations," "Exemption Relief," "Criminal Penalties," and "Enforcement of Technical Specifications Operational Safety Requirements." An appendix to 10 CFR Pt. 820 is a general statement of enforcement policy that includes tables of civil penalties and severity levels. This proposed rule was finalized effective September 16, 1993.

- "Nuclear Safety Management" (10 CFR Pt. 830) provides rules to govern the conduct of $\mathrm{DOE}$ contractors and other persons at DOE nuclear facilities. In addition to providing a definition of a nonreactor nuclear facility that significantly broadens the nature of facilities in that category, and a definition of graded approach, the subparts of $10 \mathrm{CFR}$ Pt. 830 include "Design," "Operations," and "Material Management." Within these subparts are 28 separate sections. Eleven of those sections are complete and include subjects such as "Safety Analysis Reports," "Quality Assurance Requirements," "Training and Certification," "Maintenance Management," and "Conduct of Operations." Sections that are assigned but have no content yet include subjects such as "Configuration Management," "Fitness for Duty," "Fire Protection," "Design Criteria," "Criticality Safety," and "Packaging and Transportation." 
- "Radiation Protection for Occupational Workers" (10 CFR Pt. 835) establishes radiation protection standards, limits, and program requirements for protecting workers and other persons from ionizing radiation at DOE facilities. This rule is the most detailed of the three published so far, and includes subparts that describe "Radiation Protection Programs," "Standards for Internal and External Exposure," "Monitoring in the Workplace," "Entry Control Programs," "Posting and Labeling," "Records," "Reports to Employees," "Radiation Safety Training," "Design Control," "Release of Material and Equipment from Radiological Areas," and "Accidents and Emergencies."

- "Radiation Protection of the Public and the Environment" (10 CFR Pt. 834) was issued on March 25, 1993. DOE is proposing this rule as a primary standard for the protection of the public and environment against radiation. The requirements would be applicable to the control of radiation exposures to the public and to the environment from normal operations.

Postdecommissioning activities involve final chemical and radiological surveys and preparation of a project final report. The responsible field organization will compile a Project Data Package. Long-term maintenance, surveillance, and other safety controls will be provided by the responsible program organization. The decommissioned property may be released from DOE ownership according to the requirements of DOE Order 4300.1B. DOE Order 5700.6B requires that quality assurance be maintained by using the applicable requirements of American National Standards Institute/American Society of Mechanical Engineers, NQA-1, 1983, "Quality Assurance Program Requirements for Nuclear Facilities."

DOE Order 5400.2A establishes the DOE requirements for coordinating significant environmental compliance issues by creating a process within $\mathrm{DOE}$ for resolving conflicting compliance issues. DOE Order 5400.3 establishes DOE hazardous and radioactive mixed waste policies and requirements. The order clarifies DOE's interpretation of the definition of "byproduct material" (10 CFR Pt. 962) as it relates to RCRA regulation of mixed wastes and establishes the lines of authority at DOE-HQ for RCRA implementation. CERCLA requirements are now addressed in DOE Order 5480.4. The order provides DOE policy resolving RCRA/CERCLA overlap issues, integrating NEPA with RCRA/CERCLA processes, and resolving organizational conflict of interest issues for RCRA/CERCLA contractors.

DOE Order 5440.1C provides DOE guidelines for developing and routing NEPA documentation. DOE Order 5480.3 establishes requirements for the packaging and transportation of hazardous materials, hazardous substances, and hazardous wastes. DOE Order 1540.1 establishes DOE policies for management of materials transportation activities. DOE Order 1540.2 establishes administrative procedures for the certification and use of radioactive and other hazardous materials packaging by DOE.

Other relevant DOE orders include DOE Order 5400.1, which establishes the environmental monitoring, waste minimization, and pollution prevention requirements for DOE operation, and DOE Order 5480.1B, along with DOE Order 5400.5 , both of which outline environmental protection safety and health protection policies and responsibilities.

\section{Overview of Waste Management on the ORR .}

ESWMO employs approximately 1100 people to manage waste operations on the $\mathrm{ORR}$, including approximately 450 people matrixed from other Energy Systems 
support organizations. The total fiscal year 1995 budget for ESWMO is $\$ 260 \mathrm{M}$.

Figures 1.1 and 1.2, respectively, show the distribution of this funding by expense and capital categories and by waste type.

During calendar year 1993, over $64,000 \mathrm{~m}^{3}$ of solid waste was generated on the ORR. The largest generation by volume was industrial and sanitary wastes

(Fig 1.3), which accounted for over $80 \%$ of the total volume generated. During that time period approximately $54,000 \mathrm{~m}^{3}$ $\left(190,674 \mathrm{ft}^{2}\right)$ of waste was disposed of on the ORR. LLW disposed of in the Interim Waste Management Facility, currently the only operating LLW disposal facility on the ORR, totaled $606 \mathrm{~m}^{3}\left(21,398 \mathrm{ft}^{3}\right)$.

Figure 1.4 shows volumes of waste stored on the ORR as of June 30,1994. No hazardous waste storage is shown since it is currently managed as mixed waste. Mixed waste (i.e., hazardous waste mixed with radioactive contaminants), LLW, and contaminated scrap metal comprise $99 \%$ of the stored solid waste on'the ORR; the remaining $1 \%$ is attributable to stored transuranic (TRU) waste. While TRU waste represents a comparatively small volume of the total waste inventory, it represents a large amount of radioactive decay per unit volume $\left(\mathrm{Ci} / \mathrm{m}^{3}\right)$ and resultant potential health hazard.

\section{ORR-Wide Waste Management Activities}

\section{Waste Certification}

Requirements for managing radioactive and mixed wastes are established in DOE Order 5820.2A. Heads of DOE field organizations are assigned the authority to establish waste management requirements [i.e., establishment of Waste Acceptance Criteria (WAC) and waste certification programs] for TSD facilities under their jurisdiction. One of the requirements for appropriate management of wastes generated by $\mathrm{DOE}$ operations specified by the order is the development of WAC for each TSD facility. The order also specifies that generators of waste shall implement a low-level and mixed waste certification program to provide assurance that the WAC for the receiving TSD facility are met. Generators of waste and TSD facility operators receiving the waste are jointly responsible for ensuring compliance with the TSD facility WAC. In addition, the regulations of RCRA and TSCA state that the development of a waste certification program for hazardous and toxic wastes is a responsible management practice.

In 1991 Energy Systems published a plan that initiated a consistent approach to waste certification on the ORR (CWMD 1991). A year later two guidance manuals were issued (CWMD 1992a; CWMD 1992b). Since these documents were issued, the certification process within Energy Systems has continued to develop. This has created the need to replace each of these documents with new ones that reflect the current approach of ensuring that waste certification activities among the K-25 Site, ORNL, and the Y-12 Plant are consistent. This consistent approach will result in more effective and efficient management of wastes on the ORR and will facilitate the use of off-Reservation TSD facilities.

The structure of the Energy Systems Waste Certification Program has been published (CWMD 1994), a document that, in effect, is an agreement between ESWMO and the DOE-ORO WMD on the approach and methods to be implemented to certify wastes on the ORR. Rather than providing specific waste certification requirements, this document presents the logic and method by which wastes will be certified in a consistent manner. Roles and responsibilities are defined for the organizations involved in the certification process.

The waste certification process applies to most wastes that are intended to be transferred to the ESWMO for 
ORNL-DWG 94Z-14169

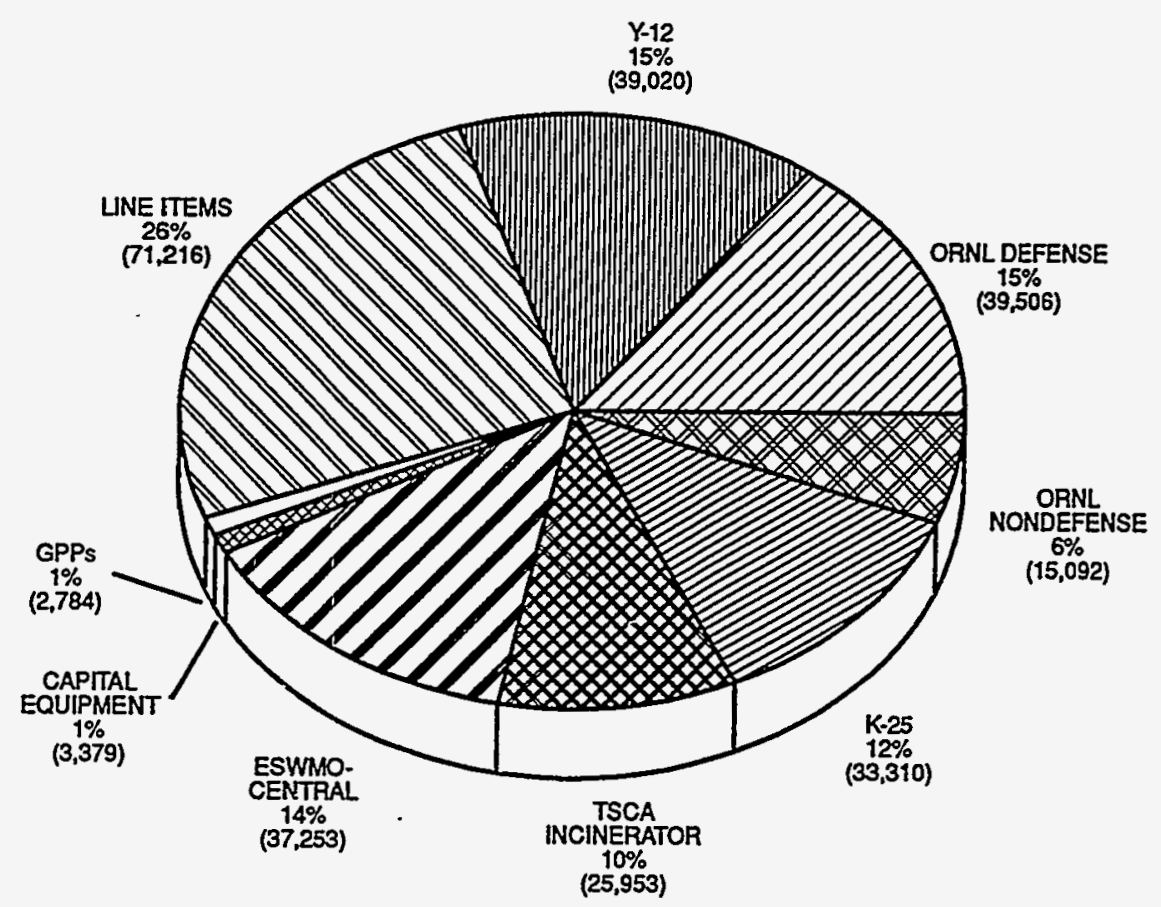

Fig. 1.1. FY 1995 distribution of expense and capital funding for waste management and corrective actions. Funding allocations are in $\$ \mathrm{~K}$.

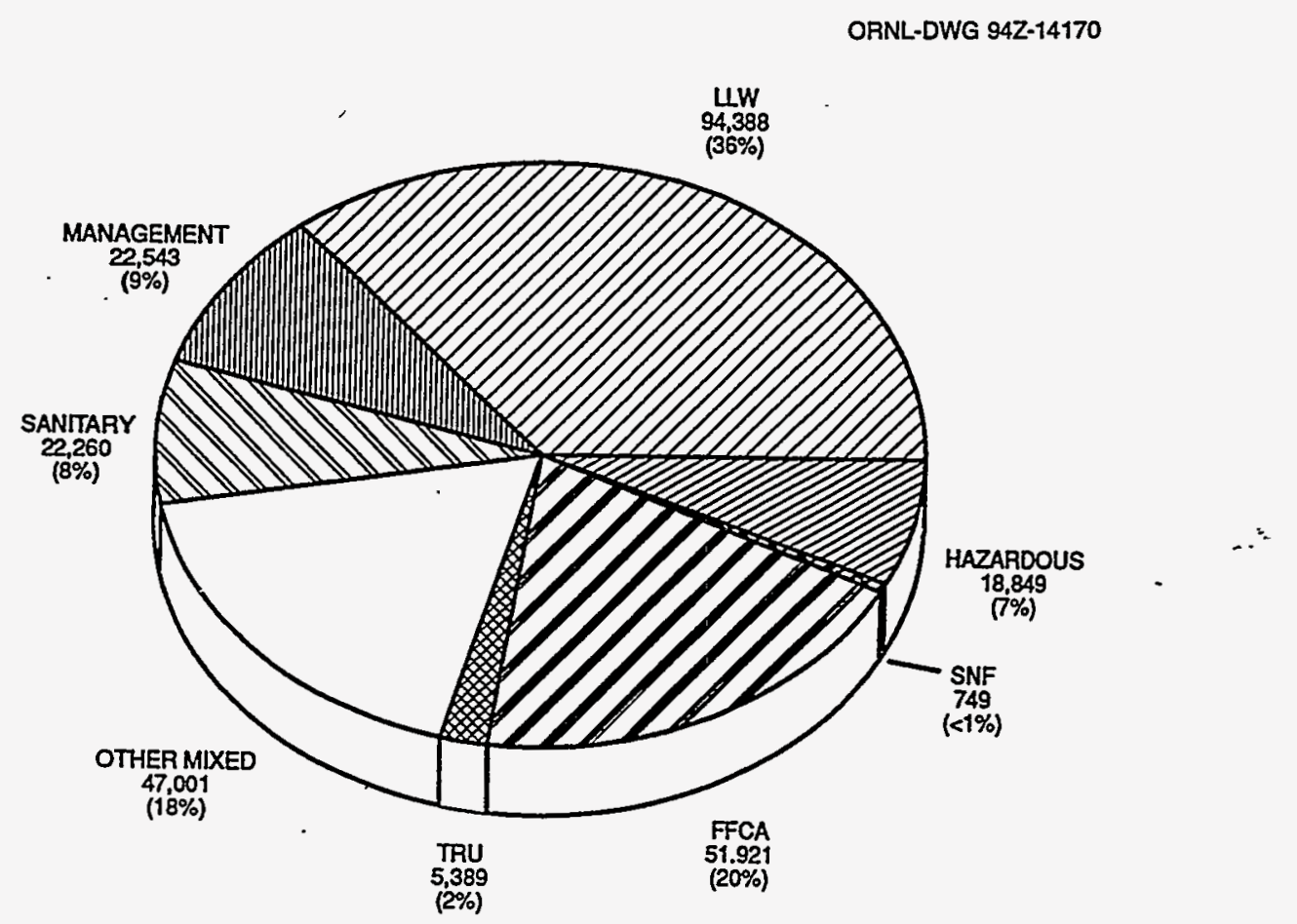

Fig. 1.2. FY 1995 distribution of funding for waste management and corrective actions by waste type. Funding allocations are in $\$ K$. 


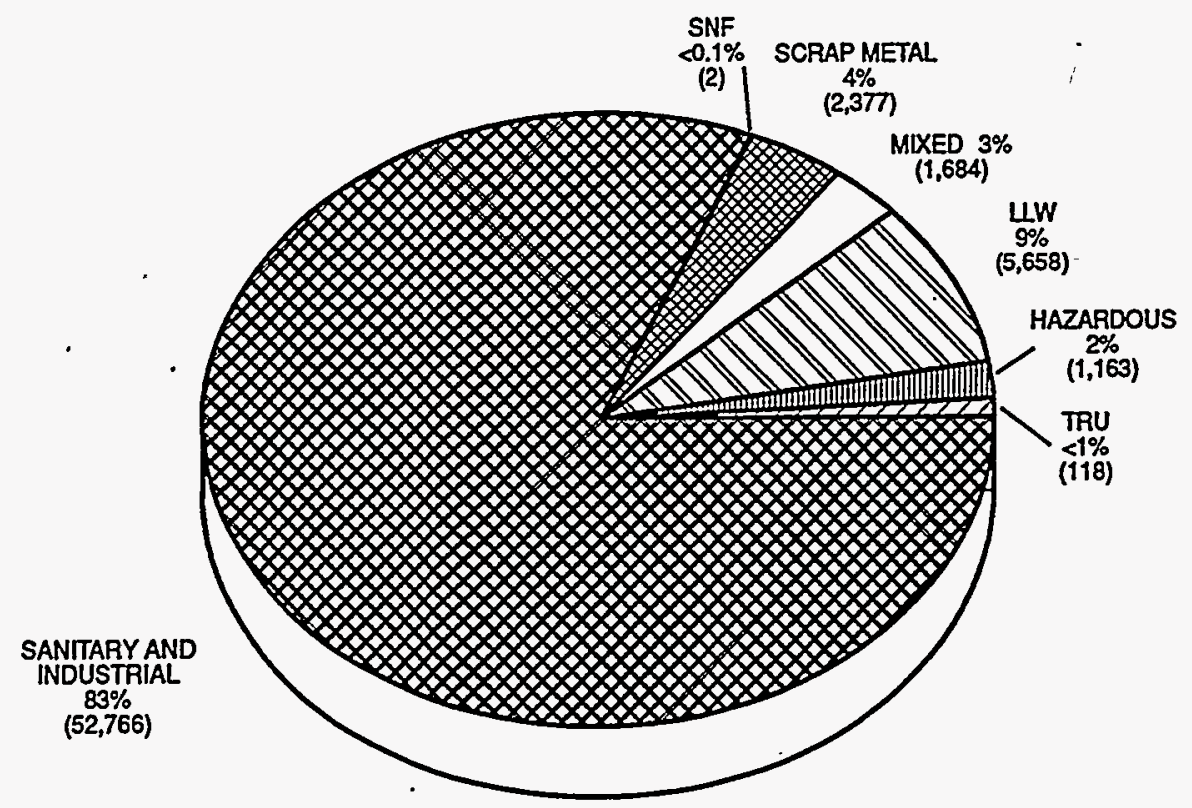

Fig. 1.3. Solid waste generation on the Oak Ridge Reservation for CY 1993 by waste type. Does not include ORNL scrap metal managed by the Plant and Equipment Division. Generation rates are in cubic meters per year.

ORNL-DWG 94Z-14172A

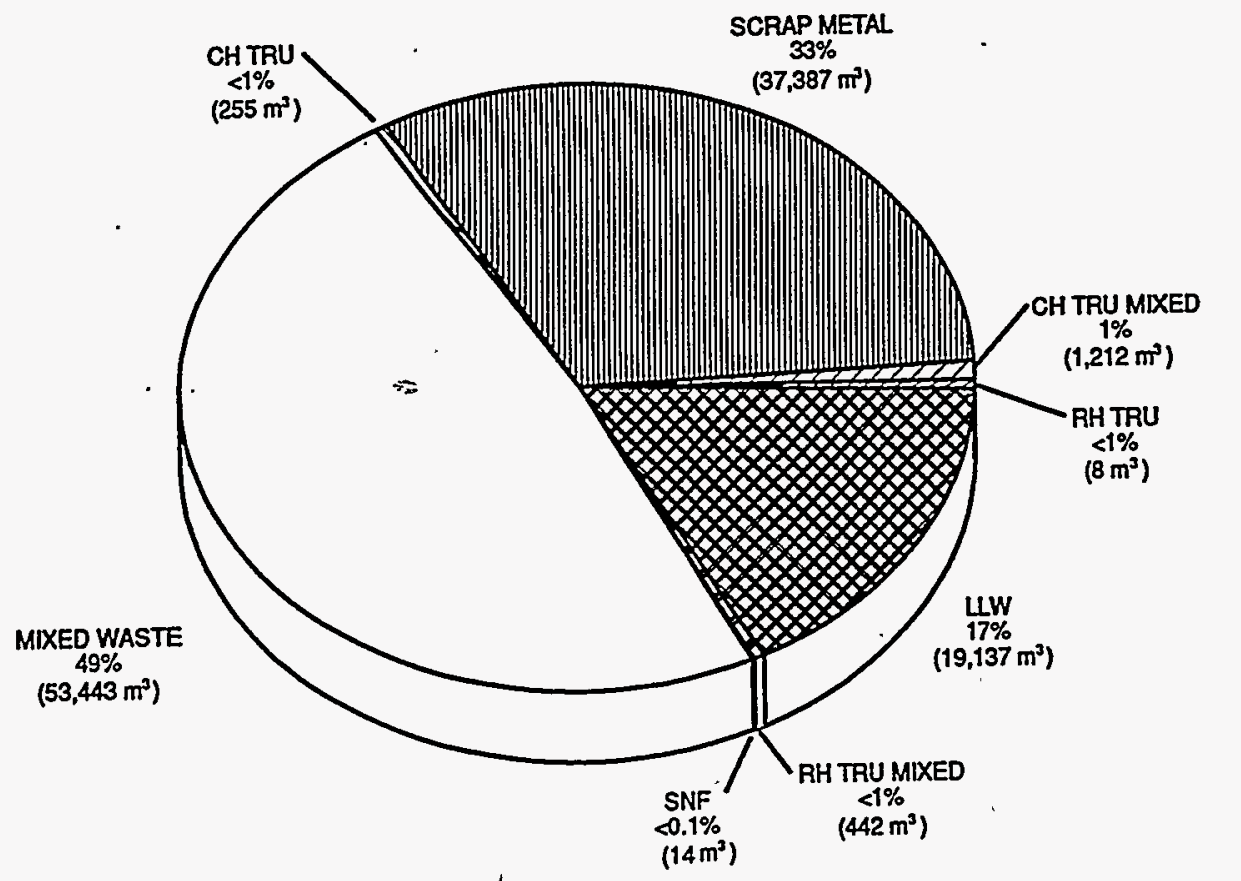

Fig. 1.4. Waste stored on the Oak Ridge Reservation as of June 30, 1994. Note that hazardous amounts are included in the mixed totals. Source: ESWMO August 1994. Oak Ridge Reservation Waste Storage Report for Period Ending June 30, 1994, Science Applications Intl. Corp., Oak Ridge, Tenn. 
management. The following wastes are required to be certified:

- low-level radioactive waste,

- TRU and TRU mixed waste,

- RCRA waste,

- TSCA waste,

- RCRA mixed waste,

- TSCA radioactive waste,

- TSCA/RCRA mixed waste,

- liquid wastes to be treated at the $\mathrm{K}-25$ Site,

- liquid wastes to be treated at ORNL, and

- liquid wastes to be treated at the Y-12 Plant.

Because of the manner in which they are generated or the management methods, it is not economically or technically feasible to certify some waste streams generated on the ORR. Therefore, it was determined that, at present, the following wastes would be excluded from the certification process:

- wastes destined for disposal in sanitary and industrial landfills,

- nonhazardous recyclable materials that are not required to be managed as waste,

- influent to the Oak Ridge Y-12 Plant Disposal Area Remedial Action Liquid Storage Facility,

- air emissions regulated solely by the CAA, and

- wastes to be received and managed by organizations other than ESWMO.

\section{Privatization}

The goal of the Private Sector Treatment Program is to identify and to implement technologies and strategies in the private sector that support ESWMO requirements including developing the technical, organizational, and economic framework to allow private sector design, construction, ownership, and operation of waste management service facilities for treating, packaging, transporting, and disposing of DOE wastes. The use of the private sector is a critical feature for providing mixed waste treatment. DOE is committed to maximizing private industry treatment of mixed waste to allow optimal compliant disposal.

In securing private sector participation, the program develops requests for expressions of interest (REOIs) and markets these REOIs through PreSolicitation Conferences. The responses received in the expressions of interest assist the program in tailoring a request for proposals that is congruous with existing technology. At that time a request for proposals is issued. Unknown commercial capability has a phased procurement. Phase $I$ is a proof of process with multiple vendors. Phase II is an industrial-scale capacity with one vendor successfully completing Phase I. Known commercial capability typically has a single-phase procurement. All phased procurements are evaluated; single-phase procurements can be either evaluated or cost-based procurements. This approach has allowed the Private Sector Treatment Program to purchase multimillion dollar treatment based on proven technology rather than a proposal.

Wherever practical, qualified 8(a) firms are identified and provided an opportunity to participate in the mixed waste treatment and disposal procurements. Fiscal year (FY) 1994 activities included:

- identification of the successful offerer of the West End Treatment

Facility-TSCA-Central Neutralization Facility Sludges-Phase I subcontract (award made November 16, 1994);

- identification of the successful offerer of the Intact Fluorescent Lamp Recycling subcontract (award to be made in December 1994);

- approval of NEPA documentation;

- completion of the Disposal Area Remedial Area-Oil Land Farm-Storm Sewer Sediment Soils Phase I Statement of Work; 
- Statement of Work for decontamination of radioactivity contaminated scrap metal for reuse;

- participation in a national working group for the private sector initiative; and

- holding of three conferences-PreSolicitation Conference for Seven Waste Streams (October 1993), Pre-Offer Conference for Inorganic Phase I (March 1994), and DOE Orders Conference for ERWM Projects (September 1994).

Plans for FY 1995 include:

- inorganic sludges Phase I completion,

- scintillation cocktails treatment and disposal,

- disposal area remedial action-Oil Land Farm-storm sewer sediments Phase I solicitation,

- crushed fluorescent lamp planning,

- photographic waste planning, and

- lab pack planning.

\section{Waste Tracking}

On May 13, 1991, DOE and the TDEC signed the TOA, which includes a provision for the establishment of a comprehensive waste-tracking system that tracks facility-wide waste from generation to disposal at the ORR and waste shipment off-site for TSD. The system includes unclassified information for all waste from all ORR facilities.

Each DOE site managed by Energy Systems has developed, or is in the process of developing, a system that will track waste in support of site-specific operations. These systems track wastes at various levels of detail and utilize different techniques. To meet the waste-tracking system requirements specified in the TOA and to support Energy Systems multisite needs, a Centralized Waste Tracking System (CWTS) is being designed to provide a consolidated reporting capability for the ORR, Portsmouth, and Paducah. Site data will be uploaded electronically from the site-specific systems:
The CWTS, part of the Centralized Waste Information Services Environment, is being designed and implemented using a multiphase approach. The first phase will consist primarily of a centralized waste information utility and will allow userinitiated queries on all waste data contained within. As agreed to by TDEC, Phase I will contain data for radioactive, RCRA hazardous, mixed and PCB wastes: Phase II will contain data for special wastes (i.e., asbestos, medical, and industrial/sanitary wastes), and waste minimization. Phase I was completed on October 31, 1993. Reevaluation of Phase I and analysis, design, development, and implementation of additional phases has been initiated to complete the requirements of the TOA and to assess additional Energy Systems needs.

\section{Waste Minimization and Pollution Prevention}

Waste minimization activities on the ORR are being implemented to reduce the volume of all waste generated, especially those that are hazardous and/or mixed and subject to RCRA LDR. Waste minimization is being achieved through the following general types of activities:

- segregation of hazardous from radioactive constituents to minimize radioactive mixed waste,

- substitution of nonhazardous for hazardous materials where technically practicable, and

- minimization of the generation of hazardous waste.

Under the LDR Program, many untreated hazardous wastes that previously were sent for disposal now require treatment. As a result of the departmental moratorium on the off-site shipment of wastes possibly contaminated with radionuclides and the conservative application of this policy, almost all hazardous waste on the Reservation is considered mixed waste. 
It is DOE policy to conduct its operations in a safe and environmentally sound manner. DOE considers protection of the environment and the public to be of paramount concern and importance. Waste minimization contributes to protection of human health and the environment by reducing risks to potentially exposed people and environmental impacts from releases of pollutants. DOE-ORO is committed to ensuring incorporation of waste minimization as part of its environmental protection goals. Therefore, the ORR approach to the LDR Program includes waste minimization as a preferred element that offers a long-term solution to LDR wastes.

To achieve waste minimization objectives, activities involving segregation, substitution, and other related actions have been initiated. Segregation of the hazardous component from the radioactive portions of a waste stream is necessary, to the extent possible, to minimize or to eliminate the generation of mixed waste. Under the current regulatory structure, DOE will identify, treat, and/or manage mixed waste, defined by the AEA as waste containing both a waste subject to RCRA, and source, special nuclear, or by-product material subject to the AEA. These wastes are typically more difficult to treat and dispose of and therefore must be minimized where possible. Process controls and housekeeping techniques to segregate the hazardous and radioactive components prior to cross contamination will be provided to minimize the generation of mixed wastes.

The practice of material substitution at the waste-producing source is effective in reducing the resulting hazardous waste generation volumes and eliminating the hazardous characteristics of the waste. Therefore, the substitution of nonhazardous solvents, such as aqueous cleaners, for hazardous solvents will be aggressively pursued to significantly reduce the amount of hazardous and mixed waste generated.
To further reduce the amounts of hazardous and radioactive wastes generated throughout the ORR, other waste minimization activities such as equipment or technology modifications, process or procedure modifications, reformulation or redesign of products, and improvements in housekeeping, maintenance, training, or inventory control and recycling and reuse will be employed. These activities will reduce the amount of waste requiring TSD as well as provide more efficient use of resources.

The overall strategy of focusing on waste minimization for these wastes translates in practice to eliminating or minimizing the generation of waste. Waste minimization consists of source reduction and recycling activities. Source reduction activities minimize or eliminate wastes at the source, while recycling activities use, reuse, or reclaim a material from a waste stream. These two activities are elements the EPA's hierarchy of environmental protection practices that encourages source reduction as the highest priority and recycling as the second priority. Source reduction is the first priority because it eliminates the problems associated with handling wastes. Waste minimization practices of source reduction and recycling reduce or eliminate the amount of waste that must be treated, stored, or disposed of by either reducing the total volume of waste, reducing the toxicity of the waste, or both, as long as that reduction is consistent with the general goal of minimizing current and future threats to human health and the environment.

\section{References}

\author{
CWMD (Central Waste Management \\ Division) 1991. Solid Waste \\ Certification Program Plan, K/WM-14, \\ Martin Marietta Energy Systems, Oak \\ Ridge K-25 Site.
}


CWMD (Central Waste Management Division) 1992a. Standard Content Guide for Site-Specific Solid Waste Certification Program Plans, K/CWM-7.2, Martin Marietta Energy Systems, Oak Ridge K-25 Site.

CWMD (Central Waste Management Division) 1992b. Guidance Manual for Developing Waste Acceptance Criteria
Documents, K/CWM-10.3, Martin Marietta Energy Systems, Oak Ridge K-25 Site.

CWMD (Central Waste Management Division) September 1994. Waste Certification Program Plan for the Oak Ridge Reservation, ES/WM-6, Martin Marietta Energy Systems, Oak Ridge K-25 Site. 


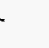




\section{Site Information}

\section{Missions and Background}

\section{Y-12 Plant Mission}

The Oak Ridge Y-12 Plant serves as a key manufacturing technology center for the development and demonstration of unique materials, components, and services of importance to the U.S. Department of Energy (DOE) and the nation. Currently, the Y-12 Plant is in the midst of refocusing its technical capabilities and expertise to better serve DOE-approved customers. Toward this end, nine Oak Ridge Centers for Manufacturing Technology have been established at the Y-12 Plant-examples of its changing mission from fabrication of components for nuclear weapons to improving private-sector manufacturing techniques. Devoted to specific areas of research, manufacturing, and measurement technologies, these Y-12 Plant centers can accommodate comprehensive development studies and support the transition of technological areas such as process, environmental management, and manufacturing technology to production.

The Y-12 Plant continues to be involved in the reclamation and storage of nuclear materials, manufacture of nuclear materials, manufacture of components for the nation's defense capabilities, support to national security programs, and provision of services to other customers as approved by DOE. Another major responsibility of the Y-12 Plant is to provide support to other Martin Marietta Energy Systems, Inc., facilities. For example, the Y-12 Plant provides housekeeping, maintenance, and engineering support to several Oak Ridge National Laboratory (ORNL) divisions located within the plant (e.g., Biology, Fusion Energy, Engineering Technology, and Operations).

The Y-12 Plant should continue to be a key link in the future security of our nation by maintaining the capability to produce required nuclear weapon components. While fewer weapon components are being built at this time, more demanding requirements are expected for turnaround time, quality, and cost containment. Considerable materials recovery work due to reductions in the number of stockpile weapons is also planned. Overall, the $\mathrm{Y}-12$ Plant continues to be a national leader in manufacturing technologies, special nuclear materials management, health and safety, environmental concerns, security, and quality.

\section{ORNL Mission}

ORNL performs leading edge research and development (R\&D) in support of DOE. Especially important elements of ORNL's mission include performing basic and applied research important to the nation, providing unique national user facilities to the scientific and technical community, and partnering with universities and industry to improve the nation's competitiveness through technology development and transfer and through contributions to the national initiative to improve science and math education. ORNL is accomplishing this 
mission through its core competencies: energy production, conservation, and utilization technologies; materials sciences and engineering; physical, chemical, and engineering sciences; biological and life sciences; environmental sciences and technologies; computational sciences; and manufacturing sciences and technologies.

The major sources of wastes at ORNL have been radioisotope production, experimental reactors, hot cells and pilot plants (i.e., chemical separations or fuel reprocessing), research (i.e., physical, chemical, and biological), accelerators, and analytical laboratories. ORNL radionuclide inventories buried in the Solid Waste Storage Areas (SWSAs) are primarily fission and activation products (e.g., ${ }^{60} \mathrm{Co}$, ${ }^{90} \mathrm{Sr},{ }^{137} \mathrm{Cs}$, and europium isotopes) rather than thorium, uranium, or transuranic (TRU) isotopes.

Major waste management activities include comprehensive coordination of waste reduction; planning; upgrading or construction of new facilities; waste collection; certification; and treatment, storage, and disposal. Wastes managed at ORNL include radioactive (i.e., low-level, spent nuclear fuel, and TRU), hazardous, mixed (i.e., radioactive and hazardous), industrial, and sanitary wastes.

\section{K-25 Site Mission}

The Oak Ridge $\mathrm{K}-25$ Site serves as the center of operations for the Energy Systems Environmental Restoration and Waste Management Programs. It is also the home of DOE's Center for Environmental Technology and Center for Waste Management; the multifaceted mission of these centers includes activities in technology development, technology transfer, engineering technology, and support for Energy Systems central functions, which include business management, engineering, computing, and telecommunications. Specific missions include management of the Toxic
Substances Control Act (TSCA) facility, a unique mixed-waste incinerator; support of risk-based cleanup programs for all contaminated facilities and natural resources; safe and compliant waste management; development and demonstration of innovative environmental technologies; support of the Hazardous Waste Remedial Action Program; and provision of cost-effective support and services to Oak Ridge K-25 Site users.

The K-25 Site continues to be the primary storage facility for low-level waste (LLW) and mixed waste generated or produced on the Oak Ridge Reservation (ORR).

\section{Background of Waste Management Practices on the ORR}

Since the beginning of operations on the ORR in 1943, significant changes have occurred in the scope of R\&D activities and in the supporting waste management requirements. While early ORR development focused on direct support of defense programs during and following World War II, the unique facilities that were established at that time formed the nucleus of the installations that now exist. Similarly, waste management requirements have changed over the years. Early waste management practices, which left significant environmental concerns unsatisfied, were a product of the limited scientific knowledge of the day and the urgency of the early mission. Compliant management of waste streams from facilities on the ORR is now the continuing responsibility of $\mathrm{DOE}$ and its managing site contractors.

Over the past decade, awareness of environmental issues has increased, and major environmental legislation has been enacted at both the federal and state levels to control existing and potential sources of pollution. As a result of this changing regulatory environment, the inspections, 
audits, and reviews that have been conducted, including evaluations by DOE

Tiger Teams, have increased markedly. These have revealed the need to accelerate activities that protect Energy Systems employees, the general public, and the environment on a more comprehensive basis, particularly through standards, practices, and procedures that reduce hazards to the environment, the public, and the employee to as low as reasonably achievable. Facilities for treatment of discharges have been constructed or are being constructed or upgraded, and results of earlier disposal practices are being corrected. Action in this area will continue to bring the Y-12 Plant, ORNL, and the $\mathrm{K}$-25 Site into greater compliance with current and future regulations and guidelines. Effluent monitoring has been used to aid waste management operations and to ensure the safety of on-site personnel, the general public, and the environment.

The ORR was placed on the National Priority List as a Superfund site in December of 1989. The Federal Facility Agreement (FFA) became effective in January 1992. It is intended to satisfy the requirements for an interagency agreement between the U.S. Environmental Protection Agency (EPA), the Tennessee Department of Environment and Conservation (TDEC), and DOE. It requires ORR cleanups to be conducted in compliance with the Resource Conservation and Recovery Act (RCRA); the Comprehensive Environmental Response, Compensation, and Liability Act; and the Superfund Amendments and Reauthorization Act. The plan and schedule for developing, implementing, and monitoring appropriate response actions at the site is in accordance with the above, the National Contingency Plan, and the National Environmental Policy Act. Specifically, the agreement establishes requirements for performing Remedial Investigation/Feasibility Studies and identifies the nature, objective, and schedule of response actions to be taken at the site. It also provides the basis for the creation of operable units, implementation of final remediation actions, requirements for underground liquid low-level waste (LLLW) tank systems to ensure structural integrity, and containment and detection of releases as well as source control for these systems pending final remedial action at the site.

In June 1992 DOE entered into a Federal Facility Compliance Agreement (FFCA) with the EPA to ensure compliance by DOE with Land Disposal Restrictions (LDRs) under RCRA. This became necessary because many of the radioactive wastes mixed with hazardous wastes (i.e., mixed wastes) generated by DOE sites had no available treatment, which resulted in a noncompliance situation. The FFCA dictates the steps required to bring ORR facilities into compliance with respect to mixed waste management.

\section{Site Descriptions}

\section{Location and Size}

The Y-12 Plant, ORNL, and the K-25 Site are located in an area of hills and valleys approximately $13 \mathrm{~km}$ ( 8 miles) southwest of the city of Oak Ridge in eastern Tennessee (Figs. 2.1 and 2.2). The ORR [14,050 ha (34,700 acres)] is in a rural setting and is bounded by the Clinch River and Tennessee Valley Authority (TVA) land on its eastern, southern, and western borders.

\section{Y-12 Plant}

The Y-12 Plant lies in a valley area bordered on the south by the Clinch River and on the north by the city of Oak Ridge. It is located $4.83 \mathrm{~km}$ ( 3 miles) from the population center of the city of Oak Ridge. Bear Creek Road, the principal access to 


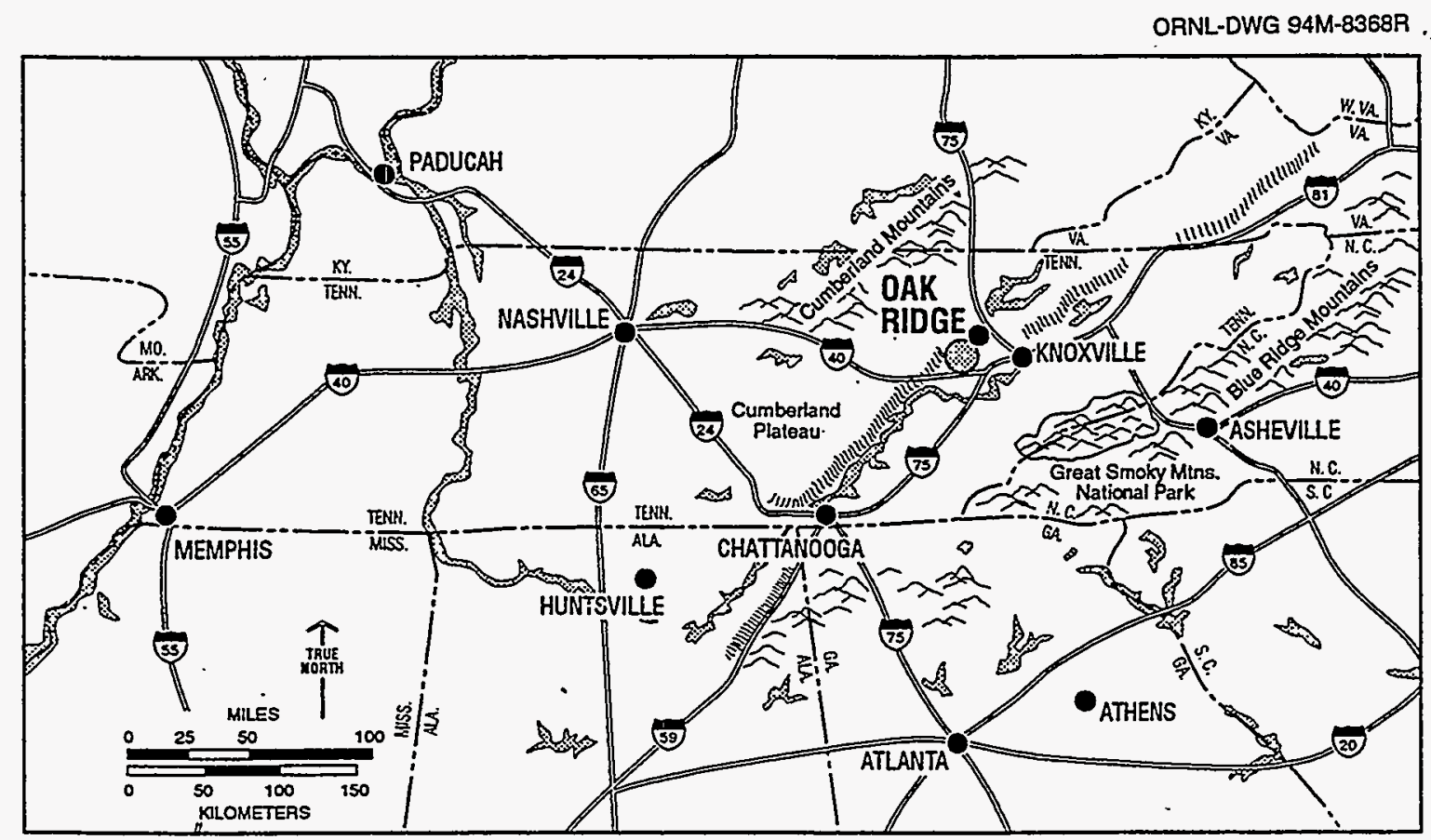

\section{LEGEND}

IIIIIIII Cumberland Escarpment

Oak Ridge Reservation $\quad--$ State Line

Fig. 2.1. Location of the city of Oak Ridge.

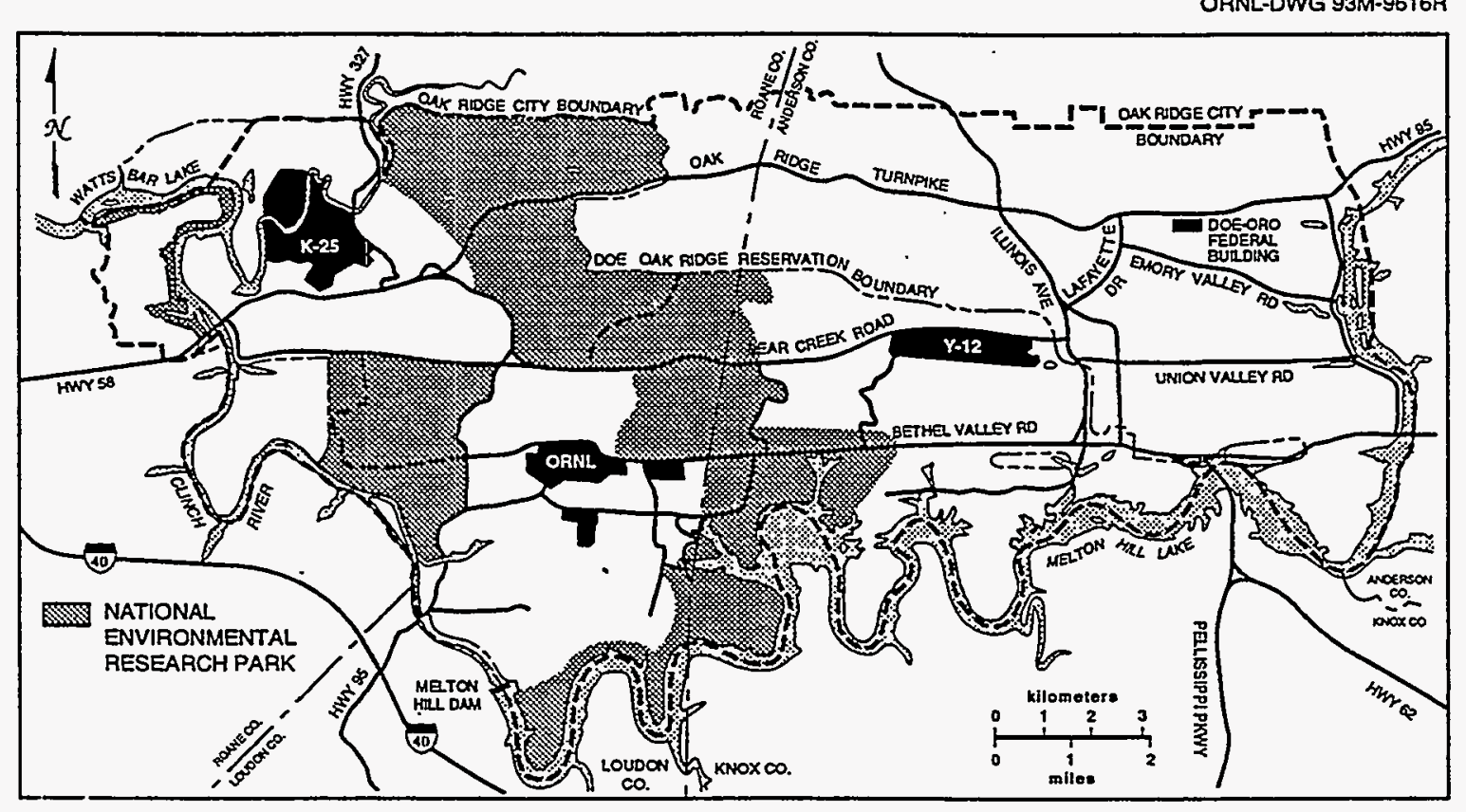

Fig. 2.2. The Oak Ridge Reservation. 
the site, runs east to west along the northern side of the plant. The main Y-12 Plant area is situated in the eastern portion of Bear Creek Valley and is bounded in the south by Chestnut Ridge and in the north by Pine Ridge. Scarboro Road marks the eastern boundary. The Y-12 Plant site area contains 328 ha (811 acres), of which approximately 243 ha (600 acres) is enclosed by perimeter security fencing.

\section{ORNL}

ORNL is located on the southern border of the federal Reservation. ORNL and its accompanying buffer zone, encompassing 3508 ha (8771 acres), is situated almost entirely within the $17-\mathrm{km}^{2}$ (7-mile $\left.{ }^{2}\right)$ White Oak Creek (WOC) drainage basin. The central ORNL Complex area is located in Bethel Valley, which runs approximately in a northeastsouthwest direction. Although the valley floor is highly developed within the central site area, the surrounding terrain is wooded. WOC passes to the south of the developed area and leaves the valley through a gap in Haw Ridge into Melton Valley. All the satellite facilities are located in Melton Valley except the Tower Shielding Facility, which is on Copper Ridge, south of Melton Valley. A number of ORNL facilities, including the Biology Division, are located at the Y-12 Plant. The central ORNL Complex, the SWSAs, and the outlying facilities occupy approximately 701 ha (1754 acres), or approximately $20 \%$ of the entire ORNL site. The remaining 2806 ha (7017 acres), or $80 \%$ of the entire ORNL site, is predominantly forested buffer zone.

Most of the land on the ORR is subject to forest management administered through the Plant and Equipment Division at ORNL. Forest management objectives are coordinated with those of other land uses on the ORR, such as waste management activities.
K-25 Site

The K-25 Site is located on a 2024-ha (5000-acre) tract of land, 294 ha (725 acres) of which is within security fences, near the junction of Poplar Creek and the Clinch River. It is approximately $40.23 \mathrm{~km}$ ( 25 miles) west of Knoxville and approximately $12.87 \mathrm{~km}$ ( 8 miles) southwest of the city of Oak Ridge.

The K-25 Site contains 350 buildings totalling approximately 1.3 million $\mathrm{m}^{2}$ (13 million $\left.\mathrm{ft}^{2}\right)$. Of this, approximately $90 \%$ [1.16 million $\mathrm{m}^{2}\left(12.5\right.$ million $\left.\left.\mathrm{ft}^{2}\right)\right]$ comprises buildings currently in the Decontamination and Decommissioning (D\&D) Program. While the large majority of the buildings are over 30 years old, adaptive reuse has allowed continued effective use of aged facilities. Emphases of real property assets are on (1) maintaining and enhancing the $\mathrm{K}-25$ Site as home base for environmental restoration, waste management, and environmental technology development and demonstration and (2) continued development of the site as a potential location for new and evolving DOE programs.

Approximately 200 ha (500 acres) of land on-site is readily available for development, containing few or no constraints. Approximately 80 ha (200 acres) of land has minor to moderate constraints. Physical factors presenting moderate constraints to development include topography, floodplains, cultural and historical sites, and contaminated lands. While these factors present sitespecific issues requiring consideration when planning for new development, reconfiguration, and/or redevelopment, they do not prevent proposed mission development. 


\section{Demography}

Except for the city of Oak Ridge, the land within $8 \mathrm{~km}$ ( 5 miles) of the ORR is predominantly rural and is used largely for residences, small farms, and pasture land. Fishing, boating, water skiing, and swimming are favorite recreational activities in the area. Figure 2.3 shows locations and populations of towns nearest the ORR.

\section{Topography}

Site topography is characterized by a series of alternating, elongated, and parallel valley troughs and ridges trending northeast to southwest in general accord with the strike of the underlying rock strata. The valleys have been eroded in areas underlain by the less resistant limestone and shale strata, while the ridges are underlain by more resistant sandstone, shale, and cherty dolomite formations.

Surface elevations range from approximately $225 \mathrm{~m} \mathrm{(740} \mathrm{ft)} \mathrm{at} \mathrm{the} \mathrm{Clinch}$ River to approximately $413 \mathrm{~m}$ (1356 ft) at the crest of Melton Hill. The succession of alternating ridges and valleys in the ORNL site area (in order from the Clinch River in the southeast to the northwest) is as follows: Copper Ridge, Melton Valley, Haw Ridge, Bethel Valley, and Chestnut Ridge.

\section{Climate}

The Oak Ridge climate is typical of the humid southern Appalachian region. The local climate is noticeably influenced by topography. The prevailing winds, as measured by an on-site meteorological tower, are from the southwest and northeast under both stable and unstable conditions. Average monthly wind speeds range from $1.6 \mathrm{~m} / \mathrm{s}(5.2 \mathrm{ft} / \mathrm{s})$ in October to $2.5 \mathrm{~m} / \mathrm{s}(8.2 \mathrm{ft} / \mathrm{s})$ in April. Differences in elevation have a measurable influence on the changes in climate along a northwestsoutheast axis. The average annual precipitation measured in the Oak Ridge vicinity is $138 \mathrm{~cm}$ (54.4 in.), ranging from $94.9 \mathrm{~cm}$ (37.4 in.) to $186.9 \mathrm{~cm}$ (76.3 in.).

A trace or more of snow has been reported each winter on record; the annual average snowfall is $26.4 \mathrm{~cm}$ (10.4 in.).

\section{Geologic and Hydrogeologic Conditions}

Nine geologic formations (Fig. 2.4) or groups ranging in age from Early

Cambrian to Early Mississippian have been mapped within the ORR. All the formations are of sedimentary origin, either chemical (limestone and dolomite) or clastic (sandstone and shale). From oldest to youngest, they include the Rome Formation, the Conasauga Group, the Knox Group, the Chickamauga Group, the Sequatchie Formation, the Rockwood Formation, the Chattanooga Shale, the Maury Formation, and the Fort Payne Chert.

In the Oak Ridge area the Knox dolomite and the Rome Formation are the principal aquifers. The Conasauga Group is a potential low-yield groundwater source. The Knox, located beneath Chestnut Ridge, is the major aquifer in the WOC basin. The thick, weathered mantle seems to have a high-infiltration capacity and serves as a reservoir feeding large solution cavities in bedrock. Springs at the base of Chestnut Ridge are a primary natural source of base flow for WOC. Groundwater discharge from the Knox beneath Copper Ridge is probably not into WOC basin but, instead, to the southeast along the Clinch River. The mean yield of springs and wells in the Knox Group used for public and industrial water supplies is $1014 \mathrm{~L} / \mathrm{min}$ (268 $\mathrm{gal} / \mathrm{min}$ ). No estimate is available for mean well yield of domestic water wells in the Knox Group.

Depth to the water table varies both spatially and temporally. At a given 


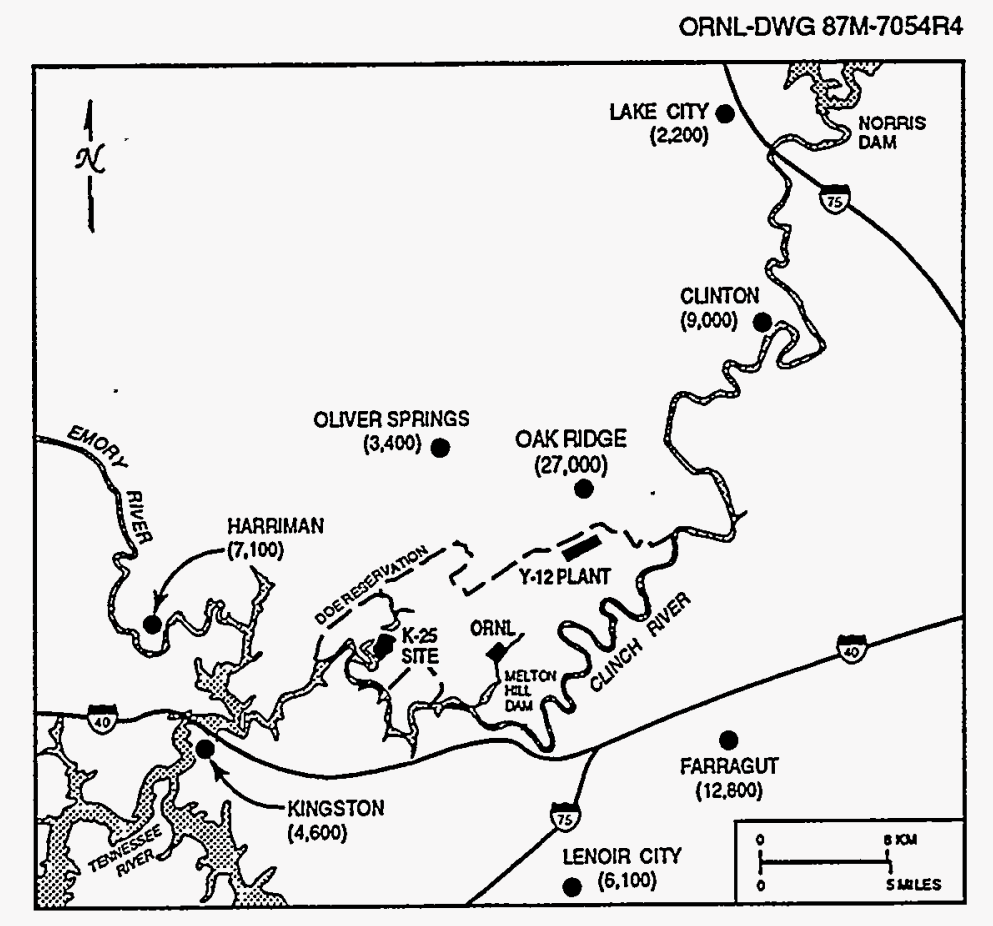

Fig. 2.3. Locations and populations of towns nearest to the Oak Ridge Reservation. (Population figures based on the 1990 U.S. census.)

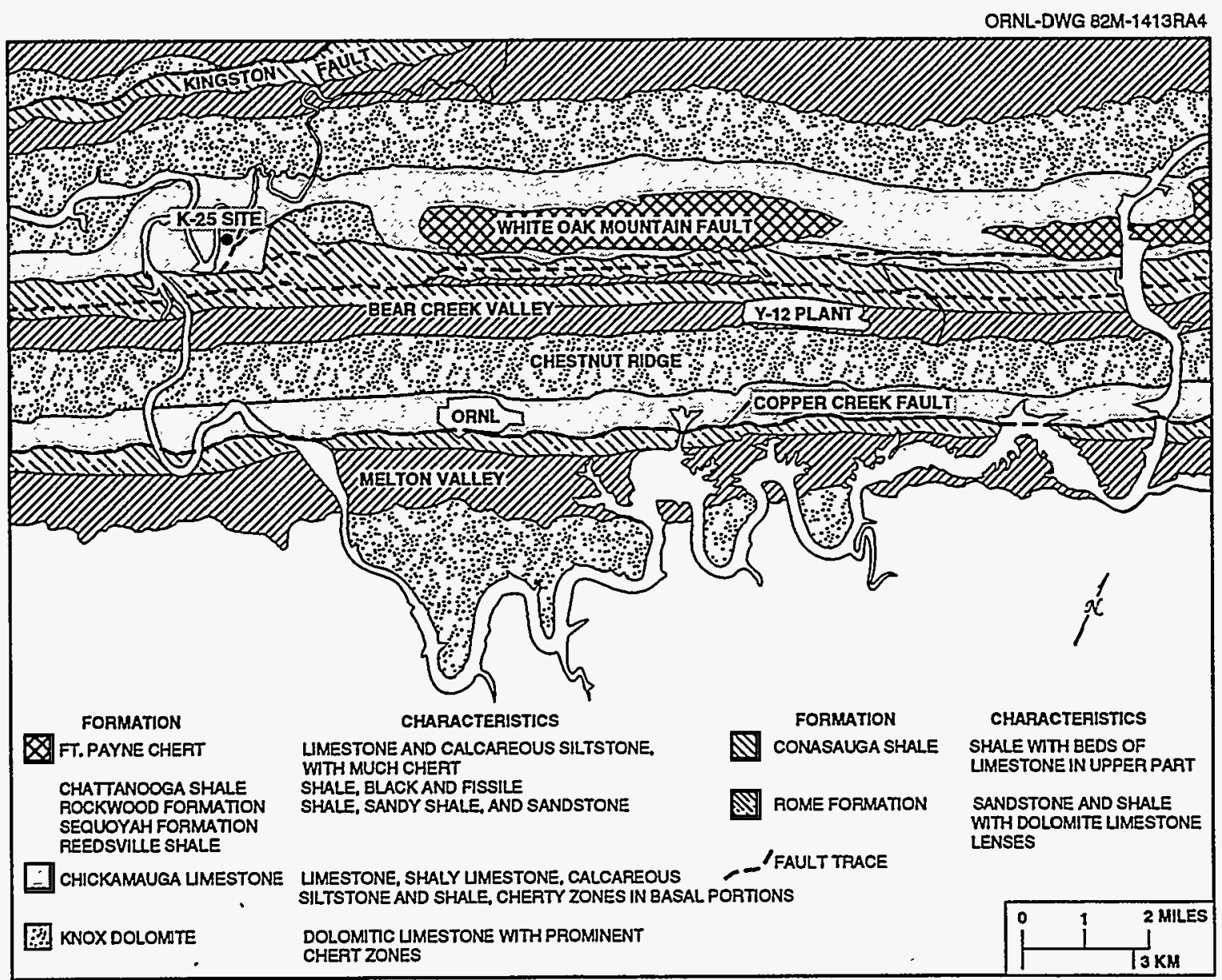

Fig. 2.4. Geologic formations within the Oak Ridge Reservation. 
location, depth to water is generally greatest during the October-December quarter and least during the January-March quarter. In Bethel Valley, depth to water table ranges from 0.30 to $10.7 \mathrm{~m}$ ( 1 to $35 \mathrm{ft}$ ), while in Melton Valley the range is from 0.30 to $20.4 \mathrm{~m}$ ( 1 to $67 \mathrm{ft}$ ). Seasonal fluctuations tend to be greatest beneath hillsides. A seasonal variation of as much as $4.6 \mathrm{~m}$ (15 ft) has been reported for Melton Valley. The major portion of the industrial and drinking water supplies in the Oak Ridge area is taken from surface water sources. However, single-family wells are common in adjacent rural areas not served by public water supply systems. More detailed information for the overall hydrologic and geologic conditions affecting the ORR has been published (Solomon et al. 1992).

Three principal fracture orientations are noted on the ORR based on bedrock outcrop mapping. One fracture set is parallel to strike of the bedrock, dipping parallel to bedding. The second fracture set is also parallel to formation strike but perpendicular to bedding dip. The dip of this set also varies with bedding plan dip and thus is a function of depth, inclined near the surface where bedding planes dip more steeply and vertical at depths where the bedding plane dip flattens. A third fracture set is perpendicular to formation strike. At least these three, but as many as five distinct fracture orientations, can be observed in a given borehole location. Furthermore, although weathered, these fractures are either maintained or in some cases enhanced in the regolith.

Groundwater is a potential source of potable water and of water for irrigation, industrial, and domestic uses. Groundwater also may provide a pathway for transport of contaminants and is, therefore, a necessary element in monitoring programs at the ORR. Groundwater on the ORR occurs as (1) localized perched water; (2) transient, shallow, subsurface stormflow in the unsaturated zone; and (3) an unconfined water table aquifer in the saturated zone. The water table marks the top of the saturated zone and generally occurs at shallower depths along low-lying areas and surface water features and at greater depths in higher topographic positions. No major confining layers have been identified such that groundwater occurs as a continuum from the water table surface to depths in bedrock.

Potable water for most nonrural areas comes from surface water. The Clinch River is the major source of surface water that receives discharges from the Oak Ridge installations. Four TVA reservoirs influence the flow and/or water levels of the lower Clinch River: Norris and Melton Hill on the Clinch River and Watts Bar and Fort Loudoun on the Tennessee River. Both groundwater and surface water are drained from the ORR by a network of small tributaries of the Clinch River. At Kingston, Tennessee, the Clinch River flows into the Tennessee River, which is the seventh largest river in the United States. Water levels of the Clinch River in the vicinity of the ORR are regulated by TVA.

Five public water supplies are located downstream within $80 \mathrm{~km}$ (50 miles) of the ORR. The K-25 Water Treatment Plant is located $4 \mathrm{~km}$ ( 2.5 miles) above the mouth of Poplar Creek and supplies drinking water to approximately 4000 employees. The Kingston Water Treatment Plant serves about 6841 persons, and its intake is located at Tennessee River kilometer 914.7 (river mile 568.4), about $0.6 \mathrm{~km}$ ( 0.37 miles) above the confluence of the Clinch and Tennessee rivers and $34.1 \mathrm{~km}$ (21.1 miles) below the mouth of Popular Creek. The Rockwood Treatment Plant serves about 7387 persons and is located downstream of Kingston on the King Creek embayment near Thief Neck Island. The remaining water plants are on Chickamauga Reservoir. 


\section{Y-12 Plant}

Cambrian-age shales of the Conasauga Group, interbedded with limestone, underlie the Y-12 Plant, which is located in the eastern portion of Bear Creek Valley. It is bounded on the south by the Knox Group (i.e., dolomitic limestone with prominent chert zones) and on the north by the Rome Formation (i.e., sandstone and shale with dolomitic limestone lenses).

\section{ORNL}

Of the nine units mapped within the Reservation, the four that underlie ORNL and the WOC drainage basin from northwest to southeast are (1) the Knox Group, a predominantly dolomite stratum of Cambrian and Ordovician ages underlying Chestnut Ridge to the north and Melton Hill and Copper Ridge to the south; (2) the Chickamauga Group of Ordovician age, which underlies the main ORNL Complex in Bethel Valley; (3) the Rome Formation, the shale, siltstone, and sandstone unit of Cambrian age that underlies Haw Ridge, separating the main ORNL Complex from the satellite facilities located in Melton Valley; and (4) the Conasauga Group, Cambrian-age shales interbedded with limestones and siltstone that underlie the waste management treatment, storage, and disposal (TSD) facilities in Melton Valley. The rock is generally covered by a mantle of residual alluvial and colluvial material in places greater than $30 \mathrm{~m}$ (100 ft) thick. Soils developed on the Rome, Conasauga, and Chickamauga are generally thin [i.e., less than $4.8 \mathrm{~m}$ (16 ft) but somewhat thicker where shale is deeply weathered]. Knox residuum is generally thick but irregular.

\section{K-25 Site}

The $\mathrm{K}-25$ Site is located at the confluence of Poplar Creek with the Clinch River. Land surface in the area ranges from

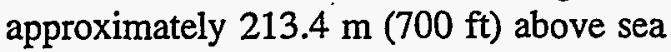

level at the bottom of the Clinch River to 304.8 and $335.3 \mathrm{~m} \mathrm{(1000} \mathrm{and} 1100 \mathrm{ft}$ ) along the ridge crests. It is located in the Tennessee section of the valley and ridge province, which is part of the southern Appalachian fold and thrust belt. The area is characterized by a succession of northeast-trending thrust faults that structurally stack and replicate the Paleozoic rocks of this area. As a result of thrusting and subsequent differential erosion, series of valleys and ridges have formed that parallel the thrust faults. In general, the more resistant siltstone, sandstone, and dolomite units form ridges in the region; the less resistant shales and shale-rich carbonates underlie its valleys. Throughout the K-25 Site, differential erosion and weathering have resulted in an overall geologic sequence where competent bedrock is overlain by a mantle of regolith (characterized by weathered, unconsolidated materials formed in place through chemical and physical weathering of the underlying parent bedrock), which is overlain by a veneer of soils or alluvial sediments.

\section{Waste Management Organizational Structures}

\section{DOE Headquarters}

The Assistant Secretary for Environmental Restoration and Waste Management (EM), reporting to the secretary of DOE, provides program policy guidance and manages the assessment and cleanup of inactive waste sites and facilities, continues safe and effective waste management operations, and develops and implements a waste R\&D Program to provide environmental technologies for treatment and disposal of wastes. The assistant secretary provides centralized management of waste management operations, environmental restoration, and applied R\&D programs and activities, 
including EM policy and guidance to DOE field offices in these areas. Figure 2.5 shows the different offices reporting to the assistant secretary for EM and their titles. The programmatic direction from DOE Headquarters to the DOE Oak Ridge Operations Office (DOE-ORO) for waste management activities is through the Office of Waste Management (EM-30). The deputy assistant secretary for Waste Management utilizes two offices to discharge operational (EM-32) and program support (EM-33) guidance. The Office of Waste Operations (EM-32) is divided regionally into divisions; Eastern Operations (EM-321) provides programmatic guidance to DOE-ORO.

\section{DOE-ORO}

DOE-ORO has placed the overall responsibility for all environmental restoration and waste management activities under the assistant manager for Environmental Restoration and Waste Management (AMERWM). Under the AMERWM are three divisions and two site offices: Environmental Restoration, Waste Management and Technology Development, and Former Sites Restoration Divisions and Weldon Springs Site and Oak Ridge K-25 Site Offices (Fig. 2.6).

Responsibility for overall planning, budget development, and program management of corrective activities and waste management operations for radioactive, hazardous, and mixed waste rests with the Waste Management and - Technology Development Division under the AMERWM. In addition to the AMERWM and its associated responsibilities, the DOE-ORO assistant manager for Construction and Engineering is responsible for renovations and new construction projects and the associated architect engineers and construction managers.

\section{Martin Marietta Energy Systems, Inc.}

The three sites on the ORR are managed for DOE by Energy Systems. As the managing and operating contractor, Energy Systems manages the environmental, safety, and health programs at the sites and supports DOE-ORO in management of the overall Environmental, Safety, and Health (ES\&H) Program. Energy Systems management structure is organized to parallel the DOE-ORO Environmental Restoration and Waste Management Organization.

Within Energy Systems, waste management, environmental restoration, and decontamination and decommissioning (D\&D) are the responsibility of the Environmental Restoration and Waste Management Programs. This organization has direct interface with the DOE-ORO AMERWM. An organizational overview of the Energy Systems Environmental Restoration and Waste Management Programs is shown in Fig. 2.7.

\section{Energy Systems Waste Management Organization (ESWMO)}

ESWMO-Central reports to the Environmental Restoration and Waste Management Programs vice president. It has responsibility for waste management activities on the ORR (Fig. 2.8). Its mission covers these broad areas:

- ORR-wide Waste Management Program coordination;

- program planning and technical support for all radioactive, hazardous, medical or infectious, mixed, industrial, and sanitary landfill operations;

- development, coordination, and operation of centralized waste treatment, storage, and disposal facilities;

- budget planning; and

- program reporting for waste management activities. 


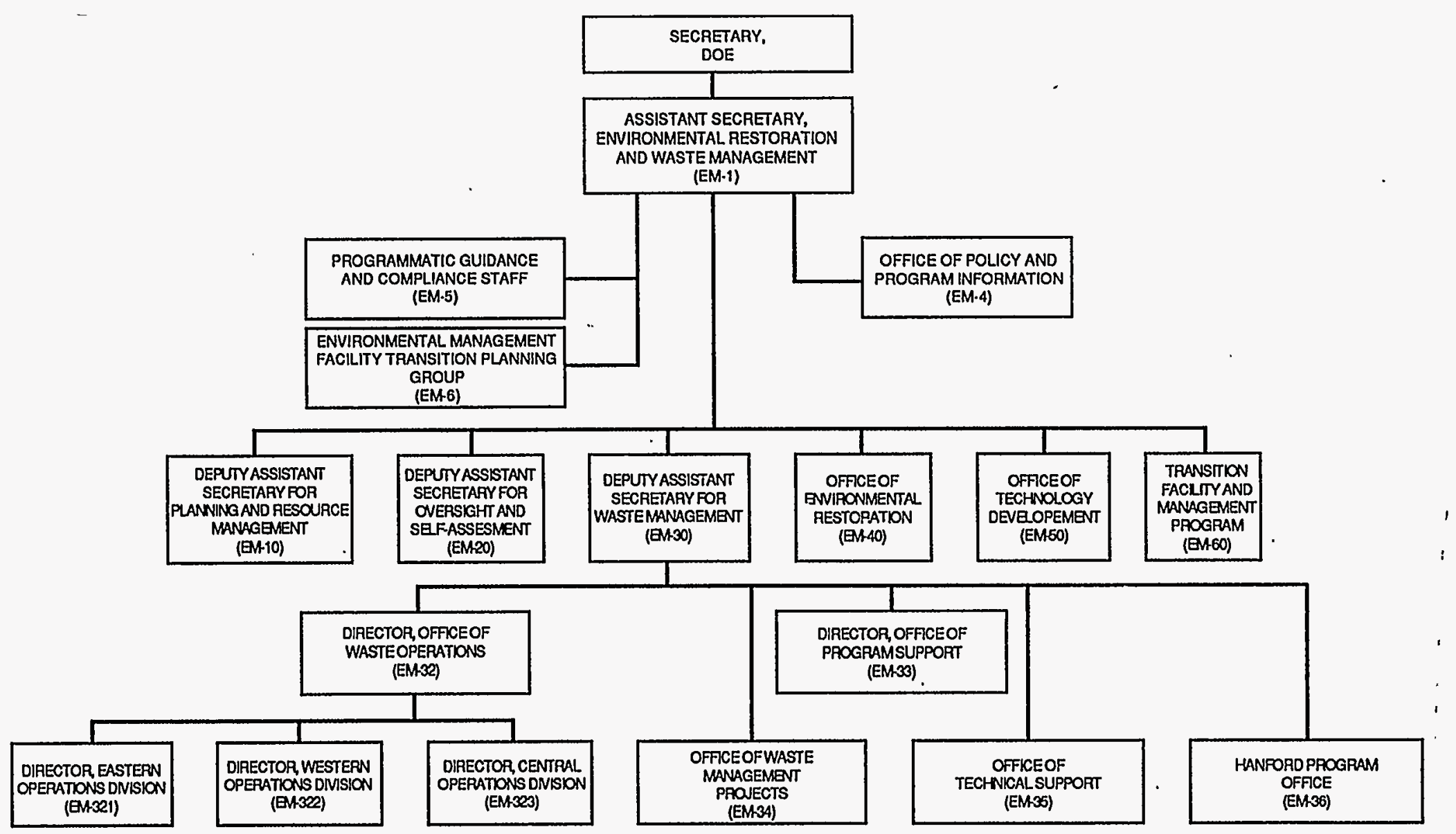

Fig. 2.5. U.S. Department of Energy Headquarters. 


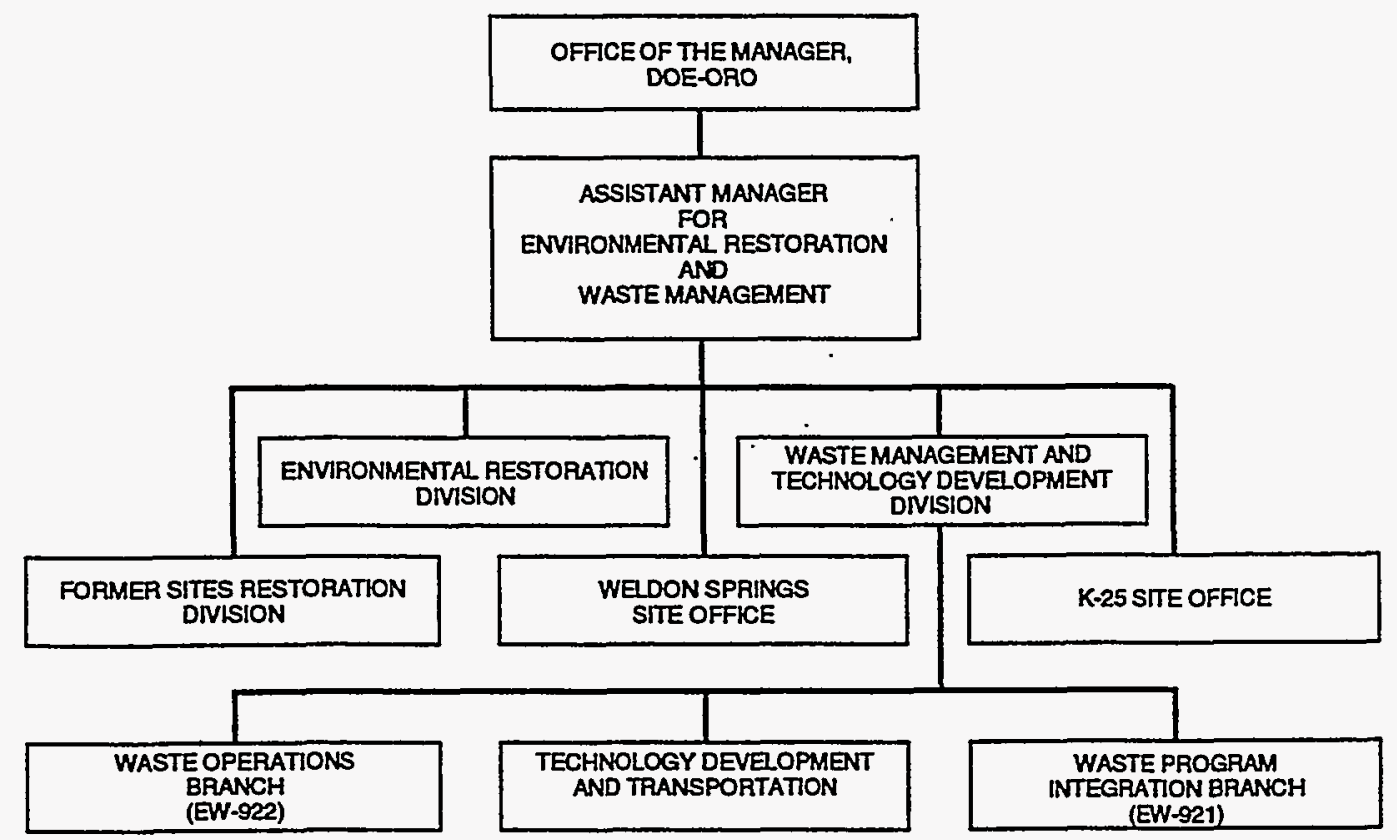

Fig. 2.6. AMERWM Organization for the U.S. Department of Energy's Oak Ridge Operations Office.

ESWMO-Central has also been assigned the responsibility for preparation and issuance of radiological Performance Assessments (PAs), as required under DOE Order 5820.2A, for ORR LLW disposal sites. ESWMO-Central assigned the responsibility for developing SWSA 6 and the Interim Waste Management Facility PA to ESWMO-ORNL.

ESWMO-Y-12. Management of wastes at the Y-12 Plant is a cooperative effort between the ESWMO-Y-12, Defense Program (DP), and Site Management Organization staffs. The DP Site Management managers report to the vice president/Y-12 Plant manager. The director of ESWMO-Y-12 reports to the ESWMO-Central manager. Activities involving the management of waste at the Y-12 Plant are driven by ES\&H guidelines generated at the federal, state, corporate, and plant levels. Personnel from Energy Systems, through ESWMO-Central, manage all wastes generated at the Y-12
Plant, including wastes generated by subcontractors.

ESWMO-Y-12 is composed of the following departments: Waste Treatment Operations; D\&D; Waste Transportation and Landfill Operations; Waste Processing; Program Interface; Waste Reduction, Planning, and Reporting; Waste Storage and Shipping Operations; Program Integration; Business Services; and Waste Management Engineering. TSD operations are conducted by the Waste Treatment; Waste Transporation and Landfill Operations; Waste Processing; and Waste Storage and Shipping Operations departments.

The Waste Treatment Operations Department provides treatment of aqueous wastes at the Liquid Storage/Treatment Facility, Groundwater Treatment Facility, and the West End Treatment Facility for the Y-12 Plant, Environment Restoration, and the Decontamination and Decommissioning Programs. They also operate the Y-12 West Tank Farm. 
ORNL-DWG 94M-11866R

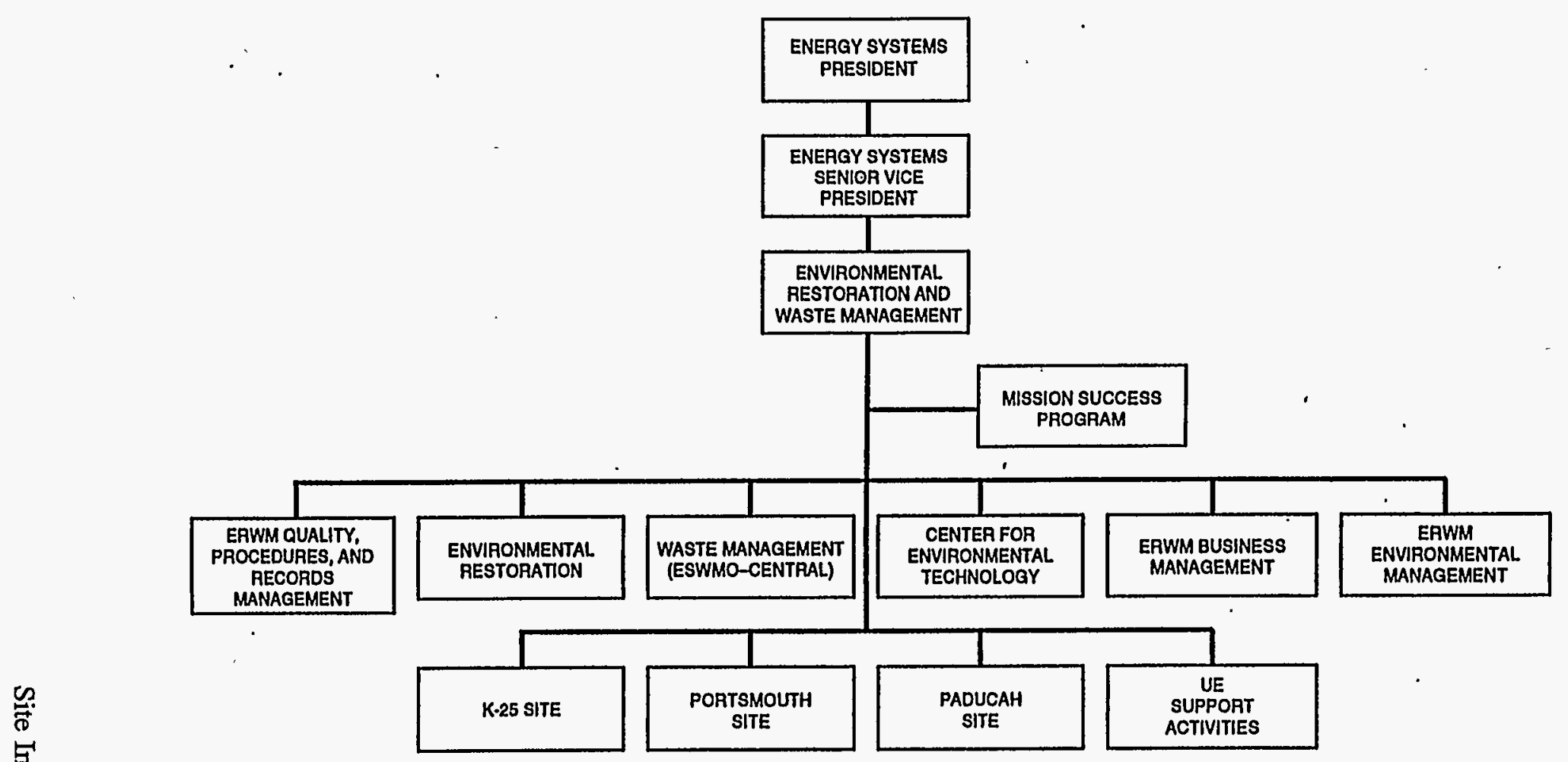

Fig. 2.7. Energy Systems Environmental Restoration and Waste Management Programs. 


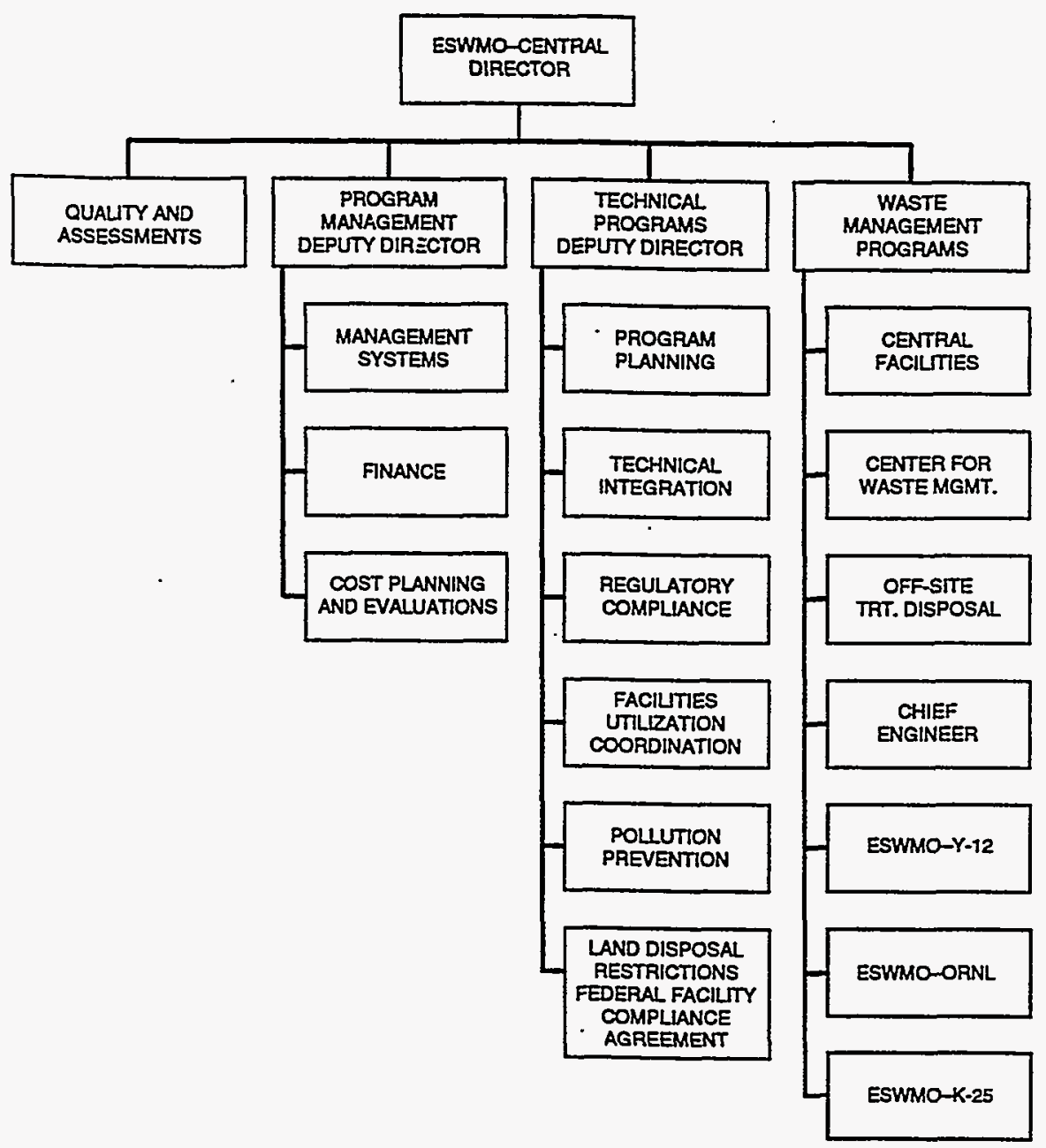

Fig. 2.8. Energy Systems Waste Management Organization.

The Y-12 Decontamination and

Decommissioning Program provides the programmatic direction, project management, and technical guidance for the D\&D activities in the plant. In addition, the D\&D Program provides management of the transition activities required to identify and to prepare unneeded facilities for D\&D.

The Waste Transportation and Landfill Operations Department provides collection and transportation of wastes and operation of classified and industrial landfills for the
Y-12 Plant. Particular functions include, as mentioned, landfill operations; RCRA, TSCA, and scrap metal management; solid waste engineering services; tanker and dumpster services; spill response; and paper recycling services and baler operations.

The Waste Processing Department operates and manages several treatment facilities. They also provide operations support services (e.g., facility engineering) for the treatment facilities they operate. 
The Program Interface Department

provides program support and

Environmental Restoration/Waste

Management interface services.

The Waste Reduction, Planning, and

Reporting Department provides services that include management of the Y-12 Plant Pollution Prevention Program and mixed waste coordination, waste information reporting, and FFCA technical support.

The Waste Storage and Shipping Operations Department provides baler operations, operation of salvage yards, certain facility operations, traffic and data processing, waste coordination and hazardous waste engineering, and sampling services.

The Program Integration Department provides compliance assessment, computer applications, training, and operations technical and information support services. Some of the functions consist of ES\&H compliance assessment, quality assurance, building management, special computer projects and support, information systems development and support, Conduct of Operations assessment and compliance, total quality management, quality control, performance indicators, and procedure maintenance and development.

The Business Services Department provides financial/budgeting services, program/activity coordination, cost estimating and scheduling services, and performance tracking and reporting.

The Waste Management Engineering Department staff are responsible for programs and projects that crosscut the entire ESWMO-Y-12. These include involvement with the Radiological Control Program, Certification Program, privatization initatives, and nondestructive analysis testing. Facility engineering staff within the other operating departments are responsible for facility and process planning, management, input to budgets, facility modification, and initation of special waste management programs such as technology demonstrations, waste certification, and interfacing with waste management planning. Figure 2.9 shows the organizational structure.

ESWMO-Y-12 interfaces with DP and Site Management organizations at the point where custody of pretreated or stored DP waste is given to ESWMO-Y-12 for further TSD.

ESWMO-ORNL. Waste management operations and remedial action functions are the responsibility of ESWMO-ORNL (Fig. 2.10). These responsibilities are grouped organizationally into two functions: (1) waste management functions that include responsibility for operations of all waste management facilities at ORNL (with the exception of the sanitary sewage system and solid sanitary waste collection and transportation, which are operated by the ORNL Plant and Equipment Division), corrective activities for bringing waste management facilities into compliance, and facility upgrades and construction of new waste management facilities and (2) remedial action functions that cover surveillance and maintenance (S\&M) of inactive waste sites, $S \& M$ of surplus radioactively contaminated facilities, and $D \& D$ of the contaminated facilities.

ESWMO-ORNL comprises two major programs, nine departments, and three special programs. The waste management component has two operations departments, four technical support departments, and three special programs that report programmatically to the Waste Management Program. The remedial action component has two departments that report programmatically to the Environmental Restoration (ERP), D\&D, and S\&M Programs. The Training Department supports both the Waste Management Program and ER, D\&D, and S\&M Program.

The Waste Management Program provides programmatic interface with ESWMO-Central and DOE. Primary responsibility is coordinating the development of the fiscal year budgets and current year work plans. The programs that report programmatically to the Waste 


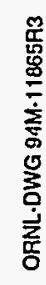

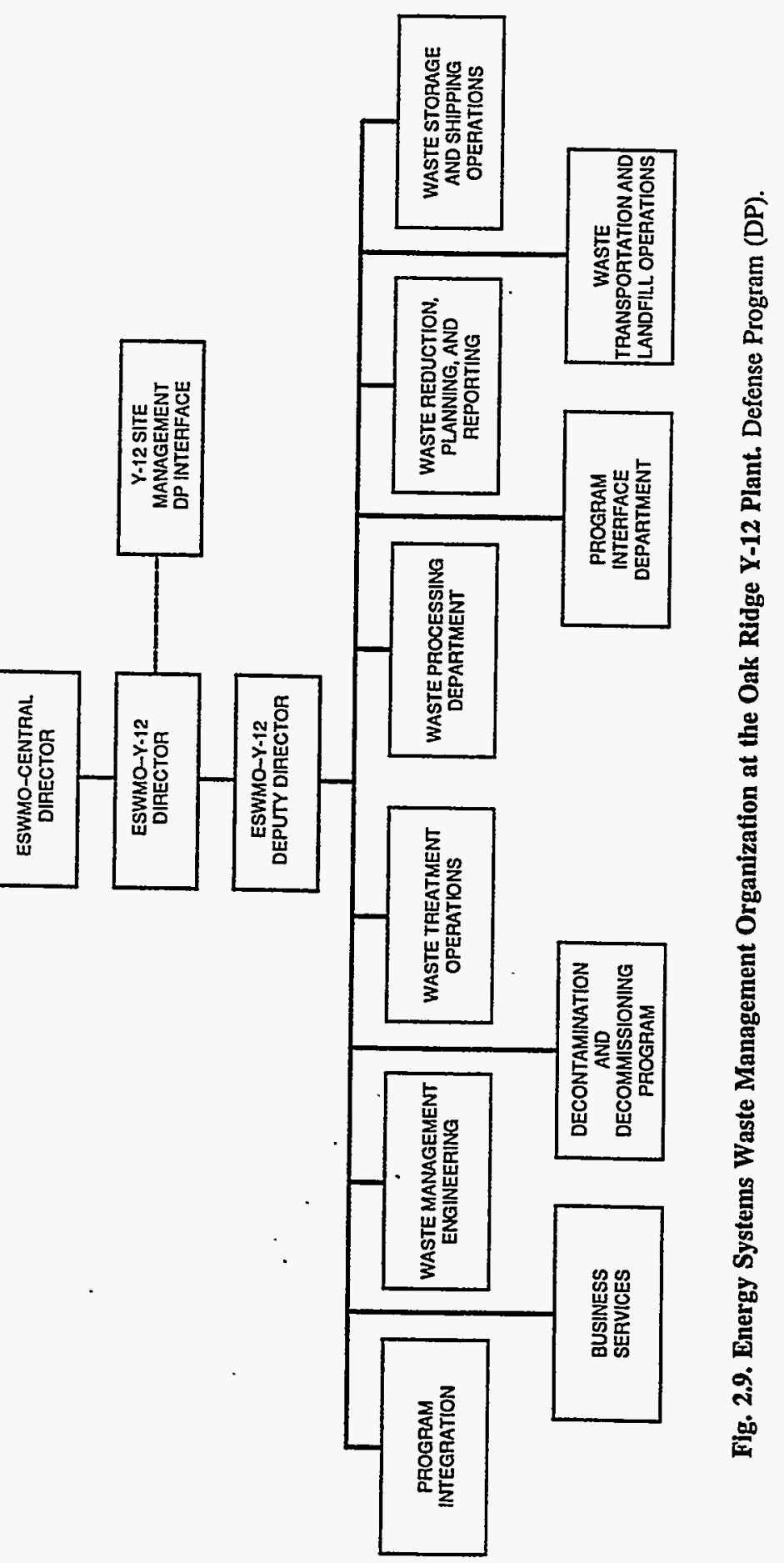




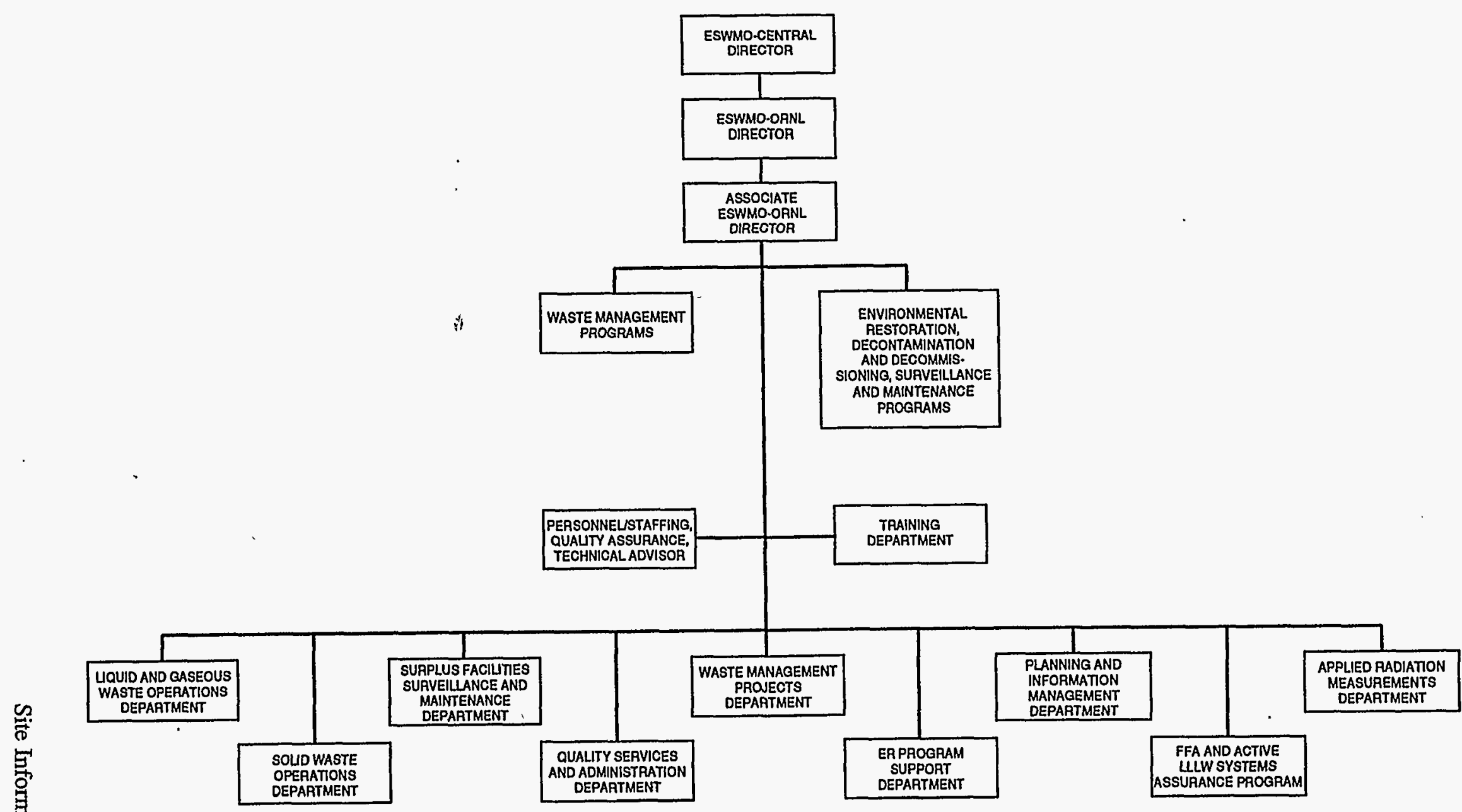

Fig. 2.10. Energy Systems Waste Management Organization at Oak Ridge National Laboratory. Federal Facilities Agreement (FFA); low-level liquid waste (LLLW); environmental restoration (ER). 
Management Program are the Liquid/Gaseous Waste Program; Solid Waste Program; TRU Waste Program; Spent Nuclear Fuel Program; Nuclear Fuel Services Project; FFA and Active LLLW Systems Assurance Program; Performance Assessment, Finance and Information Management Program; Strategic and LongRange Planning; Waste Certification; and Waste Minimization (Pollution Prevention).

The Liquid and Gaseous Waste Operation Department (LGWOD) is responsible for management of a number of ORNL liquid and gaseous waste streams. The liquid waste streams include trace amounts of radioactivity in process waste, significant amounts of radioactivity in LLLW, and various wastewater streams. The LGWOD is not responsible for sanitary liquid waste streams including coal yard runoff, sewage, or any liquid waste streams released to the watershed without treatment. The sanitary liquid waste streams are the responsibility of the Plant and Equipment Division at ORNL. The gaseous waste streams include those flows in the main ORNL plant area terminating at the 3039 stack. The LGWOD is not responsible for gaseous wastes going to other stacks at ORNL.

The Solid Waste Operation Department is responsible for storage, treatment, recycle, and/or disposal of radioactive, hazardous, and mixed wastes. It also provides oversight, together with the ESWMO-ORNL environmental protection officer and Office of Rad Protection staff, to ensure that inappropriate items are not included in sanitary solid wastes. ORNL waste management facilities include SWSA $5 \mathrm{~N}$ for TRU and special case wastes, the SWSA 6 disposal site for solid low-level waste (SLLW), the Hazardous/Mixed Waste Management Area, and other hazardous/mixed waste tanks or facilities.

The Waste Management Projects Department provides engineering support to manage line items (LIs) and general plant projects (GPPs) during functional/systems requirements definition, feasibility studies, conceptual design, detailed design, procurement, and construction. The LIs and GPPs are required for upgrading, replacing, or constructing new facilities or systems required to conduct waste management operations in an efficient, safe, and compliant manner.

The Quality Services and Administration Department provides support in fiscal analysis, division staffing, quality assurance (QA), Self Assessments, ES\&H protection, and progress tracking.

The Planning, Certification, and Pollution Prevention Department is responsible for developing and maintaining these programs. This department also provides data management services through the Waste Tracking System and Document Management Center (DMC) sections. Program support is provided to other ESWMO-ORNL departments and ESWMO-Central.

The Applied Radiation Measurements Department provides nondestructive examination and nondestructive assay of TRU and SLLW.

Three special waste management programs-Spent Nuclear Fuel, TRU Waste, and FFA and Active LLLW Systems Assurance-provide a single point of contact for ESWMO-Central, Energy Systems, DOE, State, and other stakeholders.

The ER, D\&D, and S\&M Programs are responsible programmatically for all work conducted for the ERP, which includes programmatic interfaces with the ORNL site manager of the ERP and the Energy Systems D\&D Program manager. This program also provides the interface necessary with the ORNL Capital Asset Planning Group for surplus facilities support received from DOE Energy Research.

The Surplus Facilities S\&M Department is responsible for S\&M of ORNL's surplus contaminated facilities. 
The ERP Support Department implements work performed by ESWMO-ORNL for the ORNL site manager of the Energy Systems ERP. This department is responsible for activities involving $S \& M$ of remediation sites. Also, those $D \& D$ projects that are closely associated with remediation planning and implementation are also performed by this department

ESWMO-K-25. Waste management operations at the K-25 Site are the responsibility of ESWMO-K-25. It comprises six departments: two operations departments for treatment, transportation, storage, and disposal functions and four technical service support departments (Fig. 2.11).

The Waste Treatment Operations Department operates the Central Neutralization Facility and the K-1232 wastewater treatment area.

The Waste Transportation and Storage Operations Department provides services for managing the packaging, inspection, transportation, and storage of all waste generated at the K-25 Site. The personnel in this department load and unload the waste for transport. Included are activities for storage of hazardous waste, polychlorinated biphenyl wastes, LLW, mixed wastes, fissile wastes, and classified wastes. Requirements include transportation storage provisions for the ORR. Activities include operation of container and tank storage units, implementation of inspections required by RCRA and TSCA regulations, preparation of operating procedures, and completion of corrective actions, including those for overpacking requirements for deteriorated containers.

The Waste Coordination Department is responsible for the review and approval of waste generator management plans for generated waste streams. This department is also responsible for the Waste Certification Program, the K-25 Site Waste Tracking and Reporting System, the Legacy Waste Characterization Program, and coordinating waste shipments to the
$\mathrm{K}-25$ Site or to off-site treatment/disposal facilities. Coordination of waste movement from the generators' accumulation areas is maintained through a Waste Disposal Request process that includes waste characterization and waste-tracking functions. This department maintains records of past disposals, current inventories, and forecasted generations of wastes.

Compliance and Business Management Department responsibilities include coordinating the planning and budgeting to support the K-25 Site Waste Management Program and the interfacing ERP activities; coordinating DOE Performance Measurement Team milestones; planning for waste management strategic, longrange, and current-year considerations; evaluating costs, tracking, and reporting; and preparing financial documentation. Key additional department responsibilities are managing the K-25 Site LDR FFCA Program, coordinating the Defense Nuclear Facility Safety Board recommendations for ESWMO-K-25, and managing the ESWMO-K-25 Document Center.

Waste Management Engineering is responsible for project management for all LI, GPP, and capital expense equipment projects; a Preventive Maintenance Program; Readiness Review and Value Engineering processes; and new technology evaluation and application. Other key activities include program management for pollution prevention and waste minimization activities at the $\mathrm{K}-25$ Site.

The Quality Services Department manages the programs for (1) development of waste management procedures required by the site, division, and departments;

(2) training of ESWMO-K-25 personnel;

(3) Conduct of Operations oversight and coordination; (4) Self-Assessment coordination and Quality Improvement Programs; (5) implementation guidance for Total Quality Management techniques and Performance Measurement Teams; (6) the ESWMO-K-25 commitment tracking system; (7) ESWMO-K-25 performance 


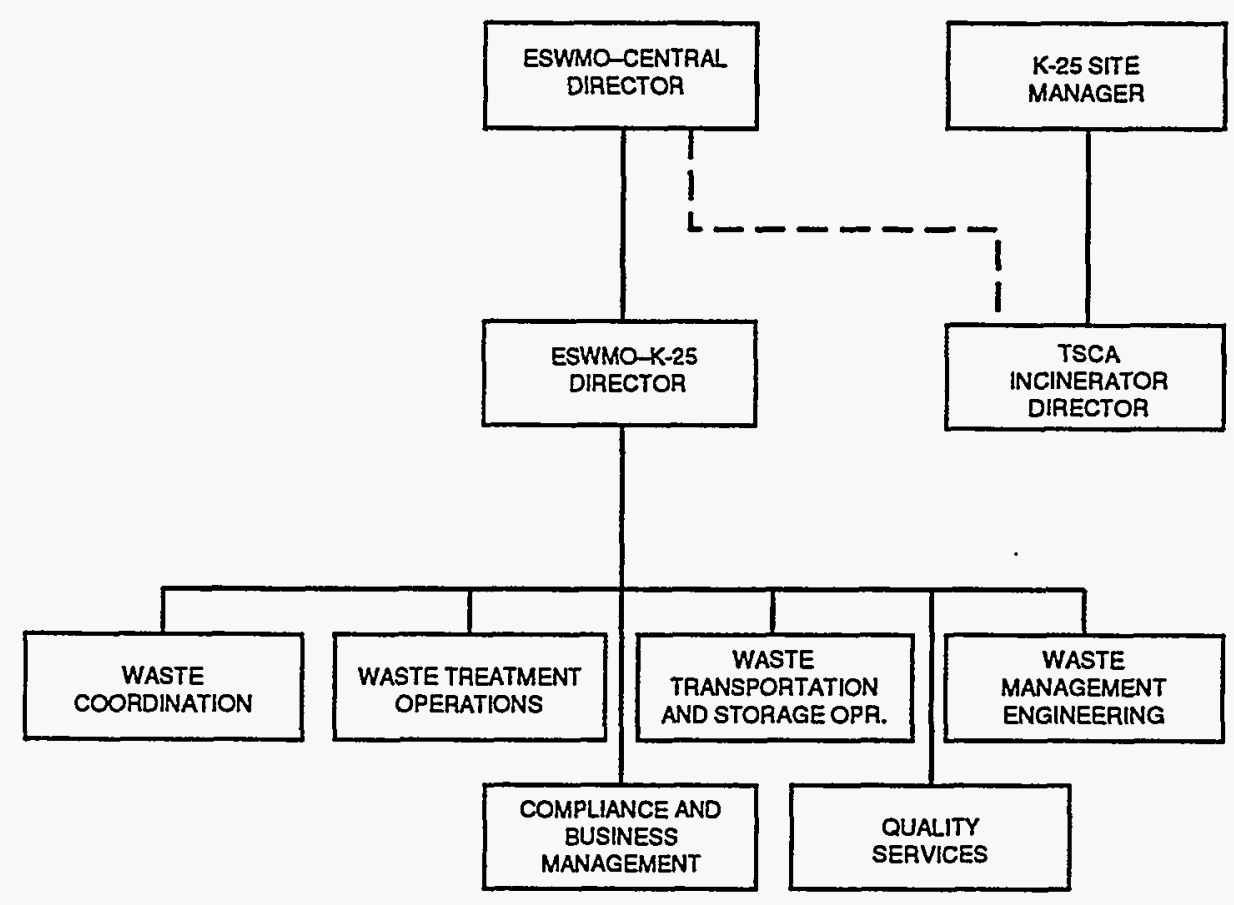

Fig. 2.11. Energy Systems Waste Management Organization at the Oak Ridge K-25 Site.

indicators; (8) lessons learned coordination;

(9) mission success guidance; and

(10) emergency drill and tabletop exercise coordination.

\section{TSCA Incinerator Division}

The TSCA Incinerator Division operates the TSCA Incinerator to provide treatment of mixed wastes generated and stored at DOE facilities in Oak Ridge, Kentucky, and Ohio. The facility works closely with ESWMO-K-25 on a daily basis in receiving waste transported by ESWMO-K-25. The TSCA Incinerator Division reports to the K-25 Site manager (Fig. 2.12). The TSCA Incinerator Division organization consists of one operating department (operations and maintenance) and a number of supporting departments including environmental air compliance, engineering and technical support, burn plan management, safety, environmental waste compliance, finance, business systems, computer networks and controls, and business administration and program assessment.

\section{Documentation Management}

Various documents have been developed to guide and to support the Waste Management Program at the Y-12 Plant, ORNL, and the K-25 Site (see Appendix A and Table 2.1).

\section{Y-12 Plant}

Record copies of Y-12 Plant procedures are maintained by the $\mathrm{Y}-12$ Plant Record Center. The Y-12 Plant Technical Library staff maintains record copies of publications and reports. Record copies of correspondence are the responsibility of either the author or 
ORNL-DWG 94M-13186R

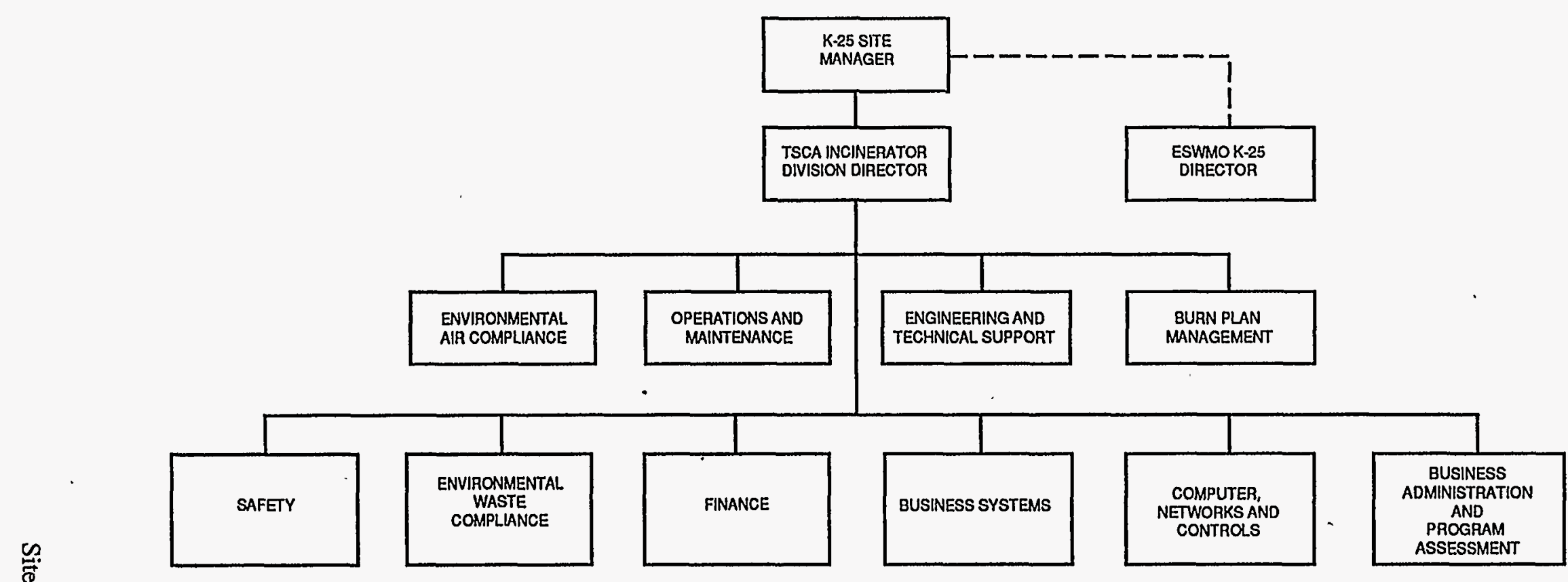

Fig. 2.12. Organizational chart for the Toxic Substances Control Act Incinerator Division. 
Table 2.1. Waste management Activity Data Sheets for FY 1995 and related regulatory drivers

\begin{tabular}{|c|c|}
\hline FY 1995 ADS & Regulatory driver \\
\hline \multicolumn{2}{|r|}{ Oak Ridge Y-12 Plant } \\
\hline 2101 & $\begin{array}{l}\text { Clean Water Act; Tennessee Water Quality Control Act (69-1030108); } \\
\text { Tennessee Waste Rule (1200-107); Solid Waste Management } \\
\text { Regulations }\end{array}$ \\
\hline 2102 & $\begin{array}{l}\text { Clean Water Act [Sects. 402, 301, 302, 304(1), and 307]; NPDES } \\
\text { permit TN0002968 }\end{array}$ \\
\hline 2103 & $\begin{array}{l}\text { Clean Water Act [Sects. 402, 301, 302, 304(1), and 307]; TDEC } \\
\text { (NPDES permit TN0002968) }\end{array}$ \\
\hline 2201 & $\begin{array}{l}\text { Clean Water Act [Sects. 402, 301, 302, 304(1), and 307]; DOE Order } \\
\text { 5820.2A; FFCA; RCRA (Tennessee Hazardous Waste Management } \\
\text { Rules (Chap. 1200-1-11); Tennessee Solid Waste Disposal Act as } \\
\text { amended and Rules Governing Solid Waste Processing and Disposal in } \\
\text { Tennessee; TSCA (Public Law 94-469) }\end{array}$ \\
\hline 2202 & $\begin{array}{l}\text { DOE Order 3820.2A; FFCA; RCRA (Tennessee Hazardous Waste } \\
\text { Management Rules (Chap. 1200-1011 and } 40 \text { CFR Pt. 261-268); } \\
\text { Tennessee Solid Waste Disposal Act as amended and Rules Governing } \\
\text { Solid Waste Processing and Disposal in Tennessee; TSCA (Public } \\
\text { Law 94-469) }\end{array}$ \\
\hline 2203 & $\begin{array}{l}\text { DOE Order 5820.2A (Chap. III); RCRA ( } 40 \text { CFR Pts. } 268.1 \text { and } \\
\text { 262.34); RCRA ( } 40 \text { CFR Pts. 268.1 and 262.34); Tennessee Hazardous } \\
\text { Waste Management Rules (Chap. 1200-1-11) }\end{array}$ \\
\hline 2204 & DOE Order 5400.1 (Chap. III); TDEC (Chap. 1200-1-7) \\
\hline 2205 & $\begin{array}{l}\text { NPDES permit TN0002968, pp. I-10, III-8, and III-9; Tennessee Water } \\
\text { Quality Control Act } 1200-4-3-.02(5)\end{array}$ \\
\hline 2206 & $\begin{array}{l}\text { Clean Water Act (Sect. 510); DOE Order 5820.2A; National Fire } \\
\text { Protection Association 1500; OSHA (29 CFR Pt. 1910); RCRA } \\
\text { (40 CFR Pt. 264); Tennessee 780-2-14 (fire protection equipment); } \\
\text { TSCA (Fire Protection 9720-58, 92-4) }\end{array}$ \\
\hline 2207 & $\begin{array}{l}\text { Clean Water Act [Sects. 402, 301, 302, 304(1), and 307); RCRA } \\
\text { (40 CFR 264); Tennessee Solid Waste Processing (120-1-1) }\end{array}$ \\
\hline 2208 & $\begin{array}{l}\text { Clean Water Act [Sects. } 402,301,302,304(1) \text {, and 307]; EPA ( } 40 \text { CFR } \\
\text { Pts. } 257 \text { and 258); RCRA (Subtitle D); Tennessee Solid Waste } \\
\text { Processing and Disposal Regulations (Chap. 1200-1-7) }\end{array}$ \\
\hline 2210 & $\begin{array}{l}\text { Clean Water Act ( } 40 \text { CFR Pt. 112.7); DOE Orders 5820.2A and } \\
\text { 5480.7A; OSHA (29 CFR Pt. 1910); RCRA ( } 40 \text { CFR Pts. } 264 \text { and 265); } \\
\text { Tennessee Department of Environment and Conservation 1200-1011; } \\
\text { Tennessee Hazardous Waste Management Regulations }\end{array}$ \\
\hline \multicolumn{2}{|r|}{ Oak Ridge National Laboratory } \\
\hline $\begin{array}{l}3101,3102,3201,3203,3204 \\
3206,3251,3252,3253, \text { and } \\
3254\end{array}$ & Federal Facility Agreement, Sect. IX and Appendix F \\
\hline $\begin{array}{l}3201,3204,3205,3207,3252 \\
3253, \text { and } 3255\end{array}$ & $\begin{array}{l}\text { National Pollutant Discharge Elimination System; Tenn. Rule 1200-4-5, } \\
\text { Water Pollution Control Regulations }\end{array}$ \\
\hline $\begin{array}{l}3201,3202,3203,3204,3205 \\
3207,3251,3252, \text { and } 3253\end{array}$ & $\begin{array}{l}\text { Federal Facility Compliance Agreement (FFCA) for National Emission } \\
\text { Standards for Hazardous Air Pollutants-Radionuclides; Resource } \\
\text { Conservation and Recovery Act (RCRA) Land Disposal Restrictions } \\
\text { FFCA; RCRA Part A and Part B permits; Tenn. Rule } 1200 \text { [1-11-.02; } \\
\text { 1-11-.02(3)(e); 1-11-.03(1)(b); 1-11-.05; 1-11-.06; 1-11-.07; 1-11-.10; } \\
\text { 1-15; 3-1 through 3-26, Air Pollution Control Regulations; and 4-1 } \\
\text { through 4-5, Water Pollution Control Regulations] }\end{array}$ \\
\hline
\end{tabular}


Table 2.1 (continued)

\begin{tabular}{|c|c|c|}
\hline \multicolumn{2}{|r|}{ FY 1995 ADS } & \multirow[t]{2}{*}{ Regulatory driver } \\
\hline & & \\
\hline 4201 & . & $\begin{array}{l}\text { NPDES permit TNO002950, outfalls } 011 \text { and } 014 \\
\text { DOE Orders } 5480.11 \text { and } 5820.2 \mathrm{~A} \\
\text { RCRA permit, incorporated state and federal regulations } \\
29 \text { CFR Pts. } 1910.120 \text { and } 1910.1001 \\
40 \text { CFR Pts. } 261 \text { and } 263 \\
49 \text { CFR Pts. } 171-179 \\
\text { Off-site shipment procedures } \\
\text { LDR FFCA }\end{array}$ \\
\hline 4207 & & $\begin{array}{l}\text { NPDES permit TN0002950, outfalls } 014 \text { and } 009 \\
\text { DOE Orders } 5820.2 \mathrm{~A} \text { and } 5480.11\end{array}$ \\
\hline 4206 & - & $\begin{array}{l}\text { DOE Orders } 4700.1 \text { and } 5820.2 \mathrm{~A} \\
40 \text { CFR Pt. } 264.175 \\
\text { RCRA permit } \\
40 \text { CFR Pt. } 765 \\
\text { NFPA standards } \\
\text { Waste Acceptance Criteria }\end{array}$ \\
\hline 4202 & ' & 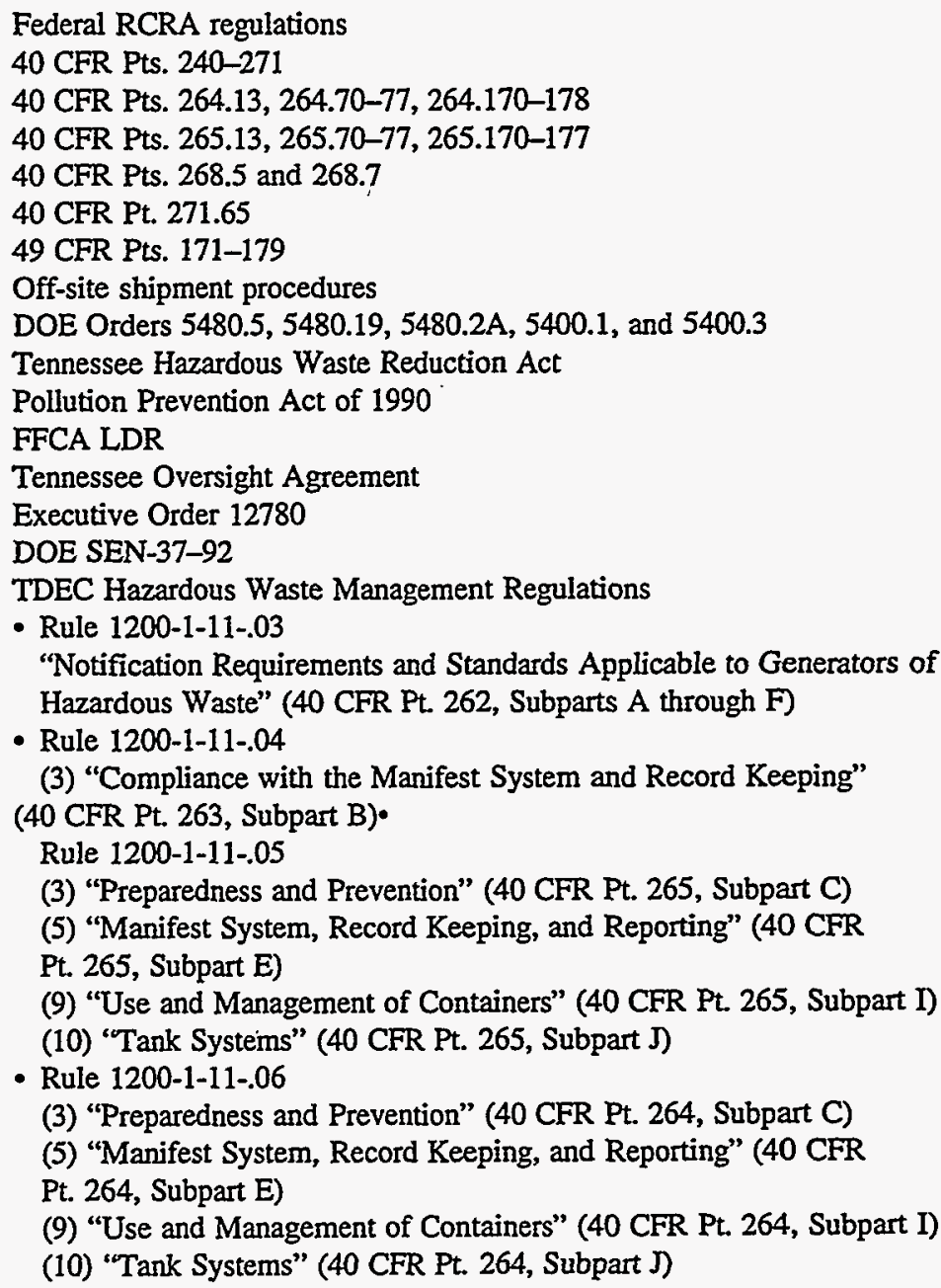 \\
\hline
\end{tabular}


Table 2.1 (continued)

\begin{tabular}{ll}
\hline FY 1995 ADS & Regulatory driver \\
\hline 4202 (continued) & TSCA Regulations and Reporting Requirements \\
- 40 CFR Pt. 704, "Recording Keeping Requirements" \\
- 40 CFR Pt. 710, "Inventory Reporting Regulations" \\
- 40 CFR Pt. 716, "Health and Safety Data Reporting" \\
SARA Regulations and Reporting Requirements \\
- 40 CFR Pt. 355, "Emergency Planning and Notification" \\
- 40 CFR Pt. 370, "Hazardous Chemical Reporting; Community Right- \\
to-Know" \\
- 40 CFR Pt. 372, "Toxic Chemical Release Reporting; Community \\
Right-to-Know" . \\
DOE Order 5820.2A, Radioactive Waste Management, Chap. III \\
DOE Order 5400.1C, General Environmental Protection Program, \\
Chap. II \\
DOE Order 5633.3, Control and Accountability of Nuclear Materials, \\
Chap. II \\
DOE Order 1324.2A, Records Disposition \\
ANSUASME NQA-1 (DOE Order 5700.6) \\
DOE Order 6430.1A
\end{tabular}

recipient of the correspondence. Guidelines for control of ESWMO-Y-12 quality records have been published (Y-12 WMD March 1993).

\section{ORNL}

At ORNL the Document Management Center (DMC) maintains quality records for the ORNL waste management operations departments (among others) by use of the Document Management System, which was conceived, designed, and configured by the DMC to meet DOE Order 5700.6C requirements for document control and quality records. The scope, requirements, and user guidelines of this QA-based system operation have been published (WMRAD July 31,1991 ). The identification of documentation to be managed is the responsibility of the division head, department heads, or their designee(s). These documents may be identified in a documentation plan and/or a QA Plan.

\section{K-25 Site}

At the K-25 Site waste management documents, including a copy of all waste management procedures, are maintained in the ESWMO-K-25 Document Center in Building K-1400. All applicable documents impacting the Waste Management Program have been reviewed and are identified in a published document (K-25 WMD May 1992).

\section{TSCA Incinerator}

All TSCA Incinerator documentation, including TSCA procedures, is maintained in the TSCA Reasource Center located in Building K-1430-A. Guidelines for control of TSCA documents have been published (TSCAID June 14, 1993).

\section{References}

K-25 WMD (K-25 Site Waste Management Division) May 1992. Compliance Protocols for the K-25 Site Waste Management Program, K/WD-19, rev. 0, Martin Marietta Energy Systems.

Solomon, D. K., et al. 1992. Status Report-A Hydrologic Framework for the Oak Ridge Reservation, 
ORNL/TM-12026, Martin Marietta

Energy Systems, Oak Ridge Natl. Lab.

TSCAID (TSCA Incinerator Division)

June 14, 1993. Document Control

Systems, TSCA-AP-170, Martin

Marietta Energy Systems, Oak Ridge

K-25 Plant.

WMRAD (ORNL Waste Management and

Remedial Action Division) July 31,
1991. Documentation Management

System Users Guide, WMRA-

DMC-102, Martin Marietta Energy

Systems.

Y-12 WMD (Y-12 Plant Waste

Management Division) March 1993.

WMD\&D Quality Assurance Plan, QAP-Y-92-WMD-001, Martin Marietta

Energy Systems. 



\section{Spent Nuclear Fuel}

Spent Nuclear Fuel (SNF) is defined as fuel that has been withdrawn from a nuclear reactor following irradiation, the constituent elements of which have not been separated or chemically processed. SNF also includes irradiated target material, blanket subassemblies, pieces of fuel, and fuel debris.

The mission of the Oak Ridge Reservation (ORR) SNF Program is safe, reliable, and efficient management of SNF stored on the ORR and preparation of it for disposition. This plan (1) outlines how this program will achieve increased safety, reduced vulnerabilities, protection of the environment, nonproliferation, and reduced costs for storage and (2) addresses interim storage of SNF based on the alternatives and options discussed in the Programmatic Draft Environmental Impact Statement (PDEIS) on SNF Management (DOE June 1994). This PDEIS discusses five alternatives: no action, decentralization, 1992/1993 planning basis, regionalization (with two options), and centralization (with five options). Although hybrid alternatives may emerge, it is the goal of this plan to identify the planned approaches for interim storage of SNF on the ORR until the Record of Decision for the PDEIS can be fully implemented.

At present, SNF is stored in a variety of different facilities, including underground retrievable dry-storage units, above-grade buildings, hot cells, and wet storage basins. On-site transportation of some of the SNF is feasible with current equipment; however, off-site transportation and some on-site transportation will require lease or procurement of shipping cask(s) licensed and certified by the U.S. Nuclear Regulatory Commission (NRC). Oak Ridge National Laboratory has procured one General Electric Model 2000 cask licensed for transport of High Flux Isotope Reactor (HFIR) fuel; delivery is expected late in 1994.

\section{Management Strategy}

The ORR SNF Program will develop and implement the resources and plans to ensure safe storage and handling of SNF now located on the ORR. This program should (1) provide interim storage and management of SNF on the ORR until a facility is available for disposition of the fuel, (2) stabilize the fuel as required for environmentally safe storage and protection of human health of both the public and workers, (3) ensure safe storage of SNF by replacing or modifying facilities that cannot meet current standards and provide safe storage of newly generated SNF, and (4) examine and characterize SNF as necessary to meet the requirements of safe storage.

In completing this mission, the ORR SNF Program, while working with stakeholders, will protect the environment and the health and safety of the public and workers while fully complying with applicable federal, State, and local laws, orders, and regulations. This program is currently addressing many unresolved issues and concerns. Many of these unresolved issues will be settled over the next few years, the most important of 
which is how and where SNF will be managed while awaiting the opening of a permanent geologic repository.

In 1993 the U.S. Department of Energy (DOE) conducted a vulnerability assessment of SNF storage facilities throughout the DOE Complex. The DOE review identified six health and safety vulnerabilities on the ORR; actions to resolve these are either complete or on schedule (U.S. DOE September 1994a). Additionally, methods for consolidating and improving the present SNF storage facilities are presented in this plan. Consolidation of SNF will help to reduce surveillance and maintenance costs and allow for deactivation of some facilities now used for storing SNF. Other facilities, such as the dry-storage facilities, will be modified to improve the capability to store SNF safely and to protect the environment.

Additional efforts will focus on transferring some of the SNF inventory [i.e., from the Oak Ridge Research Reactor (ORR), the Tower Shielding Reactor (TSR), and the Bulk Shielding Reactor (BSR)], together with some HFIR fuel, to the Savannah River Site (SRS) if allowed under the Record of Decision for the PDEIS. Transferring this fuel to SRS will help in consolidation of fuel, allow decontamination of some facilities, and provide the necessary storage space to allow HFIR to continue operating. Additional ORR storage will be needed regardless of the alternative selected in the Record of Decision for the PDEIS. New storage facilities are required to address vulnerabilities, to maintain safe and environmentally acceptable storage conditions, and to continue HFIR operation until either the central or regional facility or a geologic repository facility is available and transportation to these facilities is ensured.

\section{Current Generation and Projections}

Total inventory at ORNL consists of approximately $0.94 \mathrm{t}$ (1.03 ton) of initial heavy metal. HFIR is discharging additional SNF at the rate of about $120 \mathrm{~kg}$ $(264.6 \mathrm{lb})$ of heavy metal per year. By the year 2000, an additional amount of approximately $1 \mathrm{t}$ (1.10 ton) of initial heavy metal will be added to the SNF inventory owing to HFIR operation.

The Advanced Neutron Source (ANS) reactor may be expected to be operational after the year 2004 and would begin shipping cores to storage after several years of storage at the reactor. Storage of these spent reactor cores will be addressed in the Environmental Impact Statement for the ANS Project.

\section{Treatment}

Although no facilities currently exist on the ORR for treatment of SNF, facilities at ORNL such as Building 3525 (whose original mission was development and examination of nuclear fuel) are expected to be usable for examination, repackaging, and characterization of SNF. Depending on the alternatives selected in the Record of Decision for the PDEIS, treatment facilities for SNF could be located on the ORR.

\section{Storage}

At present, 13 facilities are used for storage of SNF on the ORR (see

Table 3.1). Homogeneous Reactor Experiment liquid fuel waste was poured into auger holes. If the current definition of SNF changes, facilities may need to be added (or removed) from this table. Also, 50 fuel assemblies are present in the HFIR pool, which has the capability to store 9 additional assemblies (93 additional when the pool is reracked). The BSR pool has 
Table 3.1. Spent nuclear fucl data on the Oak Ridge Reservation: inventories and capacities

\begin{tabular}{|c|c|c|c|c|c|}
\hline Facility & Waste type & $\begin{array}{l}\text { Heavy metal } \\
\mathrm{kg}(\mathrm{lb})\end{array}$ & Material owner & $\begin{array}{l}\text { Available capacity } \\
\text { (positions) }\end{array}$ & $\begin{array}{l}\text { Present inventory } \\
\text { (positions occupied) }\end{array}$ \\
\hline $\begin{array}{l}\text { High Flux Isotope } \\
\text { Reactor (HFIR) pool, } \\
\text { Building } 7900\end{array}$ & HFIR fuel & $505(1113)$ & DOE-DP & $\begin{array}{l}59 \text { currently, } \\
143 \text { after reracking }\end{array}$ & 50 \\
\hline $\begin{array}{l}\text { Bulk Shielding Reactor } \\
\text { (BSR) pool, Bldg. } 3010\end{array}$ & $\begin{array}{l}\text { BSR and Oak Ridge Reactor } \\
\text { (ORR) fuel }\end{array}$ & $59(130)$ & $\begin{array}{l}\text { DOE-DP (BSR) and } \\
\text { DOE-NE (ORR) }\end{array}$ & $\begin{array}{l}90 \text { plus } 27.8 \mathrm{~m}^{2} \\
\left(300 \mathrm{ft}^{2}\right) \\
\text { floor space }\end{array}$ & 73 \\
\hline $\begin{array}{l}\text { Molten Salt Reactor } \\
\text { Experiment (MSRE), } \\
\text { Building } 7503\end{array}$ & MSRE fuel & $37(82)$ & DOE-EM & $a$ & $a$ \\
\hline Building 4501 & $\begin{array}{l}\text { Misc. light-water reactor } \\
\text { fuels }\end{array}$ & $7(15)$ & NRC & $a$ & $a$ \\
\hline $\begin{array}{l}\text { Building } 9720-5 \text { vault, } \\
\text { Y-12 Plant }\end{array}$ & $\begin{array}{l}\text { Health Physics Research } \\
\text { Reactor fuel, SNAP-10A } \\
\text { and DOE demo reactors }\end{array}$ & $191(421)$ & DOE-DP & $a$ & $a$ \\
\hline $\begin{array}{l}\text { Tower Shielding } \\
\text { Reactor (TSR) }\end{array}$ & TSR fuel & $9(20)$ & DOE-DP & $a$ & $a$ \\
\hline Building 7823A & Misc. fuels & $1(2)$ & DOE-EM & $a$ & $a$ \\
\hline Building 7827 & Misc. fuels & 85 (187) & DOE-EM & $a$ & $a$ \\
\hline Building 7829 & Peach Bottom fuels & $10(22)$ & DOE-EM & $a$ & $a$ \\
\hline Building 7920 & Dresden-1 fuel & $5(11)$ & DOE-ER & $a$ & $a$ \\
\hline Building 3525 & Misc. fuels & $0.1(0.2)$ & DOE-NE & $a$ & $a$ \\
\hline Waste Area Grouping 7 & $\begin{array}{l}\text { Homogeneous } \\
\text { Reactor Experiment fuel }{ }^{b}\end{array}$ & $3(6)$ & DOE-EM & $a$ & $a$ \\
\hline Solid Waste Storage Area 6 & $\begin{array}{l}\text { KEMA Suspension Test } \\
\text { Reactor fuel }\end{array}$ & $23(51)$ & DOE-EM & $a$ & $a$ \\
\hline
\end{tabular}

${ }^{\sigma}$ Facility unavailable for any future SNP storage.

${ }^{b}$ Not stored; Homogeneous Reactor Experiment fuel is disposed of in auger holes. 
41 BSR and 32 Oak Ridge Research Reactor elements in storage and 17 more positions available-in addition to $27.8 \mathrm{~m}^{2}$ $\left(300 \mathrm{ft}^{2}\right)$ of unoccupied space. However, because of safety documentation and equipment constraints, the unoccupied space and the 17 positions are not currently usable. Seven of the Solid Waste Storage Area (SWSA) 5 North ( $5 \mathrm{~N}$ ) underground dry-storage units are empty although one unit has been found to contain water and another has been found to contain moist sand. These two dry-storage units are therefore not available for additional storage. The remainder of the existing SNF storage facilities are considered unavailable for future SNF storage. These facilities either have no additional storage capacity, are scheduled to be shut down, or are governed by institutional controls that prevent storage of additional material at the facility.

The HFIR vessel and SNF storage facilities are located in a storage basin with three water-filled sections that have current capacity for a total of 59 fuel assemblies. The HFIR fuel assemblies, constructed primarily of aluminum plates, consist of an inner element surrounded by an outer element. Each fuel assembly is stored within a stainless-steel-clad cadmium shroud. The fuel assemblies in the pool are intact and not leaking. Signs of corrosion are visible on two older assemblies. A thin layer of flocculent is on the bottom of the pool as well as europium contamination from a leaking control cylinder. $\quad=$

Reracking of the storage pool at HFIR to provide additional storage positions is now under way. The multitier, closepacked storage array will be installed in phases in the center and east sections of the pool. This will provide storage space for the SNF expected to be generated by HFIR through at least the year 2000 (DOE September 1994b).

The BSR pool contains 73 SNF elements in three fuel storage racks. The elements are from the BSR and Oak Ridge Research Reactor reactors and appear to be intact and not leaking. The pool's demineralizer system needs new resin but is functional. Water quality is maintained by feeding and bleeding the pool. A slight buildup of contaminants is present in the pool. The pool has a surface skimmer with a filtration system and is vacuumed periodically. The pool was also cleaned during liner installation in the early 1980s.

The MSRE fuel was drained into storage tanks in the drain tank cell at the facility when the experiment was concluded in 1969. The fuel was a eutectic mixture of lithium and beryllium fluorides containing uranium fluoride as the fuel and zirconium fluoride as a chemical stabilizer. The fuel is solidified in the tank system. Some fuel has migrated into the associated piping past the auxiliary charcoal bed. Because of the nature of this problem, a special team has been formed to identify the causes and appropriate corrective actions. Interim measures are planned to place the MSRE facility in a safer mode while the actions to remove the fuel salts are being planned and implemented.

Four $1.8 \times 2.4 \mathrm{~m}(6 \times 8 \mathrm{ft})$ hot cells located in Room 125 are used for handling radioactive material and storing SNF.

Room 125 contains an under-floor cavity with a total of 59 storage positions, each $20.3 \mathrm{~cm}(8 \mathrm{in}$.) in diam $\times 0.91 \mathrm{~m} \mathrm{(3 \textrm {ft } )}$ tall. Items may be inserted into, or withdrawn from, storage via lead-shielded, bottom-loading transfer casks. The capacity of the overhead crane, however, limits such handling to transfer casks of no more than $1814 \mathrm{~kg}(4000 \mathrm{lb})$. This facility has no capability for long-term storage or handling of SNF; neither does it have any other highly radioactive material requiring transfer casks greater than $1814 \mathrm{~kg}$ (4000 lb). Material currently stored at this facility will be moved to another existing or modified storage facility when space is available.

Building 9720-5 at the Oak Ridge Y-12 Plant houses the fissile components of the Health Physics Research Reactor (HPRR), a DOE Demonstration Reactor, 
and the SNAP-10A Reactor. Building 9720-5 is used to store highly enriched uranium under the sponsorship of DOE-DP. Because this material is not self-protecting, movement from the $\mathrm{Y}-12$ Plant would require significant coordination with safeguards and security as well as transportation personnel. The coolant and the fuel-moderator mixture of the SNAP-10A Reactor are pyrophoric and will require special environmental controls or stabilization for long-term storage. This material will require continuous surveillance.

Operations at the TSR were terminated in October 1992. The fuel is highly enriched aluminum-uranium plates assembled in a spherical shape. At present, approximately $56 \mathrm{~kg}(121 \mathrm{lb})$ of uranium is stored in the reactor.

Facility 7827 was built in two phases. A total of 54 storage positions are located below grade. Currently, five storage positions are empty. The first section of the facility, constructed in 1976, consists of an array of three rows, ten wells per row. The outer two rows consist of alternating 76.2and 20.3-cm-diam (30-in. and 8-in.) storage positions. The middle row consists of 40.6-cm-diam (16-in.) storage positions. The first five positions of all three rows are $3 \mathrm{~m}$ (10 ft) deep; the remaining five positions in each row are $4.6 \mathrm{~m}(15 \mathrm{ft})$ deep. The second phase, constructed in 1978 , consists of an array of four rows, six positions per row, all $20.3 \mathrm{~cm}$ (8 in.) in diam and $4.6 \mathrm{~m}$ (15 ft) deep. The facility currently contains $85 \mathrm{~kg}(187 \mathrm{lb})$ of heavy metal in miscellaneous fuels. An expensefunded project is planned for FYs 1995 and 1996 to install additional liners in each storage position in Facility 7822 to provide improved containment.

Facility 7829 contains ten storage positions, two of which are currently empty. All are $30.5 \mathrm{~cm}$ (12 in.) in diam and $4.6 \mathrm{~m}$ (15 ft) deep. This facility was constructed in 1978 to store Peach Bottom fuel elements and components. The facility currently contains about $10 \mathrm{~kg}(22 \mathrm{lb})$ of heavy metal in fuel.

Facility $7823 \mathrm{~A}$ consists of eight stainless-steel storage positions measuring from 35.6 to $50.8 \mathrm{~cm}$ (14 to $20 \mathrm{in}$.) in diam and $3 \mathrm{~m}(10 \mathrm{ft})$ deep. Each liner was fabricated of stainless steel and contained within an auger hole. The annular space between the liner and auger hole is filled with earth up to the existing grade, and a concrete collar surrounds the top. The concrete collar provides shielding and also serves to lock each liner in place (each liner has protrusions on the side), which prevents floating if groundwater were to saturate the area. The materials were placed in drums or small stainless steel capsules, such as 15.2-cm-diam (6-in.) tubes, that were lowered into the positions and backfilled with sand. Retrievable wires were left in, and the liner was covered with either a steel or concrete lid. These wells, used from 1972 to 1975, are currently closed to further storage. The facility currently contains about $1 \mathrm{~kg}(2.2 \mathrm{lb})$ of heavy metal in fuel.

Building 7920 of the Radiochemical Engineering Development Center is a multipurpose hot cell facility with the equipment, shielding, and containment provisions to process and to store large quantities of highly radioactive elements safely. The facility was specifically built to prepare and to process targets that are irradiated in HFIR to produce heavy actinide elements (i.e., berkelium, californium, einsteinium, and fermium). However, other irradiated materials, including irradiated targets and fuels from commercial reactors and the SRS reactors, have also been processed for other DOE projects. The facility includes nine heavily shielded hot cells containing nine processing cubicles $2 \times 2 \times 2.6 \mathrm{~m}$ $(7 \times 7 \times 8.5 \mathrm{ft})$ and eight tank pits [seven that are $2.7 \times 2 \times 6 \mathrm{~m}(9 \times 7 \times 20 \mathrm{ft})$ and one that is $2.6 \times 4.8 \times 3.7 \mathrm{~m}$ $(8.5 \times 15.7 \times 12 \mathrm{ft})]$. The cubicles contain the major processing equipment (e.g., valves, pumps, sampling stations, ion 
exchange columns), which may be viewed through 1.4-m-thick (4.5-ft) shielding windows. This equipment may be remotely operated and remotely maintained. Typical chemical operations include dissolution, solvent extraction, ion exchange, absorption, evaporation, and precipitation. The building features double containment that is ventilated through separate fans and high-efficiency particulate air (HEPA) filter systems with complete backup systems. The small quantity of SNF in this facility is currently in dry storage and is expected to be consolidated with other ORR SNF in the SWSA $5 \mathrm{~N}$ storage facility.

The hot cells in Building 3525 were constructed of $0.91-\mathrm{m}$-thick ( $3-\mathrm{ft}$ ) concrete walls and compatible-oil-filled, lead-glass viewing windows forming an essentially leak-tight barrier. The inside surfaces of the cell banks are lined with stainless steel to provide containment of particulate matter and to facilitate decontamination. Special penetrations are provided for the sealed entry of services, such as instrument lines, lights, water, etc. A pair of remote-controlled manipulators is located at each of 15 window stations for remote cell operations. Heavy objects within each cell bank are moved by electromechanical manipulators and a 2.7-t (3-ton) crane. Radioactive materials enter and leave the cells through three shielded transfer stations provided at the rear face of the North Cell. Two small-diameter [16.5- and 36.8-cm (6.5- and 14.5-in.)] horizontal transfer stations are used for small objects. Items up to $1.2 \times 1.2 \times 1.8 \mathrm{~m}$ $(4 \times 4 \times 6 \mathrm{ft})$ are transferred through the shielded air-lock door system. Currently installed equipment in the cells includes metallography equipment, such as metal cutting saws, guides, polishers, and micro-hardness testers; gamma-scanning equipment; shielded electron microscopes; and related items for remote mechanical disassembly of experiment capsules and physical examination of fuel elements and irradiated materials.
A decontamination cell and storage cell, located on the second floor of the building, are connected (via hatches) to the cells below. A maintenance area, incorporating "glove-wall" and "glove-box" facilities for servicing equipment items, adjoins the decontamination cell. Sliding doors separate the decontamination cell, storage cell, and glove maintenance room, and a remote crane system provides for retrieval of equipment items into, and transfer between, these second-floor facilities. Only surface-contaminated pieces of equipment are routinely removed from the cells into the second-floor facilities, but irradiated materials may also be transferred between cells through the second-floor pathway. An upper level of the second floor houses ventilation system ducts, control valves, HEPA filters, heat exchangers, and air inlets for the equipment storage area, the decontamination area, and the glove maintenance area.

The "processes" performed in the facility consist of receipt and handling of irradiated materials (fuel or nonfuel) in shielded casks, transfer of material into and out of the hot cells, disassembly, nondestructive and destructive testing of irradiated materials, packaging and shipment of irradiated materials (on-site or off-site), waste packaging for disposal, maintenance of remote equipment, and decontamination of the facility and equipment. Examination and testing activities include metrology; metallographic sample preparation by sectioning, grinding, and polishing; optical and electron microscopy; mass spectrometry of fission gases; gamma spectrometry; and other physical properties evaluations as appropriate to the experimental objectives of a particular program.

The very small.quantity of SNF in this facility is expected to be stored with other ORR SNF at the SWSA 5N dry-storage facilities. Building 3525 is a candidate for use in examining, repackaging, or 
characterizing fuel currently stored in various ORR locations.

\section{Disposal}

At present, no active disposal facilities for SNF exist on, or are planned for, the ORR. In the past, the Homogeneous Reactor Experiment fuel was disposed of in auger holes at Waste Area Group 7. KEMA Suspension Test Reactor fuel was disposed of in SWSA 6.

\section{Future Plans}

The current SNF storage facilities on the ORR have very limited additional capacity. Some modifications, revision of safety documentation, and completion of additional National Environmental Policy Act documentation might allow an increase in the capacity of the BSR pool. However, this additional space would also be limited and would not be dry storage. Existing capacity in SWSA $5 \mathrm{~N}$ storage facilities will be utilized to consolidate miscellaneous SNF that is located in ,various facilities; however, the capacity to store HFIR, BSR, Oak Ridge Research Reactor, or TSR SNF in these facilities is insufficient.

\section{Storage}

\section{Funded Construction, Upgrades, Reracking, and Related SNF Facilities}

The only SNF currently being generated on the ORR is from HFIR. Approximately one fuel assembly per month is generated and stored in the HFIR SNF pool. The other reactors (i.e., BSR, Oak Ridge Research Reactor, TSR, and HPRR) are shut down, and standby maintenance is being performed on the storage pools at BSR and TSR. The storage capacity of the HFIR pool is being increased through the installation of additional storage racks. The new close-packed, multitier array will enable the pool to accommodate more fuel assemblies. Installation of the new rack is now under way.

The HFIR organization has purchased a shipping cask to handle HFIR fuel assemblies. An amended license has been obtained from the NRC to allow shipment of the HFIR SNF in the cask (GE Model 2000). The cask, expected to be placed in service early in FY 1995, will be used to ship HFIR spent fuel assemblies to the Receiving Basin for Off-site Fuels Facility at the SRS (when allowed by DOE Headquarters and the Record of Decision for the PDEIS).

The BSR and Oak Ridge Research Reactor elements are in interim storage in the BSR pool. The TSR fuel remains in the reactor. Action is under way to obtain an amended NRC certificate for the HFIR cask to permit the fuel from BSR, Oak Ridge Research Reactor, and TSR to be shipped to SRS. The BSR pool and the TSR are in normal surveillance and maintenance. No fuel remains at the HPRR building. The HPRR fuel was so lightly irradiated that it must be safeguarded and is currently stored in Building 9720-5 at the Y-12 Plant.

The MSRE fuel has been identified as a vulnerability owing to migration of radioactive materials into piping associated with the fuel storage tanks at the MSRE Facility. Interim measures are currently under way to place the MSRE Facility into a safer shutdown mode while options for removal and storage of the MSRE fuel are evaluated and a method is selected and implemented.

Three dry-storage facilities (i.e., Buildings 7823A, 7827, 7829) in SWSA $5 \mathrm{~N}$ were identified as a vulnerability because of the potential for corrosion failure of the stainless steel liners and consequent potential for release of contamination to the environment. During surveillance water was found in one empty dry-storage position; moist sand, in 
another. An action plan has been issued that documents the activities to identify the cause of the problem and the actions planned to modify the facility to ensure safe existing storage. Table 3.2 lists the short-term storage plans for all SNF currently on the ORR.

\section{Planned New Facilities: Storage, Characterization, and Fuel Conditioning}

Currently, SNF and other associated materials are stored in various locations on the ORR. HFIR is generating additional SNF. In addition, many of the current storage facilities are not in a condition that would permit safe continued storage for extended periods of time. New storage capacity is planned on the ORR to consolidate fuel and to provide safe interim storage until a disposition location is available for the SNF. The ANS is planned as a new reactor that would begin to generate SNF in 2004. DOE is preparing an Environmental Assessment to evaluate shipping SNF from General Atomic Company to another DOE site such as the ORR for storage.

Evaluations are currently under way to determine the requirements for interim storage of SNF on the ORR. Different types of storage capability may be required for the different SNF types. The capacity of any new storage facility will partly depend on whether any of the SNF currently stored on the ORR can be shipped to SRS or other sites. On the basis of these determinations, new storage for SNF on the ORR will be proposed.

Table 3.2. Short-term storage plan for spent nuclear fuel on the Oak Ridge Reservation

\begin{tabular}{|c|c|}
\hline Location & Plan \\
\hline Bulk Shielding Reactor (BSR) & $\begin{array}{l}\text { Fuel will remain in the BSR pool until transferred to a long-term } \\
\text { interim storage facility }\end{array}$ \\
\hline $\begin{array}{l}\text { Dry-storage at Buildings } 7823 \mathrm{~A} \text {, } \\
7827 \text {, and } 7829\end{array}$ & $\begin{array}{l}\text { Fuel will be stored in existing storage positions at Solid Waste } \\
\text { Storage Area (SWSA) } 5 \mathrm{~N} \text { following modification to prevent } \\
\text { water intrusion }\end{array}$ \\
\hline Tower Shielding Reactor & $\begin{array}{l}\text { Fuel will remain at this facility until transferred to a long-term } \\
\text { interim storage facility. }\end{array}$ \\
\hline Building 3525 & $\begin{array}{l}\text { Fuel will be transferred to dry storage at SWSA } 5 \mathrm{~N} \text { following } \\
\text { modification }\end{array}$ \\
\hline Building 4501 & $\begin{array}{l}\text { Fuel will be transferred to dry storage at SWSA } 5 N \text { following } \\
\text { modification }\end{array}$ \\
\hline Building 7920 & $\begin{array}{l}\text { Fuel will be transferred to dry storage at SWSA } 5 \mathrm{~N} \text { following } \\
\text { modification }\end{array}$ \\
\hline $\begin{array}{l}\text { High Flux Isotope Reactor } \\
\text { (HFIR) }\end{array}$ & $\begin{array}{l}\text { The HFIR storage pool will be reracked to allow for additional } \\
\text { storage. Spent nuclear fuel will be periodically transferred } \\
\text { to the Savannah River Site or to a modular dry-storage facility }\end{array}$ \\
\hline $\begin{array}{l}\text { SNAP-10A Reactor } \\
\text { (Building 9720-5) }\end{array}$ & $\begin{array}{l}\text { Fuel and coolant may present a fire/reaction hazard at the present } \\
\text { storage facility. Fuel will be stabilized and transferred to a } \\
\text { storage facility }\end{array}$ \\
\hline $\begin{array}{l}\text { Health Physics Research Reactor } \\
\text { (Building 9720-5) }\end{array}$ & $\begin{array}{l}\text { Fuel will remain at this facility until transferred for other } \\
\text { use or to a long-term interim storage facility }\end{array}$ \\
\hline Demo reactor (Building 9720-5) & $\begin{array}{l}\text { Fuel will remain at this facility until transferred to a } \\
\text { long-term interim storage facility }\end{array}$ \\
\hline Molten Salt Reactor Experiment & Fuel will be stabilized to alleviate health and safety concerns \\
\hline
\end{tabular}


Conditioning and characterization requirements for SNF on the ORR are being evaluated at this time. Some fuels, such as the SNAP-10A Reactor and MSRE, are expected to need additional conditioning and stabilization. Other fuels may require additional characterization or verification to meet current quality assurance requirements. Existing hot cell facilities are expected to be upgraded for use in examining, repackaging, and characterizing SNF for storage (if required).

\section{Alternatives Under the PDEIS}

The PDEIS outlines five different alternatives, some of which have options. Table 3.3 presents the storage options and plans for the SNF stored in each facility under each of the PDEIS alternatives. Each alternative is briefly discussed in the subsections that follow. Each option is discussed separately in this plan. However, depending on the option selected by DOE in the Record of Decision that will be released in June 1995, additional facilities may be needed on the ORR to store SNF, to mitigate health and safety vulnerabilities, and to continue operation of HFIR until the SNF is transferred to other sites for either interim storage or for disposition.

\section{Alternative 1 - No Action}

The No-Action Alternative is restricted to the minimum actions necessary for the continued safe and secure management of SNF. As defined, this altemative stipulates no SNF shipments to or from DOE facilities will occur. Although SNF is generated and stored on the ORR as a result of reactor research activities, SNF is not received from off-site generators except occasionally in small quantities for specific research assignments. No off-site SNF would be shipped to the ORR under this alternative, nor would SNF be shipped off-site. These actions would affect the planned shipment of HFIR SNF to the SRS. SNF storage capacity for HFIR would have to be increased to allow continued HFIR operation.

Some SNF is also stored in dry storage facilities on the ORR; these must be upgraded to meet current standards. If the dry-storage facilities now used on the ORR are not upgraded, then the SNF must be relocated to a new dry-storage facility. Aluminum-clad SNF is also stored in the BSR and HFIR pools. These aluminum-clad fuels should be relocated to a dry-storage facility in the near term to slow cladding degradation.

\section{Alternative 2 - Decentralization}

The Decentralization Alternative would allow ORR facilities to be upgraded and/or replaced for management of SNF currently located on-site. This alternative would allow for continued operation of HFIR by allowing new dry-storage facilities for SNF that is currently located in the HFIR pool. To allow HFIR to continue operations until a dry-storage facility is available, a dry-storage cask may be acquired, or some limited shipments of HFIR fuel to SRS may be pursued. An interim, retrievable, aboveground, drystorage facility for consolidating the SNF on the ORR would be proposed. Facilities can also be prepared as necessary on the ORR for characterization and packaging of SNF for interim storage. The fuel in the MSRE and the SNAP-10A Reactor would need conditioning and stabilization before being relocated to the new facility, or the MSRE and SNAP-10A fuels would need special storage facilities.

\section{Alternative 3 - 1992/1993 Planning Basis}

The 1993/1993 Planning Basis Alternative is DOE's documented 1992/1993 plan for management of SNF from DOE and the U.S. Navy. At Oak Ridge, this alternative would be very 
Table 3.3. Long-term Interim storage options for spent nuclear fuel on the Oak Ridge Reservation

\begin{tabular}{|c|c|c|c|c|c|c|c|}
\hline Current location & $\begin{array}{l}\text { Alternative } 1 \\
\text { No Action }\end{array}$ & $\begin{array}{c}\text { Altemative } 2 \\
\text { Decentralization }\end{array}$ & $\begin{array}{l}\text { Alternative } 3 \\
92 / 93 \text { Plan }\end{array}$ & $\begin{array}{c}\text { Altemative } 4 \\
\text { Option A } \\
\text { Regionalization }\end{array}$ & $\begin{array}{c}\text { Alternative } 4 \\
\text { Option B } \\
\text { Regionalization }\end{array}$ & $\begin{array}{l}\text { Altemative 5 } \\
\text { Options A-C, B } \\
\text { Centralization }\end{array}$ & $\begin{array}{l}\text { Altemative } 5 \\
\text { Option D } \\
\text { Centralization }\end{array}$ \\
\hline $\begin{array}{l}\text { Bulk Shielding } \\
\text { Reactor }\end{array}$ & $\begin{array}{l}\text { Fuel will be } \\
\text { transferred to dry } \\
\text { storage wilhin } 10 \text { to } \\
15 \text { years due to } \\
\text { aluminum cladding } \\
\text { degradation }\end{array}$ & $\begin{array}{l}\text { Fuel will be } \\
\text { transferred to the } \\
\text { Oak Ridge interim } \\
\text { dry-storage facility }\end{array}$ & $\begin{array}{l}\text { Fuel will be } \\
\text { transferred to the } \\
\text { Savannah River Site } \\
\text { (SRS) interim } \\
\text { storage facility }\end{array}$ & $\begin{array}{l}\text { Fuel will be } \\
\text { transferred to the } \\
\text { SRS regional } \\
\text { interim storage } \\
\text { facility }\end{array}$ & $\begin{array}{l}\text { Fuel will be } \\
\text { transferred to the } \\
\text { Oak Ridge regional } \\
\text { interim dry-storage } \\
\text { facility }\end{array}$ & $\begin{array}{l}\text { Fuel will be } \\
\text { transferred to the } \\
\text { centralized interim } \\
\text { storage facility }\end{array}$ & $\begin{array}{l}\text { Fuel will be } \\
\text { transferred to the Oak } \\
\text { Ridge centralized } \\
\text { interim dry-storage } \\
\text { facility }\end{array}$ \\
\hline $\begin{array}{l}\text { Dry-storage at } \\
\text { Buildings } 7823 \mathrm{~A}, \\
7827 \text {, and } 7829\end{array}$ & $\begin{array}{l}\text { Fuel will remain in } \\
\text { dry-storage. Storage } \\
\text { will be modified to } \\
\text { address safety } \\
\text { vulnerability }\end{array}$ & $\begin{array}{l}\text { Fuel will be } \\
\text { transferred to the } \\
\text { Oak Ridge interim } \\
\text {. dry-storage facility }\end{array}$ & $\begin{array}{l}\text { Fuel will be } \\
\text { transferred to the } \\
\text { Oak Ridge interim } \\
\text { dry-storage facility }\end{array}$ & $\begin{array}{l}\text { Fuel will be } \\
\text { transferred to the } \\
\text { SRS regional } \\
\text { interim storage } \\
\text { facility }\end{array}$ & $\begin{array}{l}\text { Fuel will be } \\
\text { transferred to the } \\
\text { Oak Ridge regional } \\
\text { interim dry-storage } \\
\text { facility }\end{array}$ & $\begin{array}{l}\text { Fuel will be } \\
\text { transferred to the } \\
\text { centralized interim } \\
\text { storage facility }\end{array}$ & $\begin{array}{l}\text { Fuel will be } \\
\text { transferred to the Oak } \\
\text { Ridge centralized } \\
\text { interim dry-storage } \\
\text { facility }\end{array}$ \\
\hline $\begin{array}{l}\text { Tower Shielding } \\
\text { Reactor }\end{array}$ & $\begin{array}{l}\text { Fuel will remain at } \\
\text { existing facility }\end{array}$ & $\begin{array}{l}\text { Fuel will be } \\
\text { transferred to the } \\
\text { Oak Ridge interim } \\
\text { dry-storage facility }\end{array}$ & $\begin{array}{l}\text { Fuel will be } \\
\text { transferred to the } \\
\text { SRS interim storage } \\
\text { facility }\end{array}$ & $\begin{array}{l}\text { Fuel will be } \\
\text { transferred to the } \\
\text { SRS rcgional } \\
\text { interim storage } \\
\text { facility }\end{array}$ & $\begin{array}{l}\text { Fuel will be } \\
\text { transferred to the } \\
\text { Oak Ridge regional } \\
\text { interim dry-storage } \\
\text { facility }\end{array}$ & $\begin{array}{l}\text { Fuel will be } \\
\text { transferred to the } \\
\text { centralized interim } \\
\text { storage facility }\end{array}$ & $\begin{array}{l}\text { Fuel will be } \\
\text { transferred to the Oak } \\
\text { Ridge centralized } \\
\text { interim dry-storage } \\
\text { facility }\end{array}$ \\
\hline Building 3525 & $\begin{array}{l}\text { Fuel will be } \\
\text { transferred to dry- } \\
\text { storage following } \\
\text { modification }\end{array}$ & $\begin{array}{l}\text { Fuel will be } \\
\text { transferred to the } \\
\text { Oak Ridge interim } \\
\text { dry-storage facility }\end{array}$ & $\begin{array}{l}\text { Fuel will be } \\
\text { transferred to an } \\
\text { Oak Ridge interim } \\
\text { dry-storage facility }\end{array}$ & $\begin{array}{l}\text { Fuel will be } \\
\text { transferred to the } \\
\text { SRS regional } \\
\text { interim storage } \\
\text { facility }\end{array}$ & $\begin{array}{l}\text { Fuel will be } \\
\text { transferred to the } \\
\text { Oak Ridge regional } \\
\text { interim dry-storage } \\
\text { facility }\end{array}$ & $\begin{array}{l}\text { Fuel will be } \\
\text { transferred to the } \\
\text { centralized interim } \\
\text { storage facility }\end{array}$ & $\begin{array}{l}\text { Fuel will be } \\
\text { transferred to the Oak } \\
\text { Ridge centralized } \\
\text { interim dry-storage } \\
\text { facility }\end{array}$ \\
\hline Building 4501 & $\begin{array}{l}\text { Fuel will be } \\
\text { transferred to dry- } \\
\text { storage following } \\
\text { modification }\end{array}$ & $\begin{array}{l}\text { Fuel will be } \\
\text { transferred to the } \\
\text { Oak Ridge interim } \\
\text { dry-storage facility }\end{array}$ & $\begin{array}{l}\text { Fuel will be } \\
\text { transferred to an } \\
\text { Oak Ridge interim } \\
\text { dry-storage facility }\end{array}$ & $\begin{array}{l}\text { Fuel will be } \\
\text { transferred to the } \\
\text { SRS regional } \\
\text { interim storage } \\
\text { facility }\end{array}$ & $\begin{array}{l}\text { Fuel will be } \\
\text { transferred to the } \\
\text { Oak Ridge regional } \\
\text { interim dry-storage } \\
\text { facility }\end{array}$ & $\begin{array}{l}\text { Fuel will be } \\
\text { transferred to the } \\
\text { centralized interim } \\
\text { storage facility }\end{array}$ & $\begin{array}{l}\text { Fuel will be } \\
\text { transferred to the Oak } \\
\text { Ridge centralized } \\
\text { interim dry-storage } \\
\text { facility }\end{array}$ \\
\hline Building 7920 & $\begin{array}{l}\text { Fuel will be } \\
\text { transferred to dry- } \\
\text { storage following } \\
\text { modification }\end{array}$ & $\begin{array}{l}\text { Fuel will be } \\
\text { transferred to the } \\
\text { Oak Ridge interim } \\
\text { dry-storage facility }\end{array}$ & $\begin{array}{l}\text { Fuel will be } \\
\text { transferred to an } \\
\text { Oak Ridge interim } \\
\text { dry-storage facility }\end{array}$ & $\begin{array}{l}\text { Fuel will be } \\
\text { transferred to the } \\
\text { SRS regional } \\
\text { interim storage } \\
\text { facility }\end{array}$ & $\begin{array}{l}\text { Fuel will be } \\
\text { transferred to the } \\
\text { Oak Ridge regional } \\
\text { interim dry-storage } \\
\text { facility }\end{array}$ & $\begin{array}{l}\text { Fuel will be } \\
\text { transferred to the } \\
\text { centralized interim } \\
\text { storage facility }\end{array}$ & $\begin{array}{l}\text { Fuel will be } \\
\text { transferred to the Oak } \\
\text { Ridge centralized } \\
\text { interim dry-storage } \\
\text { facility }\end{array}$ \\
\hline
\end{tabular}


Table 3.3. (Continued)

\begin{tabular}{|c|c|c|c|c|c|c|c|}
\hline Current location & $\begin{array}{l}\text { Alternative } 1 \\
\text { No Action }\end{array}$ & $\begin{array}{c}\text { Alternative } 2 \\
\text { Decentralization }\end{array}$ & $\begin{array}{l}\text { Alternative } 3 \\
92 / 93 \text { Plan }\end{array}$ & $\begin{array}{c}\text { Altemative } 4 \\
\text { Option A } \\
\text { Regionalization }\end{array}$ & $\begin{array}{c}\text { Alternative } 4 \\
\text { Option B } \\
\text { Regionalization }\end{array}$ & $\begin{array}{c}\text { Alternative 5 } \\
\text { Options A-C, E } \\
\text { Centralization }\end{array}$ & $\begin{array}{l}\text { Alternative } 5 \\
\text { Option D } \\
\text { Centralization }\end{array}$ \\
\hline $\begin{array}{l}\text { High Flux } \\
\text { Isotope Reactor } \\
\text { (HFIR) }\end{array}$ & $\begin{array}{l}\text { When HFIR pool } \\
\text { storage capacity is } \\
\text { reached, HFIR will be } \\
\text { required to be shut } \\
\text { down. At some time } \\
\text { before aluminum- } \\
\text { cladding degrades, } \\
\text { HFIR SNF will need } \\
\text { to be placed in dry } \\
\text { storage }\end{array}$ & $\begin{array}{l}\text { Fuel will be } \\
\text { transferred to the } \\
\text { Oak Ridge interim } \\
\text { dry-stornge facility } \\
\text { as necessary to } \\
\text { allow for continued } \\
\text { operation of HFIR }\end{array}$ & $\begin{array}{l}\text { Fuel will be } \\
\text { transferred to the } \\
\text { SRS interim storage } \\
\text { facility }\end{array}$ & $\begin{array}{l}\text { Fuel will be } \\
\text { transferred to the } \\
\text { SRS regional } \\
\text { interim storage } \\
\text { facility }\end{array}$ & $\begin{array}{l}\text { Fuel will be } \\
\text { transferred to the } \\
\text { Oak Ridge regional } \\
\text { interim dry-storage } \\
\text { facility }\end{array}$ & $\begin{array}{l}\text { Fuel will be } \\
\text { transferred to the } \\
\text { centralized interim } \\
\text { storage facility }\end{array}$ & $\begin{array}{l}\text { Fuel will be } \\
\text { transferred to the Oak } \\
\text { Ridge centralized } \\
\text { interim dry-storage } \\
\text { facility }\end{array}$ \\
\hline $\begin{array}{l}\text { SNAP-10A } \\
\text { Reactor (Building } \\
\text { 9720-5) }\end{array}$ & $\begin{array}{l}\text { Fuel and coolant may } \\
\text { present a fire/reaction } \\
\text { hazard at the present } \\
\text { storage facility. Fuel } \\
\text { will be stabilized and } \\
\text { transferred to an } \\
\text { aboveground } \\
\text { dry-storage facility }\end{array}$ & $\begin{array}{l}\text { Fuel will be } \\
\text { transferred to the } \\
\text { Oak Ridge interim } \\
\text { dry-storage facility }\end{array}$ & $\begin{array}{l}\text { Fuel will be } \\
\text { transferred to the } \\
\text { SRS interim storage } \\
\text { facility }\end{array}$ & $\begin{array}{l}\text { Fuel will be } \\
\text { transferred to the } \\
\text { SRS regional } \\
\text { interim storage } \\
\text { facility }\end{array}$ & $\begin{array}{l}\text { Fuel will be } \\
\text { transferred to the } \\
\text { Oak Ridge regional } \\
\text { interim dry-storage } \\
\text { facility }\end{array}$ & $\begin{array}{l}\text { Fuel will be } \\
\text { transferred to the } \\
\text { centralized interim } \\
\text { storage facility }\end{array}$ & $\begin{array}{l}\text { Fuel will be } \\
\text { transferred to the Oak } \\
\text { Ridge centralized } \\
\text { interim dry-stomge } \\
\text { facility }\end{array}$ \\
\hline $\begin{array}{l}\text { Health Physics } \\
\text { Research Reactor } \\
\text { (Building 9720-5) }\end{array}$ & $\begin{array}{l}\text { Fuel will remain at } \\
\text { facility until } \\
\text { transferred to a } \\
\text { long-term interim } \\
\text { storage facility }\end{array}$ & $\begin{array}{l}\text { Fuel will be } \\
\text { transferted to the } \\
\text { Oak Ridge interim } \\
\text { dry-storage facility }\end{array}$ & $\begin{array}{l}\text { Fuel will be } \\
\text { transferred to the } \\
\text { SRS interim storage } \\
\text { facility }\end{array}$ & $\begin{array}{l}\text { Fuel will be } \\
\text { transferred to the } \\
\text { SRS regional } \\
\text { interim storage } \\
\text { facility }\end{array}$ & $\begin{array}{l}\text { Fuel will be } \\
\text { transfenred to the } \\
\text { Oak Ridge regional } \\
\text { interim dry-storage } \\
\text { facility }\end{array}$ & $\begin{array}{l}\text { Fuel will be } \\
\text { transferred to the } \\
\text { centralized interim } \\
\text { storage facility }\end{array}$ & $\begin{array}{l}\text { Fuel will be } \\
\text { transferred to the Oak } \\
\text { Ridge centralized } \\
\text { interim dry-storage } \\
\text { facility }\end{array}$ \\
\hline $\begin{array}{l}\text { Demo reactor } \\
\text { (Building 9720-5) }\end{array}$ & $\begin{array}{l}\text { Fuel will remain at } \\
\text { facility until } \\
\text { transferred to a } \\
\text { long-term interim } \\
\text { storage facility }\end{array}$ & $\begin{array}{l}\text { Fuel will be } \\
\text { transferred to the } \\
\text { Oak Ridge interim } \\
\text { dry-storage facility }\end{array}$ & $\begin{array}{l}\text { Fuel will be } \\
\text { transferred to the } \\
\text { SRS interim storage } \\
\text { facility }\end{array}$ & $\begin{array}{l}\text { Fuel will be } \\
\text { transferred to the } \\
\text { SRS regional } \\
\text { interim storage } \\
\text { facility }\end{array}$ & $\begin{array}{l}\text { Fuel will be } \\
\text { transferred to the } \\
\text { Oak Ridge regional } \\
\text { interim dry-storage } \\
\text { facility }\end{array}$ & $\begin{array}{l}\text { Fuel will be } \\
\text { transferred to the } \\
\text { centralized interim } \\
\text { storage facility }\end{array}$ & $\begin{array}{l}\text { Fuel will be } \\
\text { transferred to the Oak } \\
\text { Ridge centralized } \\
\text { interim dry-storage } \\
\text { facility }\end{array}$ \\
\hline $\begin{array}{l}\text { Molten Salt } \\
\text { Reactor } \\
\text { Experiment }\end{array}$ & $\begin{array}{l}\text { Fuel will be stabilized } \\
\text { and stored in a new } \\
\text { facility to alleyiate } \\
\text { health and safety } \\
\text { concems }\end{array}$ & $\begin{array}{l}\text { After fuel is } \\
\text { stabilized, fuel will } \\
\text { be transferred to the } \\
\text { Oak Ridge interim } \\
\text { dry-storage facility }\end{array}$ & $\begin{array}{l}\text { After fuel is } \\
\text { stabilized, fuel will } \\
\text { be transferred to the } \\
\text { SRS interim storage } \\
\text { facility }\end{array}$ & $\begin{array}{l}\text { After fuel is } \\
\text { stabilized, fuel will } \\
\text { be transferred to the } \\
\text { SRS regional } \\
\text { interim storage } \\
\text { facility }\end{array}$ & $\begin{array}{l}\text { After fuel is } \\
\text { stabilized, fuel will } \\
\text { be transferred to the } \\
\text { Oak Ridge regional } \\
\text { interim dry-storage } \\
\text { facility }\end{array}$ & $\begin{array}{l}\text { After fuel is } \\
\text { stabilized, fuel will } \\
\text { be transferred to the } \\
\text { centralized interim } \\
\text { storage facility }\end{array}$ & $\begin{array}{l}\text { Fuel will be } \\
\text { transferred to the Oak } \\
\text { Ridge centralized } \\
\text { interim dry-storage } \\
\text { facility }\end{array}$ \\
\hline
\end{tabular}


similar to alternative 2 except that some SNF would be shipped to SRS. The SNF currently stored at the HFIR and BSR pools, along with that stored at the TSR, would be shipped to SRS. Only 20 storage positions for HFIR assemblies are at SRS unless other arrangements can be made. If the quantity of HFIR fuel that can be shipped to SRS is limited to 20 elements, then HFIR will require dry-storage facilities to continue operation. An interim, retrievable, aboveground, dry-storage facility would be prepared for consolidating the SNF remaining at Oak Ridge. This facility would be similar to the one built under alternative 2 except it would probably be smaller.

\section{Alternative 4-Regionalization}

The regionalization alternative consists of two options. Under option A, existing and new SNF would be distributed among the Hanford site, Idaho National Engineering Laboratory (INEL), and SRS on the basis of the type of SNF. Under option B, SNF would be distributed to either an eastern or western regional site on the basis of the geographical location. The western regional site would be either Hanford, INEL, or the Nevada Test Site. The eastern regional site would be either the ORR or SRS. Also, naval reactor fuel would be stored at either the western or eastern site but not both. Under either regionalization option, storage facilities at Oak Ridge would be necessary for HFIR SNF.

Under option A, SNF at Oak Ridge would be shipped to SRS. The majority of SNF at Oak Ridge is aluminum-clad and is stored at the HFIR and BSR pools. HFIR fuel at Oak Ridge would be shipped to SRS, and dry-storage facilities to maintain HFIR operations would be acquired.

Oak Ridge could be selected as the eastern regional storage site under option B. As the eastern regional site, the ORR would receive SNF from facilities throughout the eastern United States. The
ORR also, if selected, could receive all naval reactor SNF from sites around the country.

All SNF from a DOE facility would arrive at Oak Ridge stabilized and probably canned. SNF from non-DOE and foreign research reactors would not be canned. The regional facility at Oak Ridge would have to can the non-DOE and foreign research reactor fuel and may have to stabilize, to prepare, and to recan all of the SNF received at the storage site. At present, the ORR has very limited facilities for receiving, inspection, short-term storage, preparation, canning, and interim storage of the quantities of SNF that would have to be handled if Oak Ridge were selected as a regional storage site. An SNF management complex would be built that would include the following:

- an SNF receiving, canning, and characterization facility;

- a technology development facility;

- an interim dry-storage facility; and

- an Expended Core Facility similar to INEL's (only if selected as the naval reactor SNF site).

\section{Alternative 5-Centralization}

Under the Centralization Alternative, all SNF would be shipped to one site. The Centralization Alternative consists of five options. Under four of the five options, SNF would be shipped from Oak Ridge to other sites (i.e., Hanford, INEL, SRS, or the Nevada Test Site). Under the fourth option, option D, SNF from the other sites would be shipped to Oak Ridge.

Under options A, B, C, or E, the ORR would handle its fuel in a manner very similar to alternative 4, option A. Facilities would be built or modified on the ORR only as necessary to address health and safety vulnerabilities and to maintain HFIR operations. To allow HFIR to continue operations until a dry-storage facility is available at the central facility, a dry-storage cask may be acquired, or some 
limited shipments of HFIR fuel to SRS may be pursued.

The facilities that would be built at Oak Ridge under the Centralization Alternative would be similar to those built under the Regionalization Alternative except the dry-storage facility would be about ten times larger owing to the larger SNF inventory that would be shipped to Oak Ridge.

\section{Schedules and Milestones}

Figure 3.1 lists SNF milestones.

Priorities are driven by identified health and safety vulnerabilities and by operational requirements for storage space.

Additional dry-storage capacity will be needed to provide for HFIR fuel storage capacity in 6 to 8 years (i.e., a 2001-2003 time frame depending on the HFIR operations schedule and the relocation of fuel to SRS). Following provision of additional storage capacity, SNF currently stored in wet storage should be relocated to dry storage. A new dry-storage facility will be required for this purpose. If HFIR operates through the year 2010, dry storage for approximately 200 fuel assemblies will be required. The dry-storage facility should be suitable for 40-year storage of the SNF.

Plans are to begin operation of the ANS in about 2004. HFIR is expected to cease operations about a year after the ANS begins operations. Also, because ANS fuel is expected to be somewhat similar to HFIR fuel, planned adaptations of dry storage for HFIR are expected to serve ANS as well.

The entire ANS Complex is in the design stage. At present, wet storage and handling facilities for 5 years of spent fuel storage are included in the project scope. Additional dry or wet long-term interim storage facilities will be incorporated into the scope of the ANS if needed.

Also, efforts are currently under way to address health and safety vulnerabilities.

ORNL-DWG 95M-4759

\begin{tabular}{|c|c|c|c|c|c|c|c|c|c|}
\hline ACTIVITIES & 1994 & 1995 & 1996 & 1997 & 1998 & 1999 & 2000 & 2001 & 2002 \\
\hline \multicolumn{7}{|c|}{ PROVIDE PROGRAU MANAGEMENT } & & & \\
\hline \multicolumn{10}{|c|}{ ENSURE SAFE EXISTING STORAGE } \\
\hline \multicolumn{10}{|c|}{ RESOLVE VULNERABLLITIES } \\
\hline \multicolumn{10}{|l|}{ UPGRADE SWSA SN STORAGE } \\
\hline \multicolumn{10}{|c|}{ EXANINATIONCHARACTERRATION } \\
\hline \multicolumn{10}{|l|}{ TRANSFER FUELS } \\
\hline \multicolumn{10}{|l|}{ ACQUIRE INTERIM STORAGE } \\
\hline \multicolumn{10}{|c|}{ ESTABLISH FACLLTY REOUIREMENTS } \\
\hline \multicolumn{10}{|c|}{ COMPLETE NEPA DOCUMENTATION } \\
\hline \multicolumn{10}{|c|}{ CONDUCT FEASIBIITY STUDY } \\
\hline \multicolumn{10}{|c|}{ COMPLETE CONCEPTUAL OESIGN REPORT } \\
\hline \multicolumn{10}{|c|}{ ESTABLIFH DESIGN CRITERIA } \\
\hline \multicolumn{10}{|l|}{ COMPLETE DESIGN DETAIL } \\
\hline CONSTRUCT FACRITESPRO & & & & & & & & & \\
\hline INITATE OPERATON & & & & & & & & & \\
\hline
\end{tabular}

Fig. 3.1. Schedule and milestones for spent nuclear fuel. 
Monitoring wells have been installed near the HRE disposal wells to determine whether contaminants are moving from the disposal site. The MSRE is being studied to determine how best to address the vulnerability and to stabilize the fuel. Efforts to modify the dry-storage positions at Buildings 7823A, 7827, and 7829 are now under way.

Planning based on current assumptions indicate that an interim storage facility for most SNF at Oak Ridge should be completed in 2001. To accomplish this, the line item project should be initiated in 1998 , and construction should begin in 1999.

\section{Disposition}

DOE plans to open a geologic repository at Yucca Mountain on the Nevada Test Site for the final disposition of its SNF.

\section{References}

U.S. Department of Energy June 1994. Department of Energy Programmatic Spent Nuclear Fuel Management and Idaho National Engineering Laboratory Environmental Restoration and Waste Management Programs Draft Environmental Impact Statement, DOE/EIS-0203-D, Idaho Operations Office, Idaho Falls, Idaho.

U.S. Department of Energy September 1994a. Plan of Action to Resolve Spent Fuel Vulnerabilities, Phase III, Vol. II. U.S. Department of Energy, September 1994b. Reracking of High Flux Isotope Reactor (HFIR) Spent Fuel Assemblies-Oak Ridge National Laboratory, Oak Ridge, Tennessee, DOE/EA-0935. 


\section{Transuranic Waste}

Transuranic (TRU) waste is radioactive waste contaminated with alpha-emitting transuranium nuclides (i.e., radionuclides with an atomic number greater than 92) having half-lives greater than 20 years and assay concentrations greater than $100 \mathrm{nCi} / \mathrm{g}$. Heads of U.S. Department of Energy (DOE) Field Elements can also determine that other alpha-contaminated waste, peculiar to a specific site, must be managed as TRU waste. On the ORR, TRU wastes are generated and managed only at Oak Ridge National Laboratory (ORNL). Waste contaminated with ${ }^{252} \mathrm{Cf}$, ${ }^{244} \mathrm{Cm}$, and ${ }^{233} \mathrm{U}$ in concentrations greater than $100 \mathrm{nCi} / \mathrm{g}$ are also handled as TRU waste at ORNL, although they have not been formally declared as such by the DOE Oak Ridge Operations Office.

Radioactive waste management operations include the treatment, storage, and disposal of solid, liquid, and gaseous wastes. Solid TRU waste is segregated and handled based on the radiological dose rate at the surface of the waste package. Contact-handled (CH) TRU waste is defined in the Waste Isolation Pilot Plant (WIPP) Waste Acceptance Criteria (WAC) as TRU waste that has a surface dose rate of less than or equal to $200 \mathrm{mrem} / \mathrm{h}$ and can be handled by direct means without extensive shielding. Waste requiring shielding or having a surface dose of greater than $200 \mathrm{mrem} / \mathrm{h}$ is classified as remote-handled (RH) TRU waste.

CH TRU waste consists of miscellaneous waste from glove box operations (e.g., paper, glassware, plastic, shoe covers, and wipes), discarded high- efficiency particulate air (HEPA) filters, and discarded equipment (e.g., glove boxes and processing equipment). The majority of the CH TRU waste has a surface dose rate much less than $200 \mathrm{mrem} / \mathrm{h}$.

It is generally contained within polyethylene bags inside 208-L (55-gal) stainless steel drums. Metal paint cans, plastic buckets, and other similar containers are also used to package waste inside the drums. Figure 4.1 shows newly generated (NG) CH TRU process control.

Solid RH TRU waste consists primarily of miscellaneous hot cell waste (e.g., paper, glass, plastic tubing, shoe covers, and wipes), HEPA filters from off-gas cleanup systems, and discarded equipment (e.g., processing racks, vacuum pumps, and furnaces). The unshielded individual waste packages typically have radiation levels that measure between 10 and $2000 \mathrm{rem} / \mathrm{h}$; most are below $100 \mathrm{rem} / \mathrm{h}$.

These wastes are typically contained in cylindrical concrete casks $1.4 \mathrm{~m}(4.5 \mathrm{ft})$ in diam $\times 2.3 \mathrm{~m}(7.5 \mathrm{ft})$ high. Wall thicknesses of the casks are currently either 15.2 or $30.5 \mathrm{~cm}$ ( 6 or 12 in.) thick depending on the radiation level of the contents. Most of the RH TRU wastes inside the concrete casks are also contained inside polyethylene bags. Smaller waste packages such as 11-L (3-gal) plastic buckets, 3.7-L (1-gal) paint cans, and 18.9-L (5-gal) metal cans are packaged within the polyethylene bags. Also, 37.8-L. (10-gal) fiber drums and 114- and 208-L (30- and 55-gal) carbon and steel drums have been used to package waste material 


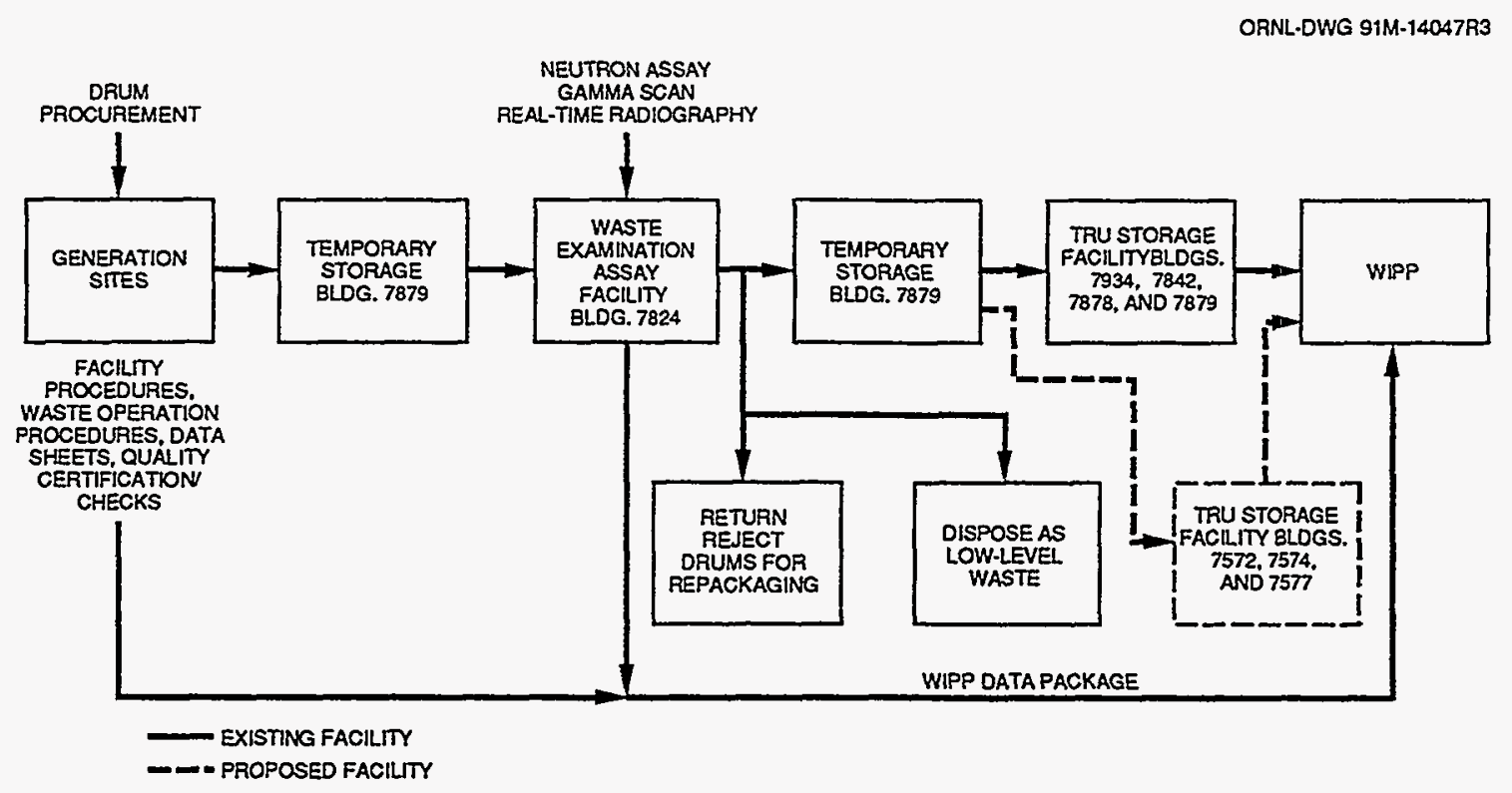

Fig. 4.1. Flow sheet for handling newly generated contact-handled transuranic waste.

before the waste is placed in concrete casks.

Five Gunite, or reinforced concrete, tanks (i.e., W-5 through W-10) are located inside the Bethel Valley Complex along Central Avenue at ORNL; the 643,520-L (170,000-gal) tanks were built in 1943. TRU sludges are in storage in these tanks that are residual heels from sluicing operations between 1980 and 1984 when most of the Gunite tank contents were removed for hydrofracture disposal at the New Hydrofracture Facility (NHF). At present, the Gunite tanks belong to the Environmental Restoration Program (ERP); they are not part of the Liquid Low-Level Waste (LLLW) System as they were in the past. The sludges in the Melton Valley storage tanks (MVSTs) are a result of past hydrofracture disposal and generation of LLLW concentrate. These sludges have a relatively high water content and a density of about 1.2 to $1.5 \mathrm{~g} / \mathrm{cm}^{3}$. The surface dose rates of these sludges are generally near $10 \mathrm{rem} / \mathrm{h}$ (unshielded). Preliminary screening tests for Resource Conservation and Recovery Act (RCRA) characteristics conducted in 1990 (Sears et al. Sept. 30, 1990) indicated that all the sludges are potentially RCRA hazardous with respect to mercury and lead, and some are also potentially RCRA hazardous with respect to chromium and cadmium, although a full RCRA characterization has not been performed.

Buried TRU waste is defined as TRU waste disposal before 1970. Records from that time period indicate several sites where buried TRU is known or suspected: (1) approximately $6200 \mathrm{~m}^{3}\left(218,940 \mathrm{ft}^{3}\right)$ of solid TRU waste commingled with solid low-level waste (SLLW) and disposed of in shallow-land burial trenches prior to 1970 [i.e., Solid Waste Storage Areas (SWSAs) 3,4 , and 5]; (2) wastes in pits and trenches from past liquid waste disposal operations (i.e., four pits and three trenches);

(3) contaminated soil sites from leaks in the liquid-processing systems (also, some contaminated soils from deteriorated waste packages in the solid waste burial sites) together with inactive contaminated pipelines; and (4) some grout sheets below the NHF (and possibly below the Old Hydrofracture Facility) that contain TRU radionuclides. The final disposition of buried TRU waste is a part of the Remedial Investigation/Feasibility Study currently in progress under the Energy Systems ERP and is not specifically 
addressed in this plan. Buried TRU waste is not a part of the WIPP mission as currently defined.

\section{Management Strategy}

\section{Since 1970 ORNL has been} segregating and storing solid alpha-emitting waste that meets the TRU definition, pending the development of an approved strategy for permanent disposal. WIPP, located in Carlsbad, New Mexico, is the intended DOE geologic disposal facility for all TRU waste. TRU waste to be shipped to WIPP must be certified in compliance with WIPP WAC. Over the past several years ORNL has been developing the procedures for certifying TRU waste for disposal at WIPP.

The proposed Waste Handling and Packaging Plant (WHPP) at ORNL was designed to process ORNL's solid TRU wastes and LLLW concentrates (including RH TRU waste sludges), as well as some RH TRU wastes from off-site, for shipment to WIPP. Because most of ORNL's TRU waste is also mixed hazardous or radioactive waste, processing in WHPP is also required for compliance with the Land Disposal Restrictions (LDRs) imposed by RCRA. The project has undergone a number of independent reviews, with positive responses, but has not been approved by DOE.

The many unresolved issues that have delayed DOE approval of the proposed WHPP at ORNL are well recognized. Delays in the opening of WIPP, uncertainties in the WAC for WIPP (including potential for major changes if treatment to meet RCRA LDR is required), absence of a formal, complex-wide TRU waste management strategy, delays in completion of the DOE Headquarters (DOE-HQ) Programmatic Environmental Impact Statement for environmental restoration and waste management, negative reaction to the high costs associated with a major project such as
WHPP - all of these have been contributory factors. However, it is the latter that appears to be the largest obstacle to DOE approval for WHPP.

An interdisciplinary team was formed to reevaluate the ORNL strategy for management of LLLW and TRU wastes with a particular focus on RH TRU wastes (e.g., contingency measures for delays in WHPP and/or WIPP). The team proposed a revision to the current strategy for managing TRU wastes. The key elements of the revised (contingent) strategy are:

- Enhance containment, as needed, for stored TRU wastes, particularly those retrievably buried; resolve major technical issues; and continue to store pending a disposal decision by DOE.

- Defer decisions on solid RH and special case (SC) TRU waste processing until improved radiological characterization, risk assessments and retrieval feasibility studies for wastes stored in trenches, technology development, and WAC development activities by the DOE are completed. Once needed information and technology [e.g., nondestructive analysis (NDA)] is available, a single capability should be developed and applied to process both stored and NG wastes.

- Develop enhanced TRU waste characterization through improved process knowledge and information derived from the pilot $\mathrm{CH}$ TRU wasteprocessing activity currently targeted for Building 3525 .

- Utilize the pilot $\mathrm{CH}$ TRU wasteprocessing activity to gain operating experience and data for design of a future CH/SC TRU waste-processing facility.

- Reduce volumes of stored LLLW supernatants as soon as possible, utilizing a variety of treatment approaches as needed, and attempt to dispose of treatment residuals as LLW rather than TRU wastes to reduce costs. Optimize management approach to take maximum advantage of off-site and/or 
on-site disposal options, which would limit the need for additional storage tank systems.

- Utilize capabilities developed for supernatant treatment until enhanced treatment, including pretreatment of LLLW from the Radiochemical Engineering Development Center (REDC), is available for NG LLLW. Continue efforts to pretreat NG wastes at the REDC to remove primarily ${ }^{137} \mathrm{Cs}$ and transuranics. Store pretreated LLLW from the REDC, along with LLLW concentrates from Bethel Valley facilities, to permit significant ${ }^{106} \mathrm{Ru}$ decay prior to final treatment.

- Proceed with development of a TRUwaste sludge solidification process, retaining the flexibility to produce either a dried/melted solid or vitrified waste form.

- First refocus and better coordinate existing technology development, then increase significantly the overall level of support for technology development needed to support the revised strategy for management of LLLW and TRU wastes at ORNL. The most critical development needs are associated with supernatant treatment, pretreatment of LLLW from the REDC, NDA nondestructive examination of solid TRU wastes, and sludge solidification.
- Conduct a Hot Cell Evaluation Study as a follow-up to this reevaluation effort to further examine the question of whether major aspects of waste characterization and processing can be performed in existing ORNL facilities.

- Communicate the revised strategy to major stakeholders as soon as reasonably possible, iterate as necessary to incorporate feedback, and attempt to gain their acceptance. In particular, work with the DOE, the U.S. Environmental Protection Agency (EPA), the Tennessee Department of Environment and Conservation, and the public to develop an acceptable revised strategy to be incorporated into the plans required by the RCRA LDR Federal Facility Compliance Agreement (FFCA) and the Federal Facility Compliance Act.

\section{Current Generation and Projections}

Table 4.1 lists solid TRU generation for CY 1993 and summarizes current generation at ORNL. No TRU waste is currently, or is projected to be, generated at the Y-12 Plant or the K-25 Site. No TRU waste is expected to be generated by the $\mathrm{ERP}$, decontamination and decommissioning activities, or remedial actions in FY 1995. Figure 4.2 shows

Table 4.1. Summary of solid transuranic waste generation at Oak Ridge National Laboratory ${ }^{a}$

\begin{tabular}{|c|c|c|c|}
\hline \multicolumn{2}{|c|}{$\begin{array}{l}\text { CY } 1993 \\
\mathrm{~m}^{3}\left(\mathrm{ft}^{3}\right)\end{array}$} & \multicolumn{2}{|c|}{$\begin{array}{c}\text { CY } 1994^{b} \\
\mathrm{~m}^{3}\left(\mathrm{ft}^{3}\right)\end{array}$} \\
\hline $\mathrm{RH}^{c}$ & $\mathrm{CH}$ & $\mathrm{RH}$ & $\mathrm{CH}$ \\
\hline 7 (258) & 111 (3918) & $3(116)$ & $82(2908)$ \\
\hline $\begin{array}{r}\text { 'There i } \\
\text { Plant or Oal } \\
\text { 'Project } \\
\text { 'Remote } \\
\text { Source: } \\
\text { Marietta En }\end{array}$ & $\begin{array}{l}\text { id transuranic } \\
\text { K-25 Site. } \\
\text { (RH); conta } \\
\text { aste Informat } \\
\text { tems, Oak R }\end{array}$ & $\begin{array}{l}\text { CH). } \\
\text { ment Sys } \\
\text { ab. }\end{array}$ & atabase, Martin \\
\hline
\end{tabular}




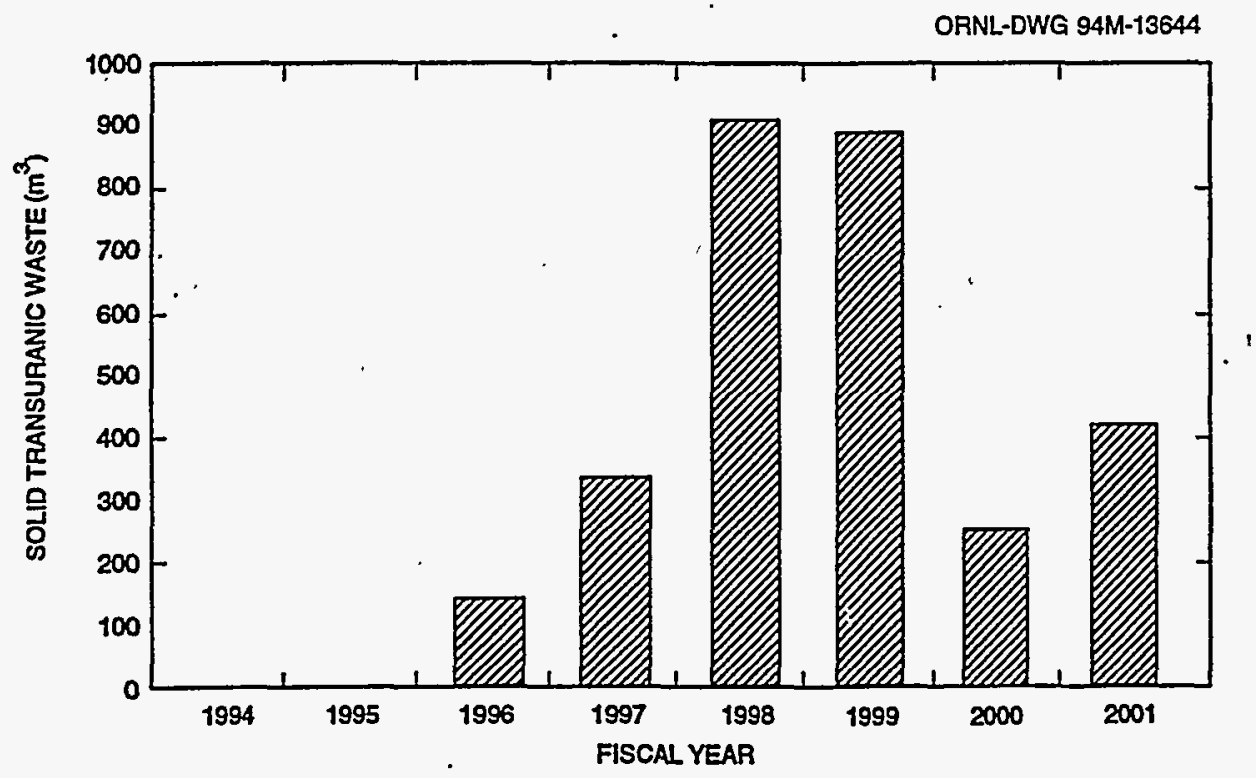

Fig. 4.2. Projected solid transuranic waste generation under the Environmental Restoration and Decontamination and Decommissioning Programs on the Oak Ridge Reservation. Source: Environmental Restoration Division December 1993. Waste Generation Forecast for DOE-ORO's Environmental Restoration OR-1 Project: FY 1994-FY 2001, ES/ER/M-102, Martin Marietta Energy Systems, Oak Ridge K-25 Site.

projections for TRU waste generation under these programs.

ORNL has one source of CH TRU waste from an off-site generator. Nuclear Fuel Services, Inc., (NFS) has a contract with DOE to ship CH TRU waste to ORNL for interim storage. ORNL received the first shipment of waste on November 19, 1992, and has received a total of 822 drums. One NFS drum was mixed $\mathrm{CH}$ TRU.

Buildings 7920 and 7930, now known collectively as the REDC, were constructed in the mid-1960s, adjacent to the High Flux Isotope Reactor (HFIR). This complex includes facilities for the production, storage, and distribution of radioactive heavy elements. This work requires recovery and purification of transplutonium elements: americium through fermium from target elements irradiated in HFIR or in the Savannah River Plant reactors.

Transplutonium radioisotopes, particularly
${ }^{252} \mathrm{Cf}$, are supplied for use in medical and industrial applications, for research on the properties of the heavy elements, and for production of super-heavy elements (i.e., atomic numbers beyond 104).

The REDC is the principal source of both stored and NG TRU-contaminated wastes at ORNL, accounting for greater than $99 \%$ of the radioactivity in liquid LLW and TRU wastes. The primary transuranics in REDC wastes are ${ }^{244} \mathrm{Cm}$ and ${ }^{252} \mathrm{Cf}$.

TRU-contaminated sludges currently being generated at ORNL are primarily the result of operations at the REDC. The existing LLLW System does not currently have provisions for handling TRUcontaminated liquids separate from nonTRU LLLW waste streams. Modification of the LLLW System to isolate TRUcontaminated liquid waste is currently being studied. 


\section{Treatment}

No facilities exist on the ORR for the treatment of $\mathrm{CH}$ or RH TRU waste.

\section{Storage}

ORNL has a significant volume of stored CH TRU waste, the majority of which is contained in 208-L (55-gal) stainless steel drums; other CH TRU waste packages include stainless steel drums, overpacks, and some large

$1.2 \times 1.2 \times 1.5 \mathrm{~m}(4 \times 4 \times 5 \mathrm{ft})$ boxes. $\mathrm{CH}$ TRU waste is stored in below-grade concrete block facilities (Buildings 7826 and 7834) and in a metal building (7879) in SWSA 5N. Table 4.2 shows the stored volume of CH TRU waste as of June 30 , 1994.

Solid CH TRU wastes are stored primarily in above-grade buildings, located in SWSAs $5 \mathrm{~N}$ and 6, and at the REDC area, while RH TRU wastes are stored in both bunkers (Fig. 4.3) and earthen trenches in SWSA 5N. A large fraction of wastes contaminated by both $\mathrm{CH}$ and $\mathrm{RH}$ TRU at ORNL may be classified more properly as SC TRU wastes. Figure 4.4 shows the locations of solid TRU waste storage facilities and trenches in the north area of SWSA 5. Sludges are stored in the MVSTs and in 11 or more of the inactive tanks. The inactive tanks containing TRU sludges are located in the main ORNL Complex and at the Old Hydrofracture Facility. In addition, unknown quantities of sludge may be stored in various active collection tanks in the LLLW System. Most of these active tanks are located primarily in the main ORNL Complex. Twenty-seven trenches in SWSA 5N were used from 1970 to 1979 to store 274 waste containers containing RH TRU. The estimated quantity of waste buried in this manner is 200 concrete casks, 72 boxes, and 2 drums. Figure 4.4 shows the location of these trenches in SWSA 5N. Figure 4.5 shows concrete casks in an RH TRU trench. Conducted under the Active Sites Environmental Monitoring Program, monitoring of the trenches focuses on groundwater monitoring wells, seeps, and samples from small tributaries. These trenches have not been used for interim storage since the RH TRU bunker (Building 7855) became available in 1979. Because some containers are known to

Table 4.2. Volumes of stored remote- and contact-handled solid transuranic wastes at Oak Ridge National Laboratory ${ }^{a b}$

\begin{tabular}{|c|c|c|}
\hline & $\begin{array}{c}\text { June } 30,1993 \\
\mathrm{~m}^{3}\left(\mathrm{ft}^{3}\right)\end{array}$ & $\begin{array}{c}\text { June } 30,1994 \\
\mathrm{~m}^{3}\left(\mathrm{ft}^{3}\right)\end{array}$ \\
\hline Remote-handled & $9(300)$ & $9(300)$ \\
\hline Contact-handled & $207(7300)$ & $255(9000)$ \\
\hline Total & $216(7600)$ & $364(9300)$ \\
\hline $\begin{array}{r}\text { Transuranic } \\
\text { Ridge K-25 Site. } \\
\text { bDoes not inc } \\
\text { Sect. 7. Classific } \\
\text { characterization } \\
\text { Data shown cove } \\
\text { Source: ESW } \\
\text { Report for Perio } \\
\text { Ridge, Tenn. }\end{array}$ & $\begin{array}{l}\text { stored at the } \mathrm{O} \\
\left(58,400 \mathrm{ft}^{3}\right) \text { of } \\
\mathrm{UU} \text { volumes was } \\
\text { lable since the J } \\
\mathrm{g} \text { June } 30 \text { of ea } \\
994 \text {. Oak Ridge } \\
30,1994, \text { Scien }\end{array}$ & $\begin{array}{l}12 \text { Plant or Oak } \\
\text { wastes covered in } \\
\text { ased on improved } \\
3 \text {, storage report. } \\
\text { Waste Storage } \\
\text { ons Int. Corp., Oak }\end{array}$ \\
\hline
\end{tabular}




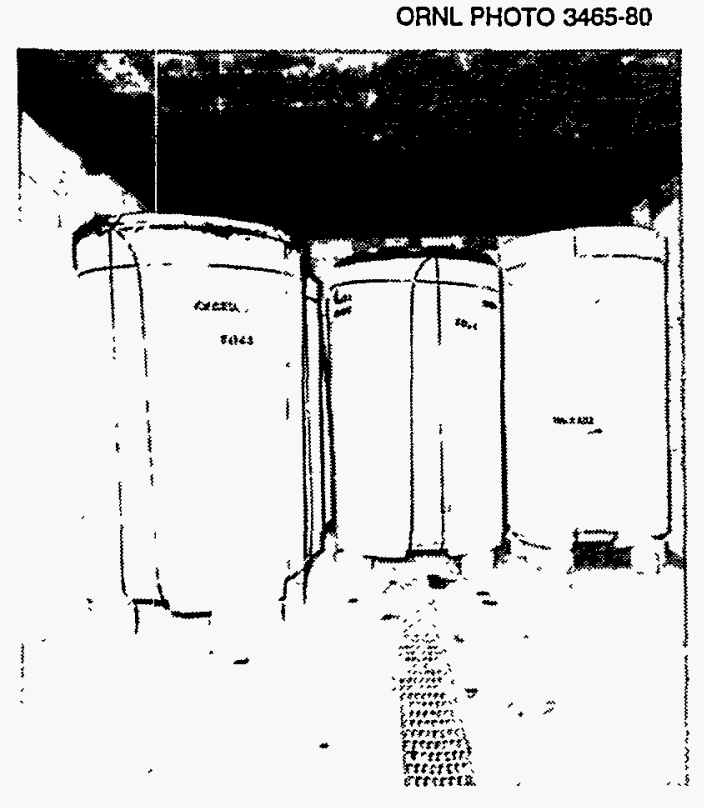

Fig. 4.3. Concrete casks in storage bunker at Oak Ridge National Laboratory.

contain lead, mercury, or oil and are considered mixed RH TRU waste, the permitting status of the buried TRU waste in the trenches in SWSA $5 \mathrm{~N}$ is currently under review by the EPA, the state of Tennessee, and DOE. Appendix B shows the operational status of waste storage facilities for TRU on the ORR.

\section{Disposal}

No facilities exist on the ORR for the disposal of CH or RH TRU waste. WIPP is the expected disposal site for TRU wastes in the DOE Complex.

\section{Future Plans}

No TRU treatment, storage, or disposal facilities currently exist at, or are planned for, the Y-12 Plant and K-25 Site.
Appendix C lists proposed line items (LIs) and general plant projects (GPPs) for TRU facilities at ORNL.

\section{Treatment}

WHPP is proposed for processing stored solid RH TRU waste and RH TRU sludges. WHPP will be designed as (1) a Sludge Mobilization Facility for mobilizing, transferring, and solidifying sludges stored in MVSTs and (2) a Packaging Facility (having five subsystems-waste solids receiving and WIPP shipment, solids processing, liquid/sludge processing, packaged waste handling, and process cell decontamination) for packaging RH TRU waste as well as for certifying $\mathrm{RH}$ and $\mathrm{CH}$ TRU waste for shipment to WIPP. WHPP will be capable of receiving casks of different sizes, off-site wastes, and liquid and sludge from ORNL's liquid waste storage tanks. The main processing cell will be remotely operated and remotely maintained and will have the capacity for unpackaging, characterizing, volume reducing, assaying, repackaging, and certifying the waste to meet the WIPP WAC.

The facility is to be located at ORNL using a combination of new or modified facilities. Approximately $90 \%$ of the $\mathrm{RH}$ TRU wastes generated by DOE Defense Programs activities are currently stored at ORNL. WHPP technologies include sorting, shredding, cutting, compacting, packaging, radiography, neutron assay, fixation, neutralization, precipitation, solidification, melting, filtration, evaporation, decontamination, servomanipulation, remote viewing, slurry mixing, and pumping. The design capacity is 3000 208-L (55-gal) drums per year. A RCRA permit is required. Figure 4.6 shows the WHPP process flow. 


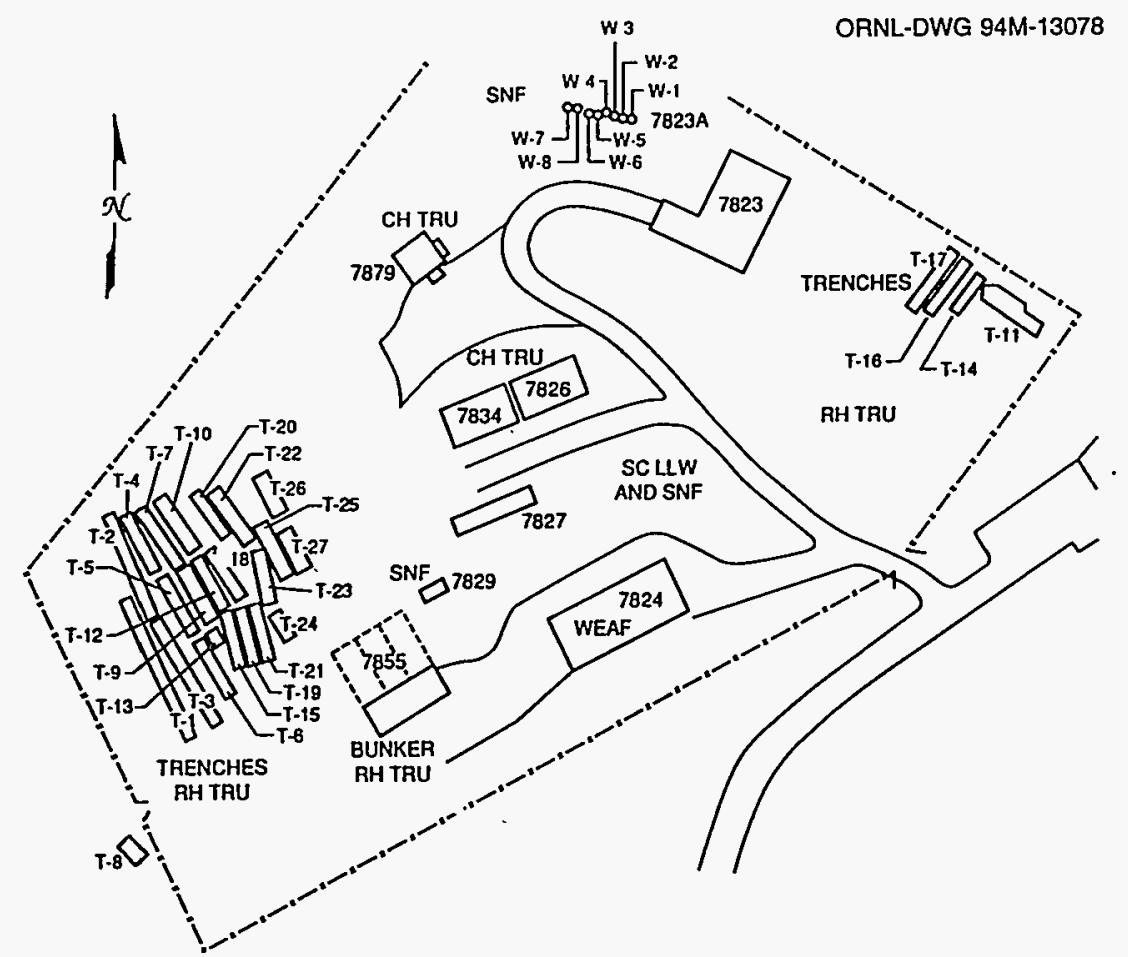

Fig. 4.4. Locations of transuranic waste storage facilities in Solid Waste Storage Area 5N. Spent nuclear fuel (SNF); Waste Examination and Assay Facility (WEAF); remote-handled (RH); contact-handled (CH).

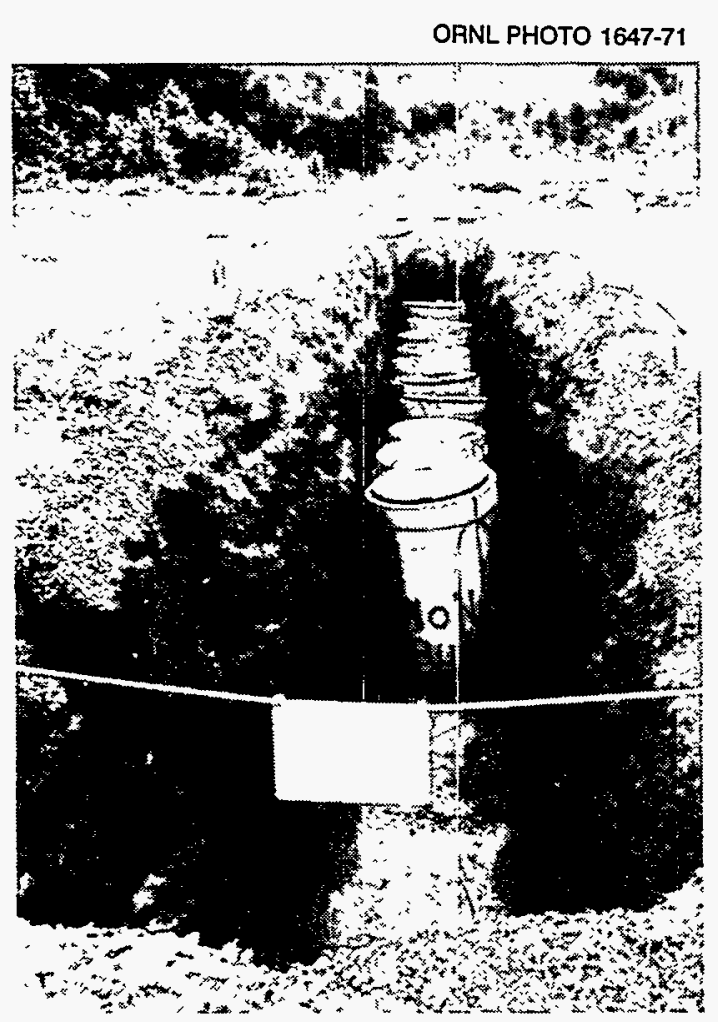

Fig. 4.5. Concrete casks for storing remotehandled transuranic waste in a trench in Solid Waste Storage Area $5 \mathrm{~N}$ at Oak Ridge National Laboratory.

\section{Storage}

\section{CH TRU}

Available CH TRU waste storage space remains limited, although additional space is being constructed in SWSA 7 at ORNL to accommodate $\mathrm{CH}$ TRU waste being received from NFS. The NFS Storage Facility did not become available June 1994 as previously expected, and the projected date of availability is unknown, although expected in 1995. Facility 7879 will store $\mathrm{CH}$ TRU waste from the NFS, pending completion of the storage facility. The CH TRU Waste Storage Facility, which is proposed for construction but delayed owing to lack of National Environmental Policy Act (NEPA) approval, is not expected to be available until sometime in FY 1995. Building 7934, which had earlier been identified for the storage of hazardous and mixed waste, will now be used for the interim storage of $\mathrm{CH}$ TRU mixed waste. Buildings 7842 and 7878 , which were used previously for 
ORNL-DWG $91 M-17278$

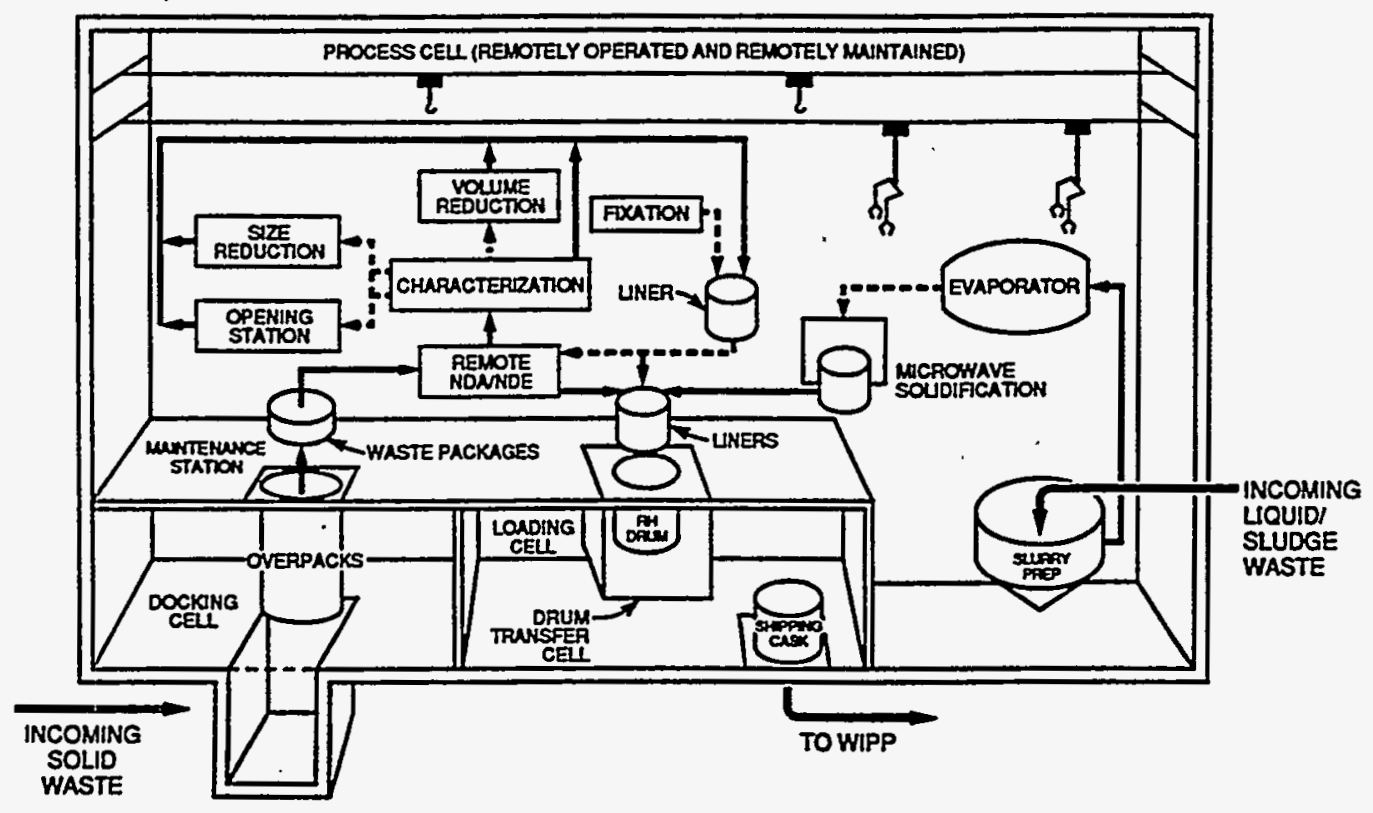

Fig. 4.6. Conceptual Waste Handling and Packaging Plant cutaway.

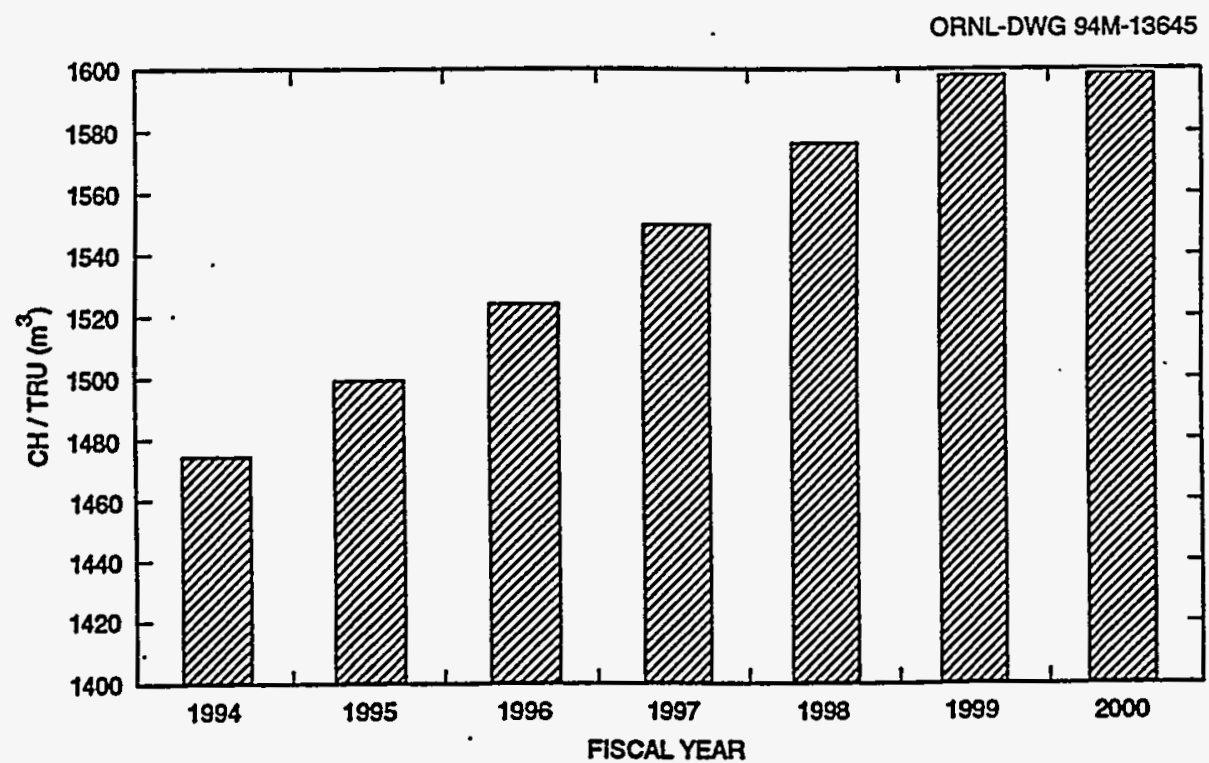

Fig. 4.7. Projected contact-handled transuranic waste for storage. Source: ESWMO August 1994. Oak Ridge Reservation Waste Storage Report for Period Ending June 30, 1994, ES/WM-23, rev. 0, Science Applications Intl. Corp., Oak Ridge, Tenn. 
SLLW staging and storage, are storing the $\mathrm{CH}$ TRU mixed waste resulting from the RCRA closure of Buildings 7826 and 7834; this transfer of these wastes was completed in March 1994. Figure 4.7 shows projected $\mathrm{CH}$ TRU storage requirements as of June 30, 1994.

\section{RH TRU}

Less than 1 year of storage space remains for RH TRU waste. The RH TRU waste is stored on a campaign basis depending on how long it takes the generator to accumulate a sufficient quantity. One or more casks of waste will likely require storage within the next year. The construction of additional RH TRU storage space has been delayed pending NEPA approval; the earliest projected availability is October 1995. The generators of RH TRU waste at ORNL have implemented changes in their processes that have reduced the quantities of RH TRU waste being generated. Generators are also segregating RH TRU waste contaminated with RCRA materials from non-RCRA RH TRU waste when possible. The mixed RH TRU waste will go to the existing permitted storage facility. Use of other facilities is being investigated for the temporary storage of non-RCRA RH TRU waste until the new RH TRU Waste Storage Bunker becomes available. Figure 4.8 shows projected RH TRU storage requirements as of June 30, 1994. Appendix D provides DOE Order 5820.2A compliance summaries.

\section{Disposal}

WIPP is the only identified disposal site for TRU waste from the ORR. The initial 5-year Test Phase for WIPP has recently had a change in strategy. DOE has decided to pursue an expanded laboratory test program using radioactive and hazardous wastes in lieu of underground tests at WIPP using radioactive waste. The redirection of the Test Phase will allow both DOE and the EPA to address the disposal certification issues more effectively. TRU waste from ORNL will be disposed of at WIPP during a 20-year Disposal Phase following a multiyear Test Phase.

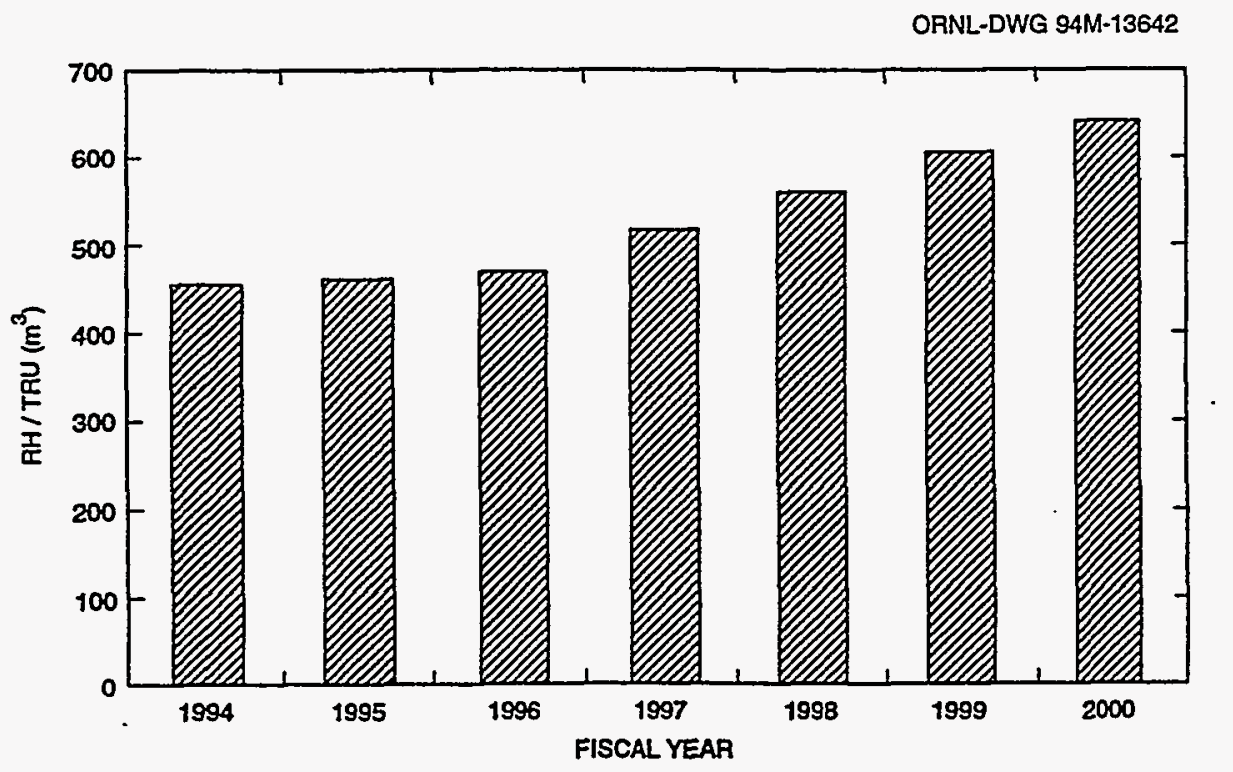

Fig. 4.8. Projected remote-handled transuranic waste for storage. Source: ESWMO August 1994. Oak Ridge Reservation Waste Storage Report for Period Ending June 30, 1994, ES/WM-23, rev. 0, Science Applications Intl. Corp., Oak Ridge, Tenn. 


\section{Waste Verification}

The ORNL Waste Examination and Assay Facility (WEAF), Building 7824, is used primarily for nondestructive , examination and assay of the contents of waste containers of $\mathrm{CH}$ TRU wastes, $\mathrm{CH}$ TRU mixed wastes, and LLW to verify compliance with specific WAC prior to being sent to other facilities for storage or disposal. WEAF can examine and assay up to 200 waste containers a month but usually averages 10 to 50 waste containers. WEAF is also used for the nondestructive assay of miscellaneous radioactive and nonradioactive nonwaste materials and research and development activities involving pulsed neutron, gamma ray, and $\mathrm{X}$-ray detection applications. WEAF is operated by the Energy Systems Waste Management Organization at ORNL, Applied Radiation Measurements Department. WEAF is located within the confines of SWSA 5 in the Melton Valley area of ORNL. A proposed new assay facility, the Central Verification Facility, would expand the throughput and efficiency of WEAF; it is planned as a 1998 LI project.

\section{Waste Minimization/Pollution Prevention}

Plans are under way to develop specific pollution prevention projects in this area in 1995.

\section{Reference}

Sears, M. B. et al. 1990. Sampling and Analysis of Radioactive Liquid Wastes and Sludges in the Melton Valley and Evaporator Facility Storage Tanks at ORNL, ORNL/TM-11652, Martin Marietta Energy Systems, Oak Ridge Natl. Lab. 


\section{Low-Level Waste}

Low-level waste (LLW) is radioactive. waste generated on the Oak Ridge Reservation (ORR) but not mixed with hazardous constituents. It is not classified as high-level waste ( $\mathrm{HLW}$ ), transuranic (TRU) waste, spent nuclear fuel, or $11 \mathrm{e}(2)$ by-product material [i.e., uranium or thorium mill tailings and waste as defined by U.S. Department of Energy (DOE) Order 5820.2A]. Test specimens of fissionable material, irradiated for research and development (R\&D) purposes only, may be classified as LLW provided the concentration of TRU radionuclides is less than $100 \mathrm{nCi} / \mathrm{g}$. HLW (i.e., waste generated as a result of fuel reprocessing and $11 \mathrm{e}(2)$ by-product material) is not generated, stored, or treated on the ORR.

LLWs generated at the Oak Ridge Y-12 Plant and the Oak Ridge K-25 Site are primarily uranium-contaminated materials. LLW generated at Oak Ridge National Laboratory (ORNL) consists primarily of mixed fission products. Small quantities of naturally occurring and accelerator-produced radioactive material are generated and managed as LLW at ORNL. Contaminated scrap metal is LLW that is segregated, stored, and treated for its reuse or decontamination and release.

Radioactive waste management operations include the treatment, storage, and disposal (TSD) of solid, liquid, and gaseous wastes. Figures 5.1 and 5.2 list the volumes of LLW generated and stored on the ORR respectively.

Each physical form of LLW is handled in different systems. Solid LLW (SLLW) is classified as contact-handled (CH) or remote-handled $(\mathrm{RH})$ based on the radiation dose at the surface of the waste package.

CH SLLW (also referred to as lowrange waste) is waste that has a radiation dose rate at the package surface of less than or equal to $200 \mathrm{mrem} / \mathrm{h}$. All SLLWs at the Y-12 Plant and the K-25 Site are $\mathrm{CH}$, while SLLWs at ORNL are both $\mathrm{CH}$ and RH. RH LLW has a surface dose rate of greater than $200 \mathrm{mrem} / \mathrm{h}$. RH LLW is subdivided into two categories for handling and long-term management: high-range (i.e., maximum contact reading less than or equal to $1 \mathrm{rem} / \mathrm{h}$ ) and very high range (i.e., contact intensity greater than $1 \mathrm{rem} / \mathrm{h}$ ). Table 5.1 lists descriptions, packaging methods, treatment, and dose rates for these and all other SLLW wastes on the ORR.

ORNL employs two systems for handling and processing liquids that contain radioactive constituents: the Liquid Low-Level Waste (LLLW) System and the Process Waste System (PWS). The LLLW System handles waste solutions with a significant amount of radioactivity including waste streams originating from $R \& D$ facilities and from other facilities such as nuclear reactors and the concentrate from the Process Waste Treatment Plant (PWTP) (Building 3544). The PWS handles all liquid waste that contains trace amounts of radioactivity, heavy metals, and organics or that has the potential to be contaminated with these constituents. 


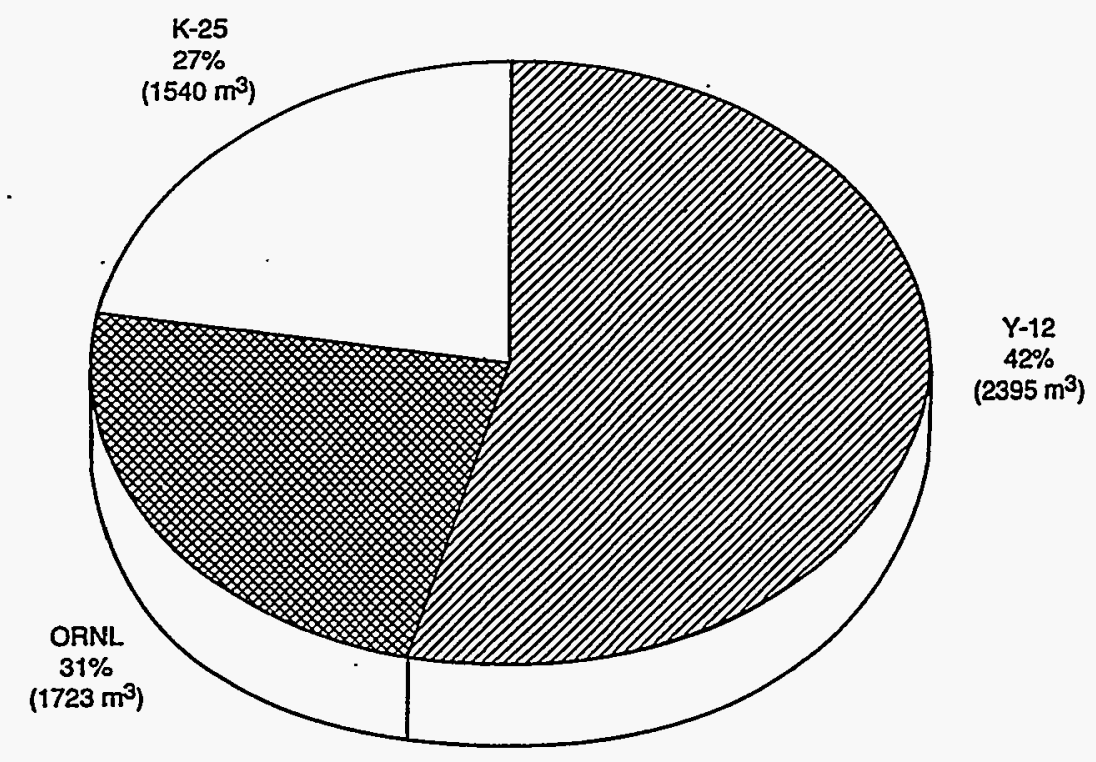

Fig. 5.1. Volumes of solid low-level waste generated on the Oak Ridge Reservation during CY 1993.

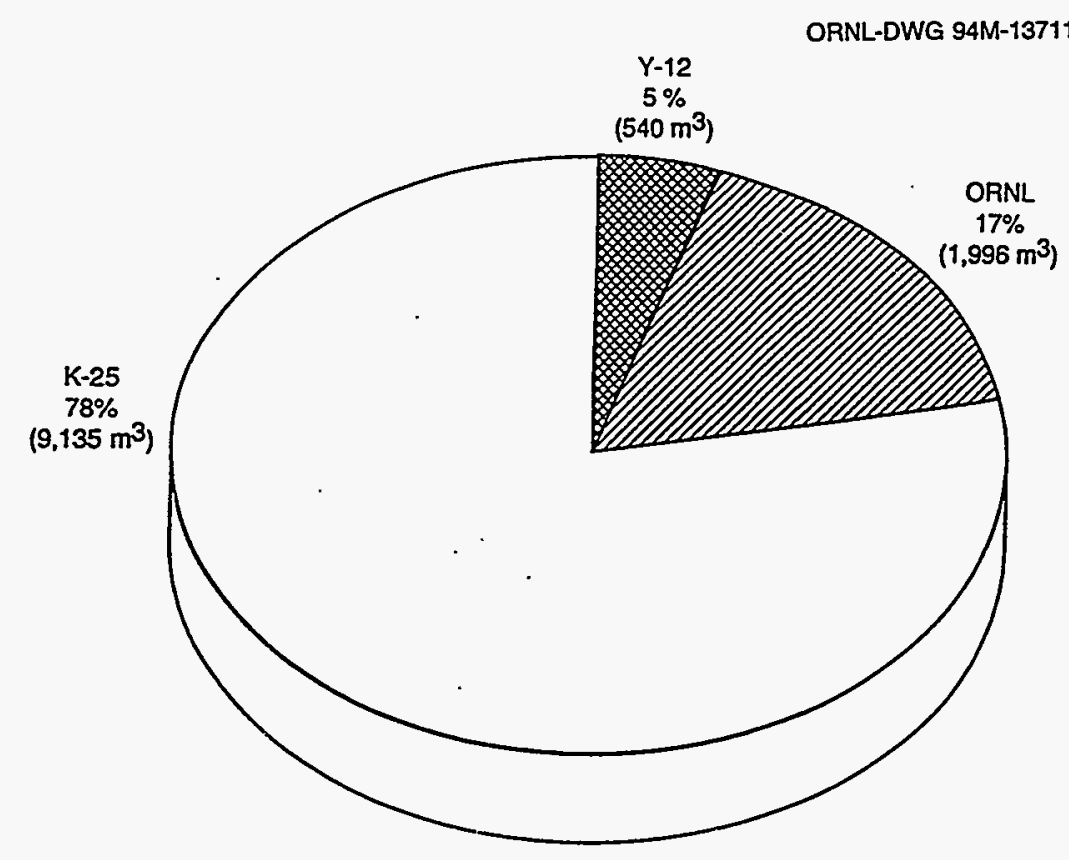

Fig. 5.2. Volumes of solid low-level waste stored on the Oak Ridge Reservation as of June 30, 1994. Source: ESWMO August 1994. Oak Ridge Reservation Waste Storage Report for Period Ending June 30, 1994, ES/WM-23, rev. 0, Science Applications Intl. Corp., Oak Ridge, Tenn. 
Table 5.1 Current solid low-level waste (SLLW) segregation categories on the Oak Ridge Reservation

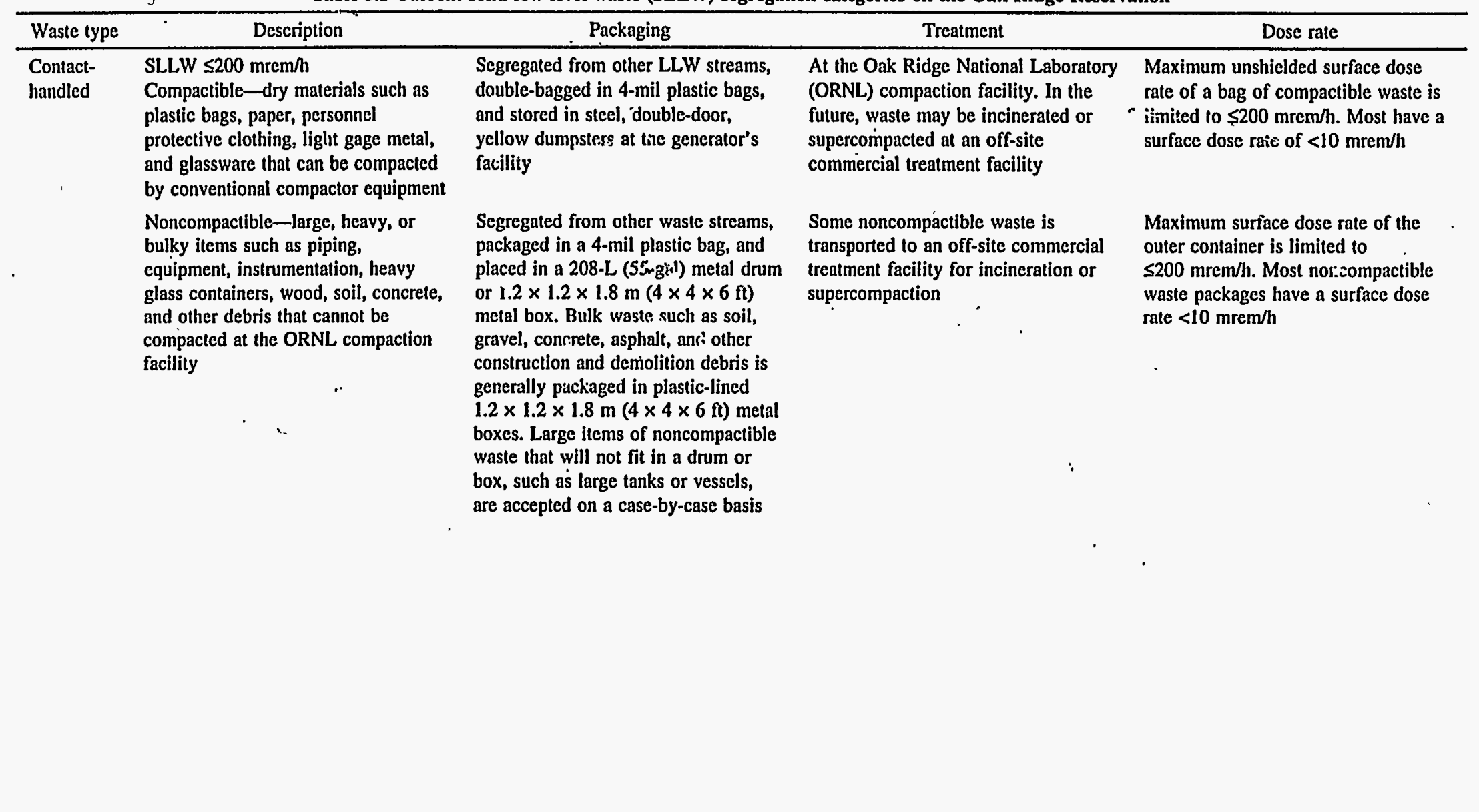


Table 5.1 (continued)

\begin{tabular}{|c|c|c|c|c|}
\hline Waste type & Description & Packaging & Treatment & Dose rate \\
\hline \multirow[t]{2}{*}{$\begin{array}{l}\text { Remote- } \\
\text { handled }\end{array}$} & $\begin{array}{l}\text { SLLW }>200 \mathrm{mrem} / \mathrm{h} \text {. Consists of } \\
\text { debris from reactors and hot cell } \\
\text { operations, ion exchange resins, } \\
\text { radioactive sealed sources, and } \\
\text { solidified supernatants from Melton } \\
\text { Valley Storage Tanks (MVSTs). It is } \\
\text { subdivided into two categories for } \\
\text { handling and long-term management: } \\
\text { high-range waste (i.e., maximum } \\
\text { coniact reading } \leq 1 \mathrm{rem} / \mathrm{h} \text { ) and very } \\
1 \text { igh range waste (i.e., contact } \\
\text { intensity }>1 \mathrm{rem} / \mathrm{h} \text { ) }\end{array}$ & $\begin{array}{l}\text { High-range waste consists of the same } \\
\text { type of materials as those in CH } \\
\text { LLW. It is generally double-bagged in } \\
\text { 4-mil plastic bags and placed inside } \\
\text { an outer container. Large items that } \\
\text { will not fit in a plastic bag may be } \\
\text { double-wrapped in plastic or placed in } \\
\text { alternate containers. Approved outer } \\
\text { containers are either 20-mil plastic } \\
\text { bags, 3.8- to 75.7-L (1- to 20-gal) } \\
\text { metal cans, or 114- or 208-L (30- or } \\
55 \text {-gal) metal drums. Very high range } \\
\text { waste consists primarily of obsolete } \\
\text { equipment and materials contaminated } \\
\text { with activation or fission products } \\
\text { from reactors and from isotope } \\
\text { production hot cells. Such wastes are } \\
\text { packaged in an inner container, } \\
\text { sealed, and placed in an outer } \\
\text { container that is typically a } 3.8-\text { to } \\
75.7-\mathrm{L} \text { (1- to 20-gal) metal can or } \\
114-\text { or } 208-\mathrm{L} \text { (30- or } 55-\text { gal) metal } \\
\text { drum. Because of its very high } \\
\text { radiation level, this waste must be } \\
\text { transported in shielded waste carriers } \\
\text { or shielded transport casks }\end{array}$ & $\begin{array}{l}\text { High-range wastes are not treated } \\
\text { because of the high dose rates }\end{array}$ & $>200 \mathrm{mrem} / \mathrm{h}$ but $\leq 1 \mathrm{rcm} / \mathrm{h}$ \\
\hline & $\begin{array}{l}\text { Very high range wet solid wastes are } \\
\text { also generated during treatment of } \\
\text { liquid } L L W \text {. Dewatered ion exchange } \\
\text { resins from reactor facilities and } \\
\text { solidified supernatants from MVSTs } \\
\text { produce an } R H \text { LLW }>1 \text { rem/h }\end{array}$ & $\begin{array}{l}\text { These waste streams are packaged in } \\
\text { large steel or high-density } \\
\text { polyethylene containers }\end{array}$ & $\begin{array}{l}\text { Very high range wastes are not } \\
\text { treated because of the high dose rates }\end{array}$ & $>1 \mathrm{rem} / \mathrm{h}$ \\
\hline
\end{tabular}


Table 5.1 (continued)

\begin{tabular}{|c|c|c|c|c|}
\hline Waste type & Description & Packaging & Treatment & Dose rate \\
\hline Fissile & $\begin{array}{l}\text { LLW containing }{ }^{233} \mathrm{U},{ }^{235} \mathrm{U},{ }^{238} \mathrm{Pu} \text {, } \\
{ }^{241} \mathrm{Pu} \text {, and/or the isotopes of } \\
\text { neptunium, americium, curium, } \\
\text { berkelium, and californium is } \\
\text { managed as fissile waste provided the } \\
\text { concentration of the transuranic } \\
\text { radionuclides with half lives } \\
>20 \text { years is }<100 \mathrm{nCi} / \mathrm{g} \text {. For } \\
\text { criticality and security reasons waste } \\
\text { containing } 21 \text { ' } \mathrm{g} \text { or } \geq ! \mathrm{g} / \mathrm{ft}^{3} \text { of }{ }^{235} \mathrm{U} \text { or } \\
\text { its fissile mass equivalent is handled } \\
\text { separately }\end{array}$ & $\begin{array}{l}\text { All fissile wastes are packaged in } \\
\text { containers that provide at least two } \\
\text { containment barriers to prevent the } \\
\text { inadvertent release of radioactive } \\
\text { material during handling }\end{array}$ & $\begin{array}{l}\text { Not treated because a treatment } \\
\text { facility is not available and existing } \\
\text { treatment facilities are not suitable for } \\
\text { fissile waste }\end{array}$ & $\begin{array}{l}\text { The dose rate of fissile packages may } \\
\text { be }>1 \mathrm{rem} / \mathrm{h}\end{array}$ \\
\hline Biological & $\begin{array}{l}\text { LLW consisting of animal carcasses, } \\
\text { tissues, excrements, änd bedding that } \\
\text { are generated when radionuclides are } \\
\text { used in biological research. Also } \\
\text { included are contaminated plants and } \\
\text { animals from the Oak Ridge } \\
\text { Rescrvation (ORR) (e.g., deer, ducks, } \\
\text { geese, trees, grass, and plants). } \\
\text { Sewage sludge from the ORNL } \\
\text { Sanitary Wastewater Treatment } \\
\text { Facility is also managed as biological } \\
\text { LLW }\end{array}$ & $\begin{array}{l}\text { Radioaclive animal carcasses and } \\
\text { tissues are frozen and stored by the } \\
\text { waste generator. Contaminated } \\
\text { vegetation sewage sludge is } \\
\text { temporarily stored at an ORNL waste } \\
\text { storage facility }\end{array}$ & $\begin{array}{l}\text { When a sufficient quantity of } \\
\text { contaminated biological waste has } \\
\text { accumulated, it is transported to an } \\
\text { off-site commercial treatment facility } \\
\text { for incineration. The treated waste is } \\
\text { packaged in metal boxes and retumed } \\
\text { to ORNL for storage or disposal }\end{array}$ & Much $<10 \mathrm{mrem} / \mathrm{h}$ \\
\hline Asbestọ & $\begin{array}{l}\text { Until the late } 1970 \text { s, asbestos was } \\
\text { used extensively at ORNL for the } \\
\text { insulation of pipes. Asbestos waste is } \\
\text { also found in floor tiles, ovens, and } \\
\text { furmaces. Asbestos waste is generated } \\
\text { during maintenance or demolition of } \\
\text { contaminated facilities. }\end{array}$ & $\begin{array}{l}\text { Generally, asbestos waste is packaged } \\
\text { in a special, asbestos-labeled, 6-mil } \\
\text { polyethylene bag, sealed with tape, } \\
\text { and placed in a second asbestos- } \\
\text { labeled polyethylene bag. Heavy } \\
\text { materials such as asbestos tiles or } \\
\text { bench tops are placed in fiberboard } \\
\text { drums }\end{array}$ & $\begin{array}{l}\text { Not treated because of the asbestos } \\
\text { dust hazard }\end{array}$ & $\begin{array}{l}\text { Maximum dose rate of packaged } \\
\text { asbestos waste is limited } 10 \leq 1 \mathrm{rem} / \mathrm{h} \text {. } \\
\text { Typical dose of packaged asbestos } \\
\text { waste is much }<10 \mathrm{mrem} / \mathrm{h}\end{array}$ \\
\hline
\end{tabular}


Table 5.1 (continued)

\begin{tabular}{|c|c|c|c|c|}
\hline Waste type & Description & Packaging & Treatment & Dose rate \\
\hline $\begin{array}{l}\text { Very low } \\
\text { activity }\end{array}$ & $\begin{array}{l}\text { Debris that is generated during the } \\
\text { decontamination and decommissioning } \\
\text { or construction of facilities and other } \\
\text { waste suich as soil, air filters, wood, } \\
\text { emply drums, laboratory equipment, } \\
\text { and personnel protective clothing. It } \\
\text { has no measurable external } \\
\text { contamination but cannot be certified } \\
\text { by routine Health Physics surveys as } \\
\text { free of internal contamination. It was } \\
\text { formerly called suspect waste }\end{array}$ & $\begin{array}{l}\text { Segregated from other LLW and } \\
\text { placed inside a } 1.2 \times 1.2 \times 1.8 \mathrm{~m} \\
(4 \times 4 \times 6 \mathrm{ft}) \text { metal box. Large items } \\
\text { that will not fit in a metal box are } \\
\text { stored in a sea-iand container }\end{array}$ & $\begin{array}{l}\text { The packaged waste is stored at an } \\
\text { ORNL storage facility until } \\
\text { transported off-site for incineration or } \\
\text { supcrcompaction at a commercial } \\
\text { treatment facility. The treated waste is } \\
\text { packaged in metal boxes and retumed } \\
\text { to ORNL for storage or disposal }\end{array}$ & $\begin{array}{l}\text { There are no extemal radiation } \\
\text { readings on packages of this waste }\end{array}$ \\
\hline $\begin{array}{l}\text { Special } \\
\text { case }(\mathrm{SC})^{a}\end{array}$ & $\begin{array}{l}\text { Three categories of SC SLLW have } \\
\text { been identified for management: } \\
\text { (I) Performance Assessment limiting } \\
\text { (PAL), (2) greater than Nuclear } \\
\text { Regulatory Commission (NRC) } \\
\text { Class C (GTCC), (3) spent fuel and } \\
\text { fuel debris }\end{array}$ & & • & \\
\hline
\end{tabular}


Table 5.1 (continued)

\begin{tabular}{|c|c|c|c|c|}
\hline Waste type & Description & Packaging & Treatment & Dose rate \\
\hline & $\begin{array}{l}\text { - SC PAL consists primarily of those } \\
\text { isotopes having long half-lives or } \\
\text { those isotopes with intermediate half- } \\
\text { lives that are environmentally mobile. } \\
\text { The isotopes of uranium account for } \\
\text { most of the volume of waste falling } \\
\text { within this class. Other isotopes } \\
\text { include Th, } \mathrm{Np} \text {, Am, Be, C, Zr, Pu, } \\
\text { and Tc. ORNL currently generates } \\
<3.25 \mathrm{~m}^{3} / \text { year (<I15 } \mathrm{ft}^{3} \text { ) of Class } \\
\text { L-III waste. The Class L-IV waste } \\
\text { designation applies to isotopes having } \\
\text { both short and long half-lives. } \\
\text { Isotopic concentrations in waste } \\
\text { exceeding either the Class L-II limits } \\
\text { (depending on the isotope, the Class } \\
\text { L-III limits) will prohibit the disposal } \\
\text { of that waste on the ORR. Currently, } \\
\text { ORNL generates } 48.3 \mathrm{~m}^{3} / y e a r \\
\text { (1705 } \mathrm{ft}^{3} \text { ) of Class L-IV waste }\end{array}$ & $\begin{array}{l}\text { No special packaging is required } \\
\text { (packaged per criteria for } \mathrm{CH} \text { or } \mathrm{RH} \\
\text { LLW as applicable) }\end{array}$ & $\begin{array}{l}\text { CH SC PAL could be treated by } \\
\text { incineration or supercompaction. RH } \\
\text { SC.PAL is not treated because a } \\
\text { treatment facility for RH waste is not } \\
\text { available }\end{array}$ & Dose rate for PAL can be $\mathrm{CH}$ or $\mathrm{RH}$ \\
\hline & $\begin{array}{l}\text { - SC GTCC consists of small } \\
\text { quantities of highly radioactive waste } \\
\text { such as sealed radiation sources and } \\
\text { activated parts from reactors. It } \\
\text { contains high-curie loadings, requires } \\
\text { special packaging, transport, and } \\
\text { handling capabilities as well as unique } \\
\text { storage facilities. The characteristics } \\
\text { and quantities of ORNL waste in the } \\
\text { SC GTCC category have not been } \\
\text { determined. Sealed sources are also a } \\
\text { subcalegory of SC loan/lease material }\end{array}$ & $\begin{array}{l}\text { No special packaging is required } \\
\text { (packaged per criteria for CH or RH } \\
\text { LLW as applicable) }\end{array}$ & $\begin{array}{l}\text { CH SC PAL could be treated by } \\
\text { incineration or supercompaction. RH } \\
\text { SC PAL is not treated because a } \\
\text { treatment facility for RH waste is not } \\
\text { available. }\end{array}$ & $\begin{array}{l}\text { Dose rate for GTCC can be } \mathrm{CH} \text { or } \\
\text { RH }\end{array}$ \\
\hline
\end{tabular}

aStorage of spent nuclear fuel on the ORR is discussed in Sect. 3 of this document. 


\section{Management Strategy}

In the previous strategy for managing LLW on the ORR (Genung et al. 1987), waste primarily destined for disposal on the ORR was classified according to its isotopic content, concentration, and the performance of a disposal facility (i.e., the facility's ability to isolate the radionuclides from the environment and postulated intruders) for a specific site location and disposal technology. Table 5.2 shows the four classes of LLW that were proposed. These classifications are still used in some instances to denote the type of LLW or a disposal technology. For example, L-I refers to low-concentration LLW or a landfill disposal facility, while L-II refers to low- to moderate-concentration LLW or a tumulus disposal facility.

Since the issuance of this proposed strategy, ORR waste management has been affected by three recent events:

- declines in ORR disposal capacity,

- changes in regulatory and operational conditions, and

- evolution of the radioactive waste disposal-class concept.
In July, 1991, the primary LLW disposal site at the Y-12 Plant, the Bear Creek Burial Ground, was closed because of concerns about potential impacts on the environment and noncompliance with $\mathrm{DOE}$ Order 5820.2A. Operations at the other major ORR LLW disposal site, Solid Waste Storage Area (SWSA) 6 at ORNL, have been significantly curtailed with the cessation of all disposal operations except the tumulus facility in the Interim Waste Management Facility (TWMF).

The declining disposal capacity has created a significant increase in storage requirements. Recently, LLW has been shipped to commercial treatment facilities for volume reduction (i.e., incineration or supercompaction) or recycle (i.e., metal smelting). The resulting residuals from the treatment processes will be returned to the K-25 Site for storage and eventual shipment to a disposal site.

Development of a Class L-I disposal facility has been deferred until after the year 2000 because of lack of funding priority and reduced need resulting from waste minimization and volume reduction activities. The most suitable sites for disposal of Class L-II LLW on the ORR

Table 5.2. Previously proposed classification system for low-level waste

\begin{tabular}{cll}
\hline Waste class & \multicolumn{1}{c}{ Isotopic content } & \multicolumn{1}{c}{ Disposal technology } \\
\hline L-I & $\begin{array}{l}\text { Low concentrations of long- and short- } \\
\text { half-life (less than 30-year) isotopes }\end{array}$ & Engineered landfill (shallow land burial) \\
L-II & $\begin{array}{l}\text { Low concentrations of long and } \\
\text { moderate concentrations of short-half- } \\
\text { life isotopes }\end{array}$ & $\begin{array}{l}\text { Engineered confinement facility } \\
\text { (tamulus or vault) }\end{array}$ \\
L-III & $\begin{array}{l}\text { Moderate concentrations of long-half- } \\
\text { life waste requiring treatment before } \\
\text { disposal } \\
\text { High levels of radioactivity not suitable } \\
\text { for disposal on the Oak Ridge }\end{array}$ & $\begin{array}{l}\text { Engineered facility with permanent } \\
\text { intruder protection }\end{array}$ \\
& Reservation & \\
\hline
\end{tabular}

Source: Genung, R. K., July 1987. Strategic Planning for Low-Level Waste Disposal Development and Demonstration Program, Martin Marietta Energy Systems, Oak Ridge K-25 Site. 
are in Bear Creek Valley. An alternate potential disposal site located at SWSA 7 has less disposal capacity than Bear Creek Valley and possesses geology and hydrology less suitable for planned tumulus-type facilities. Class L-II/TV wastes are currently being stored-awaiting construction of interim storage facilities proposed for SWSA 7 at ORNL and completion of off-site disposal plans.

Closure of existing facilities and delays in funding new facilities has indicated a need for new waste classifications as proposed in Energy Systems Waste Management Organization's (ESWMO-Central's) waste management strategy. A revised classification system has been proposed (Lee et al. 1993). Table 5.3 shows the three classes of LLW proposed in the revised strategy.

The current strategy for management of solid LLW on the ORR is as follows:

- minimize generation of LLW through segregation, process control, and recycle or reuse;

- continue disposal of ORNL LLW in the IWMF;

- expand the IWMF to meet ORNL's operational, environmental restoration, and decontamination and decommissioning (D\&D) disposal needs;

- seek new on-site disposal capacity for disposal of L-II-type wastes in an
ESWMO facility (the concentration of these wastes allowed for disposal will be based on Performance Assessments (PAs) for a specific site and disposal technology);

- utilize commercial vendors, where appropriate, for waste volume reduction and treatment to reduce storage needs;

- seek off-site disposal of LLW generated and stored at ORNL, the Y-12 Plant, and the K-25 Site in a DOE facility (these include PA-limited wastes and most wastes undergoing volume reduction); and

- store LLW until suitable disposal sites are determined.

\section{Current Generation and Projections}

Radioactive waste generation is dominated by LLW (including contaminated scrap metal), accounting for almost $82 \%$ of all radioactive wastes (i.e., LLW, TRU, and mixed waste) generated on the ORR. During CY 1993 the Y-12 Plant, ORNL, and the K-25 Site generated 2395,1723 , and $1540 \mathrm{~m}^{3}(84,593,60,832$, and $54,390 \mathrm{ft}^{3}$ ) of SLLW respectively. All SLLW generated at the Y-12 Plant and $\mathrm{K}-25$ Site is stored or treated for volume reduction prior to storage. LLW generated at ORNL is either treated, stored, or disposed of on-site. Tables 5.4 and 5.5, and

Table 5.3. Proposed revised classification system for low-level waste

\begin{tabular}{|c|c|c|}
\hline Waste class & Isotopic content & Disposal technology \\
\hline Exempt & $\begin{array}{l}\text { Contaminant levels sufficiently low to be } \\
\text { disposed of in sanitary or industrial } \\
\text { landfill with State concurrence }\end{array}$ & Sanitary or industrial landfill \\
\hline Disposable & $\begin{array}{l}\text { Wastes suitable for disposal on the Oak } \\
\text { Ridge Reservation as determined by } \\
\text { facility Performance Assessments }\end{array}$ & Engineered facilities \\
\hline Off-site & $\begin{array}{l}\text { Wastes not meeting criteria of exempt or } \\
\text { disposable classes }\end{array}$ & As determined by off-site facility \\
\hline
\end{tabular}

Source: Lee, D. W. et al. 1993. Central Waste Management Division Waste Management Division

Waste Management Strategy, ORNL/TM-12354, Martin Marietta Energy Systems, Oak Ridge Natl. Lab. 
Table 5.4. Summary of solid low-level waste generation on the Oak Ridge Reservation

\begin{tabular}{lcc}
\hline & $\begin{array}{c}\text { CY 1993 } \\
\mathrm{m}^{3}\left(\mathrm{ft}^{3}\right)\end{array}$ & $\begin{array}{c}\mathrm{CY} 1994^{a} \\
\mathrm{~m}^{3}\left(\mathrm{ft}^{3}\right)\end{array}$ \\
\hline Oak Ridge Y-12 Plant & $2,395(84,593)$ & $1,554(54,507)^{b}$ \\
Oak Ridge National Laboratory & $1,723(60,832)$ & $1,531(54,059)$ \\
Oak Ridge K-25 Site & $1,540(54,390)$ & $\frac{2,564(90,530)}{n}$ \\
\cline { 2 - 3 }$\quad$ Total & $5,658(199,815)$ & $5,649(199,096)$ \\
\hline
\end{tabular}

Projected.

Through June 1994.

Sources: 1. ORNL Waste Management Operations monthly reports.

2. Scanlan, T. F. December 1992, December 1993, and September 1993. WMRAD, Oak Ridge National Laboratory, internal correspondence to L. E. McNeese, WMRAD, Oak Ridge National Laboratory.

3. Scanlan, T. F. September 1994. WMRAD, Oak Ridge National Laboratory, internal correspondence to R. C. Mason, WMRAD, Oak Ridge National Laboratory.

4. ESWMO September 1994. Waste Management Trend Report, K/ESWMO-5, PI-94-1, Martin Marietta Energy Systems, Oak Ridge K-25 Site.

5. K-25 Site data taken from the $\mathrm{K}-25$ Waste-Tracking and Reporting System.

Table 5.5. Summary of liquid low-level waste generation on the Oak Ridge Reservation

\begin{tabular}{lcr}
\hline & $\begin{array}{c}\text { CY 1993 } \\
\text { L (gal) }\end{array}$ & \multicolumn{1}{c}{$\begin{array}{c}\text { CY 1994 } \\
\text { L (gal) }\end{array}$} \\
\hline Oak Ridge Y-12 Plant & $1,029,600(272,000)$ & $640,500(169,200)^{b}$ \\
Oak Ridge National Laboratory & $1,539,300(406,650)$ & $2,090,000(552,140)$ \\
Oak Ridge K-25 Site & $\frac{5,850(1,540)}{3,574,750(680,190)}$ & $\frac{32,480(8,580)}{2,762,980(729,920)}$ \\
$\quad$ Total & & \\
\hline
\end{tabular}

aprojected.

Through June 1994.

Sources: 1. ORNL Waste Management Operations monthly reports.

2. Scanian, T. F. December 1992, December 1993, and September 1993. WMRAD, Oak Ridge National Laboratory, internal correspondence to $L$. E. McNeese, WMRAD, Oak Ridge National Laboratory.

3. Scanlan, T. F. September 1994. WMRAD, Oak Ridge National Laboratory, internal correspondence to R. C. Mason, WMRAD, Oak Ridge National Laboratory.

4. ESWMO September 1994. Waste Management Trend Report, K/ESWMO-5, PI-94-1, Martin Marietta Energy Systems, Oak Ridge K-25 Site. 
5.6, respectively, summarize the current and projected generation of SLLW, LLLW, and contaminated scrap metal. Figure 5.3 shows Environmental Restoration Program generation projections.

\section{Treatment}

Table 5.7 provides a summary of LLW treatment on the ORR; Table 5.8, a summary of off-site treatment.

\section{Solid Low-Level Waste}

\section{Y-12 Plant}

Two LLW treatment facilities are at the Y-12 Plant: the Uranium Chip Oxidizer Facility (UCOF) and the Waste Feed Preparation Facility (WFPF). The UCOF (Fig. 5.4) thermally oxidizes depleted and natural uranium (less than $0.71 \%$ enrichment) machine chips under controlled conditions to a stable uranium oxide. Upon arrival, chips are weighed, placed into an oxidation chamber, and ignited. The oxide is transferred into drums and transported to the Depleted Uranium Oxide Storage Vaults.

The UCOF is not designed to treat uranium sawfines. Hence, sawfines are currently blended with uranium oxide and placed in the oxide vaults as a short-term treatment method. Waste Acceptance Criteria (WAC) are found in published operating procedures (Y-12 WMD August 1993).

The Trash-Monitoring Station (TMS) is not specifically considered to be a "treatment" facility, but for completeness, it is described here in the SLLW portion of this section. The TMS (Fig. 5.5) is a nondestructive examination facility that utilizes gamma scintillation detectors for the monitoring of ${ }^{238} \mathrm{U}$ in wastes. Its purpose is to minimize the amount of depleted uranium disposed of in the sanitary landfills at the Y-12 Plant. The TMS physical equipment includes a control building to house an operating technician and analyzer equipment; a canopied scanning pad on which items are placed for monitoring; a paved driveway for delivery of waste containers by trucks; and two platform-type enclosed stands, each containing a sodium iodide [NaI(TI)] scintillation radiation detector. A third detector is provided for determining background radiation.

The WFPF (Fig. 5.6) is located on West Third Street in Buildings 9401-4 and 9720-28. The Process Building, 9401-4, is used for volume reduction of SLLW materials only. The Storage Building, $9720-28$, provides interim storage for the compacted bales of solid waste before they are placed in ST-5 containers and transferred to the Above-Grade Storage Facility pending shipment to an outside veudor for treatment. WAC for this operation are found in published operating procedures (Y-12 WMD May 1994).

Table 5.6. Summary of contaminated scrap metal generation on the Oak Ridge Reservation

\begin{tabular}{lrr}
\hline & $\begin{array}{c}\mathrm{CY} 1993 \\
\mathrm{~m}^{3}\left(\mathrm{ft}^{3}\right)\end{array}$ & \multicolumn{1}{c}{$\begin{array}{c}\mathrm{CY} 1994^{a} \\
\mathrm{~m}^{3}\left(\mathrm{ft}^{3}\right)\end{array}$} \\
\hline Oak Ridge Y-12 Plant & $2,335(82,461)$ & $920(32,430)$ \\
Oak Ridge National Laboratory & $0.3(12)^{b}$ & $0.4(13)^{b}$ \\
Oak Ridge K-25 Site & $\frac{42(1,487)}{2,377.3(83,960)}$ & $\frac{103(3,651)}{1023.4(36,094)}$ \\
$\quad$ Total & 2
\end{tabular}

Projected.

${ }^{b}$ Does not include scrap metal managed by the Plant and Equipment Division. 


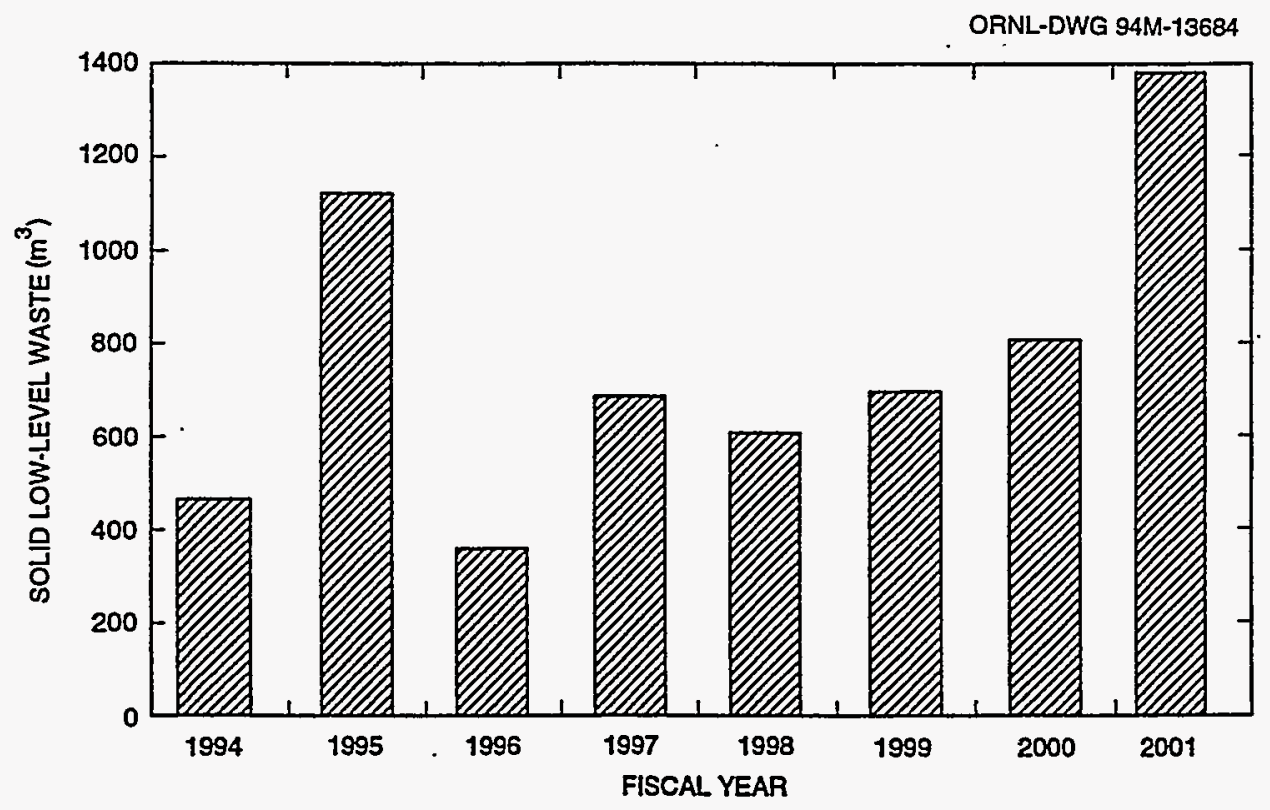

Fig. 53. Projected solid low-level waste generation under the Environmental Restoration and Decontamination and Decommissioning Programs on the Oak Ridge Reservation. Source: Environmental Restoration Division December 1993. Waste Generation Forecast for DOE-ORO's Environmental Restoration OR-I Project: FY 1994-FY 2001, ES/ER/TM-102, Martin Marietta Energy Systems, Oak Ridge K-25 Site.

Table 5.7. Summary of low-level waste treatment on the Oak Ridge Reservation ${ }^{q}$

\begin{tabular}{|c|c|c|c|}
\hline Waste type & $\begin{array}{c}\text { Treatment } \\
\text { method }\end{array}$ & $\begin{array}{l}\text { CY } 1993 \\
\mathrm{~m}^{3}\left(\mathrm{ft}^{3}\right)\end{array}$ & $\begin{array}{c}\text { CY 1994 } \\
\mathrm{m}^{3}\left(\mathrm{ft}^{3}\right)\end{array}$ \\
\hline \multicolumn{4}{|c|}{ Oak Ridge Y-12 Plant } \\
\hline Uranium saw fines, & Stabilization & $c$ & \\
\hline \multicolumn{4}{|c|}{ Oak Ridge National Laboratory } \\
\hline Compactible solids & Compaction & $434(15,327)^{d}$ & $143(5,050)^{d}$ \\
\hline $\begin{array}{l}\text { Melton Valley storage } \\
\text { tank supernatants }\end{array}$ & $\begin{array}{l}\text { Grout } \\
\text { solidification }\end{array}$ & $180(6380)$ & $180(6,380)$ \\
\hline
\end{tabular}

${ }^{\circ}$ There are no LLW treatment facilities at the Oak Ridge K-25 Site.

${ }^{b}$ Projected.

${ }^{c}$ Classified.

${ }^{d}$ Volume of LLW received prior to compaction from ORNL Waste Management Operations monthly reports. 
Table 5.8. Off-site treatment of solid low-level waste

\begin{tabular}{|c|c|c|c|}
\hline Waste type & Treatment method & $\begin{array}{l}\text { CY } 1993 \\
\mathrm{~m}^{3}\left(\mathrm{ft}^{3}\right)\end{array}$ & $\begin{array}{l}\text { CY } 1994^{a} \\
\mathrm{~m}^{3}\left(\mathrm{ft}^{3}\right)\end{array}$ \\
\hline \multicolumn{4}{|c|}{ Oak Ridge Y-12 Plant } \\
\hline Dry active waste & $\begin{array}{l}\text { Segregation, supercompaction, } \\
\text { incineration }\end{array}$ & $187(6,603)$ & $1,710(60,510)$ \\
\hline $\begin{array}{l}\text { Contaminated scrap } \\
\text { metal }\end{array}$ & Smelting & $745(26,321)$ & $1,630(57,600)$ \\
\hline \multicolumn{4}{|c|}{ Oak Ridge National Laboratory } \\
\hline Dry active waste & $\begin{array}{l}\text { Segregation, supercompaction, } \\
\text { incineration }\end{array}$ & $25(883)$ & $462(16,313)^{b}$ \\
\hline $\begin{array}{l}\text { Contaminated scrap } \\
\text { metal }\end{array}$ & Smelting & $0(0)$ & $0(0)$ \\
\hline \multicolumn{4}{|c|}{ Oak Ridge K-25 Site } \\
\hline Dry active waste & $\begin{array}{l}\text { Segregation, supercompaction, } \\
\text { incineration }\end{array}$ & $1,479(52,240)$ & $1,500(52,980)$ \\
\hline $\begin{array}{l}\text { Contaminated scrap } \\
\text { metal }\end{array}$ & Smelting & $912(32,207)$ & $1,000(35,320)$ \\
\hline
\end{tabular}

${ }^{a}$ Projected.

'Through November 17, 1994.

Figure 5.7 shows the process flow for solid low-level waste at the Oak Ridge Y-12 Plant.

\section{ORNL}

ORNL has one treatment facility for dry solid CH SLLW. The ORNL waste compaction facility (Building 7831) is located in SWSA $5 N$. Building 7831 is a metal Butler-type building approximately $12 \times 13 \mathrm{~m}(40 \times 42 \mathrm{ft})$ divided into a personnel area and compactor area $6 \times 13 \mathrm{~m}(20 \times 42 \mathrm{ft})$ each. The box compactor is used to reduce the volume of compatible CH SLLW into $1.2 \times 1.2 \times$ $1.8 \mathrm{~m}(4 \times 4 \times 6 \mathrm{ft})$ metal boxes with a compressive force of $12 \times 10^{6} \mathrm{~Pa}$ (1750 psi). Off-site commercial treatment facilities are also used to reduce the volume of a portion of ORNL's CH SLLW. Commercial services are available for supercompaction, incineration, and metal melting.
ORNL has one liquid treatment process that produces a solid CH SLLW. Process wastewater is collected and treated at the PWTP. The PWTP removes radionuclides by clarification, filtration, and ion exchange. The ferrous hydroxide sludge from the clarifier is passed through a filter press to reduce the liquid content and packaged in drums for on-site storage or disposal. Commercial vendors are used to treat ion exchange resins and LLLW evaporator concentrates at ORNL. Additional treatment facilities are not currently planned for ORNL.

\section{K-25 Site}

The only SLLW treatment facility on the K-25 Site is the $\mathrm{K}-1420$

Decontamination Facility, which has been used for the decontamination of radioactively contaminated equipment to meet radiation standards. This facility is 


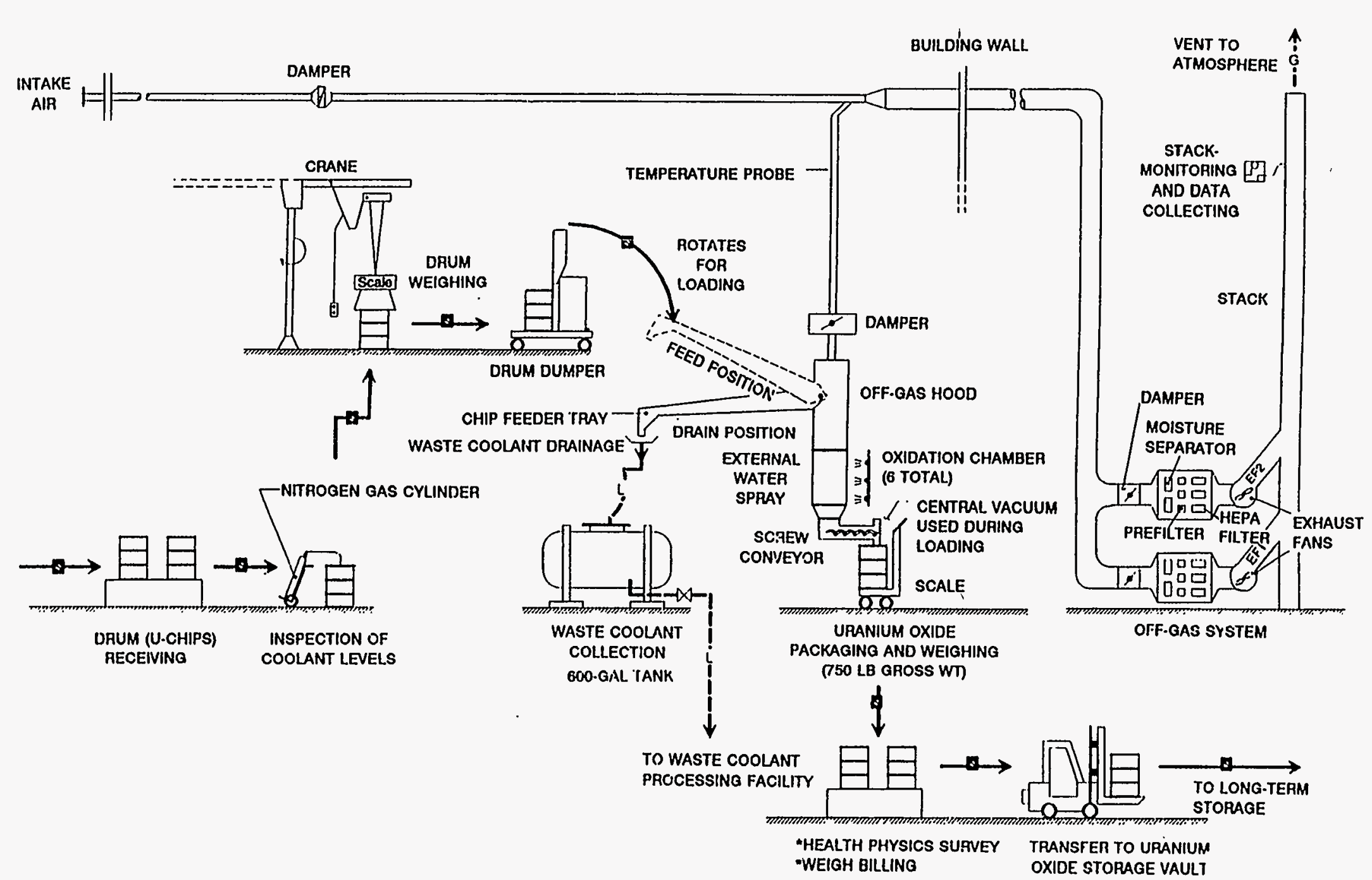

Fig. 5.4. Uranium Chip Oxidizer Facility at the Oak Ridge Y-12. Source: PAI Corporation Nov. 5, 1993. Description of Y-12 Plant Waste Management System 1993, PAI Corporation, Oak Ridge, Tenn. 


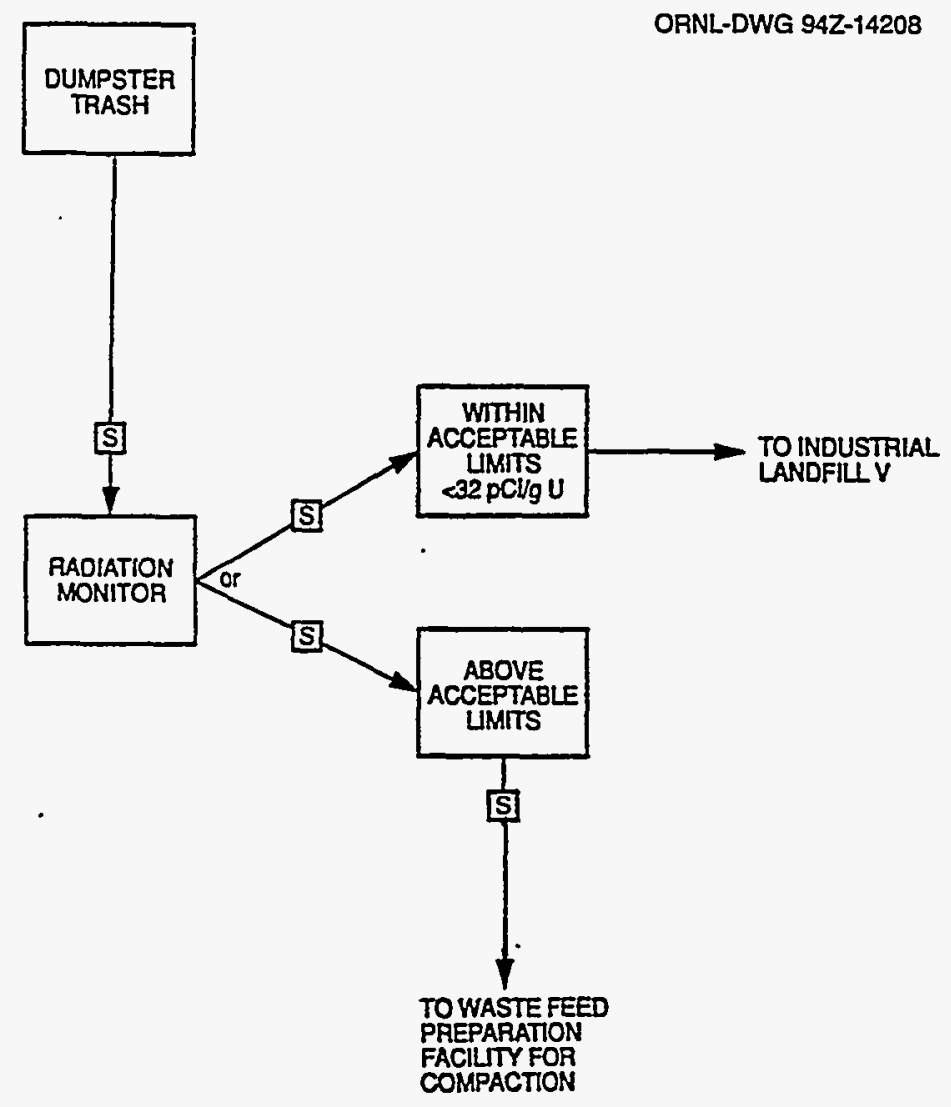

Fig. 5.5. Trash-Monitoring Station at the Oak Ridge Y-12 Plant. Source: PAI Corporation Nov. 5, 1993. Description of Y-12 Plant Waste Management System 1993, Oak Ridge, Tenn.

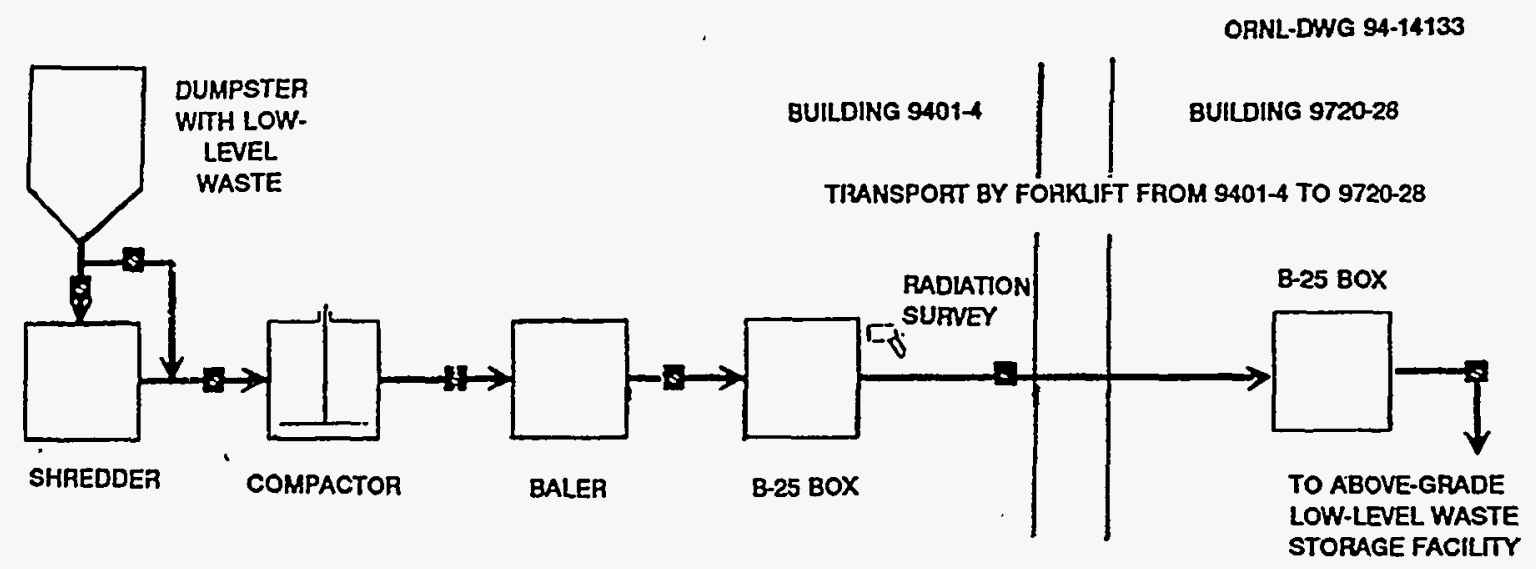

Fig. 5.6. The Waste Feed Preparation Facility at the Oak Ridge Y-12 Plant. Source: PAI Corporation Nov. 5, 1993. Description of Y-12 Plant Waste Management System 1993, Oak Ridge, Tenn. 


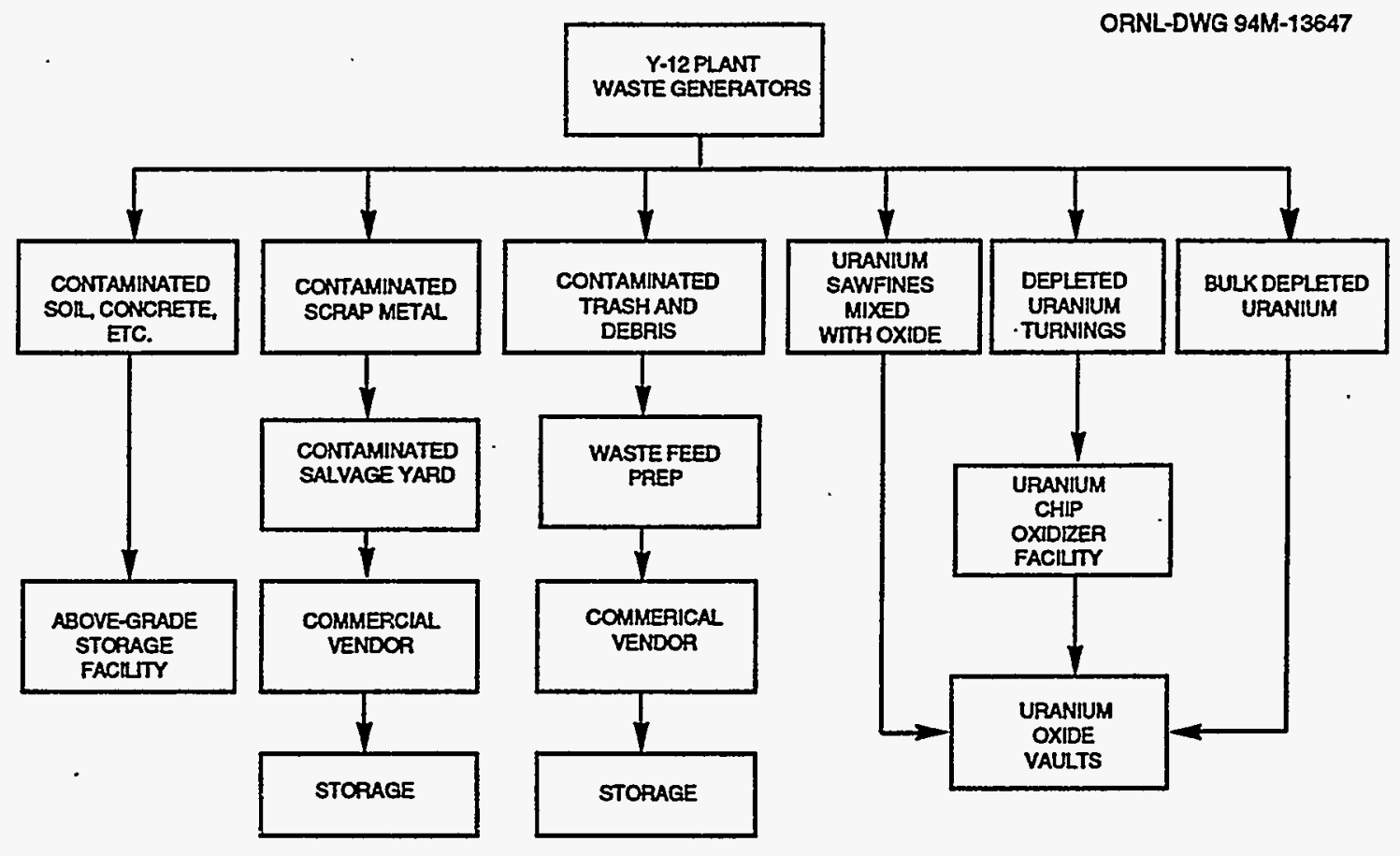

Fig. 5.7. Process flow of solid low-level waste at the Oak Ridge Y-12 Plant.

currently on standby awaiting

decontamination and decommissioning (D\&D). K-25 Site gaseous LLW treatment consists of basic equipment used in most of the ventilation systems that discharge to stacks, including fans and ducts used for transportation of air. High-efficiency particulate air filtration is employed for major sources of radionuclide emissions for Clean Air Act compliance or adherence to as low as reasonably achievable.

\section{Liquid Low-Level Waste}

\section{Y-12 Plant}

The greatest portion of LLLW at the $\mathrm{Y}-12$ Plant is also hazardous (thus mixed) owing to solvent or characteristic contamination. The primary source for LLLW is from radioactive decontamination activities.
ORNL

Facilities associated with the LLLW System at ORNL consist of collection tanks and piping, a service tank and the evaporator facilities at Building 2531, evaporator storage tanks, and Melton Valley storage tanks.

The waste accumulated in the collection tanks is transferred via underground piping to the LLLW Evaporator Facility (Building 2531) where it is concentrated in one of the two evaporator units that operate at an average volume reduction factor of 30:1. The concentrated waste is then transferred to one of several storage tanks, and the evaporator condensate is transferred to the PWTP for further treatment. Figure 5.8 shows a schematic of the LLLW System.

ORNL's LLLW Tank System is divided into two areas: Melton Valley and Bethel Valley. Currently, 40 active collection tanks are used: 10 serve the Melton Valley area, 17 serve the Bethel Valley area, and 13 are associated with the 


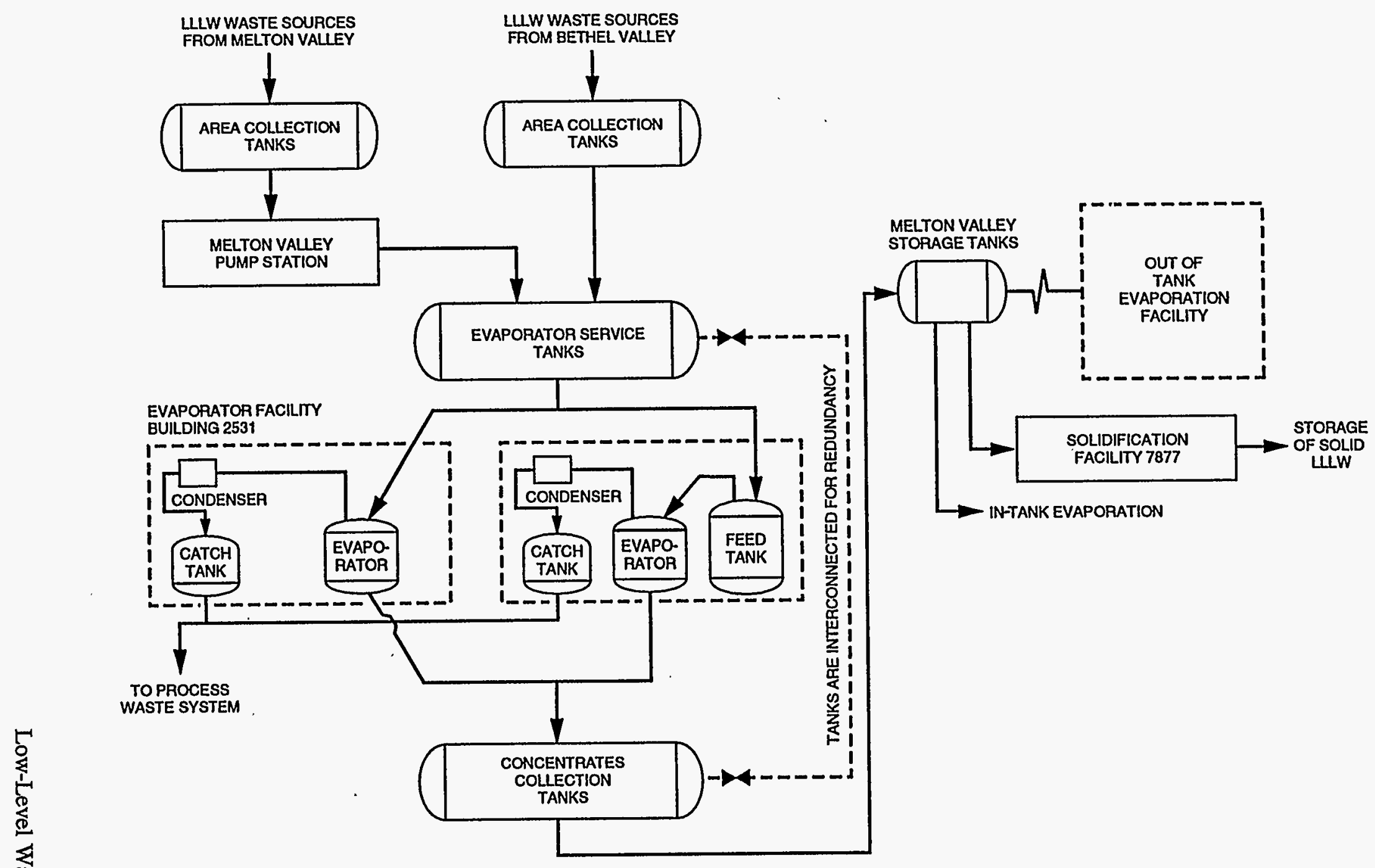

Fig, 5.8. Schematic of the Liquid Low-Level Waste System at Oak Ridge National Laboratory. 
central treatment/storage system. Also, 56 collection and storage tanks are currently inactive: 39 are owned by the Environmental Restoration Program; 17 are owned by ESWMO-ORNL or the generating division.

Most of the floor drains, collection tanks, and transfer lines in the system are singly contained. Most of the tanks associated with the centralized treatment system are doubly contained. The system was designed to work approximately 30 years; however, most of the system has surpassed its design life. LLLW solutions that accumulate in the collection tanks are periodically transferred to the Central Treatment/Storage System as shown in Fig. 5.9. The waste is collected in the evaporator service tank W-22 and then fed to evaporators $\mathrm{A} 2$ and $2 \mathrm{~A} 2$ for processing. One of the two evaporators is operated in a semicontinuous manner. The second evaporator is an in-place spare. Dilute LLLW is transferred by steam jet from feed tank W-22, as necessary, to maintain an operating level in the evaporator where the waste is concentrated to a target specific gravity of greater than 1.25. The evaporator condensate, which contains traces of radionuclides, is directed to the PWTP. When the evaporator bottoms or concentrated waste reaches a specific gravity between 1.25 and 1.5 , or when no feed is left to process, the evaporator is shut down, the contents are cooled, and the "concentrate" is transferred via steam jet to one of four storage tanks (i.e., W-21, $\mathrm{W}-23, \mathrm{C}-1$, or $\mathrm{C}-2$ ) and then pumped to $\mathrm{W}-24$ through $\mathrm{W}-31$. The transfer of the concentrate from the evaporator facility to the storage tanks is accomplished through a doubly contained stainless steel line that is cathodically protected and leak-tested before each transfer.

Major areas of the Radioactive Waste Evaporator Facility (Building 2531) include:

- Three separate stainless steel-lined vaults. These contain the evaporator feed

ORNL-DWG 91M-14039

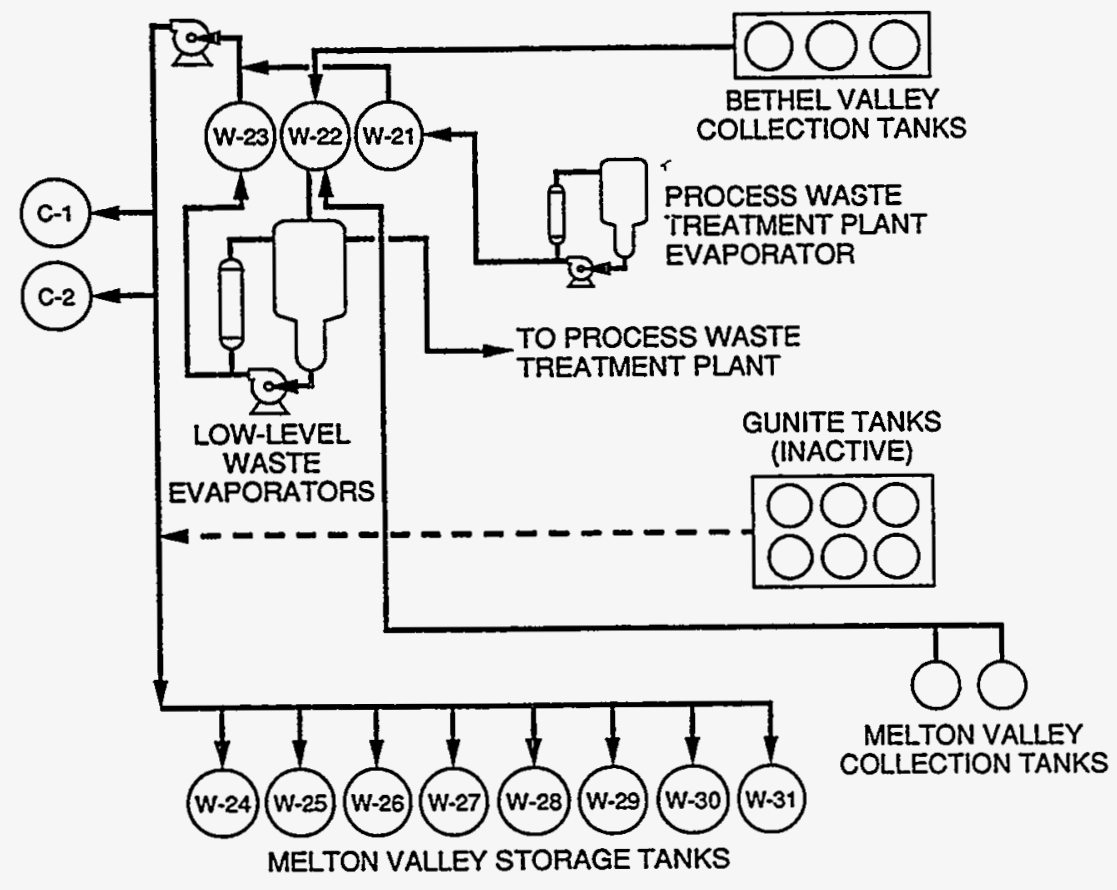

Fig. 5.9. Central Treatment/Storage System at Oak Ridge National Laboratory. 
tank W-22 and the converted evaporator feed tank W-21 (now a storage tank for concentrated liquid waste generated by the PWTP), the concentrate storage tank $\mathrm{W}-23$, and associated pumps, pipes, and controls.

- An underground pipe trench. This is used for the transfer of liquid waste from feed tank W-22 to the evaporator and concentrate to W-23 or W-21.

- The tank vault containing tanks $\mathrm{C}-1$ and $\mathrm{C}-2$. These are storage tanks for concentrated waste from the evaporator.

- Cells 1 through 4 in Building 2531 that contain the evaporators and associated equipment. Cell 1 contains the original evaporator A-2 and its feed tank, A-1. Cell 2 contains the accompanying evaporator (A-2) process equipment, which includes a condenser, vapor filter, condensate catch tank, off-gas scrubber, emergency condenser, and scrub liquor tank. Cell 4 holds evaporator $2 \mathrm{~A}-2$, and cell 3 contains the condensate filter, evaporator condenser, condensate surge tank, off-gas scrubber, and the scrub liquor tank for evaporator 2A-2.

The PWTP is designed to remove radionuclides. The processing steps are softening, clarification, filtration, and ion exchange. The influent is treated by chemical softening, which removes nonradioactive calcium and magnesium as well as radioactive cations. The clarification and filtration steps are needed to remove the precipitated cations prior to ion exchange to avoid frequent column regeneration. The remaining small amount of radioactive material is removed from the waste by the ion exchange columns. Sludge from the clarifier is passed through a filter press to reduce the liquid content and is then packed in drums for SLLW on-site storage. A number of disposal alternatives are being considered for this waste stream. The concentrated radioactive material resulting from the regeneration of the PWTP ion exchange columns is currently evaporated to approximately $40 \%$ solids and transferred to the W-21 storage tank in the LLLW System. Nitric acid is recovered in this process and is recycled within the PWTP. The capacity of the PWTP evaporator requires that a portion of the regenerant solution be sent to the LLLW evaporator for treatment. A project titled Process Waste Treatment System Upgrade has been designed to increase the capacity of the PWTP Evaporator System; this will reduce the amount of LLLW concentrate generated for permanent disposal.

The Nonradiological Wastewater Treatment Plant (NRWTP), ORNL's Building 3608, is located south of the PWTP. It collects and treats nonradioactive liquid waste streams, using processes such as chemical precipitation, air stripping, and carbon columns. Its purpose is to bring waste streams into compliance with discharge parameters (especially the PWTP effluent) established by the U.S.

Environmental Protection Agency and the state of Tennessee (Fig. 5.10).

\section{$K-25$ Site}

There are no LLLW treatment facilities at the K-25 Site.

\section{Storage}

\section{Y-12 Plant}

\section{Old Salvage Yard (OSY)}

The Old Salvage Yard is located on the west end of the Y-12 Plant, immediately east of Old Bear Creek Road, and is divided into two sections. Normal daily activity takes place in the western section outside the Perimeter Intrusion Detection and Assessment System (PIDAS) security fence. This section contains a roped-off area containing low-level contaminated scrap metal.

The eastern section of the OSY is located inside the PIDAS fence and is 
ORNL-DWG 94M-11769

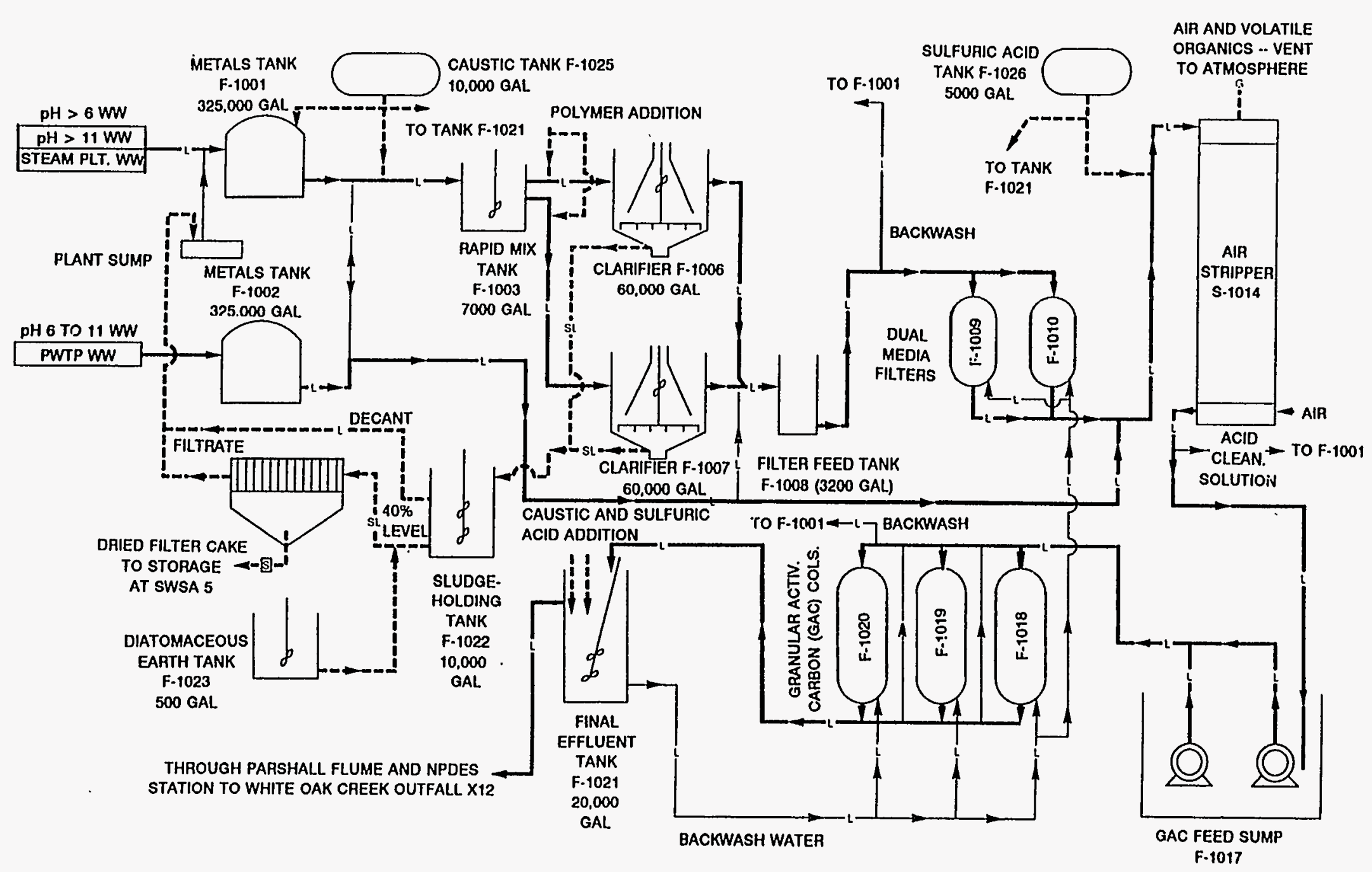

Fig. 5.10. Flow diagram of the Nonradiological Wastewater Treatment Plant at Oak Ridge National Laboratory. 
designated for the storage of large, bulky contaminated scrap metal as well as items containing a higher level of contamination. WAC for the OSY have been published (Y-12 WMD September 1990).

\section{Depleted Uranium Oxide Storage Vaults I and II}

These are the two uranium oxide storage vaults, $9825-\mathrm{A}$ and $9825-\mathrm{B}$, located on Chestnut Ridge approximately $182.9 \mathrm{~m}$ $(600 \mathrm{ft})$ north of Portal 3 (Fig. 5.11). The vaults are partially underground and constructed of reinforced concrete with a total storage volume of $906 \mathrm{~m}^{3}\left(32,000 \mathrm{ft}^{3}\right)$ per vault and a usable storage volume of $679 \mathrm{~m}^{3}\left(24,000 \mathrm{ft}^{3}\right)$.

The walls and roof are $0.46 \mathrm{~m}(1.5 \mathrm{ft})$ thick and treated with waterproofing, both internally and externally. Four $1.2 \times 1.2 \mathrm{~m}$ $(4 \times 4 \mathrm{ft})$ openings are provided in the deck-type roof slab of each vault to provide access for filling the vaults.

The vault is equipped with a 5-hp movable exhaust system with parallel $95 \%$ efficient filters and two high-efficiency particulate air filters. Exhaust is discharged through a monitoring stack. Depleted uranium oxide powder is delivered to the storage vaults in sealed 114- and 208-L (30- and 55-gal drums). Depleted uranium sawfines are delivered in 208-L (55-gal) drums mixed with depleted uranium oxide at a ratio of at least ten parts oxide to one part sawfines. Mass uranium metal can be placed in the vaults providing sparks are not generated. The vaults were constructed to provide long-term storage. Detailed operating procedures and guidelines have been published (Y-12 WMD March 1990).

\section{Classified Waste Storage Facility}

This facility is located between "N" and " $M$ " Streets, south of Second Street, and southwest of Building 9401-5. This storage facility includes areas for volume reduction of sanitary combustible trash, storage of classified wastes that may or may not be contaminated with uranium, storage of polychlorinated biphenyl-contaminated materials that may also be contaminated with uranium, and a Resource Conservation and Recovery Act (RCRA) interim status area that is not yet operating. Only solid materials are accepted. No liquids are permitted. The facility meets $\mathrm{Y}-12$ Plant security requirements for classified waste management and DOE Order 5820.2A guidelines for the management of low-level and mixed waste. The facility, located in Building 9720-25, began operation in FY 1992. WAC for this facility have been published (Y-12 WMD May 1993).

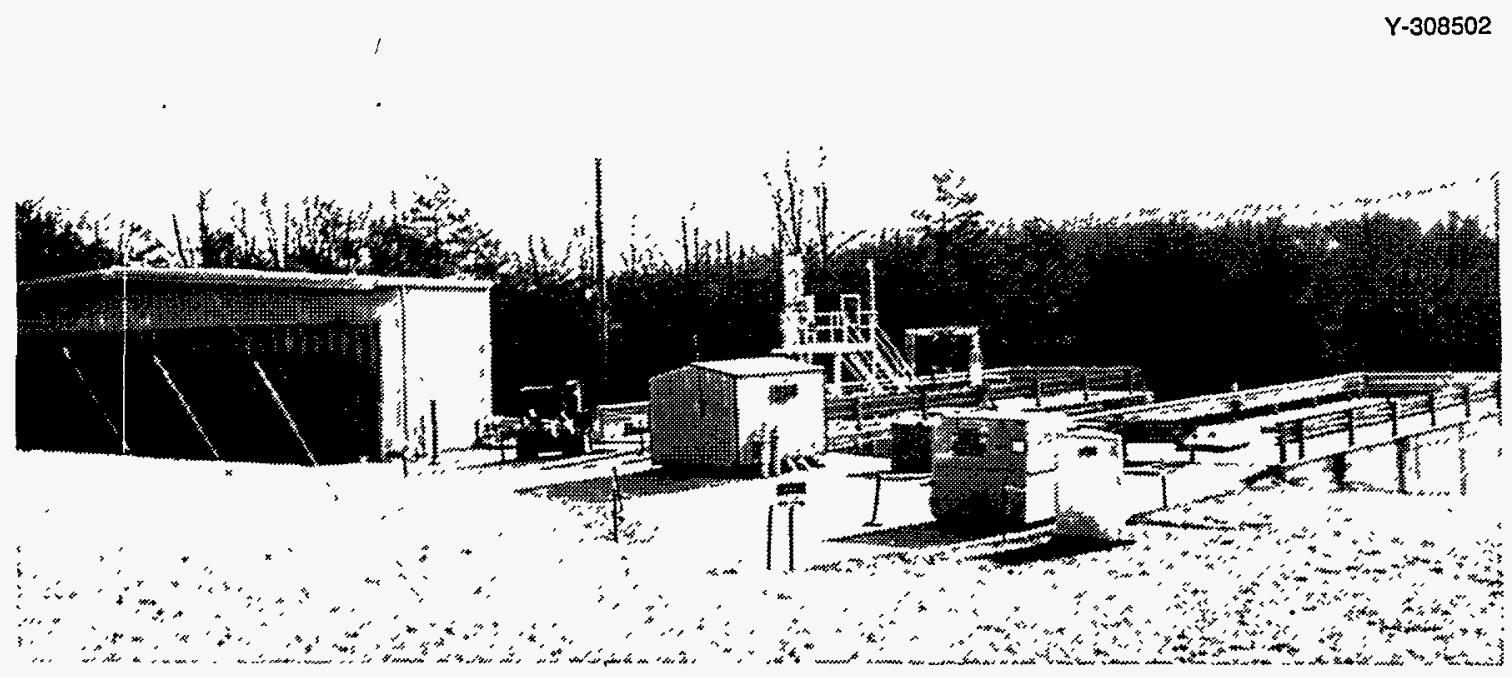

Fig. 5.11. Depleted uranium oxide storage vaults I and II at the Oak Ridge Y-12 Plant. 
Containerized Waste Storage Area (CWSA)

Situated south of the Y-12 Plant on the east end of Chestnut Ridge, this facility consists of three concrete pads measuring $15.2 \times 52 \mathrm{~m}(50 \times 170 \mathrm{ft})$ (Fig. 5.12). The central and eastern concrete pads are covered by open-sided dome tents, and each concrete pad has a $0.30-\mathrm{m}$ ( 1 - $\mathrm{ft}$ ) impermeable dike surrounding it to contain spills.

All waste stored at the CWSA is in containers such as approved carbon steel drums, original vendor drums, 1249- and 2498-L (330- and 660-gal) steel reinforced polyethylene tanks, ST-5 boxes, and $6.9-\mathrm{m}^{3}$ $\left(9-\mathrm{yd}^{3}\right)$ dumpsters. Each pad has a calculated maximum capability to store $1,022,000 \mathrm{~L}(270,000$ gal) of waste materials based on actual dike capacity and storage space for 388 ST-5 boxes or 3,168 drums.

The CWSA is a RCRA interium status unit. Radioactively contaminated wastes and mixed wastes containing ${ }^{238} \mathrm{U}$ may also be stored at the CWSA. Waste receiving guidelines for the CWSA facility have been published (Y-12 WMD October 1994). Note that four major waste streams are stored at the CWSA: SLLW, solid mixed waste, liquid mixed waste, and hazardous waste.

\section{Above-Grade Storage Facility}

Located on 13.4 ha (33 acres) in the Bear Creek Burial Grounds west of the Oak Ridge Y-12 Plant, the site is designed to allow for the maximum constructed storage area (Fig. 5.13). The site for six pads is located north of Bear Creek Road, east of the " $A$ " burial trenches, and west of the Sanitary Landfill/Oil Landfarm Area. The facility consists of several fabric buildings that are designed for the interim storage of low-level radioactive waste contained in strong, tight containers that are built to U.S. Department of Transportation specifications. WAC for this facility have been published (Y-12 WMD February 1993).

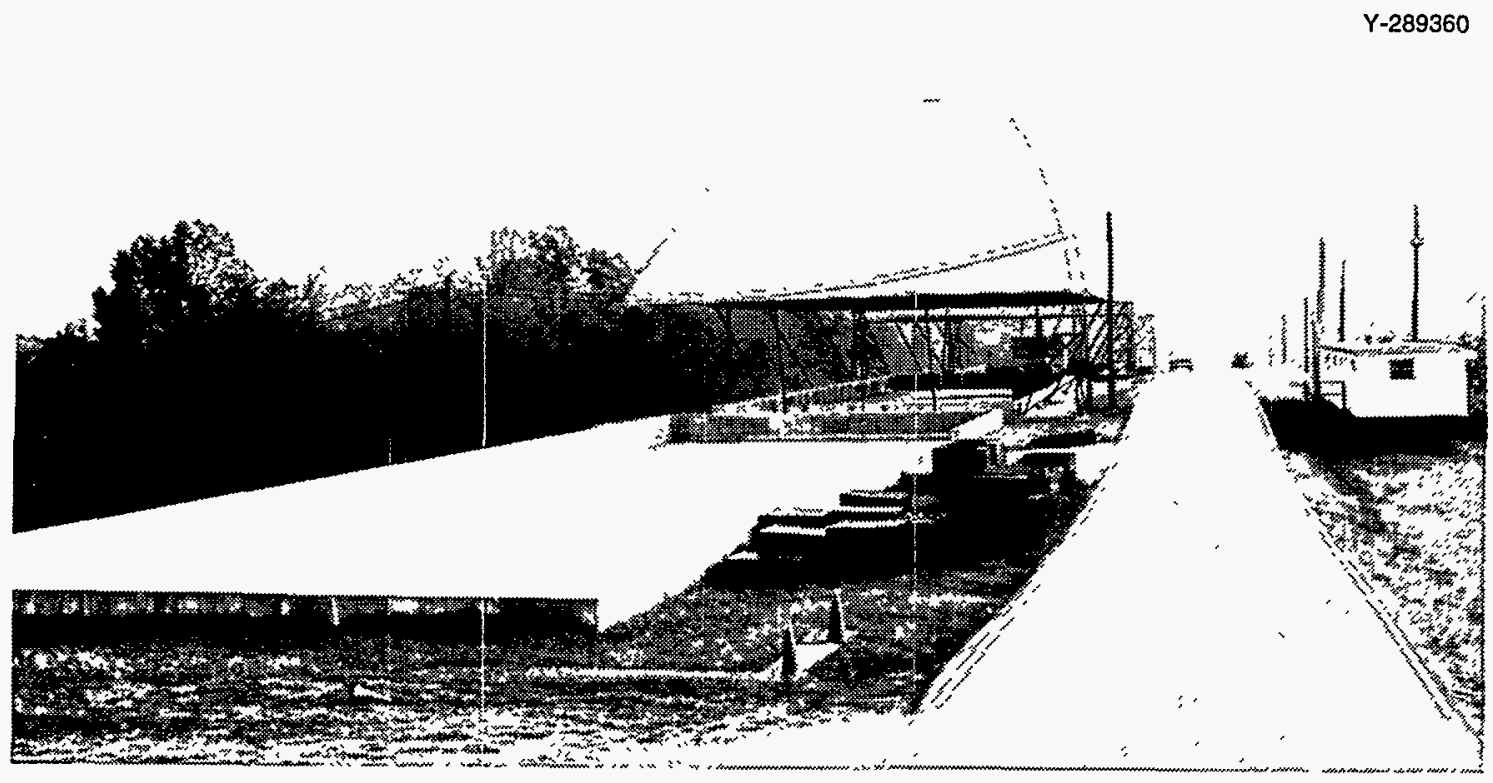

Fig. 5.12. The Containerized Waste Storage Area at the Oak Ridge Y-12 Plant.

5-24 Oak Ridge Reservation Waste Management Plan 


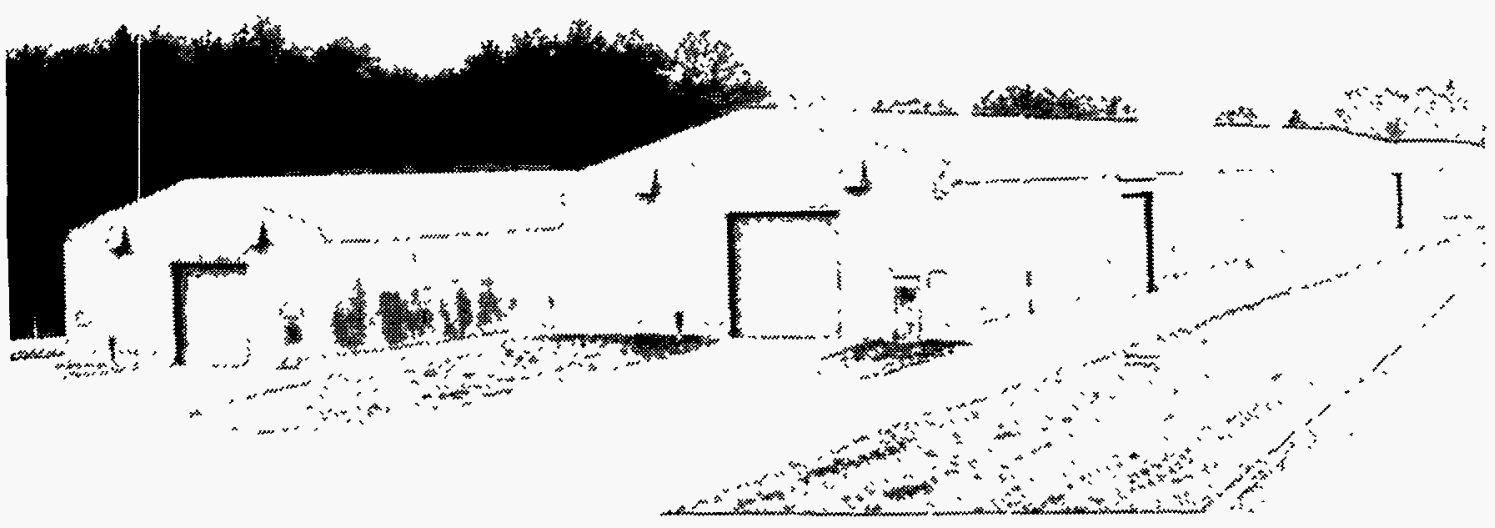

Fig. 5.13. The Above-Grade Storage Facility at the Oak Ridge Y-12 Plant.

Table 5.9 lists storage of LLW by facility at the Y-12 Plant.

\section{ORNL}

In 1986 ORNL began interim storage of some CH SLLW at the Oak Ridge K-25 Site because of limited disposal capacity remaining in SWSA 6. The intention was to store this waste until a new disposal facility was developed at another site on the ORR. Storage of CH SLLW at the K-25 Site was discontinued in 1991 because of limited storage space for RCRA waste. It was reinstated in 1993.

Some CH SLLW is currently stored at the K-25 Site in Buildings K-310-2 and $\mathrm{K}-310-3$ and in vault $31 \mathrm{X}$. The first waste stream shipped to the K-25 Site for interim

Table 5.9. Storage of solid low-level waste at the Oak Ridge Y-12 Plant

\begin{tabular}{|c|c|c|c|}
\hline Facility & Waste types & $\begin{array}{l}\text { Waste inventory } \\
\mathrm{m}^{3}\left(\mathrm{ft}^{3}\right)\end{array}$ & $\begin{array}{c}\text { Remaining capacity } \\
\mathrm{m}^{3}\left(\mathrm{ft}^{3}\right)\end{array}$ \\
\hline 9720-58 PCB Shed & $\mathrm{MW}, \mathrm{LLW}^{b}$ & $18(620)$ & $0(0)$ \\
\hline $9720-9$ & $\mathrm{MW}, \mathrm{LLW}^{b}$ & $1(35)$ & $0(0)$ \\
\hline $9720-25 S$ & TSCA, LLW ${ }^{b}$ & $139(4,900)$ & $31(1,100)$ \\
\hline $9720-31$ & $\mathrm{MW}, \mathrm{LLW}^{b}$ & $16(570)$ & $0(0)$ \\
\hline $9811-1$ OD-8 and OD-7 & MW, LLW ${ }^{b}$ & $31(1,100)$ & $0(0)$ \\
\hline $\begin{array}{l}9825-1 \text { and } 2 \text { Oxide } \\
\text { Vaults }\end{array}$ & LLW & $532.2(18,800)$ & $489.8(17,300)$ \\
\hline Above-Grade Storage & LLW & $7,054.9(249,200)$ & $76.4(2,700)$ \\
\hline $\begin{array}{l}\text { Containerized Waste } \\
\text { Storage Area }\end{array}$ & $\mathrm{MW}, \mathrm{LLW}^{b}$ & $111(3,930)$ & $0(0)$ \\
\hline Old Salvage Yard & $\begin{array}{l}\text { Contaminated scrap } \\
\text { metal }\end{array}$ & $4,741.9(167,500)$ & $0(0)$ \\
\hline Sludge Basin & LLW & $28.3(1,000)$ & $2,689.4(95,000)$ \\
\hline
\end{tabular}

"As of June 30, 1994.

bFor multiple purpose storage facilities, LLW stored volume is reported. Toxic Substances Control Act (TSCA); mixed waste (MW); polychlorinated biphenyl (PCB). 
storage was dewatered sludge from the PWTP (Building 3544) in 1986. This waste stream is fairly homogeneous and contains very low radioactivity. The PWTP waste and compactible waste in metal boxes were shipped to the K-25 Site for interim storage until 1991.To date, approximately

2500 drums of SLLW and 125

$1.2 \times 1.2 \times 1.8 \mathrm{~m}(4 \times 4 \times 6 \mathrm{ft})$ boxes from ORNL are being stored at the K-25 Site.

ORNL has constructed several abovegrade storage facilities; those currently used at ORNL include four portable Rubb structures in SWSA $5 N$. These facilities are used for interim storage of the low-activity waste streams such as contaminated soils, process wastewater sludge, biological waste, and very low activity waste. ORNL plans to store these low-activity waste streams until new disposal facilities can be developed at other sites on the ORR or access is permitted at off-site DOE disposal facilities. New storage facilities for contaminated soil and other SLLW streams are also planned.

ORNL is also storing RH SLLW and SC SLLW that does not meet the WAC for ORNL disposal facilities. RH LLW is stored in above- and below-grade storage facilities. Above-grade concrete cask storage areas in SWSA 6 and near the former ORNL Hydrofracture Facility are used to store solidified supernatants from the LLLW evaporator concentrate storage tanks. Below-grade storage wells in SWSAs $5 \mathrm{~N}$ and 6 are used to store spent fuel and fuel debris, irradiated hardware, sealed radiation sources, and other SLLW that does not meet the WAC for SWSA 6 . The cask storage area near the New Hydrofracture Facility is also used to store irradiated hardware that is too large for the below-grade storage wells. These facilities have limited remaining storage capacity; thus, additional above-grade and belowgrade storage facilities are planned at the ORNL SWSA 7 site. The plan is to store RH SLLW and SC SLLW at ORNL until suitable disposal facilities are available at off-site DOE disposal facilities. Table 5.10 lists storage of SLLW by facility at ORNL.

\section{K-25 Site}

Table 5.11 identifies LLW storage facilities that are operated by ESWMO-K-25. These storage facilities consist of several vaults in the $\mathrm{K}-25$ Building, outside storage areas, and two fabric membrane structures (K-1313A, Rubb tents I and II) used to store Y-12 Plant, ORNL, and K-25 Site LLW. Additional LLW storage exists both inside and outside Building K-33. Responsibility for the K-770 Contaminated Scrap Metal Storage Yard was transferred to Environmental Restoration in 1994, and it is no longer available for LLW storage.

Since May 17, 1991, a "No Rad Added" DOE moratorium on shipment of hazardous wastes off-site to commercial facilities resulted in the displacement of LLW in several K-25 Building vaults that were upgraded and RCRA-permitted for storage of mixed wastes. The transfer of LLW from storage vaults to outside areas has continued to be limited only to SLLW containing no free liquids and in containers acceptable for outside storage, such as ST-5 (B-25) storage containers and sea/land containers. Storage of LLW is managed in accordance with published guidelines (K-25 EMD May 1993).

Because of the history of the site and D\&D work, reevaluation of all unclaimed/unused materials currently in storage is required. As a result, additional LLW facilities will come on-line. The strategy is volume reduction of LLW and, for storage of solid LLW, the strategy is to use outdoor storage and existing facilities that are not required for mixed waste storage. The goal is to provide indoor storage for all containerized SLLW until such time that facilities become available for disposal of LLW.

The K-25 Site is currently storing a total of $42,048 \mathrm{~L}(11,108 \mathrm{gal})$ of LLLW. Most of this LLLW [31,854 L (8,415 gal)] 
Table 5.10. Storage of solid low-level waste at Oak Ridge National Laboratory

\begin{tabular}{llrr}
\hline \multicolumn{1}{c}{ Facility } & \multicolumn{1}{c}{ Waste types } & $\begin{array}{r}\text { Waste inventory } \\
\mathrm{m}^{3}\left(\mathrm{ft}^{3}\right)\end{array}$ & $\begin{array}{r}\text { Remaining capacity } \\
\mathrm{m}^{3}\left(\mathrm{ft}^{3}\right)\end{array}$ \\
\hline 7823 & CH LLW, MW & $2(65)$ & $0(0)$ \\
$7823 \mathrm{~B}$ & CH LLW & $107.6(3,800)$ & $56.6(2,000)$ \\
$7823 \mathrm{C}$ & CH LLW & $110.4(3,900)$ & $2.8(100)$ \\
$7823 \mathrm{D}$ & CH LLW & $99.1(3,500)$ & $0(0)$ \\
$7823 \mathrm{E}$ & CH LLW & $110.4(3,900)$ & $2.8(100)$ \\
7827 & CH LLW & $6(200)$ & $11(400)$ \\
7829 & CH LLW & $3(100$ & $0(0)$ \\
$7831 \mathrm{C}$ & CH LLW & $342.6(12,100)$ & $0(0)$ \\
7841 & Contaminated & $1,000(35,900)$ & $0(0)$ \\
$7842 \mathrm{~A}$ & scrap metal & $110.4(3,900)$ & $0(0)$ \\
7856 & RH LLW & $634.1(22,400)$ & $0(0)$ \\
$7878 \mathrm{~A}$ & RH LLW & $266.1(9,400)$ & $76.4(2,700)$ \\
Scrap metal & CH LLW & $1,956.2(69,100)$ & $2,392.2(84,500)$ \\
Accumulation Area & Scrap metal & & \\
\hline
\end{tabular}

${ }^{a}$ As of June 30, 1994.

${ }^{b}$ For multiple purpose storage facilities, LLW stored volume is reported. Contact-handled $(\mathrm{CH})$; remote-handled $(\mathrm{RH})$; mixed waste $(\mathrm{MW})$.

Not an ESWMO-ORNL facility. Managed as potentially contaminated material until No Rad Added procedure is approved.

is stored in 99 containers in the $\mathrm{K}-1065-\mathrm{C}$ Facility located on the west side of the $\mathrm{K}-25$ Site. K-1065-C provides protection from precipitation and has a $20.3-\mathrm{cm}$ (8-in.) reinforced concrete floor. The facility is equipped with curbing to provide secondary containment. The remaining containers of LLLW are stored in Building $\mathrm{K}-33$ and in the K-25 Building vaults, all of which have reinforced concrete flooring and curbing for secondary containment.

\section{Disposal}

The only active disposal facility on the ORR is the IWMF located in SWSA 6 at ORNL. Only wastes generated at ORNL are disposed of in the IWMF. The IWMF is an above-grade tumulus design. It occupies an area of approximately 4 ha (9.5 acres) in the southwest portion of
SWSA 6. IWMF currently consists of four tumulus pads; a fifth is under construction. Two of the pads have been filled with vaults. Each tumulus pad is approximately $18.2 \times 27.4 \mathrm{~m}(60 \times 90 \mathrm{ft})$ and $30.5 \mathrm{~cm}$ (12 in.) thick. The pads are constructed using high-density concrete and are reinforced with epoxy-coated steel rebar. The pad has concrete curbs $0.30 \mathrm{~m}(1 \mathrm{ft})$ high on the north, south, and west sides. The east side does not have a curb and is used for vehicle access during vault loading operations. Each pad provides disposal for approximately 330 vaults [approximately $897 \mathrm{~m}^{3}\left(31,680 \mathrm{ft}^{3}\right)$ ] stacked three high.

The IWMF has been designed to divert water into three sumps. The sumps are located in a monitoring system adjacent to the tumulus pads. The monitoring station is equipped for receiving, monitoring, and collecting samples from flows received 
Table 5.11. Storage of solid low-level waste at the Oak Ridge K-25 Site

\begin{tabular}{|c|c|c|c|}
\hline Facility & Waste type & $\begin{array}{c}\text { Waste inventory } \\
\mathrm{m}^{3}\left(\mathrm{ft}^{3}\right)\end{array}$ & $\begin{array}{c}\text { Remaining capacity } \\
\mathrm{m}^{3}\left(\mathrm{ft}^{3}\right)\end{array}$ \\
\hline $\mathrm{K}-1065-\mathrm{C}$ & $\mathrm{MW}, \mathrm{LLW}^{b}$ & $28(1,000)$ & $0(0)$ \\
\hline $\mathrm{K}-1066 \mathrm{H}$ & LLW & $3,926.6(138,700)$ & $795.5(28,100)$ \\
\hline $\mathrm{K}-301-1$ & MW, LLW $^{b}$ & $23(800)$ & $0(0)$ \\
\hline $\mathrm{K}-301-2$ & $\mathrm{MW}, \mathrm{LLW}^{b}$ & $11(400)$ & $0(0)$ \\
\hline $\mathrm{K}-302-4$ & $\mathrm{MW}, \mathrm{LLW}^{b}$ & $45(1,600)$ & $0(0)$ \\
\hline $\mathrm{K}-302-5$ & $\mathrm{MW}, \mathrm{LLW}^{b}$ & $20(700)$ & $0(0)$ \\
\hline $\mathrm{K}-303-3$ & $\begin{array}{l}\text { MW, LLW, contaminated } \\
\text { scrap metal }{ }^{b}\end{array}$ & $3(100)$ & $0(0)$ \\
\hline $\mathrm{K}-305-12$ & $\begin{array}{l}\text { MW, LLW, contaminated } \\
\text { scrap metal }{ }^{b}\end{array}$ & $3(100)$ & $0(0)$ \\
\hline $\mathrm{K}-306-2$ & LLW & $246.3(8,700)$ & $0(0)$ \\
\hline $\mathrm{K}-306-7$ & LLW & $294.4(10,400)$ & $19.8(700)$ \\
\hline $\mathrm{K}-309-2$ & LLW & $424.7(15,000)$ & $237.8(8,400)$ \\
\hline $\mathrm{K}-309-3$ & $\begin{array}{l}\text { MW, LLW, } \\
\text { contaminated scrap metal }\end{array}$ & $3(100)$ & $0(0)$ \\
\hline K-310-1 & $\mathrm{MW}, \mathrm{LLW}^{b}$ & $3(100)$ & $0(0)$ \\
\hline $\mathrm{K}-310-2$ & LLW & $654.0(23,100)$ & $0(0)$ \\
\hline $\mathrm{K}-311-1$ & MW, LLW & $11(400)$ & $0(0)$ \\
\hline $\mathrm{K}-33$ & LLW & $2,729.1(96,400)$ & $382.2(13,500)$ \\
\hline $\mathrm{K}-770$ & Contaminated scrap metal & $29,626.5(1,046,500)$ & $0(0)$ \\
\hline $\mathrm{K}-1313 \mathrm{~A}$ & LLW & $246.3(8,700)$ & $0(0)$ \\
\hline Vault $15 \mathrm{~A}$ & LLW & $62.3(2,200)$ & $501.1(17,700)$ \\
\hline Vault $23 \mathrm{~A}$ & MW, $L_{L W}$ & $23(800)$ & $0(0)$ \\
\hline Vault 6 & LLW & $268.9(9,500)$ & $0(0)$ \\
\hline Vault 8A & $\mathrm{MW}, \mathrm{LLW}^{b}$ & $215(7,600)$ & $0(0)$ \\
\hline
\end{tabular}

${ }^{a}$ As of June 30, 1994.

${ }^{b}$ For multiple purpose storage facilities, LLW stored volume is reported. Mixed waste (MW). Source: ESWMO August 1994. Oak Ridge Reservation Waste Storage Report for Period Ending June 30, 1994, ES/WM-23, rev. 0, Science Applications Intl. Corp., Oak Ridge, Tenn.

from the stormwater, underpad, and infiltration drain systems. The underpad sump is designed to allow monitoring of any groundwater that may accumulate under the pads. The stormwater sump collects water from the pad that is in operation. The infiltration sump is used to collect water from the pads that have been filled with vaults. Table 5.12 lists CY 1993 and projected disposal volumes for SLLW on the ORR and lists inactive disposal facilities. Figure 5.14 shows vaults stacked on the curbed concrete pad, drain lines, and the proposed tumulus cap.

Appendix B shows the current operational status of waste treatment, storage, and disposal facilities on the ORR.

\section{Future Plans}

Appendix $\mathrm{C}$ lists proposed line items (LIs) and general plant projects for LLW facilities on the ORR. 
Table 5.12. Disposal volume of solid low-level waste (SLLW) at Oak Ridge National Laboratory"

\begin{tabular}{lrr}
\hline \multicolumn{1}{c}{ Disposal unit } & $\begin{array}{c}\text { CY 1993 } \\
\mathrm{m}^{3}\left(\mathrm{ft}^{3}\right)\end{array}$ & $\begin{array}{c}\text { CY 1994 } \\
\mathrm{m}^{3}\left(\mathrm{ft}^{3}\right)\end{array}$ \\
\hline Interim Waste Management Facility & $606(21,408)$ & $274.6(9,696)$ \\
Low-range silo & $204(7,207)$ & $0(0)^{c}$ \\
High-range silo & $23.2(820)$ & $0(0)^{c}$ \\
Asbestos silo & $22.4(790)$ & $0(0)^{c}$ \\
Biological trench & $106(3,728)$ & $0(0)^{c}$ \\
\hline
\end{tabular}

There are no disposal facilities for SLLW at the Oak Ridge Y-12 Plant or the Oak Ridge K-25 Site.

'Through November 17, 1994.

cAll silos and the biological trenches were closed by. the end of CY 1993.

\section{Treatment}

At ORNL the NRWTP Access Controls Project (ADS 3253) is under way. The capital dollar amount is $\$ 396,000$; construction completion is expected in CY 1995. Construction completion is planned in CY 1994 for (1) the Stack Fans 3039 Upgrade Project (ADS 3253), which has capital dollars of $\$ 740,000$, and (2) the 3108 and 7930 Filter Pit Projects (ADS 3253), which have capital dollars of $\$ 157,000$ and $\$ 192,600$ respectively.

\section{OANL-DWG 93M-8591}

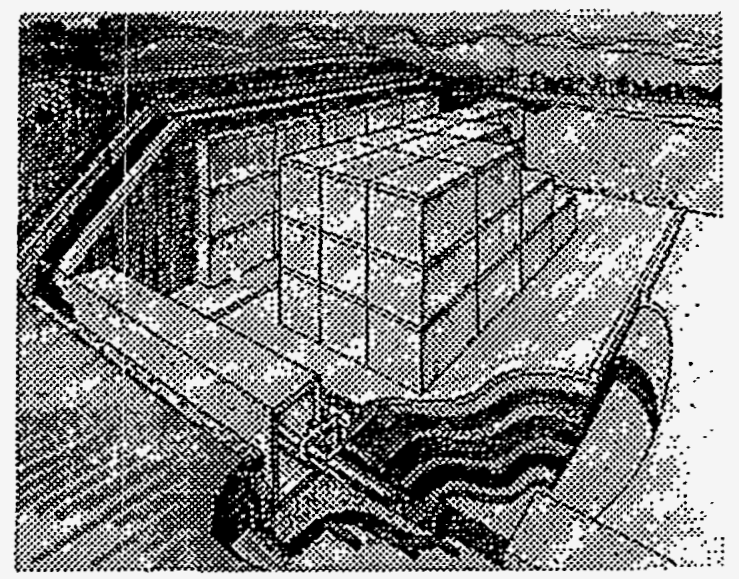

Fig. 5.14. Schematic of the Interim Waste Management Facility at Oak Ridge National Laboratory showing vaults, pad, drain lines, and proposed tumulus caps.
At the K-25 Site the Toxic Substances Control Act Incinerator will become an SLLW treatment (with DOE approval). The Low-Level Waste Compaction Facility at K-1423 will support processing of LLW for off-site shipping and disposal through waste/waste container compaction. The operation will also provide increased efficiency of storage space utilization. New treatment facilities under the Phase II D\&D Program, for the dismantling of process equipment, are scheduled for design in 1995. Construction is to begin in 1999; operations, in 2003. These two large decontamination support facilities will include compaction and shredding technologies. Details on these planned facilites have been published (Ebasco 1991). An LI project has been proposed (FY 1997) for the decontamination of scrap metal for free release. The magnitude of this $L I$ is dependent on private sector capabilities and the proposed agreement between ER and WM on scrap metal ownership.

\section{Storage}

The remaining storage capacity for SLLW on the ORR is $5469 \mathrm{~m}^{3}$ $\left(193,200 \mathrm{ft}^{3}\right)$, not including future units of the Y-12 Plant Above-Grade Storage Facility. Because some containerized 
SLLW can be stored outdoors and the outdoor storage capacity can be expanded, and because the impacts of volume reduction and off-site shipments are uncertain, there is no projected date for when the LLW storage capacity will be depleted. Current plans are to minimize outside storage and to utilize existing process buildings. Figure 5.15 shows LLW storage projections based on data available in June 1994.

Some containerized LLW continues to be stored outside because of insufficient inside storage capacity. Completion and startup of the Y-12 Plant Above-Grade Storage Facility, which contains six units, has temporarily alleviated the shortage of storage space at that site. Each unit can store over 400 boxes of LLW. In addition, the LLW storage capacity shortage at the $\mathrm{Y}-12$ Plant and the K-25 Site is being reduced by volume reduction services provided by an outside vendor. Similarly, a contract is in place to ship SLLW, biological, and very low activity waste, formerly called suspect waste, from ORNL to an outside vendor for volume reduction. Volume reduction services provided for all three sites include incineration and supercompaction. The compacted waste is returned to the originating sites for storage and eventual disposal on-site or shipment off-site for disposal.

Use of new storage space for LLW, created at the K-25 Site in Building K-33, is pending signoff of a Memorandum of Agreement between DOE-ER and the Waste Management and Technology Development Division at DOE's Oak Ridge Operations Office (ORO-WMTDD). The new K-33 space will provide an additional $26,660 \mathrm{~m}^{2}\left(287,000 \mathrm{ft}^{2}\right)$ of storage area and should eliminate outside (long-term) LLW storage.

Efforts are continuing to retrievably store the high-range waste in high-range wells in SWSA 6 until closure of SWSA 6 prohibits further storage. Above-grade storage of some of this waste at an abovegrade storage site will be investigated if

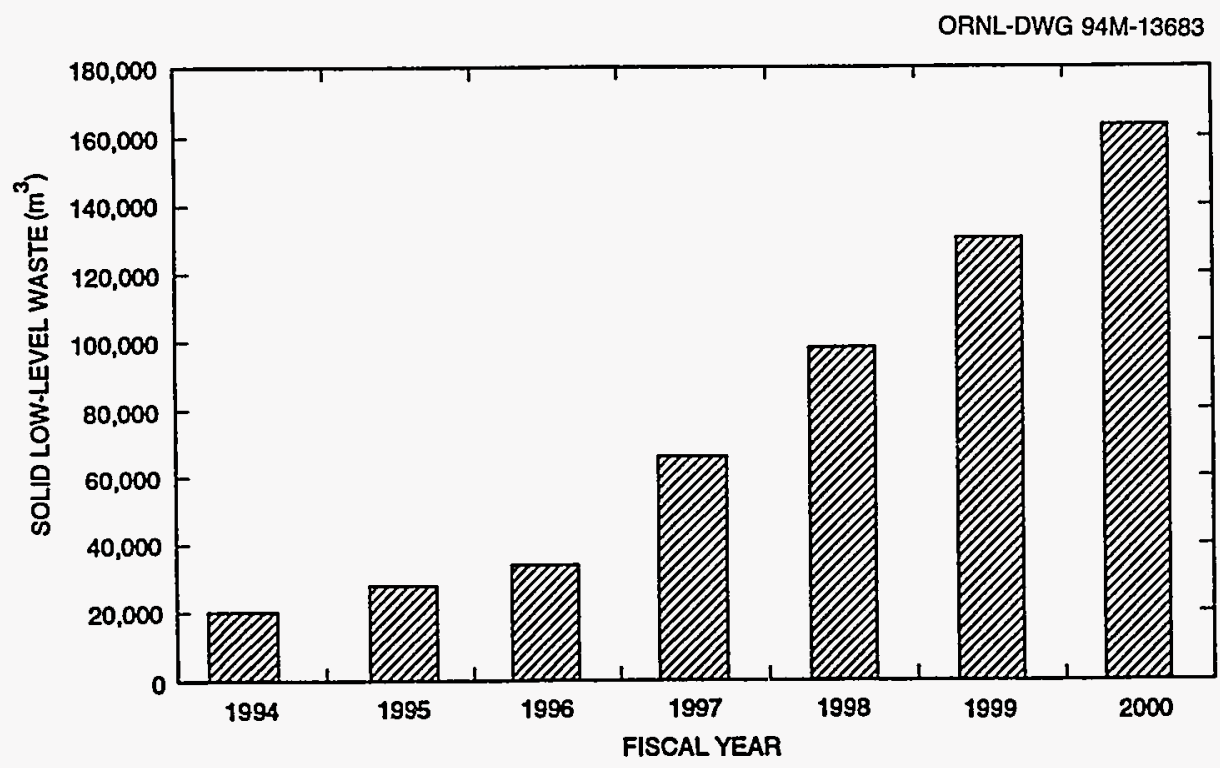

Fig. 5.15. Projected storage required for solid low-level waste. Large increases in FYs 1997-2000 assume storage of soils from the remediation of lower East Fork Poplar Creek. Source: ESWMO August 1994. Oak Ridge Reservation Waste Storage Report for Period Ending June 30, 1994, ES/WM-23, Science Applications Intl. Corp., Oak Ridge, Tenn. 
needed. The use of above-grade storage should provide enough storage space until the Class III/IV retrievable waste storage facilities are available in SWSA 7. The earliest projected availability of a SWSA 7 Class III/TV facility is January 1996, although this date may be extended owing to continued delays in the approval of National Environmental Policy Act (NEPA) documentation.

Another SWSA 7 facility is planned for below-ground storage. The capital dollar amount is $\$ 1,100,000$; implementation is planned for 1995. Approximately 300 boxes of soil with low levels of radioactive material contamination that have been collected over the last 2 years are being stored outdoors at the Y-12 Plant. It is proposed to reuse this and other excavated materials for backfill if they meet acceptable limits as proposed in a draft procedure that is currently under review.

The liquid LLW solidification project, Campaign II that was initiated in October 1993 resulted in 58 solidified waste forms using approximately $283 \mathrm{~m}^{3}\left(10,000 \mathrm{ft}^{3}\right)$ of LLLW concentrate previously stored at ORNL. These campaigns are conducted periodically to provide storage capacity for future LLLW generation. The solidified waste is being stored in casks in the SWSA 6 storage yard pending shipment to the Nevada Test Site.

One activity that will have an immediate and significant impact on SLLW storage requirements is the continued use of vendor-supplied volume reduction services such as the supercompaction, metal melting, and incineration services provided by an outside vendor. Effective utilization of the remaining LLW storage capacity can be enhanced by shipping SLLW to an off-site disposal facility. Plans for off-site shipment have been instituted, but the time for completing the necessary documentation and beginning shipments has not yet been established. The first shipments will likely occur in January 1995.
A 1994 report indicates that storage capacity is available for SLLW storage in existing buildings (ESWM April 1994). As a result, negotiations are on-going with the first building's landlord (the D\&D Program) for use of part of the building.

SLLW storage outdoors can continue but will be limited to those wastes that are physically and chemically compatible with long- term storage in their containers and that will not be adversely affected by exposure to weather conditions. Solids with low moisture content will generally meet the condition of long-term compatibility with storage containers and can be stored outdoors. Special enclosures, such as flexible membrane structures, or durable lined containers will be employed when necessary.

Beneficial reuse of soils or debris that are slightly contaminated with radionuclides could alleviate the need for increased waste storage and disposal facility space. Beneficial reuse can consist of using slightly contaminated soils as backfill for excavations in the Remedial Action Program or for constructing soil caps for closure activities. Options for beneficial reuse of soils have been proposed for a few projects, but wider application is anticipated pending approval of a soil reuse procedure that is currently under review.

Vaults K-402-8 and 402-9 in Building $\mathrm{K}-27$ are being released by the Operations Division and prepared for LLW storage. Other activities that will increase available capacity include expanding the Y-12 Plant Above-Grade Storage Facility with an ongoing FY 1993 GPP and pursuing other GPPs for additional storage facilities. Other GPPs that are already being pursued are the Class III/IV Retrievable Waste Storage Facility, consisting of both above- and belowground facilities, and the Bulk Contaminated Soil Facility. Design of the Y-12 Plant Above-Grade Storage Facility is scheduled to be completed in FY 1994; construction of additional units is pending DOE approval. 
Although previously generated contaminated scrap metal may continue to be stored outdoors in both bulk and containerized forms, where the amount of potential storage capacity for this type of waste was previously expandable, storage of newly generated contaminated scrap metal in open piles has not been allowed since October 1, 1993 (1989 at the K-25 Site). This prohibition impacts storage requirements because all future scrap metal outdoor storage must now be containerized. Minimization techniques will continue in an effort to limit the generation of additional contaminated scrap metal.

\section{Disposal}

Currently, no LLW is disposed of offsite. Six waste streams have been identified as possible candidates for disposal off-site at the Nevada Test Site (NTS) over the next 20 years (Table 5.13). Current approval for shipments to NTS of the ORNL solidified LLLW is pending.

ORNL is planning to expand the IWMF to 12 pads. The expansion could extend the life of the facility to beyond the year 2000 .

\section{Waste Certification}

In 1991 Martin Marietta Energy Systems, Inc., published a plan that initiated a consistent approach to waste certification on the ORR (K-25 WMD 1991). In 1992 two guidance manuals were issued (K-25 CWM 1992a; K-25 CWM 1992b). Since these documents were issued, the certification process within Energy Systems has continued to develop. This has created the need to replace these three documents with new ones that reflect the current approach of ensuring that waste certification activities among the K-25 Site, ORNL, and the Y-12 Plant are consistent. This consistent approach will result in more effective and efficient management of wastes on the ORR, and will facilitate the use of off-reservation TSD facilities.

A document has been published that presents the structure of the Energy Systems Waste Certification Program and becomes the agreement between Energy Systems and the DOE-ORO Waste Management and Technology Development Division on the scope and approach to the process to be used to certify wastes on the ORR (ESWMO 1994).

Table 5.13. Possible candidates for disposal off-site at the Nevada Test Site over the next 20 years

\begin{tabular}{lccc}
\hline \multicolumn{1}{c}{ Waste stream } & $\begin{array}{c}\text { Shipment volume } \\
\mathrm{m}^{3}\left(\mathrm{ft}^{3}\right)\end{array}$ & $\begin{array}{c}\text { Shipment period } \\
\text { (years) }\end{array}$ & \multicolumn{1}{c}{$\begin{array}{c}\text { Total volume } \\
\mathrm{m}^{3}\left(\mathrm{ft}^{3}\right)\end{array}$} \\
\hline $\begin{array}{l}\text { Low-level waste solidification at } \\
\text { Oak Ridge National Laboratory }\end{array}$ & $280(10,000)$ & 10 & $2,800(100,000)$ \\
$\begin{array}{l}\text { Filter cake from wastewater } \\
\text { treatment }\end{array}$ & $280(10,000)$ & 20 & $5,700(200,000)$ \\
$\begin{array}{l}\text { Low-level waste processing } \\
\text { residue }\end{array}$ & $850(30,000)$ & 20 & $17,000(600,000)$ \\
$\begin{array}{l}\text { Uranium oxide from the } \\
\text { Oak Ridge Y-12 Plant }\end{array}$ & $570(20,000)$ & 20 & $11,300(400,000)$ \\
$\begin{array}{l}\text { Bulk material } \\
\text { Classified waste }\end{array}$ & $140(5,000)$ & 20 & $113,300(4,000,000)$ \\
\hline
\end{tabular}


Waste Minimization/Pollution

Prevention

\section{Y-12 Plant}

Specifically relating to SLLW, in CY 1993 the Y-12 Plant (DP) developed improved procedures for loading, unloading, and transfer of operations (Flowers et al. 1994). This project involved documentation of a $9 \times 18 \mathrm{~m}(30 \times 60 \mathrm{ft})$ asphalt/concrete pad adjacent to a dock such that the area could be used as a nonradiological material-staging area. This allowed approximately $8.5 \mathrm{~m}^{3}\left(300 \mathrm{ft}^{3}\right)$ of mixed paper and cardboard waste to avoid the radiological area and to be disposed of as noncontaminated waste.

\section{ORNL}

The Pollution Prevention Program is an organized, comprehensive, and continuous effort to systematically reduce the quantity and toxicity of all types of wastes and environmental releases from ORNL operations. The term "pollution prevention" at ORNL equates to the DOE definition of "waste minimization." Therefore, "pollution prevention" at ORNL includes activities that involve multimedia source reduction and recycling of all wastes and pollutants for all media. This program applies to all waste streams generated by site operations.

Segregation of SLLW from other waste is an important step in the minimization process. The Environmental Sciences Division has implemented a program to reduce SLLW generation through improved segregation from uncontaminated waste. Paper towels, gloves, aluminum foil, and other items used to process contaminated fish taken from reservation streams are scanned with a radiation survey meter. Those items determined to be noncontaminated are disposed of as sanitary waste rather than SLLW.

\section{$K-25$ Site}

The K-25 Site Pollution Prevention Program described in Sect. 1 applies to all waste types.

\section{Performance Assessments}

ORNL

DOE Order 5820.2A, Chap. III, "Management of Low-Level Radioactive Waste," requires field organizations with disposal sites to prepare a site-specific radiological PA for the disposal of lowlevel radioactive waste to demonstrate compliance with the performance objectives stated in the order. In December 1993 a draft PA for continuing and future operations at SWSA 6 was submitted to the DOE Oak Ridge Operations Office (DOE-ORO). This PA provides a comprehensive analysis of the long-term performance of waste disposal operations in SWSA 6 and the compliance of the facility with the performance objectives of DOE Order 5820.2A. A call for a future revision to this $\mathrm{PA}$ is identified within it. The major technical aspects of the PA are the radionuclide release modeling, saturated and unsaturated groundwater flow and transport modeling, and pathway and dose modeling.

\section{References}

\author{
Ebasco 1991. U.S. DOE Environmental \\ Restoration of the Gaseous Diffusion \\ Plants. \\ ESWM (Energy Systems Waste \\ Management Division) 1994. Waste \\ Certification Program Plan for the Oak \\ Ridge Reservation, ES/WM-6, Martin \\ Marietta Energy Systems.
}


ESWM (Energy Systems Waste

Management Division) April 1994. An

Evaluation of the Potential To Store

Low-Level Waste in Existing Buildings

on the Oak Ridge Reservation,

ES/WM/INT-4, Martin Marietta Energy

Systems.

Flowers, P. A. et al. October 1994. 1993

Annual Report on Waste Generation and Waste Minimization Progress as Required by DOE Order 5400.1, Y/WM-208, Martin Marietta Energy Systems, Oak Ridge Y-12 Plant.

Genung, R. K. July 1987. Strategic Planning for Low-Level Waste Disposal Development and Demonstration Program, Martin Marietta Energy Systems, Oak Ridge K-25 Site.

K-25 CWM (K-25 Site Central Waste Management Division) 1992a. Standard Content Guide for Site Specific Solid Waste Certification Program Plans, K/WM-7, Martin Marietta Energy Systems.

K-25 CWM (K-25 Site Central Waste Management Division) 1992b. Guidance Manual for Developing Waste Acceptance Criteria Documents, K/CWM-10, Martin Marietta Energy Systems.

K-25 EMD (K-25 Site Environmental Management Division) May 1993. Roles and Responsibilities for the Management of Low-Level Waste-Oak Ridge K-25 Site, K/EM-40, Martin Marietta Energy Systems, Oak Ridge K-25 Site.

K-25 WMD (K-25 Site Waste Management Division) 1991. Solid Waste Certification Program, K/WM-14, Martin Marietta Energy Systems.

K-25 WMD (K-25 Site Waste Management Division) Sept. 19, 1994. Low-Level Waste Management, SPP-4601, Martin Marietta Energy Systems, Oak Ridge K-25 Site.

Lee, D. W. et al. 1993. Central Waste Management Division Waste Management Strategy,
ORNL/TM-12354, Martin Marietta

Energy Systems, Oak Ridge Natl. Lab. Y-12 WMD ( $Y-12$ Plant Waste

Management Division) March 1990.

Depleted Uranium Oxide Storage

Vaults, Y50-41-WS-007, Martin

Marietta Energy Systems.

Y-12 WMD (Y-12 Plant Waste

Management Division) September

1990. Old Salvage Yard, Y50-41-WS-012, Martin Marietta

Energy Systems. Also in CSA 17936 (rev. of 17624).

Y-12 WMD (Y-12 Plant Waste

Management Division) October 1992.

Containerized Waste Storage Area,

Facility IS-33, Y50-41-WS-031, Martin

Marietta Energy Systems. Also in

CSA 17782(R).

Y-12 WMD (Y-12 Plant Waste

Management Division) February 1993.

Above-Grade Storage Facility, Y50-41-WS-047, Martin Marietta

Energy Systems. Also in

CSA 17922(R).

Y-12 WMD (Y-12 Plant Waste

Management Division) May 1993.

Classified Waste Storage Facility,

Y50-41-WS-029, Martin Marietta

Energy Systems.

Y-12 WMD (Y-12 Plant Waste

Management Division) August 1993.

Uranium Chip Oxidation Facility

Description, Y50-41-WT-07.02, Martin

Marietta Energy Systems.

Y-12 WMD (Y-12 Plant Waste

Management Division) November

1993. Trash-Monitoring Station,

Y50-41-WS-015, Martin Marietta

Energy Systems.

Y-12 WMD (Y-12 Plant Waste

Management Division) May 1994.

Waste Feed Preparation Facility,

Y50-41-WS-016, Martin Marietta

Energy Systems. Also in CSA 17836. 


\section{Hazardous Waste}

Hazardous wastes on the Oak Ridge Reservation (ORR) are nonradioactively contaminated hazardous wastes as defined by 40 CFR Pt. 261.3 under the Resource Conservation and Recovery Act (RCRA), Toxic Substances Control Act (TSCA) materials, and U.S. Department of Transportation (DOT) regulatory guidelines for poisonous substances. The management of hazardous waste is administratively regulated by the Tennessee Department of Environment and Conservation (TDEC), which has been authorized by the U.S. Environmental Protection Agency (EPA) to enforce RCRA.

When a waste or waste stream is generated, it must be determined if it is "hazardous" as defined above. This is done by applying the following general criteria (see 40 CFR Pt. 262.11 under "Hazardous Waste Determination"):

- Is the waste excluded from regulation?

- Is the waste listed as a hazardous waste (i.e., the waste or its constituents are specifically listed in the regulations as hazardous)?

- Is the waste a characteristically hazardous waste (i.e., the waste or its constituents exhibit any of the following characteristics: corrosivity, reactivity, ignitability, or toxicity)?

Hazardous wastes found to contain any levels of radioactive contamination added by U.S. Department of Energy (DOE) operations are referred to as "mixed wastes" and are described in detail in Sect. 7 of this plan.

Some procedures have been approved for certification of "No Rad Added"; however, Martin Marietta Energy Systems, Inc., is in the process of developing and implementing procedures that will be used by waste generators to determine absolutely that no radioactivity has been added (i.e., the No Rad Added policy).

If a waste is determined to be hazardous, it must be handled in strict accordance with RCRA. The principal RCRA requirements include proper characterization and treatment, storage, and disposal (TSD) of hazardous waste.

The Oak Ridge Y-12 Plant, Oak Ridge National Laboratory (ORNL), and the Oak Ridge K-25 Site manages all hazardous wastes as mixed waste. No hazardous wastes are disposed of on the ORR.

\section{Management Strategy}

Solid hazardous waste generated on the ORR is collected, handled, and stored with treatment and disposal as the major waste management objective. Liquid hazardous wastes are treated on-site. The focus of hazardous waste management is waste minimization, characterization, verification, segregation, repackaging, and storage in preparation for shipment to commercial facilities for treatment and/or disposal. The suspension of off-site shipments in May 1991 continues to significantly affect this strategy. Hazardous waste (as characterized by the generator but not certified as nonradioactive by approved procedures) is considered mixed waste. 


\section{Current Generation and Projections}

Approximately $10,058 \mathrm{~m}^{3}\left(355,183 \mathrm{ft}^{3}\right)$ of hazardous waste was generated on the ORR during CY 1993. Table 6.1 summarizes hazardous waste generated on the ORR. Figure 6.1 shows Environmental Restoration Program generation projections.

\section{Y-12 Plant}

The Y-12 Plant generated approximately $9,920 \mathrm{~m}^{3}\left(350,370 \mathrm{ft}^{3}\right)$ of hazardous waste in CY 1993 (Table 6.1). Liquid and solid hazardous waste streams include Steam Plant wastewaters for treatment; mineral oil contaminated with polychlorinated biphenyls (PCBs); and solids, liquids, and sludges.

\section{ORNL}

Collection of hazardous waste at ORNL is performed in a proceduralized manner (Fig. 6.2). The generator of a hazardous waste prepares a request form for waste collection. The request is sent to the Hazardous Waste Operations Group, which logs the request, ensures that the waste has been properly identified, and determines its appropriate classification (e.g., toxic, reactive, ignitable). For example, lab pack and explosive wastes are collected and delivered directly to Building 7653 for storage in a predesignated area that corresponds to the waste classification. When enough is accumulated, lab pack waste is packaged by commercial TSD facility personnel into appropriate shipping containers that meet DOT requirements and is shipped to EPA-permitted commercial treatment or disposal sites (pre-off-site shipment moratorium) or to the K-25 Site for storage (current practice). Explosive waste is treated on-site at the Chemical Detonation Facility (Building 7667). Following waste classification and collection, bulk (drummed) liquid and solid hazardous wastes are delivered directly to Building 7652 to await off-site treatment or disposal. PCB-contaminated waste is collected for immediate delivery to Building 7507 and subsequent off-site treatment once certified under the approved No Rad Added procedures. Similarly, used oil acceptable for off-site recycle is delivered to Building 7651 for off-site processing.

\section{K-25 Site}

All hazardous waste generated at the $\mathrm{K}-25$ Site, including all wastes subject to RCRA and TSCA regulations, is managed as mixed waste and is described in Sect. 7 .

\section{Treatment}

\section{Y-12 Plant}

The Y-12 Plant currently treats liquid hazardous waste at two on-site facilities: the Plating Rinsewater Treatment Facility (PRTF) and the Steam Plant Wastewater Treatment Facility (SPWTF). (The SPWTF is discussed in depth in Sect 8 because wastewater is rendered nonhazardous at that facility by treatment methods.) Because the PRTF uses, in addition to its own systems, process systems within the Central Pollution Control Facility (CPCF), which is a mixed waste facility, the PRTF is discussed in detail, together with the CPCF, in Sect 7. Tables 6.2 and 6.3 summarize hazardous waste treatment on the ORR and off-site. 
Table 6.1. Summary of hazardous waste generation on the Oak Ridge Reservation

\begin{tabular}{|c|c|c|}
\hline & $\begin{array}{c}\text { CY } 1993 \\
\mathrm{~m}^{3}\left(\mathrm{ft}^{3}\right)\end{array}$ & $\begin{array}{c}\mathrm{CY} 1994^{a} \\
\mathrm{~m}^{3}\left(\mathrm{ft}^{3}\right)\end{array}$ \\
\hline Oak Ridge Y-12 Plant & $9,922(350,368)$ & $6,214(219,416)^{c}$ \\
\hline Oak Ridge National Laboratory & $354(12,500)$ & $663(23,400)$ \\
\hline Oak Ridge K-25 Site & $d$ & $d$ \\
\hline Total & $10,276(362,808)$ & $6,877(242,816)$ \\
\hline
\end{tabular}

aProjected.

bIncludes both solids and liquids. Solids include Resource Conservation and Recovery Act (RCRA) wastes from Y-12 Plant operations, waste management, and contractors; RCRA treatment residues; nonradioactive polychlorinated biphenyl (PCB) waste from Y-12 Plant operations and contractors; RCRA/PCB wastes from Y-12 Plant operations and contractors; Environmental Restoration; and RCRA and PCB from ORNL. Liquids include RCRA oils and solvents from Y-12 Plant operations; RCRA liquid wastes from Y-12 Plant operations, waste management, and contractors; RCRA wastewaters; $\mathrm{PCB}$ oils and solvents and liquid waste; RCRA/PCB oils and solvents and liquid waste; RCRA Liquid Storage Facility wastewaters; RCRA ER waste; RCRA/PCB ER waste; and hazardous waste from ORNL.

Through June.

${ }^{d}$ Hazardous waste is managed as mixed waste at the K-25 Site (see Sect. 7).

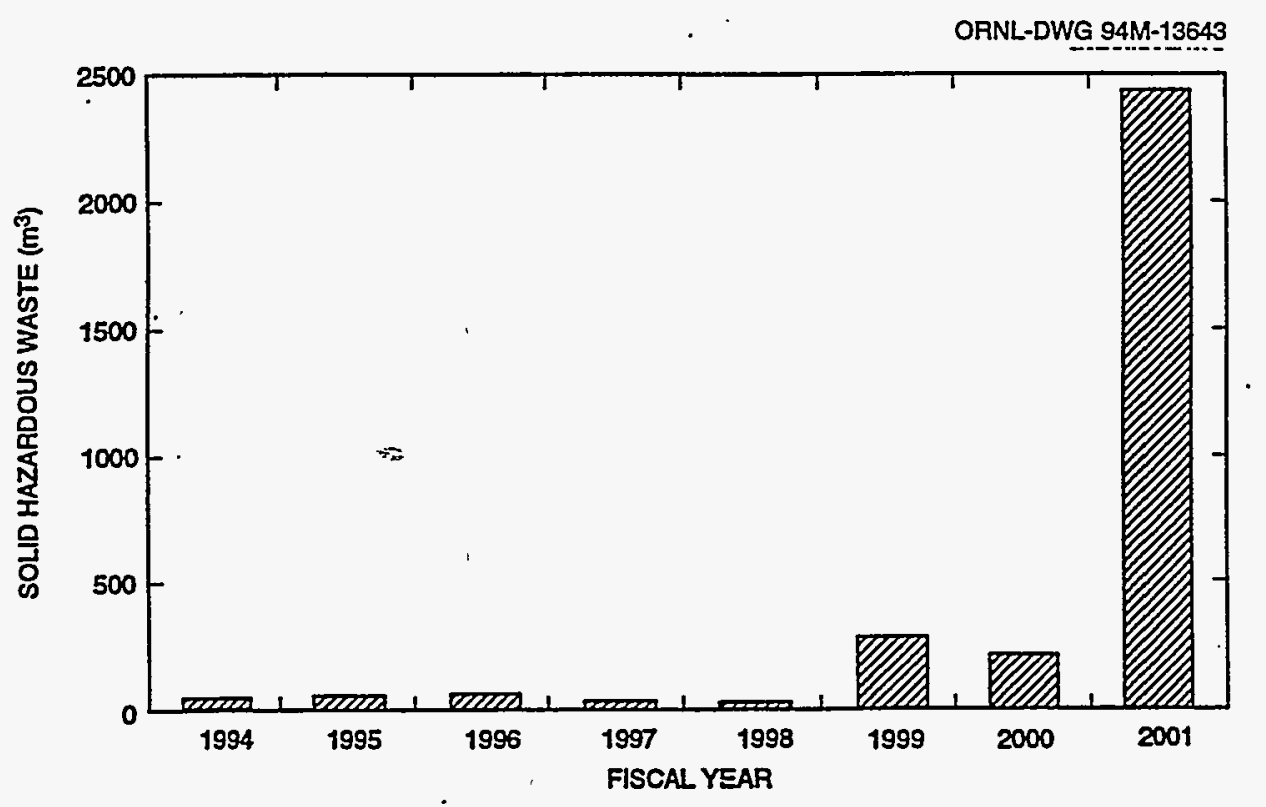

Fig. 6.1. Solid hazardous waste generation projections under the Environmental Restoration Program. Source: Environmental Restoration Division December 1993. Waste Generation Forecast for DOE-ORO's Environmental Restoration OR-1 Project: FY 1994-FY 2001, ES/ER/TM-102, Martin Marietta Energy Systems, Oak Ridge K-25 Site. 


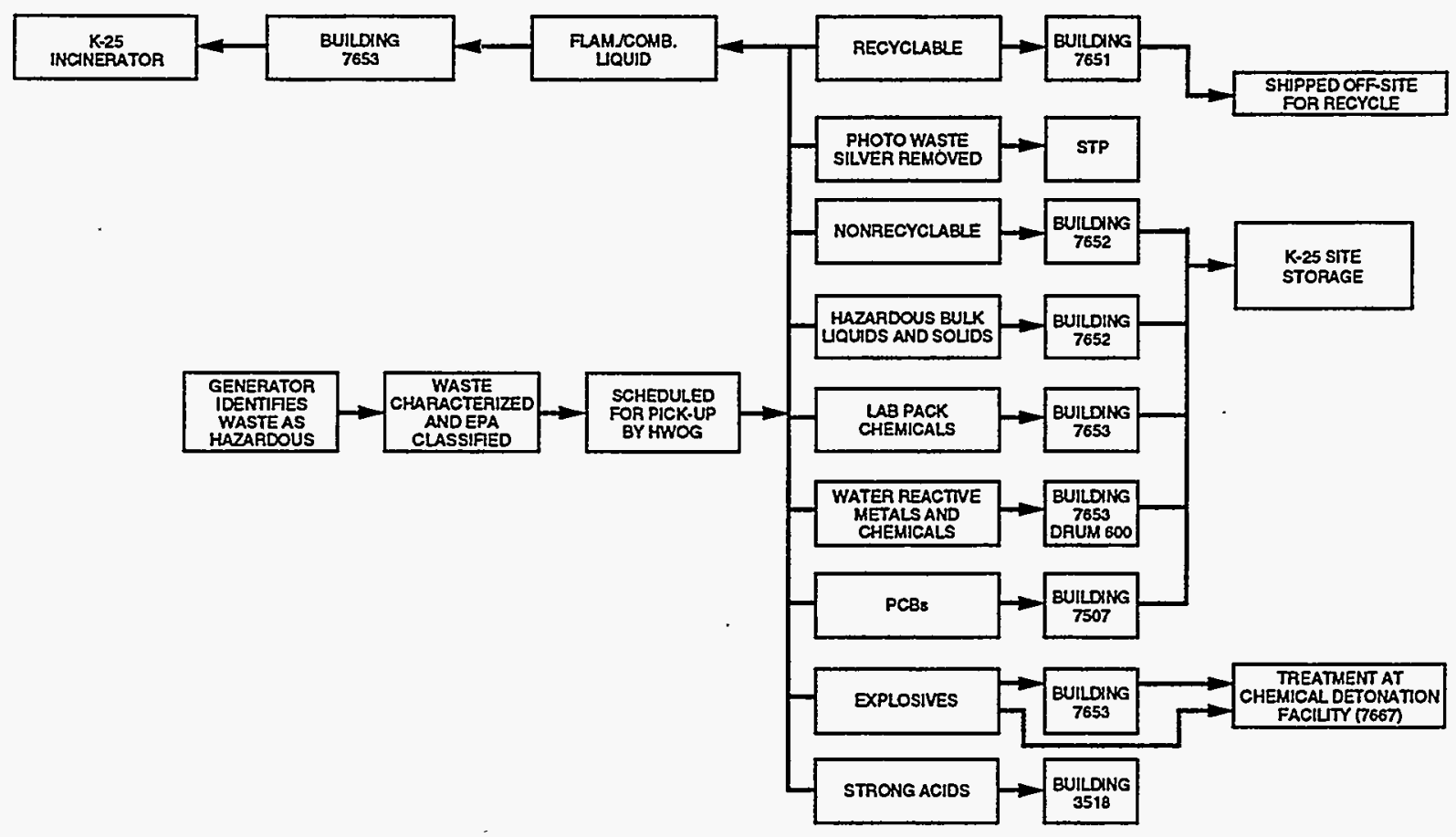

Fig. 6.2. Process flow for hazardous wastes at Oak Ridge National Laboratory.

Table 6.2. Summary of hazardous waste treatment on the Oak Ridge Reservation

\begin{tabular}{|c|c|c|c|}
\hline Waste type & $\begin{array}{l}\text { Treatment } \\
\text { method }\end{array}$ & $\begin{array}{c}\text { CY } 1993 \\
\mathrm{~m}^{3}\left(\mathrm{ft}^{3}\right)\end{array}$ & $\begin{array}{c}\mathrm{CY} 1994^{a} \\
\mathrm{~m}^{3}\left(\mathrm{ft}^{3}\right)\end{array}$ \\
\hline \multicolumn{4}{|c|}{ Oak Ridge Y-12 Plant } \\
\hline Solids & \multicolumn{3}{|c|}{ No hazardous solid waste is treated at the $Y-12$ Plant. } \\
\hline Liquids & & $8,840(312,157)$ & $5,153(217,271)^{b}$ \\
\hline \multicolumn{4}{|c|}{ Oak Ridge National Laboratory } \\
\hline $\begin{array}{l}\text { Chemical Detonation } \\
\text { Facility }\end{array}$ & Detonation & $0(0)$ & $0(0)$ \\
\hline $\begin{array}{l}\text { Steam Plant } \\
\text { regenerate }\end{array}$ & $c$ & $23,848(842,187)$ & $23,848(842,187)$ \\
\hline
\end{tabular}

No hazardous waste is treated at the K-25 Site

${ }^{a}$ Projected.

${ }^{6}$ Through June. The majority of this waste is managed as mixed waste. Includes Steam Plant Wastewater Treatment Facility wastewater.

To the Nonradiological Wastewater Treatment Plant in 1993 and coal yard runoff in 1994. 
Table 6.3. Off-site treatment of hazardous waste

\begin{tabular}{|c|c|c|c|}
\hline Waste type & Treatment method & $\begin{array}{c}\text { CY } 1993 \\
\mathrm{~m}^{3}\left(\mathrm{ft}^{3}\right)\end{array}$ & $\begin{array}{c}\text { CY } 1994 \\
\mathrm{~m}^{3}\left(\mathrm{ft}^{3}\right)\end{array}$ \\
\hline \multicolumn{4}{|c|}{ Oak Ridge Y-12 Plant } \\
\hline \multicolumn{4}{|c|}{ No hazardous waste is shipped off-site. } \\
\hline \multicolumn{4}{|c|}{ Oak Ridge National Laboratory } \\
\hline \multicolumn{4}{|c|}{ No hazardous waste is shipped off-site. } \\
\hline \multicolumn{4}{|c|}{ Oak Ridge K-25 Site } \\
\hline \multicolumn{4}{|c|}{ No hazardous waste is shipped off-site. } \\
\hline
\end{tabular}

\section{ORNL}

\section{Nonradiological Wastewater Treatment Plant (NRWTP)}

In the past, bulk non-nitrate acids were neutralized at the NRWTP and discharged to White Oak Creek via the National Pollutant Discharge Elimination System permit. This facility is a wastewater treatment unit operated under Sect. 402 of the Clean Water Act and is exempt from RCRA permitting requirements for TSD facilities.

In 1994 some of these acids went to the Central Neutralization Facility at the $\mathrm{K}-25$ Site to be used as treatment chemicals before being declared hazardous waste. The NRWTP is planned for use in the future for corrosives in storage. Many generators now neutralize corrosives to prevent generation of hazardous wastes. Products such as antifreeze and nonhazardous scintillation fluids are being treated at the Sewage Treatment Plant with proper approval documentation. These items were once sent to hazardous waste operators and disposed of off-site. This represents a significant savings over disposal costs.

\section{Chemical Detonation Facility}

The Chemical Detonation Facility (Building 7667) is located northeast of the Hazardous Waste Management Area. The site consists of two storage magazines (one for the detonation sheets and one for the electrical blasting caps), a detonation trench, and a control area. The magazines are bulletproof, fire-resistant, weatherresistant, theft-resistant, and ventilated. The magazines are separated by an earthen berm. An $18.3-\mathrm{m}$ (60-ft) radius around the detonation trench is to be kept clear of combustible materials such as trees, brush, shrubs, and tall grass. The cleared area is enclosed by a chain-link fence. The control area is the location from which the waste material is remotely detonated. The cleared area provides good visual line of sight from the control area to the detonation trench. This facility operates under RCRA interim status permit and an open-burning permit under TDEC regulations. A RCRA Part,B, Subpart X, permit application has been prepared and submitted to the TDEC. This facility renders harmless explosive or reactive wastes. 


\section{Leaking Gas Cylinder Area}

The Leaking Gas Cylinder Area at ORNL is used for the venting of damaged and excess gas cylinders. This area is located at a remote site (i.e., away from inhabited areas) off of Ramsey Drive and the Melton Valley access road. The area consists of a cleared site covered with gravel and surrounded by a fence with a locked gate. The cylinders are held in the area until the contents have bled off. Afterwards, the undamaged cylinders are returned to the vendors, and the damaged cylinders (except for radioactive) are stored until properly disposed of at the Y-12 Plant Sanitary Landfill III.

The provisions of the Clean Air Act are regulated by the TDEC through the Tennessee Air Pollution Control Regulations. The primary means of control is through the issuance of State air permits. The TDEC has indicated that the Leaking Gas Cylinder Area is exempt from permit requirements. RCRA permitting is not required for the venting of gas cylinders on-site.

ORNL does not plan to build any new facilities for storing, treating, or disposing of gas cylinders unless specific problems are identified with respect to current air pollution control regulations. Therefore, the current practice of venting cylinders at the Leaking Gas Cylinder Area will continue as previously discussed.

\section{K-25 Site}

The on-site facilities available for treatment of liquid hazardous wastes are the K-1407-H Central Neutralization Facility (CNF) and the K-1435 TSCA Incinerator (Sect. 7).

\section{Storage}

\section{Y-12 Plant}

The storage inventory of hazardous waste is that quantity which has a high potential to be certified for off-site disposal. Any remaining hazardous waste generated and placed in storage is considered mixed.

\section{RCRA Storage and Staging Facility} (Building 9720-31)

The RCRA Storage and Staging Facility is housed in Building 9720-31, which is located on the south side of West Third Street, east of the existing Fire Training Facility, Building 9817 (Fig. 6.3). It is a one-story structure constructed of lightweight concrete block masonry walls and partitions. It has a precast concrete roof deck and an impervious concrete floor slab. Building 9720-31 is used to receive and temporarily store waste from all areas of the Y-12 Plant that cannot be stored at other locations within the plant boundaries. Hazard classes and their definitions for the waste that may be stored in this facility have been published (Y-12 WM/D\&D February 1994). Under normal conditions this facility is not utilized to store PCBs or radioactive waste.

\section{ORNL}

Several facilities are currently used for the storage of hazardous waste at ORNL. The majority of waste is stored in 208-L (55-gal) drums in Building 7652; it has a capacity of $57,254 \mathrm{~L}(15,125 \mathrm{gal})$.

Inventories of waste in the various storage facilities vary monthly because these areas 


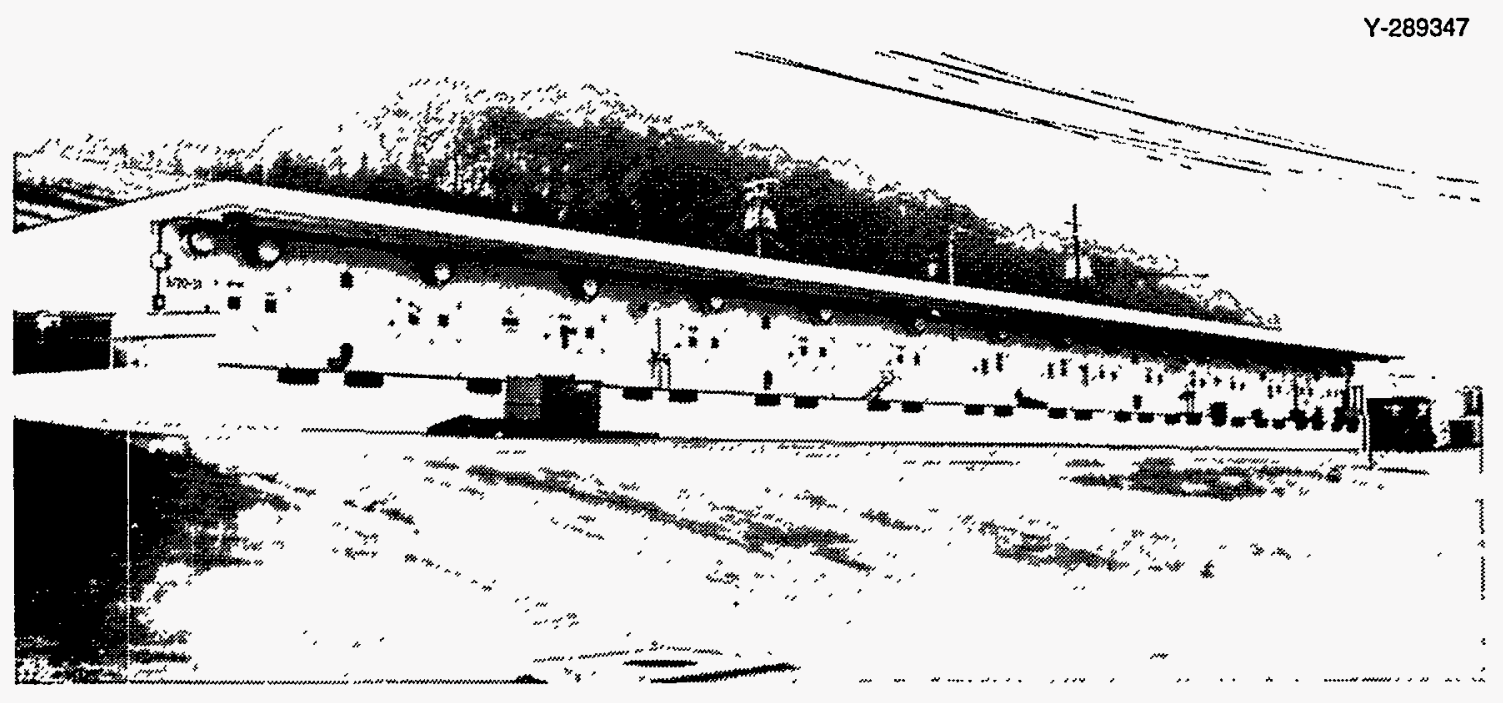

Fig. 6.3. The Resource Conservation and Recovery Act Storage and Staging Facility at the Oak Ridge Y-12 Plant.

are used for staging the waste for final disposition. With the exception of Building 7507, the storage facilities are located in the Hazardous Waste Management Area off the HPRR access road at ORNL.

\section{Building 7652-Hazardous Waste Storage Facility}

Building 7652 is used to store hazardous wastes that have been packaged, labeled, and marked in accordance with DOT regulations. The bulk waste chemicals are placed in DOT-certified drums either at their point of origin or after transfer to the facility. A maximum of $57,254 \mathrm{~L}(15,125$ gal) [275 208-L (55-gal) drums] can be stored at this facility. Drums stored in this building are segregated according to the compatibility groupings.

\section{Building 7653-Chemical Waste Storage Facility}

The facility is used for storage of small containers of laboratory chemicals and process chemical wastes. The small containers [less than $18.9 \mathrm{~L}$ ( 5 gal) or $20 \mathrm{lb}$ ] of chemical wastes are delivered to the facility and are separated by compatibility grouping for storage in the appropriate room. The chemicals are generally within the manufacturer's original container and are identified with the manufacturer's label. Each storage room is physically limited to contain not more than the equivalent number of small containers constituting 10 208-L (55-gal) drums. The maximum allowed inventory of waste in storage for the facility at any given time is the equivalent of 70208 -L (55-gal) drums, or $11,550 \mathrm{~L}$ (3850 gal).

\section{Building 7507-Hazardous Waste Storage Facility}

The maximum allowed inventory of hazardous waste in storage is $150208-\mathrm{L}$ (55-gal) drums, or 31,230 L (8250 gal). Initially, hazardous waste stored at the facility consisted of lab packs; bulk quantities of ignitable, corrosive, and/or extraction procedure toxic wastes, oxidizers, and poisons; and PCB-contaminated liquids and solids. Currently, the storage facility is utilized to store only $\mathrm{PCB}$ and PCB-contaminated waste. However, the $\mathrm{PCB}$ waste may also be identified as exhibiting a characteristic of hazardous waste. 


\section{Building 7651-Clean Oil Storage Pad}

The storage pad is used to store 208and 114-L (55- and 30-gal) drums containing used oil acceptable for unrestricted off-site release. The maximum inventory of waste in storage is $128208-\mathrm{L}$ (55-gal) drums, or 26,650 L (7040 gal). Drums are placed on pallets and doublestacked, if required, with pallets between each level. The drums are arranged in rows to provide walkway space for emergency personnel and equipment and conducting inspections.

Table 6.4 lists the hazardous waste storage inventory by facility at ORNL.

\section{K-25 Site}

See Sect. 7, "Mixed Waste." Appendix B shows the current operational status of all waste TSD facilities on the ORR.

\section{Disposal}

No hazardous wastes are disposed of on the ORR.

\section{Future Plans}

\section{Treatment}

At present, no new hazardous waste treatment facilities are planned at the $\mathrm{Y}-12$ Plant or at ORNL. Limited on-site treatment of solid hazardous waste may occur in the future at the K-1435 TSCA Incinerator (Sect. 7).

\section{Storage}

See Appendix $\mathrm{C}$ for data on planned facilities at the Y-12 Plant, ORNL, and the K-25 Site.

\section{Disposal}

There are no plans for future disposal of hazardous wastes on the ORR.

Appendix D provides DOE Order 5820.2A compliance summaries for each of the three ORR installations.

\section{Waste Certification}

The Energy Systems Waste Certification Program is discussed in Sect. 5.

\section{Waste Minimization/Pollution Prevention}

In agreement with the way that the data were gathered for the Pollution Prevention Program at the Y-12 Plant, all "hazardous" pollution prevention waste stream projects at that site are discussed in Sect. 7, "Mixed Waste."

Photographic chemicals at ORNL, which have made up a large portion of the hazardous waste stream in the past, have been practically eliminated because of a silver- recovery program that removes the RCRA hazardous component. The silver can be recycled. The remaining liquid material is being discharged to the Sewage Treatment Plant. Some hazardous solvents have also been replaced with nonhazardous; this has also reduced the total hazardous waste volume at the source.

One of the most successful pollution prevention activities at ORNL has been the reuse of unexpired surplus chemicals. At one time, unused commercial chemicals constituted $90 \%$ of the waste chemicals collected at ORNL. Approximately $30 \%$ of these containers were unopened. Lists of reusable chemicals were circulated by the Hazardous Waste Operations Group to chemical users. Many of these chemicals, which were no longer needed by their owners, have been transferred to new owners for use. 
Table 6.4. Storage of hazardous waste at Oak Ridge National Laboratory ${ }^{a}$

\begin{tabular}{llcc}
\hline Facility & \multicolumn{1}{c}{ Waste types } & $\begin{array}{c}\text { Waste inventory } \\
\mathrm{m}^{3}\left(\mathrm{ft}^{3}\right)\end{array}$ & $\begin{array}{c}\text { Remaining capacity } \\
\mathrm{m}^{3}\left(\mathrm{ft}^{3}\right)\end{array}$ \\
\hline 7651 & Clean oil & $11(400)$ & $14(500)$ \\
7652 & Hazardous waste & $43(1500)$ & $14(500)$ \\
7653 & Hazardous waste & $6(200)$ & $20(700)$ \\
7507 & $\begin{array}{l}\text { Polychlorinated biphenyls } \\
\text { (PCBs) and PCB-contaminated } \\
\text { wastes }\end{array}$ & $20(700)$ & $11(400)$ \\
& & \\
\hline
\end{tabular}

These wastes are considered mixed until certified by approved procedures.

${ }^{b}$ As of June $30,1994$. 



\section{Mixed Waste}

The Federal Facility Compliance Act (FFCAct) [(P.L. 102-386)] defines mixed waste as waste that contains (1) hazardous constituents regulated under the Resource Conservation and Recovery Act (RCRA) and (2) a source, special nuclear, or byproduct material subject to the Atomic Energy Act of 1954 (42 U.S.C. 2011, et seq.).

There are two general radiological categories of mixed waste on the Oak Ridge Reservation (ORR): mixed transuranic (MTRU) and mixed low-level waste (MLLW). The latter category comprises approximately $95 \%$ of the mixed waste on the ORR. There are 396 MLLW and 6 MTRU waste streams on the ORR requiring treatment and disposal. Under the Federal Facility Compliance Agreement (FFCA) developed for the ORR, stored and newly generated MLLWs are categorized into two distinct sets based on whether or not treatment is currently available. Socalled "Appendix A" wastes are mixed wastes with identified existing treatment. Appendix B wastes are mixed wastes without identified existing treatment or with identified existing treatment that is not currently being accepted. Appendix B wastes can be treated in existing facilities with some additional waste characterization or pretreatments or with minor modifications to existing facilities.

Naturally occurring and acceleratorproduced radioactive material (NARM), while not covered by the FFCAct, is managed as mixed waste under the FFCA for the ORR. All NARM on the ORR is generated by research activities at Oak Ridge National Laboratory (ORNL).

The mixed waste streams on the ORR have a wide range of hazardous and radiological contaminants as well as a wide range of waste matrixes. To develop treatment strategies for these varied wastes, we first segregated them into a number of waste categories that exhibit similar characteristics for treatment [i.e., similar waste matrixes and U.S. Environmental Protection Agency (EPA) waste codes]. The classification system is consistent with one developed by national U.S. Department of Energy (DOE) mixed waste projects. The categorization scheme consists of nine major waste categories that reflect EPA waste treatment requirements but that also emphasize physical characteristics of the waste streams. Therefore, a waste category may represent single or multiple EPA waste codes. The mixed wastes were grouped into seven of the nine major waste categories:

MPC Matrixed Parameter Category

1000 Aqueous Liquids and Slurries

2000 Organic Liquids

3000 Solid Process Residues

4000 Soils

5000 Debris Waste

6000 Special Waste

7000 Inherently Hazardous Waste

8000 Unknown Wastes

9000 Treated Wastes 
To ensure that waste category/treatment technology correlations were consistent with Land Disposal Restriction (LDR) treatment standards and process technical requirements and limitations, the nine major categories (treatability groups) were further divided into 35 subcategories. Twenty-one of these subcategories were required to organize the ORR mixed waste. Each mixed waste stream was assigned a category and subcategory based on the waste descriptions, waste form EPA codes provided, and review of current waste management records.

The RCRA LDRs require the treatment of hazardous waste (including the hazardous component of mixed waste) to certain standards before the waste can be land disposed, and prohibit storage of hazardous wastes that do not meet LDR standards except for accumulating sufficient quantities to facilitate proper recovery, treatment, or disposal of the waste. DOE is currently storing mixed waste inconsistent with the LDR provisions because the treatment capacity for such wastes, either at DOE sites or in the commercial sector, is not adequate or is unavailable at this time.

The FFCAct, signed on October 6 , 1992, waives sovereign immunity for fines and penalties for RCRA violations at federal facilities. However, it postpones the waiver for 3 years for LDR storage prohibition violations for DOE's mixed wastes and requires DOE to prepare plans for developing the required treatment capacity for its mixed waste at each site at which it stores or generates mixed waste. Each plan must be approved by the state or the EPA, after consultation with other affected states and consideration of public comment, and an order must be issued by the regulatory agency requiring compliance with the plan. The FFCAct further provides that DOE will not be subject to fines and penalties for LDR storage prohibition violations for mixed waste as long as it is compliant with an approved plan and order.

Treatment of MLLW will be implemented in accordance with specified standards (40 CFR Pt. 268, Subpart D). Two categories of treatment standards for LDR waste are specified in Subpart D: (1) technology-based treatment standards and (2) concentration-based treatment standards. The technology-based treatment standards (40 CFR Pt. 268.42, Table 2) specify the best technology for treatment of hazardous waste. The concentration-based treatment standards are expressed in terms of the constituent concentration in waste (40 CFR Pt. 268.43, Table CCW) or constituent concentration in waste extract (40 CFR Pt. 268.41, Table CCWE). The majority of mixed waste is required to meet the concentration-based treatment standards.

\section{Management Strategy}

Site Treatment Plans (STPs) are required for facilities at which $\mathrm{DOE}$ generates or stores mixed waste defined by the FFCAct. DOE published a notice [Fed. Regis. 58, 17875 (Apr. 6, 1993)] describing its proposed process for developing the STPs in three phases: Conceptual, Draft (DSTP), and Final (FSTP). In August 1994 a DSTP was issued covering mixed wastes on the ORR (DOE August 1994).

The purpose of that DSTP is to identify the currently preferred options for treating mixed waste at the ORR or for developing technologies when (1) technologies do not exist or (2) existing technologies need modification. The DSTP sets forth the site-specific preferred 
options-developed with the state's input and based on currently available information. The effects of these options on other DOE sites and on the overall $D O E$ program have not been evaluated in the DSTP.

The DSTP designates specific facilities for the treatment of mixed waste and proposes schedules as set forth in the FFCAct. If this is not possible, the DSTP provides schedules for alternative activities such as waste characterization and technology assessment. All schedule information presented is preliminary and subject to change. For new facilities the schedule is heavily dependent upon decisions made during the Design Phase and is contingent on funding availability. Assumptions and professional judgments related to the type of treatment technology, location of the treatment facility, contracting mechanism, project approval process, cost, etc., were used to develop the estimated schedule. Any variation in these assumptions will affect the estimated schedule.

In the future, new or developing technologies for waste management may be identified that are safer, more effective, and more cost-efficient than the current technologies considered in the DSTP. Working closely with regulators and others during the implementation of the STP, DOE will continue to evaluate and to develop technologies that offer potential advantages in the areas of public acceptance, risk abatement, performance, and life cycle cost. Should better technologies be discovered, DOE may request a modification of the STP in accordance with provisions of the STP and/or the related order.

The main strategies that guided development of the plan are as follows:

- Existing and modified on-site facilities will be used to treat mixed waste when possible.
- When available and technically appropriate (based on risk, cost, and schedule), commercial sector resources will be used tó treat mixèd wastes. Potential candidates for commercial treatment include inorganic sludges, soils, inorganic debris, and lab packs.

- TRU mixed wastes will be treated only as necessary to meet the Waste Acceptance Criteria (WAC) of the Waste Isolation Pilot Plant (WIPP).

The 396 MLLW streams are divided into 21 categories based on their matrix parameter code. The DSTP calls for 245 MLLW streams to be treated in existing on-site facilities: 32 waste streams to be treated with existing commercial capabilities, 111 waste streams to be treated in the proposed Mixed Waste Treatment Facility (MWTF), and 2 unstabilized pond sludge streams (one of which is a secondary waste generated from repackaging activities) covered by a September 1991 Tennessee Department of Environment and Conservation (TDEC) commissioner's order to be treated or disposed of using commercial resources. No plans are provided for $6 \mathrm{MLLW}$ streams that involve Comprehensive Environmental Response, Compensation, and Liability Act (CERCLA) waste or waste that has not yet been generated.

Six MTRU streams on the ORR involve both contact- $(\mathrm{CH})$ and remotehandled (RH) wastes. The DSTP calls for five of these streams to be treated in the proposed Waste Handling and Packaging Plant (WHPP) only as necessary to meet the WAC for disposal at WIPP. The remaining MTRU stream is CERCLA waste, and plans for any specific treatment or disposal activities are deferred to the Record of Decision that will be developed. 
Six existing on-site facilities will be used to treat inventoried mixed waste. The ORR is also formulating plans to construct the two new major on-site facilities described (i.e., the MWTF and WHPP). Commercial treatment of mixed waste is being pursued in concert with the construction of new facilities. The final configuration of new on-site facilities will depend on the extent to which commercial resources are available.

Owing to the congressional budget cycle, milestones will be established annually (jointly between the TDEC and the ORR) only after the budget allocation by Congress to $\mathrm{DOE}$ for the coming year. The work-off will take approximately 25 years, and the as-generated Treatment Phase is expected to be achieved in the year 2015 for large-volume waste. At that time the ORR will be fully compliant with the LDR storage prohibition requirements of RCRA.

\section{Current Generation and Projections}

The Mixed Waste Inventory Report (MWIR), required by the FFCAct, provides an inventory of mixed waste currently stored or generated, or expected to be generated over the next 5 years, at each DOE site and an inventory of treatment capacities and technologies. The interim MWIR, published by DOE in April 1993, provides information on a waste-stream-bywaste-stream basis for each DOE site that generates or stores mixed waste. DOE made updated waste stream and technology data available to the States and the EPA in May 1994 and has prepared an Updated Mixed Waste Inventory Summary. The report represents the best record of DOE's mixed waste generation and inventory at the beginning of 1994. Table 7.1 summarizes mixed waste generation on the ORR for CYs 1992 and 1993. Figure 7.1 shows Environmental Restoration Program generation projections.

\section{Y-12 Plant}

Liquid mixed wastes at the Oak Ridge Y-12 Plant consist of non-nitrate-bearing wastewaters; contaminated groundwaters; nitrate-bearing wastes generated by production operations that include nitric acid wastes, nitrate-bearing rinse waters, mixed acid wastes, waste coolants, mop water, caustic wastes, and biodenitrification sludges; cyanide wastes; organic solutions containing enriched uranium; uraniumcontaminated waste oils and solvents; mixtures of oils and chlorinated organics that may contain water; waste oils contaminated with polychlorinated biphenyls (PCBs) and/or chlorinated solvents; ignitable, nonreactive liquids; combustible/noncombustible nonreactive liquids; RCRA hazardous uranium and PCB-contaminated wastes; and acidic and caustic wastes.

Solid mixed wastes consist of RCRAlisted waste codes $F, P$, and $U$; characteristic RCRA waste code D except for D001 (i.e., solid waste that exhibits the characteristic of ignitability) and D003 (i.e., solid waste that exhibits the characteristic of reactivity) listed waste; uranium-contaminated waste; nonradioactive waste; Toxic Substances Control Act (TSCA) waste (PCBcontaminated solids); RCRA hazardous and mixed ash; RCRA hazardous classified waste; and uranium-contaminated solid combustibles.

\section{ORNL}

One of the mixed waste types generated at ORNL is mixed waste oils. Mixed waste oils are sometimes generated 
Table 7.1. Summary of mixed waste generation on the

Oak Ridge Reservation

\begin{tabular}{|c|c|c|}
\hline & \multicolumn{2}{|c|}{$\begin{array}{c}\text { Generation rate } \\
\text { (kg/year) }\end{array}$} \\
\hline & CY 1992 & CY 1993 \\
\hline \multicolumn{3}{|c|}{ Oak Ridge Y-12 Plant } \\
\hline Appendix $\mathrm{A}^{a}$ & 129,994 & 179,958 \\
\hline Appendix B & 294,854 & 154,058 \\
\hline Total MLLW & 424,848 & 334,016 \\
\hline \multicolumn{3}{|c|}{ Oak Ridge National Laboratory } \\
\hline Appendix A & 25,330 & 25,488 \\
\hline Appendix B & 110,572 & 151,437 \\
\hline Total MLLW & 135,902 & 176,925 \\
\hline MTRU $^{b}$ & 11,127 & 12,898 \\
\hline \multicolumn{3}{|c|}{ Oak Ridge K-25 Site } \\
\hline Appendix A & 603,986 & 583,737 \\
\hline Appendix B & 743,266 & 345,211 \\
\hline Total MLLW & $1,347,252$ & - 928,948 \\
\hline \multicolumn{3}{|c|}{ Oak Ridge Reservation } \\
\hline Appendix A & 759,310 & 789,183 \\
\hline Appendix B & $1,148,692$ & 650,706 \\
\hline MLLW & $1,908,002$ & $1,439,889$ \\
\hline MTRU & 11,127 & 12,898 \\
\hline
\end{tabular}

${ }^{a}$ Appendix A wastes indicate those for which treatment is available; Appendix B wastes indicate those that currently lack treatment.

'Mixed low-level waste (MLLW); mixed transuranic waste (MTRU).

Source: DOE April 1993. Mixed Waste Inventory Report, interim document.

when oils are removed from systems that have operated in radiation environments. Radiation levels in these oils and scintillation fluids are typically low (i.e., less than or equal to $10 \mathrm{mrem} / \mathrm{h}$ ). These wastes consist largely of vacuum pump oil, axle oil, refrigeration oil, mineral oil, or oil/water mixtures. Radioactive contaminants ${ }^{14} \mathrm{C},{ }^{3} \mathrm{H},{ }^{238} \mathrm{U},{ }^{239} \mathrm{Pu},{ }^{232} \mathrm{Th}$, ${ }^{137} \mathrm{Cs},{ }^{60} \mathrm{Co}$, and ${ }^{90} \mathrm{Sr}$ are common.

Radioactive-contaminated oils are being handled as RCRA waste. The strategy for dealing with these oils may continue to change as new EPA regulations on used oils are issued.
In the past, there was a large generation of hazardous scintillation fluids. Many generators have substituted nonhazardous scintillation fluids for these and reduced this waste stream. There is, however, a large volume of this mixed waste in storage. The principal components of hazardous scintillation fluids are toluene and/or xylene, culture medium, miscellaneous organics, and various radioisotopes including ${ }^{3} \mathrm{H},{ }^{14} \mathrm{C},{ }^{32} \mathrm{P}$, and ${ }^{131} \mathrm{I}$. The flash point is normally less than $60^{\circ} \mathrm{C}\left(140^{\circ} \mathrm{F}\right)$; therefore the waste is classified as ignitable. Other mixed wastes at ORNL include organic wastes, carcinogenic wastes, mercury-contaminated 


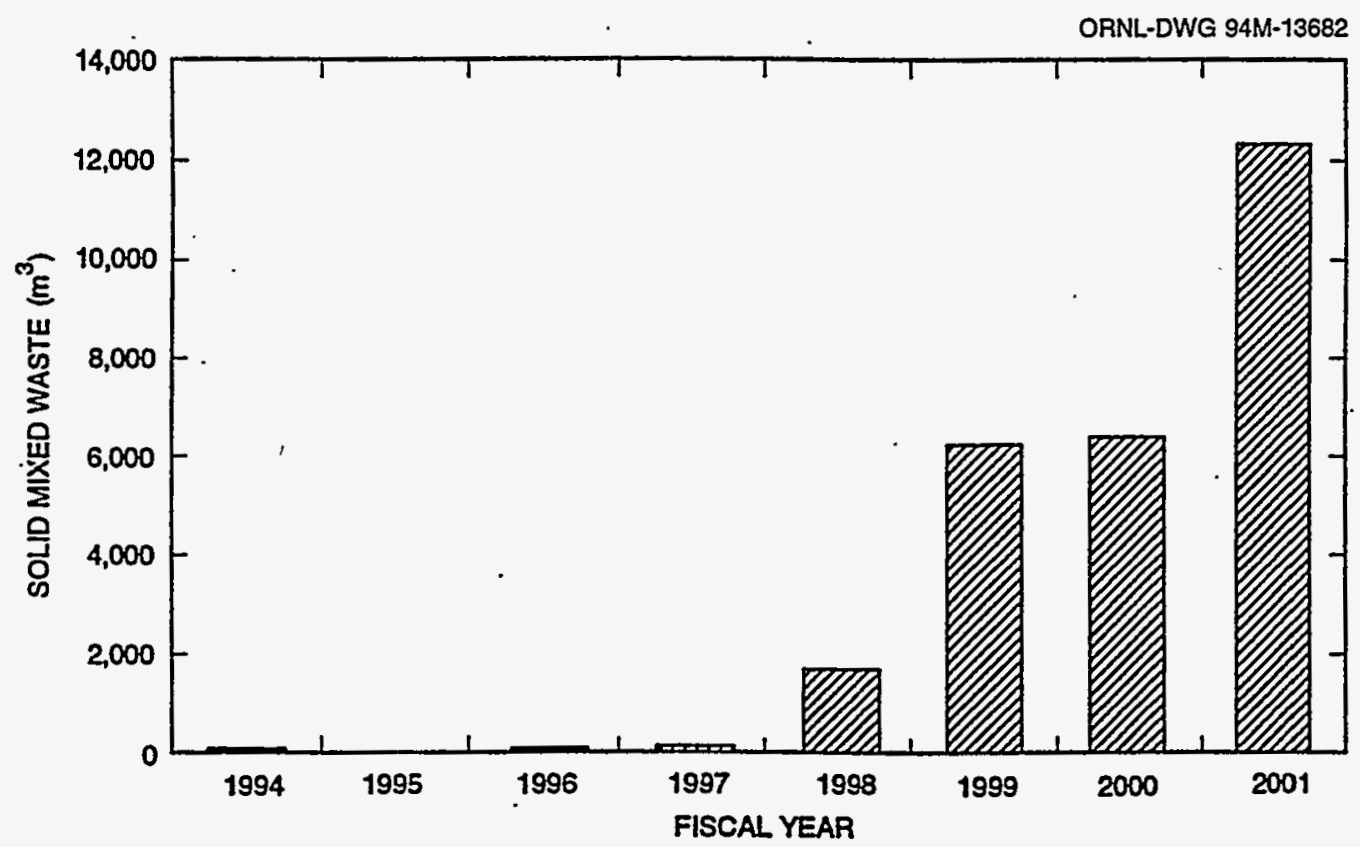

Fig. 7.1. Solid mixed waste generation projections under the Environmental Restoration and Decontamination and Decommissioning Programs on the Oak Ridge Reservation. Source: Environmental Restoration Division December 1993. Waste Generation Forecast for DOE-ORO's Environmental Restoration OR-1 Project: FY 1994-FY 2001, ES/ER/TM-102, Martin Marietta Energy Systems, Oak Ridge K-25 Site.

solid wastes, waste solvents, corrosives, poisons, and other process wastes.

\section{K-25 Site}

The general description of mixed wastes generated at the Oak Ridge K-25 Site includes liquids, solids, sludges, and soil contaminated with hazardous waste 5 and PCB constituents. Examples of the types of wastes that will be accepted for mixed waste management at K-25 Site permitted storage units include

- waste oils and petroleum-related products from general maintenance activities,

- spent halogenated solvents from garages or electrical cleaning activities,

- spent halogenated solvents used in degreasing operations from degreasing at garages,
- spent nonhalogenated solvents from maintenance activities,

- discarded paints and related materials from maintenance activities,

- aqueous- and water-contaminated waste from general maintenance activities,

- acutely toxic and toxic commercial chemical products discarded from laboratory activities,

- cyanide- or sulfide-bearing reactive wastes, and

- corrosive and toxic wastes from laboratory processes.

\section{Treatment}

\section{Y-12 Plant}

Table 7.2 summarizes liquid mixed waste treatment on the ORR. 
Table 7.2. Summary of liquid mixed waste treatment on the ORR

\begin{tabular}{|c|c|c|c|}
\hline Waste type & Treatment method & $\begin{array}{c}\text { CY } 1993^{a} \\
\text { L (gal) }\end{array}$ & $\begin{array}{c}\text { CY } 1994^{b} \\
\text { L (gal) }\end{array}$ \\
\hline \multicolumn{4}{|c|}{ Oak Ridge Y-12 Plant } \\
\hline$c$ & $c$ & $2,408,779(636,401)$ & $766,418(202,488)$ \\
\hline \multicolumn{4}{|c|}{ Oak Ridge National Laboratory } \\
\hline Mixed waste oil & TSCA Incinerator & $0(0)$ & $18,900(5,000)$ \\
\hline \multicolumn{4}{|c|}{ Oak Ridge K-25 Site } \\
\hline Mixed liquid & TSCA Incinerator & $2,309,000(610,000)$ & $2,574,000(680,000)$ \\
\hline $\begin{array}{l}\text { TSCA Incinerator } \\
\text { effluent }\end{array}$ & $\begin{array}{l}\text { Central Neutralization } \\
\text { Facility (neutralization) }\end{array}$ & $79,491,900(21,000,000)$ & $89,333,800(23,600,000)$ \\
\hline
\end{tabular}

\section{Central Pollution Control}

Facility/Plating Rinsewater Treatment Facility (CPCF/PRTF)

The CPCF and the PRTF are designed to treat non-nitrate-bearing wastes from ORR facility operations. The CPCF and PRTF are intended to process 10.2 and 30.2 million $L$ ( 2.7 and 8 million gal) of wastewater per year respectively.

The CPCF/PRTF (Figs. 7.2 and 7.3) are inside the Y-12 Plant Protected Security Area on Second Street. The CPCF is in Building 9623 near the southeast corner of Building 9201-4. It includes two containment basins adjacent to Building 9623. The PRTF is located across the street from Building 9401-2 (the Plating Shop), which produces most of the plating rinsewaters treated at the facility. The part of the PRTF that neutralizes incoming rinsewater wastes and provides equalization volume is outdoors in a diked basin. The remainder of the PRTF is located in Building 9623. The PRTF does not treat radioactively contaminated plating rinsewaters; however, the facility is described here to show its relationship to the CPCF. In addition to its own systems, the PRTF uses process systems within the
CPCF (see also the "Hazardous Waste" section).

Industrial waste liquids are delivered to the CPCF/PRTF in 18,927-L (5,000-gal) tankers and 2,271-L (600-gal) poly tanks via direct pipeline from the Plating Shop sump. The wastes received at the CPCF are accompanied by composition analysis documentation, which provides CPCF/PRTF operating personnel with information to determine the treatment scheme for the waste. However, the waste received at the PRTF by direct pipeline is accepted directly from the generating customer without composition analysis. WAC for the CPCF and the PRTF have been published (Y-12 WMD September 1993a; Y-12 WMD March 1993a; Y-12 WMD March 1993b).

The PRTF receives nonradioactive, nonfissile, heavy-metal contaminated rinsewaters from plating operations. The CPCF is the primary facility for the routine treatment of non-nitrate wastes. The CPCF directly receives concentrated acidic or caustic wastes and oily mopwater wastes containing beryllium, thorium, uranium, emulsified oils, and commercial soaps or cleaners. (It is planned that the CPCF will also receive hydrogen fluoride scrubber solution.) The CPCF also receives treated 
ORNL.DWG 94M-14175

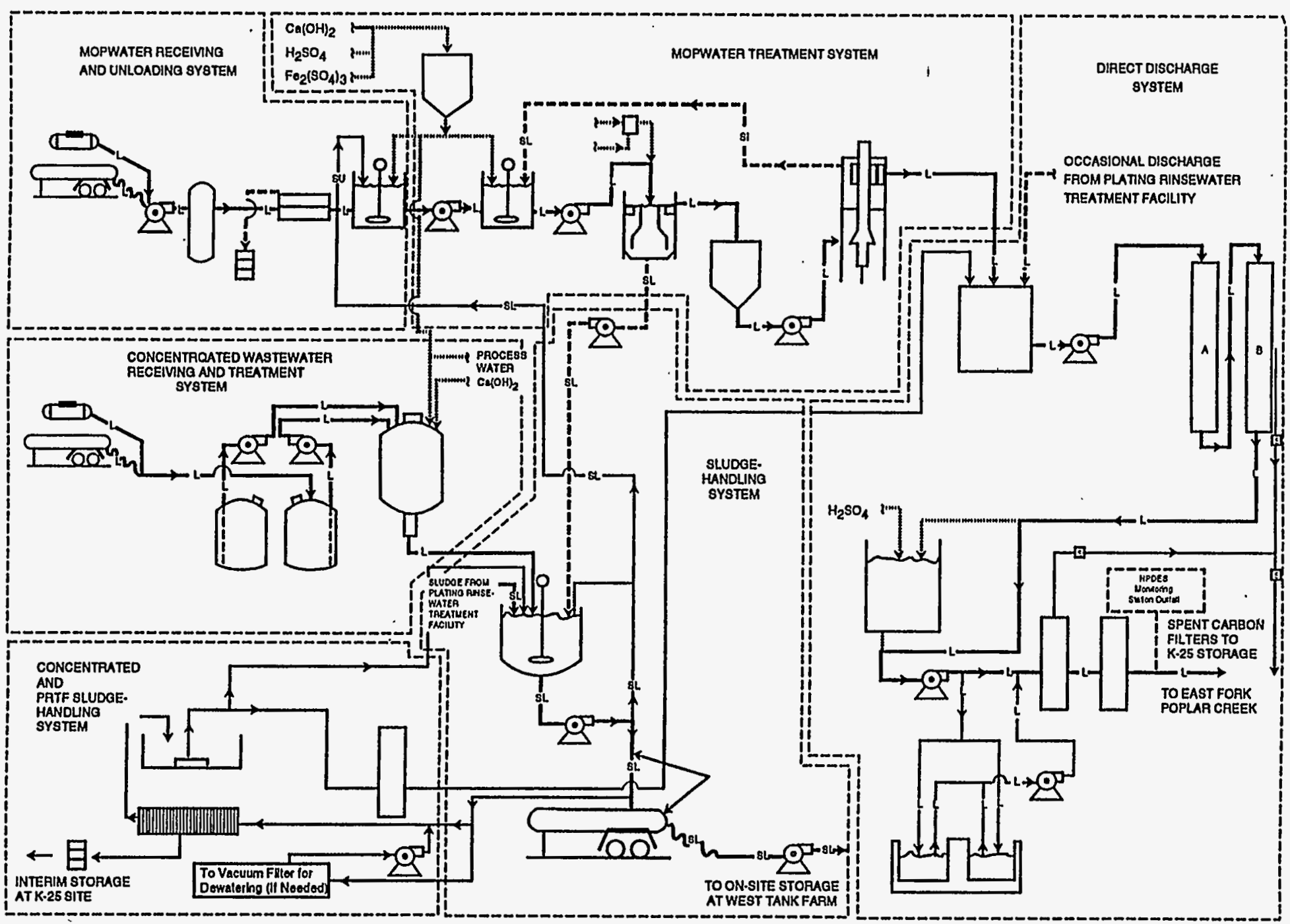

Fig. 7.2. The Central Pollution Control Facility at the Oak Ridge Y-12 Plant. Source: PAI Corporation Nov. 5, 1993. Description of Y-12 Plant Waste Management System 1993, Oak Ridge, Tenn. 


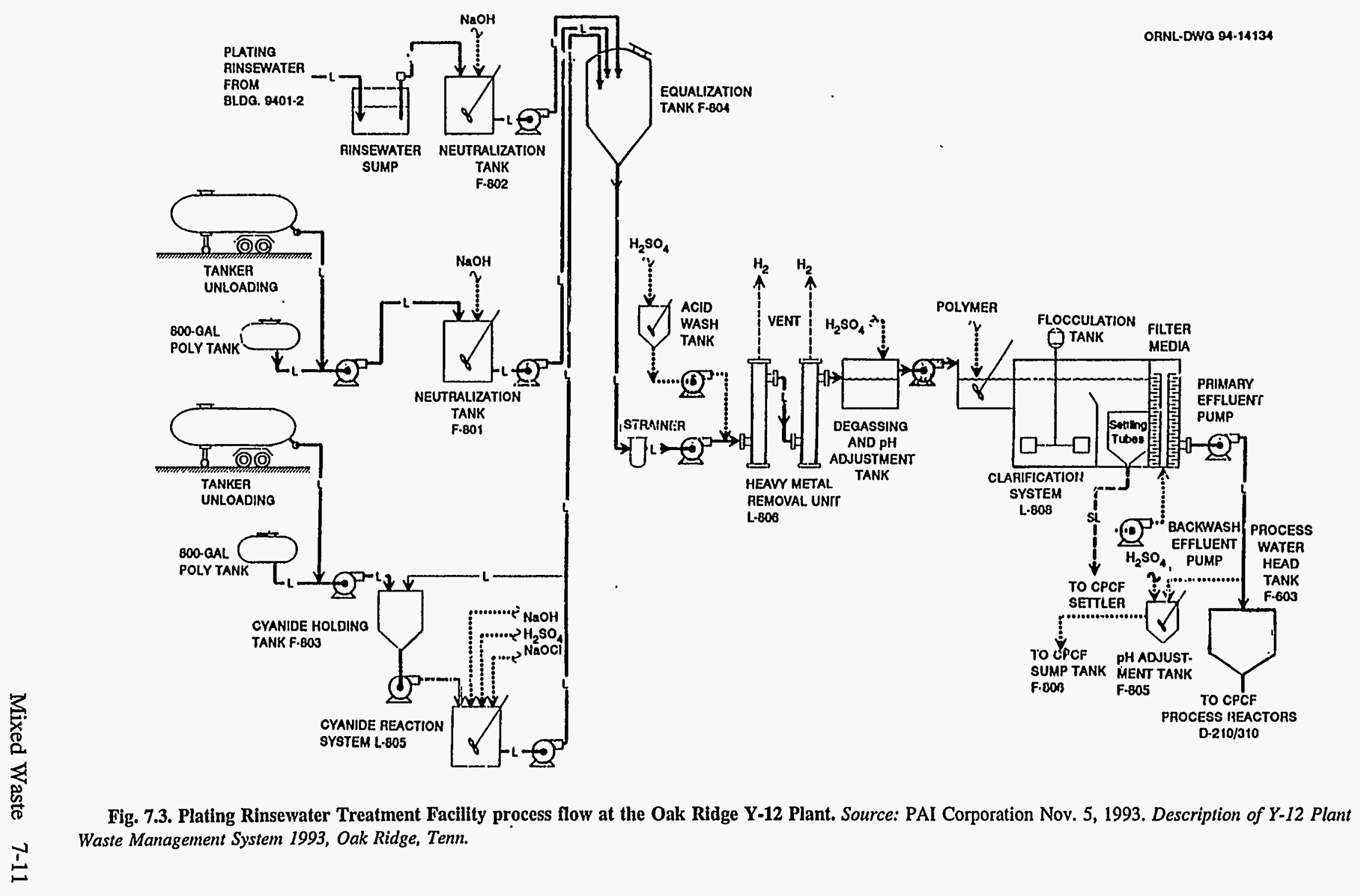


PRTF effluent for final filtration and discharge; treated CPCF effluent goes to East Fork Poplar Creek under National Pollutant Discharge Elimination System (NPDES) monitoring. Monitoring ensures compliance with discharge permit requirements issued by the TDEC and the EPA.

The CPCF/PRTF operates in a batch mode of physical, chemical, and physical/chemical processing steps. The processing includes neutralization, precipitation, flocculation, settling and decanting, liquid-liquid separation, solidliquid separation, carbon adsorption, and cartridge filtering. Approved effluent is discharged to East Fork Poplar Creek, while accumulated mopwater sludges are transferred to the West Tank Farm (WTF) for storage. Other sludges are dewatered, and the solids are placed in 209-L (55-gal) drums for interim storage and final disposal.

\section{Groundwater Treatment Facility (GWTF)}

The GWTF (Fig. 7.4) is located at the far west side of the Y-12 Plant outside the protected security area in the northeast corner of the West End Treatment Facility, Building 9616-7. It is designed to treat water collected from ponds and seeps on the ORR. The water may be contaminated with various volatile organic compounds, nonvolatile organic compounds, and/or PCBs. The PCBs are removed from the groundwater at the Liquid Storage Facility and then transported via tanker truck to the GWTF for removal of organic compounds. Effluent from the GWTF will be released through an NPDES discharge point to the East Fork Poplar Creek.

\section{Waste Coolant Processing Facility (WCPF)}

This facility (Fig. 7.5) is located in an area south of Buildings 9404-16, 9409-20, and 9416-10 and north of Building
$9720-12$, which is separated from the WCPF by West Second Street and a railroad siding. The WCPF is designed to receive, to store, and to treat biodegradable waste machine coolants from machining operations in the Y-12 Plant. The wastes are received at the WCPF in $18,927-\mathrm{L}$ (5000-gal) tankers, 2271-L (600-gal) poly tanks, 3785-L (1000-gal) dumpsters, and 208-L (55-gal) drums.

Wastes received at the WCPF are typically dilute solutions of waste machine coolants and mopwater. The wastes are sampled and then unloaded into one of two $52,996-\mathrm{L}(14,000$-gal) storage tanks. Waste from the storage tanks is transferred to a 28,391-L (7500-gal) feed tank that is used to meter the waste to the $113,562-\mathrm{L}$ (30,000-gal) extended aeration reactor.

Bacterium in the extended aeration reactor are used to bio-oxidize degradable organics to carbon dioxide and water. Oxygen is supplied to the reactor by two centrifugal blowers that also mix the reactor contents. The hydraulic retention time in the reactor is approximately 30 days. The reactor effluent flows into a settling chamber where it is separated into three phases. The bottom solids phase is recirculated back to the reactor. The floating, oily solids phase is skimmed off and transferred to a steam-jacketed ribbon blender/dryer where it is dewatered. The middle liquid effluent phase is transferred to an aerated storage tank and accumulated until a sufficient quantity has been accumulated to fill an $18,927-\mathrm{L}$ (5000-gal) tanker. The effluent in the tanker is sampled and then sent to either the CPCF or the West End Treatment Facility (WETF)/West Tank Farm (WTF) for further treatment.

Nutrient chemicals for the biooxidation process, added to the reactor as needed, consist of a nitrogen and a phosphate source. Solids generated from the ribbon blender/dryer are placed into drums and sent to the K-25 Site for longterm storage/disposal. 


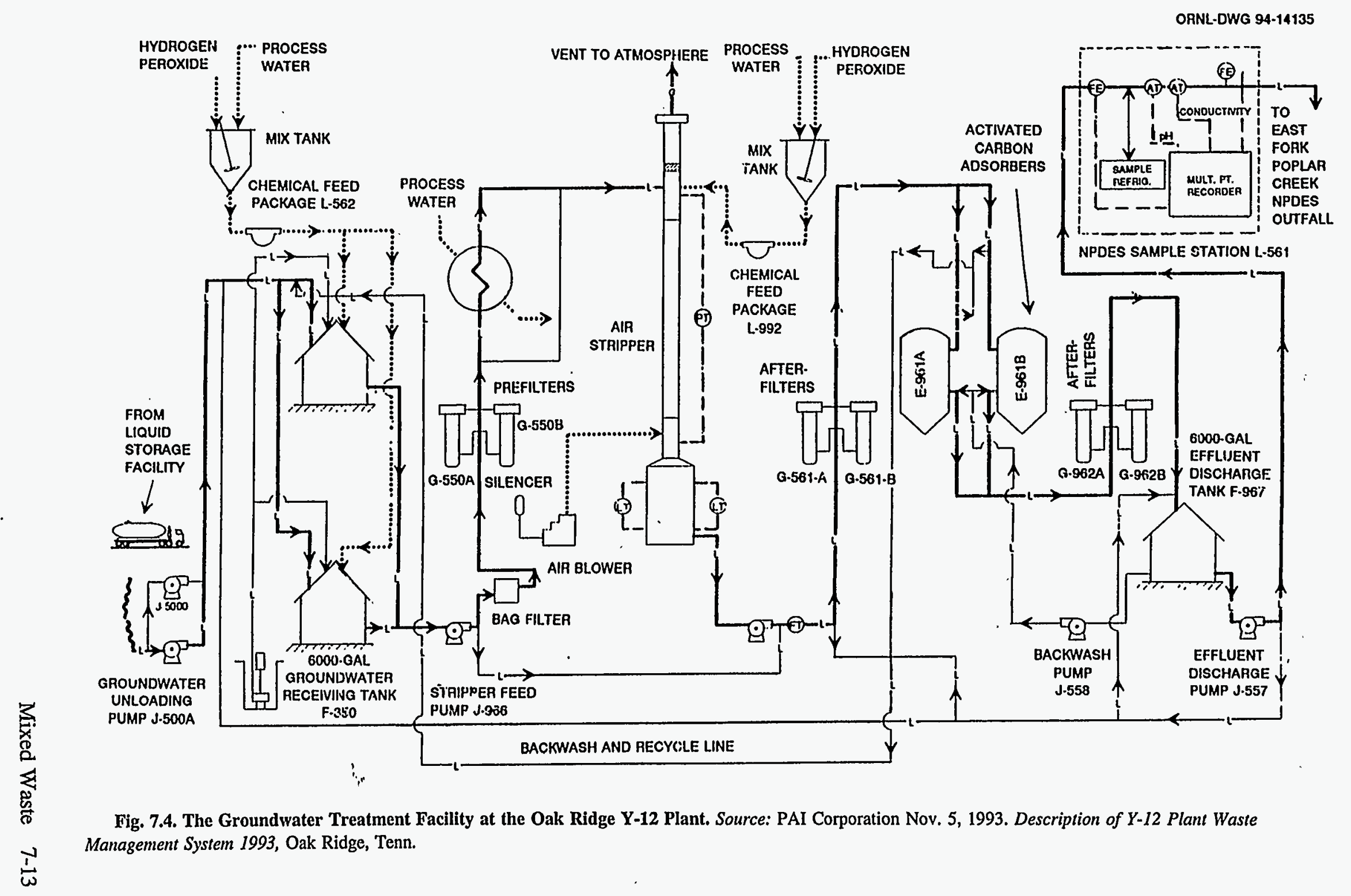




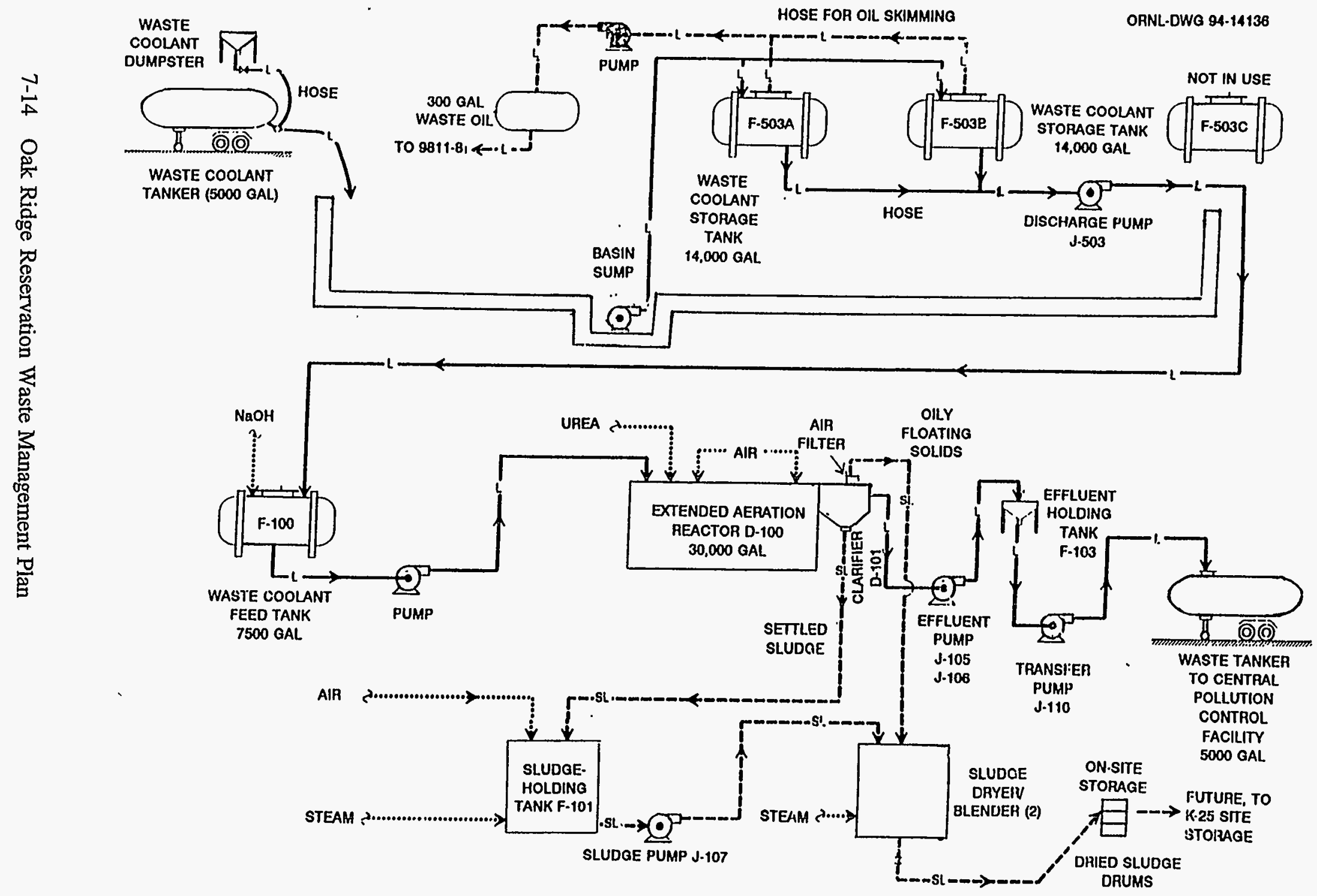

Fig. 7.5. The Waste Coolant Processing Facility at the Oak Ridge Y-12 Plant. Source: PAI Corporation Nov. 5, 1993, Description of Y-12 Plant Waste Management System 1993, Oak Ridge, Tenn. 


\section{West End Treatment Facility}

The WETF (Fig. 7.6), Building 9616-7, is located at the extreme west end of the Y-12 Plant outside the Protected Security Area. The WETF is at the end of an access road from Bear Creek Road. The principal process system groupings of the WETF are the Head End Treatment Systems, the WTF, and the Effluent Polishing Systems.

Head End Treatment Systems. Upon receipt of the waste materials, an independent material composition analysis is performed that includes determination of total uranium and ${ }^{235} \mathrm{U}$ content. This analysis ensures that the waste materials are compatible with the waste-processing operation. For unloading to be approved, the independent analysis must concur with the analyses provided by the waste generator, and the composition of the waste to be treated must be compatible with the WETF/WTF WAC (Y-12 WMD March 1993c). Wastes that do not meet these criteria are processed at another waste management facility (if acceptable for that facility) or returned to the waste generator.

West Tank Farm. The WTF performs biological waste treatment, decanting, and sludge storage. It consists of four systems: biodenitrification, bio-oxidation, sludge decanting and storage, and vacuum unloading.

Effluent Polishing Systems. The Effluent Polishing Systems, operating continuously during a campaign, remove residual heavy metals and organics from the sludge decant such that the liquid will meet the discharge permit requirements and can be released to the East Fork Poplar Creek.

Magnesium Chip Dissolver. To initiate the magnesium chip-dissolving process, three drums of magnesium chips are emptied into the dissolver vessel. The chips are supported on a perforated metal screen several inches above the bottom of the tank, and the mineral oil and water solution in which the chips were stored is drained from the dissolver vessel to the original drums. The mineral oil and water solution is returned to the generator of the magnesium chips. Next, a water and detergent solution is circulated across the chips to remove residual oil. The water detergent solution is drained from the dissolver vessel and sent to the CPCF for treatment. If necessary, the washing process is repeated. After the chips have been cleaned, $568 \mathrm{~L}$ (150 gal) of water are added to the dissolver vessel, and the circulation pump is energized. Steam sparing heats the solution to $71^{\circ} \mathrm{C}\left(160^{\circ} \mathrm{F}\right)$ required for the reaction. After the temperature is achieved, acetic acid $(70 \%$ concentration) is metered into the dissolver vessel over a 6 -h period. The rate of acetic acid addition regulates the reaction rate. Upon completion of the dissolving process, the resulting solution is allowed to cool prior to being pumped to a poly tank or into the biodenitrification system.

\section{Cyanide Treatment Unit (DP)}

The Cyanide Treatment Unit, located in Building 9201-5N, typically treats spent plating solutions and cyanide wastes that have been generated in various Y-12 Plant operations including wastes from plating shops and the Precious Metals Recovery Operations (PMRO). One of the plating shops is located across the hall from the unit; the PMRO and the unit share the same basement room in Building 9201-5N.

The design treatment capacity of the Cyanide Treatment Unit is $738 \mathrm{~L} / \mathrm{d}$ (195 gal). The $\mathrm{pH}$ of the cyanide wastes ranges from 5 to 11 . Typically, the total cyanide concentration of untreated wastes ranges from 10 to $60,000 \mathrm{ppm}$. The wastes are received, stored, and treated in 208-L (55-gal), plastic-lined drums. These containers are compatible with the wastes stored in them. The drums can be stored in four areas adjacent to the treatment area. All drums are tagged with hazardous waste labels. After treatment, if cyanide levels are less than $10 \mathrm{ppm}$, the drums are shipped to the WETF. 


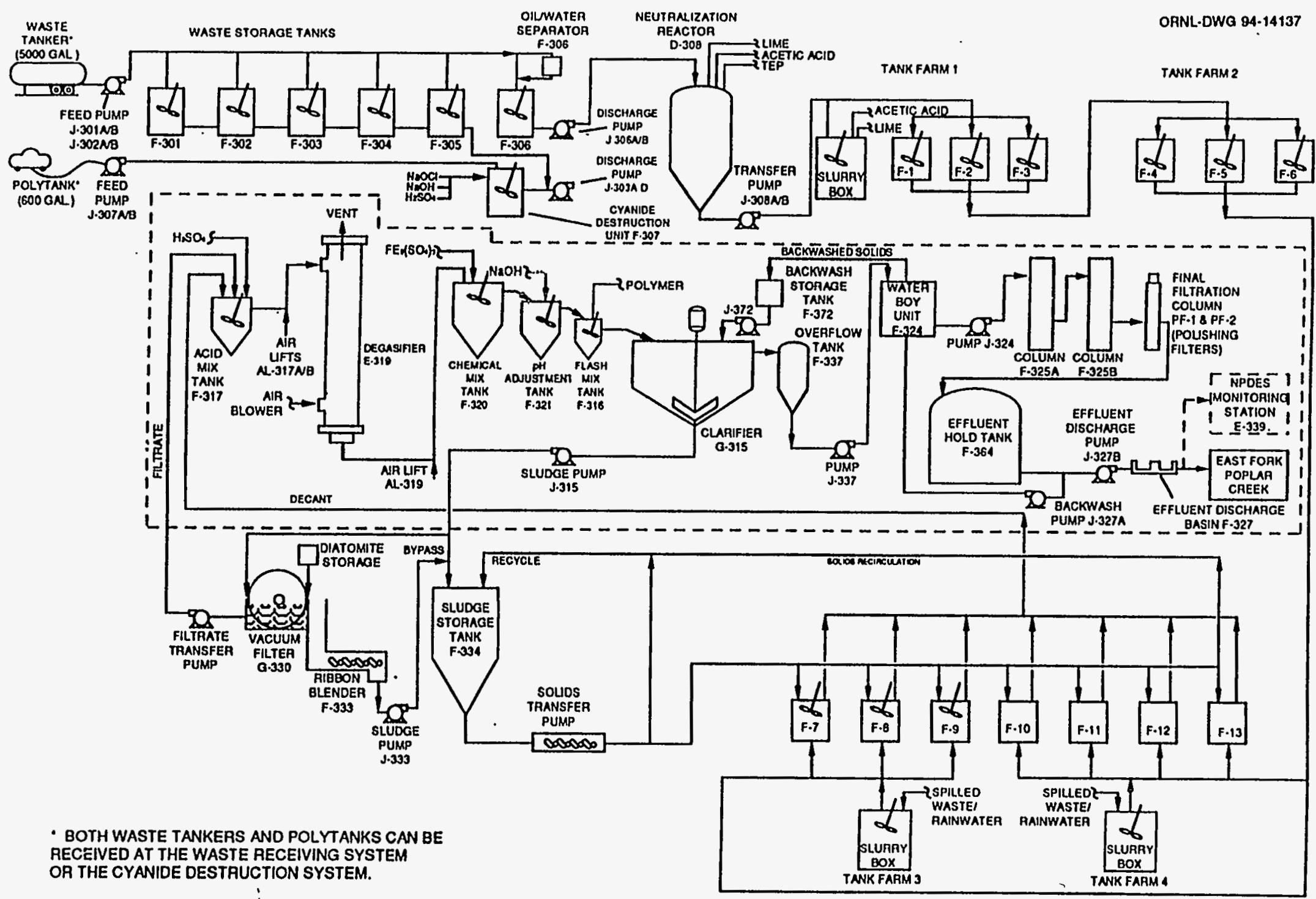

Fig. 7.6. The Y-12 Plant West End Treatment Facility. 


\section{Uranium Treatment Unit (DP)}

The Uranium Treatment Unit is located on the east side of Building 9206, outside and adjacent to the loading dock. The unit consists of 2 1136-L (300-gal) poly tanks located within a diked drum storage area that stores up to 18 208-L (55-gal) drums. The design treatment capacity of the Uranium Treatment Unit is $1893 \mathrm{~L} / \mathrm{d}$ (500 gal), and the design storage capacity of the drum storage area is $3747 \mathrm{~L}$ (990 gal).

The Uranium Treatment Unit treats organic solutions containing enriched uranium. Before these solutions can be transferred from a nuclear-safe container and treated as waste, they must be below the 400-ppm uranium concentration. The treatment unit takes waste organic solutions containing F001- and F002-listed waste with a uranium concentration less than $400 \mathrm{ppm}$, mixes this solution with depleted uranyl nitrate to create a solution in which the ${ }^{235} \mathrm{U}$ concentration is less than $1 \mathrm{ppm}$, and then adjusts the $\mathrm{pH}$ of this solution with the addition of caustic. It has been determined that this unit is no longer required; a closure plan is being prepared and will be submitted to the Tennessee Department of Environment and Conservation.

\section{Building 9818, Biodenitrification Unit} (DP)

In operation since September 1976, this Bioidenitrification Unit will accept nitrate wastes that are reduced to less than $50 \mathrm{ppm}$ nitrates by biological decomposition under anaerobic conditions. The resulting sludge is transported to the WETF.

Figure 7.7 depicts the overall process flow for mixed waste at the Y-12 Plant.
ORNL

ORNL has no facilities specifically designed for the treatment of mixed waste. The contents of tank 7075 were treated at the TSCA Incinerator before RCRA closure of that facility. The contents of 7830a (i.e., mixed waste oils) have also been treated here. Generators currently neutralize many corrosives before discharge to process drains. Plans are to treat organic mixed wastes at the TSCA Incinerator (Oak Ridge K-25 Site) per the RCRA LDR FFCA Treatment Plan. Also, mixed waste treatment is being discussed using other methods for the future.

\section{K-25 Site}

\section{Central Neutralization Facility (CNF)}

The K-1407 CNF (see Fig. 8.9 for flow diagram) consists of two $94,635-\mathrm{L}$ (25,000-gal) treatment tanks and a $227,125-\mathrm{L}(60,000$-gal) sludge thickener at $\mathrm{K}-1407-\mathrm{H}$ and a $124,919-\mathrm{L}(33,000-\mathrm{gal})$ inground reaction tank at $\mathrm{K}-1407-\mathrm{A}$. The unit at $\mathrm{K}-1407-\mathrm{H}$ provides $\mathrm{pH}$ adjustment, chemical precipitation, sludge thickening, and centrifuging for dewatering sludge generated from the treatment process. The $\mathrm{K}-1407-\mathrm{A}$ unit provides $\mathrm{pH}$ adjustment and is discharged to the $\mathrm{K}-1407-\mathrm{H}$ unit for final treatment and discharge. The $\mathrm{K}-1407-\mathrm{A}$ unit is used as a backup to $\mathrm{K}-1407-\mathrm{H}$ for the treatment of nonhazardous wastewaters from the K-1501 Steam Plant. The primary waste streams treated at CNF include the scrubber effluent from the TSCA Incinerator and process wastewaters from the K-1501 Steam Plant. 


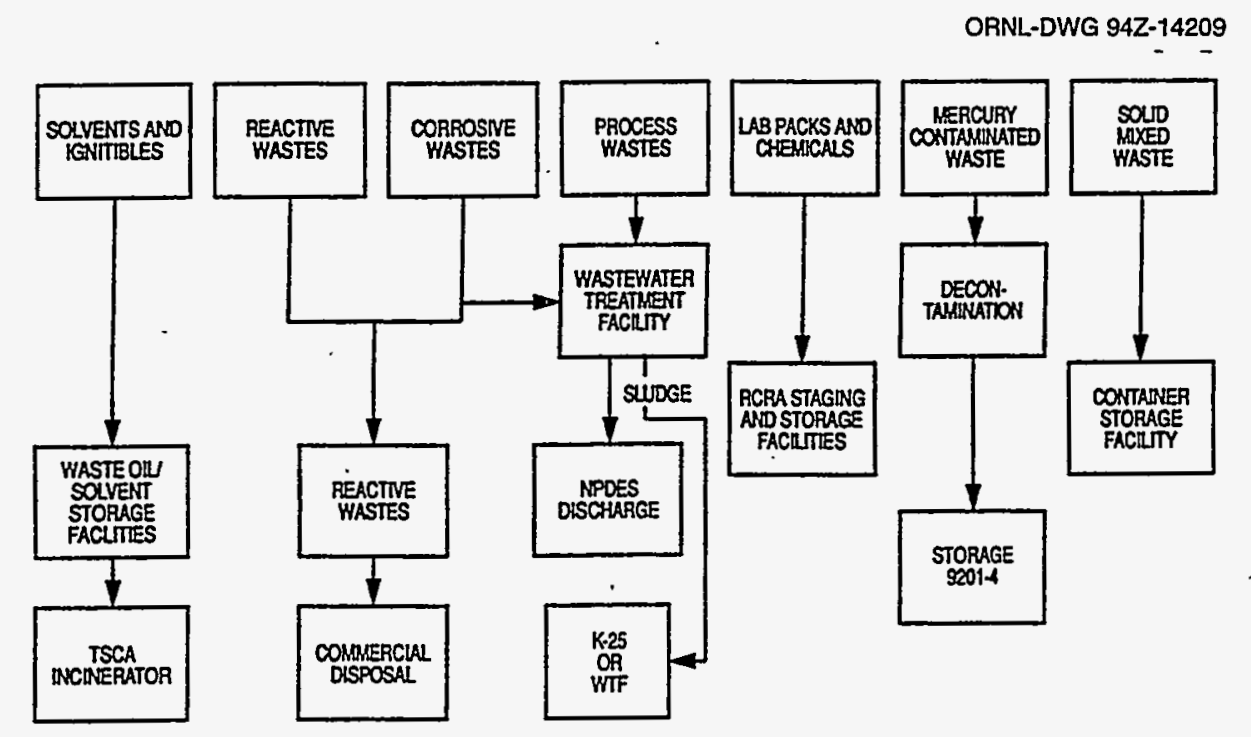

Fig. 7.7. Schematic showing mixed waste process flow at the Oak Ridge Y-12 Plant.

\section{K-1232 Treatment Facility}

The $\mathrm{K}-1232$ treatment facility was used to process significant flows of Y-12 Plant wastewater prior to startup of the WETF and the CPCF. At present, the treatment portion of $\mathrm{K}-1232$ is not in use. Current plans for this facility are to begin the process required for transfer to the Decontamination and Decommissioning Program.

\section{TSCA Incinerator}

Individual components of the incineration system are a rotary kiln, a mixing chamber, a secondary combustion chamber, a water spray quench column, a Venturi scrubber, a packed-column acid gas absorber followed by an ionizing wet scrubber, an induced-draft fan, and an exhaust stack. The waste feed system will handle organic liquids, aqueous liquids, sludges, and solids. Organic liquids can be fed to the rotary kiln or the secondary combustion chamber from several agitated feed tanks. Aqueous wastes are also fed to the rotary kiln. The liquid wastes can be atomized with air or steam. Sludges are pumped from a storage container and are lanced, with optimal steam atomization, into the rotary kiln; solids are fed to the kiln by a ram feeder.

The TSCA Incinerator is currently burning only liquid mixed wastes.

Figures 7.8 and 7.9 show the layout and process flow of the Toxic Substances Control Act Incinerator respectively.

\section{Storage}

\section{Y-12 Plant}

\section{Liquid Mixed Waste}

Waste Oil/Solvent Bulk Storage Facility, Oil Dike (OD)-7, Building 9811-1. The OD-7 is a RCRA-permitted waste oil (bulk) storage facility with diking that contains four 113,562-L (30,000-gal) tanks. Two 37,854-L (10,000-gal) tanks are out of service. A third 37,854-L (10,000-gal) storage tank (fiberglass) is currently in the process of being emptied; it will be discarded and replaced with a smaller, similar tank. 


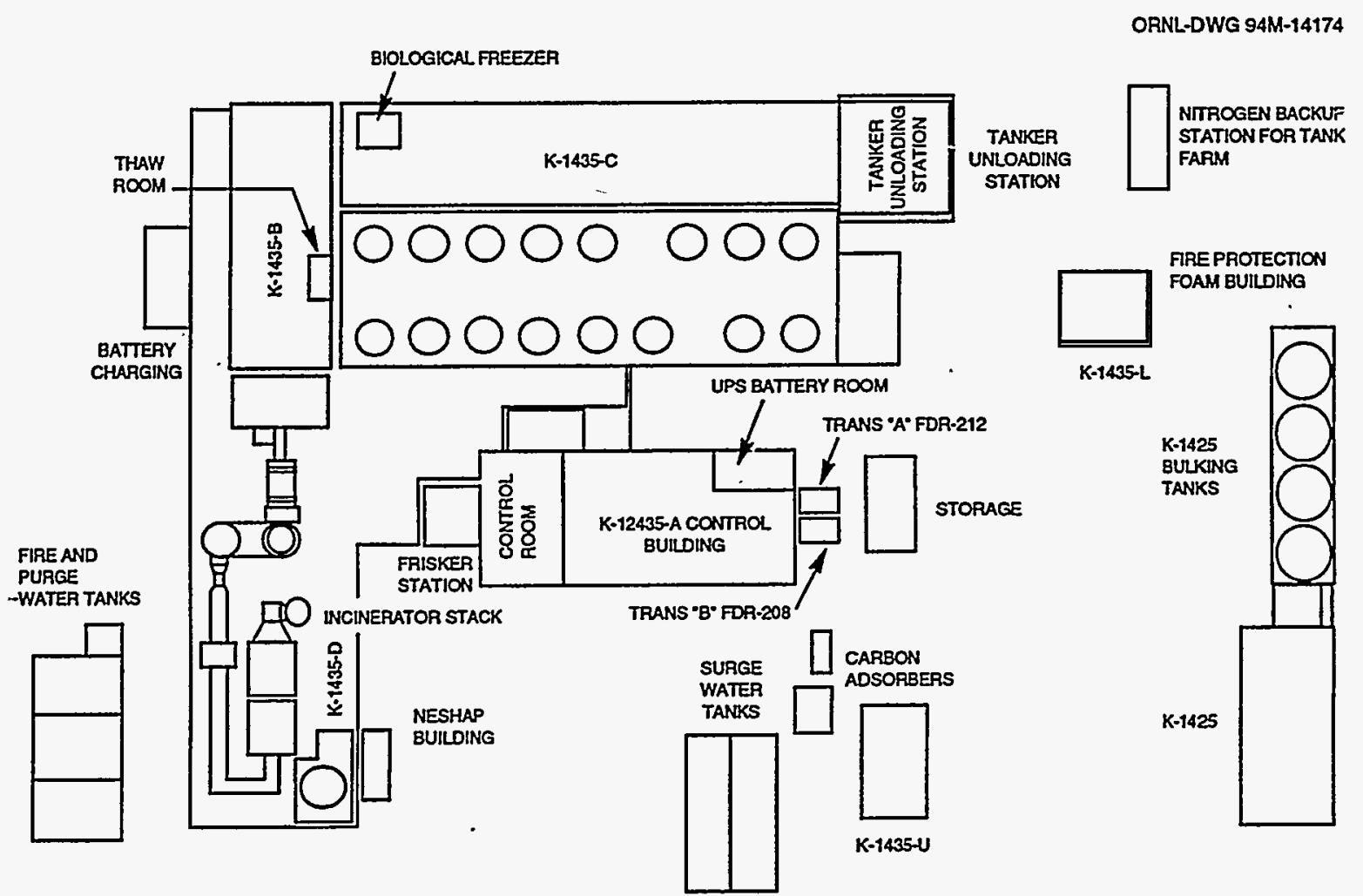

Fig. 7.8. Toxic Substances Control Act Incinerator layout.

ORNL-DWG 94M-14173

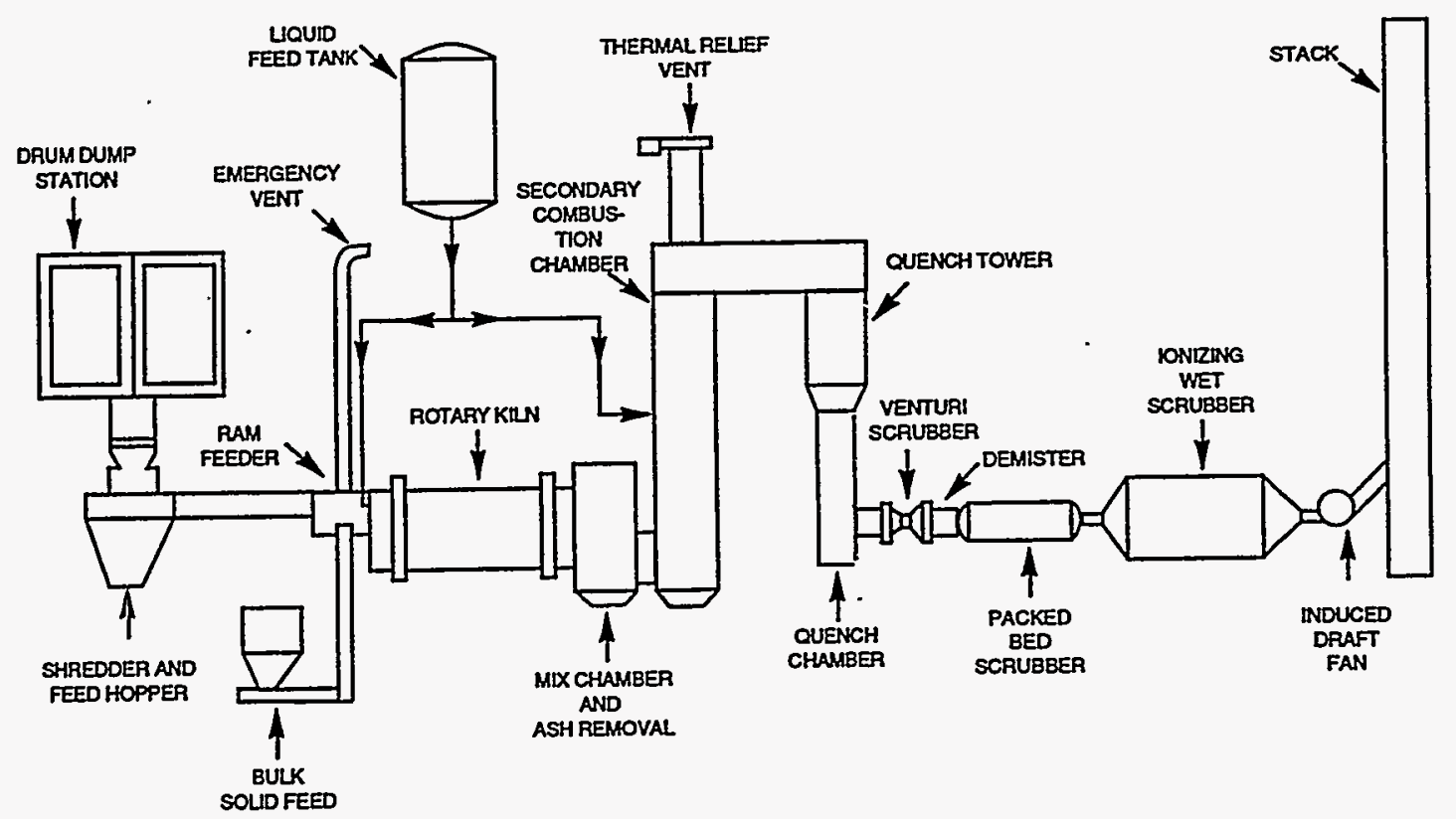

Fig. 7.9. Process flow at the Toxic Substances Control Act Incinerator. 
The facility area, near the corner of $K$ Road and West Second Street, consists of a $15.5 \times 17.7 \mathrm{~m}(51 \times 58 \mathrm{ft})$ concrete dike approximately $1.2 \mathrm{~m}$ (4 ft) high. Positioned in the dike are four $113,562-\mathrm{L}(30,000$-gal) tanks and three 37,854-L (10,000-gal) tanks.

The general functions performed at the facility involve: (1) pumping waste into the tanks, (2) storage of waste in the tanks, and (3) transferring the waste out of the tanks. Current operations consist of setting up portable pumps, compressors, and transfer lines near the eastern edge of the facility and running flexible hose to the desired tank. Either process consists of receiving a fully characterized drum of waste, opening the bung tops, sticking the flexible hose down in the drum, turning on the pump, and sucking the drum dry into the tank. The storage of waste in tanks basically consist of area maintenance and daily RCRA inspections on the tanks.

Transferring the waste out of the tanks generally consists of pumping the waste from the tanks to tanker trucks.

The primary chemical mixed wastes received at this facility are oils and solvents contaminated with uranium and PCBs. These spent solvents are categorized as F001, F002, F003, F004, and F005 wastes, as defined by 40 CFR Pt. 261.31 . Incompatible and/or reactive or ignitable wastes may not be stored at this facility. Waste-receiving guidelines have been published (Y-12 WMD September 1993b). Waste Oil/Solvent Drum. Storage Facility, Oil Dike-8, Building 9811-1. The Waste Oil Storage Facility (OD-8), Building $9811-1$, is an interim status RCRA hazardous waste storage facility. This facility, located at the north side of West Second Street, east of the intersection with $\mathrm{K}$ Road, consists of a $19.8 \times 22.8 \mathrm{~m}$ $(65 \times 75 \mathrm{ft})$ single story, high-bay metal building with a concrete floor and a capacity of approximately 1000 drums. RCRA waste oil/solvent mixtures containing various concentrations of chlorinated and nonchlorinated hydrocarbon solvents, uranium, trace PCBs $(<50 \mathrm{ppm})$, and water for specific chemical constituents are stored at OD-8 in 208- and 114-L (55- and 30-gal) drums and in 1249-L (330-gal) polyethylene tanks awaiting sampling and analytical results. A fire protection upgrade of OD-8 and OD-7 is planned for FY 1997 (line item) to meet the requirements of DOE Order 5480.7. WAC have been published (Y-12 WMD September 1993c).

Operations that occur at OD-8 include storage and handling. Handling includes sampling, repacking, overpacking, pumping, and preparation for shipment. Pumping includes using portable, pneumatic pumps and hoses to transfer liquids from the drums to new drums or tanks. The waste at OD-8 is eventually taken to other on-site bulk storage tanks (i.e., OD-9 or OD-10).

Waste OiL/Solvent Storage Facility, Oil Dike-9, Building 9811-8. The OD-9 storage facility, a RCRA Part B permitted unit, is positioned on and within a concrete pad with a raised dike designed to contain any spills that may occur during the filling, storing, or unloading of waste liquids in the storage tanks at the facility.

Five 151,416-L (40,000-gal) storage tanks are located within the dike area; space is available to add one more tank. Each tank is $4 \mathrm{~m}(13.5 \mathrm{ft})$ in diam and $12 \mathrm{~m}$ (38 ft) high. All are designed to contain liquids with a maximum specific gravity of 1.62 and to operate under atmospheric pressure.

A section of the facility, the tanker transfer bay/drum storage area, is located within a curbed $6.7 \times 22.9 \mathrm{~m}(22 \times 75 \mathrm{ft})$ concrete pad adjacent to the tank containment dike. It is designated to store 160 208-L (55-gal) drums for an additional $33,312-\mathrm{L}$ ( $8800 \mathrm{gal}$ ) of storage capacity. Polyethylene tanks containing free liquids may also be stored in this area. This same concrete pad is also used for tanker loading/unloading and used as a transfer area for moving waste from drums and containers to tanks. Two gas-filled plugs 
(in place at the ends of the two surface drains in the curved concrete pad area) constitute temporary modifications of the facility. They may be removed in an emergency to provide sufficient containment capacity for any tanker spills. These drains are discharged into the tank storage diked area.

Facility pumps are used to transfer the contaminated waste oil/solvents from the drums, polyethylene tanks, or tanker trucks to one of the $151,416-\mathrm{L}(40,000$-gal) tanks. WAC have been published (Y-12 WMD September 1994a).

Waste assigned to this facility may be stored at OD-8 to await laboratory results. Because of the anticipated lack of disposal outlets for uranium-contaminated organic liquids, this facility is projected to be used until 2010. Some wastes at this facility are transferred to the K-25 Site TSCA incinerator facility for treatment.

Flammable Mixed Waste Storage Facility, Oil Dike 10. The Liquid Organic Waste Solvent Storage Facility, OD-10, located west of the WETF, is in the northwest corner of the New Salvage Yard (Fig. 7.10). The OD-10 facility is a RCRA Part B-permitted hazardous waste storage facility. The site, including the salvage yard, is enclosed by a chain-link fence. The OD-10 Storage Facility consists of a concrete pad with a raised dike to contain any spills that may occur during the filling, storing, or unloading of waste liquids in the storage tanks at the facility.

Six storage tanks are located within the diked area: space is available for two additional tanks. Four of the tanks are 24,605-L (6500-gal) carbon steel tanks; two are 11,356-L (3000-gal) stainless steel tanks. The waste liquids are received at the facility in either drums, truck tankers, or polyethylene bulk storage tanks. The liquids are pumped into the tanks for storage.

A container storage area of approximately $185.8 \mathrm{~m}^{2}\left(2000 \mathrm{ft}^{2}\right)$ is provided within the facility. In addition to six storage tanks, the site is permitted an additional 39,970 L (10,560 gal) of drum storage. Steel 76-, 114-, and 208-L (20-, $30-$, and 55-gal) bung top drums and approved polyethylene tanks used to transport the liquid wastes to the OD-10 Storage Facility may also be used for storage. All of the waste types to be managed at this facility must be compatible with the drums in which they are stored and transported. Some of the solvents contain trace quantities of uranium. These solvents are sampled and identified before batching in the storage tanks and are kept separate from other solvents. WAC have been published (Y-12 WMD August 1993). Some of these liquid wastes are transferred to the K-25 Site TSCA incinerator for treatment.

$P C B$ and RCRA Container Storage Area, Building 9720-58. Building 9720-58 is a warehouse storage unit located on the north side of Old Bear Creek Road about one-quarter mile west of the Y-12 Plant. The facility is in close proximity to the OD-9 Waste Facility and south of the WETF. Building 9720-58 is a storage area for PCB-contaminated equipment (e.g., transformers, capacitors, and electrical switch gears). The facility is also an interim status unit for storage of RCRA hazardous waste. Waste is consolidated at this facility until waste analysis and appropriate disposal arrangements can be initiated.

The facility structure consists of a metal roof with temporary plastic sides over a $29.8 \times 11.9 \mathrm{~m}(98 \times 39 \mathrm{ft})$ concrete pad. The concrete pad is coated with a chemically resistant epoxy and surrounded by a $15-\mathrm{cm}(6-\mathrm{in}$.) curb. The pad is gently sloped from the center to the north and south sides for adequate drainage, and shallow floor gutters along the north and south sides of the building direct liquids to blind sumps located outside the southeast and northeast corners of the facility. The pad is accessed by two concrete ramps that roll over the dike area at the east and west ends of the facility; however, the east access is obstructed by a temporary plastic 


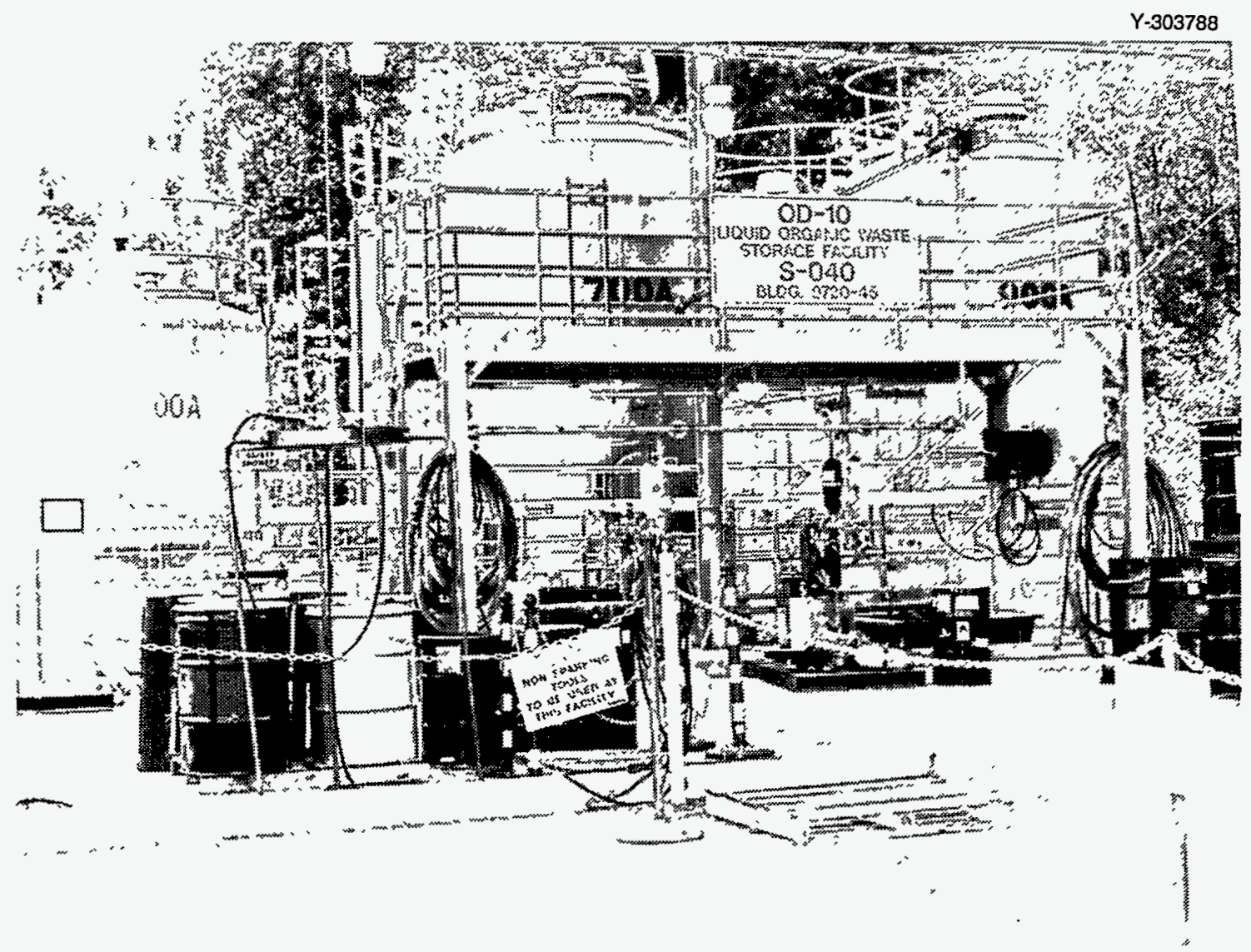

Fig. 7.10. The Flammable Mixed Waste Storage Facility, Oil Dike 10, at the Oak Ridge Y-12 Plant.

wall. The permitted capacity of this facility is as follows:

- RCRA waste materials, 580,278 L (153,310 gal); and

- PCB waste materials, $223,294 \mathrm{~L}(58,988$ gal) calculated as $\mathrm{V}_{\mathrm{PCB}}=4$ (gross containment volume - ramp area volume - total pallet volume).

Waste containers received at Building 9720-58 include U.S. Department of Transportation specification 114- and 208-L (30- and 55-gal) drums, 1249- and 2498-L (330- and 660-gal) portable tanks, $4.6 \mathrm{~m}^{3}\left(6 \mathrm{yd}^{3}\right)$ dumpsters, $2.72 \mathrm{~m}^{3}\left(96 \mathrm{ft}^{3}\right)$ B-25 boxes, and PCB-contaminated equipment. All PCB-contaminated equipment is drained of all liquids, all openings are sealed, and equipment with any continued evidence of leakage is wrapped in plastic. Cumbersome articles and equipment are banded securely to skids.

The WAC for the PCB and RCRA Storage Facility has been published ( $\mathrm{Y}-12$ WMD February 1994) and include:

- all nonignitable and nonreactive RCRA listed wastes codes F, P, and U;

- all characteristic RCRA waste code D except for D001 (i.e., solid waste that exhibits the characteristic of ignitability) and D003 (i.e., solid waste that exhibits the characteristic of reactivity) listed waste;

- uranium contaminated waste; and

- all TSCA waste (i.e., PCB contaminated waste). 
$P C B$ and RCRA Hazardous Drum

Storage Facility, Building 9720-9.

Building $9720-9$ is located on the north side of third Street southeast of the Y-12 Steam Plant. Building $9720-9$ is a $15.2 \times$ $73.2 \mathrm{~m}(50 \times 240 \mathrm{ft})$ single-story metal warehouse with a concrete floor. The building is divided in half by a 2-h-rated fire wall. A door in the center of this wall has a $15-\mathrm{cm}$ (6-in.) ramped approach that can accommodate forklift traffic between the halves. The western half of Building 9720-9 was renovated in 1988 and is used for the storage of PCB and RCRA hazardous waste generated at the $\mathrm{Y}-12$ Plant. The western half of the building has a storage capacity of $738,075 \mathrm{~L}(195,000$ gal) and is a RCRA interim status facility also used to store PCB waste. Incompatible acidic, caustic, and reactive wastes are segregated and stored in separate areas bordered by concrete roll-over dikes. A flammable waste storage room, fitted with a Class I, Div. 3, electrical system, is inside the northwest corner of the building. Renovation of the western half of the building also included covering the concrete floor with a chemical resistant epoxy paint, installing safety shower/eyebaths at the western and southern exits, and upgrading the sprinkler system.

The eastern half of Building 9720-9, separated from the western half by a $2-\mathrm{h}$ rated fire wall, is currently used for the storage of $\mathrm{PCB}$ waste. Renovation of the eastern half of $9720-9$ with a diking upgrade is planned. The eastern half of the building will eventually have a RCRApermitted storage capacity of approximately $751,095 \mathrm{~L}(198,440 \mathrm{gal})$ of RCRA hazardous waste excluding D001, D003, and ignitable $P, K$, and $U$ wastes. Incompatible or reactive wastes will not be stored in the eastern half of the building. The diking upgrade and other upgrades to the Ventilation and Fire Suppression Systems will allow for mixed and PCB waste storage throughout the facility.
Materials stored in Building 9720-9 include PCB and listed and characteristically hazardous waste generated from Y-12 Plant production and maintenance operations. Some of the wastes stored are uranium contaminated and, therefore, are designated for long-term storage because of lack of appropriate disposal technology. Waste is generally stored in steel 208-L (55-gal) drums at Building 9720-9; however, dumpsters and portable tanks are also used to store waste at this facility. WAC have been published (Y-12 WMD December 1990).

Liquid Storage Facility (LSF). The LSF is a water collection and storage system, which was built as part of the closure activities in the Bear Creek Burial Grounds. It is located in the Bear Creek Valley approximately $3.2 \mathrm{~km}$ ( 2 miles) west of the WTF. Vehicular access to it is provided through gate 4 by a $305-\mathrm{m}$ (1000ft) gravel Official Use Only roadway running north-south from Bear Creek Road.

The LSF is designed for the collection and storage of contaminated groundwater and other wastewaters received primarily from the following sources: (1) the Leachate Collection System for tributary 8 , (2) the Seep Collection Lift Station for tributary 7, (3) the Solid Storage Facility adjacent to LSF, (4) tankers and poly tanks, and (5) accumulated rainwater in the LSF diked area. (The Solid Storage Facility is currently within the ER Program.) Feed streams may contain low levels of depleted uranium, organic compounds, metals, mixed waste, or PCBs.

Major processing and storage equipment is located in a secondary containment, reinforced-concrete, diked area that has a capacity of approximately $416,395 \mathrm{~L}(110,000 \mathrm{gal})$ [or a spill of the largest tank plus $17.8 \mathrm{~cm}$ (7 in.) of rainwater]. This equipment includes a leachate holding tank, a gravity separator, an oil storage tank, a filtering unit, a monitoring station, a tanker and poly tank transfer station, and two bulk storage tanks. A heat tracing system is used to prevent 
pipes and tanks from freezing during

periods of cold weather.

The LSF can be operated automatically; however, it is normally operated in the manual mode, on a batch basis, approximately two times per week from the Seep Collection Lift Station and daily from the LCS, or as required to accommodate run-off from rainfall or leachate from the Solid Storage Facility or BCBG. Wastewater feed streams are pumped through a gravity separator, filtered, and run through a monitoring station prior to storing.

A RCRA Satellite Accumulation Area (SA-284) and a combined RCRA 90-d Accumulation Area/PCB Storage Area (AA-56/TS-09) are located in the tent/shed south of the LSF dike. (Oil storage tank F-540 is also a 1-year PCB storage Area, TS-24.) This tent/shed also contains an emergency supplies cabinet and is used to store the 1- and 10- $\mu$ cartridge filters used in the treatment operation at LSF.

However, this is not used primarily as a storage area, and good housekeeping practices are exercised to ensure that the tent/shed is kept in a neat and orderly condition.

An office trailer, equipped with a telephone, is maintained at the LSF and houses checklists and records, such as the LSF Narrative Log, visitor's log book, operating procedures, RCRA/PCB checklists, etc.

Containerized Waste Storage Area (CWSA). See Sect. 5.

Building 9212, Tank Farm (DP). The 9212 Tank Farm will provide storage for Building 9212 acidic and caustic wastes in tanks F-31 and F-33, interim storage for Building 9818 processing in tank F-32, and Building 9818 waste storage in tank F-33. All four tanks are 37,854-L (10,000-gal) stainless steel storage tanks. The 9212 Tank Farm is currently not in service.

Building 9206, Container Storage Area (DP). Building 9206 is one of two buildings at the Y-12 Plant that process enriched uranium-bearing materials, including organic solutions, for recovery of uranium. During past recovery processes, solid wastes (such as gloves, shoe scuffs, and lab coats) that are contaminated with enriched uranium were generated. These wastes were burned, and the resulting ash is stored for future recovery of the uranium contained in the ash. The ash is classified as a mixed waste owing to the presence of F-listed solvents in the original solid waste.

The ash is stored in galvanized tin cans. The cans are stored on stainless steel racks within Building 9206. Criticality spacing requirements dictate storage spacing. The areas for ash storage have a design storage capacity of approximately $12,532 \mathrm{~L}$ (3311 gal).

The ash does not contain free liquids and is analyzed for enriched uranium $\left({ }^{235} \mathrm{U}\right)$. The tin containers are taped to prevent opening, and each can is labeled with a recycle batch card (for uranium accountability) and a hazardous waste label. The cans are then placed, single stacked, on stainless steel racks or shelves. A retaining ring is welded on each storage location to prevent the can from falling over. Movement of all cans to and from the storage racks is done by hand.

Uranium-bearing solutions generated during the uranium recovery process and during laboratory analysis are also stored in this area. The solutions are stored in polyethylene bottles. The bottles are labeled with a recycle batch card, for uranium accountability, and a hazardous waste label (if hazardous). Bottles are placed in steel racks with adequate spacing to prevent criticality. Movement of all bottles to and from storage racks is done by hand. The wastes are characterized as mixed waste because of the presence of F-listed solvents and the characteristics of toxicity and corrosivity. Storage space for approximately $2513 \mathrm{~L}$ (644 gal) of solution is provided.

Building 9212, Container Storage Area (DP). Building 9212, located on the north side of the exclusion area and south of Bear Creek Road, is the other building at- 
the Y-12 Plant where materials for recovery of enriched uranium are processed. Process operations within the building generate solid waste contaminated with uranium. Like Building 9206, the solid waste was burned, and the resulting ash has been stored on stainless steel racks within Building 9212. The capacity for ash storage in the Building 9212 Container Storage Area is approximately $8717 \mathrm{I}$ (2303 gal). The ash does not contain free liquids and is analyzed for enriched uranium $\left({ }^{235} \mathrm{U}\right)$.

The containers are made of galvanized tin. The containers are taped to prevent opening and are labeled with a recycle batch card for uranium accountability and a hazardous waste label (if hazardous). The cans are then placed on stainless steel racks or shelves. A retaining ring is welded on each storage location to prevent the can from falling over. Movement of all cans to and from the storage racks is done by hand.

Uranium-bearing solutions generated during the uranium recovery process and during laboratory analysis are also stored in this area. The solutions are stored in polyethylene bottles. The bottles are labeled with a recycle batch card, for uranium accountability, and a hazardous waste label. Bottles are placed in steel racks with adequate spacing to prevent criticality. Movement of all bottles to and from storage racks is done by hand. The wastes are characterized as mixed waste because of the presence of F-listed solvents and the characteristics of toxicity and corrosivity. Storage space for approximately 5719 L (1511 gal) of solution is provided.

\section{Solid Mixed Waste}

In addition to storage of solid mixed waste at the West Tank Farm, the PCB/RCRA container storage area, the PCB/RCRA hazardous waste drum storage facility, and the containerized waste storage area (all of which have been described), it is also stored at six other facilities.

Classified Waste Storage Facility (CWSF). The CWSF is located between " $N$ " and "M" Streets, south of Second Street, and southwest of Building 9401-5. The CWSF includes areas for volume reduction of sanitary combustible trash, storage of classified wastes that may or may not be contaminated with uranium, storage of PCB-contaminated materials that may also be contaminated with uranium, and a RCRA interim status area that is not yet operational. Only solid materials are accepted. The facility meets Y-12 Plant security requirements for classified waste management and DOE Order 5820.2A guidelines for the management of low-level and mixed waste. The facility, located in Building 9720-25, began operation in FY 1992. WAC for this facility have been published (Y-12 WMD April 1994).

Building 9720-12, Classified Container Storage Area (DP). Building $9720-12$ is a storage facility for hazardous and nonhazardous classified waste and a longterm storage facility for uraniumcontaminated solid combustibles generated from process operations. Waste is stored in 208-L (55-gal) drums and ash cans (as in the 9206 CSA) at this building until waste analysis and appropriate recycle techniques can be arranged. Wastes stored at this facility are contaminated with enriched uranium and characteristic and listed hazardous wastes.

Building $9720-12$ is approximately $91.4 \times 12.2 \mathrm{~m}(300 \times 40 \mathrm{ft})$. It is equipped at the west end with a vehicle access sliding door. The RCRA Container Storage Area is located in the west end corner of the building. The drummed solid waste is stored on a polyvinyl chloride (PVC) liner. Total design capacity of the Building 972012 Container Storage Area is $123,012 \mathrm{~L}$ (32,500 gal). All RCRA hazardous waste material stored in Building 9720-12 is containerized. The wastes are normally stored in 208-L (55-gal) drums, although an overpack may be used. Some storage is 
also provided for cans of hazardous and mixed ash. The wastes can be described as combustible solid waste contaminated with enriched uranium, Toxicity Characteristic Leaching Procedure metals, and F-listed material. The waste contains no free liquids and is analyzed for enriched uranium $\left({ }^{235} \mathrm{U}\right)$.

Building 9404-7. Building 9404-7, located on the north side of Third Street and south of Building 9204-1, consists of a $7 \times 29.8 \mathrm{~m}(23 \times 98 \mathrm{ft})$ single-story brick building with concrete floor and composite shingle and wood roof. Building 9404-7 was formerly used as a pumphouse and has no electric, water, or steam utility service. The west end of the facility is accessed through a double personnel door on the west end of the building, which is used to store drums of PCB-contaminated waste solids. The facility provides for spill containment and has a capacity for 496 drums. No PCB liquids are stored in this facility. PCB wastes are generated primarily from electrical maintenance activities. PCBs are regulated by TSCA. Building 9404-7 is not used for storing RCRA hazardous waste. Storage containers must comply with the specifications of 40 CFR Pt. 761 and 49 CFR Pts. 178.8, 178.82 , and 178.115. The building has no sprinkler system or fire alarm; however, a portable dry-type fire extinguisher is mounted on the south wall.

Some PCB-contaminated waste materials accepted for disposal are stored at Building 9404-7. Operations there include delivery, storage, repacking, overpacking, and preparation for shipment. After waste has been accepted for disposal, truck drivers are dispatched to pick up and deliver the waste to the designated storage facility. Waste is delivered to Building 9404-7 on a large flatbed truck and unloaded in the graveled parking area on the west end with a fork truck, which is then used to put the waste in a designated row. WAC have been published ( $\mathrm{Y}-12$ WMD September 1994).
Waste delivered to Building 9404-7 remains in storage until it is shipped to another storage facility. Some of the waste accepted is also considered uranium contaminated and, therefore, is stored indefinitely (until suitable disposal alternatives are found).

Containers that are observed to be deteriorated at Building 9404-7 are repacked or overpacked. Solids are repacked manually by transferring the material from the deteriorated drum to the new drum by hand or with a shovel. When drums are overpacked, the entire deteriorated drum is placed inside a larger drum.

9201-4 Southeast Switchgear Room. This unit is located in the former southeast switchgear room on the ground floor of Building 9201-4 (Alpha Four). This area is located within the exclusion area of the $Y$ 12 Plant and is used to store mercurycontaminated solids such as soil and insulation in containers. The solids may also be contaminated with uranium. The total capacity for storage is approximately $64,958-\mathrm{L}(17,160 \mathrm{gal})$.

\section{ORNL}

Building 7654-Long-Term Hazardous Waste Storage Facility. Building 7654 is used for storage of mixed LLWs, the majority of which are bulk scintillation fluids and scintillation vials. The majority of mixed wastes that are transported to Building 7654 are contained in 208-L (55-gal) drums. Containers smaller than $114 \mathrm{~L}$ (30 gal) are either combined with compatible waste or lab-packed. The maximum inventory of drums in storage at any time is 300 ; total capacity is $62,459 \mathrm{~L}$ (16,500 gal). Double-stacking of drums is employed to maintain adequate aisle space. Pallets are placed between the double layers of drums. 
Building 7507W-Mixed Waste Storage $\mathrm{Pad}$. Wastes stored at this facility are similar to those stored in Building 7654; they consist of scintillation counting vials containing organic and inorganic mixtures contaminated with low levels of radioactivity. Toluene and xylene are regular constituents of the mixtures. Other wastes stored include organic wastes, carcinogenic wastes, mercury-contaminated solid wastes, waste oils, waste solvents, and other process wastes. The total capacity of the pad is $83,279 \mathrm{~L}$ $(22,000$ gal), or $400208-\mathrm{L}$ (55-gal) drums. The concrete pad has a metal cover.

Building 7823-mixed waste storage. Wastes currently stored in this facility include mixed waste oils, solvents, and other process wastes. This is a single-level, semiunderground building with a concrete floor, steel supports, wire fabric ceiling, and metal roof and walls. The facility will hold approximately 1100 208-L (55-gal) drums.

Tank 7830a-bulk mixed waste oils. Tank 7830a, located near the New Hydrofracture Facility inside Building $7830 \mathrm{a}$, provides storage for mixed waste oils contaminated with spent solvents, metals and radiological constituents. The tank has a nominal capacity of $18,927 \mathrm{~L}$ (5000 gal).

\section{K-25 Site}

$K-25$ Building. Building $\mathrm{K}-25$ is a four-story steel frame structure covered on the exterior with corrugated cementasbestos (transite) siding and has a built-up roof system. The U-shaped facility is $1516 \mathrm{~m}$ (4975 ft) long and encloses approximately $413,500 \mathrm{~m}^{2}\left(4,451,000 \mathrm{ft}^{2}\right)$. The basement area is built on grade and is divided into a series of vaults. Each vault has a grade-level entrance at one end. There are a total of 113 vaults including 27 active transformer vaults that supply power to the building and 36 vaults assigned to ESWMO-K-25 for waste storage. Those vaults containing mixed waste are RCRApermitted units with curbing for secondary containment and concrete- reinforced floors. Because storage requirements for mixed wastes are the same as those for strictly hazardous wastes, several of the vaults (and other storage facilities on-site) can be used for either mixed waste or hazardous waste. To avoid cross contamination of nonradioactive wastes, a specific storage facility will not be used to store both types of waste simultaneously. Facilities are typically not dedicated to solid or liquid waste storage. Some storage units are separated into three distinct sections so that incompatible wastes can be segregated, as required by federal regulations under RCRA. Laboratory waste acids, for example, are incompatible with waste organic and some waste bases because of the volatile nature of combined mixtures. No incompatible wastes are stored in the same diked area.

$K-27$ Building. Building K-27 was originally constructed as a gaseous diffusion process building to support the $\mathrm{K}-25$ building. Building $\mathrm{K}-27$ is a fourstory steel frame structure covered on the exterior with corrugated cement-asbestos (transite) siding and has a built-up roof system. The basement area, built on grade, is divided into a series of vaults. The $\mathrm{K}-402-1$ process vault and vault $31 \mathrm{X}$, currently empty, will be used to store mixed waste.

K-711 Hazardous Waste Storage Facility (WSU K-711). The K-711 WSU is located southwest of the main K-25 Site. This unit consists of a building that has been equipped with curbing to provide secondary containment for the unit. The secondary containment system for this unit is approximately $48 \times 10.7 \mathrm{~m}(159 \times$ $35 \mathrm{ft}$ ). This unit will store a maximum of $454,136 \mathrm{~L}$ (119,970 gal) of hazardous waste. The building is equipped with a metal roof and two $2.4 \times 3 \mathrm{~m}(8 \times 10 \mathrm{ft})$ access doors. This facility is used to store waste consisting of flammable organics and PCBs. 
K-1025-C Hazardous Waste Storage Building (WSU K-1025-C). The K-1025-C WSU is located at the northern part of the K-25 Site. This unit consists of slabs enclosed by concrete curbing and walls and is covered by a corrugated metal roof. This storage unit is approximately $12 \times 6 \mathrm{~m} \mathrm{(40}$ $\times 20 \mathrm{ft}$ ). This unit will store $52,844 \mathrm{~L}$ $(13,960 \mathrm{gal})$ hazardous waste. This unit is subdivided by concrete curbs into six separate storage areas. The floor of this unit consists of reinforced concrete.

Waste chemicals generated in small volumes from laboratories, development operations, or process operations are stored in the $\mathrm{K}-1025-\mathrm{C}$ storage facility.

K-1036-A Hazardous Waste Storage Facility (WSU K-1036-A). The K-1036-A WSU is an open shed located in the northcentral part of the K-25 Site. This unit consists of two concrete slabs enclosed by . concrete curbing and is covered by a corrugated metal roof. The unit is able to store $331,791 \mathrm{~L}$ (87,650 gal) of hazardous wastes. The larger of the two storage areas measures approximately $31 \times 9.8 \mathrm{~m}(103 \times$ $32 \mathrm{ft}$ ). The floor consists of a concrete slab with expansion joints and some superficial settlement cracks. All joints and cracks have been sealed with epoxy grout and, in some cases, silicone sealant. The larger area is completely surrounded by a concrete curb at least $66 \mathrm{~cm}$ (26 in.) high. This larger area will store $290,757 \mathrm{~L}$ $(76,810 \mathrm{gal})$ of hazardous waste. The smaller area is approximately $6.7 \times 6.4 \mathrm{~m}$ $(22 \times 21 \mathrm{ft})$ and consists of an elevated concrete slab with a concrete curb at least $22.9 \mathrm{~cm}$ (9 in.) high. The smaller area will store a maximum of $41,634 \mathrm{~L}(10,840 \mathrm{gal})$ of hazardous waste.

K-1202 Hazardous Waste Storage Tank (WSU K-1202). K-1202 consists of two $56,781-\mathrm{L}(15,000$-gal) storage tanks that provide storage for aqueous nonflammable, non-PCB wastes. Containers of waste or tankers are brought to the tanks, and the contents are transferred via a portable explosion-proof pump. These wastes will be stored until treatment at the $\mathrm{K}-1435$
TSCA Incinerator is possible. The nominal capacity of this unit is 113,562 L (30,000 gal), and the working capacity is 105,992 L (28,000 gal).

$K-1232$ (WSU K-1232). The K-1232

WSU is located within the K-1232 building in the southwestern part of the K-25 Site.

The K-1232 building is approximately $43 \times$ $17.7 \mathrm{~m}(141 \times 58 \mathrm{ft})$ with metal roofing and two roll-up doors. $\mathrm{K}-1232 \mathrm{WSU}$ is protected from precipitation because of its location inside the $\mathrm{K}-1232$ building. The floor of the $\mathrm{K}-1232$ building consists of 15.2-cm (6-in.) reinforced concrete. The entire floor of the $\mathrm{K}-1232$ building is enclosed with a concrete curb that is 5.7 $\mathrm{cm}$ high. K-1232 WSU is located in the center of the building and is approximately $43 \times 6 \mathrm{~m}(141 \times 20 \mathrm{ft})$. This unit can store a maximum of $55,365 \mathrm{~L}(14,626 \mathrm{gal})$ of hazardous waste.

$K-1302$ Gas Cylinder Storage Facility (WSU $K$-1302). The $\mathrm{K}-1302$ WSU is a room approximately $13 \times 5.5 \mathrm{~m} \mathrm{(43 \times 18}$ $\mathrm{ft})$ located in the $\mathrm{K}-1302$ building in the northeastern part of the K-25 Site. The floor and the front and side walls of this unit are constructed of reinforced concrete, the roof is a corrugated asbestos/concrete material, and the rear wall is corrugated metal. This unit will store $30,283 \mathrm{~L}(8000$ gal) of compressed gas in cylinders. This unit will be used to store only cylinders containing compressed gases. Hazardous waste solids or wastes containing free liquids will not be stored in this unit. It is possible that some of the compressed gases that will be stored in this unit may exist in a liquid state when compressed. It is highly unlikely that any of the gases stored will exist as a liquid upon exit from their containers, however. In the event that cylinders containing gases compressed into a liquid state are accepted for storage at these units, portable secondary containment systems will provide secondary containment in the event that a liquid may leak from such a cylinder. The construction material for the secondary containment system will be selected based upon its 
compatibility with the material to be contained.

K-1420-A (WSU K-1420-A). K-1420-A

WSU consists of one $113,562-\mathrm{L}(30,000$ -

gal) horizontal, aboveground tank that

provides storage for flammable liquid organic wastes that are intended to be treated at the K-1435 TSCA Incinerator.

This tank is located in the northeastern part of the K-25 Site and east of the K-25 Building. The K-1420-A WSU is used for bulk storage of liquid hazardous wastes. Wastes stored in this tank may be transferred to the K-1425 or the K-1435 tank management units for subsequent treatment in the $\mathrm{K}-1435 \mathrm{TSCA}$ Incinerator.

$K-31$ (173 units) and $K-33$ (569 units) Waste Pile Units (WPUs). The K-31 WPUs encompass approximately $50,742 \mathrm{~m}^{2}$ $\left(545,420 \mathrm{ft}^{2}\right)$ of floor space on the ground and the cell floors, and the K-33 WPUs encompass approximately $125,266 \mathrm{~m}^{2}$ $\left(1,346,943 \mathrm{ft}^{2}\right)$ of floor space on the ground floor and the cell floor. These buildings have floors of at least 6-in. reinforced concrete, are enclosed with concrete walls, and are roofed. Because these buildings were process buildings, they still contain numerous pieces of very large process equipment. These buildings were assessed, and areas within the buildings that are not being used to store existing equipment or that will not impede the decommissioning activities inside the buildings have been designated as WPUs.

The $\mathrm{K}-31$ and $\mathrm{K}-33$ WPUs are used to store only the solidified sludge that has been generated as a result of the closure of the $\mathrm{K}-1407-\mathrm{B}$ and $-\mathrm{C}$ ponds.

TSCA Incinerator Division Storage Facilities. Table 7.3 is a list of TSCA Incinerator Division storage facilities used to store containers or bulk HW and MW. A description of these facilities follows the table.

K-1425 Waste Oil/Hazardous Waste/PCB Storage. The K-1425 facility, managed by the TSCA Operations Division, is a TSCA container storage building with approximately $186 \mathrm{~m}^{2}$ $\left(2000 \mathrm{ft}^{2}\right)$ of storage area, a container staging and pour-up area, and four 85,172-L (22,500-gal) storage tanks. Containerized liquid wastes are transferred to the large storage tanks by a drum unloader system. Typical materials stored at the facility include oils, solvents, water, PCBs ( $<50 \mathrm{ppm}$ ), and hazardous and/or mixed waste organics. Approximately 408 drums of waste are contained in the storage section of the building; 336,901 L $(89,000 \mathrm{gal})$ of waste solvents and chemicals, in the tanks. These materials are generated in the various operational areas, buildings, and support service areas throughout the K-25 Site and at Portsmouth. The wastes stored in the facility will ultimately be treated in the Incinerator. Under RCRA, materials brought to the facility have previously been identified, labeled, inventoried, and logged into the facility, and the storage tank/storage area is recorded on the "Facility Operating Log."

K-1435 Container and Tank Storage. $\mathrm{K}-1435$, managed by the TSCA Operations Division, is a TSCA storage unit and also has a RCRA permit. The unit is used to store wastes that are awaiting incineration. The unit consists of a container storage area and a tank storage area. The container storage area consists of two separate areas-K-1435-B and K-1435-C. K-1435-B is for the storage of PCB-contaminated waste. This area is a semienclosed building with a curb that runs along the perimeter of the storage area to contain spills or leaks. $\mathrm{K}-1435-\mathrm{C}$ is for the storage of non-PCBcontaminated waste. The area has a canopy roof and a curb that runs along the perimeter of the storage area to contain leaks or spills. The combined nominal capacity of the container storage area is 850 drums, and the combined working capacity is 810 drums.

The K-1435 tank storage area consists of twelve $18,927-\mathrm{L}(5,000$-gal), three $37,854-\mathrm{L}(10,000$-gal), and two 3406-L (900-gal) tanks. All of the tanks are above ground and located in a diked area. The 
Table 7.3. Toxic Substances Control Act Incinerator Operations Division storage units

\begin{tabular}{|c|c|c|c|c|c|c|}
\hline \multirow[b]{2}{*}{ Unit } & \multirow[b]{2}{*}{ Type } & \multirow{2}{*}{$\begin{array}{l}\text { Permit } \\
\text { status }\end{array}$} & \multicolumn{2}{|c|}{ Capacity } & \multicolumn{2}{|c|}{ Current inventory } \\
\hline & & & $\begin{array}{c}\text { Containers } \mathrm{m}^{3} \\
\left(\mathrm{ft}^{3}\right)\end{array}$ & $\begin{array}{c}\text { Bulk } \\
\text { L (gal) }\end{array}$ & $\begin{array}{c}\text { Containers } \\
\mathrm{m}^{3}\left(\mathrm{ft}^{3}\right)\end{array}$ & $\begin{array}{c}\text { Bulk } \\
\text { L (gal) }\end{array}$ \\
\hline $\mathrm{K}-1425$ & TSCA & Part $\mathrm{B}^{a}$ & $84.9(3,000)$ & $342,580(90,500)$ & $48.1(1700)$ & $124,585(32,912)$ \\
\hline$K-1435$ & TSCAMW & Part $B^{a}$ & $168.6(5,956)$ & $340,687(90,000)$ & $56.6(2000)$ & $116,091(30,668)$ \\
\hline Totals & & & & & $104.7(3700)$ & $240,676(63,580)$ \\
\hline
\end{tabular}

${ }^{a} \mathrm{~A}$ Part B permit has been issued by the state for all storage units listed as of September 30, 1992.

waste streams stored in these tanks are PCB- and non-PCB-contaminated flammable liquids. The total nominal capacity of this unit is $347,501 \mathrm{~L}(91,800$ $\mathrm{gal})$, and the working capacity is $340,687 \mathrm{~L}(90,000 \mathrm{gal})$.

\section{Pond Waste Management Project (PWMP) Storage Facilities}

Table 7.4 is a list of storage facilities currently used by or available to PWMP to store containers of pond sludges. A description of PWMP storage vaults facilities follows the table.

$K$ - 1417 Concrete Block Casting and Storage. The K-1417 facility was used by the PWMP to store MW in 337- and 363-L (89- and 96-gal) drums. The area is used for pouring, setting, and storing stabilized waste in drums. In addition, the facility has a truck and equipment washing system that also collects run-off and spillage from the casting building. The working capacity of this unit is 80,000 337- and 363-L (89- and 96-gal) drums. The stored wastes consist of both stabilized and liquid sludge.

$K$-1419 Sludge Fixation Facility The K-1419 facility, used by the PWMP, includes a facility previously used for treatment involving stabilization of inorganic wastes. The facility includes one 9842-L (2600-gal), one 11,356-L (3000-gal), and two 56,781-L (15,000-gal) storage tanks.

$K-1065-A,-B,-C,-D$, -E Drum Storage Units (WSUs $K-1065$ ). The K-1065 WSUs are container storage units for the PWMP located on the west side of the K-25 Site. These WSUs are protected from precipitation because the WSUs are totally enclosed in a building. Each unit has a (8-in.) reinforced concrete floor and is equipped with curbing to provide secondary containment for the unit. $\mathrm{K}-1065-\mathrm{A}$ is approximately $59 \times 46 \mathrm{~m}$ $(193 \times 152 \mathrm{ft})$. The calculations for secondary containment show a capacity of $2,618,559 \mathrm{~L}(691,750 \mathrm{gal})$. However, this unit is used to store only wastes that do not contain free liquids; therefore, the maximum volume of waste that is stored in this unit is $3,885,240 \mathrm{~L}(1,026,372 \mathrm{gal})$. Each of the other units-K-1065-B, $-C,-D$, and $-\mathrm{E}$-has approximate dimensions of 59 $\times 71 \mathrm{~m}(193$ by $232 \mathrm{ft})$ and a secondary containment capacity of $3,986,417 \mathrm{~L}$ $(1,053,100$ gal). However, these units are used to store only wastes that do not contain free liquids; therefore, the maximum volume of waste stored in each of the four units is $5,867,672 \mathrm{~L}(1,550,075$ gal).

Table 7.5 summarizes mixed waste inventory and storage on the ORR.

\section{Disposal}

No mixed wastes are currently being disposed of on the ORR because no facilities for such disposal currently exist. At present, the only identified mixed waste disposal option is Envirocare of Utah, Inc. Future mixed waste disposal facilities in the DOE Complex are planned at the 
Table 7.4. Pond Waste Management Project storage units at the Oak Ridge K-25 Site

\begin{tabular}{ccccr}
\hline Unit & Type & Permit status & $\begin{array}{c}\text { Capacity } \\
\mathrm{m}^{3}\left(\mathrm{ft}^{3}\right)\end{array}$ & $\begin{array}{c}\text { Current inventory } \\
\mathrm{m}^{3}\left(\mathrm{ft}^{3}\right)\end{array}$ \\
\hline K-1417 & MW/sludge ${ }^{a}$ & Pending closure & $26,947(951,872)$ & $8,844(312,400)$ \\
K-1419 & MW/sludge & Pending closure & $135(4,760)$ & $59(2,100)$ \\
K-1065A & MW/sludge & Part B & $3,884(137,216)$ & $0(0)$ \\
K-1065B & MW/sludge & Part B & $5,867(207,229)$ & $0(0)$ \\
K-1065C & MW/sludge & Part B & $5,867(207,229)$ & $0(0)$ \\
K-1065D & MW/sludge & Part B & $5,867(207,229)$ & $0(0)$ \\
K-1065E & MW/sludge & Part B & $5,867(207,229)$ & $778(27,488)$ \\
K-31 & MW/sludge & Part B & & \\
K-33 & MW/sludge & Part B & & \\
Total (does not include K-31 or K-33) & $54,434(1,922,764)$ & $9,681(341,988)$ \\
\hline \multicolumn{5}{c}{${ }^{9}$ Mixed waste (MW). }
\end{tabular}

Hanford, Savannah River, and Nevada Test Sites. A mixed waste disposal facility to be located on the ORR is currently undergoing a feasibility study. Appendix B shows the current operational status of all waste treatment, storage, and disposal facilities on the ORR. Table 7.6 summarizes mixed waste disposal off-site.

\section{Future Plans}

\section{Treatment}

The proposed MWTF (noted earlier in this section under "Management Strategy") is a part of the DOE 5-year plan for dealing with LLW and/or mixed waste (DOE-ORO 1991). Without waste treatment, the DOE Oak Ridge Operations Office (DOE-ORO) would have to continue waste storage and be in noncompliance for some mixed waste. The MWTF Project will play an integral part in treating wastes that are identified in the FFCAs at DOEORO. It does not cover all these wastes but instead focuses on mixed waste solids.

The main mission of the MWTF is to provide a system of functional solid-mixedwaste treatment capabilities not otherwise available. It thermally, physically, or chemically alters FFCA "Appendix B" wastes to satisfy, at a minimum, LDR treatment standards and DOE Order 5820.2A requirements for disposal of these wastes as MLLW, LIW, or industrial/sanitary waste. The main goal is to provide treatment and final disposal of waste to render the waste as only RCRAlisted, nonhazardous, and/or nonradioactive. This is done by removing (1) the hazardous constituents to facilitate "delisting," (2) the radioactive constituent, and/or (3) both the listed hazardous and radioactive constituents. Following this, the treated waste will be processed into an acceptable form for final disposal.

Lack of an acceptable and proven treatment and/or disposal system has forced Environmental Restoration and Waste Management to continue to store some radioactive wastes, radioactive and TSCA wastes, and radioactive and RCRA wastes pending new treatment capabilities. The last two categories are commonly called mixed wastes.

Except for EPA codes D-018 through D-043 and other newly listed wastes for which standards have not been established, EPA RCRA-hazardous wastes are now subject to rules for LDR. These restrictions require that hazardous wastes be processed 
Table 7.5. Summary of mixed waste inventory and storage on the Oak Ridge Reservation

\begin{tabular}{|c|c|c|c|}
\hline & \multirow{2}{*}{$\begin{array}{l}\text { Inventory } \\
(\mathrm{kg})\end{array}$} & \multicolumn{2}{|c|}{$\begin{array}{l}\text { Storage } e^{b} \\
\mathrm{~m}^{3}\left(\mathrm{ft}^{3}\right)\end{array}$} \\
\hline & & June 30, 1993 & June 30, 1994 \\
\hline \multicolumn{4}{|c|}{ Oak Ridge Y-12 Plant } \\
\hline Appendix $A^{c}$ & 357,915 & & \\
\hline Appendix B & $17,555,825$ & & \\
\hline Total MLLW ${ }^{d}$ & $17,913,740$ & $17,166(606,200)$ & $16,636(587,500)$ \\
\hline \multicolumn{4}{|c|}{ Oak Ridge National Laboratory } \\
\hline Appendix A & 143,671 & & \\
\hline Appendix B & $3,127,067$ & & \\
\hline Total MLLW & $3,270,738$ & $3,367(118,900)$ & $3,194(112,800)$ \\
\hline $\mathrm{MTRU}^{d}$ & $2,173,006$ & $1,439(50,800)$ & $1,654(58,400)$ \\
\hline \multicolumn{4}{|c|}{ Oak Ridge $K-25$ Site } \\
\hline Appendix A & $25,436,979$ & & \\
\hline Appendix B & $13,347,564$ & & \\
\hline Total MLLW & $38,784,543$ & $32,969(1,164,300)$ & $23,500(829,900)$ \\
\hline \multicolumn{4}{|c|}{ Oak Ridge Reservation } \\
\hline Appendix A & $25,938,565$ & & \\
\hline Appendix B & $34,030,456$ & & \\
\hline MLLW & $59,969,021$ & $53,502(1,889,400)$ & $43,330(1,530,200)$ \\
\hline MTRU & $2,173,006$ & $1,439(50,800)$ & $1,654(58,400)$ \\
\hline
\end{tabular}

“Inventories shown are for CY 1993. Source: DOE April 1993. "Mixed Waste Inventory Report"; interim document.

'Source: ESWMO August 1994. Oak Ridge Reservation Waste Storage Report for Period Ending June 30, 1994, Science Applications International Corp., Oak Ridge Tenn.

"So called "Appendix A" wastes are mixed wastes with identified existing treatment. Appendix B wastes are mixed wastes without identified existing treatment or with identified existing treatment that is not currently being accepted.

${ }^{d}$ Mixed low-level waste (MLLW); mixed transuranic waste (MTRU).

to meet established criteria before land disposal is permitted per 40 CFR Pt. 268. Because of a nationwide lack of treatment capacity, the EPA delayed application of LDR regulations to radioactive mixed waste until May 1992. DOE and EPA Region IV have signed an FFCA to bring mixed waste generation and storage on the ORR into compliance with LDR of RCRA; this FFCA is not in effect. The FFCA established the compliance requirements for these DOE facilities and the timeframe within which certain actions must be taken. The MWTF is part of that plan and is proposed as an FY 1997 Major Systems Acquisition. After May 1992 the National Capacity Variance for these types of wastes expired. Processes included in the MWTF Project will place the treated waste in compliance with LDR regulations.

The treatment of LLW, RCRA, and mixed waste at MWTF does allow DOE to do is treat and prepare waste for final disposal in compliance with LDR. 
Table 7.6. Summary of mixed waste disposed of off-site

\begin{tabular}{|c|c|c|c|}
\hline Waste type & Disposal site & $\begin{array}{c}\text { CY } 1993 \\
\mathrm{~kg}(\mathrm{lb}) / \text { year }\end{array}$ & $\begin{array}{l}\text { CY 1994ª } \\
\text { kg (lb)/year }\end{array}$ \\
\hline \multicolumn{4}{|c|}{ Oak Ridge Y-12 Plant } \\
\hline & & $0(0)$ & $0(0)$ \\
\hline \multicolumn{4}{|c|}{ Oak Ridge National Laboratory } \\
\hline & & $0(0)$ & $0(0)$ \\
\hline \multicolumn{4}{|c|}{ Oak Ridge K-25 Site } \\
\hline $\begin{array}{l}\text { Stabilized pond waste } \\
\text { (in drums) }\end{array}$ & Environcare, Clive, Utah & $0(0)$ & $1,914,000(4,219,648)$ \\
\hline
\end{tabular}

'Projected.

\section{Y-12 Plant}

No new mixed waste treatment facilities are currently planned.

\section{$O R N L$}

ORNL currently utilizes Buildings 7654, 7507W, 7830A, and 7823 for mixed waste storage. Plans are to treat organic mixed wastes at the TSCA incinerator. The "Mixed Waste Inventory Report" has identified treatment for some of the other wastes stored in these buildings. These strategies were spelled out earlier in this document under "Management Strategy." Nonhazardous scintillation fluids have been approved by the TDEC for treatment at the Sewage Treatment Plant. Plans are to treat corrosive mixed wastes at the Process Waste Treatment Plant or in the LLLW System.

\section{K-25 Site}

The TSCA Incinerator is currently burning only liquid mixed waste and PCBs, but it may also be used for the treatment of solid mixed waste. Solids have been burned in tests and in the future may be burned in quantity. Some modification or refinement of the TSCA facility, specifically the feed system, will probably be required. TSCA is the only facility in the country that can be used for the treatment of solid mixed waste.

The Container Processing Facility is to be located at $\mathrm{K}-1423$ and will be used to clean empty containers and related equipment for reuse and/or recycle. Most of the containers are empty drums contaminated with radioactive particulate and/or substances regulated by TSCA, primarily PCBs.

Solid mixed waste is currently listed in the LDR FFCA as "Appendix B" waste; the most appropriate treatment technology is to be identified and evaluated. Treatment options, including availability of commercial facilities, new ORR facilities, and upgrades of the TSCA Incinerator, are also being assessed.

\section{Storage}

The outlook for mixed waste storage capacity is favorable because of (1) a continued relatively low rate of mixed waste generation and (2) success in conversions of existing facilities to permitted storage capacity (Fig. 7.11). The off-site shipment moratorium continues to have a negative impact on the waste storage situation, although operating procedures have been approved by DOE Headquarters for the Y-12 Plant and the 


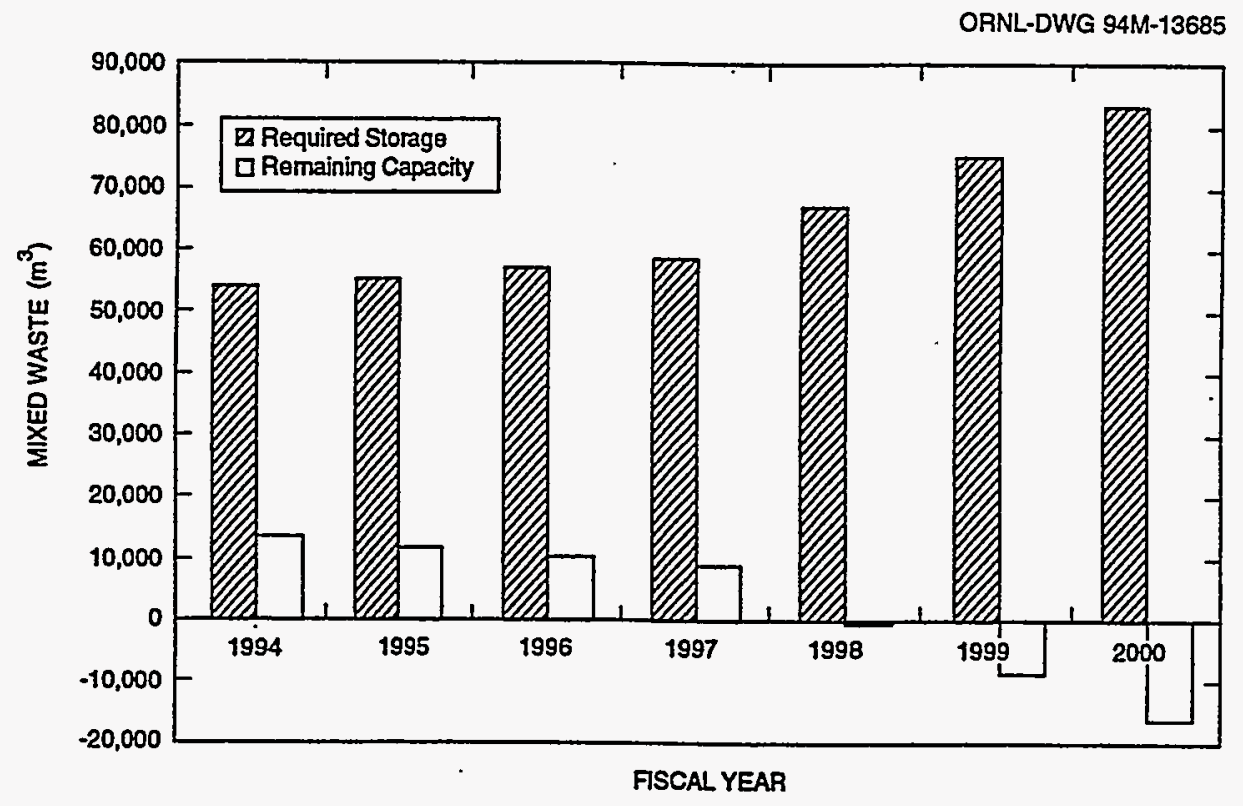

Fig. 7.11. Mixed waste storage projections. Projections include both solids and liquids. Mixed transuranic waste is not included in the projections. Source: ESWMO August 1994. Oak Ridge Reservation Waste Storage Report for Period Ending June 30, 1994, ESWM-23, rev. 0, Science Applications Intl. Corp., Oak Ridge Tenn.

K-25 Site that allow shipment of some hazardous waste packages that meet the release criteria for surface contamination or for which process knowledge is sufficient to demonstrate that no radioactivity has been added. Mixed waste shipments between ORR facilities have been expedited where available storage capacity is insufficient at one facility but can be accommodated at another facility. However, this activity has no effect on the overall capacity available on the ORR. The available storage capacity for flammable wastes is limited and remains a concern.

CH TRU mixed "suspect" RCRA waste resulting from RCRA closure of Buildings 7826 and 7834 at ORNL is being stored on a temporary basis in Buildings 7934, 7842, 7878, and 7879. Buildings 7842 and 7878 had been used previously for solid lowlevel waste staging and storage. CH TRU mixed suspect RCRA legacy waste is also stored in the Solid Waste Storage Area (SWSA) $5 \mathrm{~N}$ trenches.
Because of a backlog of unused space and lack of additional funding, the Mixed Waste Storage Expansion Project at the K-25 Site ended in June 1994. Seventeen vaults (19 vault equivalents) were refurbished during the project, which yielded a combined permitted waste storage area of approximately $25,110 \mathrm{~m}^{2}$ $\left(270,000 \mathrm{ft}^{2}\right)$. Vault $\mathrm{K}-303-5$ is also now available for temporary LLW storage. Although the refurbishing of vault $\mathrm{K}-303-5$ was discontinued because of lack of funding, equipment removal, trench fill, and floor scrabbling were completed. Future use of vaults K-301-5A and ..: $\mathrm{K}-306-25 \mathrm{~A}$ is also anticipated.

A revised plan (DOE-ORO March 1993) was submitted to the EPA in March 1993 in compliance with an FFCA (Docket No. 92-02 FFR). The plan determined that adequate storage exists or is planned until 1998 for the LDR-prohibited waste categories that were evaluated except TRU waste. The EPA responded in August 1993 that the revised storage plan satisfies EPA 
requirements, but final approval was not given pending amendment and approval of the FFCA appendices. The appendices have been amended; however, documented approval of the storage plan is still pending.

The off-site shipment and disposal by the Mixed Waste Disposal Initiative of 78 drums of Pond Waste Management Project (PWMP) stabilized pond sludges was executed on August 10, 1994. Movement of remaining sludges from the $\mathrm{K}-1417$ storage yard into the $\mathrm{K}-1065$ buildings is ongoing and is expected to be completed by December 1994.

Programmatic, regulatory, and budgetary constraints are unpredictable and may adversely affect the schedule of subsequent shipments off-site.

The contract for the sale of large quantities of lithium hydroxide monohydride was not in place by August 1993 as expected. Bids for the total volume of lithium hydroxide monohydride were received in July and are currently being evaluated by DOE and Martin Marietta Energy Systems, Inc., personnel. If a bid award can be placed this year, it will be possible to move the majority of the material from the 17 vaults by the summer of 1996. If and when the lithium materials are finally removed, those vaults could be refurbished and converted to mixed waste storage areas.

Shipments of mixed waste and hazardous waste to off-site treatment and disposal facilities should be resumed as quickly and as extensively as possible. Because of the uncertainties associated with the timing and extent of future off-site shipments, the impact on future storage requirements is also uncertain. Thus, it is difficult to factor that consideration into planning efforts on a quantitative basis. For now, the assumption is that most mixed waste generated on the ORR will be stored or treated on-site in the near term. The exception is waste that will be covered by the recently approved procedure for shipment of wastes from the $K-25$ Site and the Y-12 Plant that meet the release criteria for surface contamination.

Mixed waste (including radioactive TSCA or RCRA waste but excluding TRU waste) will be stored to the maximum extent possible in a combination of existing storage facilities and existing structures that can be converted to storage; any additional required capacity should be provided by new construction. Appendix $C$ shows new Y-12 Plant storage facilities planned for mixed waste. Comparison of all available storage on the ORR (including 30 vaults in Buildings K-25 and K-27 planned for refurbishment) with the total projected waste generation indicates that adequate capacity will be available for mixed waste (excluding flammable wastes) storage through 1998-assuming all currently planned projects proceed as scheduled. After 1998 the volume of waste generated is projected to exceed available storage capacity.

Refurbishment of the vaults in Building $\mathrm{K}-25$ was halted in FY 1994 because of an excess of capacity and a lack of funding. Upgrade of additional units in the next few years continues to be an option; however, plans to refurbish additional vaults are on hold.

The status of existing facilities identified for potential use as mixed waste storage units (e.g., the vaults that contain lithium monohydride and facilities associated with the PWMP) will continue to be monitored. The PWMP facilities $\mathrm{K}-1065, \mathrm{~K}-33$, and $\mathrm{K}-31$ may not be emptied of PWMP wastes or otherwise released from the PWMP as planned because of recent changes in the interim remedial action at $\mathrm{K}-1417-\mathrm{A}$ and $\mathrm{K}-1417-\mathrm{B}$. Current plans are to privatize the stabilization of the sludges. In the interim, some drums are individually repacked and stored. Thus, availability of the storage facilities now containing this waste may be delayed indefinitely. A small amount of additional storage capacity will be provided by new construction projects, such as the ORNL Mixed Waste Storage 
Facility, though the specific time of their availability remains uncertain (primarily because of permitting and funding considerations).

Many uncertainties exist related to the acquisition of additional storage space in existing buildings that are currently occupied with other materials and/or by other programs. Despite these uncertainties, the use of those facilities for additional waste storage capacity is preferred to construction of new facilities. While the existing facilities continue to hold promise, a firm projection of when the project will be needed cannot be made with a high degree of confidence. If the options for using existing storage space cannot be realized as anticipated, delays or other adverse impacts on their availability may create a need for construction of new storage facilities.

\section{Disposal}

Near-term plans are to ship selected mixed waste streams to Envirocare of Utah, Inc., for disposal. Appendix $\mathrm{C}$ lists proposed line items and general plant projects for mixed waste facilities on the ORR.

Appendix $D$ provides DOE Order 5820.2A compliance summaries for each of the three ORR installations.

\section{Waste Characterization}

ORR mixed wastes have been adequately characterized for storage and treatment planning. However, many wastes require additional characterization for treatment implementation.

As is previously noted, approximately one quarter of inventoried ORR streams are Appendix A wastes that have existing treatment available. These streams (e.g., liquid organic wastes destined for incineration at the TSCA Incinerator) typically are characterized in sufficient detail to ensure that the WAC of the treatment facility are met. The remaining three quarters are Appendix B wastes that currently lack treatment. Some of the large-volume wastes in this group are generally well characterized.

The analytical data for some of these streams may not be sufficient, and further characterization activities could be required prior to treatment implementation. The remaining Appendix B wastes are not well characterized for treatment; debris wastes are the most problematic. An integrated waste characterization effort, therefore, is being pursued to advance the various elements of the ORR mixed waste management program leading to the treatment and disposal of these Appendix B streams. Waste characterization data are needed to support (1) treatability studies, (2) mixed waste disposal, (3) conceptual and detailed design of the proposed ORR MWTF, (4) commercial treatment initiatives, (5) treatment of additional aqueous and organic liquid waste streams in existing on-site facilities, (6) technology demonstration activities, and (7) treatment of combustible solids in the TSCA Incinerator.

A team consisting of representatives from all affected organizations has been assembled to integrate the overall effort. At present, the current focus is to prepare sampling and analysis plans to support offsite shipments of waste for treatability studies, for disposal of specific waste streams at Envirocare of Utah, Inc., and to facilitate treatability study design. In addition a prioritization method is being developed to schedule waste characterization activities. Finally, an electronic database is being developed that will allow waste characterization data to be integrated with requests for disposal and the FFCAct MWIR. 


\section{Waste Tracking}

Waste tracking at the ORR sites involves an integrated effort to develop the data analysis and reporting capability necessary to support waste minimization needs. Waste tracking is used to produce timely and accurate waste reduction reports and accounting systems. It includes technical support to integrate ORR site data acquisition methods and key data elements.

A Central Waste-Tracking System (CWTS) is being developed to collect common information about waste from the various ORR sites from point of generation to final disposition. This information will be integrated and reported in terms of type, quantity, and location or disposition of waste. The centralized system will produce data for establishing waste generation baselines, trending analysis, and external . manipulation and reporting. The centralized waste tracking system will be capable of interfacing with several other systems for querying the data and generating reports.

Use of an interface system with the CWTS will be explored for recognizing and manipulating raw data, relating the data to actual waste minimization (source reduction) projects, and developing true cause-and-effect and cost analyses. An interface system for the centralized wastetracking system will alleviate the extensive reporting requirements that currently exist and the increasing requirements that are envisioned. This effort will enable centralizing the reporting function and providing an analysis tool specifically designed for waste minimization.

A waste minimization interface system will use the data on input material; material usage; type of waste, volume, and generating system; generation date; and other relevant information. A method will be developed to track materials being recycled or reclaimed and to quantify the volumes of waste eliminated resulting from waste minimization efforts.

This computerized system will be used to identify waste reduction opportunities, to document minimization achievements, and to provide essential feedback to successfully guide future efforts. The system will track program progress. The data collected by the system will be used to meet internal and external reporting requirements. The system developed under this program will be designed to facilitate reporting waste minimization data and accomplishments.

\section{Waste Minimization/Pollution Prevention}

Waste minimization activities on the ORR are being implemented to reduce the volume of all waste generated, especially those that are hazardous and/or mixed and subject to RCRA LDR. Waste minimization is being achieved through the following general types of activities:

- segregation of hazardous from radioactive constituents to minimize radioactive mixed waste,

- substitution of nonhazardous solvents for hazardous solvents where technically practicable, and

- minimization of the generation of hazardous waste.

To achieve waste minimization objectives, activities involving segregation, substitution, and other related actions have been initiated. Segregation of the hazardous component from the radioactive portions of a waste stream is necessary, to the extent possible, to minimize or to eliminate the generation of mixed waste. Under the current regulatory structure, DOE will identify, treat, and/or manage mixed waste as defined in the opening paragraph of this section. These wastes are typically more difficult to treat and dispose of and therefore must be minimized where possible. Process controls and housekeeping techniques to segregate the hazardous and radioactive components prior to cross contamination will be 
provided to minimize the generation of mixed wastes.

The practice of material substitution at the waste-producing source is effective in reducing the resulting hazardous waste generation volumes and eliminating the hazardous characteristics of the waste. Therefore, the substitution of nonhazardous solvents, such as aqueous cleaners, for hazardous solvents will be aggressively pursued to significantly reduce the amount of hazardous and mixed waste generated.

To further reduce the amounts of hazardous and radioactive wastes generated throughout the ORR, other waste minimization activities (such as equipment or technology modifications, process or procedure modifications, reformulation or redesign of products, and improvements in housekeeping, maintenance, training, or inventory control and recycling and reuse) will be employed. These activities will reduce the amount of waste requiring treatment, storage, and disposal as well as provide more efficient use of resources.

The overall strategy of focusing on waste minimization for these wastes translates in practice to eliminating or minimizing the generation of waste. Waste minimization consists of source reduction and recycling activities. Source reduction activities minimize or eliminate wastes at the source, while recycling activities use, reuse, or reclaim a material from a waste stream. These two activities are elements of the EPA's hierarchy of environmental protection practices that encourages source reduction as the highest priority and recycling as the second priority. Source reduction is the first priority because it eliminates the problems associated with handling wastes. Waste minimization practices of source reduction and recycling reduce or eliminate the amount of waste that must be treated, stored, or disposed of by either reducing the total volume of waste, reducing the toxicity of the waste, or both, as long as that reduction is consistent with the general goal of minimizing current and future threats to human health and the environment.

Pollution Prevention Opportunity Assessments (PPOAs) are the primary means of identifying, screening, and analyzing options to reduce the generation of waste. The key components of a PPOA include (1) determining the quantity of material generated in a workplace that is disposed of as waste, (2) assessing the usage of hazardous materials and the subsequent production of hazardous waste, and (3) identifying those processes and operations that need to be improved or replaced to promote waste minimization. The assessment provides a basis for prioritizing the specific modifications to site processes or other waste minimization options that are developed during the assessment. Targeted waste streams are those with a high potential for success in meeting established goals. Remaining waste streams also are assessed-but at a lower priority. Information processing of PPOA findings is performed as necessary for technical exchange and data acquisition to facilitate waste minimization analyses and reporting.

PPOAs at ORR facilities have identified processes for waste minimization opportunities and associated projects that have been implemented. Waste minimization evaluations are also implemented in the design process of new projects. Formal PPOAs are conducted at ORR facilities using the PPOA methodology outlined in DOE/EPA Model PPOA Guidance. PPOAs are also accomplished through the "Performance Improvement Process" and "Pride in Excellence" teams as Best Management Practice and process improvement efforts.

PPOAs of all waste-generating operations at the ORR will be conducted by waste assessment teams. The leader of each waste assessment team has line responsibility and familiarity with the site's production and waste management operations. Each team typically consists of 
a small core of individuals familiar with the sites's production operations who will direct the focus of the assessment efforts and guide the data gathering. Each team will include members who have knowledge in the following areas:

- federal, state, and local hazardous waste statutes and regulations;

- production and waste minimization principles and techniques;

- quality control requirements; and

- purchasing and material control/inventory.

The order and areas of site operations to be assessed are first determined. Each team then develops process flow diagrams, material balances, process descriptions, and waste stream characterizations for the assigned assessment area. Evaluation of this technical data leads to the identification of process inefficiencies that can be modified or corrected to reduce waste generation. Alternatives for segregation, substitution, and waste minimization are then developed. Options are screened to produce a reduced set that warrants further, more detailed technical and economic evaluation. The potential technical success and economic benefit/cost of each resulting option is then assessed. The options are then ranked in order of preferred implementation. The highest priority normally will be given to projects that reduce waste generation at the source, followed by projects that recycle all or part of a waste stream. The results of the evaluation, including final rankings and ranking criteria, are documented and reported. Implementation of process modifications or other preferred options determined by a PPOA is the responsibility of the waste-generating operation and is accomplished as resources permit.

\section{References}

DOE-ORO 1991. DOE Environmental Restoration and Waste Management Five-Year Plan, Oak Ridge, Tenn. DOE-ORO March 1993. Land Disposal Restrictions Waste Storage Plan, DOE/OR-1079, Oak Ridge, Tenn.

DOE August 1994. Site Treatment Plan for Mixed Waste on the U.S. Department of Energy Oak Ridge Reservation, draft, DOE/OR-2016, Vols. I-IV, Oak Ridge, Tenn.

Y-12 WMD (Y-12 Waste Management Division) December 1990. PCB and RCRA Hazardous Waste Drum Storage, Building 9720-9, 50-41-WS-019, Martin Marietta Energy Systems; also CSA 17842(R).

Y-12 WMD (Y-12 Waste Management Division) March 1993a. PRTF Operating Parameters, Y50-41-WT-11.11, Martin Marietta Energy Systems, Oak Ridge Y-12 Plant.

Y-12 WMD (Y-12 Waste Management Division) March 1993b. PRTF Wastewater Receiving Operations, Y50-41-WT-11.23, Martin Marietta Energy Systems, Oak Ridge Y-12 Plant.

Y-12 WMD (Y-12 Waste Management Division) March 1993c. Head End Treatment System Description, Y50-41-WT-09.01, Martin Marietta Energy Systems, Oak Ridge Y-12 Plant; also CSAs 15895(R), 17568, and 17591.

Y-12 WMD (Y-12 Waste Management Division) August 1993. Liquid Organic Waste Storage Facility (OD-10), 50-41WS-002, Martin Marietta Energy Systems. 
Y-12 WMD ( $\mathrm{Y}-12$ Waste Management Division) September 1993. CPCF-Receive and Unload Waste, Y50-41-WT-08.02, Martin Marietta Energy Systems, Oak Ridge Y-12 Plant; also CSA 17543.

$Y-12$ Plant WMD (Y-12 Waste Management Division) September 1993b. Waste Oil/Solvent Bulk Storage Facility, Oil Dike 7, Building 9811-1, 50-41-WS-027, Martin Marietta Energy Systems.

Y-12 WMD (Y-12 Waste Management Division) September 1993c. Waste Oil/Solvent Drum Storage Facility, Oil Dike 8, 50-41-WS-028, Martin Marietta Energy Systems.

Y-12 WMD (Y-12 Waste Management Division) February 1994. PCB and RCRA Staging and Storage Facility, Y50-41-WS-023, Martin Marietta Energy Systems; also CSA 17709.
Y-12 WMD (Y-12 Waste Management Division) April 1994. Classified Waste Storage Facility, Y50-41-WS-029, Martin Marietta Energy Systems; also CSA 17779.

Y-12 WMD (Y-12 Waste Management Division) September 1994a. Waste Oil/Solvent Storage Facility, Oil Dike 9, Building 9811-8, Y50-41-WS034, Martin Marietta Energy Systems.

Y-12 WMD (Y-12 Waste Management Division) September 1994b. PCB Drum Storage Facility, Building 9404-7, 50-41-WS-018, Martin Marietta Energy Systems.

Y-12 WMD (Y-12 Waste Management Division) October 1994. Containerized Waste Storage Area, Facility IS-33, Y50-41-WS-031, Martin Marietta Energy Systems; also CSA 17782(R). 


\section{Industrial and Sanitary Wastes}

Industrial and sanitary wastes represent the largest volume of all waste types that must be treated and disposed of on the Oak Ridge Reservation (ORR). Industrial and sanitary wastes consist of both the solid and liquid portions of waste generated from sanitary sewage, steam plant operations (see note at bottom of Table 8.2), general refuse, coal yard runoff, and construction and demolition debris. Industrial and sanitary solid wastes do not contain Resource Conservation and Recovery Act (RCRA), Toxic Substances Control Act (TSCA), or hazardous substances and free liquids. They include garbage, refuse, sewage sludge, asbestos, construction debris, cafeteria waste, and discarded materials.

The Oak Ridge Y-12 Plant discharges liquid industrial waste to East Fork Poplar Creek and Bear Creek through permitted outfalls and liquid sanitary waste to the Oak Ridge city sewer system. Discharges to the East Fork of Poplar Creek and Bear Creek primarily result from the treatment of wastes and from stormwater runoff or once-through cooling water.

The continuous liquid sanitary (i.e., sanitary and domestic) effluent includes all waste streams that are discharged to White Oak Creek (WOC) via the Sewage Treatment Plant at Oak Ridge National Laboratory (ORNL). This includes all septic tanks or holding tanks.

At the Oak Ridge K-25 Site, liquid sanitary wastes (i.e., conventional liquid wastes) include nonradioactive waste streams that are discharged either directly or following treatment to the Clinch River, Poplar Creek, or Mitchell Branch. Liquid sanitary waste sources at the K-25 Site include sanitary sewage wastes and-area runoff of rainwater.

The Tennessee Department of Environment and Conservation (TDEC) regulates both solid and liquid industrial and sanitary wastes at each of the sites through the Tennessee Solid Waste Disposal Act, rules governing solid waste processing and disposal in Tennessee, and through National Pollutant Discharge Elimination System (NPDES) permits issued for each site's liquid effluents under the Clean Water Act (CWA). Table 8.1 shows TDEC classifications of solid waste disposal facilities and associated waste types.

\section{Management Strategy}

The strategy for industrial waste disposal on the ORR involves minimization of waste generation, use of commercial recycle markets, and disposal in the Industrial Landfill II (ILF II), IIF V, and the Construction/Demolition Landfill VI (CDL VI) at the Y-12 Plant. The Anderson County Chestnut Ridge Landfill will still be used for organic wastes such as animal bedding, cafeteria wastes, and fly ash. Because landfill disposal costs continue to increase, commercial recycle markets will continue to be used when appropriate to assist in waste reduction. New disposal capacity will be developed on-site as needed.

The management strategy for sanitary liquid wastes on the ORR must comply with U.S. Environmental Protection Agency, CWA, and TDEC regulations as 
Table 8.1. State of Tennessee industrial and sanitary solid waste disposal facility classifications

\begin{tabular}{cl}
\hline Class & \multicolumn{1}{c}{ Facility and waste description } \\
\hline I & $\begin{array}{l}\text { Refers to a sanitary landfill that serves a municipal, institutional, and/or rural } \\
\text { population and is used for disposal of domestic wastes, commercial wastes, } \\
\text { institutional wastes, municipal wastes, demolition/construction wastes, farming wastes, } \\
\text { discarded automotive tires, and dead animals }\end{array}$ \\
& $\begin{array}{l}\text { Refers to a landfill that receives waste generated by one or more industrial or } \\
\text { II }\end{array}$ \\
& $\begin{array}{l}\text { ganufacturing plants and is used, or is to be used, for disposal of solid waste } \\
\text { domestic wastes, institutional wastes, farming wastes, demolition/construction wastes, } \\
\text { discarded automotive tires, and dead animals. Additionally, a Class II disposal facility } \\
\text { may also serve as a monofill for ash disposal from the incineration of municipal solid } \\
\text { waste } \\
\text { III }\end{array} \quad \begin{array}{l}\text { Refers to a landfill that is used, or is to be used, for the disposal of farming wastes, } \\
\text { landscaping wastes, and/or certain special wastes having similar characteristics }\end{array}$ \\
IV & $\begin{array}{l}\text { Refers to a landfill that is used, or is to be used, for the disposal of } \\
\text { demolition/construction wastes and/or certain special wastes having similar } \\
\text { characteristics as inert waste }\end{array}$ \\
V & Refers to a land-farming facility \\
VI & Refers to a surface impoundment used for disposal of solid waste
\end{tabular}

'Disposal facility class currently exists on the Oak Ridge Reservation.

Source: Bureau of National Affairs Mar. 18, 1990. Tennessee Solid Waste Processing and Disposal Regulations, Rules of Tennessee Department of Health and Environment, Division of Waste Management, Chap. 1200-1-7, "Solid Waste Processing and Disposal."

well as U.S. Department of Energy orders. Programmatic strategies include sampling and analysis of various wastewater sources prior to discharge to wastewater treatment facilities, effluent sampling and analysis of sanitary wastewater prior to discharge to receiving streams according to NPDES regulations and the City of Oak Ridge Industrial User Permit for the Y-12 Plant, examination of the toxic effects of sanitary wastewater on the receiving stream, reduction of hydraulic loading by eliminating groundwater infiltration, and aggressive pursuit of environmental programs that will keep discharge concentrations below NPDES permit levels. sanitary wastes were generated on the ORR in CY 1993. As is shown in Table 8.2, the Y-12 Plant is the single largest generator of this waste group at $43,934 \mathrm{~m}^{3}$ (1.5 million $\mathrm{ft}^{3}$ ) (i.e., $83 \%$ of the total generation). ORNL and the K-25 Site generated approximately $11 \%$ and $6 \%$ respectively.

The Environmental Restoration Program (ERP) has published waste generation projections from remedial action and decontamination and decommissioning activities. Table 8.2 shows waste generation estimates for the three sites. Figure 8.1 shows ERP generation projections.

\section{Current Generation and Projections}

Approximately $52,766 \mathrm{~m}^{3}$ $\left(1,863,208 \mathrm{ft}^{3}\right)$ of solid industrial and

\section{Treatment}

Table 8.3 summarizes the volumes of industrial and sanitary wastes treated on the ORR. Liquid sanitary waste streams are discharged to the Oak Ridge city sewer 
Table 8.2. Summary of industrial and sanitary solid and liquid waste generation on the Oak Ridge Reservation ${ }^{a}$

\begin{tabular}{lrr}
\hline \multicolumn{1}{c}{ Site/waste form } & CY 1993 & \multicolumn{1}{c}{ CY $1994^{b}$} \\
\hline Oak Ridge Y-12 Plant & & \\
$\quad$ Solid & & \\
Liquide $^{c}$ & $43,934(1,551,349)$ & $20,605(727,576)^{d}$ \\
Oak Ridge National Laboratory & $145(38)$ & $128(34)^{d}$ \\
$\quad$ Solid & & \\
Liquid & $5,618(198,404)$ & $5,700(199,000)$ \\
Oak Ridge K-25 Site & $28(7)$ & $61(16)$ \\
Solid & & \\
Liquid & $3,214(113,455)$ & $3,200(112,977)$ \\
\hline
\end{tabular}

Table numbers do not reflect generation by Portsmouth, Paducah, or off-site projects.

${ }^{b}$ Projected.

${ }^{c}$ Cubic meters $\left(\mathrm{ft}^{3}\right)$. Solids at the $\mathrm{Y}-12$ Plant include trash, debris, and scrap metal waste from Y-12 Plant operations, contractors, and waste management. Also included is classified waste and treatment residues.

'Through June 1994.

Liters (gal) $\times 10^{6}$. Liquids include oils and solvents, liquid waste and wastewaters from Y-12 Plant operations, contractors, and waste management; Central Pollution Control Facility/Plating Rinsewater Treatment Facility wastewater; Steam Plant wastewater; environmental restoration; and liquid waste received from ORNL and the K-25 Site. Note that Steam Plant Wastewater Treatment Facility (SPWTF) wastewater is considered Resource Conservation and Recovery Act hazardous prior to treatment. Treatment renders wastewater nonhazardous. For classification purposes, SPWTF wastewater is included in total generation.

Includes cafeteria waste total.

system or to the environment via NPDESpermitted discharge points after treatment, sampling, and analysis. Figures 8.2 through 8.4 provide an overview of the NPDES and perimeter monitoring locations for each of the sites.

\section{Y-12 Plant}

The Y-12 Plant treats industrial and sanitary wastes in two manners: industrial solid waste is compacted for volume reduction at the Building 9720-25 Baler Facility (Y-12 WMD September 1992); Steam Plant operations wastewater and coal yard runoff are treated at the Defense Programs Steam Plant Wastewater Treatment Facility (SPWTF) (Fig. 8.5).
The SPWTF provides flow equalization, $\mathrm{pH}$ adjustment, chemical precipitation, clarification, and sludge dewatering for coal pile runoff, ion exchange regeneration wastewater, boiler blowdown, and demineralizer waste. The treatment facility utilizes automated processes for continuous operation. All solids generated during treatment are nonhazardous and are disposed of in the industrial landfills. The wastewater, considered RCRA hazardous prior to treatment, is rendered nonhazardous by the SPWTF. The treated effluent is monitored prior to discharge to East Fork Poplar Creek. All Y-12 Plant sewage treatment is performed by the city of Oak Ridge. The Y-12 Plant utilizes no other off-site facility for treatment of industrial or sanitary waste. 


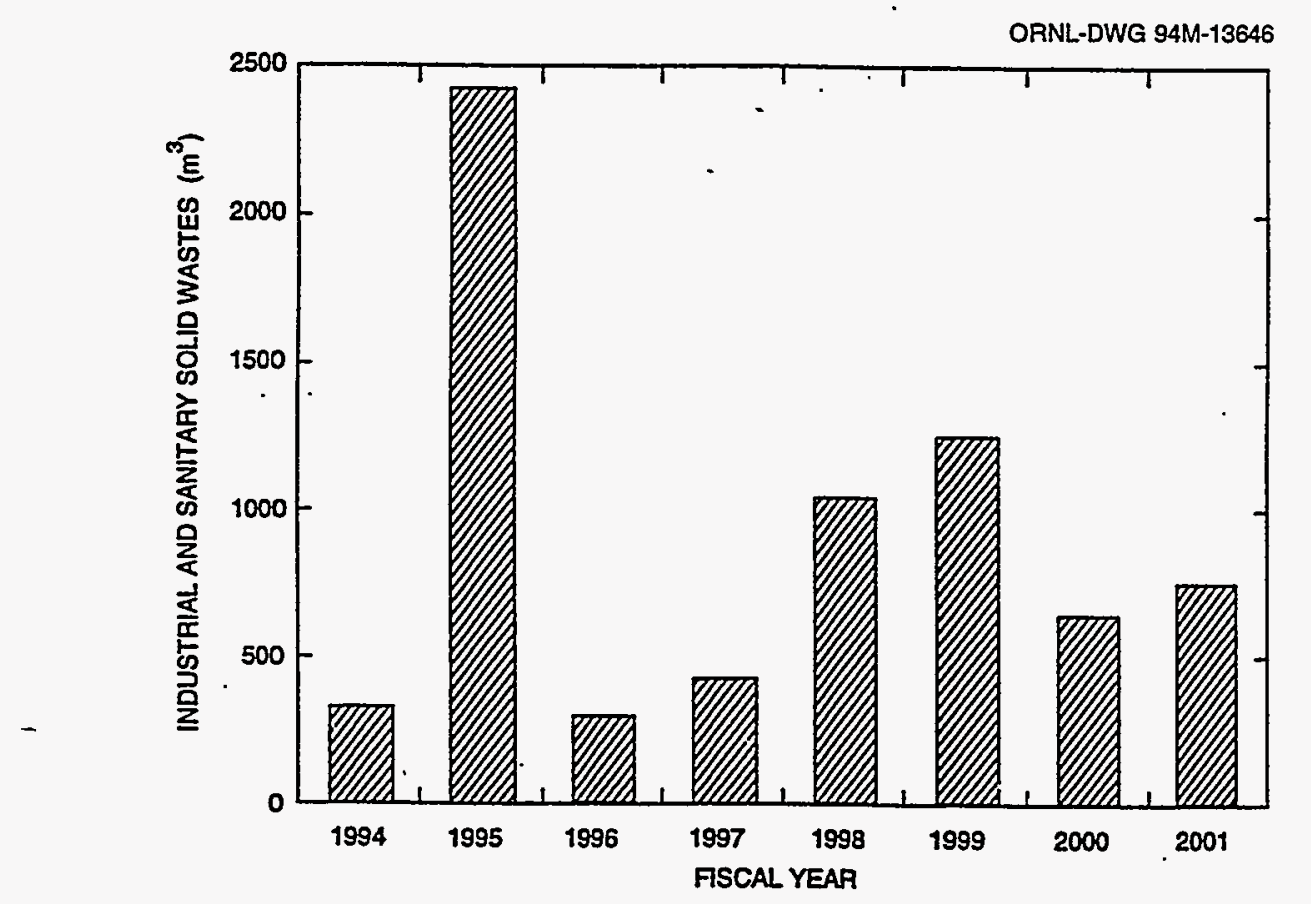

Fig. 8.1. Projected Environmental Restoration Program industrial and sanitary solid waste generation on the Oak Ridge Reservation. Source: Environmental Restoration Division December 1993. Waste Generation Forecast for DOE-ORO's Environmental Restoration OR-I Project: FY 1994-FY 2001, ES/ER/TM-102, Martin Marietta Energy Systems, Oak Ridge K-25 Site.

\section{ORNL}

Rainfall runoff from the ORNL Steam Plant coal yard storage area-plus additional wastewater from the sulfuric acid tank diked area runoff, Steam Plant boiler blowdown, and water softener regenerate-is collected in a collection basin. The coal pile runoff contains fines and trace amounts of heavy metals from the coal. This acidic wastewater is pumped from the pond to a neutralization tank (Fig. 8.6) where a lime slurry adjusts the $\mathrm{pH}$ and precipitates out heavy metals. A polymer is added upstream from the flocculation tank to aid in coagulation in the clarifier. The precipitated solids are removed from the bottom of the clarifier and are dewatered in a sludge rotary vacuum filter using diatomaceous earth as a filter aid. The resulting $264 \mathrm{t} /$ year (290 tons/year) of filter cake, determined by the TDEC to be a special waste, is disposed of at the Y-12 Plant ILF V. The supernatant from the clarifier, which is not considered an industrial waste or a sanitary waste, flows by gravity to the lower holding pond and into WOC via an overflow wier.

The Sewage Treatment Facility (Fig. 8.7) treats sanitary and laundry wastewater. It is an extended aerationactivated sludge unit followed by mixed media tertiary filtration of secondary effluent dewatering and on-site sludge drying in open-air sludge-drying beds. This extended aeration system was designed to handle a hydraulic load of 1.1 million $\mathrm{L} / \mathrm{d}$ $(300,000 \mathrm{gal} / \mathrm{d})$. The plant operates in a continuous mode.

Sanitary wastewater from the facility flows by gravity into a large wetwell. Lift pumps are used to transport the wastewater to the influent header box where the wastewater flows by gravity into the extended aeration-mixed liquor basin. Following the $30-\mathrm{h}$ extended aeration period, the mixed liquor flows by gravity 
Table 8.3. Industrial and sanitary liquid wastes treated on the Oak Ridge Reservation

\begin{tabular}{|c|c|c|c|}
\hline Facility & Treatment method & $\begin{array}{c}\text { CY } 1993 \\
L(\text { gal }) \times 10^{6}\end{array}$ & $\begin{array}{c}\text { CY 1994 } \\
\text { L (gal) } \times 10^{6}\end{array}$ \\
\hline \multicolumn{4}{|c|}{ Oak Ridge Y-12 Plant } \\
\hline $\begin{array}{l}\text { Steam Plant Wastewater } \\
\text { Treatment Facility }\end{array}$ & & $144(38)^{c}$ & $128(34)$ \\
\hline \multicolumn{4}{|c|}{ Oak Ridge National Laboratory } \\
\hline $\begin{array}{l}\text { Sewage Treatment } \\
\text { Facility }\end{array}$ & $\begin{array}{l}\text { Extended aeration } \\
\text { activated sludge }\end{array}$ & $331(88)$ & $366(97)$ \\
\hline \multicolumn{4}{|c|}{ Oak Ridge K-25 Site } \\
\hline Bldg. K-1203 & Extended aeration & $415(110)$ & $415(110)$ \\
\hline $\begin{array}{l}\text { Central Neutralization } \\
\text { Facility }\end{array}$ & $\begin{array}{l}\text { Neutralization, } \\
\text { settling, and } \\
\text { filtration }\end{array}$ & $71(19)$ & $80(21)$ \\
\hline
\end{tabular}

\footnotetext{
${ }^{\circ}$ Projected.

${ }^{b}$ Steam Plant Wastewater Treatment Facility wastewater is considered Resource Conservation and Recovery Act hazardous before treatment, at which time it becomes nonhazardous.
}

FFY 1993 data.

to the clarifier. Here, the supernatant from the clarifier overflows the sawtooth weir and flows by gravity to the mixed bed filtration media for tertiary treatment. The bacteria and other solids settle out in the clarifier. This settled sludge is sent to the sludge-splitter box. Depending on operational requirements, some solids are returned to the extended aeration system or are dewatered in the drying beds. Supernatant from the mixed bed filter media is chlorinated in a chlorine contact chamber and discharged through a,Parshall flume to WOC. Accumulated sludge from the mixed bed filter media is backwashed and returned to the extended aerationmixed liquor tanks or the waste lagoon. The waste lagoon is an old oxidation pond that has been converted into a surge basin to collect wastewater overflow. The mixed media tertiary filtration system was introduced at a later date to provide additional treatment that would satisfy more stringent regulatory requirements.
Dry solids are loaded into B-25 boxes and transported as a suspect waste to the Interim Waste Management Facility at Solid Waste Storage Area 6. New methods of sanitary waste sludge handling being investigated by ORNL include land disposal in conjunction with the city of Oak Ridge sanitary waste sludge, filling of B-25 boxes with sludge from sludge-drying beds prior to tumulus storage, incineration at Scientific Ecology Group, and contracting with outside vendors for volume reduction. Other wastewaters that contain slight amounts of radioactive or hazardous materials, or may be periodically contaminated, are considered to be lowlevel process wastes (see Sect. 5).

\section{K-25 Site}

The K-25 Site operates one sanitary sewage treatment system, Building K-1203 (Fig. 8.8), that consists of an extended aeration treatment plant with a rated 

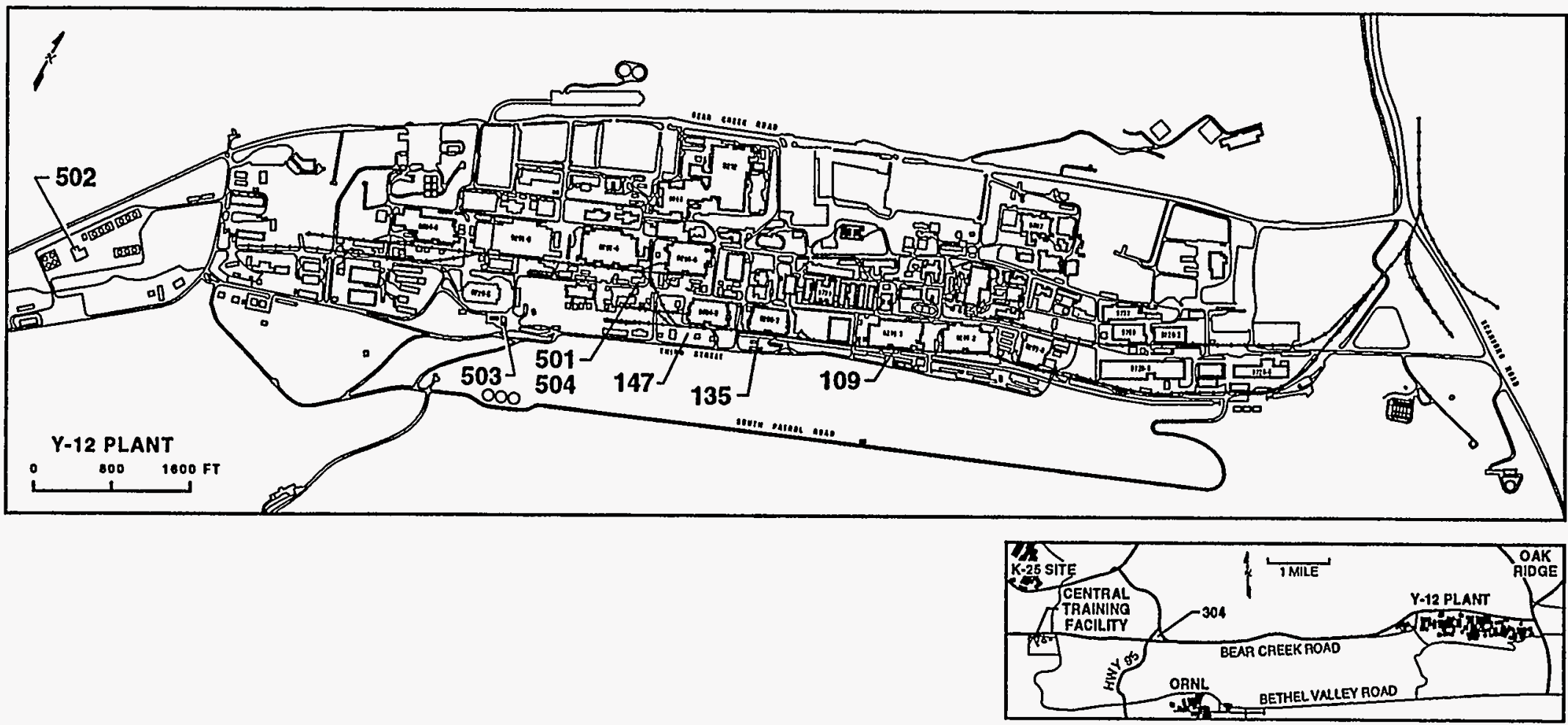

Fig. 8.2. National Pollutant Discharge Elimination System discharge locations at Oak Ridge Y-12 Plant. 


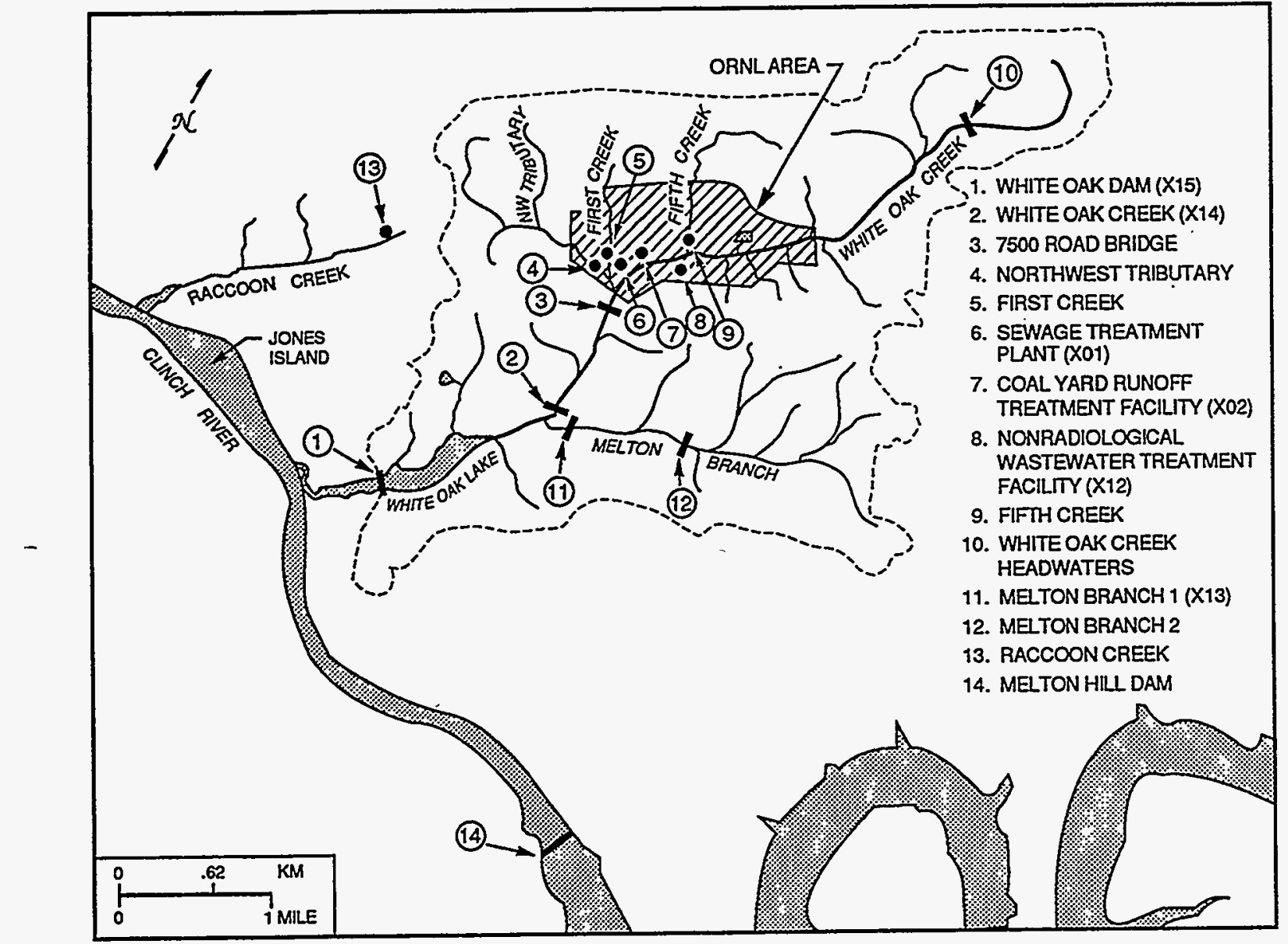

Fig. 8.3. ORNL surface water, NPDES, and reference sampling locations. Bars (I) indicate sampling locations that have weirs.

capacity of approximately 750 million $\mathrm{kg} /$ year ( 0.6 million gal/d) and a current demand for usage of approximately 400 million $\mathrm{kg} / \mathrm{year}(0.3$ million gal/d). Treated effluents from this system are discharged into Poplar Creek, which eventually runs into the Clinch River.

Surface runoff within the K-25 Site is drained by Mitchell Branch and Poplar Creek, both of which flow into the Clinch River. Improvements to the surface runoff system include drainage channeled by swales, where appropriate, rather than by piped drain systems. This technique is used to moderate stream flows by enhancing percolation to groundwater systems and reducing runoff quantity and rate. A storm sewer survey to characterize water quality was conducted in 1987, and results were incorporated into the NPDES permit renewal application. Funds have been requested for a comprehensive storm drain survey to be completed prior to submittal of the NPDES permit application in 1996.

The Central Neutralization Facility (CNF) is a multifaceted wastewater treatment facility that is physically separated into two individual units (Fig. 8.9): one is for hazardous and/or mixed waste streams; the other, for conventional liquid waste streams. The main purpose of the $\mathrm{CNF}$ is to treat wastewater to ensure compliance with NPDES discharge limits on $\mathrm{pH}$, heavy metal concentrations, and suspended solids. Building K-1435 TSCA scrubber solutions 


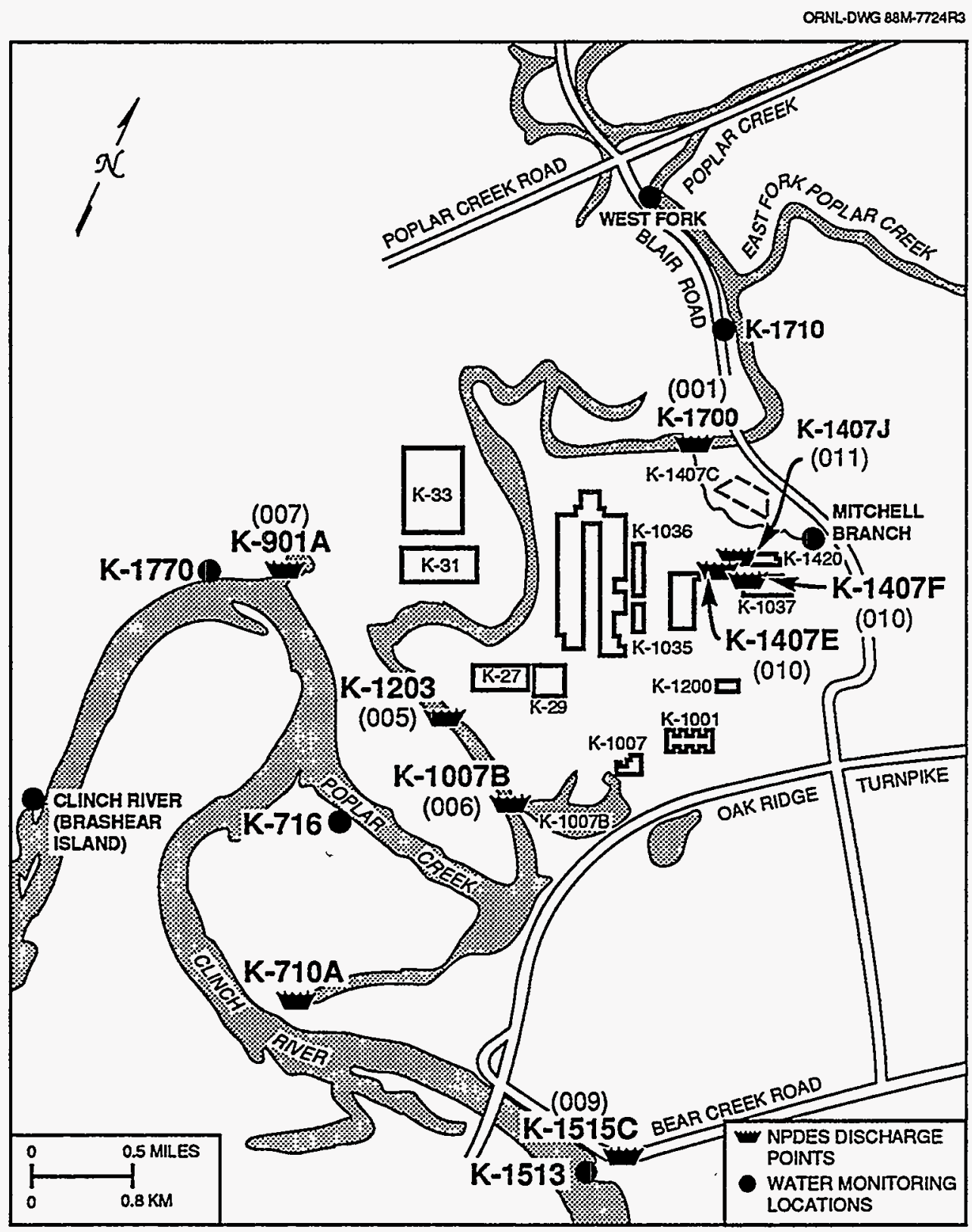

Fig. 8.4. National Pollutant. Discharge Elimination System discharge locations at the Oak Ridge K-25 Site.

and other miscellaneous waste streams are treated at the CNF. Nonhazardous waste streams treated (i.e., neutralized) through the CNF primarily include Building K-1501 Steam Plant effluents. All wastewaters treated at the CNF are discharged through the NPDES outfall at the K-1407-J basins.

All process water discharges from the plant pass through an NPDES monitoring point. All discharges from site storm drains are monitored in accordance with the requirements of the NPDES permit issued in October 1992.

No off-site treatment facilities exist for ORNL and K-25 Site industrial and sanitary wastes. The Y-12 Plant utilizes the city of Oak Ridge's sewage treatment facilities. 


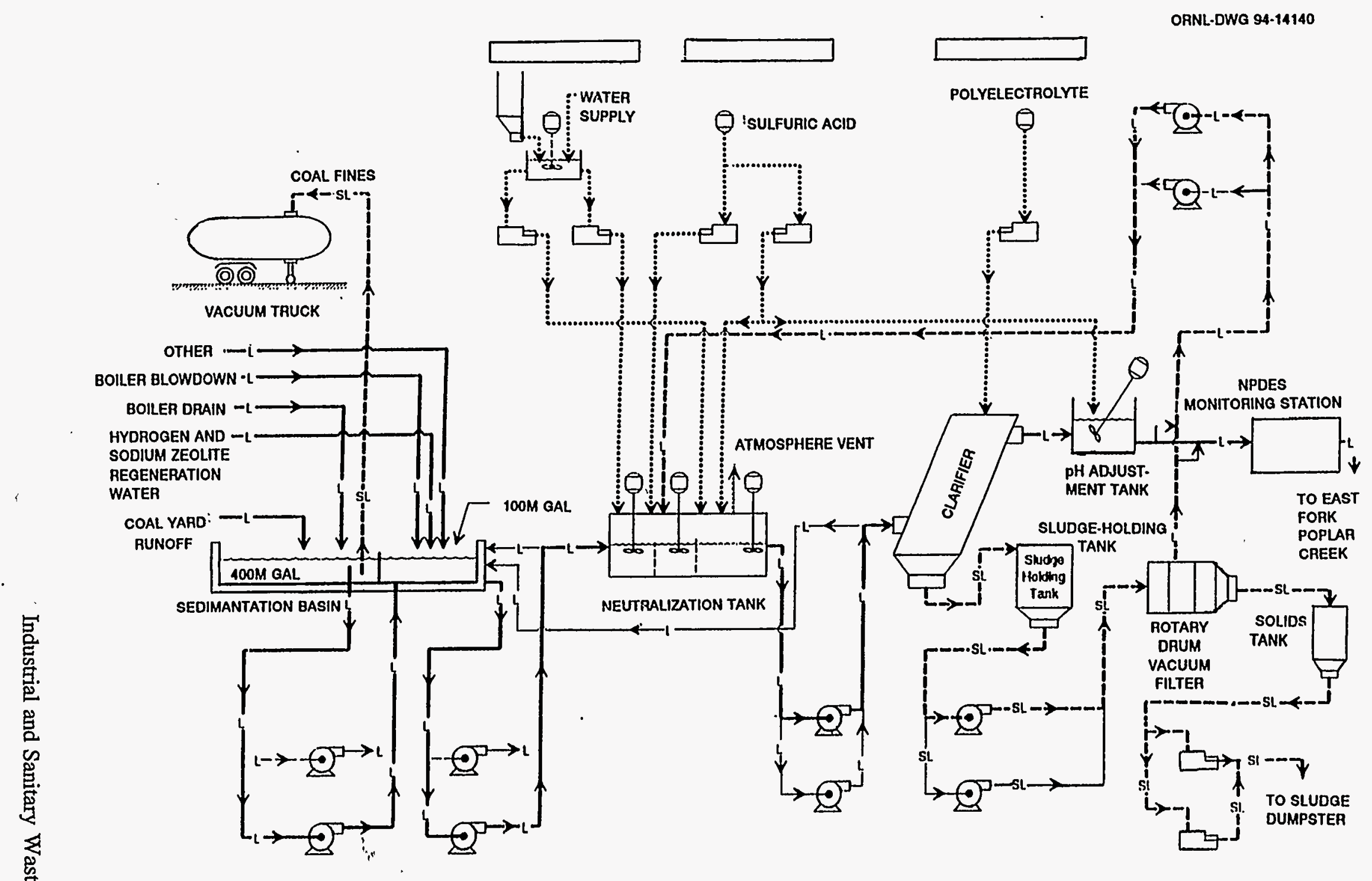

Fig. 8.5. Steam Plant Wastewater Treatment Facility process flow at the Oak Ridge X-12 Plant. Source: PAI Corporation Nov. 5, 1993. Description of Y-12 克 Plant Waste Management System 1993, Oak Ridge, Tenn. 


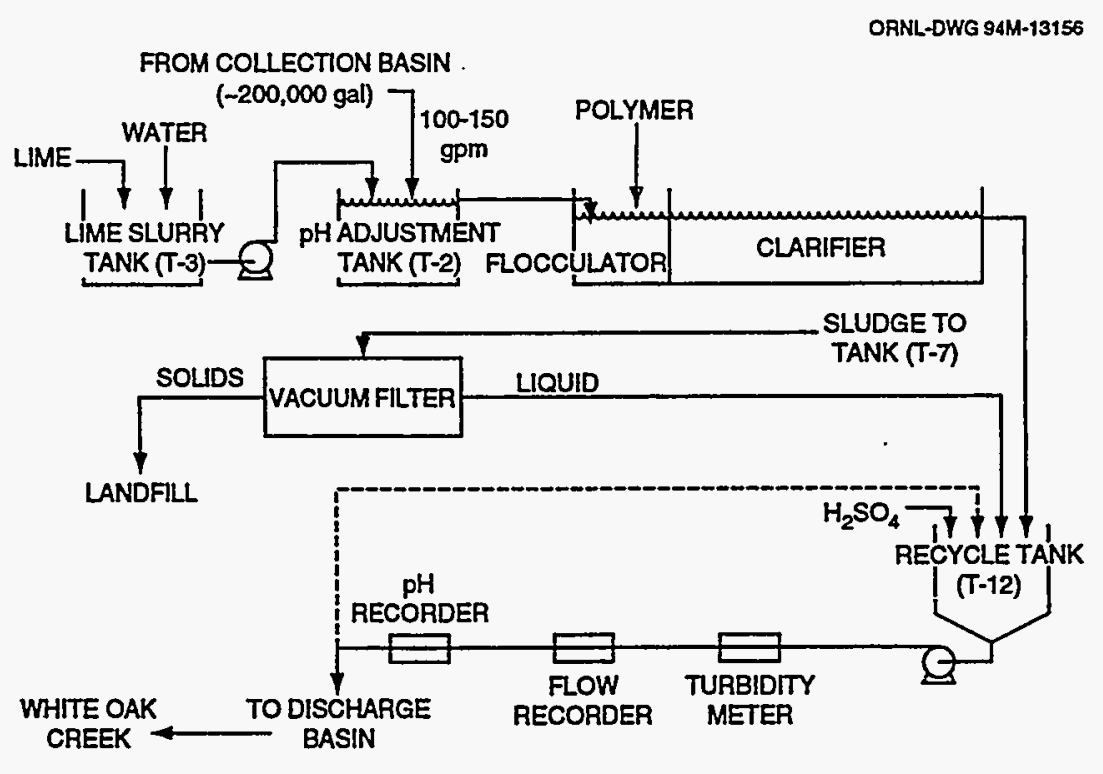

Fig. 8.6. Flow diagram of the Coal Yard Runoff Treatment Facility at Oak Ridge National Laboratory.

\section{Storage}

No dedicated storage facilities currently exist at the K-25 Site for industrial and sanitary solid wastes. Upon generation, sanitary solid waste is collected and transported for disposal at the Y-12 Plant ILF V, or CDL VI.

At the Y-12 Plant scrap metal is delivered to the Salvage Yard for storage. Temporary storage of industrial liquids is provided at the West Tank Farm Full Parking Lot. Wastewaters are temporarily stored there prior to treatment while awaiting analytical results. Contaminated scrap metal is stored as low-level waste. Temporary storage facilities for waste scrap metal and waste wood exist on-site at ORNL.

The New Salvage Yard (NSY) (Fig 8.10), operated by ESWMO-Y-12, is used for the storage and sale of surplus materials generated at the $\mathrm{Y}-12$ Plant that are not radioactively contaminated, are non-RCRA hazardous, and are unclassified. Activities associated with the NSY include the transporting, storage, segregation, and sale of surplus items. Items stored at the
NSY are considered unusable as originally intended and cannot be repaired or recycled in an economical manner within the Y-12 Plant. These items are stored at the NSY until they can be sold. The NSY is located on the north side of Bear Creek Road approximately one mile west of the intersection of Bear Creek Road and Old Bear Creek Road. Waste Acceptance Criteria have been published (Y-12 WMD April 1994).

The Y-12 Plant East End Waste Storage Facility, also known as the Car Wash Treatment Facility, provides a collection system for wastewater from carcleaning operations in and near Building 9712 (Fig. 8.11). The facility includes a sump pump, secondary. containment, storage tanks, and appropriate pumps and piping. There are two $113,562-\mathrm{L}$ (30,000-gal) storage tanks. One tank is located at the garage; the other, at the car wash. The tanks were put in place in 1984 and 1987. No wastewater treatment is performed; the facility collects, stores, samples, and discharges the wastewater. When the tanks become full, the wastewater is sampled and then disposed of 
ORNL DWG 85-932R

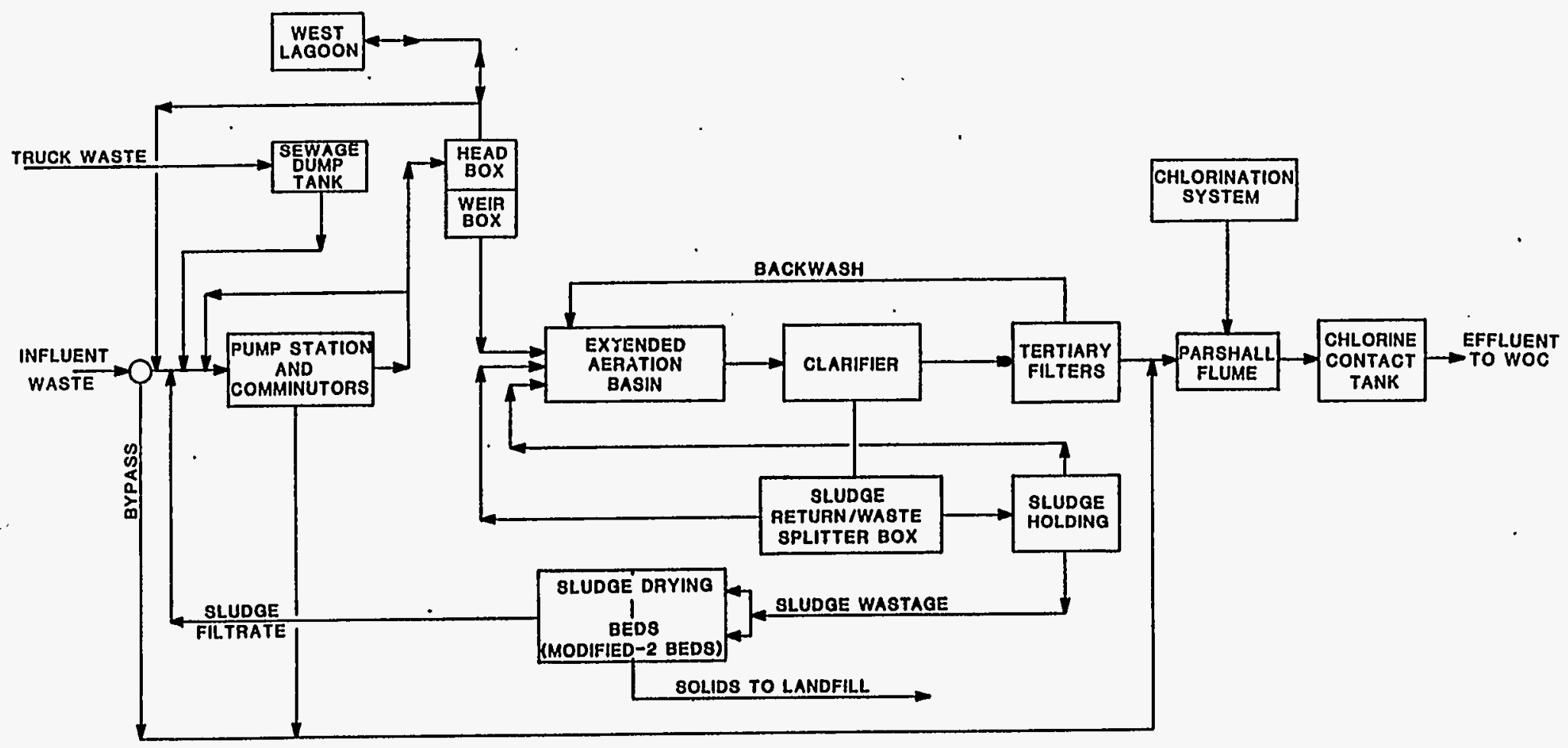

Fig. 8.7. Flow diagram for the Sewage Treatment Facility at Oak Ridge National Laboratory. 


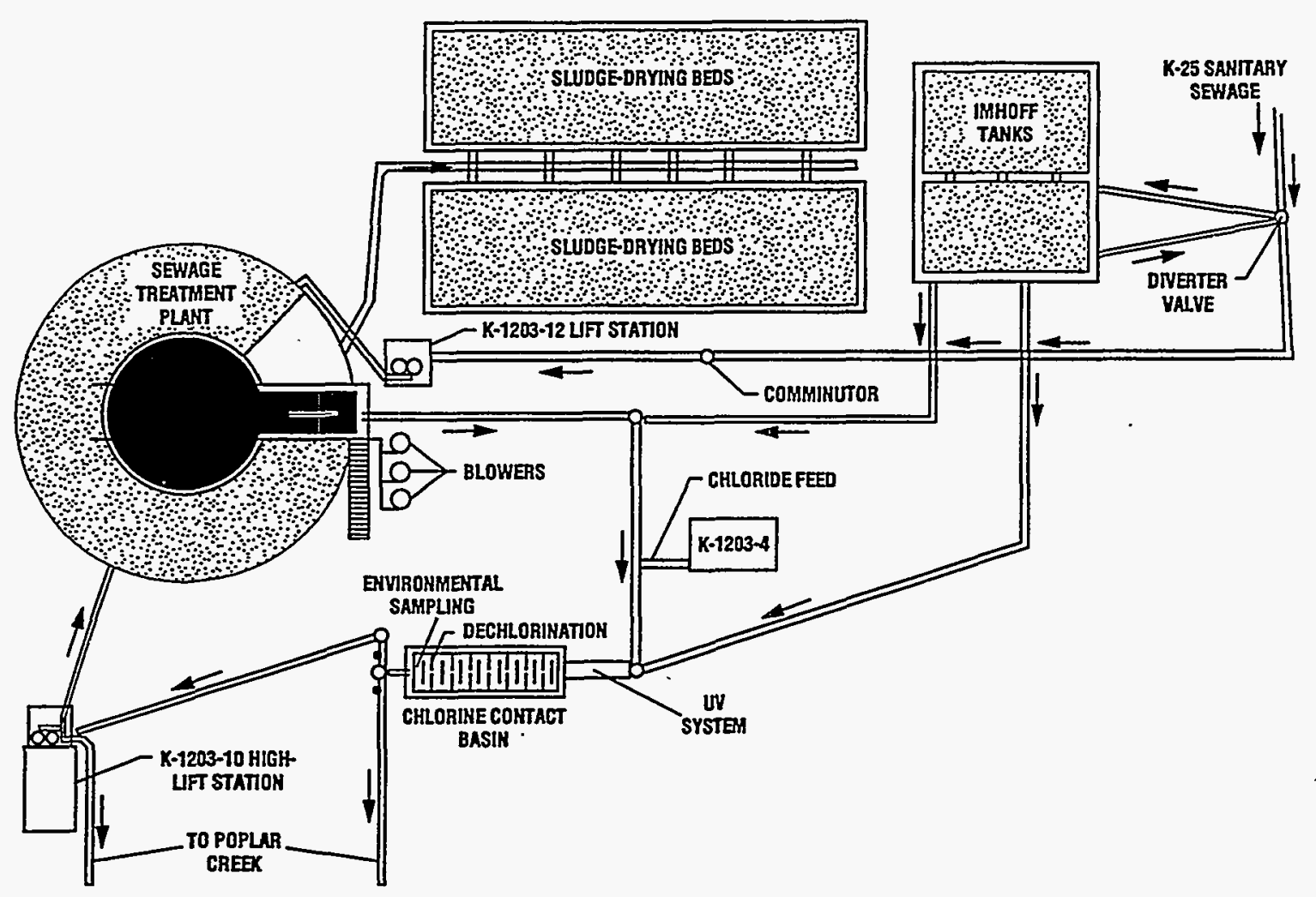

Fig. 8.8. Flow diagram for the Oak Ridge K-25 Site Sewage Treatment System (Building K-1203).

depending on the sample results. If acceptable, the wastewater is sent to the sanitary sewer. Otherwise, the wastewater is sent to the Central Pollution Control Facility.

Sanitary wastewaters on the ORR are collected, treated, and discharged according to the parameters set forth in the NPDES permit for each site.

\section{Disposal}

All industrial and sanitary solid waste streams on the ORR are disposed of at the Sanitary Landfill (SLF) II, ILF V, and the CDL VI located on Chestnut Ridge, south of the Y-12 Plant (Figs. 8.12 and 8.13) (Y-12 WMD September 1990; Y-12 WMD January 1994; Y-12 WMD September 1994). Classified industrial and sanitary solid wastes are disposed of in Industrial Waste Landfill IV. These waste streams are verified, either through analysis or generator knowledge, as meeting the SLF II and ILF V Waste Acceptance Criteria and are then transported for disposal.

Y-12 Plant procedures governing the disposal of industrial and sanitary wastes have been published (Y-12 WMD May 1994). Energy Systems Waste Management Organization also has operating procedures for each of its facilities. These procedures contain detailed Waste Acceptance Criteria that govern the disposal of industrial and sanitary waste. Cafeteria wastes are sent off-site from the Y-12 Plant to the Chestnut Ridge Landfill for final disposal. Steam Plant flyash is also sent to this landfill. 


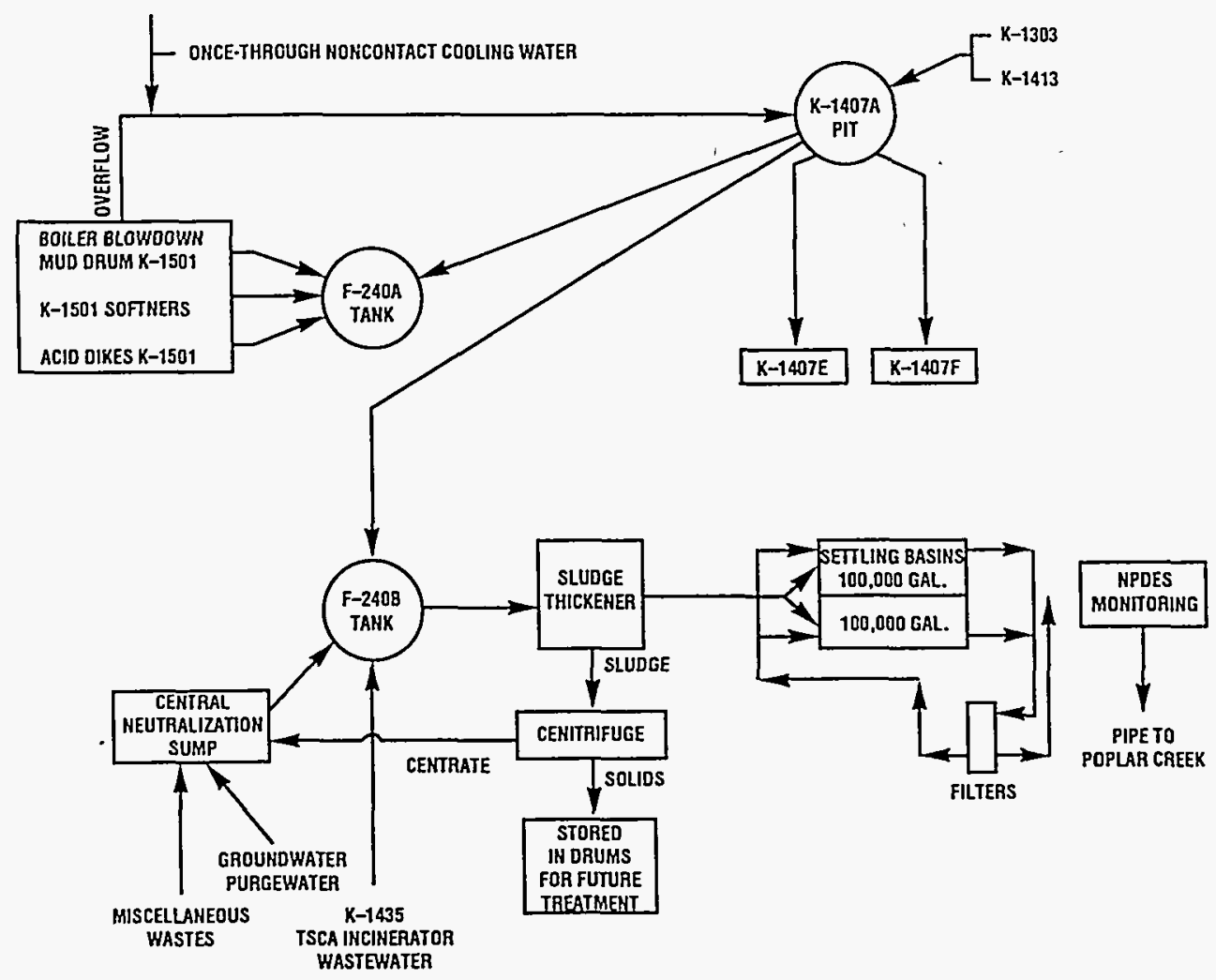

Fig. 8.9. Flow diagram for the Oak Ridge K-25 Site Central Neutralization Facility (CNF). Wastes for K-1303 and K-1413 were previously treated at the CNF. If these streams are generated in the future, they will be characterized also.

The only disposal facility on the K-25 Site for conventional waste is the Fill Area I located north of the main plant and west of Blair Road. This 2.8-ha (7-acre) grasscovered area is not in use but will be available for disposal of construction and demolition materials with approval from the TDEC.

The Chestnut Ridge Landfill is also used for disposal of K-25 Site cafeteria waste. Other conventional solid waste at the K-25 Site is collected and transported to landfills at the Y-12 Plant. Paper, cardboard, plastic, organics, and glass are disposed of at the ILF V, and construction materials are disposed of at CDL VI. Cardboard and paper are recycled when feasible. Asbestos and fiberglass wastes are currently disposed of at SLF II but will be disposed of at ILF V as soon as SLF II is closed, which will probably occur in FY 1995. Also, spoils materials (e.g., rock, concrete, and brick) currently disposed of at SLF II will be disposed of at CDL VI. Details of the Waste Management Program for industrial and sanitary wastes at the Y-12 Plant, ORNL, and the K-25 Site have been published (WMRAD July 17, 1992; K-25 WMD October 1994; Y-12 WMD May 1994). 


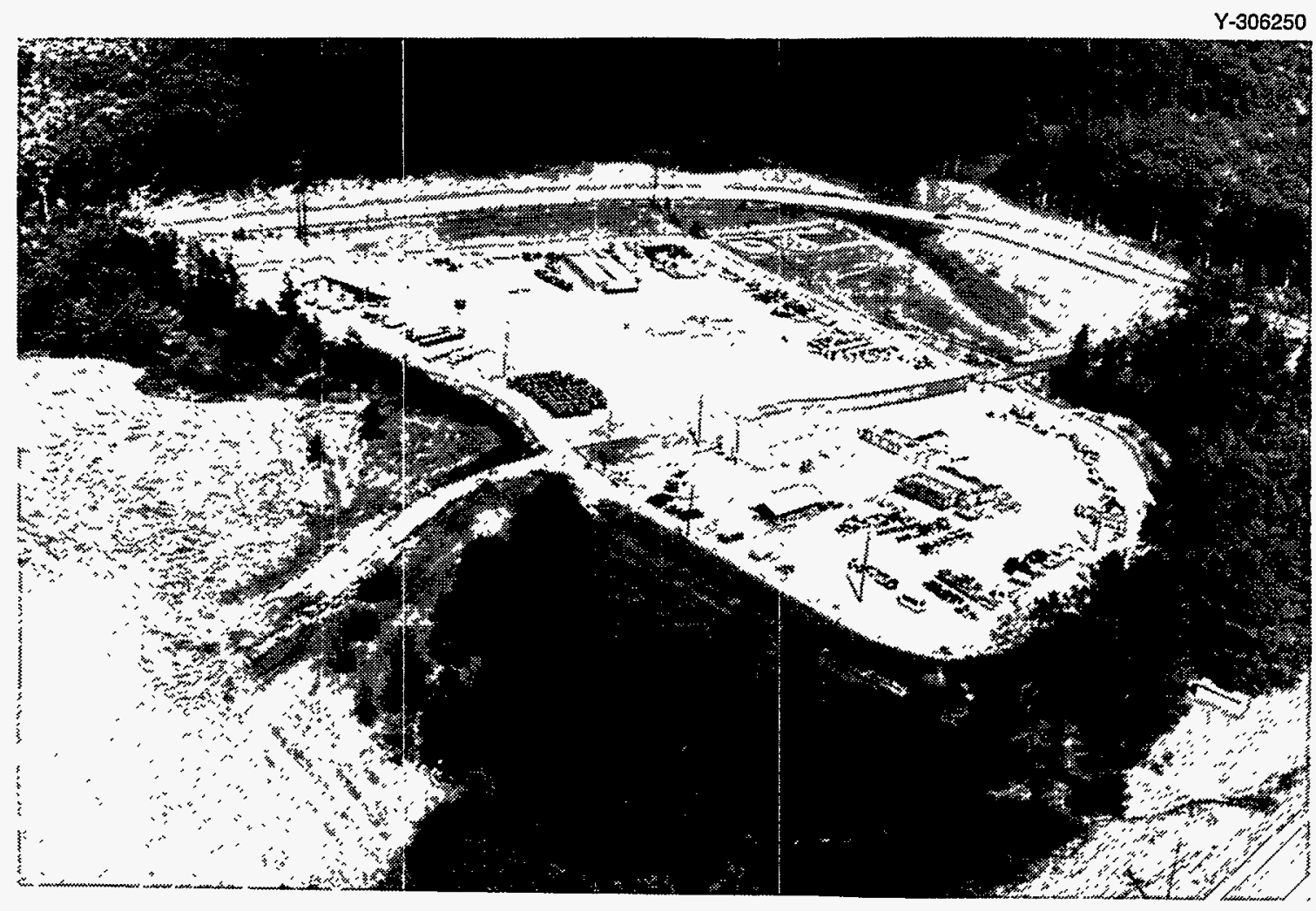

Fig. 8.10. The New Salvage Yard at the Oak Ridge Y-12 Plant.

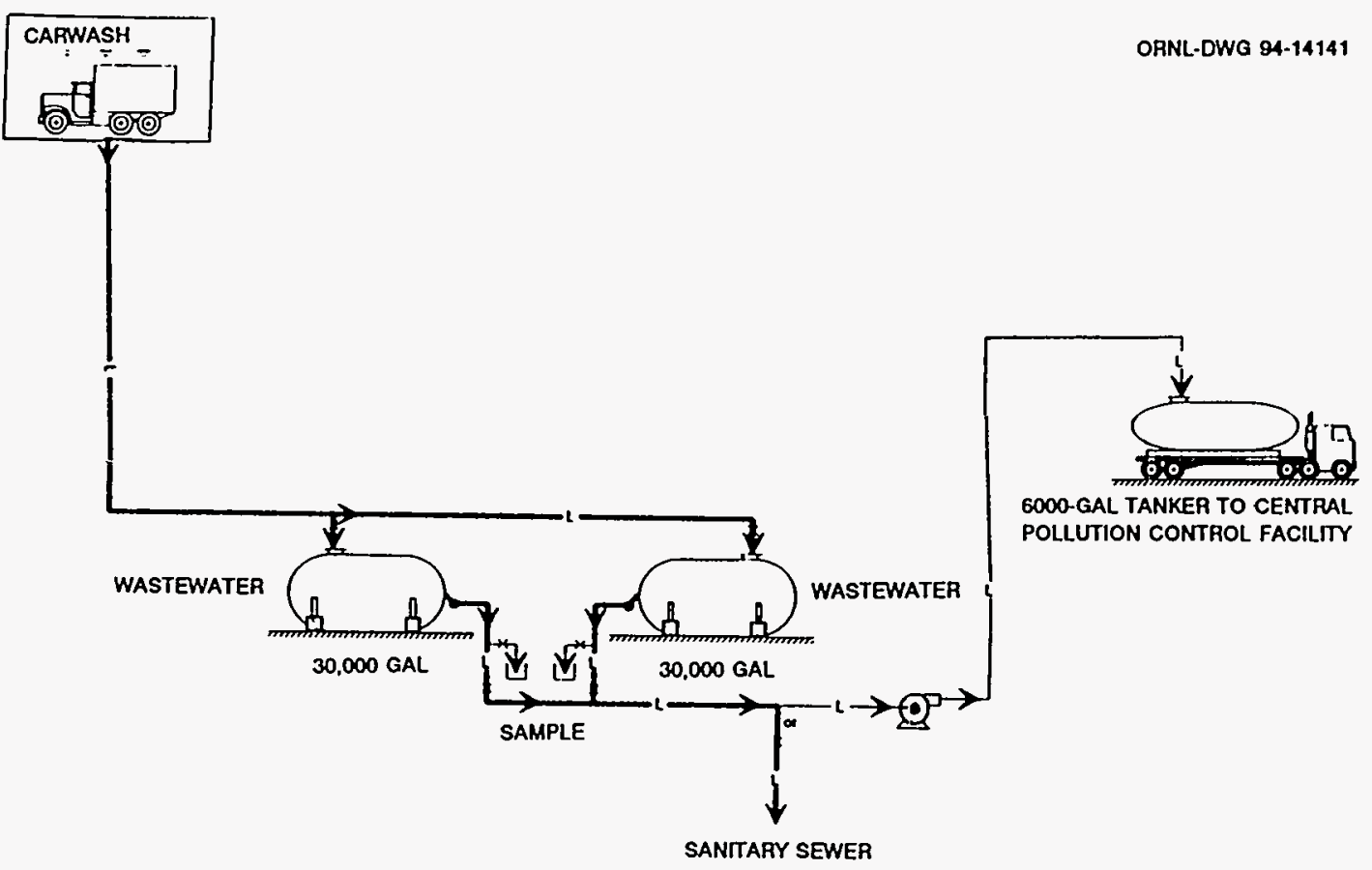

Fig. 8.11. East End Waste Facility at the Oak Ridge Y-12 Plant.

8-16 Oak Ridge Reservation Waste Management Plan 


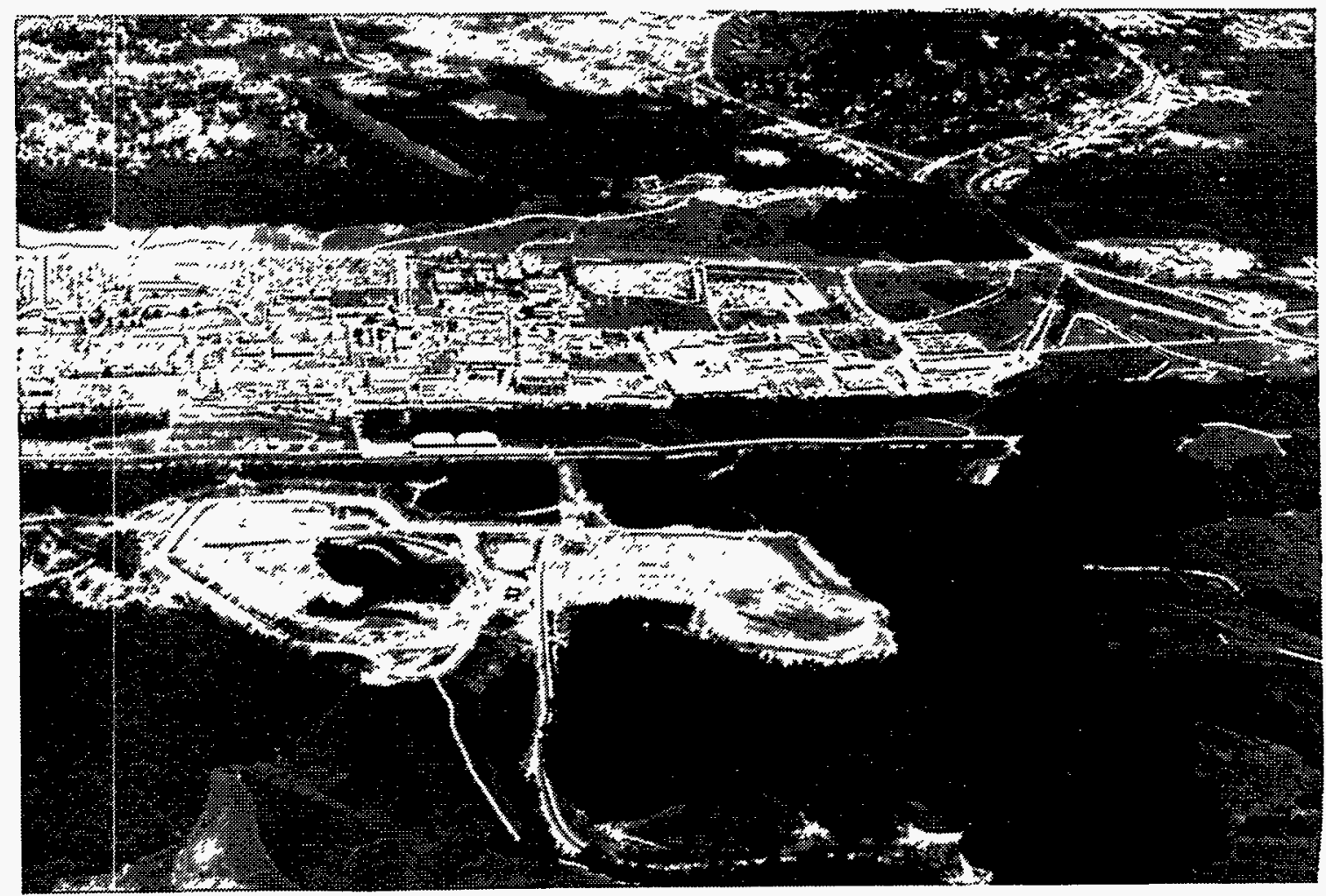

Fig. 8.12. Industrial Landfill $V$ at the Oak Ridge Y-12 Plant.

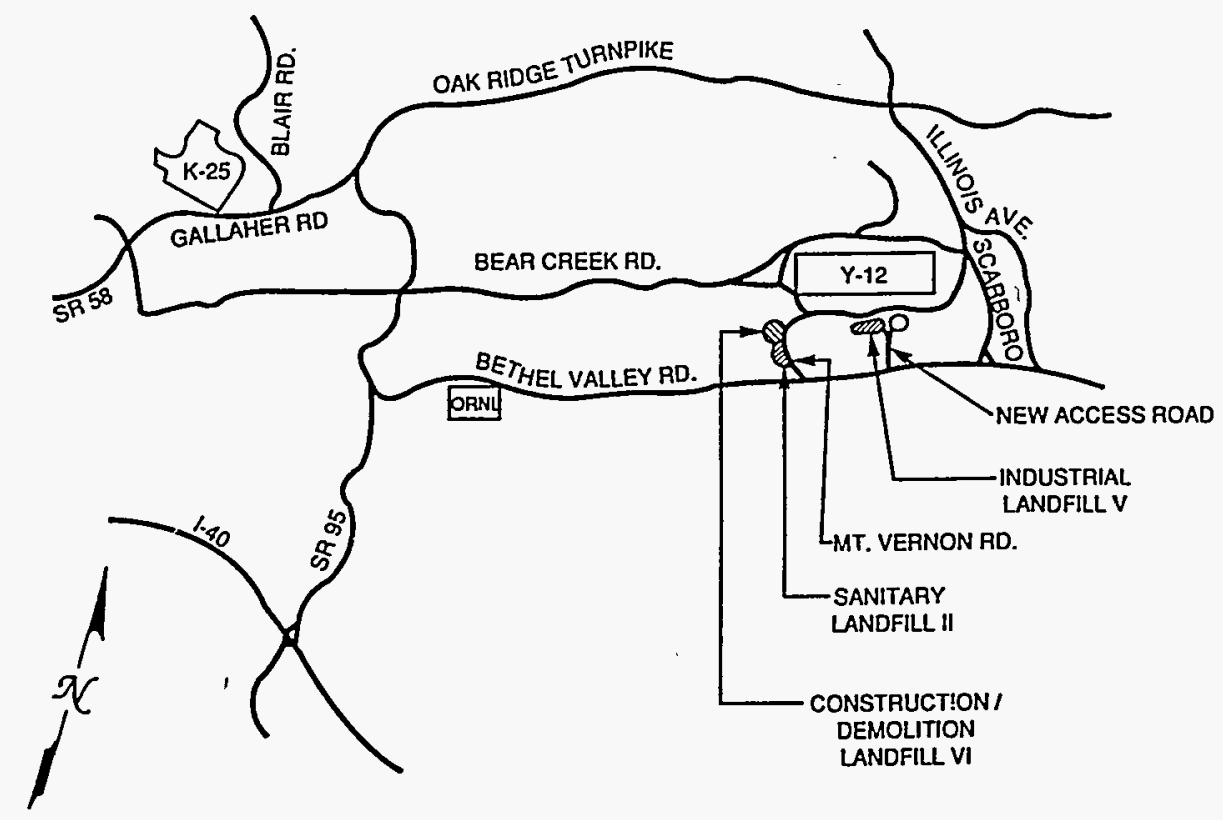

Fig. 8.13. Industrial Landfills II and V and Construction/Demolition Landfill VI locations near the Oak Ridge Y-12 Plant. 
The new industrial and sanitary waste disposal capacity for ORR is about 93,500 $\mathrm{m}^{3}\left(3.3 \times 10^{6} \mathrm{ft}^{3}\right)$. As is shown in Table 8.4 , the total disposal capacity is provided by the ILF $V$ and CDL VI facilities. The ILF V is a Class II facility, and the CDL VI is a Class IV facility according to state of Tennessee regulations for solid waste disposal (Table 8.1).

Tables 8.5 and 8.6 list the waste types to be disposed of at these two facilities. Table 8.7 lists discharges not considered industrial or sanitary waste.

Appendix B shows the current operational status of all waste treatment, storage, and disposal facilities on the ORR.

\section{Future Plans}

\section{Treatment}

\section{Y-12 Plant}

See Appendix C for a list of treatment facilities planned.

ORNL

See Appendix $\mathrm{C}$ for a list of treatment facilities planned.
K-25 Site

CNF Pipeline Extension Project. To comply with the NPDES permit requirements, the CNF pipeline is to be extended to change the discharge point to the Clinch River. The estimated cost is approximately $\$ 1.1 \mathrm{M}$; the estimated completion date is 1995 .

Proposed CNF Upgrade. If approved, the CNF will be upgraded to treat the types and quantities of wastes projected for the future, to ensure compliance with increasingly restrictive regulations, and to meet NPDES permit requirements. The estimated cost is about $\$ 20 \mathrm{M}$; construction is proposed to begin in 1997.

\section{Storage}

\section{Y-12 Plant}

At present, there are no new industrial and sanitary waste storage facilities planned for the Y-12 Plant.

ORNL

There are no plans for on-site storage of sanitary or industrial wastes at ORNL.

Table 8.4. Summary of industrial and sanitary waste disposal capacity on the Oak Ridge Reservation

\begin{tabular}{lll}
\hline & \multicolumn{1}{c}{$\begin{array}{c}\text { Industrial } \\
\text { Landfill V }\end{array}$} & \multicolumn{1}{c}{$\begin{array}{c}\text { Construction } \\
\text { Demolition } \\
\text { Landfill VI }\end{array}$} \\
\hline $\begin{array}{l}\text { Disposal class } \\
\text { Design capacity, } \mathrm{m}^{3}\left(\mathrm{yd}^{3}\right)\end{array}$ & $1,1 \times 10^{6}\left(1.5 \times 10^{6}\right)$ & $1.19 \times 10^{5}\left(1.55 \times 10^{5}\right)$ \\
$\begin{array}{l}\text { Beneficial occupancy } \\
\begin{array}{l}\text { Projected capacity utilization rate } \\
\text { (yd } 3 \text { /year) }\end{array}\end{array}$ & 51,875 & December 1993 \\
Design life (years) & 43.1 & 36,000 \\
\hline
\end{tabular}


Table 8.5. Waste types for disposal at the Y-12 Industrial Landfill V

\begin{tabular}{|c|c|}
\hline Waste group & Description \\
\hline Primary waste stream & $\begin{array}{l}\text { Paper and cardboard } \\
\text { Plastic and rubber } \\
\text { Animal bedding } \\
\text { Organic garbage } \\
\text { Textile products } \\
\text { Empty containers (not otherwise listed as special wastes) } \\
\text { Glass (not otherwise listed as other wastes) } \\
\text { Special wastes (categories of special wastes will be subject } \\
\text { to approval by the TDECDSWM before acceptance at the ILFV) } \\
\text { Noninfectious institutional waste } \\
\text { Treated medical waste } \\
\text { Miscellaneous metals }\end{array}$ \\
\hline Secondary waste stream & $\begin{array}{l}\text { Brick } \\
\text { Concrete } \\
\text { Masonry materials } \\
\text { Lumber } \\
\text { Paving materials } \\
\text { Sheetrock/gypsum } \\
\text { Roofing materials } \\
\text { Polyethylene sheeting } \\
\text { Rebar (embedded in concrete) } \\
\text { Vitrified clay materials (e.g., tile, pipe, block) } \\
\text { Insulation materials (e.g., fiberglass, rockwool, styrofoam) } \\
\text { Building siding materials } \\
\text { Miscellaneous metals associated with building demolition } \\
\text { Window and door glass associated with building demolition } \\
\text { Miscellaneous building demolition materials } \\
\text { Soil } \\
\text { Rock } \\
\text { Gravel } \\
\text { Road spoil } \\
\text { PVC pipe } \\
\text { Paneling } \\
\text { Flooring }\end{array}$ \\
\hline Special waste & $\begin{array}{l}\text { Asbestos waste } \\
\text { Baled waste } \\
\text { Beryllium oxide wastes } \\
\text { Bottom ash (interim), Y-12 Plant } \\
\text { Coal pile runoff sludge, K-25 Site } \\
\text { Coal yard runoff basin sludge, Oak Ridge National Laboratory } \\
\text { Dead animals } \\
\text { Empty aerosol cans and pressurized gas cylinders } \\
\text { Empty hazardous material containers } \\
\text { Empty paint cans } \\
\text { Empty pesticide containers } \\
\text { Fly ash, Oak Ridge National Laboratory } \\
\text { Fly ash, Y-12 Plant } \\
\text { Petroleum-product contaminated soil } \\
\text { Steam Plant Wastewater Treatment Facility sludge, Y-12 Plant }\end{array}$ \\
\hline Other waste & Glass \\
\hline
\end{tabular}


Table 8.6. Waste types for disposal at the Y-12 Plant Construction/Demolition Landfill VI (CDL VI)

\begin{tabular}{|c|c|}
\hline Waste group & Description \\
\hline Construction/demolition waste & $\begin{array}{l}\text { Brick } \\
\text { Concrete } \\
\text { Masonry materials } \\
\text { Lumber } \\
\text { Paving materials } \\
\text { Sheetrock/gypsum } \\
\text { Roofing materials } \\
\text { Polyethylene sheeting } \\
\text { Rebar (embedded in concrete) } \\
\text { Vitrified clay materials (e.g., pipe and block) } \\
\text { Insulation materials (e.g., fiberglass, rockwool, and styrofoam) } \\
\text { Building siding materials } \\
\text { Miscellaneous metals associated with building demolition } \\
\text { Window and door glass associated with building demolition } \\
\text { Miscellaneous building demolition materials } \\
\text { Special wastes (categories of special wastes will be subject to approval } \\
\text { by the TDEC/Division of Solid Waste Management before acceptance } \\
\text { at the CDL VI.) } \\
\text { Soil } \\
\text { Rock } \\
\text { Gravel } \\
\text { Road spoil } \\
\text { PVC pipe } \\
\text { Paneling } \\
\text { Flooring }\end{array}$ \\
\hline Inert waste & $\begin{array}{l}\text { Sediment from clean-out of siltation ponds for the facility } \\
\text { Wood pallets }\end{array}$ \\
\hline Special waste & $\begin{array}{l}\text { Bottom ash (interim), Y-12 Plant } \\
\text { Fly ash, Oak Ridge National Laboratory } \\
\text { Fly ash, Y-12 Plant }\end{array}$ \\
\hline
\end{tabular}

$K-25$ Site

There are no plans for constructing storage facilities at the $\mathrm{K}-25$ Site for industrial and sanitary solid wastes.

\section{Disposal}

\section{Y-12 Plant}

See Appendix C for a list of disposal facilities planned.
ORNL

At present, no disposal facilities are planned.

\section{K-25 Site}

At present, no disposal facilities are planned.

Appendix $C$ lists proposed line items and general plant projects for industrial and sanitary waste facilities on the ORR.

Appendix D provides DOE Order 5820.2A compliance summaries for each of the three ORR installations. 
Table 8.7. Discharges on the Oak Ridge Reservation not considered industrial or sanitary waste

\begin{tabular}{|c|c|}
\hline Waste type & Description \\
\hline \multicolumn{2}{|r|}{ Oak Ridge Y-12 Plant } \\
\hline Stormwater runoff & $\begin{array}{l}\text { All storm sewers carrying stormwater runoff from the Y-12 Plant to the East Fork } \\
\text { Poplar Creek are permitted by the Y-12 Plant National Pollutant Discharge } \\
\text { Elimination System (NPDES) permit. Sources primarily originate from rainwater } \\
\text { falling on parking lots and rooftops. }\end{array}$ \\
\hline \multicolumn{2}{|r|}{ Oak Ridge National Laboratory } \\
\hline Stormwater runoff & $\begin{array}{l}\text { Approximately } 130 \text { stormwater discharges at ORNL have NPDES discharge permits. } \\
\text { These discharges all empty into receiving streams. Their sources originate from } \\
\text { storm drains, parking lot runoff, roof drains, once-through cooling, and process and } \\
\text { laboratory drains. These discharges require sampling and analysis to verify that each } \\
\text { discharge is within NPDES permit limits }\end{array}$ \\
\hline $\begin{array}{l}\text { Once-through } \\
\text { cooling water }\end{array}$ & $\begin{array}{l}\text { Once-through cooling water for air compressors and other water-cooling systems at } \\
\text { ORNL is dechlorinated in a large percentage of cases. Following dechlorination, the } \\
\text { water is discharged as stormwater to the receiving stream }\end{array}$ \\
\hline $\begin{array}{l}\text { Cooling tower } \\
\text { blowdown }\end{array}$ & $\begin{array}{l}\text { Cooling tower blowdown contains an assortment of biocides, corrosion inhibitors, } \\
\text { and scale-preventive chemicals. Regulatory agencies have permitted ORNL to } \\
\text { discharge cooling tower blowdown directly to the receiving streams }\end{array}$ \\
\hline $\begin{array}{l}\text { Effluent from } \\
\text { Coal Yard Runoff } \\
\text { Treatment Facility }\end{array}$ & $\begin{array}{l}\text { Wastewaters from coal yard runoff, including sulfuric acid tank-diked area runoff, } \\
\text { Steam Plant boiler blowdown, and water softener regenerant are treated. The treated } \\
\text { clarifier effluent, plus the supernatant from the vacuum filter, flows by gravity to } \\
\text { the lower holding pond and into White Oak Creek via an overflow wier. This liquid } \\
\text { effluent is considered neither an industrial wastewater nor a sanitary wastewater }\end{array}$ \\
\hline \multicolumn{2}{|r|}{ Oak Ridge K-25 Site } \\
\hline Stormwater runoff & $\begin{array}{l}\text { At the K-25 Site, } 136 \text { storm drain outfalls are grouped into four categories based on } \\
\text { the types of wastewater or stormwater being discharged through the drains. Their } \\
\text { sources originate from cooling water discharges, building roof drains, parking lots, } \\
\text { grassy areas, cylinder yards, chemical storage areas, and switchyards. These } \\
\text { discharges require sampling and analysis on specified schedules to verify that each } \\
\text { discharge is within the NPDES permit limits. }\end{array}$ \\
\hline
\end{tabular}

\section{Waste Certification}

\section{Y-12 Plant}

There is no specific certification for industrial waste or sanitary wastewater at the Y-12 Plant.

\section{ORNL}

Waste Operations, the ESWMO-ORNL environmental protection officer, and the Radiological Controls Group survey these areas for improper disposal of RCRA and radiological items.

\section{K-25 Site}

Relative to solid conventional wastes, requirements are in accordance with the landfill permits existing for the Y-12 Plant sanitary landfills. Radioactive waste defined as having greater than $32 \mathrm{pCi}$ of uranium contamination per gram of waste is specifically excluded from disposal. The K-25 Site monitors surficial contamination in accordance with the Y-12 Plant landfill contamination limits. The Y-12 Plant is responsible for all necessary environmental monitoring to meet applicable and governing regulations for solid waste. 
Conventional liquid wastes at the $\mathrm{K}-25$ Site are collected, treated, and discharged according to the parameters set forth in the NPDES permit for the site. All process water discharges from the $\mathrm{K}-25$ Site, including discharges from site storm drains, pass through an NPDES monitoring point and are sampled and analyzed in accordance with the permit requirements.

\section{Waste Minimization/Pollution Prevention}

\section{Y-12 Plant}

The Y-12 Plant currently recovers or recycles the following: scrap metal, ethylene glycol, asphalt, toner cartridges, aluminum beverage cans, silver recovery, mixed waste paper, file folder waste, and cardboard. Specifically, DP had several accomplishments in the area of solid sanitary waste for CY 1993 (Flowers, P. A. et al. October 1994).

In off-site beneficial use/reuse activities beginning in 1993, a replacement toner cartridge was found that comes with three additional refills in its toner cartridge box, which reduces the frequency of sending the cartridges off-site for recycling. In CY 1993 a total of 1.57 metric tons $(t)$ of batteries were recycled, and a total of $12.5 \mathrm{t}$ of tires were recycled for retread. Also, a tube grinder was purchased and is used to recycle wood at the Y-12 Plant. All noncontaminated, non-pressure-treated scrap wood is processed through a 3-m (10-ft) tube grinder to produce mulch, which reduces landscaping costs, improves site appearance, and drastically increases the life of the landfill.

\section{ORNL}

Conservation and avoidance of disposal costs are motivators for recycling through reuse, swapping, off-site sales, and recovery. Throughout ORNL, recycling methods are encouraged and rewarded through the incentive programs.

Corrugated boxboard, white paper, aluminum cans, phone books, and toner cartridges are recycled at ORNL. Items must be from (1) areas not posted as radiological areas or (2) areas having prior statistically based radiation surveys and approval from the site radiological protection organization. The market value of white office paper covers the cost of collection and transportation. The cardboard is sold for $50 \%$ of the official board price, which has averaged $\$ 12.50 /$ ton. Proceeds from sales of aluminum cans collected for recycling are donated to a local charity. (Aluminum cans are the property of employees purchasing beverages from the vending machines; they are not the property of DOE.)

As of March 1994, $4627 \mathrm{~kg}(10,200 \mathrm{lb})$ of phone books and 1077 toner cartridges have been sent for recycle. Diversion of these streams from the landfill has been a high priority.

The primary value of the paper, cardboard, and aluminum recycling programs is not the income from the sale of the recyclable material but the unused landfill space. The cost of operation of the Y-12 Centralized Sanitary Landfill is approximately $\$ 20 / \mathrm{yd}^{3}$. (This amount represents only landfill operation costs; it does not include collection or transportation costs.)

Until recently, solid sanitary pollution prevention and waste reduction had not been as high a priority as it had been for radioactive and hazardous waste because potential hazards to human health and the environment and the cost for disposal per unit volume were significantly less.

However, sanitary waste disposal costs will increase significantly as a result of transportation, emplacement, monitoring, and new site development costs. Economic incentives to reduce sanitary waste volume will continue to grow rapidly, especially in the area of bulky general refuse. Therefore, reuse and recycling of other sanitary waste 
streams, such as wood, are also being evaluated to further reduce the sanitary waste stream at ORNL.

The Knoxville Recycling Coalition is used by ORNL for its white paper recycling program. Cardboard is compacted on-site before being recycled.

\section{K-25 Site}

Aluminum cans, cardboard, phone books, toner cartridges, lead-acid batteries, cafeteria cooking oil, and file folder wastes are recycled. Recycling programs are planned for used oils, antifreeze, glass, and styrofoam wastes. Scrap metal, tires, computer cards and printer paper, film, and office furniture are sold for further use or recycled.

\section{References}

Flowers, P. A. et al. October 1994. 1993 Annual Report on Waste Generation and Waste Minimization Progress as Required by DOE Order 5400.1, Y/WM-208, Martin Marietta Energy Systems.

K-25 WMD (K-25 Site Waste Management Division) October 1994. Management of Sanitary (Commercial) Waste and Construction and Demolition Waste, SPP-4608, Martin Marietta Energy Systems.
WMRAD (ORNL Waste Management and Remedial Action Division) July 17, 1992. ORNL Industrial Waste Control for SLF II Wastes, EPM 6.1, in ORNL Environmental Protection Manual, Martin Marietta Energy Systems, Oak Ridge Natl. Lab.

Y-12 WMD (Y-12 Waste Management Division) September 1990. Y-12 Centralized Sanitary Landfill II, Y5041-WS-017, Martin Marietta Energy Systems.

Y-12 WMD (Y-12 Waste Management Division) September 1992. Baling Operation-Bldg. 9720-25, Y50-41-WS043, Martin Marietta Energy Systems.

Y-12 WMD (Y-12 Waste Management Division) January 1994. Industrial Landfill V, Y50-41-WS-070, Martin Marietta Energy Systems.

Y-12 WMD April 1994. Classified Waste

Storage Facility, Bldg. 9720-25, Y50-41-WS-029, Martin Marietta Energy Systems.

Y-12 WMD (Y-12 Waste Management

Division) September 1994.

Construction/Demolition Landfill VI, Y50-41-WS-014, Martin Marietta Energy Systems.

Y-12 WM/D\&D (Y-12 Waste Management/Decontamination and Decommissioning Organization) May 1994. Transfer, Storage, or Disposal of Waste, 70-903, Martin Marietta Energy Systems. 
3a. Safety Analysis Reports issued and planned

3b(3)c. Documents supporting periodic assessment of waste storage tank integrity

$3 \mathrm{~b}(4)$. Documentation of contingency actions of past year; corrective actions schedule

3c(3). TRU Waste Certification Plan

$3 g(2)(h)$. Closure plan for TRU interim storage facilities

\section{Chapter I. High-Level Waste}

\section{Oak Ridge Y-12 Plant}

Not applicable.

Oak Ridge National Laboratory

Oak Ridge K-25 Site

Oak Ridge Y-12 Plant

Oak Ridge National Laboratory

Oak Ridge K-25 Site

Oak Ridge $Y-12$ Plant

Oak Ridge National Laboratory

Oak Ridge K-25 Site

Chapter II. Transuranic Waste

Oak Ridge Y-12 Plant

Oak Ridge National Laboratory

\section{Oak Ridge K-25 Site}

Oak Ridge Y-12 Plant

Oak Ridge National Laboratory

Not applicable.

Not applicable.

Not applicable.

Not applicable.

Not applicable.

Not applicable.

Not applicable.

Not applicable.

\section{Not applicable.} Lab.

Not applicable.

Not applicable.
WMRAD June 1992. Oak Ridge National Laboratory Contact-Handled Transuranic Waste Certification Program Plan, WMRA-WMPC-402,

Martin Marietta Energy Systems, Oak Ridge Natl. Lab.

WMRAD Oct. 16, 1992. Waste Acceptance Criteria for Contact-Handled Transuranic and Mixed Oxide Wastes from Nuclear Fuel Services, Inc., WMRA-WMPC-106, Martin Marietta Energy Systems, Oak Ridge Natl.

International Technology Corporation September 1991. RCRA Closure

Plan, Transuranic Retrievable Drum Storage Facility, Building 7826,

Oak Ridge National Laboratory (TN 1890090003), Martin Marietta

Energy Systems, Oak Ridge Natl. Lab. 
Principal documentation requirements identified in DOE Order $5820.2 \mathrm{~A}$ (continued)

International Technology Corporation September 1991. RCRA Closure Plan, Transuranic Retrievable Drum Storage Facility, Building 7834, Oak Ridge National Laboratory (TN 1890090003), Martin Marietta Energy Systems, Oak Ridge Natl. Lab.

Environmental Compliance and Health Protection Division June 1989. Part B RCRA Permit Application for Existing Remote-Handled

Transuranic Concrete Cask Storage Facility, Building 7855, rev. 1, Martin Marietta Energy Systems, Oak Ridge Natl. Lab.

Oak Ridge K-25 Site

3(i). Documents developed under Buried TRU-Contaminated Waste Program
Oak Ridge Y-12 Plant

Oak Ridge National Laboratory

\section{Oak Ridge K-25 Site}

Not applicable.

Not applicable.

Trabalka, J. R. July 1987. Buried TRU Waste and TRU-Contaminated Soils and ORNL Remedial Action Program Sites; Program Strategy and Long-Range Planning, ORNL/RAP-8, Martin Marietta Energy Systems, Oak Ridge Natl. Lab.

WMRAD September 1987. Buried TRU Waste and TRU-Contaminated Soils at Oak Ridge National Laboratory, ORNL/RAP-24, Martin Marietta Energy Systems, Oak Ridge Natl. Lab.

Not applicable.
$3 b(1)$. Radiological Performance Assessment of disposal facilities

3e(2). Waste Acceptance Criteria for each LLW TSD facility

\section{Chapter III. Low-Level Waste}

Oak Ridge Y-12 Plant

Oak Ridge National Laboratory

Oak Ridge K-25 Site

Oak Ridge Reservation
The Y-12 Plant has no LLW disposal facilities.

WMR:AD February 1994. Performance Assessment for Continuing and Future Operations at SWSA 6, ORNL-6783, Martin Marietta Energy Systems, Oak Ridge Natl. Lab.

The K-25 Site has no disposal facilities.

ESWMO-Central July 1994. Waste Acceptance Criteria for the Oak Ridge Reservation, ES/WM-10, Martin Marietta Energy Systems, Oak Ridge K-25 Site. Effective March 1, 1995, all sites will operate under this single comprehensive Waste Acceptance Criteria document. 
Principal documentation requirements identified in DOE Order 5820.2A (continued)

Par. Installation

Documentation

Oak Ridge Y-12 Plant

Y-12 ESWMO facility Waste Evaluation Criteria are contained in individual operating procedures.

Oak Ridge National Laboratory $\quad$ WMRAD August 1993. Waste Acceptance Criteria for High Flux Isotope Reactor Pool Cleanout, WMRA-WMPC-410, Martin Marietta Energy Systems, Oak Ridge Natl. Lab.

WMRAD Apr. 1, 1993. Waste Acceptance Criteria for Remote-Handled Solid Low-Level Waste Storage, WMRA-WMPC-205, Martin Marietta Energy Systems, Oak Ridge Natl. Lab.

WMRAD June 1994. Waste Acceptance Criteria for Radioactive Solid Waste Disposal at SWSA 6, WM-WMPC-413, Martin Marietta Energy Systems, Oak Ridge Natl. Lab.

Parrott, Jr., J. R. July 1991. ORNL Liquid Waste Treatment Systems Waste Acceptance Criteria , WM-WMCO-201, Martin Marietta Energy Systems, Oak Ridge Natl. Lab.

Oak Ridge K-25 Site

Existing Waste Acceptance Criteria:

1. Conner, G. D. July 1993. Waste Acceptance Criteria for Storage, Martin Marietta Energy Systems, Oak Ridge K-25 Site.

2. Conner, G. D. November 1989. The K-25 Site Contaminated Scrap Metal Yard Acceptance Criteria and Operating Procedure, Martin Marietta Energy Systems, Oak Ridge K-25 Site.

3. Snyder, B. S. November 1991. Waste Acceptance Plan and Analytical Protocol for the K-1435 Toxic Substances Control Act Incinerator, Martin Marietta Energy Systems, Oak Ridge K-25 Site.

4. Conner, G. D. and McGaha, M. A. February 1990. Central Neutralization Facility, Martin Marietta Energy Systems, Oak Ridge K-25 Site.

Anticipated Waste Acceptance Criteria for FY 1995:

Effective March 1, 1995, all sites will operate under a single comprehensive document: ESWMO-Central July 1994. Waste Acceptance Criteria for the Oak Ridge Reservation, ES/WM-10, Martin Marietta Energy Systems, Oak Ridge K-25 Site. 
Principal documentation requirements identified in DOE Order $5820.2 \mathrm{~A}$ (continued)

Par.

3e(4). Status of audits of certification activities by operators of Oak Ridge Y-12 Plant

facilities to which the waste is sent by the generator

Oak Ridge National Laboratory

Oak Ridge K-25 Site

$3 g(2)$. Documents forecasting waste to be shipped by generators to off-site disposal facilities
ESWMO

Oak Ridge Y-12 Plant

Oak Ridge National Laboratory

Oak Ridge K-25 Site
Documentation

The waste acceptance and waste certification program for waste generators at the $\mathrm{Y}-12$ Plant is driven primarily by the following documents: Waste Acceptance Criteria for the Oak Ridge Reservation, ES/WM-10; and Waste Certification Program Plan for the Oak Ridge Reservation, ES/WM-6. ESWMO-Y-12 Plant facilities Waste Evaluation Criteria are contained in individual operating procedures.

There is no formal audit program for generators. ESWMO-ORNL does informal assessments of generator facilities, memos of which are generated and filed. Operations does scrutinize generator manifests before accepting waste. This is compared with the Waste Acceptance Criteria.

There is no formal audit program for generators. Operations examines and verifies generator manifest before accepting waste.

Frye, C. E. April 29, 1994. Energy Systems Waste Management Organization, Martin Marietta Energy Systems, Oak Ridge National Laboratory, Oak Ridge, Tenn., "Response to Generator Waste Forecasts Requested by Department of Energy Nevada Operations Office," letter to L. L. Radcliffe, U.S. Department of Energy, Oak Ridge Operations Office.

Frye, C. E. Sept. 30, 1994. Energy Systems Waste Management Organization, Martin Marietta Energy Systems, Oak Ridge National Laboratory, Oak Ridge Tenn., "Request for Data for Utilization of the National Mixed Waste Disposal Contract for FY 1995 and FY 1996," letter to L. L. Radcliffe, U.S. Department of Energy, Oak Ridge Operations Office.

No documents were prepared.

SAIC August 1994. Oak Ridge Reservation Waste Storage Report for Period Ending June 30, 1994, ES/WM-23, rev. 0, Oak Ridge, Tenn.

Heacker, F. K., Jr. November 1992. Request for Off-Site Disposal of PCB Capacitors, WTDO-RRB3-92, Martin Marietta Energy System, Oak Ridge K-25 Site. 


\section{Principal documentation requirements identified in DOE Order 5820.2A (continued)}

Par.

Installation

3i(4)(d). Reports justifying on-site disposal of waste exceeding Oak Ridge Y-12 Plant Class $\mathrm{C}$ limits

Oak Ridge National Laboratory

\section{Oak Ridge K-25 Site}

3i(8). National Environmental Policy Act documentation

supporting selection of new LLW disposal sites

\section{ESWMO}

\section{Oak Ridge Y-12 Plant}

Oak Ridge National Laboratory

Oak Ridge K-25 Site
Documentation

Sams, T. L. August 1993. Mixed Waste Disposal Initiative Project: $A$ Comprehensive Conveyance Study for the Off-site Shipment of Oak

Ridge K-25 Site Stabilized Pond Wastes, ES/ER/TM-64, Martin Marietta Energy Systems, Oak Ridge K-25 Site

Sams, T. L. April 1993. Project Management Plan for the Mixed Waste Disposal Initiative Project for the Oak Ridge K-25 Site Pond Waste Disposal, ES/ER/TM-67, Martin Marietta Energy Systems, Oak Ridge K-25 Site.

Not applicable.

No GTCC waste was disposed of at ORNL this fiscal year.

Not applicable.

Frye, C. E. April 29, 1994. Energy Systems Waste Management Organization, Martin Marietta Energy Systems, Oak Ridge National Laboratory, Oak Ridge, Tenn., "Response to Generator Waste Forecasts Requested by Department of Energy Nevada Operations Office," letter to L. L. Radcliffe, U.S. Department of Energy, Oak Ridge Operations Office.

Frye, C. E. Sept. 30, 1994. Energy Systems Waste Management Organization, Martin Marietta Energy Systems, Oak Ridge National Laboratory, Oak Ridge Tenn., "Request for Data for Utilization of the National Mixed Waste Disposal Contract for FY 1995 and FY 1996," letter to L. L. Radcliffe, U.S. Department of Energy, Oak Ridge Operations Office.

A preliminary draft EIS was prepared by NUS Corporation for DOEORO. This document was issued for comment in October 1993. It addresses waste management activities on the ORR. The draft EIS includes siting of proposed new LLW facilities.

No documents were prepared.

No documents were prepared.

No documents were prepared. 
Principal documentation requirements identified in DOE Order 5820.2A (continued)

3j(1). Closure plans for LLW disposal sites

Oak Ridge Y-12 Plant

Oak Ridge National Laboratory

Oak Ridge K-25 Site

\section{Decommissioning of Radioactively Contaminated Facilities}

3a(1). Field organization documentation listing all

Oak Ridge Y-12 Plant contaminated facilities and their jurisdictional (DOE) program

responsibility

Oak Ridge National Laboratory

Oak Ridge K-25 Site

$3 \mathrm{c}(1)$. Postoperational documentation recording the potential for reuse and recovery of materials and equipment and the

schedule for decommissioning contaminated facilities
Oak Ridge Y-12 Plant responsibility. Program."
The Y-12 Plant has no disposal sites for LLW.

Bechtel National January 1994. Revised Closure Plan for Waste Area Grouping $\sigma$ at Oak Ridge National Laboratory, Oak Ridge, Tennessee, DOE/OR/01-1234\&D1, San Francisco.

The Oak Ridge K-25 Site has no disposal sites for LLW. the Y-12 Site, YIER-180, provides instructions on how to formally declare the status of facilities in the "Surplus Facilities Inventory and Assessment" database, which gives contamination and program

Ford, M. K., and Holder, L., Jr., July 1992. Surveillance and Maintenance Plan for the ORNL Decontamination and Decommission Program FY 1993-2002, ORNL/ER-130, Martin Marietta Energy Systems, Oak Ridge Natl. Lab.

Wade, T. E. (ORNL) May 16, 1988. Memorandum to T. J. Garrish, J. F. Decker, and J. LaGrone (DOE-ORO), "Approval of Memorandum of Agreement Concerning Management of ORNL Remedial Action

Gist, C. S. May 1992. Management Plan for the DOE Field Office, Oak Ridge, D\&D Program, DOE/OR-975, Martin Marietta Energy Systems, Oak Ridge Natl. Lab.

Although the plans and schedules are not final until the Remedial Investigation/Feasibility Study is concluded, several Y-12 Plant documents provide the groundwork for recovery of materials/equipment reuse, among which are the $Y-12$ Facility Shutdown Criteria,

YWM-165, August 1993, and the Office of Facility Transition and Management Plan for the Y-12 Site, Y|ER-180, April 1994 
Principal documentation requirements identified in DOE Order 5820.2A (continued)

Par. Installation

Documentation

Oak Ridgc National Laboratory

Burwinkle, T. W., et al. June 1987. The ORNL Surplus Facilities

Management Program Long-Range Plan, Revision 1

ORNL/TM-8957/R1, draft, Martin Marietta Energy Systems, Oak Ridge Natl. Lab.

Oak Ridge K-25 Site

ER 1988. Feasibility Study for the ORGDP Diffusion Facilities

Permanent Shutdown Implementation Project: Phase I of D\&D, K-5754, Martin Marietta Energy Systems, Oak Ridge K-25 Site.

ES 1988. Centrifuge Facility Decontamination and Decommissioning Plan, K/TS-11874, rev. 1, Martin Marietta Energy Systems, Oak Ridge K-25 Site.

- Ebasco 1991. U.S. DOE Envirommental Restoration of the Gaseous Diffusion Plants.

ES 1993. Oak Ridge K-25 Site Technology Logic Diagram, K-2073, OSTI. [Note: Potential for materials recovery from decontamination and decommissioning (D\&D) of gaseous diffusion plants (GDPs) is discussed in Chap. 9, vol. 1, of this document.]

K-25 WMD August 1994. Strategic Plan for the D\&D Program at the K-25 Site, Martin Marietta Energy Systems, Oak Ridge K-25 Site. Under final review by DOE.

3d(3). Decommissioning project plans
Oak Ridge Y-12 Plant

Oak Ridge National Laboratory
ER. December 1993. Project Management Plan for the Decontamination and Decommission of Building 9201-4 at the Oak Ridge Y-12. Site-December 1993, YLER-160.

Myrick, T. E., Schaich, R. W., and DeVore, J. R. April 1984. Metal Recovery Facility Decommissioning Project Plan-April 1984,

ORNL/TM-9018, Martin Marietta Energy Systems, Oak Ridge Natl. Lab.

Myrick, T. E., Schaich, R. W., and Williams, F. W. August 1983.

Fission Product Development Laboratory Cell Decommissioning Project Plan-August 1983, ORNL/TM-8779, Union Carbide Corp., Nuclear Div., Oak Ridge Natl. Lab. 
Principal documentation requirements identified in DOE Order 5820.2A (continued)

Oak Ridge K-25 Site

Oak Ridge Y-12 Plant

Oak Ridge National Laboratory

Oak Ridge K-25 Site
G. J. Mandry April 1992. Metal Recovery Facility Cell G

Decontamination Project Plan for Cell $G$ of the Metal Recovery Facility at Oak Ridge National Laboratory, Martin Marietta Energy Systems, Oak Ridge National Laboratory.

Current schedules for specific D\&D Program activities at the K-25 Site are described in Bailey, H. L. and Prince, B. E. September 1992. Life Cycle Baseline Summary for ADS 4701, K-25 Site D\&D: FY 95 Validation. Current activities are directed primarily at removal of hazardous materials from various facilities to reduce surveillance and maintenance costs. Project-specific documentation is available through the D\&D Program organization. No firm plans and schedules have been established for most final decommissioning projects. Exceptions as of the end of FY 1994 include the Powerhouse Area Demolition and the Cooling Tower Demolition Projects-pilot projects for managing future $D \& D$ at the Oak Ridge sites. [See response to $3 c(1)$ for updated strategic plan for D\&D.]

Although not currently in a documentable format, subsequent to all $D \& D$ efforts, "post-closure verification" will be conducted, and a formal report will be issued that includes a description of the project, final status of the property, and lessons learned from the project. [Ref. Programmatic Assessment for DOE Order 5820.2A, Sect. L1, p. 59, No. ch.v.3.d(5)(a).]

Schaich, R. W. December 1983. Final Report on the Decontamination of the Curium Fabrication Facility, ORNL/TM-8276, Union Carbide Corp., Nuclear Div., Oak Ridge Natl. Lab.

Not currently applicable.

\footnotetext{
"Reporting is limited to documents issued in FY 1994 unless the most recent revision of an existing document was issued earlier.
} 
Spent nuclear fuel (SNF) waste treatment, storage, and disposal facilities on the Oak Ridge Reservation

\begin{tabular}{|c|c|c|c|c|c|c|}
\hline Site & Facility & $\begin{array}{l}\text { Waste } \\
\text { type }\end{array}$ & Facility description & $\begin{array}{l}\text { Facility } \\
\text { status }\end{array}$ & $\begin{array}{l}\text { Permitting } \\
\text { status }\end{array}$ & $\begin{array}{r}\text { Environmen } \\
\text { monitoring }\end{array}$ \\
\hline \multicolumn{7}{|c|}{ A. Treatment facilities } \\
\hline $\begin{array}{l}\text { Oak Ridge } \\
\text { Y-12 Plant }\end{array}$ & \multicolumn{6}{|c|}{ There are no SNF treatment facilities at the Y-12 Plant. } \\
\hline $\begin{array}{l}\text { Oak Ridge } \\
\text { National } \\
\text { Laboratory }\end{array}$ & \multicolumn{6}{|c|}{ There are no SNF treatment facilities at ORNL. } \\
\hline $\begin{array}{l}\text { Oak Ridge } \\
\text { K-25 Site }\end{array}$ & \multicolumn{6}{|c|}{ There are no SNF treatment facilities at the K-25 Site. } \\
\hline \multicolumn{7}{|c|}{ B. Storage facilities } \\
\hline \multirow{2}{*}{$\begin{array}{l}\text { Oak Ridge } \\
\text { Y-12 Plant }\end{array}$} & Vault $9720-5$ & & & & & \\
\hline & Building 9720-5 vault & $\begin{array}{l}\text { Health Physics Research } \\
\text { Reactor fuel, SNAP-10A and } \\
\text { DOE demo. reactors }\end{array}$ & Vault & Continue to operate & NA & $\begin{array}{l}\text { Routine } \\
\text { inspectons }\end{array}$ \\
\hline \multirow{7}{*}{$\begin{array}{l}\text { Oak Ridge } \\
\text { National } \\
\text { Laboratory }\end{array}$} & $7823 A^{\prime}$ & SNF & $\begin{array}{l}\text { Eight stainless stecl } \\
\text { wells }\end{array}$ & Continue to operate & NA & \\
\hline & 7827 & $\begin{array}{l}\text { SNF, sealed sources, and other } \\
\text { irradiated material }\end{array}$ & $\begin{array}{l}\text { Fifty-four stainless } \\
\text { steel wells }\end{array}$ & Continue to operate & NA & \\
\hline & $\begin{array}{l}\text { High Flux Isotope Reactor } \\
\text { (HFIR) pool, Building } \\
7900\end{array}$ & HFIR fucl & Reactor pool & Continue to operate & NA & $\begin{array}{l}\text { Routine } \\
\text { inspections }\end{array}$ \\
\hline & $\begin{array}{l}\text { Bulk Shielding Reactor } \\
\text { (BSR) pool, Bldg. } 3010\end{array}$ & $\begin{array}{l}\text { BSR and Oak Ridge Reactor } \\
\text { (ORR) fuel }\end{array}$ & Reactor pool & Continue to operate & NA & $\begin{array}{l}\text { Routine } \\
\text { inspections }\end{array}$ \\
\hline & $\begin{array}{l}\text { Molten Salt Reactor } \\
\text { Experiment (MSRE), } \\
\text { Building } 7503\end{array}$ & MSRE fucl & Storage tank system & Continue to operate & NA & $\begin{array}{l}\text { Routine } \\
\text { inspections }\end{array}$ \\
\hline & Building 4501 & Misc. light-water reactor fuels & Shielded casks & Continue to operate & NA & $\begin{array}{l}\text { Routine } \\
\text { inspections }\end{array}$ \\
\hline & $\begin{array}{l}\text { Tower Shielding Reactor } \\
\text { (TSR) }\end{array}$ & TSR fuel & Fuel in plates & Continue to operate & NA & $\begin{array}{l}\text { Routine } \\
\text { inspections }\end{array}$ \\
\hline
\end{tabular}


Spent nuclear fuel (SNF) waste treatment, storage, and disposal facilities on the Oak Ridge Reservation (continued)

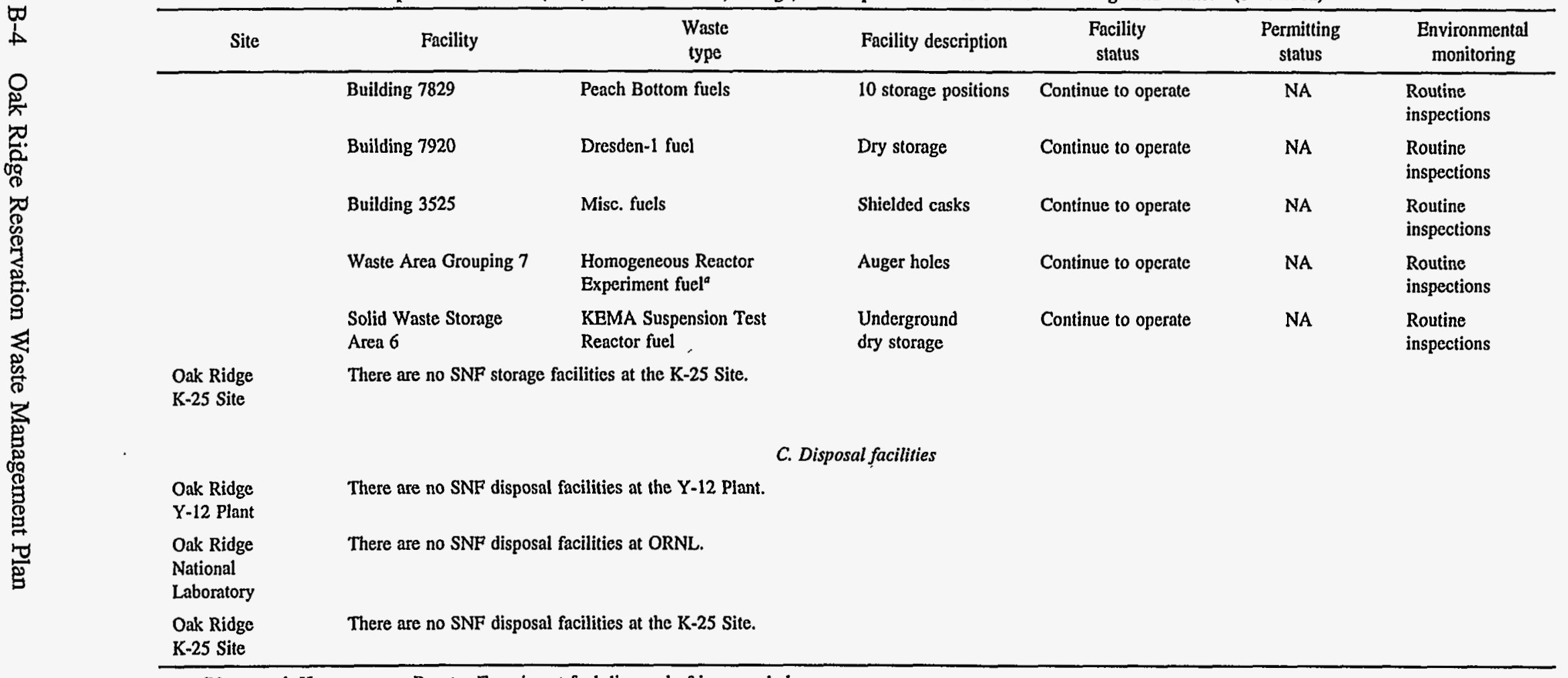

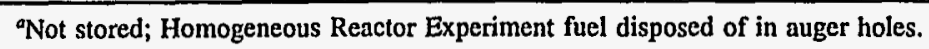


Transuranic waste treatment and storage facilities on the Oak Ridge Reservation

\begin{tabular}{|c|c|c|c|c|c|}
\hline Site & Facility & $\begin{array}{l}\text { Waste } \\
\text { type }\end{array}$ & Facility description & $\begin{array}{l}\text { Permitting } \\
\text { status }\end{array}$ & $\begin{array}{c}\text { Environmental } \\
\text { monitoring }\end{array}$ \\
\hline \multicolumn{6}{|c|}{ A. Treatment facilities } \\
\hline \multicolumn{6}{|c|}{ There are no transuranic (TRU) waste treatment facilities on the Oak Ridge Reservation (ORR). } \\
\hline \multicolumn{6}{|c|}{ B. Storage facilities } \\
\hline $\begin{array}{l}\text { Oak Ridge Y-12 } \\
\text { Plant }\end{array}$ & \multicolumn{5}{|c|}{ There are no TRU waste storage facilities at the Y-12 Plant. } \\
\hline \multirow[t]{7}{*}{$\begin{array}{l}\text { Oak Ridge } \\
\text { National } \\
\text { Laboratory }\end{array}$} & $\begin{array}{l}\text { Buildings } 7826 \text { and } \\
7834\end{array}$ & $\begin{array}{l}\text { Solid contact- } \\
\text { handled }(\mathrm{CH}) \text { TRU } \\
\text { (drum/box) }\end{array}$ & $\begin{array}{l}\text { Long-term underground } \\
\text { cells }\end{array}$ & NA & $\begin{array}{l}\text { Routine } \\
\text { inspections }\end{array}$ \\
\hline & Building 7842 & $\begin{array}{l}\text { Solid CH TRU } \\
\text { drums }\end{array}$ & Long-term building & Interim & $\begin{array}{l}\text { Routine } \\
\text { inspections }\end{array}$ \\
\hline & Building 7855 & $\begin{array}{l}\text { Solid remote- } \\
\text { handled (RH) TRU }\end{array}$ & $\begin{array}{l}\text { Long-term underground } \\
\text { bunker }\end{array}$ & $\begin{array}{l}\text { Part B } \\
\text { permitted }\end{array}$ & $\begin{array}{l}\text { Routine } \\
\text { inspections }\end{array}$ \\
\hline & Building 7878 & $\begin{array}{l}\text { Solid CH TRU } \\
\text { drums }\end{array}$ & Long-term building & Interim & $\begin{array}{l}\text { Routine } \\
\text { inspections }\end{array}$ \\
\hline & Building 7879 & $\begin{array}{l}\text { Solid CH TRU } \\
\text { drums }\end{array}$ & $\begin{array}{l}\text { Temporary staging } \\
\text { building }\end{array}$ & Interim & $\begin{array}{l}\text { Routine } \\
\text { inspections }\end{array}$ \\
\hline & Building $7934^{\circ}$ & $\begin{array}{l}\text { Solid CH TRU } \\
\text { drums }\end{array}$ & Long-term building & Interim & $\begin{array}{l}\text { Routine } \\
\text { inspections }\end{array}$ \\
\hline & $\begin{array}{l}\text { Solid Waste } \\
\text { Storage Area } 5 \mathrm{~N} \\
\text { trenches }\end{array}$ & Solid RH TRU & Long-term trenches & NA & $\begin{array}{l}\text { Routine } \\
\text { inspections }\end{array}$ \\
\hline $\begin{array}{l}\text { Oak Ridge K-25 } \\
\text { Site }\end{array}$ & \multicolumn{5}{|c|}{ There are no TRU waste storage facilities at the K-25 Site. } \\
\hline \multicolumn{6}{|c|}{ C. Disposal facilities } \\
\hline \multicolumn{6}{|c|}{ There are no TRU waste disposal facilities on the ORR. } \\
\hline
\end{tabular}




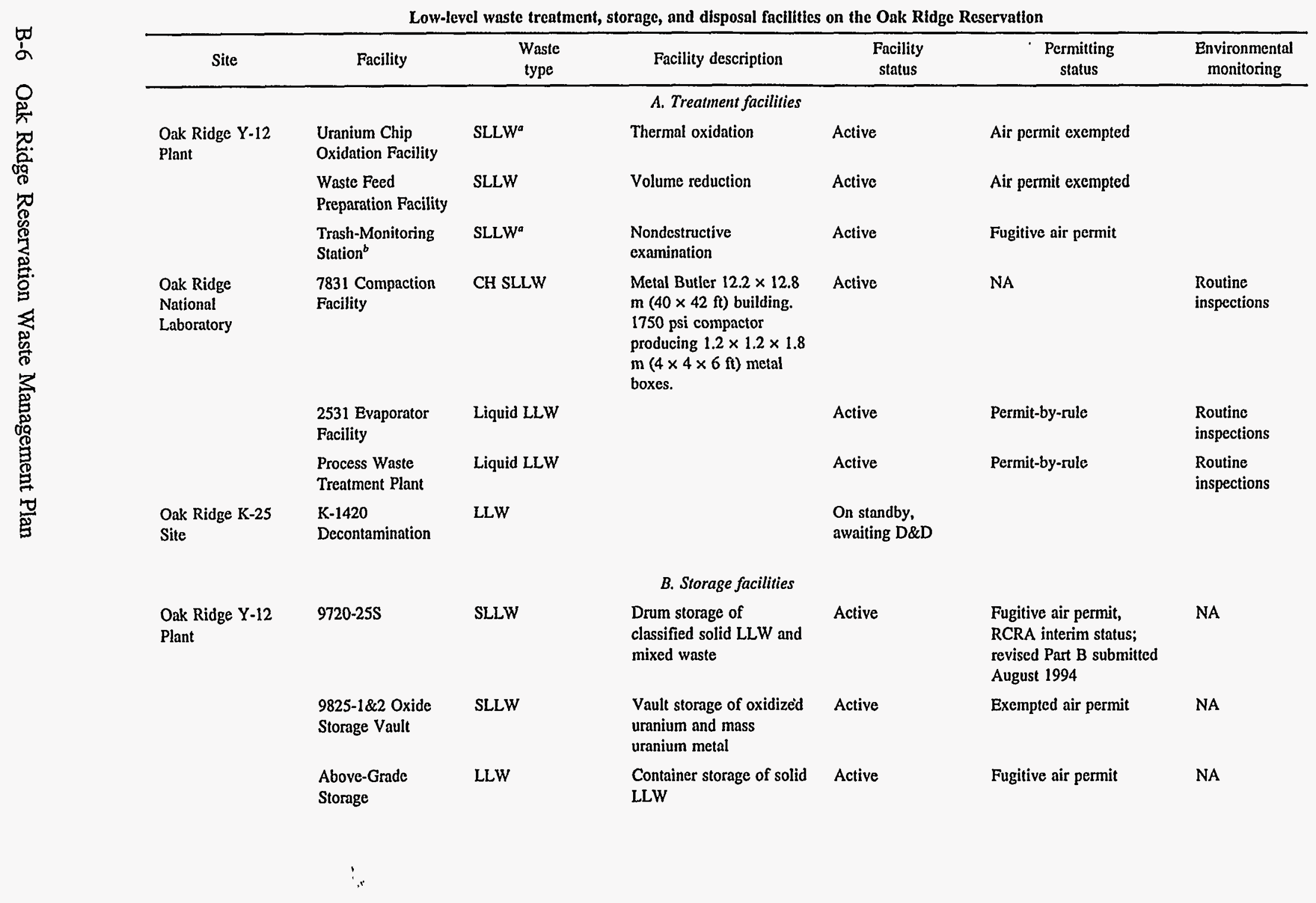




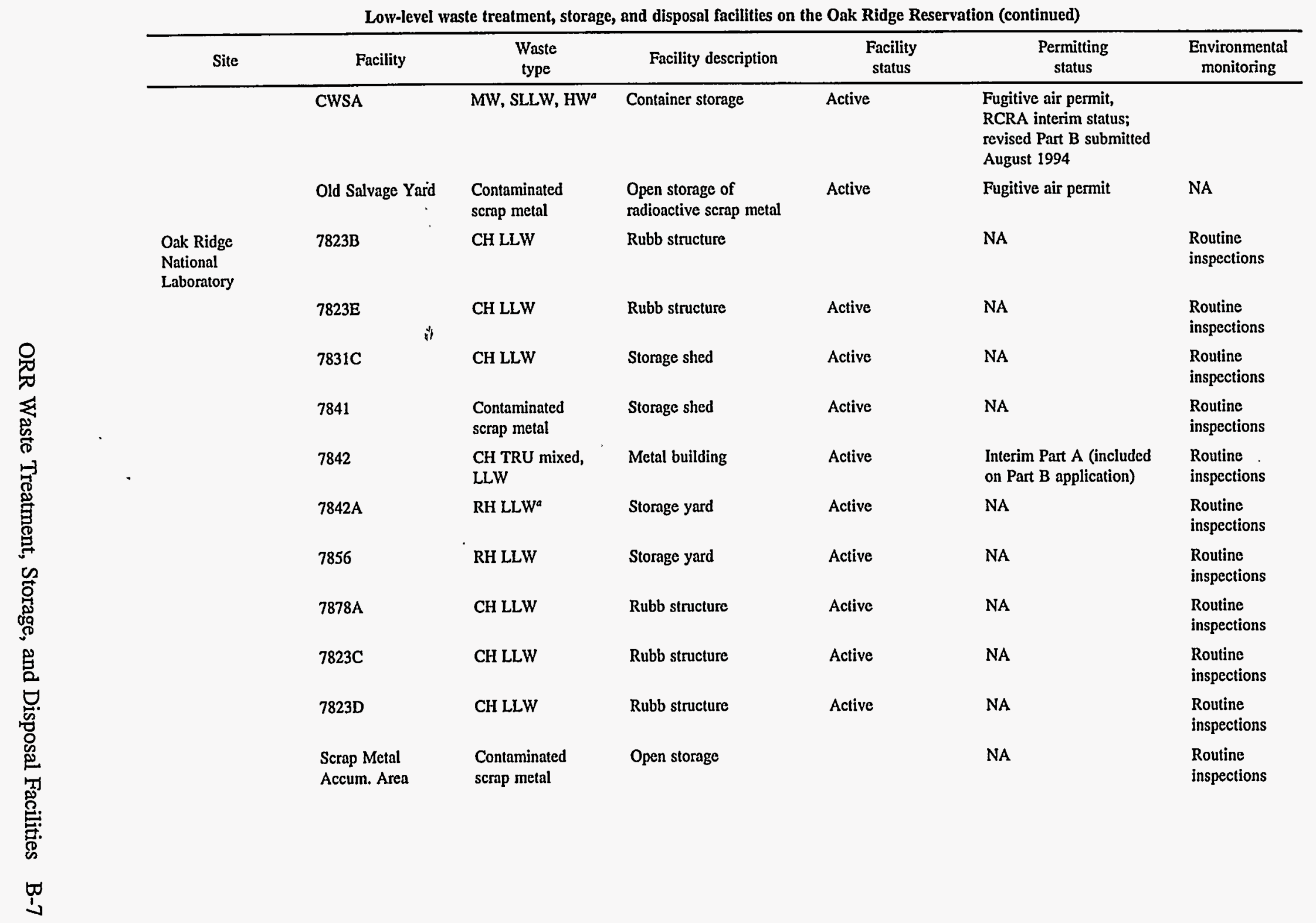


Low-level waste treatment, storage, and disposal facilities on the Oak Ridge Reservation (continued)

\begin{tabular}{|c|c|c|c|c|c|c|}
\hline Site & Facility & $\begin{array}{l}\text { Waste } \\
\text { type }\end{array}$ & Facility description & $\begin{array}{l}\text { Facility } \\
\text { status }\end{array}$ & $\begin{array}{l}\text { Permitting } \\
\text { status }\end{array}$ & $\begin{array}{c}\text { Environmental } \\
\text { monitoring }\end{array}$ \\
\hline \multirow[t]{11}{*}{$\begin{array}{l}\text { Oak Ridge K-25 } \\
\text { Site }\end{array}$} & Vault 6 & LLW & $\begin{array}{l}\text { K-25 Building } \\
\text { Transformer vault } 6\end{array}$ & Active & NA & $\begin{array}{l}\text { Operational } \\
\text { and personnel }\end{array}$ \\
\hline & K-303-5 & LLW & $\begin{array}{l}\text { K-25 Building WSU } 032 \\
\text { vault }\end{array}$ & Active & NA & $\begin{array}{l}\text { Operational } \\
\text { and personnel }\end{array}$ \\
\hline & Vault $15 \mathrm{~A}$ & LLW & $\begin{array}{l}\text { K-25 Building WSU } 044 \\
\text { Vault } 15 \mathrm{~A}\end{array}$ & Active & NA & $\begin{array}{l}\text { Operational } \\
\text { and personnel }\end{array}$ \\
\hline & $\mathrm{K}-306-2$ & LLW & $\begin{array}{l}\text { K-25 Building WSU } 069 \\
\text { vault }\end{array}$ & Active & NA & $\begin{array}{l}\text { Operational } \\
\text { and personnel }\end{array}$ \\
\hline & K-306-7 & LLW & $\begin{array}{l}\text { K-25 Building WSU } 076 \\
\text { vault }\end{array}$ & Active & NA & $\begin{array}{l}\text { Operational } \\
\text { and personnel }\end{array}$ \\
\hline & $\mathrm{K}-309-2$ & LLW & $\begin{array}{l}\text { K-25 Building WSU } 008 \\
\text { vault }\end{array}$ & Active & NA & $\begin{array}{l}\text { Operational } \\
\text { and personnel }\end{array}$ \\
\hline & $\mathrm{K}-310-2$ & LLW & $\begin{array}{l}\text { K-25 Building WSU } 004 \\
\text { vault }\end{array}$ & Active & NA & $\begin{array}{l}\text { Operational } \\
\text { and personnel }\end{array}$ \\
\hline & $\mathrm{K}-1066-\mathrm{H}$ & LLW & $\begin{array}{l}\text { Outside concrete storage } \\
\text { area }\end{array}$ & Active & NA & $\begin{array}{l}\text { Operational } \\
\text { and personnel }\end{array}$ \\
\hline & $K-1313-A$ & LLW & $\begin{array}{l}\text { Fabric membrane } \\
\text { structure (Rubb Tent) }\end{array}$ & Active & NA & $\begin{array}{l}\text { Operational } \\
\text { and personnel }\end{array}$ \\
\hline & $\mathrm{K}-33$ & LLW & $\begin{array}{l}\text { Building K- } 33 \text { outside } \\
\text { concrete and inside areas }\end{array}$ & Active & NA & $\begin{array}{l}\text { Operational } \\
\text { and personnel }\end{array}$ \\
\hline & $\mathrm{K}-770$ & LLW & $\begin{array}{l}\text { Open-air tract [ } 12 \text { ha ( } 30 \\
\text { acres) }\end{array}$ & Active & NA & $\begin{array}{l}\text { Operational } \\
\text { and personnel }\end{array}$ \\
\hline
\end{tabular}

$\begin{array}{ll}\text { Oak Ridge Y-12 } & \text { There are no LLW } \\ \text { Plant } & \begin{array}{l}\text { disposal facilities } \\ \text { at the } Y-12 \text { Plant. }\end{array}\end{array}$

\section{Disposal facilities}


Low-level waste treatment, storage, and disposal facilities on the Oak Ridge Reservation (continued)

\begin{tabular}{|c|c|c|c|c|c|c|}
\hline Site & Facility & $\begin{array}{c}\text { Waste } \\
\text { type }\end{array}$ & Facility description & $\begin{array}{l}\text { Facility } \\
\text { status }\end{array}$ & $\begin{array}{l}\text { Permitting } \\
\text { status }\end{array}$ & $\begin{array}{c}\text { Environmenta } \\
\text { monitoring }\end{array}$ \\
\hline $\begin{array}{l}\text { Oak Ridge } \\
\text { National } \\
\text { Laboratory } \\
\end{array}$ & IWMF & SLLW & $\begin{array}{l}\text { 4-ha (9.5-acre) site using } \\
\text { tumulus technology. } \\
\text { Concrete pads reinforced } \\
\text { with epoxy coated rebar. } \\
\text { Stormwater, underpad, } \\
\text { and infiltration collection } \\
\text { systems with sumps. } \\
\text { Each pad has } 330 \text {-vault } \\
\left.\left.\text { [897 } \mathrm{m}^{3} \text { ( } 31,680 \mathrm{ft}^{3}\right)\right] \\
\text { capacity. Currently, two } \\
\text { pads are full; two pads } \\
\text { are available (expansion } \\
\text { to ten pads is possible) }\end{array}$ & Active & $\begin{array}{l}\text { Draft performance } \\
\text { assessment completed }\end{array}$ & $\begin{array}{l}\text { Sump collects } \\
\text { drainage from } \\
\text { pads for } \\
\text { routine } \\
\text { radiation } \\
\text { monitoring }\end{array}$ \\
\hline $\begin{array}{l}\text { Oak Ridge K-25 } \\
\text { Site }\end{array}$ & None & & & & . & \\
\hline
\end{tabular}

${ }^{\text {a} C o n t a c t-h a n d l e d ~(C H) ; ~ T o x i c ~ S u b s t a n c e s ~ C o n t r o l ~ A c t ~(T S C A) ; ~ m i x e d ~ w a s t e ~(M W) ; ~ t r a n s u r a n i c ~(T R U) ; ~ I n t e r i m ~ W a s t e ~ M a n a g e m e n t ~ F a c i l i t y ~(I W M F) ; ~ s o l i d ~ l o w-~}$ level waste (SLLW); hazardous waste (HW); remote-handled (RH).

'Trash-Monitoring Station included for completeness (not considered "treatment" facility). 
Hazardous waste treatment, storage, and disposal facilities on the Oak Ridge Reservation

\begin{tabular}{|c|c|c|c|c|c|c|}
\hline Site & Facility & $\begin{array}{l}\text { Waste } \\
\text { type }\end{array}$ & Facility description & $\begin{array}{l}\text { Facility } \\
\text { status }\end{array}$ & $\begin{array}{l}\text { Permitting } \\
\text { status }\end{array}$ & $\begin{array}{c}\text { Environmental } \\
\text { monitoring }\end{array}$ \\
\hline \multicolumn{7}{|c|}{ A. Treatment facilities } \\
\hline $\begin{array}{l}\text { Oak Ridge } \\
\text { Y-12 Plant }\end{array}$ & $\begin{array}{l}\text { Plating Rinsewater } \\
\text { Treatment Facility }\end{array}$ & $\begin{array}{l}\text { Nonradioactive, } \\
\text { nonfissile, heavy- } \\
\text { metal contaminated } \\
\text { rinsewater }\end{array}$ & $\begin{array}{l}\text { Treatment of non-nitrate- } \\
\text { bearing wastes }\end{array}$ & Active & $\begin{array}{l}\text { Air permit exempted, } \\
\text { RCRA permit-by-rule }\end{array}$ & \\
\hline & $\begin{array}{l}\text { Steam Plant } \\
\text { Wastewater } \\
\text { Facility (see } \\
\text { Industrial/Sanitary) }\end{array}$ & & & & & \\
\hline $\begin{array}{l}\text { Oak Ridge } \\
\text { National } \\
\text { Laboratory }\end{array}$ & Building 7667 & $\begin{array}{l}\text { Explosive } \\
\text { chemicals }\end{array}$ & $\begin{array}{l}\text { The Chemical Detonation } \\
\text { Facility provides } \\
\text { treatment by detonation } \\
\text { to certain intrinsic } \\
\text { hazardous wastes that } \\
\text { cannot be shipped to, or } \\
\text { accepted by, off-site } \\
\text { vendors }\end{array}$ & $\begin{array}{l}\text { Continue to } \\
\text { operate }\end{array}$ & $\begin{array}{l}\text { Interim status; Part B } \\
\text { permit application } \\
\text { submitted to the TDEC in } \\
\text { 1989; open-burning } \\
\text { permit under TDEC air } \\
\text { permit }^{a}\end{array}$ & $\begin{array}{l}\text { Routine } \\
\text { inspections }\end{array}$ \\
\hline $\begin{array}{l}\text { Oak Ridge } \\
\text { K-25 Site }\end{array}$ & $\begin{array}{l}\text { Central } \\
\text { Neutralization } \\
\text { Facility }\end{array}$ & Liquid & $\begin{array}{l}\text { Mixed low-level and } \\
\text { hazardous aqueous } \\
\text { treatment through pH } \\
\text { adjustment, chemical } \\
\text { prescription, settling, and } \\
\text { filtration }\end{array}$ & Active & $\begin{array}{l}\text { NPDES, RCRA permit- } \\
\text { by-rule }\end{array}$ & $\begin{array}{l}\text { Discharge } \\
\text { monitoring, } \\
\text { sampling }\end{array}$ \\
\hline & TSCA Incinerator ${ }^{a}$ & Liquid & $\begin{array}{l}\text { Incineration of aqueous } \\
\text { waste utilizing a rotary } \\
\text { kiln, mixing chamber, } \\
\text { water spray quench } \\
\text { column Venturi scrubber, } \\
\text { acid gas absorber, draft } \\
\text { fan, and exhaust stack }\end{array}$ & Active & & $\begin{array}{l}\text { NESHAP } \\
\text { sampling, } \\
\text { continuous } \\
\text { emission } \\
\text { sampling, and } \\
\text { flue monitors }\end{array}$ \\
\hline
\end{tabular}


Hazardous waste treatment, storage, and disposal facilities on the Oak Ridge Reservation (continued)

\begin{tabular}{|c|c|c|c|c|c|c|}
\hline Site & Facility & $\begin{array}{l}\text { Waste } \\
\text { type }\end{array}$ & Facility description & $\begin{array}{l}\text { Facility } \\
\text { status }\end{array}$ & $\begin{array}{l}\text { Permitting } \\
\text { status }\end{array}$ & $\begin{array}{l}\text { Environmental } \\
\text { monitoring }\end{array}$ \\
\hline \multicolumn{7}{|c|}{ B. Storage facilities } \\
\hline $\begin{array}{l}\text { Oak Ridge } \\
\text { Y-12 Plant }\end{array}$ & $9720-31$ & $\begin{array}{l}\text { Hazardous, solid } \\
\text { low-level, mixed }\end{array}$ & Storage/staging facility & Active & $\begin{array}{l}\text { Fugitive air; RCRA } \\
\text { interim status; revised } \\
\text { Part B submitted August } \\
1994\end{array}$ & \\
\hline \multirow[t]{4}{*}{$\begin{array}{l}\text { Oak Ridge } \\
\text { National } \\
\text { Laboratory }\end{array}$} & Building 7507 & $\begin{array}{l}\text { Polychlorinated } \\
\text { biphenyl (PCB) } \\
\text { oils (drum) }\end{array}$ & $\begin{array}{l}\text { Temporary staging } \\
\text { building }\end{array}$ & $\begin{array}{l}\text { Continue to } \\
\text { operate }\end{array}$ & Interim status & $\begin{array}{l}\text { Routine } \\
\text { inspections }\end{array}$ \\
\hline & Building 7651 & $\begin{array}{l}\text { Recyclable oils } \\
\text { (drum) }\end{array}$ & $\begin{array}{l}\text { Temporary staging } \\
\text { building }\end{array}$ & $\begin{array}{l}\text { Continue to } \\
\text { operate }\end{array}$ & Interim status & $\begin{array}{l}\text { Routine } \\
\text { inspections }\end{array}$ \\
\hline & Building 7652 & $\begin{array}{l}\text { Bulk solids/liquid } \\
\text { (drum) }\end{array}$ & $\begin{array}{l}\text { Temporary staging } \\
\text { building }\end{array}$ & $\begin{array}{l}\text { Continue to } \\
\text { operate }\end{array}$ & Part B permitted & $\begin{array}{l}\text { Routine } \\
\text { inspections }\end{array}$ \\
\hline & Building 7653 & $\begin{array}{l}\text { Lab-pack } \\
\text { chemicals (small } \\
\text { container) }\end{array}$ & $\begin{array}{l}\text { Temporary staging } \\
\text { building }\end{array}$ & $\begin{array}{l}\text { Continue to } \\
\text { operate }\end{array}$ & $\begin{array}{l}\text { Interim status; Part B to } \\
\text { be resubmitted }\end{array}$ & $\begin{array}{l}\text { Routine } \\
\text { inspections }\end{array}$ \\
\hline \multirow[t]{8}{*}{$\begin{array}{l}\text { Oak Ridge } \\
\text { K-25 Site }\end{array}$} & $\mathrm{K}-301-1$ & Hazardous/mixed & $\begin{array}{l}\text { K-25 Building Waste } \\
\text { Storage Unit (WSU) } \\
011 \text { vault } 4\end{array}$ & Active & Part B & $\begin{array}{l}\text { Operational } \\
\text { and personnel }\end{array}$ \\
\hline & $\mathrm{K}-301-1$ & Hazardous/mixed & $\begin{array}{l}K-25 \text { Building WSU } \\
012 \text { vault } 4 \mathrm{~A}\end{array}$ & Active & Part B & $\begin{array}{l}\text { Operational } \\
\text { and personnel }\end{array}$ \\
\hline & $\mathrm{K}-301-2$ & Hazardous/mixed & $\begin{array}{l}K-25 \text { Building WSU } \\
013 \text { vault } 4 B\end{array}$ & Active & Part B & $\begin{array}{l}\text { Operational } \\
\text { and personnel }\end{array}$ \\
\hline & $\mathrm{K}-301-4$ & Hazardous/mixed & $\begin{array}{l}\text { K-25 Buidling WSU } 015 \text {, } \\
\text { vault } 5 \mathrm{~A}\end{array}$ & Active & Part B & $\begin{array}{l}\text { Operational } \\
\text { and personnel }\end{array}$ \\
\hline & K-301-4 & Hazardous/mixed & $\begin{array}{l}\text { K-25 Building WSU } \\
016 \text { vault }\end{array}$ & Active & Part B & $\begin{array}{l}\text { Operational } \\
\text { and personnel }\end{array}$ \\
\hline & K-302-4 & Hazardous/mixed & $\begin{array}{l}K-25 \text { Building WSU } \\
023 \text { vault }\end{array}$ & Active & Part B & $\begin{array}{l}\text { Operational } \\
\text { and personnel }\end{array}$ \\
\hline & $\mathrm{K}-302-5$ & $\begin{array}{l}\text { Hazardous/mixcd/ } \\
\text { LLW }\end{array}$ & $\begin{array}{l}\text { K-25 Building WSU } \\
024 \text { vault } 8 \mathrm{~A}\end{array}$ & Active & Part B & $\begin{array}{l}\text { Operational } \\
\text { and personnel }\end{array}$ \\
\hline & $\mathrm{K}-302-5$ & Hazardous/mixed & $\begin{array}{l}\text { K-25 Building WSU } \\
025 \text { vault }\end{array}$ & Active & Part B & $\begin{array}{l}\text { Operational } \\
\text { and personnel }\end{array}$ \\
\hline
\end{tabular}




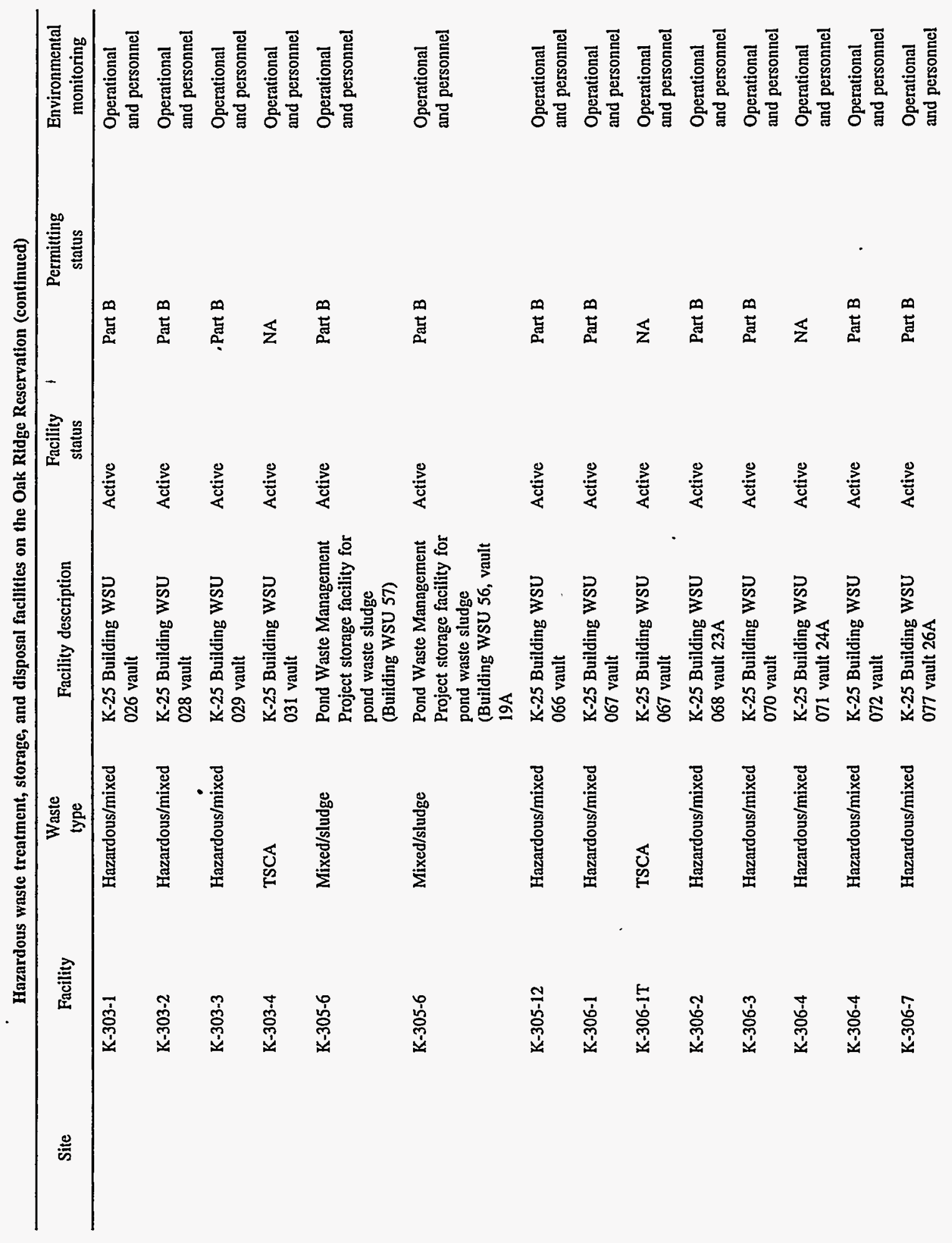


Hazardous waste treatment, storage, and disposal facilities on the Oak Ridge Reservation (continued)

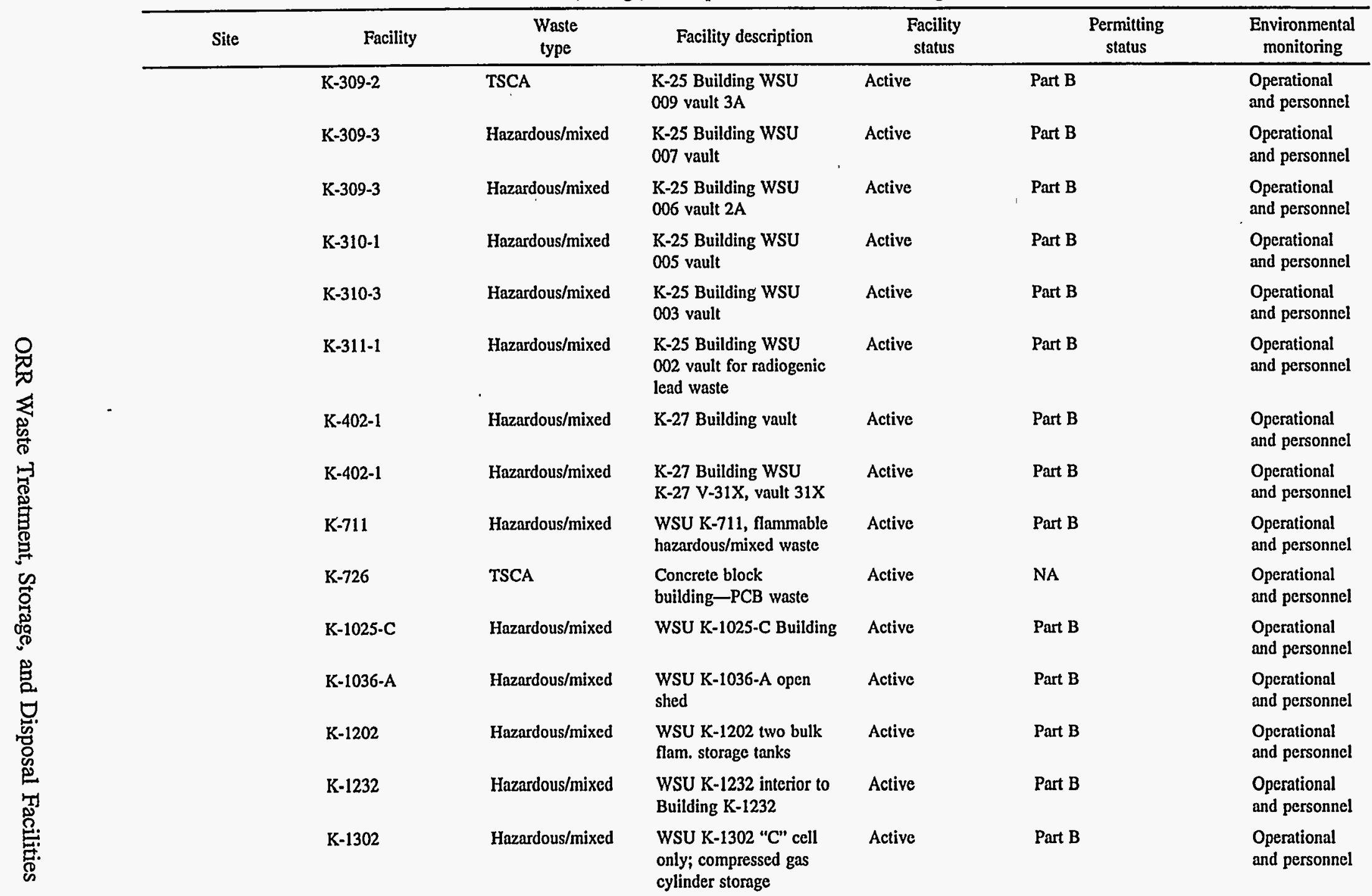

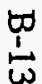


Hazardous waste treatment, storage, and disposal facilities on the Oak Ridge Reservation (continued)

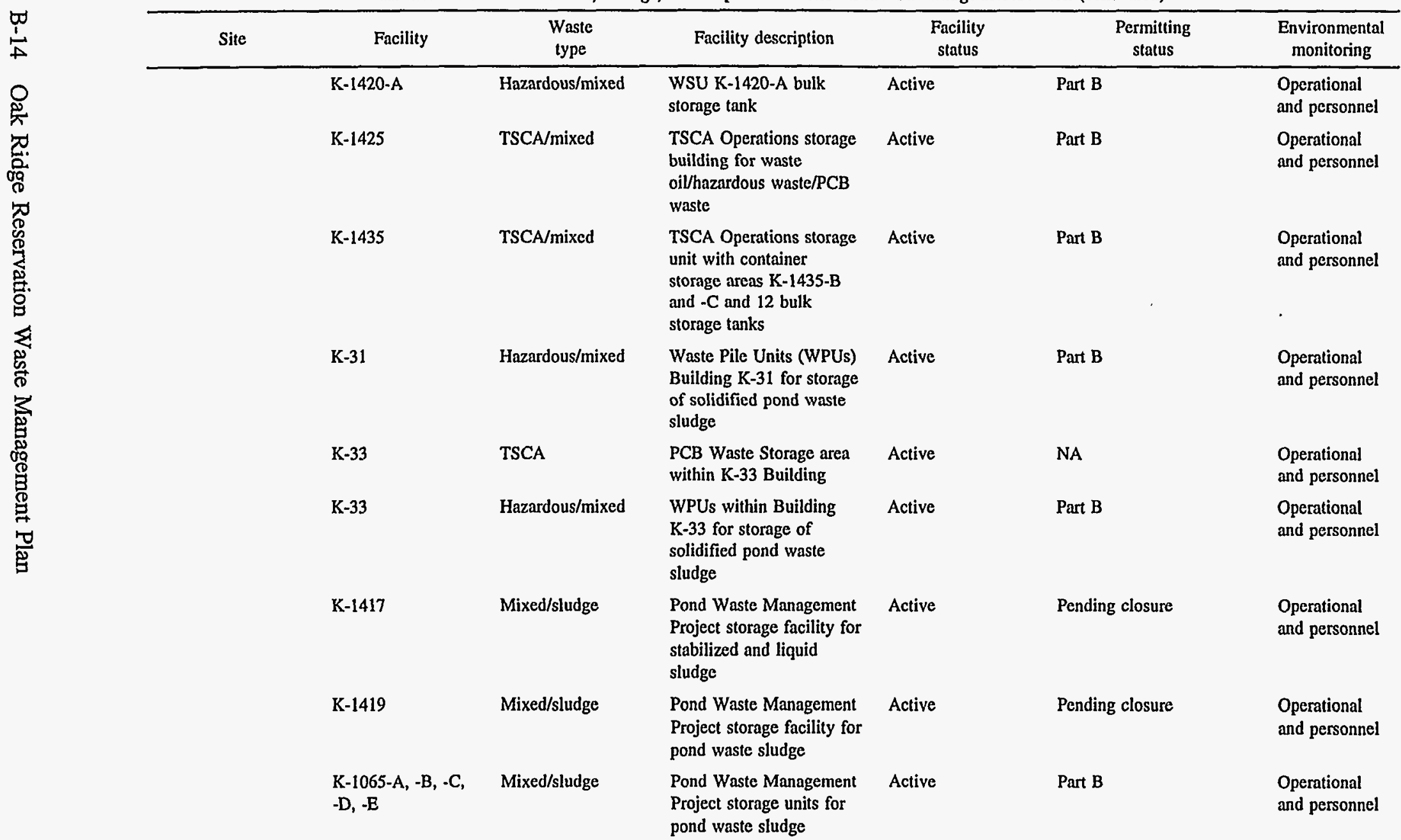

Oak Ridge

There are no hazardous waste disposal facilities at the Y-12 Plant. 
Hazardous waste treatment, storage, and disposal facilities on the Oak Ridge Reservation (continued)

\begin{tabular}{|c|c|c|c|c|c|c|}
\hline Site & Facility & $\begin{array}{l}\text { Waste } \\
\text { type }\end{array}$ & Facility description & $\begin{array}{l}\text { Facility } \\
\text { status }\end{array}$ & $\begin{array}{l}\text { Permitting } \\
\text { status }\end{array}$ & $\begin{array}{c}\text { Environmental } \\
\text { monitoring }\end{array}$ \\
\hline $\begin{array}{l}\text { Oak Ridge } \\
\text { National } \\
\text { Laboratory }\end{array}$ & $\begin{array}{l}\text { There are no } h \\
\text { Laboratory }\end{array}$ & dispos & at Oak Ridge Nationa & & & \\
\hline $\begin{array}{l}\text { Oak Ridge } \\
\text { K-25 Site }\end{array}$ & There are no d & es at the & for solid, liquid, or ga & Irdous waste. & & \\
\hline
\end{tabular}

${ }^{a}$ Toxic Substance Control Act (TSCA); Resource Conservation and Recovery Act (RCRA); Tennessee Department of Environment and Conservation (TDEC); National Pollutant Discharge Elimination System (NPDES). 
Mixed waste treatment, storage, and disposal facilitics on the Oak Ridge Reservation

\begin{tabular}{|c|c|c|c|c|c|c|}
\hline Site & Facility & $\begin{array}{l}\text { Waste } \\
\text { type }\end{array}$ & Facility description & $\begin{array}{l}\text { Facility } \\
\text { status }\end{array}$ & $\begin{array}{l}\text { Permitting } \\
\text { status }\end{array}$ & $\begin{array}{l}\text { Environmental } \\
\text { monitoring }\end{array}$ \\
\hline & & & A. Treatment facilities & & & \\
\hline \multirow[t]{5}{*}{$\begin{array}{l}\text { Oak Ridge } \\
\text { Y-12 Plant }\end{array}$} & $\begin{array}{l}\text { Central Pollution } \\
\text { Control Facility/ } \\
\text { Plating Rinsewater } \\
\text { Treatment Facility }\end{array}$ & $\mathrm{LMW}^{a}$ & $\begin{array}{l}\text { Treatment of radioactive } \\
\text { contaminated non-nitrate } \\
\text { wastewater: mop water, } \\
\text { acidic waste, caustic } \\
\text { waste, hydrogen fluoride } \\
\text { scrubber waste, rad and } \\
\text { nonrad plating rinsewater }\end{array}$ & Active & $\begin{array}{l}\text { - RCRA permit-by-rule } \\
\text { - Air permit exempted } \\
\text { - NPDES permit } \\
\text { outfalls } 501 \text { and } 504^{a} \\
\text { - Landfill permit NA }\end{array}$ & \\
\hline & $\begin{array}{l}\text { Groundwater } \\
\text { Treatment } \\
\text { Facility }\end{array}$ & LMW & $\begin{array}{l}\text { Treatment of uranium- } \\
\text { contaminated } \\
\text { groundwater, PCB oils, } \\
\text { organics }^{a}\end{array}$ & Active & $\begin{array}{l}\text { - RCRA permit-by-rule } \\
\text { - Air permit source } \\
\text { O31254P } \\
\text { - NPDES permit } \\
\text { outfall } 512 \\
\text { - Landfill permit NA }\end{array}$ & \\
\hline & $\begin{array}{l}\text { Waste Coolant } \\
\text { Processing } \\
\text { Facility }\end{array}$ & LMW & $\begin{array}{l}\text { Treatment of machine } \\
\text { coolant, mop water }\end{array}$ & Active & $\begin{array}{l}\text { - RCRA interim status; } \\
\text { revised permit-by-rule } \\
\text { - Air permit exempted } \\
\text { - NPDES permit outfall } \\
\text { not required } \\
\text { - Landfill permit NA }\end{array}$ & \\
\hline & $\begin{array}{l}\text { West End } \\
\text { Treatment } \\
\text { Facility/West } \\
\text { Tank Farm }\end{array}$ & LMW & $\begin{array}{l}\text { Treatment of nitrate- } \\
\text { bearing wastewaters: } \\
\text { nitric acid waste, nitrate- } \\
\text { bearing rinsewaters, } \\
\text { mixed acid wastes, waste } \\
\text { coolant mop water, } \\
\text { caustic waste }\end{array}$ & Active & $\begin{array}{l}\text { - RCRA permit-by-rule } \\
\text { - Air permit source } \\
737019 \mathrm{P} \\
\text { - NPDES permit } \\
\text { outfall } 502 \\
\text { - Landfill permit NA }\end{array}$ & \\
\hline & $\begin{array}{l}\text { Cyanide Treatment } \\
\text { Unit (DP) }\end{array}$ & LMW & $\begin{array}{l}\text { Treatment of spent } \\
\text { plating solutions }\end{array}$ & Active & $\begin{array}{l}\text { - RCRA interim status } \\
\text { Part B submitted } \\
\text { September } 1994 \\
\text { - Air permit source } \\
\text { - NPDES permit NA } \\
\text { - Landfill permit NA }\end{array}$ & \\
\hline
\end{tabular}


Mixed waste treatment, storage, and disposal facilities on the Oak Ridge Reservation (continued)

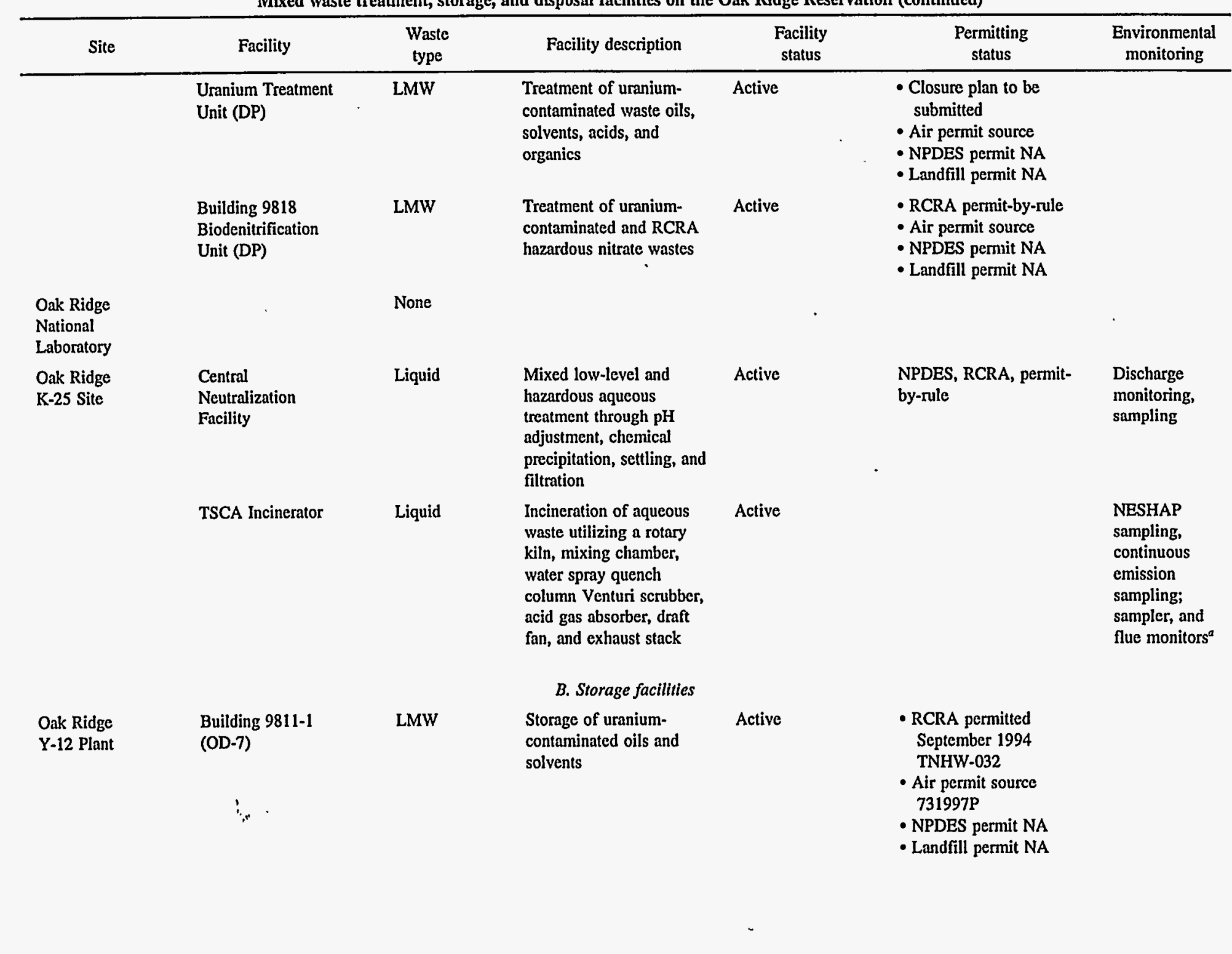


Mixed waste treatment, storage, and disposal facilities on the Oak Ridge Reservation (continued)

\begin{tabular}{|c|c|c|c|c|c|c|}
\hline Site & Facility & $\begin{array}{l}\text { Waste } \\
\text { type }\end{array}$ & Facility description & $\begin{array}{l}\text { Facility } \\
\text { status }\end{array}$ & $\begin{array}{l}\text { Permitting } \\
\text { status }\end{array}$ & $\begin{array}{c}\text { Environmental } \\
\text { monitoring }\end{array}$ \\
\hline & $\begin{array}{l}\text { Building 9811-1 } \\
\text { (OD-8) }\end{array}$ & LMW & $\begin{array}{l}\text { Storage of uranium- } \\
\text { contaminated oils and } \\
\text { solvents }\end{array}$ & Active & $\begin{array}{l}\text { - RCRA interim status; } \\
\text { revised Part B } \\
\text { submitted August } 1994 \\
\text { - Air permit fugitive } \\
\text { - NPDES permit NA } \\
\text { - Landfill permit NA }\end{array}$ & \\
\hline & $\begin{array}{l}\text { Building 9811-8 } \\
\text { (OD-9) }\end{array}$ & LMW & $\begin{array}{l}\text { Storage of uranium- } \\
\text { contaminated } \mathrm{PCB} \text { oil }\end{array}$ & Active & $\begin{array}{l}\text { - RCRA permitted } \\
\text { September } 1994 \\
\text { TNHW-032 } \\
\text { - Air permit source } \\
\text { 032988P } \\
\text { - NPDES permit NA } \\
\text { - Landfill permit NA }\end{array}$ & \\
\hline & $\begin{array}{l}\text { Building 9720-45 } \\
\text { (OD-10) }\end{array}$ & LMW & $\begin{array}{l}\text { Storage of radioactive- } \\
\text { contaminated flammable } \\
\text { waste and PCB oils }\end{array}$ & Active & $\begin{array}{l}\text { - RCRA permitted } \\
\text { September } 1994 \\
\text { TNHW-032 } \\
\text { - Air permit tanks } \\
\text { exempted, drums } \\
\text { fugitive } \\
\text { - NPDES permit NA } \\
\text { - Landfill permit NA }\end{array}$ & \\
\hline & Building $9720-58$ & LMW & $\begin{array}{l}\text { Storage of } \\
\text { PCB-contaminated } \\
\text { equipment, radioactive- } \\
\text { contaminated hazardous } \\
\text { waste }\end{array}$ & Active & $\begin{array}{l}\text { - RCRA interim status; } \\
\text { revised Part B } \\
\text { submitted August } 1994 \\
\text { - Air permit fugitive } \\
\text { - NPDES permit NA } \\
\text { - Landfill permit NA }\end{array}$ & \\
\hline & Building 9720-9 & LMW & $\begin{array}{l}\text { Storage of radioactive- } \\
\text { contaminated flammable } \\
\text { waste and PCB oils }\end{array}$ & Active & $\begin{array}{l}\text { - RCRA interim status; } \\
\text { revised Part B } \\
\text { submitted August } 1994 \\
\text { - Air permit fugitive } \\
\text { - NPDES permit NA } \\
\text { - Landfill permit NA }\end{array}$ & \\
\hline
\end{tabular}


Mixed waste treatment, storage, and disposal facilities on the Oak Ridge Reservation (continued)

\begin{tabular}{|c|c|c|c|c|c|c|}
\hline Site & Facility & $\begin{array}{l}\text { Waste } \\
\text { type }\end{array}$ & Facility description & $\begin{array}{l}\text { Facility } \\
\text { status }\end{array}$ & $\begin{array}{l}\text { Permitting } \\
\text { status }\end{array}$ & $\begin{array}{c}\text { Environmental } \\
\text { monitoring }\end{array}$ \\
\hline & $\begin{array}{l}\text { Liquid Storage } \\
\text { Facility }\end{array}$ & LMW & $\begin{array}{l}\text { Storage of uranium- } \\
\text { contaminated } \\
\text { groundwater, PCB oils, } \\
\text { organics }\end{array}$ & Active & $\begin{array}{l}\text { - RCRA permit-by-rule } \\
\text { - Air permit not } \\
\text { required } \\
\text { - NPDES permit } \\
\text { not required } \\
\text { - Landfill permit NA }\end{array}$ & \\
\hline & $\begin{array}{l}\text { Containerized } \\
\text { Waste Storage } \\
\text { Area }\end{array}$ & LMW & $\begin{array}{l}\text { Storage of RCRA waste, } \\
\text { mixed waste }\end{array}$ & Active & $\begin{array}{l}\text { - RCRA interim status; } \\
\text { revised Part B } \\
\text { submitted August } 1994 \\
\text { - Air permit fugitive } \\
\text { - NPDES permit NA } \\
\text { - Landfill permit NA }\end{array}$ & \\
\hline & $\begin{array}{l}\text { Building } 9212 \\
\text { Tank Farm (DP) }\end{array}$ & LMW & $\begin{array}{l}\text { Storage of uranium- } \\
\text { contaminated and RCRA } \\
\text { hazardous waste }\end{array}$ & Active & $\begin{array}{l}\text { - RCRA permit-by-rule } \\
\text { - Air permit source } \\
\text { - NPDES permit NA } \\
\text { - Landfill permit NA }\end{array}$ & \\
\hline & West Tank Farm & $\mathrm{SMW}^{a}$ & $\begin{array}{l}\text { Storage of mixed sludge, } \\
\text { contaminated carbon, } \\
\text { spent filter material }\end{array}$ & Active & $\begin{array}{l}\text { - RCRA permit-by-rulc } \\
\text { - Air permit source } \\
737019 \mathrm{P} \\
\text { - NPDES permit NA } \\
\text { - Landfill permit NA }\end{array}$ & \\
\hline & Building 9720-58 & SMW & $\begin{array}{l}\text { Storage of nonreactive, } \\
\text { nonignitable mixed; PCB- } \\
\text { contaminated equipment }\end{array}$ & Active & $\begin{array}{l}\text { - RCRA interim status; } \\
\text { revised Part B } \\
\text { submitted August } 1994 \\
\text { - Air permit fugitive } \\
\text { - NPDES permit NA } \\
\text { - Landfill permit NA }\end{array}$ & \\
\hline & $\begin{array}{l}\text { Building 9206, } \\
\text { Container Storage } \\
\text { Area }\end{array}$ & LMW, SMW & $\begin{array}{l}\text { Storage of uranium- } \\
\text { contaminated organic } \\
\text { solutions and lab salvage }\end{array}$ & Active & $\begin{array}{l}\text { - RCRA interim status; } \\
\text { revised Part B } \\
\text { submitted September } \\
1994\end{array}$ & \\
\hline & $\begin{array}{l}\text { Building } 9212 \text {, } \\
\text { Container Storage } \\
\text { Area }\end{array}$ & LLW, SMW & $\begin{array}{l}\text { Storage of uranium- } \\
\text { contaminated organic } \\
\text { solutions and lab salvage }\end{array}$ & Active & $\begin{array}{l}\text { - RCRA interim status; } \\
\text { revised Part B } \\
\text { submitted September } \\
1994\end{array}$ & \\
\hline
\end{tabular}


Mixed waste treatment, storage, and disposal facilities on the Oak Ridge Reservation (continued)

\begin{tabular}{|c|c|c|c|c|c|c|}
\hline Site & Facility & $\begin{array}{l}\text { Waste } \\
\text { type }\end{array}$ & Facility description & $\begin{array}{l}\text { Facility } \\
\text { status }\end{array}$ & $\begin{array}{l}\text { Permitting } \\
\text { status }\end{array}$ & $\begin{array}{c}\text { Environmental } \\
\text { monitoring }\end{array}$ \\
\hline & Building 9720-9 & SMW & $\begin{array}{l}\text { Storage of radioactive- } \\
\text { contaminated solid mixed } \\
\text { waste }\end{array}$ & Active & $\begin{array}{l}\text { - RCRA interim status; } \\
\text { revised Part B } \\
\text { submitted August } 1994 \\
\text { - Air permit fugitive } \\
\text { - NPDES permit NA } \\
\text { - Landfill permit NA }\end{array}$ & \\
\hline & CWSA & SMW & $\begin{array}{l}\text { Storage of RCRA } \\
\text { hazardous, mixed waste }\end{array}$ & Active & $\begin{array}{l}\text { - RCRA interim status; } \\
\text { revised Part B } \\
\text { submitted August } 1994 \\
\text { - Air permit fugitive } \\
\text { - NPDES permit NA } \\
\text { - Landfill permit NA }\end{array}$ & \\
\hline & $\begin{array}{l}\text { Classified Waste } \\
\text { Storage Facility, } \\
9720-25\end{array}$ & SMW & $\begin{array}{l}\text { Storage of classified and } \\
\text { mixed waste }\end{array}$ & Active & $\begin{array}{l}\text { - RCRA interim status; } \\
\text { revised Part B } \\
\text { submitted August } 1994 \\
\text { - Air permit fugitive } \\
\text { - NPDES permit NA } \\
\text { - Landfill permit NA }\end{array}$ & \\
\hline & $\begin{array}{l}\text { Building } 9720-12 \text {, } \\
\text { Classified } \\
\text { Container Storage } \\
\text { Area (DP) }\end{array}$ & SMW & $\begin{array}{l}\text { Storage of classified } \\
\text { RCRA hazardous waste }\end{array}$ & Active & $\begin{array}{l}\text { - RCRA interim status; } \\
\text { revised Part B } \\
\text { submitted September } \\
1994 \\
\text { - Air permit NA } \\
\text { - NPDES permit NA } \\
\text { - Landfill permit NA }\end{array}$ & \\
\hline & Building 9404-7 & SMW & $\begin{array}{l}\text { Storage of radioactive- } \\
\text { contaminated solid PCB } \\
\text { waste }\end{array}$ & Active & $\begin{array}{l}\text { - RCRA permit not } \\
\text { required } \\
\text { - Air permit fugitive } \\
\text { - NPDES permit NA } \\
\text { - Landfill permit NA }\end{array}$ & \\
\hline & $\begin{array}{l}\text { Building 9201-4, } \\
\text { Southeast } \\
\text { Switchgear Room }\end{array}$ & SMW & $\begin{array}{l}\text { Storage of mercury- } \\
\text { contaminated solids } \\
\text { contaminated with } \\
\text { uranium }\end{array}$ & Active & $\begin{array}{l}\text { - RCRA interim status; } \\
\text { revised Part B } \\
\text { submitted August } 1994 \\
\text { - Air permit source } \\
\text { - NPDES permit NA } \\
\text { - Landfill permit NA }\end{array}$ & \\
\hline
\end{tabular}


Mixed waste treatment, storage, and disposal facilities on the Oak Ridge Reservation (continued)

\begin{tabular}{|c|c|c|c|c|c|c|}
\hline Site & Facility & $\begin{array}{l}\text { Waste } \\
\text { type }\end{array}$ & Facility description & $\begin{array}{l}\text { Facility } \\
\text { status }\end{array}$ & $\begin{array}{l}\text { Permitting } \\
\text { status }\end{array}$ & $\begin{array}{l}\text { Environmental } \\
\text { monitoring }\end{array}$ \\
\hline \multirow[t]{5}{*}{$\begin{array}{l}\text { Oak Ridge } \\
\text { National } \\
\text { Laboratory }\end{array}$} & Building $7507 \mathrm{~W}$ & $\begin{array}{l}\text { Mixed solids/ } \\
\text { liquids (drums) }\end{array}$ & Long-term covered pad & Interim status & $\begin{array}{l}\text { Part B permit application } \\
\text { has been submitted for } \\
\text { approval }\end{array}$ & $\begin{array}{l}\text { Routine } \\
\text { inspections }\end{array}$ \\
\hline & Building 7654 & $\begin{array}{l}\text { Mixed solids/ } \\
\text { liquids (drum) }\end{array}$ & Long-term building & $\begin{array}{l}\text { Interim status; } \\
\text { Part B resubmitted }\end{array}$ & $\begin{array}{l}\text { Part B permit application } \\
\text { has been submitted for } \\
\text { approval }\end{array}$ & $\begin{array}{l}\text { Routine } \\
\text { inspections }\end{array}$ \\
\hline & Building 7823 & $\begin{array}{l}\text { Mixed solids/ } \\
\text { liquids (drum) }\end{array}$ & Long-term building & $\begin{array}{l}\text { Interim status; } \\
\text { Part B submitted }\end{array}$ & Continued storage & $\begin{array}{l}\text { Routine } \\
\text { inspections }\end{array}$ \\
\hline & Tank 7075 & & & & $\begin{array}{l}\text { RCRA closure complete } \\
\text { August } 1994\end{array}$ & $\begin{array}{l}\text { Routine } \\
\text { inspections }\end{array}$ \\
\hline & Tank 7830a & Mixed oils & Long-term tank & $\begin{array}{l}\text { Interim status; } \\
\text { Part B submitted }\end{array}$ & Will be permitted & $\begin{array}{l}\text { Routine } \\
\text { inspections }\end{array}$ \\
\hline \multirow[t]{9}{*}{$\begin{array}{l}\text { Oak Ridge } \\
\text { K-25 Site }\end{array}$} & K-301-1 & Hazardous/mixed & $\begin{array}{l}\text { K-25 Building Waste } \\
\text { Storage Unit (WSU) } \\
011 \text { vault } 4\end{array}$ & Active & Part B & $\begin{array}{l}\text { Operational } \\
\text { and personnel }\end{array}$ \\
\hline & K-301-1 & Hazardous/mixed & $\begin{array}{l}\text { K-25 Building WSU } \\
012 \text { vault } 4 \mathrm{~A}\end{array}$ & Active & Part B & $\begin{array}{l}\text { Operational } \\
\text { and personnel }\end{array}$ \\
\hline & $\mathrm{K}-301-2$ & Hazardous/mixed & $\begin{array}{l}\text { K- } 25 \text { Building WSU } \\
013 \text { vault } 4 \mathrm{~B}\end{array}$ & Active & Part B & $\begin{array}{l}\text { Operational } \\
\text { and personnel }\end{array}$ \\
\hline & $\mathrm{K}-301-4$ & Hazardous/mixed & $\begin{array}{l}\text { K- } 25 \text { Building WSU } 015 \text {, } \\
\text { vault } 5 \mathrm{~A}\end{array}$ & Active & Part B & $\begin{array}{l}\text { Operational } \\
\text { and personnel }\end{array}$ \\
\hline & $\mathrm{K}-301-4$ & Hazardous/mixed & $\begin{array}{l}\text { K-25 Building WSU } \\
016 \text { vault }\end{array}$ & Active & Part B & $\begin{array}{l}\text { Operational } \\
\text { and personnel }\end{array}$ \\
\hline & $\mathrm{K}-302-4$ & Hazardous/mixed & $\begin{array}{l}\text { K-25 Building WSU } \\
023 \text { vault }\end{array}$ & Active & Part B & $\begin{array}{l}\text { Operational } \\
\text { and personnel }\end{array}$ \\
\hline & $\mathrm{K}-302-5$ & $\begin{array}{l}\text { Hazardous/mixed/ } \\
\text { LLW }\end{array}$ & $\begin{array}{l}\text { K-25 Building WSU } \\
024 \text { vault } 8 \mathrm{~A}\end{array}$ & Active & Part B & $\begin{array}{l}\text { Operational } \\
\text { and personnel }\end{array}$ \\
\hline & $K-302-5$ & Hazardous/mixed & $\begin{array}{l}\text { K-25 Building WSU } \\
025 \text { vault }\end{array}$ & Active & Part B & $\begin{array}{l}\text { Operational } \\
\text { and personnel }\end{array}$ \\
\hline & K-303-1 & Hazardous/mixed & $\begin{array}{l}\text { K-25 Building WSU } \\
026 \text { vault }\end{array}$ & Active & Part B & $\begin{array}{l}\text { Operational } \\
\text { and personnel }\end{array}$ \\
\hline
\end{tabular}


Mixed waste treatment, storage, and disposal facilities on the Oak Ridge Reservation (continued)

\begin{tabular}{|c|c|c|c|c|c|c|}
\hline Site & Facility & $\begin{array}{l}\text { Waste } \\
\text { type }\end{array}$ & Facility description & $\begin{array}{l}\text { Facility } \\
\text { status }\end{array}$ & $\begin{array}{l}\text { Permitting } \\
\text { status }\end{array}$ & $\begin{array}{l}\text { Environmental } \\
\text { monitoring }\end{array}$ \\
\hline & K-303-2 & Hazardous/mixed & $\begin{array}{l}\text { K-25 Building WSU } \\
028 \text { vault }\end{array}$ & Active & Part B & $\begin{array}{l}\text { Operational } \\
\text { and personnel }\end{array}$ \\
\hline & K-303-3 & Hazardous/mixed & $\begin{array}{l}\text { K-25 Building WSU } \\
029 \text { vault }\end{array}$ & Active & Part B & $\begin{array}{l}\text { Operational } \\
\text { and personnel }\end{array}$ \\
\hline & K-303-4 & $\mathrm{TSCA}^{a}$ & $\begin{array}{l}\text { K-25 Building WSU } \\
031 \text { vault }\end{array}$ & Active & $\mathrm{NA}$ & $\begin{array}{l}\text { Operational } \\
\text { and personnel }\end{array}$ \\
\hline & $\mathrm{K}-305-6$ & Mixed/sludge & $\begin{array}{l}\text { Pond Waste Management } \\
\text { Project storage facility for } \\
\text { pond waste sludge } \\
\text { (Building WSU 57) }\end{array}$ & Active & Part B & $\begin{array}{l}\text { Operational } \\
\text { and personnel }\end{array}$ \\
\hline & $\mathrm{K}-305-6$ & Mixed/sludge & $\begin{array}{l}\text { Pond Waste Management } \\
\text { project storage facility for } \\
\text { pond waste sludge } \\
\text { (Building WSU 56, vault } \\
\text { 19A }\end{array}$ & Active & Part B & $\begin{array}{l}\text { Operational } \\
\text { and personnel }\end{array}$ \\
\hline & $\mathrm{K}-305-12$ & Hazardous/mixed & $\begin{array}{l}\mathrm{K}-25 \text { Building WSU } \\
066 \text { vault }\end{array}$ & Active & Part B & $\begin{array}{l}\text { Operational } \\
\text { and personnel }\end{array}$ \\
\hline & $\mathrm{K}-306-1$ & Hazardous/mixed & $\begin{array}{l}\text { K-25 Building WSU } \\
067 \text { vault }\end{array}$ & Active & Part B & $\begin{array}{l}\text { Operational } \\
\text { and personnel }\end{array}$ \\
\hline & $\mathrm{K}-306-1 \mathrm{~T}$ & TSCA & $\begin{array}{l}\text { K-25 Building WSU } \\
067 \text { vault }\end{array}$ & Active & $\mathrm{NA}$ & $\begin{array}{l}\text { Operational } \\
\text { and personnel }\end{array}$ \\
\hline & $\mathrm{K}-306-2$ & Hazardous/mixed & $\begin{array}{l}\text { K-25 Building WSU } \\
068 \text { vault } 23 \mathrm{~A}\end{array}$ & Active & Part B & $\begin{array}{l}\text { Operational } \\
\text { and personnel }\end{array}$ \\
\hline & $\mathrm{K}-306-3$ & Hazardous/mixed & $\begin{array}{l}\text { K- } 25 \text { Building WSU } \\
070 \text { vault }\end{array}$ & Active & Part B & $\begin{array}{l}\text { Operational } \\
\text { and personnel }\end{array}$ \\
\hline & K-306-4 & Hazardous/mixed & $\begin{array}{l}\text { K-25 Building WSU } \\
071 \text { vault } 24 \mathrm{~A}\end{array}$ & Active & NA & $\begin{array}{l}\text { Operational } \\
\text { and personnel }\end{array}$ \\
\hline & K-306-4 & Hazardous/mixed & $\begin{array}{l}\text { K-25 Building WSU } \\
072 \text { vault }\end{array}$ & Active & Part B & $\begin{array}{l}\text { Operational } \\
\text { and personnel }\end{array}$ \\
\hline & K-306-7 & Hazardous/mixed & $\begin{array}{l}\text { K-25 Building WSU } \\
077 \text { vault } 26 \mathrm{~A}\end{array}$ & Active & Part B & $\begin{array}{l}\text { Operational } \\
\text { and personnel }\end{array}$ \\
\hline & K-309-2 & TSCA & $\begin{array}{l}\text { K-25 Building WSU } \\
009 \text { vault } 3 A\end{array}$ & Active & $\mathrm{NA}$ & $\begin{array}{l}\text { Operational } \\
\text { and personnel }\end{array}$ \\
\hline
\end{tabular}


Mixed waste treatment, storage, and disposal facilities on the Oak Ridge Reservation (continued)

\begin{tabular}{|c|c|c|c|c|c|c|c|}
\hline & Site & Facility & $\begin{array}{l}\text { Waste } \\
\text { type }\end{array}$ & Facility description & $\begin{array}{l}\text { Facility } \\
\text { status }\end{array}$ & $\begin{array}{l}\text { Permitting } \\
\text { status }\end{array}$ & $\begin{array}{l}\text { Environmental } \\
\text { monitoring }\end{array}$ \\
\hline & & K-309-3 & Hazardous/mixed & $\begin{array}{l}\text { K-25 Building WSU } \\
007 \text { vault }\end{array}$ & Active & Part B & $\begin{array}{l}\text { Operational } \\
\text { and personnel }\end{array}$ \\
\hline & & K-309-3 & Hazardous/mixed & $\begin{array}{l}\text { K-25 Building WSU } \\
006 \text { vault } 2 \mathrm{~A}\end{array}$ & Active & Part B & $\begin{array}{l}\text { Operational } \\
\text { and personnel }\end{array}$ \\
\hline & & $\mathrm{K}-310-1$ & Hazardous/mixed & $\begin{array}{l}\text { K-25 Building WSU } \\
005 \text { vault }\end{array}$ & Active & Part B & $\begin{array}{l}\text { Operational } \\
\text { and personnel }\end{array}$ \\
\hline & & $\mathrm{K}-310-3$ & Hazardous/mixed & $\begin{array}{l}\text { K-25 Building WSU } \\
003 \text { vault }\end{array}$ & Active & Part B & $\begin{array}{l}\text { Operational } \\
\text { and personnel }\end{array}$ \\
\hline 0 & & $\mathrm{~K}-311-1$ & Hazardous/mixed & $\begin{array}{l}\text { K-25 Building WSU } \\
002 \text { vault for radiogenic } \\
\text { lead waste }\end{array}$ & Active & Part B & $\begin{array}{l}\text { Operational } \\
\text { and personnel }\end{array}$ \\
\hline \& & & $K-402-1$ & Hazardous/mixed & K-27 Building vault & Active & Part B & $\begin{array}{l}\text { Operational } \\
\text { and personnel }\end{array}$ \\
\hline हैं & & $K-402-1$ & Hazardous/mixed & $\begin{array}{l}\text { K-27 Building WSU } \\
\text { K-27 V-31X, vault } 31 \mathrm{X}\end{array}$ & Active & Part B & $\begin{array}{l}\text { Operational } \\
\text { and personnel }\end{array}$ \\
\hline 衂 & & K-711 & Hazardous/mixed & $\begin{array}{l}\text { WSU K-711, flammable } \\
\text { hazardous/mixed waste }\end{array}$ & Active & Part B & $\begin{array}{l}\text { Operational } \\
\text { and personnel }\end{array}$ \\
\hline 胥 & & $\mathrm{K}-726$ & TSCA & $\begin{array}{l}\text { Concrete block } \\
\text { building-PCB waste }\end{array}$ & Active & NA & $\begin{array}{l}\text { Operational } \\
\text { and personnel }\end{array}$ \\
\hline 点 & & $\mathrm{K}-1025-\mathrm{C}$ & Hazardous/mixed & WSU K-1025-C Building & Active & Part B & $\begin{array}{l}\text { Operational } \\
\text { and personnel }\end{array}$ \\
\hline 然 & & K-1036-A & Hazardous/mixed & $\begin{array}{l}\text { WSU K-1036-A open } \\
\text { shed }\end{array}$ & Active & Part B & $\begin{array}{l}\text { Operational } \\
\text { and personnel }\end{array}$ \\
\hline 焉 & & $\mathrm{K}-1202$ & Hazardous/mixed & $\begin{array}{l}\text { WSU K-1202 two bulk } \\
\text { flam. storage tanks }\end{array}$ & Active & Part B & $\begin{array}{l}\text { Operational } \\
\text { and personnel }\end{array}$ \\
\hline 䒿 & & $\mathrm{K}-1232$ & Hazardous/mixed & $\begin{array}{l}\text { WSU K-1232 interior to } \\
\text { Building K-1232 }\end{array}$ & Active & Part B & $\begin{array}{l}\text { Operational } \\
\text { and personnel }\end{array}$ \\
\hline 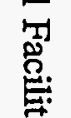 & & $\mathrm{K}-1302$ & Hazardous/mixed & $\begin{array}{l}\text { WSU K-1302 "C" cell } \\
\text { only; compressed gas } \\
\text { cylinder storage }\end{array}$ & Active & Part B & $\begin{array}{l}\text { Operational } \\
\text { and personnel }\end{array}$ \\
\hline 悹 & & K-1420-A & Hazardous/mixed & $\begin{array}{l}\text { WSU K-1420-A bulk } \\
\text { storage tank }\end{array}$ & Active & Part B & $\begin{array}{l}\text { Operational } \\
\text { and personnel }\end{array}$ \\
\hline
\end{tabular}


Mixed waste treatment, storage, and disposal facilities on the Oak Ridge Reservation (continued)

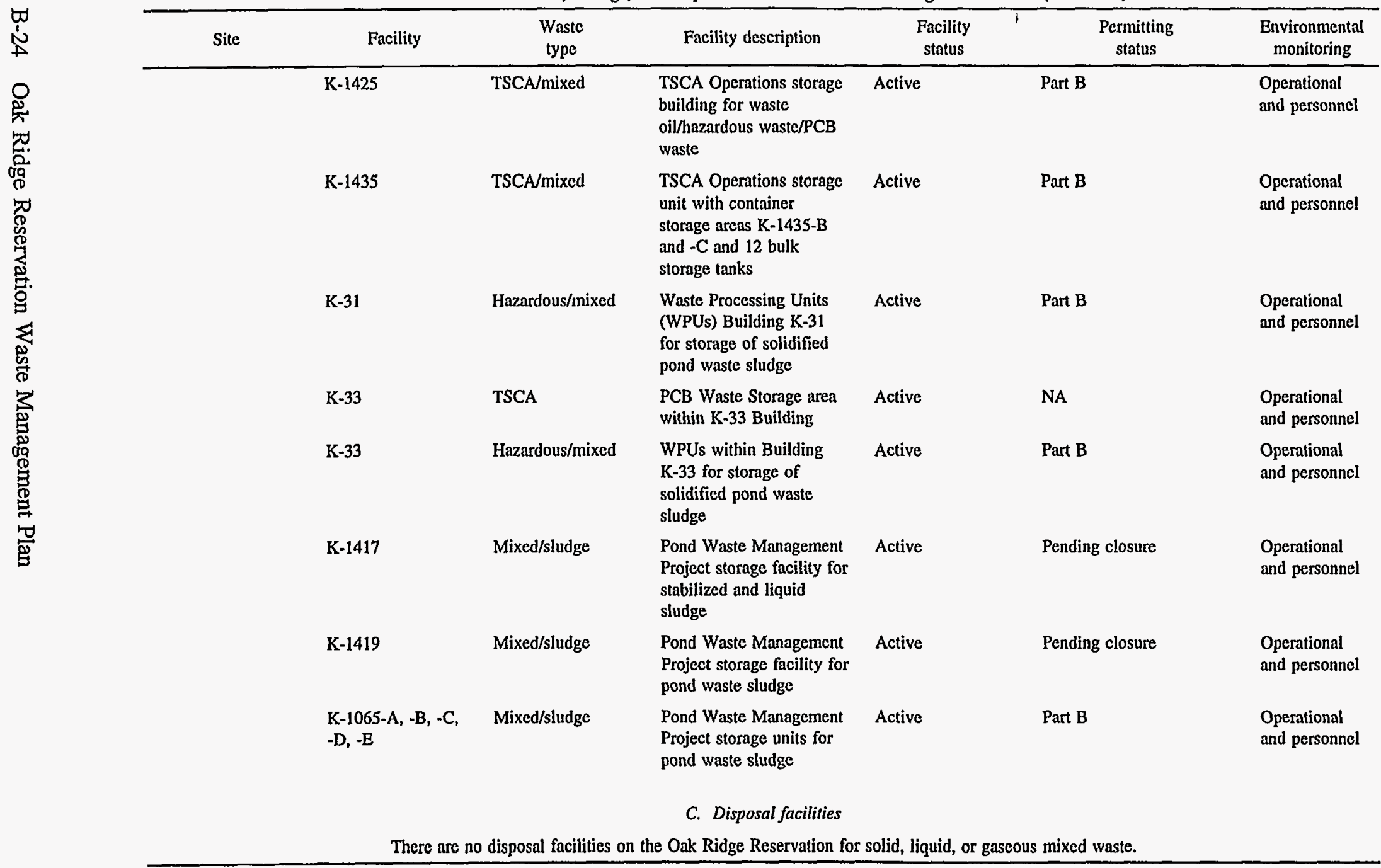

a Resource Conservation and Recovery Act (RCRA); National Pollutant Discharge Elimination System (NPDES); polychlorinated biphenyl (PCB); National Emission Standards for Hazardous Air Pollutants (NESHAP). 
Industrial and sanitary waste treatment and disposal facilities on the Oak Ridge Reservation

\begin{tabular}{|c|c|c|c|c|c|c|}
\hline Site & Facility & $\begin{array}{l}\text { Waste } \\
\text { type }\end{array}$ & Facility description & $\begin{array}{l}\text { Facility } \\
\text { status }\end{array}$ & $\begin{array}{l}\text { Permitting } \\
\text { status }\end{array}$ & $\begin{array}{l}\text { Environmental } \\
\text { monitoring }\end{array}$ \\
\hline \multicolumn{7}{|c|}{ A. Treatment facilities } \\
\hline \multirow[t]{2}{*}{$\begin{array}{l}\text { Oak Ridge Y-12 } \\
\text { Plant }\end{array}$} & $\begin{array}{l}\text { Industrial Waste } \\
\text { Baler Facility } \\
\text { Compactor/Baler }\end{array}$ & Solid sanitary & $\begin{array}{l}\text { Sanitary waste volume } \\
\text { reduction }\end{array}$ & Active & TDEC fugitive air permit ${ }^{a}$ & NA \\
\hline & $\begin{array}{l}\text { Steam Plant : } \\
\text { Wastewater } \\
\text { Treatment Plant }\end{array}$ & $\begin{array}{l}\text { Liquid industrial } \\
\text { and hazardous } \\
\text { wastes }\end{array}$ & $\begin{array}{l}\text { Chemical treatment } \\
\text { followed by fiiltration }\end{array}$ & Active & $\begin{array}{l}\text { RCRA permit-by-rule, } \\
\text { NPDES permit, source air } \\
\text { permit }^{a}\end{array}$ & $\begin{array}{l}\text { Discharge } \\
\text { monitoring, } \\
\text { sampling }\end{array}$ \\
\hline \multirow[t]{2}{*}{$\begin{array}{l}\text { Oak Ridge } \\
\text { National } \\
\text { Laboratory }\end{array}$} & $\begin{array}{l}\text { Sewage Treatment } \\
\text { Facility } \\
\qquad\end{array}$ & Liquid sanitary & $\begin{array}{l}\text { Activated sludge aeration } \\
\text { with settling and filtration } \\
\text { ponds. Design throughput } \\
1,135,624 \mathrm{~L} / \mathrm{d} \\
(300,000 \mathrm{gal} / \mathrm{d})\end{array}$ & Active & NPDES & $\begin{array}{l}\text { Discharge } \\
\text { monitoring, } \\
\text { sampling }\end{array}$ \\
\hline & $\begin{array}{l}\text { Coal Yard Runoff } \\
\text { Treatment Facility }\end{array}$ & Liquid & $\begin{array}{l}\text { Chemical treatment } \\
\text { followed by vacuum } \\
\text { filtration. Semicontinuous } \\
\text { design, } 568 \mathrm{~L} / \mathrm{min} \\
(150 \text { gal) } \mathrm{max} .\end{array}$ & & NPDES & $\begin{array}{l}\text { Discharge } \\
\text { monitoring, } \\
\text { sampling }\end{array}$ \\
\hline \multirow[t]{3}{*}{$\begin{array}{l}\text { Oak Ridge K-25 } \\
\text { Site }\end{array}$} & CNF & Liquid industrial & $\begin{array}{l}\text { Hazardous, mixed low- } \\
\text { level, and nonhazardous } \\
\text { aqueous treatment } \\
\text { through pH adjustment, } \\
\text { chemical precipitation, } \\
\text { settling, and filtration }\end{array}$ & . & $\begin{array}{l}\text { NPDES, RCRA permit- } \\
\text { by-rule }\end{array}$ & $\begin{array}{l}\text { Discharge } \\
\text { monitoring, } \\
\text { sampling }\end{array}$ \\
\hline & $\mathrm{K}-1203$ & Liquid sanitary & $\begin{array}{l}\text { Extended aeration with } \\
\text { sludge neutralization }\end{array}$ & & NPDES, RCRA & $\begin{array}{l}\text { Discharge } \\
\text { monitoring, } \\
\text { sampling }\end{array}$ \\
\hline & & & B. Storage facilities & & & \\
\hline \multirow[t]{3}{*}{$\begin{array}{l}\text { Oak Ridge Y-12 } \\
\text { Plant }\end{array}$} & Old Salvage Yard & $\begin{array}{l}\text { Solid sanitary } \\
\text { scrap metal }\end{array}$ & Temporary storage & Active & $\begin{array}{l}\text { TDEC fugitive air } \\
\text { emissions }\end{array}$ & \\
\hline & New Salvage Yard & $\begin{array}{l}\text { Solid sanitary } \\
\text { scrap metal }\end{array}$ & Temporary storage & Active & Air permit not required & \\
\hline & $\begin{array}{l}\text { West Tank Farm } \\
\text { Full Parking Lot } \\
\text { (WTF-FPL) }\end{array}$ & Liquid sanitary & Temporary storage & Active & $\begin{array}{l}\text { NPDES, RCRA permit- } \\
\text { by-rule }\end{array}$ & \\
\hline
\end{tabular}


Industrial and sanitary waste treatment and disposal facilities on the Oak Ridge Reservation (continued)

\begin{tabular}{|c|c|c|c|c|c|c|}
\hline Site & Facility & $\begin{array}{l}\text { Waste } \\
\text { type }\end{array}$ & Facility description & $\begin{array}{l}\text { Facility } \\
\text { status }\end{array}$ & $\begin{array}{l}\text { Permitting } \\
\text { status }\end{array}$ & $\begin{array}{c}\text { Environmental } \\
\text { monitoring }\end{array}$ \\
\hline & $\begin{array}{l}\text { East End Waste } \\
\text { Storage Facility }\end{array}$ & $\begin{array}{l}\text { Wastewater from } \\
\text { car-cleaning } \\
\text { operations }\end{array}$ & $\begin{array}{l}\text { Collection, storage, } \\
\text { sampling, and discharging } \\
\text { wastewater }\end{array}$ & Active & & \\
\hline & & & C. Disposal facilities & & & \\
\hline \multirow[t]{4}{*}{$\begin{array}{l}\text { Oak Ridge Y-12 } \\
\text { Plant }\end{array}$} & $\begin{array}{l}\text { Industrial } \\
\text { Landfill V }\end{array}$ & $\begin{array}{l}\text { Solid sanitary/ } \\
\text { industrial }\end{array}$ & $\begin{array}{l}\text { TDEC Class II disposal } \\
\text { facility }\end{array}$ & Active & $\begin{array}{l}\text { Fugitive air permit, } \\
\text { NPDES permitted outfall } \\
\text { sampling permit } 26 \text {, } \\
\text { landfill permit, RCRA } \\
\text { permit not applicable }\end{array}$ & $\begin{array}{l}\text { Groundwater } \\
\text { wells, } \\
\text { leachate, and } \\
\text { air monitoring }\end{array}$ \\
\hline & $\begin{array}{l}\text { Construction/ } \\
\text { Demolition } \\
\text { Landfill VI }\end{array}$ & $\begin{array}{l}\text { Solid construction/ } \\
\text { demolition debris }\end{array}$ & $\begin{array}{l}\text { TDEC Class IV disposal } \\
\text { facility }\end{array}$ & Active & $\begin{array}{l}\text { Fugitive air permit, } \\
\text { landfill permit, RCRA } \\
\text { permit not required }\end{array}$ & $\begin{array}{l}\text { Groundwater } \\
\text { wells and air } \\
\text { monitoring }\end{array}$ \\
\hline & $\begin{array}{l}\text { Sanitary } \\
\text { Landfill II }\end{array}$ & $\begin{array}{l}\text { Solid sanitary/ } \\
\text { industrial }\end{array}$ & $\begin{array}{l}\text { TDEC Class II disposal } \\
\text { facility }\end{array}$ & Active & $\begin{array}{l}\text { Fugitive air, landfill } \\
\text { permit, RCRA permit not } \\
\text { required }\end{array}$ & $\begin{array}{l}\text { Groundwater } \\
\text { wells and air } \\
\text { monitoring. }\end{array}$ \\
\hline & $\begin{array}{l}\text { Industrial Waste } \\
\text { Landfill IV }\end{array}$ & $\begin{array}{l}\text { Classified solid } \\
\text { industrial }\end{array}$ & $\begin{array}{l}\text { TDEC Class II disposal } \\
\text { facility }\end{array}$ & Active & $\begin{array}{l}\text { Fugitive air, landfill } \\
\text { permit, RCRA permit not } \\
\text { required }\end{array}$ & $\begin{array}{l}\text { Groundwater } \\
\text { wells and air } \\
\text { monitoring }\end{array}$ \\
\hline $\begin{array}{l}\text { Oak Ridge } \\
\text { National } \\
\text { Laboratory }\end{array}$ & $\begin{array}{l}\text { No facilities at } \\
\text { ORNL }\end{array}$ & $\begin{array}{l}\text { Solid sanitary/ } \\
\text { industrial }^{b} \\
\text { construction/ } \\
\text { demolition }^{c}\end{array}$ & NA & NA & NA & NA \\
\hline $\begin{array}{l}\text { Oak Ridge K-25 } \\
\text { Site }\end{array}$ & Site Fill Area I & $\begin{array}{l}\text { Construction and } \\
\text { demolition } \\
\text { materials }\end{array}$ & $\begin{array}{l}\text { Located on Pine Ridge } \\
\text { north of main plant and } \\
\text { west of Blair Road. Grass } \\
\text { cover on } 2.8 \text { ha ( } 7 \text { acres). }\end{array}$ & $\begin{array}{l}\text { Pending approval } \\
\text { for disposal }\end{array}$ & & \\
\hline
\end{tabular}

${ }^{a}$ National Pollutant Discharge Elimination System (NPDES); Resource Conservation and Recovery Act (RCRA); Tennessec Department of Environment and Conservation (TDEC).

${ }^{b}$ Goes to $\mathrm{Y}-12$ Site Landfills II and V.

'Goes to Y-12 Site Landfill VI. 


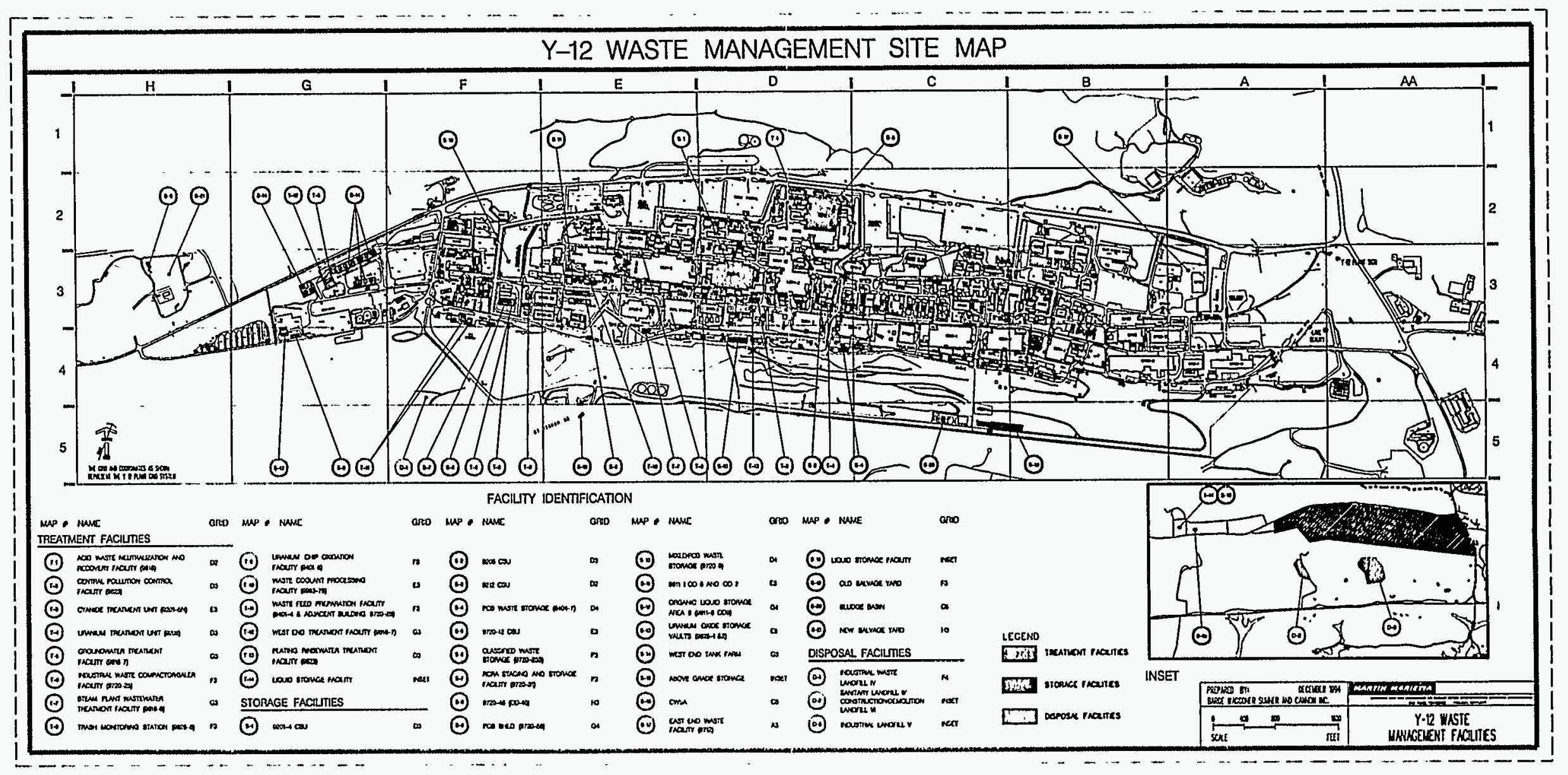




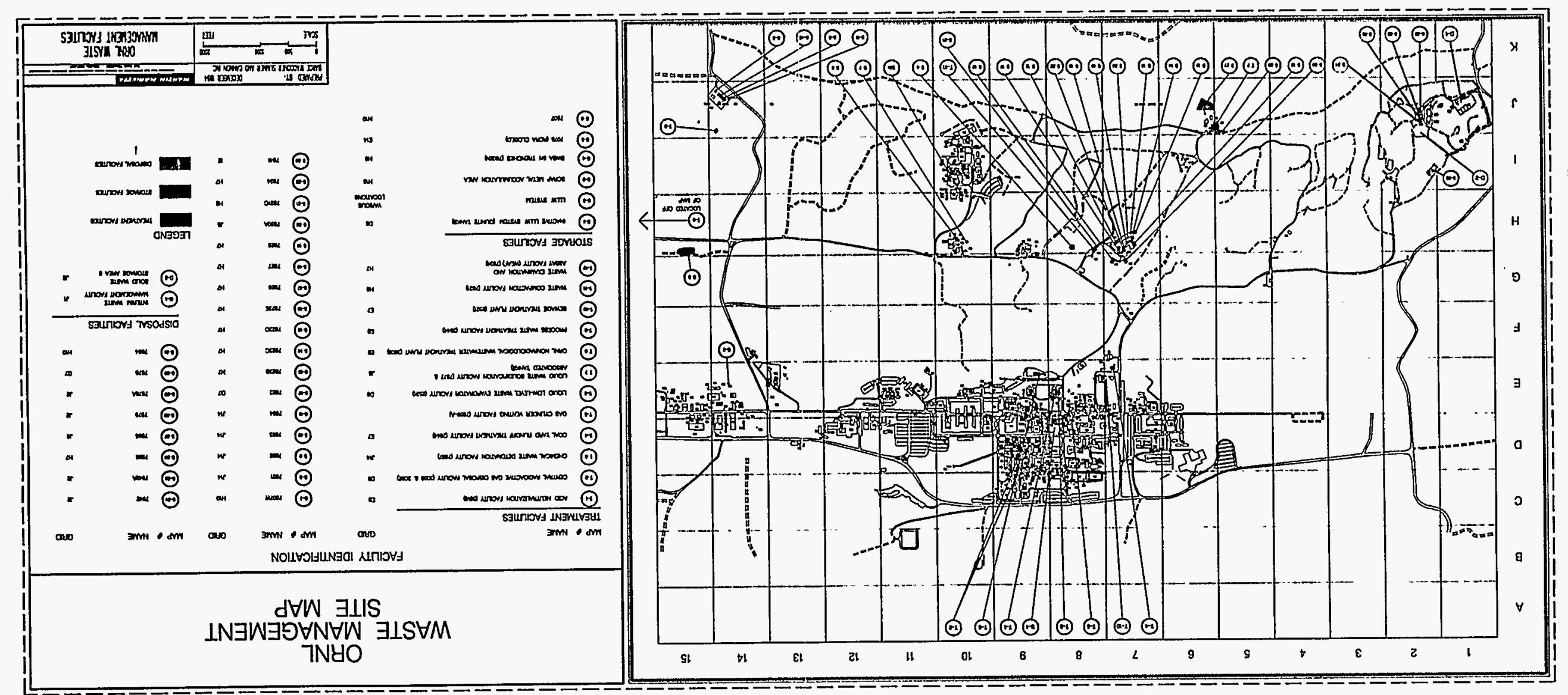


Line item and general plant projects for spent nuclear fuel

\begin{tabular}{|c|c|c|c|c|c|c|}
\hline Site & $\begin{array}{l}\text { ADS } \\
\text { No. }\end{array}$ & $\begin{array}{l}\text { Project } \\
\text { title/type }\end{array}$ & FY & $\begin{array}{l}\text { Total cost } \\
\text { estimate } \\
(\$ \times 1000)\end{array}$ & $\begin{array}{c}\text { Capability } \\
\text { code }^{a}\end{array}$ & $\begin{array}{c}\text { Beneficial } \\
\text { use date }\end{array}$ \\
\hline $\begin{array}{l}\text { Oak Ridge } \\
\text { Y-12 Plant }\end{array}$ & & & Not applicable & & & \\
\hline $\begin{array}{l}\text { Oak Ridge } \\
\text { National } \\
\text { Laboratory }\end{array}$ & 8207 & Dry Cask Storage Project (LI) & 1998 & 14,000 & $S$ & TBD \\
\hline $\begin{array}{l}\text { Oak Ridge } \\
\text { K-25 Site }\end{array}$ & & & Not applicable & & & \\
\hline
\end{tabular}

${ }^{\circ} \mathrm{O}=$ operations, $\mathrm{S}=$ storage, $\mathrm{T}=$ treatment, $\mathrm{D}=$ disposal. 
Line item and general plant projects for transuranic waste

\begin{tabular}{|c|c|c|c|c|c|c|}
\hline Site & $\begin{array}{l}\text { ADS } \\
\text { No. }\end{array}$ & $\begin{array}{c}\text { Project } \\
\text { title/type }\end{array}$ & FY & $\begin{array}{l}\text { Total cost } \\
\text { estimate } \\
(\$ \times 1000)\end{array}$ & $\begin{array}{l}\text { Capability } \\
\text { code }^{a}\end{array}$ & $\begin{array}{c}\text { Beneficial } \\
\text { use date }\end{array}$ \\
\hline $\begin{array}{l}\text { Oak Ridge } \\
\text { Y-12 Plant }\end{array}$ & \multicolumn{6}{|c|}{ There are no transuranic waste treatment, storage, or disposal facilities at the Y-12 Plant. } \\
\hline \multirow{7}{*}{$\begin{array}{l}\text { Oak Ridge } \\
\text { National Laboratory }\end{array}$} & 3207 & Waste Handling and Packaging Plant & 1998 & 350,000 & $\mathrm{~T}$ & TBD \\
\hline & 3207 & Retrievable Cask Storage Bunker & 1998 & 6,000 & $s$ & TBD \\
\hline & 3207 & Central Verification Facility & 1998 & 40,000 & $\mathrm{C}$ & TBD \\
\hline & 3204 & $\begin{array}{l}\text { Remote-Handled Transuranic Waste Storage Bunker } \\
\text { (Building 7883) }\end{array}$ & 1989 & 1,100 & $s$ & 1995 \\
\hline & 3204 & $\begin{array}{l}\text { Contact-Handled Transuranic Storage Facility } \\
\text { (Building 7572) }\end{array}$ & 1990 & 1,050 & $\mathbf{s}$ & 1995 \\
\hline & 3202 & $\begin{array}{l}\text { Nuclear Fuel Services, Inc., Waste Storage Facility } \\
\text { (Building 7574) }\end{array}$ & 1991 & 1,100 & $s$ & 1995 \\
\hline & 3204 & Transuranic Waste Storage Facility (Building 7577) & 1997 & 1,100 & $\mathbf{s}$ & TBD \\
\hline $\begin{array}{l}\text { Oak Ridge } \\
\text { K-25 Site }\end{array}$ & \multicolumn{6}{|c|}{ There are no transuranic waste treatment, storage, or disposal facilities at the K-25 Site. } \\
\hline
\end{tabular}

${ }^{\circ} \mathrm{O}=$ operations, $\mathrm{S}=$ storage, $\mathrm{T}=$ treatment, $\mathrm{D}=$ disposal, $\mathrm{C}=$ certification. 
Line item and general plant projects for low-level waste

\begin{tabular}{|c|c|c|c|c|c|c|}
\hline Site & $\begin{array}{l}\text { ADS } \\
\text { No. }\end{array}$ & $\begin{array}{c}\text { Project } \\
\text { title/type }\end{array}$ & FY & $\begin{array}{l}\text { Total cost } \\
\text { estimate } \\
(\$ \times 1000)\end{array}$ & $\begin{array}{l}\text { Capability } \\
\text { code }^{a}\end{array}$ & $\begin{array}{l}\text { Beneficial } \\
\text { use date }\end{array}$ \\
\hline $\begin{array}{l}\text { Oak Ridge } \\
\text { Y-12 Plant }\end{array}$ & 2203 & Production Waste Storage Facilities $(\mathrm{LI})^{b}$ & 1989 & 25,500 & $S$ & 1995 \\
\hline \multirow[t]{15}{*}{$\begin{array}{l}\text { Oak Ridge } \\
\text { National Laboratory }\end{array}$} & 3253 & $\begin{array}{l}\text { Bethel Valley Liquid Low-Level Waste } \\
\text { (LLLW) Collection and Transfer (CAT) } \\
\text { System Upgrade (LI) }\end{array}$ & & & & \\
\hline & & $\begin{array}{l}\text { - Phase I } \\
\text { - Phase II }\end{array}$ & $\begin{array}{l}1988 \\
1088\end{array}$ & 35,000 & o & 1995 \\
\hline & & - Phase II & 1988 & 30,000 & 0 & TBD \\
\hline & 3253 & $\begin{array}{l}\text { Melton Valley LLLW CAT System } \\
\text { Upgrade (LI) }\end{array}$ & 1992 & 41,000 & 0 & 1996 \\
\hline & 3253 & $\begin{array}{l}\text { Bethel Valley Federal Facility Agreement } \\
\text { (FFA) Upgrades (LI) }\end{array}$ & 1994 & 20,500 & o & TBD \\
\hline & 3253 & $\begin{array}{l}\text { Melton Valley Storage Tank Capacity } \\
\text { Increase (LI) }\end{array}$ & 1994 & 48,000 & 0 & TBD \\
\hline & 3253 & $\begin{array}{l}\text { Oak Ridge Reactor/Bulk Shielding } \\
\text { Reactor LLLW Upgrade (GPP) }\end{array}$ & 1992 & 1,100 & $s$ & 1995 \\
\hline & 3204 & FFA compliance-Building 3019A (GPP) & 1992 & 1,085 & 0 & 1995 \\
\hline & 3253 & 3108 Filter Pit Enclosure (GPP) & 1993 & 157 & 0 & 1995 \\
\hline & 3253 & 7930 Filter Pit Cover (GPP) & 1993 & 193 & 0 & 1995 \\
\hline & 3253 & $\begin{array}{l}\text { Pretreatment of Radiochemical } \\
\text { Engineering Development Center } \\
\text { (Building 7920) LLLW (GPP) }\end{array}$ & 1994 & 1,100 & o & 1995 \\
\hline & 3204 & $\begin{array}{l}\text { New Hydrofracture Facility Cell Plug } \\
\text { Enclosure (GPP) }\end{array}$ & 1994 & 538 & 0 & 1995 \\
\hline & 3204 & Solid Waste Storage Area (SWSA) 8 (LI) & 1994 & 14,000 & $\mathbf{s}$ & 1998 \\
\hline & 3204 & SWSA 6 Improvements (GPP) & 1990 & 309 & $S$ & TBD \\
\hline & 3204 & Bulk Contaminated Soil Facility (GPP) & 1991 & 1,100 & $\mathbf{S}$ & TBD \\
\hline
\end{tabular}


Line item and general plant projects for low-level waste (continued)

\begin{tabular}{|c|c|c|c|c|c|c|}
\hline Site & $\begin{array}{l}\text { ADS } \\
\text { No. }\end{array}$ & $\begin{array}{l}\text { Project } \\
\text { title/type }\end{array}$ & FY & $\begin{array}{l}\text { Total cost } \\
\text { estimate } \\
(\$ \times 1000)\end{array}$ & $\begin{array}{l}\text { Capability } \\
\text { code }^{a}\end{array}$ & $\begin{array}{c}\text { Beneficial } \\
\text { use date }\end{array}$ \\
\hline \multirow{14}{*}{$\begin{array}{l}\text { Oak Ridge } \\
\text { National Laboratory } \\
\text { (continued) }\end{array}$} & 3204 & $\begin{array}{l}\text { Class L-III/IV Retrievable Storage } \\
\text { Facilities (GPP) }\end{array}$ & 1991 & 1,100 & $S$ & 1996 \\
\hline & 3204 & $\begin{array}{l}\text { Class L-III/IV Aboveground Storage } \\
\text { Facility (GPP) }\end{array}$ & 1992 & 481 & $S$ & 1996 \\
\hline & 3204 & $\begin{array}{l}\text { Solid Low-Level Waste Staging Facility } \\
\text { (GPP) }\end{array}$ & 1994 & 760 & 0 & TBD \\
\hline & 3207 & $\begin{array}{l}\text { ORNL Process Waste Treatment } \\
\text { Facility (LI) }\end{array}$ & 1993 & 21,000 & 0 & 2001 \\
\hline & 3205 & $\begin{array}{l}\text { Process Waste Treatment System } \\
\text { Upgrade (LI) }\end{array}$ & 1993 & 6,000 & $\mathrm{O}$ & 1998 \\
\hline & 3253 & $\begin{array}{l}\text { Chlorine Treatment for Cooling } \\
\text { Water (GPP) }\end{array}$ & 1991 & 700 & $\mathbf{T}$ & 1995 \\
\hline & 3253 & Outfall 302 Storm Rehabilitation (GPP) & 1992 & 1,065 & $\mathrm{O}$ & 1995 \\
\hline & 3253 & $\begin{array}{l}\text { Nonradiological Wastewater Treatment } \\
\text { Plant Access Controls (GPP) }\end{array}$ & 1993 & 460 & 0 & 1995 \\
\hline & 3253 & $\begin{array}{l}\text { Contaminated Sumps Pumping } \\
\text { Modifications (GPP) }\end{array}$ & 1994 & 575 & $\mathrm{O}$ & 1995 \\
\hline & 3253 & Upgrade Stack Fans (3039) & 1991 & 740 & 0 & 1995 \\
\hline & 3253 & $\begin{array}{l}\text { Waste Operations Control Center } \\
\text { expansion }\end{array}$ & 1991 & 1,196 & $\mathrm{O}$ & 1996 \\
\hline & 3204 & Liquid/Gaseous Waste Support Facility & 1992 & 1,100 & 0 & 1995 \\
\hline & 3253 & $\begin{array}{l}\text { Upgrade Hot Off-Gas System at } 3039 \\
\text { Stack }\end{array}$ & 1994 & 733 & 0 & 1995 \\
\hline & 3253 & Ventilation Systems Upgrade ( 3500$)$ & 1992 & 1,000 & 0 & TBD \\
\hline
\end{tabular}




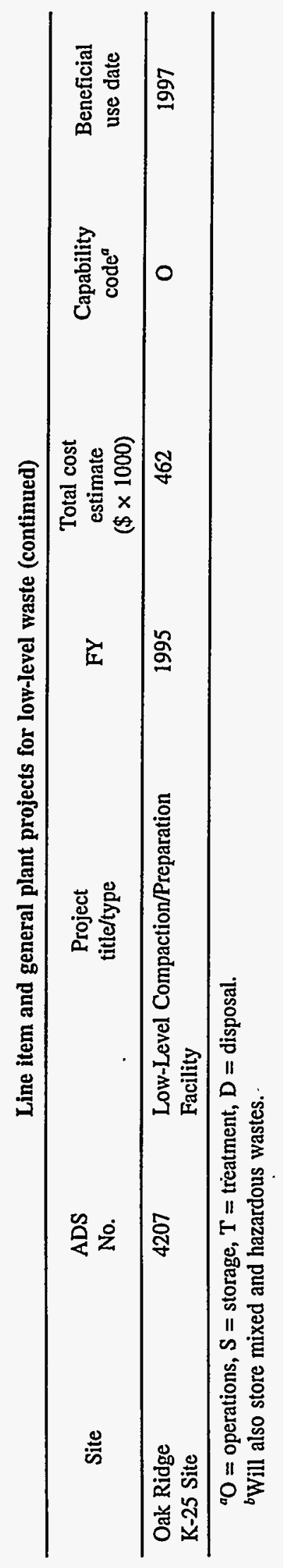

Planned ORR Waste TSD Facilities C-7 
Line item and general plant projects for hazardous waste

\begin{tabular}{|c|c|c|c|c|c|c|}
\hline Site & $\begin{array}{l}\text { ADS } \\
\text { No. }\end{array}$ & $\begin{array}{l}\text { Project } \\
\text { title/type }\end{array}$ & FY & $\begin{array}{l}\text { Total cost } \\
\text { estimate } \\
(\$ \times 1000)\end{array}$ & $\begin{array}{l}\text { Capability } \\
\text { code }^{a}\end{array}$ & $\begin{array}{l}\text { Beneficial } \\
\text { use date }\end{array}$ \\
\hline $\begin{array}{l}\text { Oak Ridge } \\
\text { Y-12 Plant }\end{array}$ & 2203 & Production Waste Storage Facilities $(21)^{b}$ & 1989 & 25,500 & $S$ & 1995 \\
\hline $\begin{array}{l}\text { Oak Ridge } \\
\text { National } \\
\text { Laboratory }\end{array}$ & 3253 & $\begin{array}{l}\text { Polychlorinated biphenyl } \\
\text { (PCB)/hazardous waste storage, } \\
\text { Building } 7652 \text { Annex }\end{array}$ & 1989 & 200 & $S$ & TBD \\
\hline \multirow[t]{8}{*}{$\begin{array}{l}\text { Oak Ridge } \\
\text { K-25 Site }\end{array}$} & $4207-1$ & $\begin{array}{l}\text { Central Neutralization Facility (CNF) } \\
\text { Pipeline Extension Project }\end{array}$ & 1996 & 1,000 & o & 1996 \\
\hline & 4207 & CNF Upgrade & 1996 & 30,000 & $\mathrm{~T}$ & Est. 1998 \\
\hline & 4206 & $\begin{array}{l}\text { Toxic Substances Control Act } \\
\text { (TSCA)/CNF Pipeline Replacement }\end{array}$ & 1996 & 1,000 & 0 & 1996 \\
\hline & 8206 & Lab Pack Facility & 1996 & 1,300 & 0 & 1997 \\
\hline & 8206 & Container Processing Facility & 1995 & 950 & $\mathbf{T}$ & 1995 \\
\hline & ER & CNF/SW 31 Spring Water & 1995 & 5,000 & $\mathrm{~T}$ & 1995 \\
\hline & 4207 & TSCA Off-gas Treatment & 1996 & 9,000 & $\mathrm{~T}$ & Est. 1998 \\
\hline & 4206 & K-1036-A Upgrade to PCB Storage & 1995 & 262 & $\mathbf{S}$ & 1996 \\
\hline
\end{tabular}

${ }^{a} \mathrm{O}=$ operations, $\mathrm{S}=$ storage, $\mathrm{T}=$ treatment, $\mathrm{D}=$ disposal.

${ }^{b}$ Will also store mixed and low-level waste. 
Line item and general plant projects for mixed waste

\begin{tabular}{|c|c|c|c|c|c|c|}
\hline Site & $\begin{array}{l}\text { ADS } \\
\text { No. }\end{array}$ & $\begin{array}{l}\text { Project } \\
\text { title/type }\end{array}$ & FY & $\begin{array}{c}\text { Total cost } \\
\text { estimate } \\
(\$ \times 1000)\end{array}$ & $\begin{array}{l}\text { Capability } \\
\text { code }^{a}\end{array}$ & $\begin{array}{l}\text { Beneficial } \\
\text { use date }\end{array}$ \\
\hline \multirow{2}{*}{$\begin{array}{l}\text { Oak Ridge } \\
\text { Y-12 Plant }\end{array}$} & 2203 & Production Waste Storage Facilities (LI) & 1989 & 25,500 & $S$ & 1995 \\
\hline & 2210 & OD-7 and -8 Upgrades ${ }^{c}$ & 1995 & 4,100 & $S$ & 1998 \\
\hline \multirow{2}{*}{$\begin{array}{l}\text { Oak Ridge } \\
\text { National } \\
\text { Laboratory }\end{array}$} & 3253 & Expand Mixed Waste Storage & 1989 & 827 & $s$ & 1996 \\
\hline & 3204 & Mixed Waste Storage Facility & 1993 & 1,100 & $S$ & TBD \\
\hline \multirow[t]{8}{*}{$\begin{array}{l}\text { Oak Ridge } \\
\text { K-25 Site }\end{array}$} & $4207-1$ & $\begin{array}{l}\text { Central Neutralization Facility (CNF) } \\
\text { Pipeline Extension Project }\end{array}$ & 1996 & 1,100 & o & 1996 \\
\hline & 4207 & CNF Upgrade & 1996 & 30,000 & $\mathrm{~T}$ & Est. 1998 \\
\hline & 4206 & $\begin{array}{l}\text { Toxic Substances Control Act } \\
\text { (TSCA)/CNF Pipeline Replacement }\end{array}$ & 1996 & 1,000 & o & 1996 \\
\hline & 8206 & Lab Pack Facility & 1996 & 1,300 & 0 & 1997 \\
\hline & 8206 & Container Processing Facility & 1995 & 950 & $\mathrm{~T}$ & 1995 \\
\hline & ER & CNF/SW 31 Spring Water & 1995 & 5,000 & $\mathrm{~T}$ & 1995 \\
\hline & 4207 & TSCA Off-gas Treatment & 1996 & 9,000 & $T$ & Est. 1998 \\
\hline & 4206 & $\begin{array}{l}\text { K-1036-A Upgrade to Polychlorinated } \\
\text { Biphenyls Storage }\end{array}$ & 1995 & 262 & $\mathbf{s}$ & 1996 \\
\hline
\end{tabular}

${ }^{\circ} \mathrm{O}=$ operations, $\mathrm{S}=$ storage, $\mathrm{T}=$ treatment, $\mathrm{D}=$ disposal.

${ }^{b}$ Also will store hazardous and LLW.

"Also stores LLW.

${ }^{d}$ See also hazardous waste. 
Line item and general plant projects for industrial and sanitary wastes

\begin{tabular}{|c|c|c|c|c|c|c|}
\hline Site & $\begin{array}{l}\text { ADS } \\
\text { No. }\end{array}$ & $\begin{array}{l}\text { Project } \\
\text { title/type }\end{array}$ & FY & $\begin{array}{c}\text { Total cost } \\
\text { estimate } \\
(\$ \times 1000)\end{array}$ & $\begin{array}{l}\text { Capability } \\
\text { code }^{a}\end{array}$ & $\begin{array}{c}\text { Beneficial } \\
\text { use date }\end{array}$ \\
\hline \multirow[t]{6}{*}{$\begin{array}{l}\text { Oak Ridge } \\
\text { Y-12 Plant }\end{array}$} & 2208 & $\begin{array}{l}\text { Industrial Landfill V and Construction } \\
\text { Demolition Landfill (CDL) VII, Phase II }\end{array}$ & 1995 & 9,600 & D & 1999 \\
\hline & 2206 & CDL VI & 1991 & 619 & $\mathrm{D}$ & 1994 \\
\hline & 8206 & Landfill IV Upgrade & 1993 & 1,198 & $\mathrm{D}$ & 1996 \\
\hline & 2101 & Steam Plant Ash Disposal & 1990 & 19,675 & $\mathrm{D}$ & 1994 \\
\hline & 2204 & Industrial Waste Compaction Facility & 1993 & 9,300 & $\mathrm{~T}$ & 1997 \\
\hline & 2205 & Plant Drains Wastewater Treatment Upgrade & 1993 & 6,700 & $\mathbf{T}$ & 1997 \\
\hline \multirow{6}{*}{$\begin{array}{l}\text { Oak Ridge } \\
\text { National } \\
\text { Laboratory }^{b}\end{array}$} & $3402 / 3255$ & Upgrade Sanitary Sewer System & 1994 & 16,000 & $\mathrm{~T}$ & 1999 \\
\hline & 3253 & Wastewater Piping Replacement & 1988 & 1,140 & o & 1994 \\
\hline & 3253 & Surface Water Monitoring & 1988 & 800 & 0 & 1995 \\
\hline & 3253 & Chlorine Treatment for Cooling Water & 1991 & 700 & $\mathrm{~T}$ & 1995 \\
\hline & 3253 & Outfall 302 Storm Rehabilitation & 1992 & 1,065 & o & 1995 \\
\hline & 3253 & Outfall Dechlorination & 1993 & 501 & o & 1995 \\
\hline \multirow[t]{2}{*}{$\begin{array}{l}\text { Oak Ridge } \\
\text { K-25 Site }\end{array}$} & 4207 & $\begin{array}{l}\text { Central Neutralization Facility (CNF) } \\
\text { Upgrade }\end{array}$ & 1996 & 30,000 & $\mathrm{~T}$ & 1998 \\
\hline & $4207-1$ & CNF Pipeline Extension Project & 1996 & 1,100 & 0 & 1996 \\
\hline
\end{tabular}

${ }^{\circ} \mathrm{O}=$ operations, $\mathrm{S}=$ storage, $\mathrm{T}=$ treatment, $\mathrm{D}=$ disposal.

bNo general plant projects are planned for industrial solid wastes at ORNL. ORNL amounts are $\$ \times 1000$. Dates in last column indicate when ORNL construction is expected to be completed. 
DOE Order 5820.2A Implementation Summary ${ }^{a}$ (continued)

\begin{tabular}{|c|c|c|c|c|}
\hline Chap./par. & Requirement & $\begin{array}{l}\text { Oak Ridge } \\
\text { Y-12 Site }\end{array}$ & $\begin{array}{l}\text { Oak Ridge } \\
\text { National Laboratory }^{b}\end{array}$ & $\begin{array}{l}\text { Oak Ridge } \\
\text { K-25 Site }\end{array}$ \\
\hline All of Chap. I & High-level waste & $\mathrm{NA}^{d}$ & $\mathrm{NA}$ & NA \\
\hline II.3.a(1) & $\begin{array}{l}\text { Any material that is known to be, or suspected of being, } \\
\text { contaminated with transuranium radionuclides shall be } \\
\text { evaluated }\end{array}$ & - & $\mathrm{C}$ & 一 \\
\hline II.3.a(2) & $\begin{array}{l}\text { The lower concentration limit for transuranic waste (greater } \\
\text { than } \mathrm{nCi} / \mathrm{g} \text { of waste) }\end{array}$ & 一 & $\mathrm{C}$ & - \\
\hline II.3.a(3) & $\begin{array}{l}\text { Radionuclides in concentrations of } 100 \mathrm{nCi} / \mathrm{g} \text { of waste or less } \\
\text { shall be considered to be low-level waste }\end{array}$ & - & NC & 一 \\
\hline II.3.a(4) & $\begin{array}{l}\text { Mixed transuranic waste meeting the requirements of the } \\
\text { Waste Isolation Pilot Plant (WIPP) Waste Acceptance Criteria } \\
\text { (WAC) shall be sent to the WIPP }\end{array}$ & 一 & NC & - \\
\hline II.3.b(1) & $\begin{array}{l}\text { Controls shall be directed to reducing the gross volume of } \\
\text { waste generated }\end{array}$ & 一 & C & 一 \\
\hline II.3.b(2) & Transuranic waste shall be assayed & 一 & $\mathrm{NC}$ & - \\
\hline II.3.b(3) & $\begin{array}{l}\text { Mixed transuranic waste shall be treated to destroy the } \\
\text { hazardous waste component }\end{array}$ & - & 一 & - \\
\hline II.3.b(4) & $\begin{array}{l}\text { Transuranic waste shall be treated to remove or destroy the } \\
\text { classified characteristic(s) prior to certification }\end{array}$ & - & - & - \\
\hline II.3.c(1) & $\begin{array}{l}\text { Transuranic waste shall be certified, pursuant to WIPP WAC, } \\
\text { and placed in interim storage }\end{array}$ & - & NC & - \\
\hline II.3.c(2) & $\begin{array}{l}\text { Uncertified transuranic waste shall not be sent to WIPP except } \\
\text { by special permission }\end{array}$ & 一 & NC & 一 \\
\hline II.3.c(3) & $\begin{array}{l}\text { All transuranic waste certification sites shall prepare a } \\
\text { certification plan }\end{array}$ & - & $\mathrm{NC}$ & 一 \\
\hline II.3.c(4) & Each certification plan shall define controls & - & $\mathrm{NC}$ & 一 \\
\hline II.3.c(5) & Certification plans shall be submitted for review & - & $\mathrm{NC}$ & 一 \\
\hline II.3.c(7) & $\begin{array}{l}\text { The Environmental Evaluation Group's comments on } \\
\text { certification and associated quality assurance plans shall be } \\
\text { resolved }\end{array}$ & 一 & NC & 一 \\
\hline
\end{tabular}


DOE Order 5820.2A Implementation Summary ${ }^{a}$ (continued)

\begin{tabular}{|c|c|c|c|c|}
\hline Chap./par. & Requirement & $\begin{array}{l}\text { Oak Ridge } \\
\text { Y-12 Site }\end{array}$ & $\begin{array}{l}\text { Oak Ridge } \\
\text { National Laboratory }\end{array}$ & $\begin{array}{l}\text { Oak Ridge } \\
\text { K-25 Site }\end{array}$ \\
\hline II.3.c(8) & $\begin{array}{l}\text { Approved certification and associated quality assurance plans } \\
\text { shall be implemented }\end{array}$ & - & NC & - \\
\hline II.3.c(10)(2) & $\begin{array}{l}\text { Corrective actions taken as a result of a finding shall be } \\
\text { verified }\end{array}$ & - & $\mathrm{C}$ & - \\
\hline II.3.c(11) & $\begin{array}{l}\text { Failure to resolve and close out previous audit findings shall } \\
\text { result in suspension of certifying authority }\end{array}$ & - & NC & - \\
\hline II.3.d & Transuranic waste packaging & - & $\mathrm{NC}$ & - \\
\hline II.3.c(1) & $\begin{array}{l}\text { Temporary storage at generating sites: transuranic waste shall } \\
\text { be segregated }\end{array}$ & - & C & - \\
\hline II.3.e(2) & $\begin{array}{l}\text { Certified transuranic waste shall not be commingled with } \\
\text { noncertified transuranic waste }\end{array}$ & - & C & - \\
\hline II.3.e(3) & $\begin{array}{l}\text { Transuranic waste in storage areas shall be protected from } \\
\text { unauthorized access }\end{array}$ & - & C & - \\
\hline II.3.e(4) & Transuranic wastes in storage shall be monitored periodically & 一 & $\mathrm{C}$ & - \\
\hline II.3.e(5) & $\begin{array}{l}\text { Transuranic waste storage facilities shall minimize the } \\
\text { possibility of fire, explosion, or accidental release }\end{array}$ & - & C & - \\
\hline II.3.e(6) & $\begin{array}{l}\text { Facilities that store transuranic waste shall have a contingency } \\
\text { plan }\end{array}$ & - & $\mathrm{C}$ & - \\
\hline II.3.e(7) & $\begin{array}{l}\text { Transuranic waste shall be stored in such a way as to maintain } \\
\text { radiation exposures as low as reasonably achievable }\end{array}$ & - & $\mathrm{C}$ & - \\
\hline II.3.f(1) & $\begin{array}{l}\text { Transuranic waste shipments shall comply with the provisions } \\
\text { of DOE and U.S. Department of Transportation (DOT) } \\
\text { regulations }\end{array}$ & - & C & - \\
\hline II.3.f(2) & $\begin{array}{l}\text { Transuranic waste shipments by truck shall be by a } \\
\text { DOE-controlled carrier system }\end{array}$ & - & $\mathrm{NC}$ & - \\
\hline II.3.f(3) & $\begin{array}{l}\text { Shipping papers shall provide the information required by } \\
\text { DOT, WIPP, and the U.S. Environmental Protection Agency } \\
\text { (EPA) }\end{array}$ & - & $\mathrm{NC}$ & - \\
\hline
\end{tabular}


DOE Order 5820.2A Implementation Summary ${ }^{a}$ (continued)

\begin{tabular}{|c|c|c|c|c|}
\hline Chap./par. & Requirement & $\begin{array}{l}\text { Oak Ridge } \\
\text { Y-12 Site }\end{array}$ & $\begin{array}{l}\text { Oak Ridge } \\
\text { National Laboratory }{ }^{b}\end{array}$ & $\begin{array}{l}\text { Oak Ridge } \\
\text { K-25 Site }\end{array}$ \\
\hline II.3.f(4) & $\begin{array}{l}\text { Distribution of the shipping papers shall be shipper, carrier, } \\
\text { and WIPP }\end{array}$ & - & NC & - \\
\hline II.3.f(5) & $\begin{array}{l}\text { Appropriate EPA and state authorizations/permits shall be } \\
\text { obtained }\end{array}$ & - & NC & 一 \\
\hline II.3.f(6) & Placarding of shipments shall be carried out & - & $\mathrm{C}$ & 一 \\
\hline II.3.f(7) & $\begin{array}{l}\text { All shipments of transuranic waste shall be in or on "exclusive } \\
\text { use" vehicles }\end{array}$ & 一 & $\mathrm{C}$ & - \\
\hline II.3.g(2)(a) & $\begin{array}{l}\text { New interim storage facilities' proximity to groundwater and } \\
\text { areas of seismic activity or floodplains shall be identified }\end{array}$ & - & NC & 一 \\
\hline II.3.g(2)(b) & $\begin{array}{l}\text { Interim storage: facilities shall be consistent with the } \\
\text { requirements of applicable Resource Conservation and } \\
\text { Recovery Act (RCRA) regulations }\end{array}$ & - & NC & - \\
\hline II.3.g(2)(c) & $\begin{array}{l}\text { An environmental monitoring system shall be provided to } \\
\text { detect any release and migration of major radioactive and } \\
\text { hazardous components }\end{array}$ & 一 & NC & - \\
\hline II.3.g(2)(d) & $\begin{array}{l}\text { The storage facility design shall minimize the possibility for } \\
\text { the unauthorized entry of persons }\end{array}$ & - & NC & - \\
\hline 11.3.g(2)(e) & $\begin{array}{l}\text { Incompatible waste types shall be placed in separate packages } \\
\text { stored in segregated areas }\end{array}$ & - & $\mathrm{C}$ & 一 \\
\hline II.3.g(3) & Existing interim storage sites shall be reviewed for consistency & - & NC & 一 \\
\hline II.3.g(2)(f) & $\begin{array}{l}\text { Waste storage facilities shall be designed and operated to } \\
\text { minimize the exposure of personnel to radiation and chemicals }\end{array}$ & 一 & C & 一 \\
\hline 11.3.g(2)(g) & $\begin{array}{l}\text { The storage facility operator shall inspect or verify routinely } \\
\text { the condition of waste packages }\end{array}$ & 一 & $\mathrm{C}$ & - \\
\hline II.3.g(2)(h) & $\begin{array}{l}\text { The storage facility operator shall prepare plans that identify } \\
\text { and describe how the site will be closed }\end{array}$ & 一 & $\mathrm{NC}$ & 一 \\
\hline II.3.g(2)(i) & $\begin{array}{l}\text { Underground storage fanks for the storage of transuranic waste } \\
\text { shall comply with the requirements of RCRA }\end{array}$ & - & $\mathrm{NC}$ & - \\
\hline
\end{tabular}


DOE Order 5820.2A Implementation Summary ${ }^{a}$ (continued)

\begin{tabular}{|c|c|c|c|c|}
\hline Chap./par. & Requirement & $\begin{array}{l}\text { Oak Ridge } \\
\text { Y-12 Site }\end{array}$ & $\begin{array}{l}\text { Oak Ridge } \\
\text { National Laboratory }\end{array}$ & $\begin{array}{l}\text { Oak Ridge } \\
\text { K-25 Site }\end{array}$ \\
\hline II.3.g(2)(j) & $\begin{array}{l}\text { Permits shall be acquired, as necessary, from appropriate } \\
\text { regulator entities }\end{array}$ & - & C & - \\
\hline II.3.g(4) & $\begin{array}{l}\text { Certified waste shall be stored in a manner unlikely to alter the } \\
\text { certification of the waste package }\end{array}$ & - & C & - \\
\hline II.3.g(5) & $\begin{array}{l}\text { Operators of interim storage facilities shall receive data } \\
\text { package information }\end{array}$ & - & C & - \\
\hline II.3.g(6) & $\begin{array}{l}\text { The generator of the certified waste is responsible for } \\
\text { describing the waste form and waste package content }\end{array}$ & - & NC & - \\
\hline II.3.g(7) & $\begin{array}{l}\text { Waste that has been certified by a generator and shipped to an } \\
\text { interim storage site shall be reshipped to WIPP }\end{array}$ & - & C & - \\
\hline II.3.g(8) & $\begin{array}{l}\text { The interim storage site is the shipping originator for stored } \\
\text { waste certified at the site }\end{array}$ & - & NC & - \\
\hline II.3.h(3) & $\begin{array}{l}\text { Prior to shipment of waste, WIPP shall validate the data } \\
\text { package }\end{array}$ & - & - & - \\
\hline II.3.h(4) & WIPP activities upon receipt & - & - & - \\
\hline II.3.h(5) & WIPP: operations demonstration period & - & - & - \\
\hline II.3.h(6) & WIPP decision for or against permanent disposal & - & - & - \\
\hline II.3.h(7) & WIPP underground portion and surface facilities & - & - & - \\
\hline II.3.h(8) & WIPP following closure & - & - & - \\
\hline II.3.i(2) & $\begin{array}{l}\text { Each waste site shall be characterized to include information } \\
\text { on types and quantities of radioactive and hazardous chemicals }\end{array}$ & - & NC & - \\
\hline II.3.i(3) & $\begin{array}{l}\text { Each DOE site will develop a closure strategy for the waste } \\
\text { site }\end{array}$ & - & NC & - \\
\hline II.3.i(4) & Each DOE site will develop a site closure plan & - & NC & - \\
\hline II.3.j & $\begin{array}{l}\text { Transuranic waste operations shall be conducted in accordance } \\
\text { with requirements of the ANSI/ASME Nuclear Quality } \\
\text { Assurance-1 }\end{array}$ & - & NC & - \\
\hline
\end{tabular}


DOE Order 5820.2A Implementation Summary" (continued)

\begin{tabular}{|c|c|c|c|c|}
\hline Chap./par. & Requirement & $\begin{array}{l}\text { Oak Ridge } \\
\text { Y-12 Site }\end{array}$ & $\begin{array}{c}\text { Oak Ridge } \\
\text { National Laboratory }\end{array}$ & $\begin{array}{l}\text { Oak Ridge } \\
\text { K-25 Site }\end{array}$ \\
\hline III.3.a & $\begin{array}{l}\text { DOE LLW that has not been disposed of prior to issuance of } \\
\text { this order shall be managed on the schedule developed in the } \\
\text { Implementation Plan }\end{array}$ & $\mathbf{C}$ & C & $\mathbf{C}$ \\
\hline III.3.b(1) & $\begin{array}{l}\text { Field organizations with disposal sites shall prepare and } \\
\text { maintain a site-specific radiological performance assessment }\end{array}$ & - & - & 一 \\
\hline III.3.b(2) & $\begin{array}{l}\text { Field organizations shall prepare and maintain an overall } \\
\text { Performance Assessment (PA) }\end{array}$ & 一 & - & - \\
\hline III.3.b(3) & $\begin{array}{l}\text { Monitoring measurements to evaluate actual and prospective } \\
\text { performance should be made at locations as required }\end{array}$ & - & NC & - \\
\hline III.3.c(1) & $\begin{array}{l}\text { Technical and administrative controls shall be directed to } \\
\text { reducing the gross volume of waste generated }\end{array}$ & C & $\mathbf{C}$ & $\mathrm{C}$ \\
\hline III.3.c(2) & All DOE LLW generators shall establish auditable programs & $\mathrm{C}$ & $\mathbf{C}$ & $\mathrm{C}$ \\
\hline III.3.c(3) & $\begin{array}{l}\text { Each DOE LLW generator shall separate uncontaminated waste } \\
\text { from LLW }\end{array}$ & $\mathrm{C}$ & $\mathbf{C}$ & NC \\
\hline III.3.c(4) & $\begin{array}{l}\text { A design for a new process or process changes shall } \\
\text { incorporate principles that will minimize the generation of } \\
\text { LLW }\end{array}$ & $\mathrm{C}$ & $\mathbf{C}$ & $\mathrm{C}$ \\
\hline III.3.d(1) & LLW shall be characterized & $\mathrm{C}$ & C & C \\
\hline III.3.d(2) & $\begin{array}{l}\text { Waste characterization data shall be recorded on a waste } \\
\text { manifest }\end{array}$ & $\mathrm{C}$ & $\mathbf{C}$ & C \\
\hline III.3.4(3) & $\begin{array}{l}\text { The concentration of a radionuclide may be determined by } \\
\text { direct methods or by indirect methods }\end{array}$ & $e$ & $\mathbf{C}$ & $\mathrm{C}$ \\
\hline III.3.e(1) & $\begin{array}{l}\text { Waste shipped from one field organization to another shall be } \\
\text { done in accordance with the requirements established by the } \\
\text { operations office of the receiving facility }\end{array}$ & 一 & NC & $\mathrm{C}$ \\
\hline III.3.e(2) & WAC shall be established for each LLW TSD facility & $\mathrm{C}$ & $\mathbf{C}$ & C \\
\hline III.3.e(3) & $\begin{array}{l}\text { Generators of waste shall implement an LLW certification } \\
\text { program }\end{array}$ & $\mathrm{C}$ & C & $\mathrm{C}$ \\
\hline
\end{tabular}




\begin{tabular}{|c|c|c|c|c|}
\hline Chap./par. & Requirement & $\begin{array}{l}\text { Oak Ridge } \\
\text { Y-12 Site }\end{array}$ & $\begin{array}{l}\text { Oak Ridge } \\
\text { National Laboratory }\end{array}$ & $\begin{array}{l}\text { Oak Ridge } \\
\text { K-25 Site }\end{array}$ \\
\hline III.3.e(4) & $\begin{array}{l}\text { Generator LLW certification programs shall be subject to a } \\
\text { periodic audit }\end{array}$ & C & C & C \\
\hline III.3.e(5) & WAC for TSD facilities & $\mathrm{C}$ & $\mathrm{C}$ & $\mathrm{C}$ \\
\hline III.3.f(1) & $\begin{array}{l}\text { Waste shall be treated by appropriate methods so that the } \\
\text { disposal site can meet the performance objectives }\end{array}$ & - & - & - \\
\hline III.3.f(2) & $\begin{array}{l}\text { Waste treatment techniques shall be implemented to meet } \\
\text { performance requirements }\end{array}$ & C & NC & C \\
\hline III.3.f(3) & The development of large-scale waste treatment facilities & $\mathrm{C}$ & - & NC \\
\hline III.3.f(4) & $\begin{array}{l}\text { Operation of waste treatment facilities shall be supported by } \\
\text { adequate documentation }\end{array}$ & $\mathrm{C}$ & C & NC \\
\hline III.3.g(1) & $\begin{array}{l}\text { The volume of waste and number of shipments of LLW shall } \\
\text { be minimized }\end{array}$ & $\mathrm{C}$ & NC & C \\
\hline III.3.g(2) & $\begin{array}{l}\text { Generators shall provide an annual forecast to the off-site } \\
\text { disposal facility }\end{array}$ & 一 & NC & NC \\
\hline III.3.g(3) & $\begin{array}{l}\text { Generators must receive advance approval from the receiving } \\
\text { facility }\end{array}$ & $\mathrm{C}$ & NC & C \\
\hline III.3.g(4) & $\begin{array}{l}\text { Each package of waste must comply with the labeling } \\
\text { requirement of DOE } 1540.1\end{array}$ & $\mathrm{C}$ & C & $\mathrm{C}$ \\
\hline III.3.h(1) & LLW shall be stored by appropriate methods & $\mathrm{C}$ & C & C \\
\hline III.3.h(2) & $\begin{array}{l}\text { Records shall be maintained for all LLW that enters and leaves } \\
\text { the storage facility }\end{array}$ & $\mathrm{C}$ & C & C \\
\hline III.3.h(3) & $\begin{array}{l}\text { The development and operation of a waste facility shall be } \\
\text { supported by documentation }\end{array}$ & $\mathrm{C}$ & C & C \\
\hline III.3.h(4) & $\begin{array}{l}\text { Storage of wastes to allow for nuclides to decay or until wastes } \\
\text { can be disposed of by approved methods }\end{array}$ & - & $C$ & C \\
\hline III.3.i(1) & $\begin{array}{l}\text { LLW shall be disposed of by methods appropriate to achieve } \\
\text { the performance objectives }\end{array}$ & - & C & - \\
\hline III.3.i(2) & $\begin{array}{l}\text { Engineered modifications for each disposal site shall be } \\
\text { developed through the PA model }\end{array}$ & - & C & - \\
\hline
\end{tabular}


DOE Order 5820.2A Implementation Summary ${ }^{\alpha}$ (continued)

\begin{tabular}{|c|c|c|c|c|}
\hline Chap./par. & Requirement & $\begin{array}{l}\text { Oak Ridge } \\
\text { Y-12 Site }\end{array}$ & $\begin{array}{l}\text { Oak Ridge } \\
\text { National Laboratory }\end{array}$ & $\begin{array}{l}\text { Oak Ridge } \\
\text { K-25 Site }\end{array}$ \\
\hline III.3.i(4) & $\begin{array}{l}\text { Disposition of waste designated as greater-than-Class } \mathrm{C} \text { must } \\
\text { be handled as special case }\end{array}$ & - & C & - \\
\hline III.3.i(5)(a) & $\begin{array}{l}\text { Waste must not be packaged for disposal in cardboard or } \\
\text { fiberboard boxes }\end{array}$ & 一 & $\mathrm{C}$ & $\mathrm{C}$ \\
\hline III.3.i(5)(b) & $\begin{array}{l}\text { Liquid wastes, or wastes containing free liquid, must be } \\
\text { converted to a form that contains as little freestanding and } \\
\text { noncorrosive liquid as is reasonably achievable }\end{array}$ & - & $\mathrm{C}$ & $\mathrm{C}$ \\
\hline III.3.i(5)(c) & $\begin{array}{l}\text { Waste must not be readily capable of detonation or of } \\
\text { explosive decomposition or reaction at normal pressures and } \\
\text { temperatures, or of explosive reaction with water }\end{array}$ & 一 & $\mathrm{C}$ & $\mathrm{C}$ \\
\hline III.3.i(5)(d) & $\begin{array}{l}\text { Waste must not contain, or be capable of generating, quantities } \\
\text { of toxic gases, vapors, or fumes }\end{array}$ & - & C & $\mathrm{C}$ \\
\hline III.3.i(5)(e) & $\begin{array}{l}\text { Waste in a gaseous form must be packaged at a pressure that } \\
\text { does not exceed } 1.5 \mathrm{~atm} \text { at } 20^{\circ} \mathrm{C}\end{array}$ & - & C & $\mathrm{C}$ \\
\hline III.3.i(5)(f) & Waste must not be pyrophoric & - & C & $\mathrm{C}$ \\
\hline III.3.i(6) & $\begin{array}{l}\text { Disposal of wastes containing amounts of radionuclides below, } \\
\text { regulatory concern }\end{array}$ & $e$ & - & - \\
\hline III.3.i(7) & Disposal site selection & - & $\mathbf{C}$ & 一 \\
\hline III.3.i(8)(a) & $\begin{array}{l}\text { Design criteria shall be established prior to selection of new } \\
\text { disposal facilities, new disposal sites, or both }\end{array}$ & - & $\mathrm{NC}$ & - \\
\hline III.3.i(8)(b) & $\begin{array}{l}\text { Disposal units shall be designed consistent with disposal site } \\
\text { hydrology, geology, and waste characteristics }\end{array}$ & - & C & - \\
\hline III.3.i(9)(a) & $\begin{array}{l}\text { Development and implementation of operating procedures by } \\
\text { field organizations }\end{array}$ & - & - & 一 \\
\hline III.3.i(9)(b) & $\begin{array}{l}\text { Permanent identification markers for disposal excavations and } \\
\text { monitoring wells shall be emplaced }\end{array}$ & 一 & $\mathrm{C}$ & - \\
\hline III.3.i(9)(c) & $\begin{array}{l}\text { Operating procedures shall include training for disposal facility } \\
\text { operating personnel }\end{array}$ & - & $\mathrm{C}$ & 一 \\
\hline
\end{tabular}


DOE Order 5820.2A Implementation Summary ${ }^{a}$ (continued)

\begin{tabular}{|c|c|c|c|c|}
\hline Chap./par. & Requirement & $\begin{array}{l}\text { Oak Ridge } \\
\text { Y-12 Site }\end{array}$ & $\begin{array}{c}\text { Oak Ridge } \\
\text { National Laboratory }\end{array}$ & $\begin{array}{l}\text { Oak Ridge } \\
\text { K-25 Site }\end{array}$ \\
\hline III.3.i(9)(d) & $\begin{array}{l}\text { Waste placement into disposal units should minimize voids } \\
\text { between containers }\end{array}$ & $e$ & $\mathrm{C}$ & - \\
\hline III.3.i.(9)(e) & $\begin{array}{l}\text { Operations are to be conducted so that active waste disposal } \\
\text { operations will not have an adverse effect on filled disposal } \\
\text { units }\end{array}$ & - & $\mathrm{C}$ & - \\
\hline III.3.j(1) & $\begin{array}{l}\text { Development of site-specific closure plans by field } \\
\text { organizations }\end{array}$ & - & - & - \\
\hline III.3.j(2) & $\begin{array}{l}\text { During closure and postclosure, residual radioactivity levels for } \\
\text { surface soils shall comply with DOE decommissioning } \\
\text { guidelines }\end{array}$ & - & NC & - \\
\hline III.3.j(3) & $\begin{array}{l}\text { Corrective measures shall be applied to new disposal sites or } \\
\text { individual disposal units if conditions could jeopardize } \\
\text { attainment of the performance objectives }\end{array}$ & - & NC & 一 \\
\hline III.3.j(4) & $\begin{array}{l}\text { Inactive disposal facilities, disposal sites, and disposal units } \\
\text { shall be managed in conformance with RCRA, CERCLA, and } \\
\text { SARA }\end{array}$ & - & C & - \\
\hline III.3.j(5) & $\begin{array}{l}\text { Closure plans for new and existing operating LLW disposal } \\
\text { facilities shall be reviewed and approved }\end{array}$ & - & - & - \\
\hline III.3.j(6) & $\begin{array}{l}\text { Termination of monitoring and maintenance activity at closed } \\
\text { facilities or sites shall be based on an analysis of site } \\
\text { performance }\end{array}$ & - & NC & - \\
\hline III.3.k & Environmental monitoring & $\mathrm{C}$ & NC & NC \\
\hline III.3.1(1) & Quality assurance & $\mathrm{C}$ & C & C \\
\hline III.3.m(1) & Development of record-keeping system by field organizations & $\mathrm{C}$ & - & $\mathbf{C}$ \\
\hline III.3.m(2) & Waste manifest record-keeping requirements & $\mathrm{C}$ & C & C \\
\hline IV.3.a(1) & $\begin{array}{l}\text { Management and disposal of waste covered under this chapter } \\
\text { in quantities too large for acceptance at DOE LLW disposal } \\
\text { sites }\end{array}$ & 一 & $\mathrm{NC}$ & - \\
\hline
\end{tabular}


DOE Order 5820.2A Implementation Summary ${ }^{a}$ (continued)

\begin{tabular}{|c|c|c|c|c|}
\hline Chap./par. & Requirement & $\begin{array}{l}\text { Oak Ridge } \\
\text { Y-12 Site }\end{array}$ & $\begin{array}{c}\text { Oak Ridge } \\
\text { National Laboratory }^{b}\end{array}$ & $\begin{array}{l}\text { Oak Ridge } \\
\text { K-25 Site }\end{array}$ \\
\hline IV.3.a(2) & $\begin{array}{l}\text { Small volumes of } 11(\mathrm{e}) \text { byproduct material and naturally } \\
\text { occurring and accelerator produced radioactive material waste } \\
\text { may be disposed of at DOE LLW sites }\end{array}$ & $e$ & $\mathrm{C}$ & - \\
\hline IV.3.a(3)(a) & $\begin{array}{l}\text { Naturally occurring and accelerator produced radioactive } \\
\text { material mixed with the RCRA hazardous chemicals shall be } \\
\text { managed as hazardous waste under RCRA }\end{array}$ & - & NC & - \\
\hline IV.3.a(3)(b) & $\begin{array}{l}\text { Byproduct } 11 \mathrm{e}(2) \text { [or a combination of } 11 \mathrm{e}(2) \text { byproduct and } \\
\text { naturally occurring and accelerator produced radioactive } \\
\text { material] mixed with RCRA hazardous chemicals }\end{array}$ & - & $\mathrm{NC}$ & - \\
\hline IV.3.b & $\begin{array}{l}\text { Waste management practices shall be conducted in accordance } \\
\text { with applicable requirements of ANSI/ASME Nuclear Quality } \\
\text { Assurance-1 }\end{array}$ & 一 & $\mathrm{C}$ & 一 \\
\hline V.3.a(1) & $\begin{array}{l}\text { The decommissioning programs (general): each field } \\
\text { organization shall prepare and maintain a complete list of } \\
\text { contaminated facilities both operational and excess under its } \\
\text { jurisdiction }\end{array}$ & C & - & $\mathrm{C}$ \\
\hline V.3.a(2) & $\begin{array}{l}\text { The decommissioning programs (general): operational records } \\
\text { for all contaminated facilities shall be maintained by the } \\
\text { cognizant field organization for use in preparing } \\
\text { decommissioning plans }\end{array}$ & $e$ & - & NC \\
\hline V.3.a(3) & $\begin{array}{l}\text { The decommissioning programs (general): planning for facility } \\
\text { decommissioning shall be initiated during the design phase for } \\
\text { new facilities and prior to termination of operations for } \\
\text { existing operational facilities }\end{array}$ & C & $\mathrm{C}$ & C \\
\hline V.3.a(4) & $\begin{array}{l}\text { Program offices shall be responsible for placing the facility in } \\
\text { a safe storage condition, providing surveillance and } \\
\text { maintenance, and decommissioning the facilities under their } \\
\text { jurisdiction when they become excess to programmatic needs }\end{array}$ & $\mathrm{C}$ & - & C \\
\hline V.3.a(5) & $\begin{array}{l}\text { Responsibility for contaminated facilities may be transferred } \\
\text { from one program organization to another }\end{array}$ & $\mathrm{C}$ & $\mathrm{NC}$ & - \\
\hline
\end{tabular}


DOE Order 5820.2A Implementation Summary ${ }^{a}$ (continued)

\begin{tabular}{|c|c|c|c|c|}
\hline Chap./par. & Requirement & $\begin{array}{l}\text { Oak Ridge } \\
\text { Y-12 Site }\end{array}$ & $\begin{array}{c}\text { Oak Ridge } \\
\text { National Laboratory }\end{array}$ & $\begin{array}{l}\text { Oak Ridge } \\
\text { K-25 Site }\end{array}$ \\
\hline V.3.a(6) & $\begin{array}{l}\text { The DP and NE decommissioning programs exist for the } \\
\text { primary purpose of managing and decommissioning the } \\
\text { contaminated facilities currently assigned to them }\end{array}$ & $\mathrm{C}$ & $\mathrm{C}$ & - \\
\hline V.3.a(7) & $\begin{array}{l}\text { Decommissioning expertise gained by } \mathrm{DOE} \text { and its contractors } \\
\text { is available at most major DOE facilities and should be utilized } \\
\text { by DOE programs }\end{array}$ & $\mathrm{C}$ & $\mathrm{C}$ & $\mathrm{C}$ \\
\hline V.3.b & $\begin{array}{l}\text { Facilities in which radioactive or other hazardous materials are } \\
\text { utilized shall be designed to simplify decontamination and } \\
\text { decommissioning }\end{array}$ & $e$ & $\mathrm{C}$ & NC \\
\hline V.3.c(1) & $\begin{array}{l}\text { DOE Program organizations shall identify contaminated } \\
\text { facilities under their jurisdiction, document the potential for } \\
\text { reuse and recovery of materials and equipment, and develop } \\
\text { sckedules for decommissioning them }\end{array}$ & NC & NC & NC \\
\hline V.3.c(2) & $\begin{array}{l}\text { Program organizations shall ensure that adequate surveillance } \\
\text { and maintenance is performed for their surplus facilities to } \\
\text { meet applicable radiation, hazardous chemical, and physical } \\
\text { safety and security standards to reduce potential public and } \\
\text { environmental hazards. }\end{array}$ & $\mathrm{C}$ & $\mathrm{C}$ & $\mathrm{C}$ \\
\hline V.3.d(1) & $\begin{array}{l}\text { Baseline data for each decommissioning project shall be } \\
\text { collected to support a thorough physical, chemical, and } \\
\text { radiological characterization }\end{array}$ & $\mathrm{NC}$ & NC & $\mathrm{NC}$ \\
\hline V.3.d(2) & $\begin{array}{l}\text { The CERCLA, SARA, and/or RCRA status of each project } \\
\text { shall be identified, and a remedial investigation/feasibility } \\
\text { study be performed if required }\end{array}$ & C & C & C \\
\hline V.3.d(3) & $\begin{array}{l}\text { Technical engineering planning for each decommissioning } \\
\text { project shall be conducted during the environmental review } \\
\text { process }\end{array}$ & C & $\mathrm{C}$ & $\mathrm{C}$ \\
\hline V.3.d(4)(a) & $\begin{array}{l}\text { The decommissioning project shall be conducted in accordance } \\
\text { with guidance from DOE Headquarters program offices and the }\end{array}$ & $\mathrm{NC}$ & $\mathrm{NC}$ & $\mathrm{C}$ \\
\hline
\end{tabular}


DOE Order 5820.2A Implementation Summarya (continued)

\begin{tabular}{|c|c|c|c|c|}
\hline Chap./par. & Requirement & $\begin{array}{l}\text { Oak Ridge } \\
\text { Y-12 Site }\end{array}$ & $\begin{array}{c}\text { Oak Ridge } \\
\text { National Laboratory }^{b}\end{array}$ & $\begin{array}{l}\text { Oak Ridge } \\
\text { K-25 Site }\end{array}$ \\
\hline V.3.d(4)(b) & $\begin{array}{l}\text { Approval of MA- } 22 \text { shall be obtained before initiating } \\
\text { activities to demolish a DOE-owned facility }\end{array}$ & NC & NC & $\mathrm{C}$ \\
\hline V.3.d(4)(c) & Status reports on project activities shall be prepared & NC & NC & $\mathbf{C}$ \\
\hline V.3.d(4)(d) & $\begin{array}{l}\text { Information on waste generation shall be provided to the } \\
\text { Integrated Data Base Program }\end{array}$ & NC & C & $\mathrm{C}$ \\
\hline V.3.d(4)(e) & $\begin{array}{l}\text { Decommissioning operations shall be considered a waste } \\
\text { generator }\end{array}$ & NC & NC & $\mathrm{C}$ \\
\hline V.3.d(5)(a) & $\begin{array}{l}\text { After decommissioning operations have been completed, a final } \\
\text { radiological and chemical survey report and a project final } \\
\text { report shall be prepared }\end{array}$ & $\mathrm{NC}$ & NC & NC \\
\hline V.3.e(1) & $\begin{array}{l}\text { Waste management practices shall be conducted in accordance } \\
\text { with applicable requirements of ANSI/ASME QA-1 and other } \\
\text { appropriate national consensus standards }\end{array}$ & C & C & C \\
\hline VI.1 & $\begin{array}{l}\text { Sites are required to list and describe the waste management } \\
\text { documentation }\end{array}$ & $\mathrm{NC}$ & $\mathbf{C}$ & $\mathbf{C}$ \\
\hline VI.3 & Waste Management Plan outline, format for WMP, Exec. Sum. & C & C & C \\
\hline
\end{tabular}

${ }^{a} \mathrm{C}$, full compliance; $\mathrm{NC}$, noncompliance.

${ }^{b}$ Includes the High-Flux Isotope Reactor.

Includes the Toxic Substances Control Act Incinerator.

${ }^{d} \mathrm{NA}$, used only if a complete DOE chapter is not applicable; a dash indicates not applicable for a single entry.

Not included in Y-12 Plant assessment. 


\section{INTERNAL DISTRIBUTION}

1. E. L. Allred

2. P. E. Arakawa

3. A. E. Armstrong

4. J. K. Bailey

5. R. D. Bailey

6. C. L. Baker

7. J. S. Baldwin

8. K. A. Balo

9. B. O. Barritt

10. L. D. Bates

11. T. A. Bowers

12. C. W. Broughton

13. T. W. Burwinkle

14. C. E. Buttram III

15. P. J. Campbell

16. R. M. Cannon

17. W. F. Carden

18. L. D. Charles

19. W. S. Christenberry

20. D. E. Coffey

21. H. T. Conner, Jr.

22. K. W. Cook

23. D. G. Cope

24. H. L. Crothers, Jr.

25. E. L. Crowe

26. G. R. Cunningham

27. T. L. Dahl

28. J. S. Dalton

29. D. L. Daugherty

30. C. E. Daugherty

31. K. D. Delius

32. M. F. P. Delozier

33. L. F. Denton

34. J. G. Dorsey

35. K. M. Downer

36. M. B. Dyer

37. R. S. Eby

38. K. G. Edgemon

39. C. H. Estes

40. R. L. Faulkner

41. P. A. Flowers

42. C. S. Fore

43. J. R. Forgy, Jr.

44. P. J. Franco

45. J. L. Frazier

46. C. H. Fritts
47. C. E. Frye

48. H. R. Gaddis

49. J. K. Gilpin

50. R. O. Green, Jr.

51. D. F. Hall

52. L. E. Hall

53. H. E. Harper

54-58. J. E. Heiskell, Jr.

59. J. R. Hightower, Jr.

60. C. C. Hill

61. F. J. Homan

62. R. L. Hooks

63. J. H. Hooyman

64. S. C. Howard

65. R. A. Hudson

66. C. W. Hutzler

67. R. J. Hydzik

68. P. P. Jessen

69. I. W. Jeter

70. L. S. Jones

71. C. C. Jones

72. C. Jones, Jr.

73. M. A. Kane

74. T. E. Kent

75. M. A. King

76. C. M. Laborde

77-81. J. W. Lay

82. L. W. Little

83. L. W. Long

84. S. H. Lowe

85. L. A. Lundberg

86. J. R. Lyons II

87. J. J. Maddox

88. A. P. Malinauskas

89. C. A. Manrod

90. N. J. Marsicek

91. R. C. Mason

92. D. L. Mason

93. J. C. Massey

94-103. W. R. McCauley

104. B. C. McClelland

105. D. W. McCune

106. T. J. McLaughlin

107. N. G. McRae

108. S. A. Meacham

109. R. J. Mehlon 
110. L. J. Mezga

111. M. E. Mitchell

112. W. H. Moon, Jr.

113. T. W. Morris

114. M. E. Musolf

115. F. R. Mynatt

116. C. T. Neal

117. C. M. Noakes

118. H. M. Oakes

119. R. C. Orrin

120. J. C. Parker, Jr.

121. J. R. Parrott

122. C. H. Peterson

123. R. N. Pointer

124. J. E. Powell

125. J. K. Prazniak

126. J. T. Price

127. R. E. Pudelek

128-137. S. H. Reece

138. A. L. Rivera

139. P. H. Roush

140. S. T. Rudell

141. G. D. Robbins

142. T. F. Scanlan

143. F. J. Schultz

144. C. B. Scott

145. M. J. E. Shelton

146. W. K. Simon
147. B. E. Skaggs

148. M. L. Sollenberger

149. R. C. Stewart

150-154. J. E. Stone

155. L. E. Stratton

156. J. S. Suffren

157-181. F. J. Sweeney

182. T. D. Taylor

183. J. R. Trabalka

184. M. W. Tull

185-189. J. W. Turner

190. D. M. Wasserman

191. H. D. Whitehead, Jr.

192. C. Whitmire, Jr.

193. M. L. Whitten

194. M. C. Willard

195. J. L. Williams

196. M. L. Willoughby

197. G. H. Winebarger

198. S. T. Wright

199. ORNL Patent Office

200. Central Research Library, ORNL

201. ESWMO Document Management Center

202-203. ORNL Laboratory Records

204. ORNL Laboratory Records RC

205-209. K-25 Site WMD Document Center

\section{EXTERNAL DISTRIBUTION}

210. E. Addington, U.S. Department of Energy, Oak Ridge Operations Office

211. B. C. Demonia, U.S. Department of Energy, Oak Ridge Operations Office

212. R. E. Frounfelker, U.S. Department of Energy, Oak Ridge Operations Office

213. W. C. Gilbert, U.S. Department of Energy, Oak Ridge Operations Office

214. K. Ma, U.S. Department of Energy, Oak Ridge Operations Office

215. T. Noe, U.S. Department of Energy, Oak Ridge Operations Office

216. D. M. Perez, U.S. Department of Energy, Oak Ridge Operations Office

217-226. W. H. Rice, U.S. Department of Energy, Oak Ridge Operations Office

227. L. L. Radcliffe, U.S. Department of Energy, Oak Ridge Operations Office

228. L. C. M. Roddye, U.S. Department of Energy, Oak Ridge Operations Office

229. J. L. Sager, U.S. Department of Energy, Oak Ridge Operations Office

230. T. S. Tison, U.S. Department of Energy, Oak Ridge Operations Office

231. D. Underwood, U.S. Department of Energy, Oak Ridge Operations Office

232-233. Office of Scientific and Technical Information 